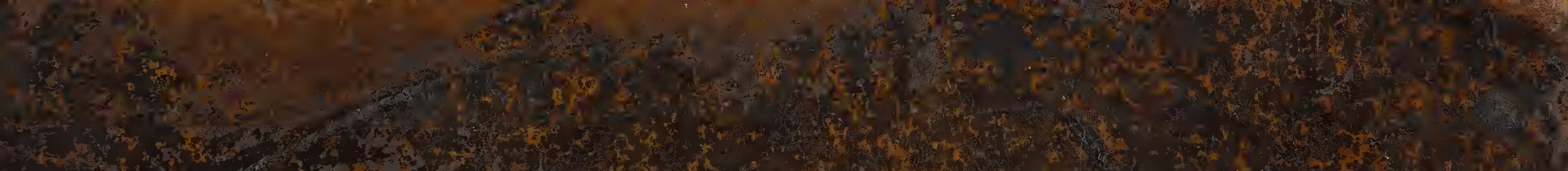

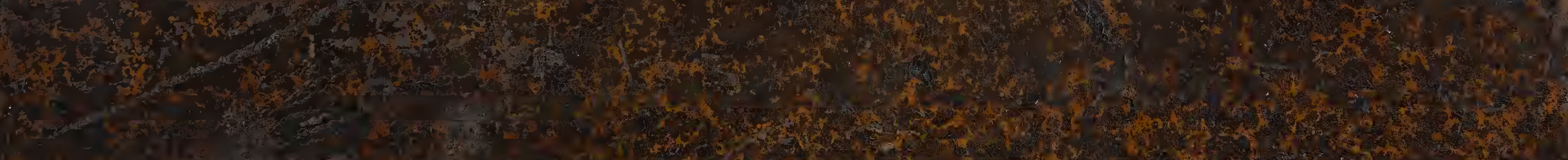

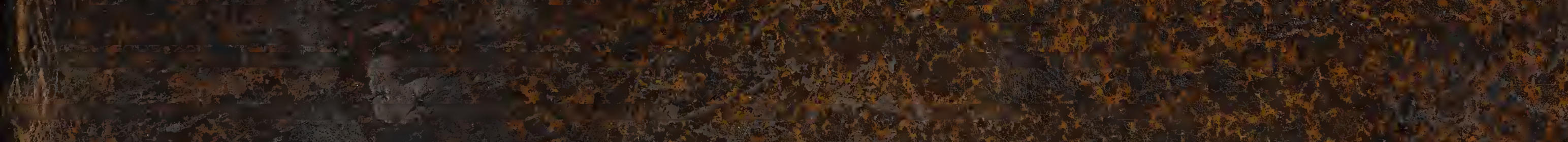

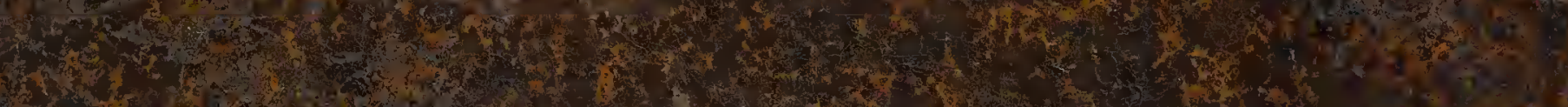

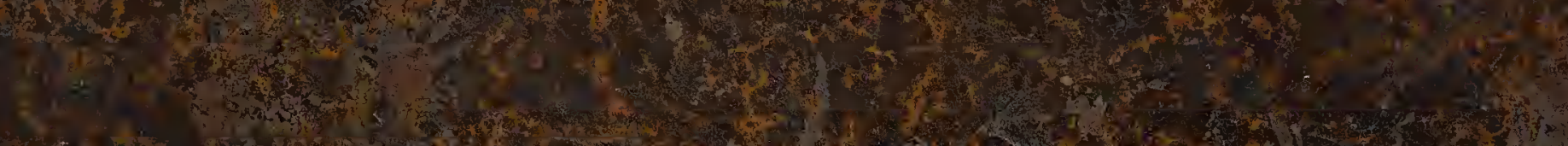

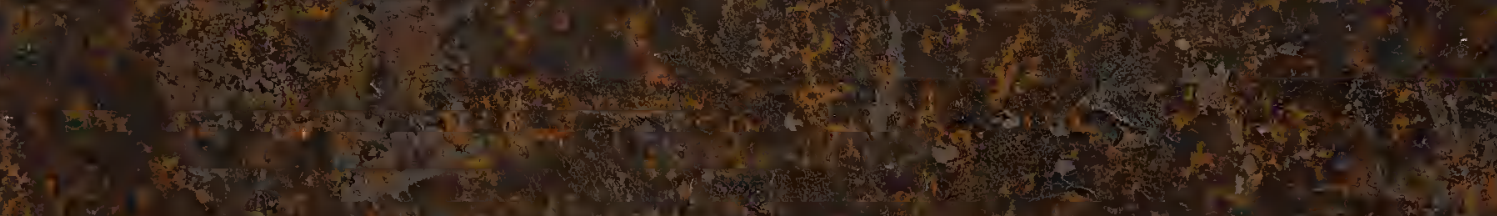
If -2.

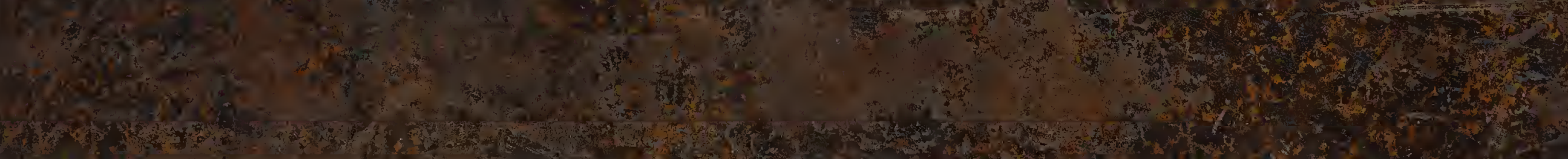

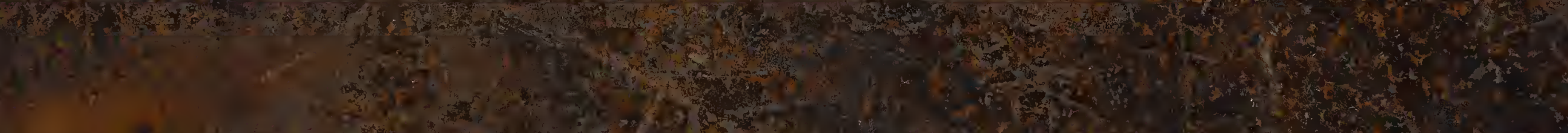

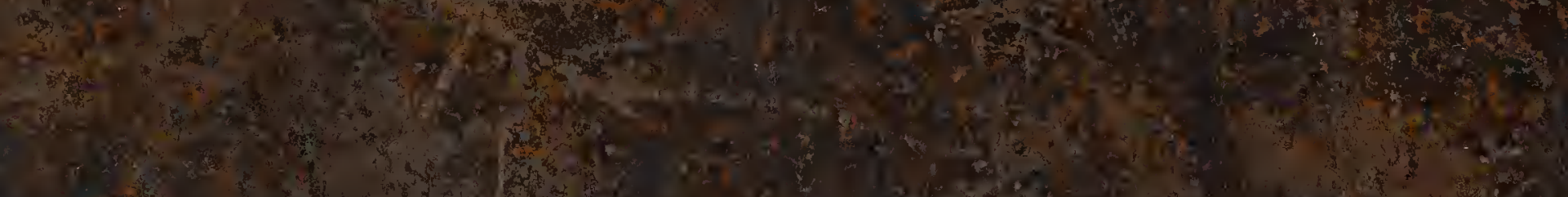
(3) 
NrP11205

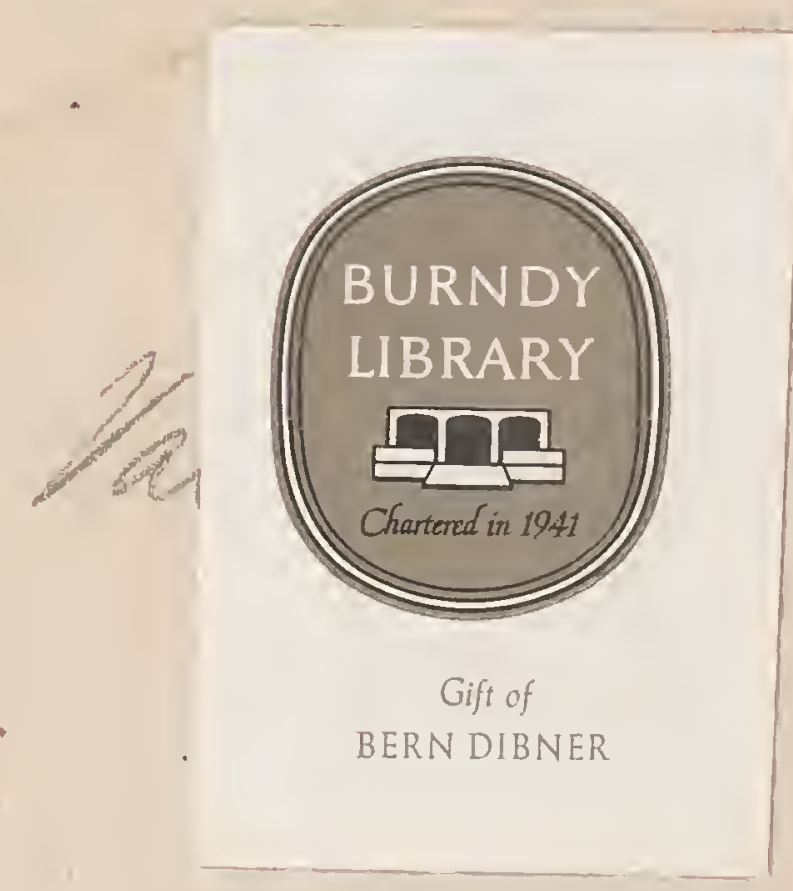

The Dibner Library

of the History of

Science and Technology

SMITHSONIAN INSTITUTION LIBRARIES

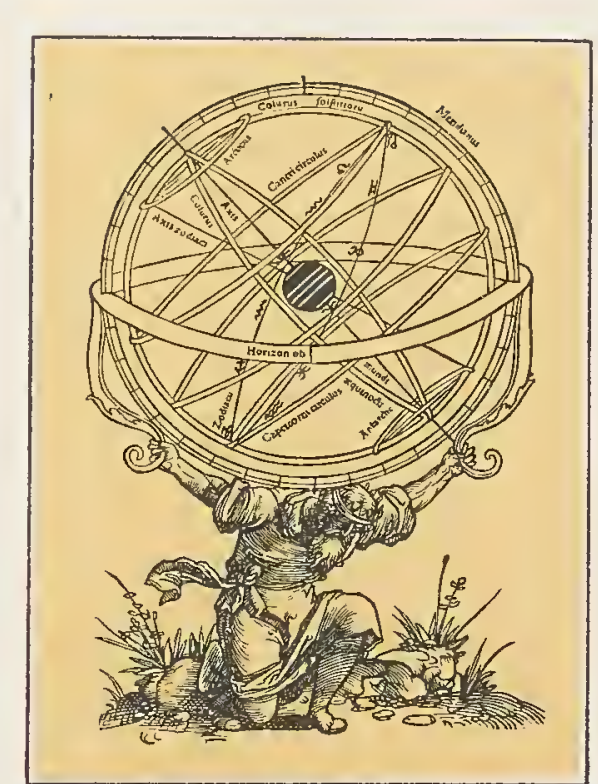

3 




\section{EN TIBI LECTOR}

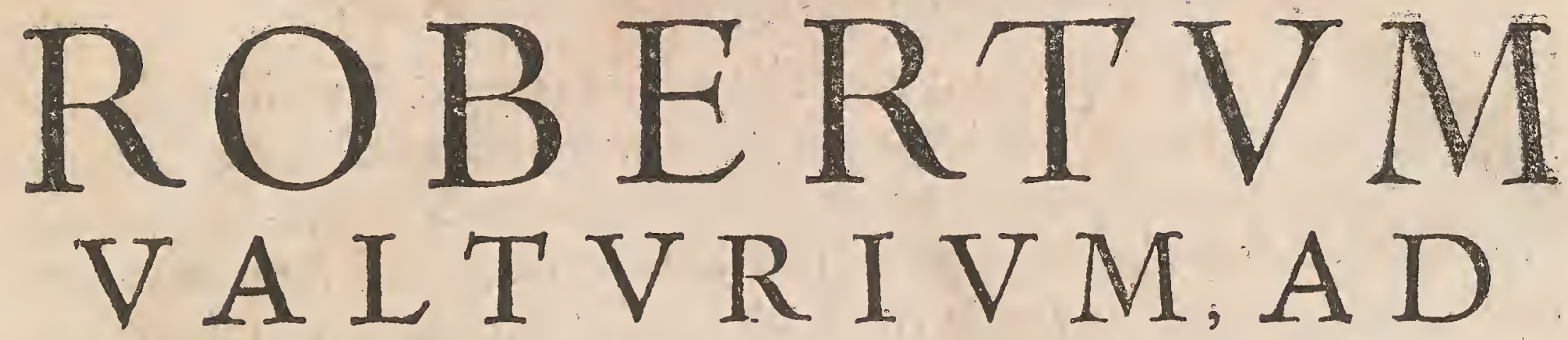

I L L V T REM HEROA SIG IS MVNdum Pandulphum. Malateftam Ariminenfum regem,de

RE M I L I T A R I Libris XII multò emaculatius, ac picturis, qux plurimæ in eo funt, elegantioribus expreffum, quàm cum $\mathrm{Ve}$ ronæ inter initia artis chalcogra phicx Anno M.cccclxxxiii.

to inuulgaretur. St

$\overrightarrow{\mathrm{e}}$
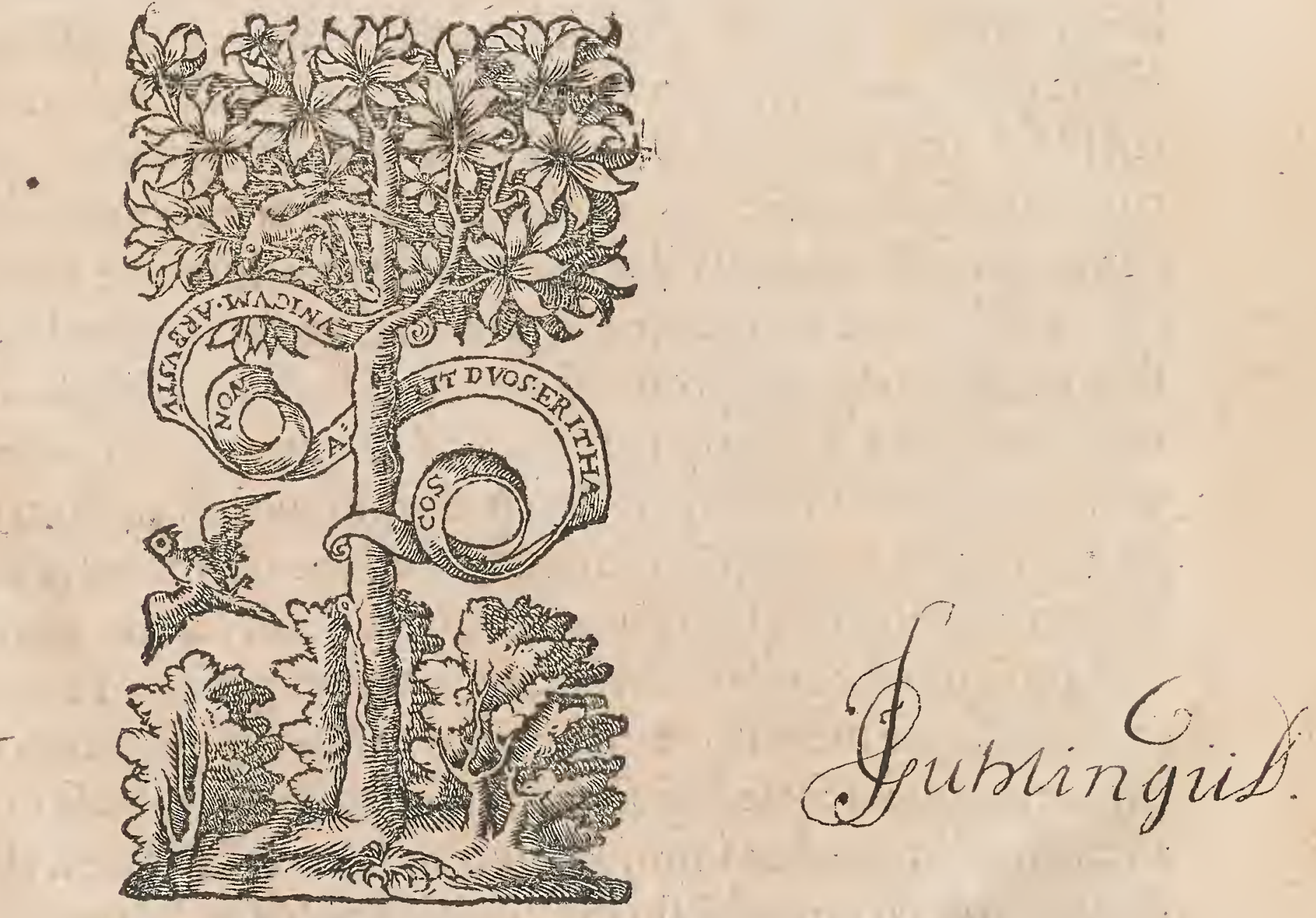

$$
\text { PAR IS IIS, }
$$

Apud Chrifianum Wechelum, fub infigni

fcuti Bafilienfiso I. D. XXXII.

so Menfe Iulio. of 
1 2. Ifi vniuerfa quecung hic coeli ambitus complectitur, vir praftantif-

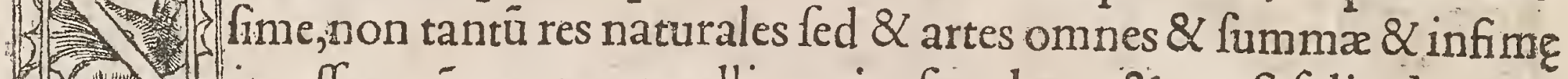
- ita effent cóparatæ vt nulli pprius fuus locus \& quafi folitudo quæ. 1. dam ab aliis rebus omnibus tributa fit, fed pmixta inuicem et quadam cöfufa cyclopædia conftarent, facile fruiffem mihi perfuaderi abfurde facturü fi librum de re Militari infcriptú tibi homini iurifconfultiffimo legédum afferrem: verùm quando contrà habent omnia, vt ei qui vere publica velit tractare rei quog Militaris \& aliarú ité compluriū artiú vifus fit, quod vel imprimis in fpledidiffima tua O L I V E R I O R V M familia licet agnofcere que nihil bonorú autorum relinquit intactú vt pace $\&$ bello fuis femper qooptime confulat, nihil videor facturus minus, præfertim cum eximii illi legú conditores Romani nó inferioré armis qu toga operä reipub.nauarint. Indigne enim bono viro nedú iurifconfulto fecerit qui rép. fllentibuslegibus, armis oppreffam neglexe rit, quã củ aliarú artiú adminiculis, tú ex rerú bellicarú aưtoribus petitis documé tis licebit, fi non inferendis plagis, quả ne Turcarum quidé nunc fatis grauiter ac minitabunde imminentiú reipub. chriftianæad noftram perfuafioné pertra hendorú cópendiofiflimâ rationé quidá pùtant, euitand is certe quæ illatæ fuerint et quodámodo, vt ille ait,ex vna ciuitate in aliá fugiendo ppugnare. Aut, fi cui id forte magis placebit, quod philofophis frequens eft, apud quos contraria contrariorú admonét, puter voluiffe fubindicare non ferè magis q̃ tuã volunta tem ac profeffioné, agni illius fine macula imbellitaté ac innocentiam à furioro Marte abhorrere.lam qui me fanguina riú ac germanico, hoc eft, vt ferè perfuafum eft, bellico fpiritu prouectú æneos nodos furori diffoluere cauillabuntur, id velim expédant, egóne qui priftinas calamitates ac belli peftes oculis fubiicio \& vniuer fos alieno malo fapere doceo, plus cômuni hominum vitx cómodem, an illi $q$ contéptis et perpetua obliuionis caligine obrutis quęcung fupioribus fecus lis incómode tentata funt, humanü genus nouis femper periculis obiiciüt fuóg malo quãtum hæc vita miferiarú habeat vt experiantur autores funt. Vides vir humaniff. qux me rationes induxerint vt tux dignitati non veritus fim librum exhibere non ita forte dignú $q$ in tantorú virorú oculos fe ingerat, quóqg cóflio in eiufmodi autor bus impriméd is $\&$ animo verfer: qux fi tibi probabutur, naAus fuero quod quærebã, fin difplicebút, duplici mihi nomine impetrabiliorem veniã polliceor, tum $q$ beneficio breuioris chartæ anguftis cancellis conclufus paucioribus te obtúdam, tủ quia Vegetio \& Geometria Dureri propediể æeden dis aliquid illi tuæ naufee fi qua eft deceflurú puto. Vale vir clariffime \& Valtu rii noftri contemplatione memineris vt tenebrofa $\&$ à Vulcano concinnata ar ma lucidis \& à patre luminum expeditis qux vel Achillis clypeum facile penetra rint retüdas ac intra fua mœnia cohibeas, quo minus in perniciem tranquil litatis humang aliquà poffint erumpere, Lutetiæ M.D.XXXII.quinto idus Iulii. 


\section{ILLVSTRI PANDVLPHO MALATESTAE}

principi Ariminenfi Paulus Ramufius A rimineri-

fis, iuris vtriufque confultus $S$. P . dicit.

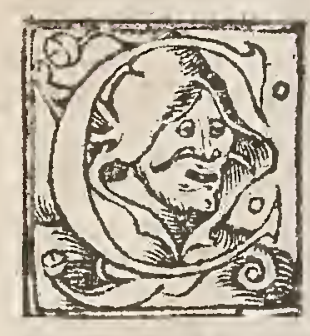

Lariffima progenitorum tuorum facinora toga $\&$ bello magnifice gefta, me ciuem tuum coëgere, côfcriptum accurat iflimé opus de rè militari conterranei mei Roberti Valturii ad te tranfmittere, quod incuria caftigantium pariter $\&$ imprimentium ab archetypo diffimile \& deuians multis mendis deforme neglectumque iacebat. Illud fane pro viribus dum Veronæ fub Magnifico \& Clariflimo Antonio Venerio à publico iure reddendo vacarem, non fine paruo labore fuccifiuis horis recog noui, vit pro eo iure quo conciui meo debebam, id in priftinum nitorem $\&$ doct is legen dum reftituerem: cuius laboriofam caftigationem, $\&$ diuin i prope oper is huius emolumentum tuo nomini, princeps iocundiffime, dedicaui, quò docunienta illa percurrens, facile intelligas quâtopere maiores tui in eo genere excelluerint; adeò vt fi militiæ pracepta ftratagematáque nulla literarum monumentis tradita effent,potuiffent abundè ex Malateftarum genere ftrenui ac inuicti armorum duces cúctas gentes huiufce difciplinæ peritia gettis fuis condocere, exemplárque continua bellorum exercitatione ac latiffimo triumphorum fplendore \&. pręlentibus \& futuris pręltare. Adeft fere ante oculos Robertus Malatefta, $\mathrm{Si}$ gifmüdo patre ortus, cuius memoria oborte lachrymę fcripta demoliürur. Hic octauum $\&$ decimú agens annum aduerfus eximios Piconi populos ab Anconitanis delectus imperator, $\&$ tot holtibus fratis captisóp quadringentis, victoria triumphóq potitur. Non multò pòłt quum Fani teneret imperium, obfeffus a Pio romano pontifice equite peditégue potentiffimo, ipfe parua manu romanos milites fxpius in fugam vertit. Ad trigelimum ætatis annum Romæ com moratus, vbi onnes tanti viri fpeciem \& virtuté admirabantur, Sigifnundum patrem Arimini obiiffe præfenfit, quem vniuerfa Italia \& Achaia ducem excellentufimum prius fuerat experta: aduolat Ariminum Robertus morore ple nus, quem ciues ad vnü exoptantes fibi principem delegere . Interea Pauli pontificis maximi florentifimæarmatorum copiæ Arimini fuburbanü rubefcente aurora clam fubintrauerunt, Robertus verò inuicto animo grandem romanorum exercitum parua ty ronum manu pellit fugat $\dot{q}_{\text {, }}$, cuius ob egregia facino ra Florentini omnium confenfu militum imperatorem fibi delegere aduerfus ingentes Sixti pontificis maximi \& illuftriflimi Ferdinandi regis vires, quibus maxime vniuerfa premebatur Hetruria, fpiritum emiffura ni Robertus inclytus virtute, fcientia rei militaris auctoritate præftò ad fuiffet. Matt hæum Capua num militix ducem ad Thrafumenú lacum vertit in fugam, reliquis militibus foedilima nota fub iugum ise compulfis: is profectò fuis armis fuáó virtute digniffimus quifereniffimi imperii Veneti dux nulitum maximus aliquando, capitolinas arces $\&$ romanam eccleliam feruaturus, totius fenatus fuffrägiis glori offlimè conftitueretur. Audiat nunc quęefo vniuerfus chrifit populus, \& cogtio 


\section{RAMVSIVS PANDVLPHO.}

fcat romanzecclefie ad interitum pene vulnera: $V$ enerat fapientifimus $C$ alabrię dux iamiam romuleas arces euerfurus, accurrit veluti Papyrius $C u r$ tor $\&$ Furius Camillus, Pub. Decius, Curius Dentatus, Valerius Publicola, R obertus Malatefta,iuffu fereniffimi fenatus Veneti; affueti perpetuö ecclefia n cóferuare, Calabrum ducem tantopere minantem conferto Marte fugere coégit, cuius. caftra proftratis vexillis, direptis impedimentis, gloriofiffima victoria cepit, duces egregios \& milites quadringentos in triumphum Roman fpoliis \& milita ribus fignis onuftus deducit:veniétem Sixtus fummus pótifex amplectitur, collaudat, a dmiratur tâtis periculis liberatus. R obertus verò dux inclytus fümis in conflictu penè diei laboribus $\&$ ætu fatigatus in morbum incidit, languinisç profluuio à nobis emigrauit, inter diuos candidatus laurea m perpetuò virétem recepturus, qué gratus \& pientiffimus pontifex maximus ante obitum deplorâs vifere conftituit, $\&$ ipfum ecclefiæ verum feruatorẽ terrenæ labis cótagione pur gatum, larga $\&$ indulgenti venia ad caleftem triumphum códonauit. Moritur ita Romæ Robertus Malatefta anno xtatis fux quadragefimo,dux abüdans bellicis laudibus, $\alpha$ in $x$ de diui Petri conditur elatus moerore publico . Quorfum hæc dicet quifpiam? vt tanti principis, quem Venetorum fenatus

\& vniuerfa deplorat Italia, alıquid literarum monumentis mandarem, vtóp magnificis progenitorum tuorum exemplis ex ardefcens \& paternæ virtutis æmulatione acrius ad virtutis gloriam euehare, \& fapius legendo accuratè caftigatum opus, Ramufios tibi deditifimos \& domefticarum laudum pręcones recognofcas. Vale.

\section{Eiufdem Pauli Ramufii epigramma,}

Armorum fulmen iacet hic Malatefta Robertus,

Cuius preftantes gloria vicit auos.

Nam poft mille acies fuperatas Marte fecundo,

Dum foluit patrios obfidionelares,

Ágmina proftrauit Túcos immiffa peragros,

Et Calabri fudit fortia caltra ducis.

Occubuit polthæc inter fera pralia,certe

Non potuit fato candidiore mori. 
heroa Sigifmundum Pandulphum Malateftam fplédidiffimum.

Ariminenfium regem ac imperatorem femper inuictum Roberti Valturii rei militaris librorum pręfatio.

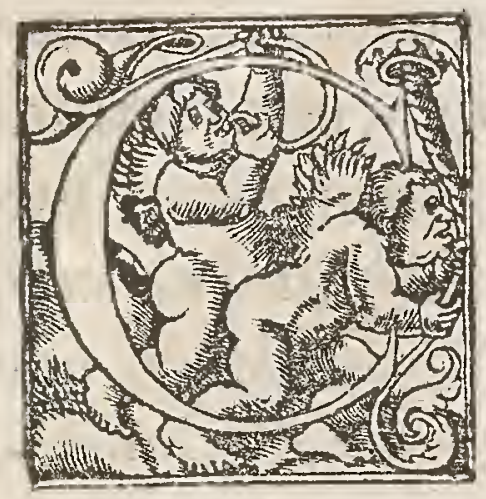

Redo equidem, nec fum nefcius, dux \& Imperător inclyte, SIGISMVNDE PANDV L P HE, (tanta eft liuoris \& inuidię noftri huius fæculi malignitatíf(g puerfitas)ğ multos hoc meú inceffuros opufculum, quờd in tanta feilicet pröbatiflimorum vtriufque lingue fcriptorum copia qui accuratè \& eleganter rei militaris pracepta tradiderunt,ego potiffimum aufus fim temere ac ieiunè libros de tanta re cóminifci : in qua primùm céforum aciem ftruam quàm coepti mei rationem reddanı, quàm de perfcriptione operis huius differédum quicquam putem. Inter iftos itaqg qui mea legent, nouum immo antiquum \& admirabile hominum genus fore fcio,nec mihi fo li,vltimo hominum,verùm primis ac maximis importunum, quibus nihil ritè fiat,quibufcum loqui fi coeperis, faftidiant fingula, fua licet non edât : indignen túrque,nunquam in fententia permanentes, fi veluti muta $\&$ rationis expertia vitam filentio prætereas. Nonnulli, veluti fues in luto grünientes,quum norint forfan ad hanc immortalitatis \& glorix partem ex literarum \& ingenii fui conatibus afpirare non poffe, nec inuenire, nec explicare fermone quod fuerit inuentum, incaffum me laboraffe contendent: \& quoniam nixa ipfi fuo minime iu uabuntur, nullum adiuuari poffe cenfebunt . Alii veluti apum fuci, \& impros biffimi fycophätx, folita libidine omnibus detrahendi, \& ad fingulaquxq carpenda proni $\&$ ingeniofi, non deerunt interpretes qui calumniabuntur fingulorum ordinem,eo pacto fcientie phamam fibi aucupari credentes:qui puerilis iactantix ftudio tenebuntur obnoxii,quum olim confueuerint adolefcentes ab infigni accufatione aliqua primum nomen aufpicari.Phormionis peripateticæ fectx philofophi,\& Sergii Galbę perfrmilem me dicent. Alii,cum nitida ego ve illi cute, $\&$ corpore propter vmbram molli, nullo vnqua mu vulnére admiffo, de re militari, de fortitudine ac ignauia ducum, de inftruenda acie, de loco caftris capiendo idoneo, multífque id genus,verba facturus fim, ad eủ maxime ducems qui $\&$ caftris nutritus fit, $\&$ exercitus maximos duxerit femper inuicus . Erunt \& alii porrò difficiles, monftruofi,lucifugi,qui fallam fcientix perfua fionem in duent: fub peritiæ tamen oftentatione, ac doctrinarum fuarum opinione, multa fibi arrogantes, \& intra fefe nefcio quid ineptè cornicantes, quióp non tam crimi nibus quàm maledictis annitentur obruere : quorum voces tumentiáque verba minime perhorrefcens, nihilo pluris ego faciam quàm Demetrius ille quem dicere folitum accepimus,eodé fibi loco voces effe imperitorum quo $\&$ ventre red ditos crepitus: quum nihil pene interfit qua parte corporis, furfum an deorfum turpiter fonent. Acrius vrgebunt alii, $\&$ inculcabunt mihi illud fatyricum, Tenet infanabile multos Scribendi cacoêthes, illius obliti non minoris in fatyra, Eft quòdam prodire tenus,fi non datur vltrà: 


\section{ROBERTVS VALTVRIVS}

quos omnes etfi poffum iure meo repercutere, malim tamen equo animo intachos linquere, maxime quú haudquaquá ex eorú fim numero qui æmulis carere velint: \& eo fint ftudio, \& ingenio prouecti, vt nihil reprehenfibile, nibil nifi ad vnguem perfectum habeant. Non pigebit igitur, fr qua me inconfultè præterierint(quanquam mea, diligétia \& curiola perf'crutatione veterum ex libris explorata omnia effe (ciam) vel amicorum, vel eruditorum monitu, fi vera fuerint, emendatione corrigere : fi minus, Democriti potius rifum quàm. Heraclyti lachrymas fequi velle. Non enim æegrèferam, hane effe de fcriptis meis exiftimationem, vt qui nefciunt, doctıflimos, grauiffimos fanctiffimólque viros ab amulis quibus referta funt omnia perperàm talia perpeffos effe intelligant. Atq̧̣ vt à poétis initium fumam, qui funt multò antiquiores quàm hiftorici,quàm oratores, quàm cæera fcriptorum genera, Homerus primus omnis philologiæ dux \& antiquitatis parens, diu inarumíg omniú inuentionú fons \& origo fuit, haudquaquam tamen fic pofteritatis ftudia reftrinxit, quin æmulos haberet quàm plures, qui labétem, \& cedentem oneri, $\&$ dormitanté eum nonnunguam appellent: fed Zoilum illum imprimis, quod mirabere, qui à Macedonia Alexandriam profectus optauit fibi cognomen ve Homeromaftix appel laretur,quum fua Ptolomæo regi contra Iliadem \& Odyffeam fcripta comparata recitaret, quanquam ante annos mille diem obiiffet Homerus. Maronem vatem Mantuanum, difciplinarú omnium cognitione ad vngué excultum, \& cuius anima, vt inquit Flaccus, candidiorem alıam non tulit terra, ab C. Caligu la,nullius ingenii: à M. Vipranio Repertore, ab Cornificio, Euangelo, Camillo Pictore, Hærennio, Perillo, Fauftino, Octauiọ́ Auito, ac mult is aliis non tanq̈ imitatoré, fed defloratoré, \& veterum cópilatoré publicumóq furé nouimus effé notatum. Hęc eadem à maliuolis paffus eft $\mathrm{P}$. Terentius Comicorum fummus, qui comodiarum prologos in defenfionem fcænis dedit. Vrgebant enim coma dias eum omnes à Polydoro ac Menandro tranfuliffe, \& à Lalio Scipionéque. in fcriptis fic adiutum ve meritò non fua fed aliena pro fuis edentem crimina rentur. Sunt qui non tam $a b$ his qui tum adolefcentuli forte fuere quàm à $\mathbf{Q}$. Sulpicio Gallo qui confularibus lud ss fabularum dâdarum initium fecerit, vel ¿2. Eabio Labeone, \& M. Pópilio confulari vtroq ac poéta viris, vtpote quorum operam, $\&$ in bello, $\&$ in ocio, \& negocio nedum Terentius fed S.P.Q ple runq $R$. Euerit expertus. Quis M. T. Cicerone doctrinarum luce in eloquendo ornation? quis foelicior in explicando?quis in perfuadendo potentior?qui in arce romanæ eloquentix ftetit? id nedum inter xtatis fux homines, verim apud po. fteros affecutus, vt eius non Arpinatis cuiufpiā hominis, fed animatæe diuinæóg potius eloquentia nomen habeatur? obtrectatorum tamen morfus euitare non potuit quominus in eorum línguas incideret. Hunc enim Græci repetũdarum dignum accufari cenfent, $q$ ea literis mandaret qua haud primum ex fe forent inuenta:criminanturalii incompofitè eum logui, $\&$ non modo tumidum, fed redundantem, in repetitione nimium denique, atque verbofum, quũ tamen mos fit ei profundam rerum fientiam fub breuitate verborum tegere. Martianus. Capella, vitiofifimum in claufulis reperiri eum, turbantem numeros quadam 


\section{SIGISM VNDO PANDVLPHO}

permixta confufione, dicit. Nonnulli quog inter maximos viros tam prodigiofi extiterunt, in quibus funt Gallus Afinius Caluus, \& Largus Lycinius(cuius liber in fuggillationê eius atọ notam etrá inuulgatus fertur,infami titulo Ciceromaftix) vt (cribere aufi fint, oratorem maximum improprièatque inconfultè locutum:quos itidem( $v e$ in oratione etia fua $V$ atiniana teft is eft) ob infignemi lingua feftiuitatem, confularem eum f́curram minus puduit appellare : quódq magis mirabere(tanta eft iudiciorum varietas)extat eiufdem Ciceronis de opti mo genere dicendi liber, tale támque ex alto fumptum opus, vt idem in epiftolis agrè attigit, à $\mathrm{M}$.tamen $\mathrm{Bruto}_{\text {; }}$ ad quem \& cuius precibus fcriptus erat; erudito viro licet $\&$ fcribentis amico,non probatur. Quis Demothene in tanta graiorum hominum eruditione, oratorix artis praceptis $\&$ dicendi vfu ac maieftate preftantior? \& quanquam quum dicturus effet, concurfus in audienda caufa ex omni Græcia fieri folitos monumentis atticis atque latinis memorix proditum fit,attamen hic iple huius qué modo diximus Ciceronis aures per fape non implet. Quis Epicurum intoleranda fuperbia detrahentem omnibus non au. divit? Pythagora, Empedocli,Democrati?quem a micum licet, totis voluminibus laceraffe traditur, quòd in philo ophra paululum à fe fursóp in fanis opinio. ribus difcordarent? Democritum à quo quæ frebat in philolophicis curcta di dicerat, \& quem exigua mutatione verború in omnibus fequebatur, hunc acrius inurebat : népe qui magiftro caruiffe gloriaretur \& videri vellet. Secuts lunt is hac decra hédi lididine É picurum Metrodorus atque Hermacus, fupradictos. groģ philofophos lacerât es,nec vilius magnitudini parcentes aut gloriæ, quan do idem Epicurus mirum in modum Platonem fpernit \& contumelioffirme Arifotelem vexat, aduerfus Tritamum hominem in dicendi nitore tantum,vt ob diuinam eius eloquentiam Ariftoteles Theophraftum appellaret: Scito fermone \& Attico inuenitur fcripfffe etiam fominam,ac meretriculam quidem: Fuit $\&$ Zeno iple maledicus, \& a pernator nö modice,qui et Chryfippum philofophum acuriffimum, \& eiuldem fectæ nominans contemptim,non Chryfip pum led Chryfippam femper diceret: nec modo qui tum erant, Apollodorum fiue cæreros coæt anos conuitiis ac maled ictis incefferet, fed parentem immo de. um phil fophix Socraté, latino verbo vfus quó mordacior credo effet, fcur ram. Atticum appellaret. Similiter qui de Platone Xenophontég, duobus Socraticæe a monitat is luminibus exquifitiffime fcripfere, nó abfuife a b jpfis notus quofdam tacitos \& occultos fimultatis \& 2 mulationis mutue putauerüt. Fuit \& An nei Senece in Fabium Quintilianum, \& Quint1liani in Senecam detractio non leuis, \& quanquarm a mbo excellenti ingenio \& doctrina viri, eodem cælo genici, quos ætas, quos profeffio penè iunxerit, feiunxit tamen adcó parium immo difparium peftis liuor, vt nec Fabius Senecam ore pleno probare poffit, nec ille de Fabio, par pari referés, nifi contéptiffimè loqui.Liuium hiftoricú celeberrimum, tametf lacteum alii, alii vberem $\&$ beatum eloquentix fontem vocent, Caius tamen, ferox fateor princeps, fed minime rudis, vt Senecæ dicta, coma miffiones meras $\&$ fine calce arenam effe dixit, fic verbofum hunc in hiftoria negligentémque carpit, cui \& Pollio patauinitatem quampiam dicit inefle. 


\section{ROBERTVS VALTVRIVS}

Saluftianæ orationis breuitatem qua nihil apud eruditos elegantius, nihil po. teft effe perfectius, maligne etiam reprehendere infcitég obtrectare plerique conati funt. V tóp ad fanctos patres conuertatur oratio, quis Hierony mi contentiones non audiuit,non legit? cum Ruffino A quilienfe? cú louinia no? cum Vigilantio ? quem nonnunquả proprio, nonnunquá mutato nomine dormitãtem appellat? Quss eiufdem cum Auguftino non vidit epıltolas? à quibus quü con tentionis ftudium et volutas forte abfit, more fanctorum in quibus illi duo omni genere doctrinæ \& vitæ fanctimonia omnium iudicio excelluerunt,emulationis tamen non parux fpeciem quádam prę fe tuliffe haud dubie vifi funt.Cyprianum in omni genere oratoriæ artis ad mirabilem, \& cuius ingenii facilitatem, copiam, \& fuauitatem admiramur omnes, à peritis tamé quibufdam accufari derideriog folitum legimus,et vna fui nominis litera immutata, Caprianum appellari, quòd ingenii tam diuitis venam ad dominicam orationem ac humilia quædam alia literarum ignaris folú enodanda conuertiffet .Ad poftremum quum conftet ingeniis omnis æui pręcellentibus vnum hoc venenum vnámque labem inuidiam extitiffe, non mirum tibi, Sigifmunde, nec cuipiā videri debet, fi contra me pufillum hominem $\&$ indoctum fcholafticı quidam \& circúforanei rabulæ latrent atque defæuiant. Quocirca lectorem etiam humanitatis iure poftulo,quifquis ille erit qui viderit hæc, ne iurgiis infectetur, conterat,vel deteftetur : verum fiab initio legerit, perlegat quoq, \& in legendo quæ alibi norit. (quum nihil fcribi omnino noua inquifitione poffit) minime tanquam iniqua repudiet, fatifque effe iudicet, non effe hæc, nec in compitis, neque in tabernis literarum ludi valde protrita. Illud denique peto,vt non erudiendi oftentandióp noui aliquid magis quàm reftau randi gratia que deperdita erát clarorum virorum monumenta, quafi maiorum demonftratione veftigiorum, icripta hæc ex's iftimentur: atque vt eiufce deperdita rei notitia plenior habeatur, ab ipfis(vt ita loquar) cunabulis feriptores eius auctores recéfebo, quos \& multos \& præclaros,tam Gracorum quàm Latinorum aliarumóg gentium fuiffe comperio, Demetrium fcilicet Phanoftrati filium, Phalereum, Democritum, Xenophontem, Pyrrhum Epirotarum regem maximum, Iphicratem Athenienfem, Anachar fim Scytham, Cincium, Iulium Higinum, Catonë Cenforium, Marcum Varronem,M.T.Ciceronem, Cornelium Celfum,Martianum, Modeftinum, Marcellum, Sextum Iulium Frötinum, Vegetium Renatum, Patrinum, his minus omif fis quxà Romulo, Numa Pompilio, Tullo Hoftilıo, Anco Martio, Tarquinio Prifco,Seruio Tullo ex regibus:ex Cæfarum verò \& Auguftorum familia, Iulio Carare, Diuo Aug. Diuo Traiano Adrianóg inftituta,inuêta,cómutata vel reuocata funt : quorū pene omnium libri qui fcripferút cum vel temporum vitio, vel ractura quadam noftra deperiffent, illíg ipfi qui fato minus effent abfumpti in multis deficerent qux ad rem fpectare videbâtur, fufcepi laborem noux huius commentationis, tuo tantum nomini dedicandum . Nullus enim oc. currebat alius, (neque amore aut errore teneor)in tanto nobilium ducum $\& \mathrm{im}$ peratorú numero,cui iure fuo munus hoc dedicari dignius poffet : quippe qui hac folus tempeltate caltrorum filius, exercituum pater, optimifquibufq doçtri 


\section{SI G IS VNDO PANDVLPHO.}

nis \& artibus belli imbutus, clariffimis exacti temporis ducibus peculiari qua. dam amoris gratia militaris huius rei afficeris, vitam illoru m ac gefta fudens emulari. Eóg libentius id effeci,quòd concilium celeftium terreftriumque in fedibus inmortalitatis te collocaffe videbam, omném que incly tæ domus tux glo riam fubditorumque populorum fpem in tuam poteftatem tranftulife, ve non aliter ac dei nutu fine dubio factum fit, quòd tam arduus ecclefie romanæ cafus emerferit, quo heroicam diuinámque illam virtutem tuam facile poffes oftédere. Nec egre feres, de te audiens quod aliquando de fummatibus viris \& illuftribus dictum eft \& literarum cuftodix traditum:vt enim Hectorem \& A chillem troiani belli celebritas claros fecit, innumerabilis Xerxem exercitus, \& Maratho nia pugna Milciadem, Camillum Galli, Manlium capitolina defenfio, Scipiones Carthago, Cymbri \& Theutones Marium, P ompeium Mithridates atque pyratæ, Cęfarem Britannia, Gallia,ato Theffalia, fic te diuina figna per omnes Italiæ oras, per omnes exteras nationes, notifimum clariflimumóp red̀diderunt, cum Eugenio Pontifice Maximo, omnium qu fanctiflimo præfide, tu gentibus eius aduerfus egregium fane ducem Frácifcum Sphortiam focerum tuum po. tentiffimum, ac acerrimum dominici tunc gfegis hoftem, aduerfuśg Florentinum Venetúmque populum Imperator inuictus adelfes, ac facrofanctam ec.clefiam eius gétr bus laceram, \& armis oppreffam, breui temporis curriculo contra cómunem onnium opinionem ad fummum dignitatis fux culmen inftinctu diuinitats, mentis magnitudine, ductúque tuo, conflio et auctoritate provexeris. Neque aliter illum iplum caltrenfem impetum atq̧ conatum tuú qui pręcefferat, contra hæc ipfa ecclefiaftica figna \& illuftrem Tarraconenfium regem Alphonfum Philippúmque Mariam, Infubrium, L y gurumóg ducem bellicofie fimü reor extitiffe, nifi quia maxima vi maximóg̨ difcrimine modefia tua illu ftranda erat, ac veluti cæli temperiem venti imbresq́p commédant, ita ad augendum tue dignitatis cumulum apud pontificem, a pud omne genus hominum, illum tunultum, hüc fpectatiffimum triüphum praceffiffe crediderim, vt quot in illo turpitudinis notas extingueres, tot in te triüphales coronæ refulgerent. Con uenientiffimum pręterea videbatur vt cui merito omnia debeo $\&$ imperio fub fum,ipfi meum, fi quid effet, præc cæteris dicaretur ingenium, fperans denique id fore morte obita, vt ad polteros aliquảdo non inglorius commigrem \& viuam: vbi fi immortalitatem illâ quam omnes expetunt,pauci verò affequuntur, vel ip fe non affequar, gaudebo tamen tuo augufto paternóque nomine, cui hoc de re militari opus infcripli confecraúque, me diuturnam lucem $\&$ fempiternã quan dam gloriam adepturum, qui fortaffe fine te, qui multis me ad fribendum rationibus impulifti, in tenebris abiectus iacuiffem. Sit itaque tuo tantú nomini di. catum,et quid de te mihi pollicear videas oblecro. Nũquã enim huiufce libri exordio nomen ipfum legetur tuum, quum paffim \& vbig gentium fublime magnificúmq prædicetur, quin mihi f́plendoris \& gratię plurimú fit allaturum. $\mathrm{Pu}$ tabunt etenim fnguli ad quos liber ifte puenerit, non parua nec inutilia fe percepturos, dü tam fplendidü,tam pręcellens, tä illultre ipfs primis apicibus nomë 
ROBERT. VALT. SIGISM VNDO.

tuum intuebuntur \& legent. Sufcipe igitur clementiffime ac optime princeps, SIGISMVNDE PAND V L P HE, gratiflimis vlnis munufculum hos, exiguum licet, ab animo tamen tibi deditifimo tuíg amantiff mo profectum, intentílog leges quum alpirare tibi inter plurima frepentium occupationum tuarum agmina licebit. Inuenies profecto plurima in hoc opere qux tibi fint aut voluptati maximę legiffe, aut ornamento vidiffe, aut vfui meminife: quippe qux preceptis \& exemplis fuis oblectare atque inftruere bene inftitutum animum poffint:de cuius caufis nil attinet plura nune diffe rere, quum quidem fingulæ partes eius deftinatis aliquot volu minibus explicandæe fint, quas ordine fuo túc demum pro fequar, quom prafatus fuero pauca quadam de ipfius rei origine $a b$ aliis pene omnibus omif fa fcriptoribus, quả reor ad vniuerlę eti am rei defcriptionem ab aliis quoque pluribus intactam maxime profuturam. Vale. 


\section{Dantis Tertii Aligeri,}

Qui modo Romuleam feruarat ab holtibus vrberis;

Et capitolini culmina cællfa Iouis,

Quíque ducem Calabrûm caftris fpoliarat \& armis,

In'́p omni foelix agmine victor erat;

Marmore dux Venetum iacet hoc, Malatefta Robertus,

Fecit adhuc tantum non Libitina nefas.

Cur fraudata rapis iuuenem fortuna, putabas

Nunquid,dum numeras parta trophæa, lenem?

Eiufdem,

Quifquis funefto validas fub Marte cohortes;

Et fequitur miffas per freta falfa rates,

llle Ragufeum tollat fuper aftra Boninum

Ingeniợ viri præmia digna ferat, Impreffit quoniam quonam modo bella gerantur,

Machina vel quatiat monia quxque folo.

\section{IER R A T A}
Pagina
Linea
25
3
94
35
和
13
Gra $\begin{array}{ll}\Sigma^{2} \mathrm{x} & 25 \\ \text { ibidem } & 23 \\ \text { ibidem } & 27\end{array}$
alioquin dux agminis femper. Tum tenuit experienti Aiax.
Legè
vt reliqux actionum
Sagmina,inquit, à te donec Craffranus hic \& 8 . capite quinto.
Haius loci occafione fubit mihi,bone lector, te orare vt cum in huiufmodi loca aliquot incides negligétiå nolträ ne incufes, qubus feftinâte prelo ac autóré fępe ta cête Valturio non libuit incóperta in formam mutare diuerfam ab exemplari. 282
215
259
289
correcta funt
43
40
i
in titulo
Vicarium tibi expedi
nuдím
vehicula duo tormëtaria Lib.X 
Nomina autorum prxcipua(nam omnia perfequi effet infinitum) à quibus qux xii Valturii de re militari libris continentur defumpta funt.

\begin{tabular}{|c|c|c|}
\hline Acron & Euclides & Nigidius \\
\hline Ambrofius & Eudoxus & Opppius \\
\hline Ammianus marcellinus & Euripides & Oribafrus \\
\hline Apollonius Tyaneus & Eufebius Cæratienfis & Orofius \\
\hline Apuleius & Eutropius & Pacuuius \\
\hline Ariftophanes & Fabius Quint. & Palladius \\
\hline Ariftoteles & Fauftinus & Pandect $x$ \\
\hline Afconius pædianus & Feneftella & Perfius \\
\hline Athanafius & Firmianus & Petronins Arbiter \\
\hline Augultinus & Flauius Vopifcus & Pherecides \\
\hline Auguftus Cæfar & Florus. & Pittacus \\
\hline Berofus & Frontinus & Pindarus \\
\hline Biblia facra & Galenus & Plato \\
\hline Boétius & Gellius & Plautus \\
\hline Cæfar & Germanicus cæ£ar & Plinius \\
\hline Cxcilius & Gratianus & Plinius nepos \\
\hline C. Caligula & Gregorius & Plutarchus \\
\hline Calfiodorus & Helius Lampridius & Polybius \\
\hline Cenforinus & Heraclytus & Prifcianus \\
\hline Cicero & Hefrodus & Propertius \\
\hline Claudianus & Hieronymus & Rabanus \\
\hline Clefbius Alexandrinus & Hyrcius & Salluftius \\
\hline Columella & Homerus & Seneca \\
\hline Cornelius Celfus & Horatius & Seruius \\
\hline Cornificius & Iofephus & Stephanus \\
\hline Curcius & Iphicrates & Suetonius \\
\hline Dares phrygius & Iulianus & Terentius \\
\hline Demonactes & Iultinus & Tertullianus \\
\hline Demolthenes & Iuuenalis & Theocritus \\
\hline Dion & Laërtius & Theophraftus \\
\hline Dionyfius & Liuius & Thucydides \\
\hline Diofcorides & Lucanus & Tibullus \\
\hline Donatus & Lucullus & Trogus \\
\hline Draco & Iycurgus & Valerius Maximu \\
\hline Druid $x$ & Macrobius & Varro \\
\hline Egefippus & Martialis & Vegetius \\
\hline Epicurus & Martianus Capell. & Victruuius \\
\hline Ennius & Mafurius Sabinus & Virgilius \\
\hline Epimenides & Menander & Vlpianus \\
\hline Euangelus & Neuius & Xenophon \\
\hline
\end{tabular}




\section{ROBERTI \\ VALT VRII}

AD MAGNANIMVM ETILLVSTREM Heroa Sigifmundum Pandulphum Malateftani fplen-

DIDISSIMVM ARIMINENSIVM REGEM ac imperdtorem femper inuictum, Rei Militaris Libri XII.

(

De prima er fecunda Rei Bellice origgne, apud quas nationes primubit orta or unde Res bellica dicta fit,

CAP

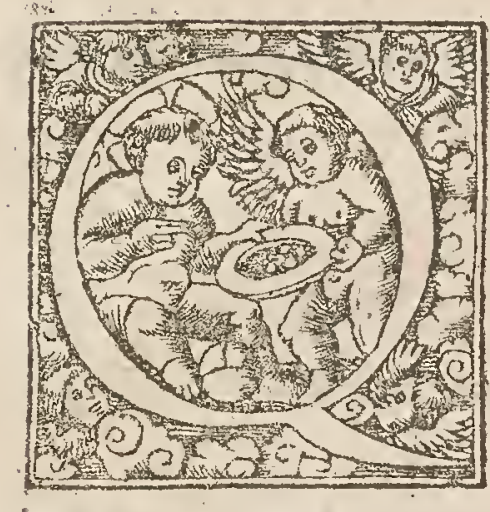

Vum inter omnes prifcx auctoritatis viros, qui Xenophonte ac Cicerone duce, clariore mentis ratione viguerunt, non du bium frt, per fe hominis vim imbecillam ac fragilem nimis, non fatis effe quo res omnes domi $\&$ foris fibi commodas ad vitam poffet amplecti,alteriúfoģ indigere, legitimam maris \& fima $\&$ maximè neceffaria vitx focietas iniretur, $\&$ quod alteri plerumqg deeffet, prafto fumeretur ex altero: tuni etiam, quum victus non vti primum pa$l_{2} m \&$ in propatulis campis, fed intra domefticos parietes accurandus erat, neceffe fuit alterum foris fub diuo effe qui labore $\&$ induftria compararet quę tectis includerentur, fruges, \& alimenta: quum verò partæ res intra limen effent congeftx, alium effe qui $\&$ congefta feruaret ad vfus vitz neceffarios. Iure igi tur \& natura comparata eft opera mulierís ad domefticá diligentiam, viri auté operam omnem \& curam ad exercitationem forenfem \& extraneam, ad inedi am \& vigilias, eftus \& algores, tum etiam itinera $8<$ labores pacis $\&$ Belli, cx-

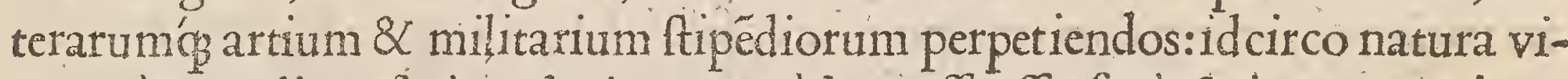
ros quàm mulieres fecit audaciores, quòd neceffe effet foris \& in aperto vitam tuentibus nonnunquàm naanu $\&$ viribus iniuriàn propulfare. Huiufmodi aút homines, aliis belli propulfatores $\&$ arma tenentes, aliis cuftodes, aliisóg milites notiori vocabulo libuit appellare: quo fit vt hæc militaris res ad commoda vi tæ confequenda, fecundum naturam apud coetus iure fociatos confiliág homi num, quæ nofftri homines ciuitatem a ppellant, honeftiffimis orta \& procreata principiis, ad falutế vutilitatêmq hominibus tradita \& conceffa videatur. Eius rei originem, prifca illa $\&$ abfoleta à memoriáque hominum multum remota mecum ipfe reputans, cur ad vrbium conditores feu rei ciuilis rectores teferatur non fatis intelligo. Antıquiffima enim rei huius bellica initia fuifle conperio, longéog ante vrbes legéf́g códitas, ante æris ferríģ vfum adinuenta: fiue ad louem illu magnum quem in coelo comitatum exercitu deorum pariter \& dæmonum Plato defcribit, procurantes prafectos \& prafides habentem, radi ces agentia: fiue ad prifcos vfog illos homines inertes \& ex terra genitos vt poëta meminit.

Terrea progenies duris caput extulit aruis:

fue corruptione aliqua, alioue quouis modo abfg parentibus natos $\&$ referuatos, ieris multarúmq rerum ignaros, quum nullum tunc neq naturale neq ciA vile ius 
uile ius defcriptum, nulla initia fapientia, nullæ diffenfiones nec inimicitix,neque bella oborta forent. Nam

Nondum vefanos rabies nudauerat enfes, vt Germanicus. Cafar in Arateo carmine loquitur,

Nec confanguinèis fuerat difcordia nota:

immo nec alienigenis quidē, quum nulli omnino gladii qui tunc ftringerêtur effent, quum poena ex cupiảitate, amentia, nequitia, improbitate aucta, per fce lus, prædas, direptiones, fanguinem $\&$ crudelitatem perfecta Bellica res à beluis vel quòd beluarum more propter alimonian $\&$ fpecus qux tunc pro domibus illis erant, vnguibus \& dentibus pugnarent : vel quód beluarum fit pernitiofa diffenfio, dicta \& appellata non infcitè videbatur Horatio,

Quum prorepferunt primis animalia terris,

Mutum \& turpe pecus glandem ato cubilia propter

$\checkmark$ nguibus \& pugnis dehinc fuftibus, atọita porrò

Pugnabant armis qux mox fabricauerat vfus:

nufi rem hanc ab initio fecundum naturam profectam túncque rudem ac penć fortuitam ad difciplinâ peritię́g ftudia primi reuocaffent, quales Affyrii quos primos bella fini.imis intuliffe conftat, quanğ non horrida multum nec difficilia, quod rudes adhuc ad refiftendum gentes effent, nec etiam multæ nec ma gnx, quú poft Noẻ diluuium anni non multo amplius quàm mille fluxiffent, vbi Ninus rex Beli filius, fupra quem nihil praclarú in libris relatum inuenio, Veforem illum Aegyptium \& Scythix regem Taneum rèmotis bella populis inferentes', nec imperium fibi, fed populis fuis gloriam quærentes victoria fola contentos femper excipio, omnes quæà Syriz finibus adufop vltima Lybie gé tes nationéfog lubegit, quo tempore inter fefe infidiari coepere \& gloriam ex hu mano fibi fanguine comparare: Siue quales $A$ bantes, qui propè pugnandi ac prater cæteros manus cum hoftibus conferendi folum peritiam habuere. Nam vt Antilochus refert,

Hac crebros tendunt arcus, nee verbera funda

Expediunt; fæuáfö ferox Mars æquore cædes

Infert, fed rigido geritur res comminus enfe:

Hac illi apprime pugna certare periti,

Euboioe genus acre virûm Bellóo fuperbum:

Siue quales Cretenfes, quorú patria prima remis \& fagittis inclảruit: Siue quales acérrimi omnium bellatorum Chalibes, per quos erutum $\&$ domitú eft primitus ferrum. vel ve. Hefrodo quog placet, in Creta eos qui vocati funt $\mathrm{Dactyli}$ Idei: A phris \& Theffalis hanc alii partim gloriam dabunt, quòd ex his primitus pugnam ex equis Centauri fecundum Pelion montem incolentes docu erint inire, lafciuáf ptios prælium fuftibus, quos phalangas vocant, feciffe memorentur: Erunt $\&$ qui contra hos pugnent veluti Daci; Medi fiue Thraces, quos bellicofos adeo fuiffe femper non dubium eft, vt ipfum Martem apud ipfos fabulæ natum effe confirment. Galli verò fuo quodam iure ab his quos modo diximuis hanc pal 
nam repetent, fuámg omnino effe contendent, quum fe Druidum feritentia omnes à Dite patre cui terrena vis omnis atọn natura dedicata eft, pugnæ natos pradicent, liberóf $q_{3}$ fuos nifi quum adoleuerint vt munus militia fuftinere pof fint, palam ad fe adire non patiantur. A thenienfibus hane tribuent alii, quoniam eorum ciuitas qua nihil habuit Gracia clarius, nihil antiquius, à Miner

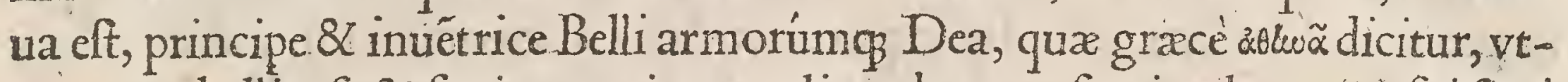
pote qux bellicofa \& fapiens regionem eligendam cenfuerit talem, qux fui fimi les viros editura effet. Permulti deniog Spartiatis cócedent, quorum difciplina quid quantúmue bellicis actionibus conduxerit vt teliquos miffos faciam, $\mathrm{Ma}$ harbalis prættantiflimi ducis \& Xanthippi declaretur exemplis. Huius enin mercenarii militis fiue ducis opera $\&$ arte, triginta milia Romanorü cæla funt, Regulo corum duce, cum quingentorum equitum numero in vincula coniecto: illo Lacedæmonio quoq Hannibal fecundo punico bello poftquàm alpibus patefactis in Italiã traiecie, vfus ductore \& accincto \& acri \& expedito fem-

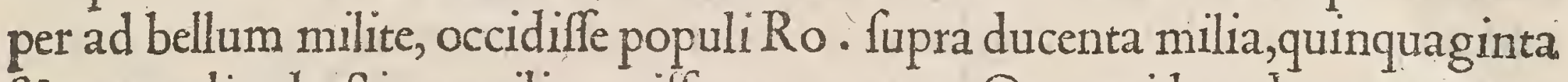
\& eo amplius hoftium milia cepiffe memoratur. Quo quidem duce, vt cætera. filean, illa maxima Cannenfi mirabilitéró horrenda clade de Romanis procul dubio eflet actum, nifi mora peruadenda vrbis obftitiflet, ipfáṕn militia tanta rerum agitatione lógo poltliminio $a b$ interitu penè reuocata fuiffet in lucem, quę deniqg omni ftudio exculta, non principatuum omnium que circa fe effent Sabinorum, Hetrufcorum, Latinorum, Hernicorum, Volfcorum \& Auruncorum, totius' $\$$ I talix populorum folin Romanis peperit, verùm omnium fe rè remotiffimarú gentium ac nationú terrarú orbis reges ac dominos fecit.

\section{Quid res Militaris, or in qutot partes diftributa fecundum Iphicratis traditionem, or quod trí bus rebus, ut reliquad actionum, ndtura, doctrind or exercitatione confumitur; quodq́; plurimis liberalium artium ftudijs inberendum fit ei, qui fe cum gloria cateris imperaturum profiteattur.}

\section{CAP. II.}

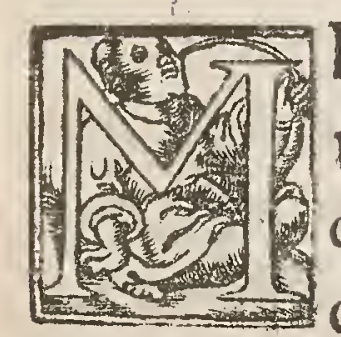

IL IT A R I S res, eft ciuilis quædam pars facultáfqg honoratiffi$\mathrm{ma}$, ad reliquas ciuilis potentix partes tuendo continendas, fecundum naturam maximè neceffaria, legitiméçad hoc ipfum variis diuerforum temporum exêplis electione ac facramento adacta. Hęc vt Iphicrates tradit, in Pedıtes, Equites, Phalägèm, Dúcémọ̣ diftributa eft. Ma nibus pedites frmiles funt, pedibus verò equites, ipfa phalanx thoraci $\&$ pectori,capiti autem imperator: qui vt Ariftoteli placet,mentis atq animi inftar eft. Rurfus tribus hæc rebus, natura, doctrina \& exercitatione confumitur. Natu rx namg principiis fortes creantur ex fortibus $\&$ bon is, eftóg in iuluencis, eft in Equis patrum virtus, nec imbellem progenerant aquilæ columbam,vt Flac cus inquit . Maxima quog huic rei adiumenta conferre doctrinam \& infitutionem quis dubitat? quum in praliis quondam omnibus artibus ftudiorum liberalium excultis, veluti feminario ducú prafectorúmqü,pręcipuus honos haberetur : quumóg ad militian euntibus apud maiores noftros dari foliti fint A ii cufto 
cuftodesatọ magiftri quibus primo anno erudirentur, quod nec poétam maximum præterit de Pallante canentem atqु dicentem,

Sub te tolerare magiftro

Militian graue Martis opus.

Porrò confuetudinis \& exercitationis ea vis eft vt dimicätium animus femper fit pronus ad cæedem ardénf $\not \beta$ in praliis, ad quæ fi inconfuetum militem duxe ris,non fecus ac mulierem videris: \& quanquám Tyronum ætas Veteranorum potior effe foleat, veterani tamen ex confuetudine cæteris audendi exemplum præ fe ferent, quum videamus ex militum turba fapenumerò faucios efferri: 8 quidem Tyroné illum \& à confuetudine pugnæ alienum, leui qnanğ ictu vulneris fulpicione pallentem effominatiffimúmg eiulatum edentem:veteranum verò præliis affuetum, vulneribus innutritum, ac poft fanguinem fape etiam victoria potitum, quum nonnunquam grauiter impellatur,feriatur, deiiciatur, alacrem iterum ad cædem exurgere, chirurgum \& vnguenta fpernentem. Quū itaç ad perfectam huius rei actionem hæc tria infint, vt antè diximus, natura, doctrina \& exercitatio, neceffe eft vndecunos expolitum effe debere, qui fe preftantem cæteris profiteatur: quocirca huius rei ducem, ingeniofum $\&$ ad difciplinas fingulas maiorump inftituta capeffenda docilem atop verfilem effe oportet: haud enim ingenii vis abfog difciplina \& rerum plurimarum maxima rúmø exercitatione, aut difciplina, ingen o \& exercitatione deftituta, confum matum ducem potelt effingere: quòd fi qui aliter forfan putent, falluntur maximè, \& in fummo omnium errore verfantur: químg nulla fit ars, nulla difci plina tam fuis abfoluta partibus vt non quoqg cæterarum adiumêta defideret, $v t$ in bellicæ huius rei quota maxime parte verfatur inftrumentis, quum alter fpicula telis \& fagittis exacuat, alii baliftarum forpionumg fymmetriis \& téperaturis infiftant, cælatis alii frænis,cæeterifop id genus qux ad hominú equorúmģ fructuram pertinent occupentur, non alienum cenleri debet fi huic militari difciplinæe plurima liberalium \& optimarú artium ornamenta conftituta quibus inhærendú putem. Sit itaģ in primis literatus dux \& faluberrima philofophia præcepta æmuletur, hiftorias multiplices memoriter complectatur: oratoriæ poéticæó facultatis non fit ignarus : Muficx, Arithmeticæ, Geometrix, aftrorum coelíq rationes pro facultate cognitas habeat: iuris ac legum di uerfarum gentium varietatem calleat, medend $i$ cognitionem haud afpernetur, gymnafticæ \& militari exercitationi ac otio belliciśó, poftremo rebusaliis ad laureas \& triumphos tanquàm maximè neceffariis totus incumbat : quæ cur ita fint, feorfum hx fint caufx.

De literis hif̧; qui maximè earum fuddis incubuere, plurima mentoratu digna,

CAP. III

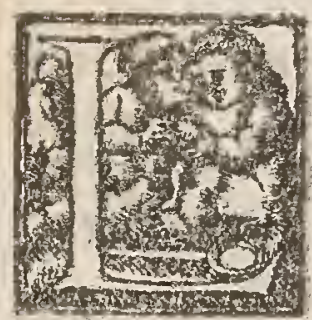

I ER A T V M ducem effe oportet in primis \& eruditum, vt diximus. Sunt enim literæ ad excoledam vitam \& ad comparandam gloriam fempiternâmø rerum geftarum memoriam propagádam adiumétum ei maximum roburóq validiffimum.Literaturam auté intelligo, non vulgarem, non craffam, $\&$ barbaram iftam qua vtútur quı núc in caftris verfantur duces, fed preclaram $\&$ accuratam illam cum rerú multa- 
rum fcientia coniunctam. $\Lambda^{\dagger}$ am neg pracepta illorum, qui fripferunt, nec eorum exempla de quibus fcribitur fatis intelliget qui non ifta fuerit eruditione perpolitus: A d quam comparandam, quum diligentia noftra maximè opus fic $\&$ cura, quum incidant tempora nonnunquàm $\&$ horæ quibus ab huiulmodi rebus bellicis vacare neceffe fit, quum non femper gerantur bella, \& finguli di es ac noctes aliquid habeant intercapedinis, quo domi contineri $\&$ cum veteribus tuis a micis, id eft, libris effe feorfum posfis, ante omnia tinctum effe oportet ingenium \& quafi initiatum præceptoris optimi opera. Quod confiderans Philippus,Macedonum Rex fapientisfimus, A lexandrum filium præceteris li terarum inductoribus quibus eius curam demandauerat, A riftoteli fummo id. remporis philofopho tradidit literis imbuendum, quo illam, quam modo dixi literaturæ \& eruditionis excellentiam adipilceretur: quod nec rex ille prudentiffimus feciffet, nifi forte $a b$ Alexandro fratre Thebanis obfes datus triennio apud Epaminundam, Itrenuifinum imperatorem et fummum philofophum eruditus effet, nec tantus philofophus hoc fibi munus fufcepiffet fí nö honeftiffimaru artiu femina ab optimo tractari preceptore debuiffent: in qua re extac illius adhuc epiftola ad Ariftotelé, de Alexandro filio in hunc modú fcripta.

Filium mihi genirum fcito, quo equidé diis gratias habeo,non tam pindè. quia natus eft, đ̊ pro eo quòd eú nafci contigit têporibus vitæ tux. Spero enim fore vt educatus eruditusóg à te, dignus exiftat et nobis et harü reıü fufceptione. $O$ fapientisfimam et tanto principe dignam vocem, qui ita demum eum putauit dignum fore fufceptione regni, $\propto$ tantarum rerum adminiftratione, fi $l i$ teris \& difciplinis erudiretur, atop planè ita fuit : fuapte enin natura primum conuerfatione, deinde doctrina,\& præceptis tanti philofophi ornatus Rex ita egit,vt ipfe Deo genitus Deóop frmillimus crederetur. A riftotele enim primum exacta pueritia per quinquennium, et porro Callithene vfus rhetoribus, orbem terrarum aggreflus, innumeras hoftium copias ac gentes expugnauit, 8 totum penè orbem fuis victoriis illuftrauit: cunóp ea tempeftate armis exercitam com munem prope Afram teneret,potentisfimúmg \& Perfarum \& Medorum regë Darium præliis \& victoriis vrgeret, quáti literas \& ip fe rex feciffe, quantúm ornamenti illis pofuiffe vifus eft, ex his liquet infpicere: in illis enim tátis negotiis literas ad Ariftotelem mifrt, quibus in hunc modum queftus eft,

Haud abs te rectè factú eft, $q$ f peculatiuas edidifti difciplinas: qua eim re crete ris iả nos ipfi p̧cellemus, fi ea quis eruditi fumus ftudia oibus coeperí effe coïa? Quippè ego doctrina anteire malim, q̈ copiis atog opulentiis. Cupidı ea fortaf fè vox \& inuidi hominis ad vtilitate fuã omnia reuocãtis, fed ex hoc facilior eft cöiectura quantú literis tribuerit, quippè qui cú cæteris rebus concertatores inefle fibi non egrè ferret, in his ne æmulü quidé vellet habere. Quæanimi excolendi cura, quod ftudium Antigono, praclaro ctiâ Macedonū regi fuerit, facile percipi poteft ex Perfeo, Philonidég eius preceptoribus,atọ ex his, vtrefere A pollonius Tyrius, que de Zenone ad eum in hunc modum confcripta funt,

Antogonus rex Zenoni philofopho falutem. Ego fortuna me quidem \& gloria vitam tuam anteire exiftimo, caterum difciphnis ftudiisq́ liberalibus 
\& perfeeta foelicitate quam tute poffides, longê abs te pracelli fentio Quocir ca te orare ftatui vti ad me proficifcaris, id mihi perfuadens, te preces meas mi nimè irritas fieri paffurum. Tu igitur modis omnibus enitere vt tuo contuber nio fruamur, hoc pro certo habens, te non mei tantu m fed omnium fimul Ma cedonü eruditorem fore. Nam qui Macedonia regem erudit atọ ad virtutem imbuit, eum \& fúbditos quofọ inftruere ad fortitudinem $\&$ probitaten certú eft: nam cuiufmodi fuerit dux, tales vt plurimum fubditos fieri necefle eft: nec ab re,aliámqg ob caufam, fi principi literarú Homero credimus, Peleum regem Achilli filio Phœnicem prefeciffe ferunt, quàm vt attritus non folum dicendi, fed gerendi quog $v$ fu, pariter inclareret clariorgs euaderet. Quid ille Themifto cles, quem ego Grail fanguinis virorum clariflimum $\&$ vnum ex omnibus totius Græciæ callidiffimum \& prudentiffimú imperatorem aufim dicere? Nóne in difciplinis percipiedis præceptores habuit \& eos quanquàm Anaxagoram \& Meliffum philolophum Emniftes Imbrotus affirmet,tamen temporum rati one diligenter infpecta qua illum erraffe conftat, Mnefiphilo affentiendum ma gis videtur, quippe qui eum $\mathrm{P}$ hearei difcipulum fuiffe affeueret,ad eam folum eruditionem quam bellicx rei facultatem dicimus capeffendam, quanquàm na turæ bonitate fidens prius ipfe contemplerat? Dionem Syracufanum omni di fciplinarum genere erudiuit Plato, cuius quăto deinde ftudio Dyonifius iunior ad fe flagitarit aduentum, quantiog eum fecerit, vtpote qui illo tempore plus cx teris amauerit Archita Pythagorei fcripta, ad eum demonftrat epifola. Valuit etiam a pud veteres diu eiufdem Platonis fententia, qui tum deniç res publicas cenfuit fore beatas, fi aut philofophi regnarent, aut reges philofopharen tur. Nec Ifocrates aliis artibus Timotheum Cononis praftantiffimi imperatoris filium, fummum ipfum imperatorem, hominémg doctiffimum inftruxit. Quid ipfius Epaminunde fummi philofophi fum míg ducis eruditio, quam in co pracipuan fuiffe accepimus? nonne ea quoog in Lyfram Pythagoreum refertur? Archelaum prudentem rei bellicæ naualiûmq commentorem preliorú, adeò lirerarum ftudiis inhęrentem nouimus, vt Euripidi Tragico confiliorum fummam crederèt omnem, cuius fuprema haud profequi contétus rex \& fumptu \& impenfa funeris, fecta barba \& attófo crine mocrorem quem animo ingentem conceperat vultu publicauit. Pyrrhum quợ Epirotarum regem ma ximum bello, non folum lectitaffe libros cum effet rex, verumetiam multa literis demandaffe rei militaris præcepta nouimús. Ponorum dux inclytus $\mathrm{Han}$ nibal, vir tantus tantisóp confractus bellis, nonnihil temporis etiam literis tribuiffe dicitur cum effet in caftris : quippe qui prater Sylenum Sofylao Lacedemonio literarum gracarum vfus eft doctore. Tradunt $8 \mathrm{Mu}$ Mas virgines cum Libero patre profectas in caftra, hifộ cū bonis artibus apprimè eruditæe effent dux ille oblectabatur : fecutus eft eum Sylenus quoque pædagogus ac nutritor optimarumóg inftitutor ftudiorum, qui ei plurimum ob virtutéac gloriã res@ bellicas contulit ornamenti . Nec admiraberis Mithridatem Ponti regem, clarifimúńg ducem annos duos \& feptuaginta natum fecú philofophos omnes immenfe fublimitatis femper habentem, omniúmque ante fe genitorum 


\section{DE RE MILITARI LIB. I.}

ftudia literarú qquantem facile vel fuperantem. Latini verò duces vel Romano. rum proceres et $\bar{i}$ non fint eruditione exteris forfan pares, omnes tamen fere do cti 8 literis clari euafere. Nam Cato primus Porcix gentis animi vigore praftantiffimus, literis etiam expoliri preftantiffimum cenfuit, quàm ferò, inde exiftimari poteft, $q$ latinis iam pridem, ab Q. Ennio verò iam fenex $\&$ in Sardinia Prator græcis literis eruditus eft, adeóóg vt probabilis prifca illa eloquén tia, non folum orator $\&$ hiftoricus, fed iuris confultiffimus, literarimģ omniü cupidıffimus fuerit, quarũ $\&$ fi fenior(vt ante diximus)ftudium arripuit, tant ũ tamen in eo progreflus eft vt non facile reperiri queat, neqg gracarum neq lati narum rerum quidpiam, quod ei fuerit incognitum: Huius quogg fucceffor ac propior atati noftræa alius Cato, in literis difciplinisóp percipiendis tardior licet effet, Saperdone tamen pædagogo primú \& Antipatro philofopho ac Tyrio excultus, deinde tam inexhaufta legendi auiditate ferebatur, vt veluti librorú helluo maximè Stoicorum nedum inter domefticos $\&$ priuatos parietes, fed ne in curia quidem contra inanem vulgi opinionem quum Senatus cogeretur fe.dens fefe contineret quominus obuoluta circùm toga cos lectitaret ad animi cultum, quafi quendam humanitatis cibum, nihil ftudio rei publicæ adimens: \& Scipionem A phricanú fuperiorem à re militari atç vrbana ftudium ad lite ras reuocantem legimus, \& quanquàm ingenii eius monumenta nulla extent, nulla literis mandata inueniantur, non tamen fine literis $P$ ierii ${ }^{\prime}{ }_{3}$ artibus arma exercuiffe fcimus: femper enim eius,vt poëta Claudianus meminit, Hærebat doctus lateri, caftrisóg folebat

Omnibus in medias Ennius ire tubas, quím que foclicibus aufpiciis victor rediens fubacta Carthagine triumpharet, ficut fuum bellica, ita Ennii caput Martia voluit laurea infigniri: \& quod ma ius nirabiliusóg fatebere, ipfus poétæe ftatuam \& effigiem in monumêtis \& fepulchris Corneliæ gentis collocari,clarumóq illud nomen, imò verò fpolium ex. tertia orbis parte raptum in itinere cum poêtæ titulo legi,ratus rerum fuarum memoriañ extingui non poffe, fi literarum illius diuini poétæl lumen accederet. Paulus Aemilius deuicto Perfe, Romana difeiplina qua ipfe doctus erat,ve filii etiam imbuerentur fummopere curauit:quúmģ ob rem ipfam petiiffet $a b$ Athenienfibus vti fibi quàm probatiffimum philofophum mitterent ad erudi endos liberos, victorem item ad triumphum exequendum, Athenienfes Metrodorum elegerunt, profeffi eundem in vtrog, defiderio preftantiffimum, $q d^{s}$ ita Paulus quogi iudicauit: néq hoc contentus Paulus, quum quid ocii ex publicis muneribus fupereffet,eorum eruditioni intererat,miro erga filiorum eru ditionem amore fuccenfus . Nullum à fudiis literarum diem intermifffe Iuliü Cæfarễ traditur, quem poëtarun collegiun communium ftudiorum caufa cü per ocium liceret ingredientem; $\&$ in maxima difficultate itinerum, $\&$ in mediis bellorum aftibus fcribentem libros \& legentem, fimul'́g dictantem \& audientem frequenter accepimus. Diuus Cæefar Auguftus, Diui Iulii filius, tanto paternis vertigiis Atudio inh æafffe traditur, vt grauiflimis bellorum $\&$ impe rii curis oppreffus, \& coniuratorum obfeffus infidiis, horas $\&$ momenta colli- 
gerer, nec vllum tempus inutiliter labi fineret, Apollodoro Pergameo dicendi magiftro vfus:nec eo contentus, ad diuerfa literarum fudia ineunda, prater Sperareum philofophum \& Afnium Pollionem, Valerium Meffalam, Pariuńq geminum clarisfimos dicendi artifices, Virgilium Maronem \& plærof $\$$ alios illius temporis pötas habuit fecum, non tam imperio qu dulci conuictu \& morum conitate à fodalitio in omnivita comites, Horatium Flaccun in primis, vt ad Iulium Florum de fe taliter foribentem legimuss

Ciuilisóg rudem belli tulit æetus in arma

Cáfaris Augufti non refponfura lacertis.

Vnde fimul primum me dimifere Philippi,

Decifis humilem pennis inopenióp paterni

Et laris \& fundi paupertas impulit audax

$V t$ verfus facerem.

Ouidium nec minus deinde, qui hæe ait,

Illa dies libycis qua victor Celar in oris

Perfida magnanini contudit arma luba,

Dux mihi Cælar erat fub quo meruifle tribunus

Glorior,officio prafuit ille meo.

Hanc ego militia fedem, tu pace parafti

Inter bifquinos vfus honore viros.

Quanquàm hunc fuo indignum contubernio tandem vindicás, in Scythiam vbi diem obiit relegauit, cuius relegationis alperitaté diuturnitatém $\$$ his verbis fuis queftus eft;

In Scythia nobis quinquénis ol ympias acta eft,

lam tempus luftii tranfit $\&$ alterius.

Perftat enim fortuna tenax votisóp malignum

Oppofuit noftris inuidiofa pedem.

Ix his autem vtriufque linguæ auctoribus, quos fudiofius Auguftus lectitabat,illa cupidus hauriebat,qua vel præcepto vel exemplo ad eruditionem vite morumģ elegantiam pertinerent priuatæ vel publicæ difciplinæ. Hæc \& memoriter annotata tenens, quum res exigeret, vel amicos,vel notos exercitus, vel prouinciales aut vrbanos magiftratus, tali annotatione ad verbum excerpta commonefacere folebat, vt ea nó fibi primú fed antiquis iam tunc curæ fuiffe perfuaderet: id deniqg ex talium auctorú eruditorumóg hominum ingeniis vno tempore confluentibus affecutus, vt non minus his quàm omnibus Romanis legionibus illuftratus fit. Nam quid tantum fibi conferre potuerunt quin $\$$ \& triginta illæ tribus Romani populi, vel tot bellicofifime legiones, quantum vel Maro fol us heroico, vel Flaccus tier oico fimul \& lyrico darmine contulit ad nominis fui diuturnitate? Interière illa quidé cum duce fuo, cæterum tantotum poétarum præconio eius res cläriflimæ geftæ nunquàm defuturæ fuperfunt. Fuit in Lucullo mirabilis quædam ingenii præcellentia, maxima literarú rotiusóp veteris Academicæ philofophiæ cognitio ac elegans dicẻdi copia,qui \& Afcolonitam Antiochum acutisfimú doctisfimüǵg dicendi artificé amicum. 
fibi fociümq vitze fecerit. Simili quoqgardore P. Craffus in caftrenfi expeditione quum in Afiam ad Ariftonicum regem debellädum conful traieciffet, tantus pręter latinam graiz lingux ardor infediffe perhibetur, vteam in plurima diuifam genera per fingulas partes eius ac numeros penitus cognolceret, quae res maximum ei omnium amorem conciliauit. Nec Syllam illum beatum atg folicem, nec Pompeium quidé magnum imp. nec $Q$. Fabium,nec M.Brutum,nec Traianum,nec Adrianun, nec Maximum,nec M.deniq Antonium Aurelium qui ob literarum fapientix́́ ftudium \& ardorem philofophus di. ctus eft, ab hac egregia literarum cognitione alienos fuiffe comperio, quum \& orationes $\&$ epiftolas $\&$ libros fcripfiffe memorix proditum fit. In maximam quog $\&$ ampliffimam tui nominis laudem cedit, magnanime princeps Sigifmunde, nultum lectitare, multum audire, difputare, patientérq refelli: quumq plurima fcias \& omnia bonarú artium femina calitus tibi conceffa communis omnium eruditorum teneat opinio, quotidie tamen aliquid difcere nonnullis horis liberis, fapientumg colloquiis infiftere in conuiuiis publicis \& priuatis, grauiflimis ac profundiffimis rerum naturaliú quxftionibus $\&$ rationibus oblestari,ingeniis illuftribus oratorum \& poetarum tui temporis fauere, copiis $\&$ honoribus illuftrare, facras ædes inftaurare, bibliothecáf̣ nonas maximis impenfis tuis illis erigere: data mihi ac plerifo aliis librorum perquirendorum facultate, nó xtati tux folum, verum pofteritati profutura: quo quid melius, quid fummo duce ac principe ad immortalitate dignius effe queat, nec fcio nec fatis intelligo : maximè quum ea tria hac in iuueuili ærate tua adeptus videare, quæ multris fenio denegata funt,vel gerédo fcilicet aliquid magnum $\&$ illuftre quod de te fribant auetores idonei, quod plerique tam poëtx, $\ddot{q}$ oratores $\&$ hiftorici faciunt:vel fcribendo aliquid, quod legant pofteri, qualia funt plurima materna humanarum diuinarumó̧ rerú carmina elegantiflimè per te edita,\& multis iam oris ac variis regionibus decantata: vel infigne aliquod opus extruendo erigédóg̣, veluti arx nobilis fiue maius caftellum tui nominis, co aftu militari $\&$ arte bellica pracellens vt eius pulchritudo, fitus atq difpofitio non ciuium modo fed omnium oculos intuétium in femet haud immerito alliciat atç perftringat: campi enim planicies vndiqg eft perfpicua,loci fpecies monibus paribus. Primó verfus vrbé a mbitu hemicycli formam habens, promuralis eius vix credibilis relatu profunditas qux pyramidum inftar procliuis à fundamentis erigitur, a mpliffima latitudine ad fummitaté altitudine pedum quinquaginta, feneltris centü fexaginta fupra terram,totidemóp infia ex ordine per interualla quxdam dimiffis, vbi baliftr lapidum ac fagittarum ad propulfandos holtiles impetus ac omnem inteftinam feditionem, fi quando cótingerent collocentur. Faftigii autem fpatium craflitudóg tanta, vt plures occurrentes fefe minime impediant, foffa prima interior quam perennis fontis aqua interluit, centum pedum latitudine, quing \& triginta éóp amplius altitudine. Totius molis ambitus qui coctili laterculo \& perpolito eft lapide trecentos quinquaginta paffus per vniuerfum complectitur fpatium: ex altera parte \& poltrema quae vergit in quadrum, pomerium \& murus communis vrbis elt duplici ponte ac turris latitudine 
titudine fupra quàn cuiquam credibile fit, ad eius tutelam cum magnis propu gnaculis \& crate ferrea, area interius amplifsima \& puteo vtring mirabili habitationũ ferie fuóç cuftode diftincta, à fronte vrbê ipfam profpicit, primóç in veftibulo vallum cuftodibus munitum porta perexigua, dua bus deinde latifimis fupra foffam turribus, parum de induftria editis, viridi prima puniceo colore, altera ligneo ponte gemino verfatili ac penfili: hoc tranfgreffo, fpatiü $\&$ area quedam mole totam ambiés inelt qua terra ad primi muri firmitate ege fta oppletur. Alterius deide muri altitudo I v,latitudo verò viginti pedú eminét Ipatio: Turres fex octoginta pedúaltitudine, à fúdamétis latifsimis ad fưmmü penè faftigiü terra opplete, vndeuiginti vlnis $\tilde{q}$ murus ifte altiores fưnt. In fum. mo auté cófummationép cuiuflibet turris pedü latitudo dece $\&$ quinq, vbi ab omniũ turrium latere habitacula defenforum, octo feneftris ad baliftas fimili modo lapidú fagittarṹq fexdecim æque difpofita funt . Huius autem muri me diü à dextris occupat la pis quadrato marmore ornatifsimus, qui vt carmëliteris aureis incifum indicat, Sigifmundum Pandulphum totius molis auctorem celebrat: porta deide præluftris ad læuam paulo ingredientibus cernitur, marmo re calato ac preclaro artificio ad vnguem expolita, $\&$ in cuius fümo elephätus ex alabaitrite indico, antiquiffimú Malateftarú infigne auro plurimo \& aucto ris fui Sigifnundi $\mathrm{P}$ andulphi nomine maiufculis quibufda literis præfulgens circúfeptus eft. Media autem loci totius intercaped ine murus quidã medius ar cem geminófap eius cuftodes, area etiam fuas puteo $\&$ fabrili domodifcriminat, penes qué fublimis regia tua eft non æque quadrilatera baf̊ à fúdamentis q̈latifsima, triplici portarú obice cataractis imminétibus, minis ac propugnaculis minitantibus, fiuo cuftode, multiplici habitatione, puteo profundiffimo ornatif fima, ad afcendendum cochlea, armamentario onini telorum $\&$ tormentorum genere referto minaci proceritate mirabilis, vtpote quæaltıfimorum cacumina mótium fuperet ac maris æquora late prof́piciat, Præterire'deniq nequeo quod ab initio inftitueram, quum fit non Ariminex tantum vrbis $\&$ arcis firmiffima falus \& tutela, fed Italicæ magnificentiæ vera admiratio, tota nanque moles penfilis quum fit plurimos aditus atque receffus habens, \& à quibus armati exercitus vrbem verfus, per abditos fpecus educi poffunt, nullo incolentium ciuium percipiente, quóque ab omni externa oppugnatione inteltináque iniuria effe queat immunis, altera aqua extrinfecus latè patens inftar fimiliter amnis irrigua circumfluit foffa, magnæ mentis \& præcellentis ingenii opus fanê : vtrinque enim per ambitum latifsimis eft firmifsima muris cum propugnaculis $\&$ aggeribus : denfifsimis deinde turribus à fundamentis erecta, anguftífque vt fuprà munita feneltris, aqua ac terra tenus cum defenforum habitaculis, paruis machinis ac fagittariis æquè difpofitis, tanta firmitate tam mirifica vtriu que foffr intertitii, habitationum difpofitione ad peditatum omnem equitatumque continendum vt diffoluere eans. nec crebri arietum impulfus queant, nec metallicæ vis vlla machinæ poffit diruere, incertúmque munimentum loci huius ne totius, an pulchritudo plus admirationis apud homines fit habitura. Taceo facras celebréfque Deo di. 
dicatas ędes, prætereo fortunæ fanum, fcenam gallicam, cateráfop per te inftauratas vrbes,erecta oppida, conftructas arces, fexcentág id genus nomé tuum literis oftedentia, qua vna in re fi te ceteris huiufce atatis principibus cóferamus \& regibus, omni genere laudis excellere iure ipfo pradicaberis: maximè quum hæc quidem alus latiflimis defixa radicibus innitatur, \& folida adeò ftabiliśṕp fit \& infinita fecula duratura vt nec vetuftate corrüpi pofsit nec ex memoria ho minú obliuione deleri. Quảm laudabilis igitur et imitatione digna tui $\&$ horü quos modo diximus principú vit̨ inftitutio, 9 prima vitę tépora \& media pa triæ, ex trema verò fibi imperent vt ipfe leges monét quę maioré annis ocio red dunt, $q$ Licini Domitianiog Cafarıs \& aliorum quorundam improbanda deteftandáq,quos fortuna opibus, loco, imaginum domefticarum fplendore ac di gnitate cęteris pręfecit,econtra verò ipfr vitio fuo, libidine, ignauia,turpiç ocio inquinati excidere? Ille enim literas vomicam, virus ac peftem publicam appellare folitus erat: Alterum quum facietas hominum aut honefti cuiufpiam negotii aliquâdo odium occepiffet velletọ́ illam expuere curam \& folicitudiné ex animo, \& voluptate aliqua refici,incomitatum fe intra regios parietes fingu lis diebus recipietem claufis foribus nihil aliud amplius quàm mufcas càptan tem acutifsimọ́p ftilo præfigentem accepimus. Sed origo illum ruftica forfan excufat:etfi enim ad cæareum vfog nomen afcenderit, naturam tamen fubrufticam $\&$ agreftem haudqua q̃ exuerat. Verum enim eft illud Flacci, Fortuna non mutat genus. Huius vero tam foed o fudio, tam abominandæ occupationi \& fui principatus initis quibus is delectabatur aucupiis venia fortaffe dan da effet, modo temporis reliquum claris actionibus confumpfiffet, nec exofum ex tetris facinoribus maiore odio $\mathrm{q}$ ex hoc ridiculo negotio nominandum fe pofteris praftitifet: Quid plura? Nullum denique Romanum ferè imperatorë qui ceteris omnibus exemplo fit, prater Cn. Marium vnum, fiue M. Marcellum huius egregia literaturæ expertes fuiffe comperies, quíq literarum fudia falrem prater hunc vnum quem paulò ante diximus Licinum non probarint, nó admirati ac fummo quodam ftudio profecuti fint. Obftrepant vt libet $\&$ irrideant alii, noftri temporis duces, noltríg reges \& principes qui virtuti bellum ac literis indicunt, fimulatóg contemptu vel ingenii tarditatem vel fegniciem fuam ac focordiam tegunt: Audacter tecum dixerim, Sigifmunde fupellex regia $\&$ augufta $\&$ ornamenta ducum, \& principum erant olim libri $\&$ literz. Vnde illud Pifftrati probatur ab omnibus qui Athenienfiú tyrannus quum effet, hanc diuinam librorum fupellectilem ciuibus fuis primus ad legendü inuulgaffe publicép prabuiffe dictus eft: quos deinceps accuratius eorum nume ro ab Athenienfibus aucto, Xerxes Athenarum vrbe potitus abitulit afportaríg iuffit in Perfas quośg itidé multis poft faculis interiectis Seleucus rex hic et Nicanor dictus in Graciá,iņ́́ ipfam A theniêfú vrbë vti condignú fuit rurfus cenfuit reportâdos: increbuitón fic cura \& voluptas quada permultis cogëdi in vnum volumina diuerfarú gentiú diuerfarǘṕ artiü, vt Alexander \& ei qui fue ceffere in cóficiendis bibliothecis a nimú intederent. Sic magnus atç ingens po ftea librorü numerus ac penè incredibilis in Aegypto cóquifitus ató cófectug eft: ad 
elt:ad quadraginta enim vel vt alibi reperio quadringenta, vt Orofio $\&$ Senecaz feptingéta fermè, vt Gellio \& Amiano Marcellino placet feptingêta voluminú milia Prolomxis regibus vigiliis intêtis ćōpofita bello priore Alexãdrino dum diripitur cinitas diclatore Cæfare à militibus fortè auxiliariis incenfa claffe,fiâ ma partem vrbis inuadente, qua tum fingulare profecto monumétum curæftu diíg maiorum condebatur conflagraffe produntur: quod elegantix regum cu rxóg opus egregium fuiffe ait Liuius, quem Seneca carpit: non id elegantix cu ræọ regiæ opus dicens fed ftudiof luxurix, immò ne id quidem, fed fe ipfum conquifitis fpectaculis inaniter oftentátis $\&$ Liuii tamen dictum $\&$ tolom factum vtcumg forfan regix opes excufant, $\&$ in longum publicis vfibus profpiciens primum, ac confulens immortalitati tantorum virorum in hoc tamen certe laude digniffinus $q$ facras literas non vtiles modo fed neceffarias fumma diligétia atç imipenfa per lectos ad tantũ opus viros in gręcam linguam ex he bręo fonte transfudit. Parem curam \& ftudium cogendorum fimul librorum fecuti funt ex ducibus primoribusq́g vrbis Rome plures, eorũ'g primus Aemilius Paulus Imp. Perfe, potentiffimo Macedonú rege deuicto. Dehinc Lucullus è pontica præda: pott hos Iulius Cæfar dato M. Varroni negocio bibliothecas vtrufop lingure qu maximas poffer comparandi, dirigendi, publicandíq. Proba tur quog in hoc Domitianus qui liberalia ftudia licet imperii initio neglexerit, bibliothecas tamé incendio abfumptas reperare curaffet exéplaribus vndiqg petitis mifsífque Alexandriam qui defcriberent emédaréntque. Tollitur in coe lum præc cæteris \& A finii Pollionis Romæ fimile inuentum, qui primus bibli othecas grecas fimul atọ̆ latinas addicis auctorú imaginibus dicendo ingenia hominum, R.P, fecit: qua an priores \& maiore librorü copia inibi fuerint an Alexandriç et Pergami,qui bibliothecas magno certamine inftituere, nó facile dixerim. De priuatis aufin dicere, non regios huiufmodi apparatus, fed alios xquantibus facile vel fuperátibus: Sereno quidem Samonico,ingenti doctrina viro, fed maiore cura pulcherrimarum literarum multorumó̧ voluminú, duo \& fexaginta milia librorum fuife legimus: quos omnes Gordiano iuniori cu ius patri fuiffet amiciffimus ille mories reliquit : nobilem fane thefaurũ \& preclaram generof animi \& humani generis hæreditatem. Hanc igitur græcarum ac latinarum literarú copiam diuinam ${ }^{\prime} \not$ librorum fupellectilem atop peritiam, tanquả maximum abfolutiflimumóp mortalibus bonum fummo opere perqui rendam in delitisóg habendam futuris ducibus ac imperatoribus cenfeo: in terdumós Corn. Cællo affentiri cogor, qait fummum bonum fapientiam: fum mum autem malum, doloren corporis: quum nec erus ratio mihi videaturabfurda. Nam quoniam duabus inquit partibus conftamus, animo fcilicet $\&$ cor pore: quarum prior, melior: deterius, corpus eft: fummum bonum elt, melioris partis optimum: fumnum autem malum eft, peffimun deterioris . Eft auten optimum in animo fapientia, eft in corpore peffimum dolor:vt 1 gitur fummú malum dolere,fic fummum hominis bonum fapere, vt opinor, fine vlla dubitati one concluditur: of fi qui illam affequi poterüt, non ad oftentatione, fed ad decus, dignitatem, ad commodum ac patriæ vtilitatem, hi mihi videntur folicita 
tem ac beatitudinem facile poffe contingere. Alia enim bona humana fi củ hoc conferantur,parua ea funt quidem $\&$ exigua $\&$ ab huius q̃ longiffimè dignitate præftantiá̧́ remota. Præclarum quiddam fcio dices, Sigifmunde, eft multis imperio eminere, fed fpeciofa magis $\ddot{q}$ tranquilla imperii facies eft, $\&$ qua nulla curiofior, nulla minus libera: immo nulla magis ferua, vt Senecx placet, conditio eft. Gladiis enim ceruicibus appédentibus, imminêt haftæ vndiø \& f picula, ipfi cuftodes timentur \& comites, nihil non aufuri,ira illos vel inopia vel auaritia militari ad quauis facinora facile iritante. Sic Pertinax non ab alio $\mathrm{q}$ a fu is militibus interfectus eft, fic poftmodü duo Maximini pater \& filius, fic Balbi nus \& Maximus, fic Probus dux clariffimus, fic Gratianus \& Valentinianus iu nior optimi fratres: ille à fuis legionibus, hic à fuo comite proditus: fic innume rabiles alii a fuis hoftibus inuicti, fuis exercitibus periere: \& quos milites, focios ac comites appellabant,inuenere carnifices. Adde $q$ omnis æas in imperio reprehêd itur: fenex enim quifọ in habilis videtur, iuueni quoģ additur \& furor. Pulchra eft generis dignitas, fed quid aliud q quxdam ex progenitorum meritis pueniens laus videtur? pretiof diuitix, fed externa rapacis fortun $x$ munera, quæ dum quiæruntur cruciant: parta, oblectando molliunt,cupidinêmq fuccë dút: qux illa pro fua libidine perturbat atq permifcet, cui videtur tradit, aufert habentibus: \& rurfum quum vifum fuerit, non fperantibus reddit, corím $\$$ bo nos fimul \& malos fine vllo difcrimine atç delectu participes fieri finit. Illuftrif fima rerúmque omnium blandiffima eft gloria, fed inftabilis \& periculis multis obnoxia, vtpote qux fapius fortunæ $\vec{q}$ virtutis eft beneficium: qua $8 \mathrm{rihi}$ inanius effe Theophraftus dixit, nihil pernitiofus Satyricus: patriam nãģ obru it olim gloria paucorú et laudis tituliqg cupido. Formæ dignitas grata eft, fed vel fragile bonum vel nulla potentia formæe eft, inquit $\mathrm{Nafo}$, quam $\&$ alienum quo que bonum Bion, deceptionem tacitam Theophraftus, modici verò temporis ryrannidem appellauit Socrates, naturæ ptiuilegium Plato,regnum folitarium Carneades, eburneum detrimentum Theocritas, vitæ flofculü celeriter decidét ë Satyricus, feftinat inquit,decurrere velox Flofculus anguftę miferęó breuifima vitæ Portio,dum bibimus, dum ferta, vngnenta, puellas Pofcimus, obrepit non intellecta fenectus. Iocunda valitudo. Sed inconfulta iocunditas quar negligentes \& incautos ferre foleat poffeffores, $\&$ perfape morbos accerfere quos malx valitudinis intentio declinaffet. Optabile robur: at nulle tantum corporis vires que vel labore immodico vel morbo acri vel cuncta rodente fenio non frangantur, non conficiantur. Sic Herculemdomitorem gentium ab hominibus inuictū, vis latentis mali vicit. Sic Milonem Crotonienfem, athletam illuftrem patulis in parte media hifcens ramis arbor vna detinuit, dilacerandún feris præbuit . Literarum autem $\&$ humanarum rerum difciplina cum virtute coniuncta, hac omnia declinare 8 effugere poffe videtur incommoda. Hanc enim non cafus, nec fortuna violare nec calumnia auferre, nec morbus corrūpere,nec ferrum minuere, nec labefactare fenectus poteft: Immo quum cæetera tempori ced ant, fola hac literarü monumen ta, téporis diuturnitate pubefcunt. 


\section{th. \\ ROBERTI VALTVRII DE RE MILITARI LIBER SECVNDVS.}

Qưd naximos huic dijciplina fructus afferat philo ophise or biftoriarum cognitio, quodds maximi duces hifforian ferupfere.

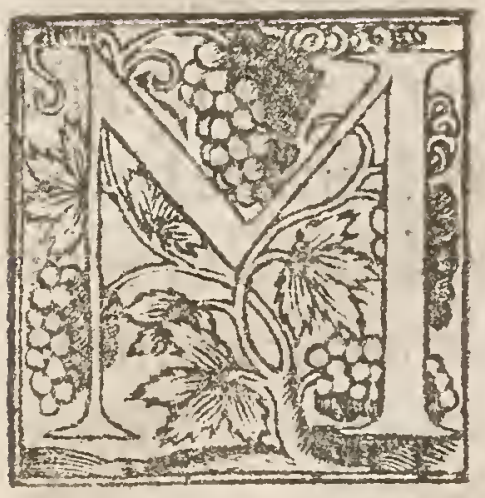

Vlta igitur literarum ftudia quum fint, vt antè diximus, Impe rator inuicte Sigifmunde Pandulphe, qua fummum decus $\&$ ornamentum ducibus queant afferte, erit $\&$ in re hacilla præpollens philofophix tum hiftoriarum omnis aui fummopere peroptanda cognitio: nam quigh docti \& excellëtes viri qui vf diftribuunt, vt pars altera fit in præcept is $\&$ inftitutis,pars altera in hiftoriis col locata. Illa enim viuendi rationem \& legem quum præ fe ferat tradátque hominum officia, quid fit honeftü,quid turpe,quid vtile, quid quem qu deceat, quid non 8 catera quidem acri ingenio excogitata in medium afferat,cum tamen per fefe explicantur, fegnius legentium animos iritant factúque quodam modo incredibilia iudicantur, vbi verò praclara rerum ac temporum teftis accedit hiftoria,faces quafdam ac ftimulos fic comparat vt obfcurum haud fit men tes hominum ita tepefcentium, clariffimorum facinorum memoria ad glorix et immortalitatis fudium vehementer accendi: quod genus $P$ ythagoræ, Demo criti, Platonis \& Ariftotelis cxterorimque philofophorim præcepta iubent vt acerbiffimos cruciatus \& maxima vitæe difcrimina ineamus, vt fidem iureiu rando hoftibus datam non fallamus, vt coniunctiones pactionéfque bellicas $\&$ hoftiles non perturbemus, eorum quidem probabitur oratio,ad rem auté proficifcentibus torpebit animus, phorrefcet cadétque: quòd fi L. Bruti facinus in expellendo Tarquinio, aut Scipionis Naficæ inuicti animi magnitudinem \& robur contra Tyberium Gracchum, aut M. Attilium Regulum, Caflium Sce uam Centurionem, Attilium militem, aut L. Sicinium Dentatum, plebeium Tribunum, vel Cynegirum quempiam ex hiftoriarú monumentis quafi teftes adduxeris, quis eft adeò vecors, a deò exanimis vt eorum exemplis non excitetur, non animetur, non impellatur ad patriæincolumitatem, ad fui fuorúmque falutem vindicandam, conferuandam, difcrimina mortéque pro nihilo ducat. Sic enim Mylciadis trophæa fomnos eripuifte Themiftocli, fic alii funt ad imi tandos præftantiffimos duces Alexandros,Scipiones, Fabios, Catones, Regulos, Curfores, Valerios, Marcellos, Aemilios, Cafares denique ac reliquos innumerabiles crebro rumore virtutum fuarum incredibili ardore compulf. Porro fialiam hiftoriæ vim libet infpicere, reperiemus eá non minimam nec mediocrem ducibus in coufultando auctoritaté, $\&$ in gerendo peritiam accommodare pof $f_{e}$ : quòd fi vetefum res geftas memoria repetamus, inueniamúfop maximas res publicas, præcellentiflima regna, potentílsimos diuerfarum getium populos, grauifsimo fenum adoleuiffe floruiff'eque confilio, $q$ hi temporum diuturnita e, multarü gentium vertigine \& experientia multa fcife, permulta vidiffe crede 
rentur, quanti faciemus totius antiquitatis ftudiofos homines atq peritos, quibus non vnius fenatus $\&$ imperii, neq vnius xtatis, fed omniú penè gentium omnium'q́ fæculorum res, vilæ cognitǽq fint?quæ omnia Cicero nofter hiftoriam defcribens, paucis \& his quidem verbis expreffit, Hiftoria eft teftis tempo rum, lux veritatis, memoria vita, magiftra vitæ, nuntia vetuftat is . Ex qua defcriptione, temporum rationes, hominum tes geftas, vniufcuiufque vitam, natu ram, formam, cogitatus, conflilia, mores, naturæ infolita opera, fortunæque in fperatos euentus accipies: hac in re aderit quoque fcriptorum genus, quali cafrrenfe,egregiü fanè atque præcellens, quos ad pacis vfum bellíque tempora le gere atop manu verfare operæ pretiun fit: Verum apud exteros quidem Hero dotus ille imprimis atque Thucydides: ille enim Perfico bello merens, quo tem pore Xerxes in Græciam duxit exercitum, quantü hoc dicendi genere valuerit, eius hiftoria elegantiflime fcripta declarat: Hic veró non fecus cum in re bellica al iquandiu verfatus effet, tandem fe contulit ad fcribendam hiftoriam, in qua ita claruit vt cum eius fama in bello non obfcura effet, naiorem ex eo ftu dio $\underset{\mathrm{q}}{\mathrm{ex}}$ armis fibi laudem et gloriam coppararet. Idem etiam de Timotheo Co nonis filio liceret dicere, qui quum funmus Imperator fuiffet, elegantifsime $\mathrm{p}$ fcripfit hiftoriam, \& quod mag is fcio admirabere, $\mathrm{f}$ Probum non legeris, $\mathrm{Han}$

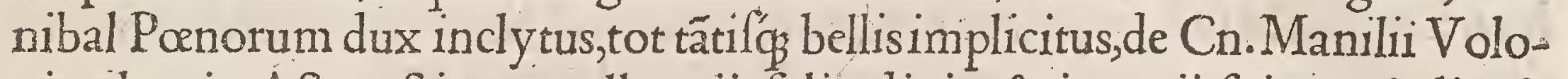
nis rebus in Afra geftis nonnulla ocii, folitudinis, \& ingenii fui græcis literis monumenta reliquit. Iofephus hebraus genere, \& Galilæorum dux à Vefpafiano captus Titóque filio eius relictus, Hiero folymis Romá veniens, nonne bellum quod cum Romanis geffere Iudæi omnium maximum atrocifsimúmque, feptem libris digeftum, patri filóque imperatoribus obtulit ftatuámque pmeruit? Mitto alios antiquitatum libros ab exordio mundi ad quartúdecimum vf que Domitianı Cxfaris annum, ab eo quoģ quorundam fententia ita vti funt apud nos latinis literis $\&$ orationis venuftate confcriptos. funt qui cum fcripfiffe literis græcis putent, poltea vero in latinum verfos illos è græco, quidam à Ruffino Aquilegienfi, alíque ab aliis traductos malint. Ex noftris quoque duci bus nonnullis cum militaffent hoc idem quod externis propofitum fuit,vt nec in armis xtatem totam contererent, verum ab negotio caftrêfi ad hiftoricum ocium, \& ab hiftorico ad caftrenfe aliquando fe mutuò conferrent. Vnde M. Porcius Cato quem honoris ac differentize caufa, modò prifcum, modò fuperiorem, aliquando maiorem, fape familix Porcix principem, plerumque Cenfo rinum docti vocant, Originum libros fcripfit, egregium quidem opus atque dif fufum, $\&$ in quo fi vfquam alibi hiftoriæ plurimæ $\&$ antiquitatis monumenta extant, eiufce rei feptê funt lıbri cófcripti, fed primus qux fint Romanis à regi bus res gefta cótinet, fecuudus et tertius cuiufque ciuitatis Italicæ cöditoré, or tư̆ $\&$ originem, quamobrem Originü libros in fripfiffe vifus eft: quartus bellum primum Carthaginenfe, quintus fecundum, terribile atque memorandú qưd Hannibale duce cum $\mathrm{Po}$. Ro Carthago fubiit. Qux autem funt co fuperftite bella deinde confecta, fextus \& feptimus vfque ad preturam Sergii Galba referunt, expofitis etiam in Italia \& Hifpania quæ aut effent aut viderentur

$B$ ii admiratione. 
admiratione dignifsima. Nobilem deinde ducem Q. Fabium, qui etiam roma na hiftorix friptor eft \& cuius orationes Thucydidis orationibus $\tilde{q}$ fimiles fu iffe afferunt, miris in collum laudibus fuperior tollit ętas, quanquam ex pictura magis q̃ ex literatura nomen inuenerit. Confimili ratione Syllam Luculli res clarilsime geftas, memorix hominum demandantem acceprmus, \& ad eum ip. fum qui commentariis maiore quodam orationis cultu $\&$ fplendore eam ipfam hiftoriam expolire potuiffet. Magna etiam huiufce rei D. Iulii Cafaris inter cateros acta cura ef, in fcribendis fiquidem Gallici ciuilif' $\$$ belli Pompe iani commentariis(fic enim libros fuos appellauit)hanc diligentiam adhibuit vt fingulis libris fingulorum annorū res geftas colligeret: libros igitur feptem de bello Gallico \& tres de ciuili Pompeiano fcripfit, fuperioribus autem octauum poit eum necatum addidit Hirtius. Is namplibro vno qux deerant de bello Gallicoad finem cum integritate fuppleuit: poftremo libri funt tres de $\mathbf{A}$ lexandrino, de Aphricano, de Hifpanienfi bello fripti, horum auctorem Suetonius qui antiquus \& nobilis eft fcriptor, effe incertum refert, quòd eos fcriptos aliiab Hirtio alii ab Oppio effe putent: Hirtius autem in fuo octauo qui eft vt dixi de bello Gallico ita prafatur, quòd ifti etiam tres de bellis qux in A lexandria deinde gefsit Cælar fcripti ab eo haud dubiè videantur: quæ hoc in loco à me dicta fint vt vera ac teftimonio Hirtii \& Suetonii approbantur,infcriptiones tamen folent memini quxdam haud minus falf $\tilde{q}$ varix inueniri, os aliqui Iulio Cæfari,quidam Iulio Calfo, nonnulli Hirtio,multi Suetonio non iftos aut illos modò, fed quos nominaui libros omnes de Cæfaris geftıs(funtenim numero quatuor $\&$ decem) infcribant: fed vt libet difponant illi, Hirtium nos ac Suetonium fecuti fumus. Eadem Cafariana tempertate Afinius Pollio, Dalnatico triumpho etiam infignis prætermittendus non videtur: et quáquam eloquentix fux nulla fuperfint monumenea, eum tamen hiftoriarum fcriptorem nobilifsimum fuiffe memorix proditum eft. Marcus autem Varro quem. etiam militaffe conftat, quantum hoc ftudio romanis rebus profuerit, de temporum defcriptionibus, de patrix atate libri ab eo accuratifsime fcripti clarè teftantur. Quid Cicero nofter, orator amplifsimus $\&$ imperator? nonne cum militaffet, hoc literarum genus ita excoluit $v t$ de temporibus fuis fcripferit, totámque Cyri hiftoriam à Xenophonte confcriptam legendo contriuerit pariter \& excufferit: annales etiam ab co effe confcriptos atque de Cofmographia libros Pri.Cæfarienfis refert, \& fragme̋tum adhuc fupereft. Fuerunt $\&$ alii præ. ter hos Romanorum Augufti,maximi ac nobilifsimi principes ducéfque, orbis ac rerum fummam adepti, hoc fcribendi munus minimè afpernati, Octauianus Auguftusi mprimis \& Claudius: ille enim rerum à fe geftarum libros tres ac decem cum effet in Hifpania Cantabrico tenus bello edidit, hic verò hiftoriam Tito Livio hortante in adolefcentia, Sulpitio verò adiuuante aggreffus eft: in principatu etiam fuo plurima cum literis huiufmodi complexus fuerit hi Itoriæque fux initium fumpferit polt cædem obitumque $\mathrm{C}$ faris dictatoris, pri oris materiz duos, pofterioris vnum \& quadragita libros reliquit. Huius etiam literarix \& hiftorica fama tả cupidum $\mathrm{Hadrianum}$ fuiffe nouimus, vt rerum fúarum. 
fuarum volumina notauerit, familiaribus libertil' fuis nominibus corum infcriptis inuulganda contulerit: Gordianus deniqg fenior, Panegyricum fue lau des Antoninorum omnium qui fuperiori tempore fuerant oratione foluta con gefsit in libros, \& etiam Antoniniados, hoc eft, Antonini Pii \& Antonini Mar ci elegantiflimis verfibus in triginta libris vitam illorum \& bella publice priuatimós gefta perfcripfit. Taceo alios innumeros reru $m$ geftarum auctores, fine quibus praclara fuperioris temporis vtriufigh lingux regum \& ducú acta, aut penè deperiffent, aut effent in tenebris perpetua obliuione fepulta:vtóp ad vrbium iam maximarum nomina conuertatur oratio, nónne fuo iam igne cöfum ptum effet llion? Num confumpte Thebæ? num Micenæ? Lacedæmon, Atheng̨? num Corinthus, Carthaginis Byrfa, ac veteris monia Babylonis? quid Roma denique ipfa,vnica quondam mundi gloria ac clarorum tot virorum patria $\&$ domicilium? nihil profectó, nifr $\&$ græcis $\&$ latinis rerum geftarum fcriptionibus fufcitaretur: hac enim re vna muti loquuntur, abfentes adfunt, mortui vi s uunt: Mortuorum enim vita(vt inquit Cicero)in viuorum memoria confiftit: quò fit $v t$ res $a b$ noftra ærate memoriáque remotas melius cognof camus, fi modo fint claris auctoribus illuftratæ, $\bar{q}$ que recentior dies attulit: cum qui ne vnquam vrbem viderint, illuftres tamen Romanos réfque corum magnificè geftas ita norint vt res omnis penè longe melius qu qui à multis faculis citra inde oriundi funt cognouifle videátur. Poftremò ad ea qua adeunda ineundáque funt locorü genera, nihil conducibilius q̊ regionü terreftriü aut maritimarü fcientia, cum non folü agros, fyluas, nemora, faltus, montes, flu mina, lacus, ftagna, por * tus, \& maria, fed tot oras orbis \& vrbes, fparsáque imperia et populorü diffonas difsidentesóğ liguas ita defcribit, vt nó tã ore ac mẽte $\dddot{q}$ oculis legere te reputes . Quocirca et præclarü(vt inquit Flaccus) et vitle nobis exéplar ppofuit Vlyxes, Qui domitor Troix, multorum prouidus vrbes;

Et mores hominum infpexit,latúmque per aquor.

Dum fibi dum fotiis reditum parat, afpera multa

Pertulit,aduerfis rerum immerfabilis vndis.

lllud quog in eodem genere Alexandri $\mathrm{C}_{\mathfrak{x}}$. inftitutum frenumero fcitum et memoratu dignum mihi videri folet, qui fapientes obeundis in rebus confliarios hiftoricos confulebat, \& milites veteres $\&$ benemeritos ac locorü gnaros, vt fi quid huiufcemodi fuperiori ætate bene actú effet, vel vfu pbaret, vel melius ac prudentius cerneret. Præclarum \& illud quoọ Demetrii Phalerii, Ptolemeum Aegyptium admonentis vt libros in quibus iufti regis officia \& illuftruu prin cipum vitx ac mores literis demandati effent, \& ftudiofè legeres $\&$ de manibus nung̈ emitteret. Huic cófentaneum non minus eft quod à Scipione Aphricano, diuino homine obferuatum inuenimus, qui non tâtũ fudii operæó Xenophōtis lectioni in qua Cyri vita cótineri dicebatur impendiffet, ni bello vel pace ex iftimaffet eam fibi lectionem plurimum pfuturam: nec Cato ille Prifcus aliam ob caufan manu fe fua nato res geftas maiufculis literis exaraffe teftatur, nifi vt domi maiorum virtutis fimulacra filio vfui forent et adiuméto. Qux cum ita fint, egregium fanè có fumatúmq̧ belli ducem neminem effe poffe arbitramur, 
qui non harum rerü cognitione \& doctrina ad ea qux fibi propolita funt munera tractanda inftructus atque ornatus accefferit, qui non ea qua de bonis rebus \& malis, de contemnenda pecunia, gloria propaganda,frangendis cupidita tibus, conformandis hominum moribus, excipiendis periculis ac morte, pro ho neftate appetenda fapientiflimi viri maiores noltrimonumentis fuis fcripta no bis reliquerunt, non modo audierit, legerit, verfauerit, verum etiam in his exercuerit fe diutius, \& earum exempla ab omni memoria antiquitatis cognouerit, cognitáque tenuerit,non minora denique priuatim publicéque Pythagorã, $\mathrm{De}$ mocritum, Zenonem, Chryfippum, Platoné, A riftotelem, Liuium, Saluftium, Herodotum, Thucydidem, Ephorum, Theopompum, cæterófque fapientes egiffe afferëtes, $\vec{q}$ fr duxiffèt exercitus, geffiffent honores, leges tuliffent, nec folum palmas \& coronas his tribui oportere, fed etiani decerni triumphos \& inter de orum fedes eos dicandos iudicare.

De Eloquentia quantúmque huic ip $\int a$ rei conducats

Cap. I. Diicienda eft huic,ni fallimur, llla qux rectè à preclaro poëta flexa(1) 2 (a) nima dicta eft omnium regina rerum oratio, hac quam modo dix 1 imus hiftoria formofior multo \& illuftrior. Sed cum duplex fit orati Lenis ratio \& in altera fermo fit, in altera contétio, non elt id quiden dubium quin orationis contentio maiorem vim habeat ad gloriâ: ea elt enim quam eloquentian dicimus. Sed tamen difficile dictu quantopere conciliet ani mos comiras affabilitáfque fermonis. Extant epiftolæ Philippi ad Alexädrum, Antipatris ad Caffandrum, \& Antigoni ad Philippum filium, quibus pracipi unt vt oratione benigna multitudinis animos ad beniuolentiam alliciant, militélque blando appellando fermone deliniant. Qux auté in multitudine cum contentione habetur oratio,ea fæpe vniuerfam ita excitat gloriam, vt flagrãtes cupiditate animi ab improbitate, auaritia, luxuria, ignauia, defidia, flagitio deterreantur: Remiffi verò atque languentes metúque abiecti, ad virtutem, dignitatem, decus ac gloriam excitentur, inducantúque in f pem cogitationémque meliorem: qux fingula licet nifi ab his qui naturas hominú vímque omné humanitatis caufáfque eas quibus mentes aut incitantur,aut refl ectútur, quos phi lofophos effe nouimus, \& quibus hi loci potiflime debentur, profpiciantur,tamen nefcio quo pacto \& ira \& mifericordia omnífque animi fufcitatio in po teftate eft oratorum:quorum foelicem ac beatam eloquentiam ab omni populo fuife fpectatam, \&veluti numen quoddam celebratam non ambigimus, quum neque nos lateat ab ea quàm frepe tyrannos vrbibus eiectos atque fublatos, feda tas difcordias, mitigatam inuidiam, turbulentos ac feditiofos ciues oppreffos, plurimos ad honores ac imperia magna prouectos, plurimáfque partas vrbes, quę ita fuiffe fuperiorú tēporú demóftrat euétus, et clariffimorú virorú illuftriúç

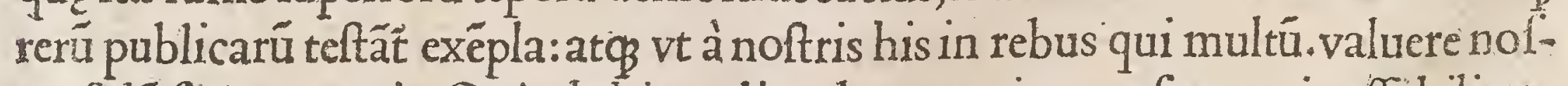
tra fidé fumat oratio, Quis dubitat aliter hac comitate et fermonis affabilitate nuilitaríq facủdia et bellis accommodata fieri potuiffe $q$ à L. Bruto, fpectatę no bilitatis viro factũ effe fcimus, q̊potêtiflimú regé expulerit; ciuitatéğ ppetuo iugo liberarit. Paulo etia polt reges exactos, quis nefcit hac ipfa oratione plebé arma- 
tam variis fttimulata iniuriis $\&$ à pat tibus diffidété prope ripä A nienis fluminis

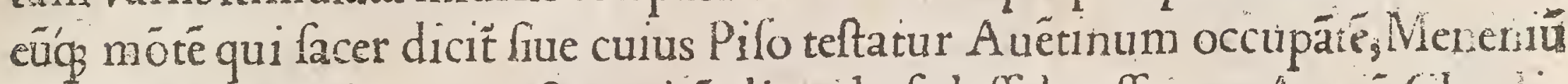
A grippan graué ea tempeftate virü dicendo fedaffe? poffumus A ppiú Claudium ampliffimũ virú fenectute ac oculorú orbitatc côfectum his ârumerare, qui à filiis lectica per forum deuectus in curiam, his auditis qux in lenatu \& pręclarè \& humaniter à Cynea dicta erãt, quũ \& liberationé capt iuorú \& aùi liư ad fubigêdam Italiä Po.Ro.Pyrrhus offerret,ac pro his nihil aliud ga amicitiam fibi tarentinisós fecuritatem poftularet,pluribus ad eam rem inclinantibus, ma gnifica oratione auctor fuit vt eiufmodi pacis qux plurimum turpitudinis \& infidiarum habitura erat,foedus nullo pacto reciperent. Poflumus merito $M$. Tullium Ciceronem fermonis \& contentionis praftantia omnipotétem dicese qui Verrem audaciffimum hominem fceleftum $q$. criminitus fuis oppreffit, \& ferociffimis feptum armis nihilóp non aufurum Catlinam inermis exterruit, ac de incendio vrbis $\&$ ciuium fanguine cogitantem trufit in exilium: qui me nia romana,tceta, templa,capitolii arcem, bonorum lares,totum deniqg corpus imperii impendenti iam præripuit ruinæ: quo merito primus omnium(ve inquit Plinius) parens patrix appellatus, vt qui primus in toga triumphumi linguxǵp lauream meruit,facundiæ literarúmq latinarum æquè parens,omnium triumphorum lauream adeptus maiorem, quanto plus eft ingeni romani terminos in tantum promouife $\mathrm{g}$ in perii. Addidit etiam Cæa farem dictatorem iplius quondam Ciccronis hoftem de eo talia fcripfiffe,ex teftibus inimicitia fi dem fibi fumens: qui $\&$ ipfe quantum militari valuerit eloquentia, nemini mediocriter etiam erudito ambigendum effe cenfeo:quippe qui aut difertiflimos dicendi artifices aquauit,aut exceffit eloquio. acculator namq 3 Dolobellix plus g militare fit munus, fum mi oratoris officium impleuit: in qua quidem accufa tione extorqueri fibi caufam optimam L. Cottx patrocinio queftus eit, quo verbo facúdià vim expreffit,vt Valerio videtur. Nimirum vertum extorquere hanc vim habet,vt reusille nó ex facili fed ex arctiffimo quidem indiffolubilíg laqueo verbi vbi cæfareo eloquio victus er at, præreptus videietur : poft quam accufationem(vt Suetonius inquit)haud dubie principibus patronis an numeratus eft. Enumerare poffem quibus pralis eius oratio ita nilitum aninos incenderit vt periculi omnis immemores, læti etiam \& exuliâtes in fer rum ruerent, quas ingentis exercitus feditiones,comprefferit, quot armatorum milia folus \& inermis oratione terruerit, vfqueadeo vt ad nutum perorantis inuenti fint, $\&$ qui colla porrigerent, $\&$ qui ferirent qui verò gemeret nemo, nif $\&$ narratio longior foret. Nec Auguftum nnter multa animi ingeniíq fui bona ab huius quam modo diximus paternę eloquentį ftudiis abhorrentem nouimus: Nam vt de illo fcriptum eft, genus loquendi fecutus elegans \& temperatum,pre cipuã curã duxit fenfú animi quàm aptiffimè exprimere, $\&$ amicos irrifit verba infolita \& obfcura captantes, $\&$ hoftem increpuit vt infanum ea fcribétem quę admirationis plufö intelligentix allatura effent animis audientium. Nec eft $\mathrm{m}$ hi de eloquentia clarorum ducum fcribéti Afrinius ipfe Pollio filentio obruendus,quem ( vt appareat fuum cuigg iudicium fore )medium inter duos eloquen 
đifimos latinorum M. Tullium \& T. Liuium Seneca conftituit, ita non fpernéndus auctor. Tres enim vult effe eloquentix principes, quos in epiftola quadam videtur omnibus præferre, fecundum faciens Pollionem, cuius orationem Ciceronianæ diffimilem falebrofam \& exilientem dicit, \& vbi minimè expectes relicturam. Si verò Portri Catonis quifpiam quærit eloquentian in oräda caufa, oratorix artis magnum ea ætate derus illi partum dices, quippe qui omnis generis eloquentix eius orationes tam multas pro fe, pro aliis $\&$ in alios egerit, ficó perorauerit vt non ab re romanus in vrbe Demofthenes diceretur: id etia fibi nactus præc cateris vt eius proprium fit quater et quadragies caufam dixiffe, nec quem $\ddot{q}$ frpius odio: \& inimicorum fimultate petitum, ac femper inuictum \& abfolutum: cuius eloquentix vim atq̧ naturam quum ipfe probè noffet,ac iuuentutem hortaretur ad audacter pugnandum, afferebat verbo magis quàm enfe, \& voce quàm manu plerumqs euerti \& confternari hoftes folere. Excellen tem \& egregiam quoop L. Crafli facundiam fi aliunde nefciremus hinc liceret intelligere, quòd in libris de oratore M. Cicero mortem eius magnificentiffimê deplorans, omnes illum femper eloquentia, paucis verò ante obitum diebus fefe etiam viciffe commemorat. Certatim quoop fecum eloquentize fudiotos ad cú locum quem nouiffimè pedibus ille calcauerat, polt ipfus mortem rediiffe,captus dulcedine \& recordatione fermonis quem ex co nuper audierat, \& velut iterum auditurum. Addit etiam id vni Craflo fingulariter contigiffe, vt quo tiens peroraret totiens folito altius ac fine exemplo locutus videretur. Enimueroquia fama huivs aliquanto apud vulgus ignotior eft non alienum exiftima. ui duo etiam M. Tulli dicta fubiicere, quibus de hac re prę cúctis fides habenda eft. Nanque apud eum ita friptum inuenio, Craffo dicente,nemo tam arro gans qui fimiliter fe vnquam dicturum effe confideret: \& iterum, omnibus auditis oratoribus, fine vlla dubitatione fic ftatuo $\&$ iudico, neminem omnium tot $\&^{r}$ tanta quanta fint in Craffo habuiffe ornamenta dicédi.Idem de M. An tonio teftis adeft. Siquidem cum quodam in loco de hoc dépg fuperiore finul loquens dixerit fuiffe vtrum $\phi$ tum ftudio $\&$ ingenio $\&$ doctrina prętátem om nibus, tum in fuo genere perfectum, vt neq in Antonio deeffet ornatus orationis nees in Craffo redundaret, alio tamen loco omnium quos ipfe audiffet eloquentifimum ait A ntonium, quafi de induftria dubium relinquens, quò tanta. rum laudum ftateram potiflimum inclinaret. Verũ fama huius vulgatior videtur, cui multü adiecit nouiffimus dies quo migrauit è vita:in illa enim tépefta te Mariana vbi nullus mifericordix portus erat, iuffi fcelerum miniftri Antonium trucidare, vbi dom^um eius peruenere, Antonium intuétes ac alium alius ad cędem hortaretur præmitterếtọ,tanta fuit oris illius dulcedo, led quędam perfuadendi dea potius, vt loqui quum inciperet, milites omnes præter vnum Annium eius oratione deliniti, diftrictos iam $\&$ vibratos gladiosincruentos va ginis tedderent, ac à fummo furore protinus ad fummam mifericordiam conciderent. Huius eft etiam ille ad perfuadendum efficax actus orationis, cuius in oratore fuo aliifóp in locis meminit Cicero: cum enim M. A quilium qui conful fuerat \& dux apud fenatum \& populum clarus, omni tandem honore fpolia- 
tum \& ad extrema fallacis fortunx pręcipitatum fenem in capitali caufa defen deret, in medio orationis ardore $\&$ deformem fqualentémque reum fubftulit putrémque eius difcindens tunicam ac generof quondam tunc miferandi pe ctoris cicatrices iudicibus oftẽtans fimul'́p ad C. Marium qui inter aftantes exat verfus, \& vit collegæ dudum mifereretur multis cum lachrymis oftentans, mifericordiam omnium concitauit: vtóp ad exteros prolabatur oratio, quibus ca fere in hoc quidem fermonis genere non poffumus, occurrit nune qui primas militaris huius eloquentix partes fibi vendicat $P$ iffitratus, quem rara quadam eloquentia florentem A thenienfibus imperitaffe patientibus atp vltro ei deferétibus imperium conftat: quod ne magis obliuione quàm iudicio factum exi ftimetur, ex eo coniici poteft, maxime quum Solon orientem Pififtrati tyrannidem multo antè prof picies, euocata concione pfectus in publicú lorica arma tus \&cly peo, infidias et improbos conatus eius a peruiffet:neg folum orientem, verü quum reličta patria depofitis ante curiâ armis in Aegyptum indignabun dus nauigaflet,ató inde Cyprum profectus pòtt ad Crofum pueniens atop inde in Ciliciam Pififtratum in tyrannide perfeuerãtem didiciflet, eos rurfus per epi ftolam fic monuit, Siquidem per veftram vecordiam dira toleratis, nihil in hac parte diis acceptum referatis, ipfi enim vobis horum caufa eftis, qui pignora ve duram feruitutem pateremini dediftis: veftrum verò vnufquifque vulpis veltigiis inced it, omnibus autem leuis \& ftolida mens eft: quippe viri linguan fermonem'g varium \& plenum aftu \& fallacia attenditis, rerum exitum confiderare nefcitis. Huius quoque tyrannidis \& eloquentix fucceffor Pericles dicendo tam frmilis fuit, vt qui hunc audirent, illum fe audire arbitratentur, fi modo vnquàn eum audire contigiffet: hoc tamen ifte præltantior, quòd alter elo quentiam armis adiuuerat: huic eloquétia fola fatis fuit ad imperiü, quod $\&$ di uturnum geffit \& magnificum. Quadraginta enim annos rempub. tenuit, codémque tempore $\&$ vrbanis rebus prefuit \& bellicis inermis ipfe. Sed tamen ar mata fultus eloquentia, dictu mirabile vt quum aduerfus omnium falutem diceret, cum voluptate fúma omnium audiretur. Quid Alcibiades, Clinę filius, Atheniefrum \& ipfe imperator fummus mari ac terra, nónne tanta eloquentia praftitifle ad tantä́g rei militaris gloriam peruenifle perhibetur vt vtra $\not$ in illo duce laus de excellétia certare videatur! qui quod ad reliquos attinet tâtum dicendo valuit vt nemo ei dicédo poffet refiftere. Hanc itıdem oris orationiśc vim at $\$$ potentiam apud Homericum Neftorem, veluti quodam ingenti fpea culoclarius licet inf picere: nam quum duo totius exercitus columina diffideret, Agamemnon regno pollens \& Achilles potens bello, defideratur vir cuius ore melle dulcior proflueret oratio, $\&$ peritia multa memoratus, qui Atridx fuperbram fedet, Pelidx ferociam compefcat ató eos auctoritate auertat, 'exemplis moneat, oratione permulceat. Similiter apud eundem poétam quum in concilio Grxcorum Agamemnon fopitis fomno membris, quod de inftruendo pra lio videracefferret in medium, Neftor fidem relatis concilians, exercitui non mi nus eloquentia q̃ reliqua omnis multitudo ferro \& viribus fuit adiuméto. Eadem ratione dux ille inclytus Gracix non tantum, immo nunquam (f Cices 
ronicredimus) optabat ve Aiacis fimiles haberet milites, fed vt fapientes fini les Neftoris . Quod fifibi concederetur, non dubitat quin breui tempore Troia foret peritura. Adhec etiam accedit focraticus ille Xenophon, qui optimum di cebat vel tribunos vel equitú prafectos eloquentia pręftantes parare vel oratores idoneos in cócionibus caftrenfibus adhibere, qui equitibus peditibúfq vi orati onis \& copia terrorê incutiant metu quò meliores fiant: fedent etiam \& ad tran quilliorem partem traducant, fr quando temerè cócitati fuerint: nec aliam ob

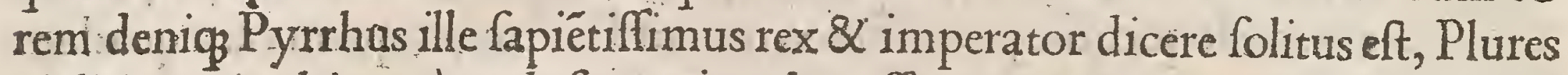
a Cynnea verbis quàm ab fe armis vrbes effe partas: nifi q omnia Euripidis fententia conficit oratio, qux haud hoftile ferrum conficete potelt

De poètis, qui fructus ex eis, o gui audiendi, quíque repudiandi fint.

CAP.IT:

mque finitimi fint oratoribus poétæ regeśg fuperiori tempore 8 inclyti duces quum bellum initưri effent facra mufis de more antê perfoliuerent; vtpote qux difciplinæ iudiciorum'óp meminiffent, quó 12 28 faciles ac prompta periculis adeffet $\&$ facinora præliantium memoratu digna redderentur. eos audiendos legendóf qq quum inhæreant penitus métibus efle operæ pretium arbitramur: maximè quum magnam fpeciem doatrinæ atç fapientix præfeferant: Cxterum hi quum multiformes variíp fint, vt Tragici, Comici, Épici,Melici \& Ia mbici ac dithyräbici,apúdo alios poêta rum alii ceforia notatione digni, alii habeantur in prætio, vt facile fecerni poffit ex his quilectione noftra digni quiue exigendi fint, diuifonis gradibus explicandum eft. Poétæ itaque omnes aut tantum conciliandx auribus voluptatis aut orationis quoque ad meliores vitæ vias gratia fabulas finxere, auditü in prinis mulcent: veluti fcenici, de quibus nihil aliud eft quod dixerim in pręeri tia quàm $q$ Romani veteres apud quos nung $\vec{q}$ Tragoedie fiue Comodie probare fua in fcenis ac theatris flagitia potuiffent,eos non admiffuri fuerant nifi confuetudo vitæ pateretur, à rebus diuinis Liberi patris, A polliniṣ́́ füpto principio:abhis enim Tragoedia \& Comodia fumplerunt exordiü, dictáque Tragœ dia proinde codem nomine quo facer hymnus Liberi patris, cum hymnus ille fortia facta \& laudes Liberi patris cócinebat: ita \& hæc tragoedia non nifi magnorum \& fortium virorum vitia reprehendebat,vel ex vocis valtitate nominatta quæ concauis repercuffionibus roborata,talem fonum videtur efficere,vt pene ab homine non videatur exire: erigitur aute in hyrcinos pedes, quia fi quis inter paftores tali voce placuiffet, capri munere donabatur: vel $\phi$ hyrco ornabatur inter alia præmia eius carminis friptor, vel quia corium hyrci plenum muifó folenne præmium cantoribus erat, vel $q$ ora fua fecibus perliniebät $S c e$ ntčl, ante vlúm perfonarú ab Aefchylo repertum, fex enim gracè dicitur тpv३s: \& his quidem caufis tragcedix nomen inuentum. Simili modo quum pòt lon go tempore Apollini nomio vel Arifteo, id eft paftorum vicinorumue prefidi deofacra \& ludi inuenti celebrarêtur circum Atticx pagos \& vicos \& villas \& compita vbi ruftici geftientes humanos actus latiffinis carminibus irridebant facer hymnus Apollinis cantus effet, qui comodia dicebatur, vt opinor à pagis cantilena compofito nomine, vel à graco quod eft comeflatum ire cantantes, 
confuetum eft ibi quog ficut in facris Liberi reprehenforia carmina recitari, fed qua non reprehenderent nifi vitia agricolarun \& médicorum hominum quorum ille erat conuentus maximè apud Gracos, etiam primum fuit lege con ceffum, ve quod vellet Tragoedia frue Comodia quodam quafi ludo, falla \& faceta reprehenfione compofita \& dignitate orationis \& vilitate corrigédorum morum nominatim de quo vellet diceret:quod fuis téporibus profuit multum; quium vnufquilọ caueret culpá ne publico lpectaculo derideretur. Poftea veró quàm victor populus \& prius A thenienfis, poftmodum Italicus copit agros \& vrbes extendere $\&$ multitudine ciuium creuere factiones $\&$ vitia,tantóque poëtx pro materia vitiorum acrius reprehenderent vt etiam ad nobiles vfque confcenderent, nec folum homines improbos in repub.\& feditiofos, cæaterum non nullos virtute ac magiftratuú dignitate præftátes nulla laceffiti iniuria,vt Neui us fepenumero Metellos lacefferet atop vexaret,nobilitas indignata legem dedit ne quis nominatim reprehéderet quemquam. Horatius, Lufit amabiliter donec tam fxuus apertam In rabiem verti coepit iocus ac per honeftas Ire domos impune minax, doluere cruento Dente laceffiti, furt intactis quoque cura Conditione fuper communi: quin etian lex Ponáque data malo quę nollet carmine quenquam Defcribi. Hac lege fue poena quum aliquanto tépore filuiffent à con fuetudine prifca deterriti,nihil'g dictarent, rurfus aliud genus dictaminis ador ti funt: ibi enim Saryra fumpfit exordium qua à Satyris quos in iocıs femper petulätes deos fcimus effe vocitata eft, quidá aliunde nomen praue putant: Harc igitur Satyra eiufmodi fuit vt in ea duro veluti $\&$ agrefti ioco de vitiis ciuiũ ta mé fine vllo proprii nominis titulo,carmé effet: quod item genus comodį mul tis obfuit poetis quum in fufpicionem potentibus ciuibus veniffent, illorum facta defcripfiffe in peius ac deformaffe ftilo carminis. Hoc igitur malo coacti funt omittere fatyram \& aliud genus carminis, hoc eft, nouam comodiam inuenire: $\phi$ Græci quamquam impudentius, tamen conuenientius licere volue runt,cum viderét fuis diis accepta \& g tata effe opprobria, non tantum hominú verumetiam ipforum deorum in fcenicis fabulis, frue à poétis effent illa cóficta, Gue flagitia corum vera conmemorarétur $\&$ agerentur in theatris, atọ ab eo* rum cultoribus: vtinam folo rifu, ac non etiam imitatione digna viderentur, quale eft illud apud Terentium, dum flagitio Iouis optimi maximi adolefcentum nequitiam incitaret.Quid enim ingenui iuuenes aut virgines ipfefacient, quum hæc \& fieri fine rubore $\&$ fpectariab hominibus libenter cernant?nónne admonebuntur quid facere poffint, \& inflämabuntur libidine quæ vifu maximè concitatur? At Romani quàmuis noxia iam fufpicione premerentur vt illos deos colerent quos videbant fibi voluiffe fcenicas turpitudines confecrari, fua tamé dignitatis mèmores ac pudoris actores taliú fabularú haudquaquam hono rauere more Græcorú : fed artem ludicrā fcenámque totam in probro duxere, genus id hominü non modo honore ciuium reliquorum carere, fed etram tribu immoueri notatione cenforia voluerunt. Nam quáquam ibi actus mufici et pru dentifimi feculi dicta floruerunt, xtas tamen fubfequens mifcens ludicra prifcorú inuenta traxit ad vitia, \& quod honeftx caufa delectationis repertum era 
ad voluptates corporeas præcipitatis mentibus impulerunt: quo factum eft $v e$ paulatim honeftiffmx difciplinx improborum confortia fugientes, verecunda fe exinde confideratione fubtraherent: $\&$ confultè id quidem $\cdot$ Quid enim aliud quàn libidines edocent \& inftigant hiftronum impudentifimi motus, quorum eneruata corpora, $\&$ in mulierum inceffum habitum' $\$$ mollita impu dicas foeminas immodeltis geltibus mentiuntur? Quid de mimis dixerim? corruptelarum impudentixque omnis difciplinam humanarum rerum imita tione preferentibus, qui docent adulteria dum fingunt, $\&$ fimulatis ftupris eru diunt ad vera? quòd fi nullus fcænicis ad honores dabatur locus, confentaneum videtur vt ipfi poëtæe talium fabularum compofitores, qui duodecim etiam tabularum lege prohibentur famam lædereciuium, non minus quàm fcænici actores habeantur eiecti. Plato etiam quum recte formaret qualis effe ciuitas de beret quam finxit, quámque optimis moribus $\&$ optimo rei publica ftatu, tan quam aduerfarios poétas omnes (Homerum tamen excipiens quem honora biliter ad monet phanum ei conftituens \& vnguenta fuperfundens) vrbe pellen dos cenfuit, ne rectam opinionem de deo fabulis forte deftruerét, deorum iniu rias indignè ferens, animófque ciuium, taliü lectionefucari corrumpíque. Huic illud quoque apud Läcedæmonios perfimile probatur,qui A rchilochi poëtr li bros è ciuitate fua afportari iuffere, quòd eorum parum verecundam, parú continentem ac pudicam lectionem non virtutum femina fed labem quandam po tius \& iuuentutis corruptelam viam'q̧ ad obfcona fingula præftruentem arbitrarentur. His proximi funt qui auditum etiam mulcent, fed illecebris ac foedis amoribus referti, lafciuix omnis \& intemperantix legem præferentes : quales Marfum Pedonem, Aediuium Zetulicium, Portium Theium Lacedæmonium:Meminiun, Titydem, Cynnam, Cornificiü, Anferem, Hortenfun, Seruium, Gallum,Catullum,Caluum, Propertium, Tibullum, A picium, mulierem Lefbiam: Nafonemóp poftremo omniun lafciuifimum fue M. Valeriü Mar tralem: \& quicqurd Melicorum, frue Lyricorum, fue Dithyrambicorú erit hu iufmodi:quod dictú licentius ac procacius videatur: quum horum omnium libri potius Veneris militiam quàm Martis ftudium \& inftituta perftruere videantur. Molliunt enim fortiffimorum hominú a nimos dulcedine fua, \& ita mol lunt vt non legantur modo fed edifcantur: fićṕp ad malam rei domefticx difciplinam vitámque omnem quum accefferint neruos virtutis omnes elidunt . Sunt Epici alii qui fumma vi eloquentiæ carminíque pracellétia per turpia licet $\&$ in digna nonnunquam effluant : perplurima tamen ac maxima per cla riffimos duces bella memoratu digna fub honeftis rerum figmentis ac velami nibus ad varium optimúmque degend $æ$ vite genus propius videntur accedere. Hi funt qui fuppliciis \& poenis improbos homines variis terrent agitant' $\mathrm{q}$ terroribus, eos qui econtra iufti probíg, fuerint, \& ob patriam pugnando vulnera paffi, Quique facerdotes cafti dum vita manebat, Quique pii vates et $P$ hoebo di gna locuti:Inuentas aut qui vitam excoluere per artes, Quíq fui memores alios fecere merendo, puros, impatibiles $\&$ beatos in colum prouehivirtutum meri is, vel in campos quofdam fortunatos rapi hic vbi mira voluptate fruantur:

Hoc in 
Hoc in genere quùm multi nobis occurrant poétæ, omnium clariffimi Honterus \& Maro primi fe ingerunt. Apud illum nanque operæ preciú eft videre quæ prouifio ducum in bello, qui aut aftus aut fortitu do militum, quod infidiarum genus vel cauendú vel inferendum, quæ deinde monitio, quod conflium, quod genus Aeneas prælio Troianorü dux, Græcos magna vi pulfos in caftra redegërat: quumq́p audacius furgeret ac iam totum agmen obiiceret caftris, aduo lat ad eü Hector \& fenfim circun fpectég agere monet, affirmans eum qui exer citum ductitet, non tam audacem quàm cautum effe debere, quod quanti exiftimandum eft præfertim ab Hectore audaciffimo traditum, tute Sigifmunde tecum verfa atque peruolue. A pud eundem quogg poêtam Iris fue fomnus vt alii interpretantur, nónne ad Atridem miffus quum dormientem comperiffet, corripit eum verbis negatíg dormiend um effe, cui tot populorum, tot gentium falus cómiffa eft, ac tantarum denique rerum incumbit prouifo? Poltremo quum rebus dubiis \& afflictis fpectatores deligendi funt, qui noctis intempeftre filétio caftra hoftium penetrent, nónne Vlyxes inibi cum Diomede deliguntur,veluti confilium \& auxiliü, veluti mens \& manus, animus quoque \& gladius?Quifquis igitur concionator aü imperator fümus effici voluerit, Achillis aut $\mathrm{Aga}$. memnonis fe fimilem fieri cupit, is fe in huius poëtx difciplinam tradat,librǘp de manibus nunquam deponat, quod ab Alexandro ficut ex ipfus pcipi poreft epiftolis factum fuiffe proditum eft. Is enim rex difcendi legendi'ç auidus, Ili $\Rightarrow$ adem in qua rei militaris viaticum exiftimare folebat \& appellare, $A$ riftotele exponente perdidicit,eam femper vnà cum pugione fub puluino iacentê tenere folitus, qui itidem quanti eundem poëtan facere vifus fit, ex hoc maxime liquet: hic enim quum inter fpolia Darii regis deuicti vnguétorum fcrinium re periffet auro gemmífque expolitum ac eius fcrinii varios vfus amici oltêtarent" immo inquit librorum Homeri cuftodra detur,vt preciofifimum humani ani mi opus quàm maxime diuiti opere conferuetur. Apud hunc verỏ huius quem modo diximus Homeri in omnibus ferè emulü Maronem, deeffe quid poteft? cuius poêfim nedum viaticum, cæterum totius penè rei militaris effe difciplinam non dubium eft, in belli tempora pacíque diuifam? Quod etfi fatis diuia ni operis eius conftet initio, apud cos tamen qui mentem eius enucleatius perfcrutantur potifimom eft intueri. Nam fi militaris iufticix formam et tremendum confulis imperium ab eo quxris, occurrit tibi ilico in primis Brutus, deinde Torquatus rigidis fafcibus, immo fruis fecuribus in filios patriam \& rei bellicæ difciplina acerrime vendicantes. Si fortitudinem, aderit Horatius Cocles qui pro ponte fuplicio ftans, minitantem Porfennam exercitúque eius qui grauiffimo bello Romanos vrgebat, aufus elt $\&$ potuit dum pro falute patrie di micat donec pons ipfe folueretur à tergo in arcëdo holte fuftinere. Si luedis periculis publicis priuata piacula, Decii prafto funt, vt illis cadétibus \& iran de orum fanguine fuo placãtibus romanus liberaretur exercitus.Prætereo Camilli victoria de Gallis, Colfi clariffime res geftas. Fabricii 8 Curii victus tenuitatem corúmque duritiam \& continentiam, Fabii moram et plurima huiufmodi in bello \& pace non minus egregia mentem fubeuntia: qua onnia poétam no 
bilem minime latuere dicétem, Interea mufis animus dum mollior ętas, Et quze mox initure legas, nec definat vng̈ Tecum graia loqui,tecum romana vetuftas. Antiquos euolue duces, affuefce futuræ Militix, Latium retro te confer in equü. Libertas quafita placet, mirabere Brutú. Perfidian dãnans Metii fatiabere po nis. Trifte rigor nimius, Torquati refpice mores. Mors impéfa bonú, Decios ve nerare ruentes. Vel folus quid fortis agat te póte foluto Oppofitus Cocles, Muti te fláma docebit.Quid mora profpiciat, Fabius:quid rebus in arctis Dux gerat oftendet Gallorum ftrage Camillus. Difcitur his nullos meritis obfiftere cafus, Prorogat æternam feritas tibi punica famam Regule, fucceffus fuperent aduerfa Catonis:Difcitur hinc quãtú paupertas fobria poffit, Pauper erat Curius regem quú vinceret auro, $\mathrm{P}$ auper Fabricius $\mathrm{P} y$ rrhi quú fperneretaurum, Sordida Serranus tiexit dictator aratra, Luftratæ lictore cafæ facel' $\not$, falignis Poltibus affixi,collectæx cófule melles, Et fulcata diu trabeato rura colono. Præteriës ita q̧ reliquos ex noftris, exterorü nonnullos Tirtheumóp Lacedæmoniorú poëtam ac ducé dicam imprimis, cuius cópofito carmine $\&$ pro cócione habito, tãta vi animorú deuictis Meffanis deniqg cócurfum eft, vt rarò vnquã cruentius praelium exarferit, tametri antea cóflictibus Lacedæmonii à Meffanis fufr metúǵ periculi propterea territi,certamine defiftendum arbitrarêtur. Thucydidem prate rea „nónne quém imperatorë Athenienfes in exiliū egere Tragodiarum conditorem reuocauere, deinde maxma bellorú tépeftate permoti?duos duces non $a b$ re delegere, Periclem fpectatæ virtutis virũ $\&$ Sophoclem Tragodiarũ fcriptorem?qui diuifo exercitu \& Spartanorú fines late populati funt, \& multas Afræ ciuitates Athenienfiú imperio adiecerunt. Quid Diopité, \& Meneftheum, Leofthenem \& Charedemu fubticeo? nónne his artibus \& rei bellica peritia amplitudiné adeptos fcimus, tempub. Periclis, Ariftidis \& Solonis more gerédo?vt pote omni ex parte abfolutam \& vtrinque excultã \& idoneâ? Quifg; enim horum virorum videbatur, vt inquit Archilochus $\&$ Mauorte deo grarifo Helicone camænis, Affiduus cultor munus vtrunç tenens. Apud agreftiores denique barbaros et nationes nónullas, vt apud Galatas, tanti funt poéta, atque fapi entix cedit ira, Marsóg reueretur mufas, vt quum inftructa acie exercitus eductis enfibus iactil"q iaculis propinquant, non fetum amici,verum holtes quo. que,eorum interuentu à pugna conquiefcant.

De Mufica $O$ in quo cum re Iilititri commercium eius fit.

Cap. IIIr?

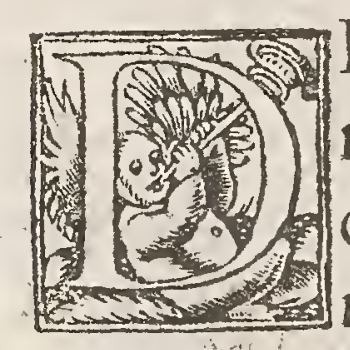
Ifciplina autem cantuum \& modorum quam muficen dicunt, non minns in ftudio erat quàm dicendi emulat io ac nitor. Iṕa nanq̧ mo dulis fuis \& numeris, inftitutio erat ad ingenuos animi mores ratiopetum quafi furenté atọ ftrenuum inducêdum. Etenim quum hrc ipfa difciplina fit in modos fiue tonos, numerosíg diftributa, repente vt diffimilium concordia quả harmoniam vocant diftinguitur: fic audientium animi difponútur ad vnum quéog ipforü, ad a lios quidem cópofitè et mediocriter, vt ad Doricum quem fatentur omnes conftantem ac firmü effe, morem'ó cötinerevirilem prudentia ac caftitatis auctorem:ad alios violenter, vt ad eum qui $P$ hrygiuseft, qui 
\& ita excitat, dißtrahit rapitóg animú ad pugnas, votúg furoris inflámat,vt vix apud fefe videatur, quéadmodú de Pythagora fcriptú eft, q violétosac debacch tes adolefcétes fub huiufmodi fono incitatos, fpódeo fuccinente, ad compofrtx métis ttanquillitaté reddiderit. Nam quú mulieris cuiufpiá dilectę domú vellent amburere foréfque perfringere, vbi $\mathrm{P}$ ythagoras intellexit tibiarum $\mathrm{Phrygiiq}$ modi fono adolefcentes raptos furere, $8 \mathrm{r}$ multorum perfuafionibus coptis nolle defiftere, mutari modum pracepit, atç ita tarditate modorum furenté illorum petulâtrã cófedaffe. Simili mod o de Timotheo Milefio inuulgatú eft, qui quum in Alexádri cóuiuio effet et hunc qué Phrygiü diximus modularetur,vfq̣adeo regé excitaffe fertur, vt ad arma capiéda profiliret,atģiterủ ad comeffatores epu láf̣̂ reduxiffe, modulatione mutata. Eúdem etiā ferüt Alexandrü Xenophöte canête manú ad arma mififfe. Süt et modi alii diuerforũ etiä idiomatú vocabulis defignati,ut Acolius, q animi tépeltates fedat, [ónúópiam placatisattribuit.Ia fius, qui intellectú obtufis acuit et terreno defiderio grauatis cæeleftiú bonorú appetetı operator indulget. Lydius, qui cótra nimias animæ curas tædiáọ repertus, remiffióe reparat et oblectatioe corroborat, Itridé enim et in numeris dicêdü, quũ et alii moré contineát grauius, alii verò cócitêt, alii liberaliores, alii violêti ores afferāt motus, quo fit vt morủ animorǘq̣ maximæ mutationes fiãt. Nam f numéri modióp ad métem vfop peruenerint, æquèanimú atọ ipfi funt afficiant neceffe eft.Ideo lafciuia mollis diffolutáç més mollibus \& impudicis modis de lectatur,afperior rurfus durioribus gaudet, mediocribus auté que manfueta, ex quo internofci potelt, quãta fit nobis cognatio cú harmonicis modulationıbus, quú et multi quoop fapiêtum dixerint, alii quidé aninã effe harmoniam, aliive

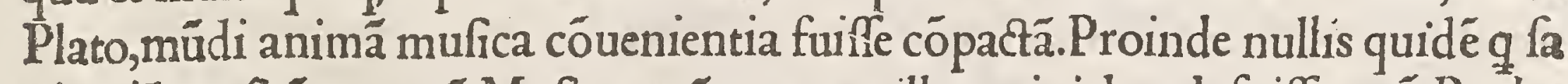
pientiā profitêtur, curã Muficæx quãtum ętas illa recipiebat defuiffe, quú Pytha goras inuétor atक eú fecuti aliquot præcipui philofophi, imbibita \& affupta à veteribus opinione cuncta cỏpleuerint, müdü hüc quatuor elemétis ea refonantia effe cófectũ quã poftea fit lyra ad fimilitudinem veræe teftudinis imitata,cuius Mercuriü quog neruis trium chordarú,triũ anni téporú inftar, repertorem tradunt. Tres enim inftituit voces, acutã, graue, $\&$ mediâ. A cutam ab æftate,ab hyeme grauē,à vere autủnóg̣ mediä,tantáq proinde vtiliffima procuranté $A$ ftronomi inter ftellas requirédã efle putauerunt, perfuadëtes cæleftë effe muficã, quảdolyræ formã cóprehendere potuerür inter fidera collocatả. Detractoribus auté \& humile et a biectú huius difciplinæ exercitiú effe dicentibus, $q$ aiunt for didos homines ac viles muficä exercere, haud quaḡ difficile êt refpōdere, fi fpeetetur quibus modis $\&$ inftrumétis, et quoufq illi indulgendú ab his $q$ ad virtu

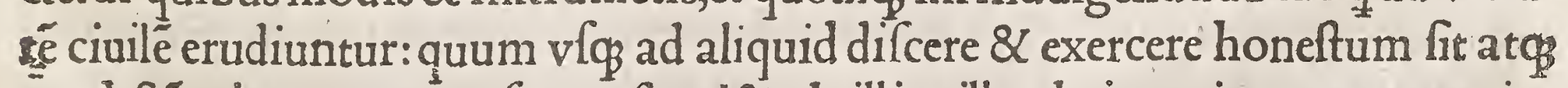
modeftü,ad extremum vf $\$$ profequi \& ab illius illecebris capi, turpe atque indecorum: \& quum nihil vetet modos quofdá et inftruméta muficæ illud quod aiüt efficere, clarú eft oportere difciplinã eius neog imped iméto effe cæeteris operatióibus, neque corpus molle $\&$ inutile reddere ad bellicas ciuilef'óp exercitationes: quod vtigg fiet, fi neq̣illis tëporibus multú impartiemur, qux ad certa mé ar tificii pertinent, neog circa admirabilia quadam $\&$ fuperuacanea, fed cò vique

$$
\text { C ii vt }
$$


vt gaudere valeamus probabilibus modis, et non cómuni fenfu muficæ folû vê turba vilium feruorü, ac puerorú. Quú autem fonorum qui materies cátilenaxũ funt, triformé cóftet effe naturä, quod triứ mufarú nnmerus efficit, quú aut fci licet voce editur,ficuti eorú eft qui faucibus canút:aut fpiritus, ficuti tubarum \& tibiarú: aut inteffone \& pulfu, ficuti in neruis et citharis et ty mpanis et quibufdã aliis qua cócaua feriédo canora funt,ex his qui fit voce modus quàm decés fit quấq́ ingenuis progredi in ea liceat,ex Philippi \& Catonis fentetia intue ri licet. Hic enim quia frbi vifú eft bene cãtare nō ferii hominis effe, nimirü $M$. Senatoré nó ignobilem, fpatiatoré et fefcemium vocat.llle verò in inflitutiöe ad filiü, quü eum accepiffet fuautter quodam in loco ceciniffe, vrbane eft obiurgatus: Non te pudet inquiés $q$ ita pulchrè canere fcias? fatis eft enim regi, canentibus audiédi ocio fupereffe : at pmultú quidem videtur impartiri mufis, fi cæteris his de rebus concertátıbus fpectatorem ipfe tâtum fe prabeat: quum nec lus vnquá ingenuus adolefcens quú ipfe loué fit intuitus, Phidiā fe fieri cócupiuerit,nę̧ Polycletú: etfi vehemëter eorú opera fit admiratus. Et quang̈ hoc ardens muficx ftudiū non horü quos modo diximus duorü principú métes incefferit, iuuafit tamen \& occupauit aliquorú animos peffimorü, Caii maximè quî adeò cãtandi voluptate efferebatur vt ne publicis quidé fpectaculis tempararet. L.Sylla vir tâti nominis"optime ètiá cătaffe dicitur. Nero quá vocis curã habuerit cóferuâdx vel angendæ, nemini quidé mediocriter erudito in dubiü venit, neơ ab his id iniuria factú quifpiā forte dixerit . Eft enim haud dubie muficæe pars hęc potens multú et effectus eius fupra fidé varii, quú multos ad laticiấina nem, ad amatoria carmina, ad reliquas voluptatis illecebras, multos ad virtuté, fanctū \& deuotú gaudiú, piáfọ nonnunquá lachrymas moueat: quæ varietas in diuerfas fententias magna etiâ fanctorú patrú traxit ingenia. Nempe Hieronymus canêdi fududiú improbaffe vifus eft, cum inquit, deo, nó voce, fed corde can tatur: nec in tragœdiarú modũ guttur $\&$ fauces medicamine leniend $x$ funt, vt in ecclefia theatrales modi audiantur.Vnde fit plerúg,tefte Gregorio, vt in facro minifterio, dú blanda vox quæritur, cógrua vita negligatur,\& câtor miniIter deú moribus ftimulet, quũ populú vocibus oblectat. A mbrofius pietatis appe tés, vt caneretur inftituit. Athanafius vanitatis fugitás, canédi viú in ecclefiis eú approbat, qui tam exiguo vocis flexu fit,vt pronunciâti vicinior fit: ne volupta tis, aut vanitatis,aut lafciuiétis \& proftitutę vocis luxu affectúq riâtur animula. Auguftinus difficile hinc inde fibi negotiú dubietate exortum intuens, ita fluctuo inquit inter periculú voluptat is \& experimentú falubritatis, magílọ adducor nó quidé irretractabilé fententiá proferens, Cantâdi dico con fuetudiné a pprobari in ecclefia, vt per oblectamenta aurium infirmior animus in affectú pietatis affurgat: tamé cum mihi accidit vt me amplius cantus ḡ res qux cantatur moueat, poenaliter me peccare cófiteor, \& tunc mallem non audire cantantem: quanquãa alio in loco aperte denunciet, nos nó propter fuperfti tionem prophanorü debere muficáfugere, fi quid inde vtile ad intelligendas facras fcripturas capere potuetimus, nec ad eorum theatricas nugas couerti fi aliquid de citharis $\$$ de organis, quod ad fpiritualia capienda valeat, difputemus. 
Neqgenim $\&$ literas difcere non debemus quia earư deum dicunt effe Mercurium, aut quia virtuti iufticix têpla dedicarût,et qux corde geftáda funt in lapid ì bus adorare maluerunt, propterea nobis iufticiæ virtus fugiêda eft. Qui veró exs fpiritu et ore fit modus, nó aliter improbâdus nobis erit, ac de Minerua \& Al cybiade rationabiliter teftãtur antiqui. A iuntenim illâa tibiarú reptricé eas abie ciffe, ob deformitaté oris infenfá: huic verò ab auunculo Pericle trbiarú ftudio tradito fimiliter obtigiffe,qui quum ab infigni tibicine ad ipfú accito, oblatas tibias ori applicuiffet, \& collecto fpiritu genas inflaffet,animaduerfa vultus de formitate erubuit, $\&$ abiectastibias a pernatus fregit, meruitóp tenera licet ætate exêplo effe,vt totius populi confenfu ex tunc Athenis tibiarú vfus qui poft vi ćoriẩ côtra Medos aflupptus \& receptus adeò fuerat, vt ingenui omnes addifce rent,improbaretur.Nec Athenienfiú modo, nec veteris illius celebratiffimę quó dã Græcix qux pớt tellus I tala eft, virorú illuftriū folum, fed maiorú quoqg noftrơü,multarum'q̣ aliarú nationũ $\&$ populorum fides $\&$ tibias folennibus epu lis, choris, $\&$ cốcionibus adhibere veteris inftituti fuiffe côperio, quum illorú laus des qui fortiter pro patria occubuiffent,et eorú vituperationes qui metu id age• te detrectaffent, cãtu $\&$ tibiis prolequerétur: quippe quę etiā ludis pariter communes \& luctibus. Ouidius, Temporibus veterü tibicinis vfus auorum Magnus, $\mathscr{Q}$ in magno femper honore fuit.Cantabat phanis,câtabat tibia ludis.Can tabat moeftis tibia funeribus. Et quanq a ab ingenuis \& grauibus illis ad meribi bulos quofdã helluones leuiffimos \& fordidiffimos eft huiufmodi tibiarũ ftudiư $v t$ antea forte prolapfü, apud multas tamen nationes $\&$ bellicofifimos populos in côferédis bellis, veluti difciplinã quandã militaré fuiffe,multorum côftat exemplis. Spartiatarú enim militia imprimis ad modú ac tibiā proficif́cebar̆, nee adhibebatur vlla fine modulo anapafti ped is cohortatio . Itaqgillorú afpectus pulcher erat \& formidabilis:qui \& numeris ad tibiā incederent, neq̧ phalâgis ordinê mifcerent, nę̧ animis turbáretur: fed manfuete \& hilariter à módulo in difcrimê inducerétur, quum certú videatur, neọ̧ metú neq̧ furorẻ nimiú illis ori ri poffe qui ita fe habuerint, fed firmã porius \& côftãtem animi magnitudine fpei audentix́ǵ a dmixtã. Nec aliter Lydos Halyacte etiā rege fuo bellü Milefiis inferête inire prelia folitos accepimus, quú nó folü inter pugnã̃tis exèrcitus aci. es tibicines habuerit, fed fiftulatores \& fidicines, quod Cretenfes itidé non tibia fed cithara quafi magiftra ac duce fingulos eorú bellicos actus regéte non $a b$ re feciffe memorãtur. Nã veluti Laconicus ille poëta inquit, Serpit et in ferrum ci tharæ fonus ipfe canorz. Et quid aliud in noftris legionibus litui fue cornua, tubæ, claffica, buccinæ frue tym pana fibi volunt, quàm vt his in bello \& progreffioni \& item receptui cãtetur: aut nimis remiffos excitädo, aut plus iufto cỏ citatos reuocädo?quod poëtarum maximú minime fugit dicétem, Aere ciere vi ros Martémqg accendere cãtu. Nec cantu folum accédi remittiọ virorum animos conftat,verum equorum, quibus docilitas tanta eft, vt vniuerfus Sybari tani exercitus equitatus ad fymphonix cantum faltatione quadam moueri 8 excitari folitus inueniatur. Caterum Sigifmunde Pandulphe qui ex pulfu et fit dium intenfione fit modus quo pacto in eo quifog agat, plurimum refert . Nam C ii frvt 
fi vti tu tecum aliquando foles fapientiflime princeps poft magnas curas, difficiles $\&$ illuftres bellorú occupationes relaxâdi ac reparädi animi gratia, vel amicorum vel propter virtuté quis agat, nö illiberaliter fed modeftè ab his aliquid voluptatis affumet:nec abfurde hanc muficx parté bellice fortitudini coniunxiffe te quifpiâ admiretur, Mercuriû maximè imitãté qui Palæeftram docuit \& ly ram primus inueuit: qui verò id ipfum propter alios vt audiêtes oblectet fape vti videbitur, turpiter ac indecorè agere, quü finis cuius fit gratia improbus fit 8 merito improbádus vfus, nec aliter qu quonsodo multa inftrumétorú antiquo rú improbata funt, veluti Pentades \& Barbiti \& qux ad voluptaté audientium intédebant, et heptagona $\&$ cuncta qux indigent perita manuú gefticulatione. Itaç profitendú puto nó hẩc qua iftis inftumétis cófumitur omni dedita ope ra pracipi, \& qux in theatris olim \& in fcrnis effominata \& impudicis modis, infracta non ex parte minina, quæue nec fera nec varia fit, fed fimplex, morata,

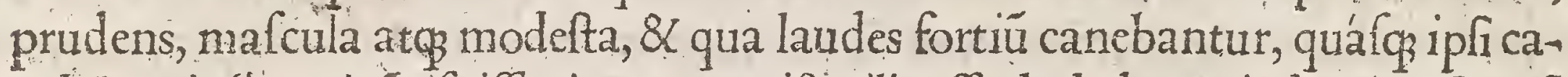
nebāt,cuiufóq qui tü fuiflet ignarus quifq sille eflet habebatur indoctior.Quod Themiltocli attico, Græcorü impera tori clariffimo eò quòd lyrâ inter epulâdú recufaffet accidiffeCic.teftis elt. Epaminúdã verò Thebanú hấc fortaffis infami am declináté pręclare fídibus cócinétem accepimus: et Achillen Homerus inducit à pugna redeutê in hac re acquiefcere folitú, non amatoria quidem fed virorü fortiü gefta modulatem. Ouidius húc nó modo fed Alcy dẻ fidibus doctü, muficifo iftitute difciplinis his verbis expreflit, ,lle manus olim miffurus in $\mathrm{He}$ ctora læto Creditur \& lyricis detinuiffe modis. Venerat Alcydes exhaufta parre labo rú, Iuffạg reftabant vltima pene viro. Nero verò quátum ftudio citharaz deditus fuerit, incredibile dictu eft, cú neq quicö omitteret eorum quę eius generis artifices ex induftria factitare folent. Id verò eiufdé ftultú penitufợ ridiculü, q nocte illa qux fibi vitæ fuit vltima in terris, inter querelas quas vicina mors \& præfens metus doloŕç dictabãt, crebrius atque miferabilius, nó quód tantus princeps, caterú quòd tátus muficus deperiret defleuit infoelix. Multa præterea poffent Adriani, Alexâdri, Seueri et aliorü maiorú exempla in medium proferri, fed vereor ne fi fuero in tạliü enumeratione diutius immoratus, aut oblitus effe propofri videar, aut crimen loquacitatis incurram.

De Arithmetica or militari Geometrid.

Cap. $V$ :

N. I Inum et confentaneum propterea vifum eft eas difciplinas attinge(o. (1) re qux Geometricis numeros rationibus \& multiplicationes habent I. (3) notas. Magnú nanģ adiumentú afferunt ad eorü qux fupra nos fứ - vím naturamọ́ éxplicandă, maximü ad ea que infra, vt ad locorúinterualla,ędificiorúğ magnitudines, profunditates a quarü,inftrumétorü quorun dam infra fcriptorú arte dimetiédas: quả rem vt eft hominú genus nimis folers atç folicitum, Chaldxi primi inueniffe et Acgyptii nó diffimili feruore calen tes tranftulifle memorätur, qui rationê huius difcipline generaliter colligétes ad hxc omnia qua diximus quicquidue poteft formis generalibus cótineri aptam ita effe docuerunt vt ea fine nihil horum poffit ad agnitionem veriffimã perue nire. Eudoxum etiã \& Architä inchoaffe variis eä formis $\&$ celaturịs illuftrãtes memorie 
memorię prodituinuenimus. Hi enim artis obfcuratis fub pectoribus ingenii latétes rationes, obductas propofitiones demôftrationefóp per fenfum ac infturumétorum exépla inuulgarunt, ambo in cöparädis produxerunt inftrumétis, femifcriptis quibulda lineolis figurifóp geometricis nachinameta förmâtes. Quo circa in eos moleftè cócitus eft Plato $q$ doctrina huius tâtę dignita té ac prę̂ãtua fuftiliffent, qux à cogitatione \& rebus incorporeis ad fenfibilia quędã prolapfa effet;quafi ad fui vfü corpore \& mercenaria indigerec inertia. In qua re operofă porro ac mirificâ quọ A Archimedis \& Scopine Siculi Syracuís induftria à nominatiffimis artiú fcriptoribus fuiffe fpectatã atọ probatã nó ambigimus. Multa nang organica \& gnomonica numero naturalibufịg rationibus inuen. ta atọ explicata pofteris reliquerunt, maximąa fibi gloriâ prę cæeteris vindicâtes. Arçhimedes præcipue, ærei côcauióp orbis \& globi cæleftis inuétor. Erat enim ea tépeltate obfeffis dura obfidione à Marcello Syracufis, vir ille huius difciplinæf fudio ante alios omnes $\&$ doctrina præcellens : admirabilior tamen artifex fabricatorọ́ muraliú ac bellicorú tormëtorú, quibus varia milfilium genera $\&$ immenfex magnitudinis faxa incredibili fragore \& celeritate iaculata vexant holtes, leuíg monéto labefactâtur muri \& moñia quâtiutur, quibuf'óg vfus ad obfidioné patrię propulfä̀dá aduer fus romanú exercitú \& Marcellú ducé vnus Archimedes.ex täte vrbis ciuiu numero haud dubie tardiore effecit. Quam tar ditatếquú Marcellus tandé vrbe potitus viétorię fuę magno impédiméto fuiffe cóperiffet, eius tamé èregia opèra delectatus, quú eam vrbé diripiédá permitte ret difcurrentiu militú furori, vinu de tot milibus ciuiu vita donatum excipit $A$ chinedem, pluris illü merito quàm vniuerfü populü faciens: Ceterú in tanto tumultu quátuș captæ vrbis in difcurfu effe poterat; dú artis fux lineamétis \& for mis quas in puluereille defcrip ferar totus incubuit, introgreflus interea vnus ex militibus Ro inter rapine-fitim \& imperatorii præcepti menoria hęfitabüdus, Rtricto mucrone fupra verticê cogitâtis vt nomen fữu ederet iubebat. Sed is cui oculos atø̧ aures ingens animi cura cócluferat,ferociter percunctãti et quifnam is eflet feifcitâti,certum aliquid refpondere nó curans, oppofita quin immo tan tum manu ne pulueré fibi fuum cofunderet obfecrans, militi cótemptione ira to trucidầdi fui caufam præbuit. Cuius mortis mifertus dux Ro.immunitatem fruftra fibi deftinatâ in affines eius trâftulit fibiọ̣ quod vnicú fupererat fieriọ̧ potuit, funeris ac fepulture curam exibuit. Huius etia fepulchrü fphæra \& Cylindro in fummo eius fculptú \& incifum multo pòtt tempore difiectum \& fuis etian ciubus incognitum inter denfffimas vepres obftum fe reperiffe et ignorantibus indicaffe dum in Sicilia quxftor eft Romani princepséloquii Cicero gloriatur. Hoc itaç modo hifog auctoribus oblabantem paffim \& inuulgatan artis huius imitationem fabricandorum induftria machinamentorum à Geo. metria delapfa conficicitur, ac diutius philofophia neglecta vna militaribus ac nochanicis artibus inftrumentis eiufmodi enumerata fecernitur. 
Per vmbram quoö,turris vel erecti ft: piris eorủ altitudo deprehéditur :

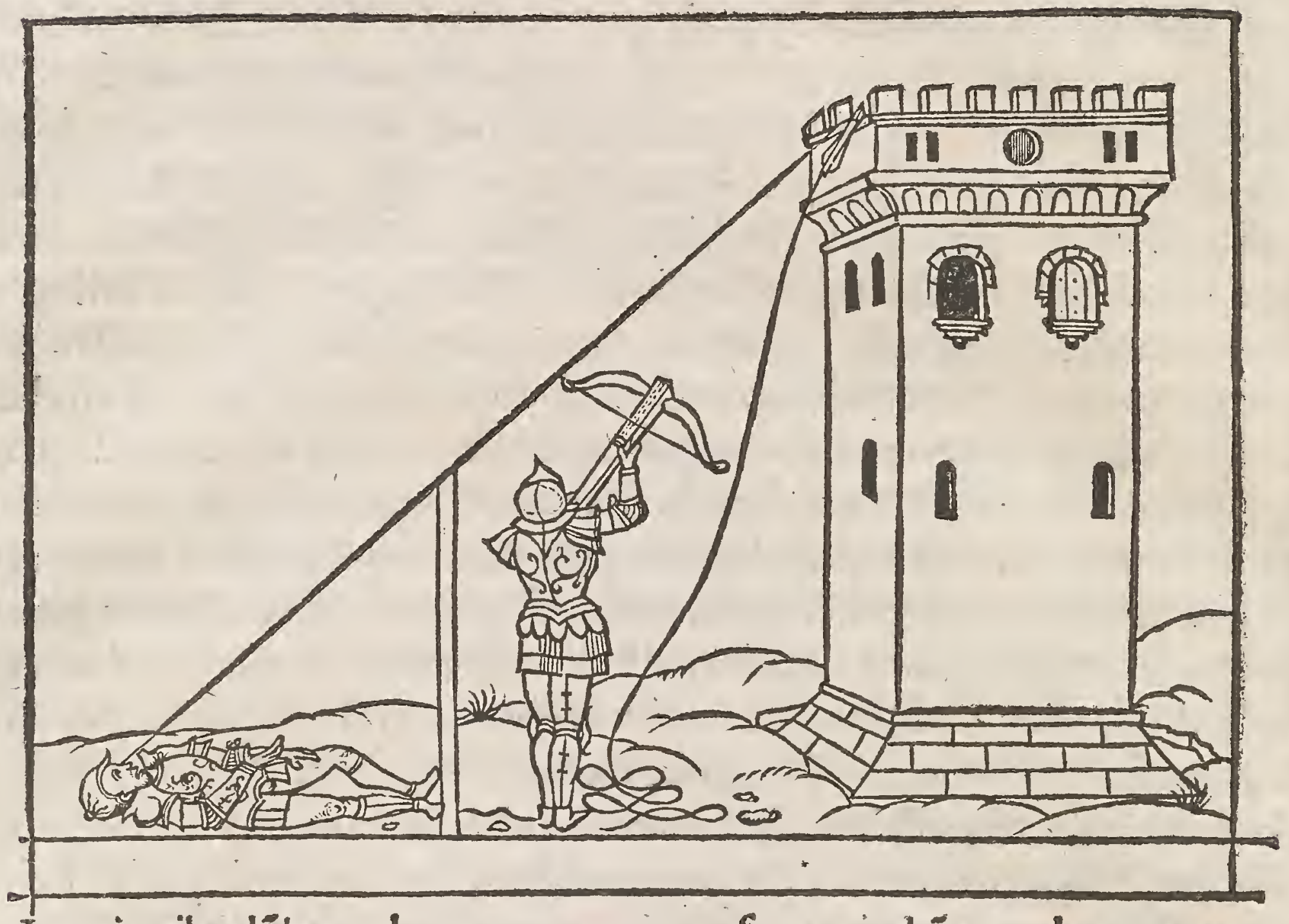

Inanis pila plübea vel ænea, manu cum ferrea, in húc modum, qua in aquâ demiffa cötinget in profundü trahi: quod vbi tetigerit, mox refliens furfum a cëdet. Vbi igitur immergi coperit,cóputa in merfi one ip fa téporis momenta, móxque lanceam demittens, pedum alei. cudiné vel cubitorú quảtitaté dîfribue, \& fanè quod in minori aquz fuerit inuétú, in oi maiori copia index tibi ac certiflim

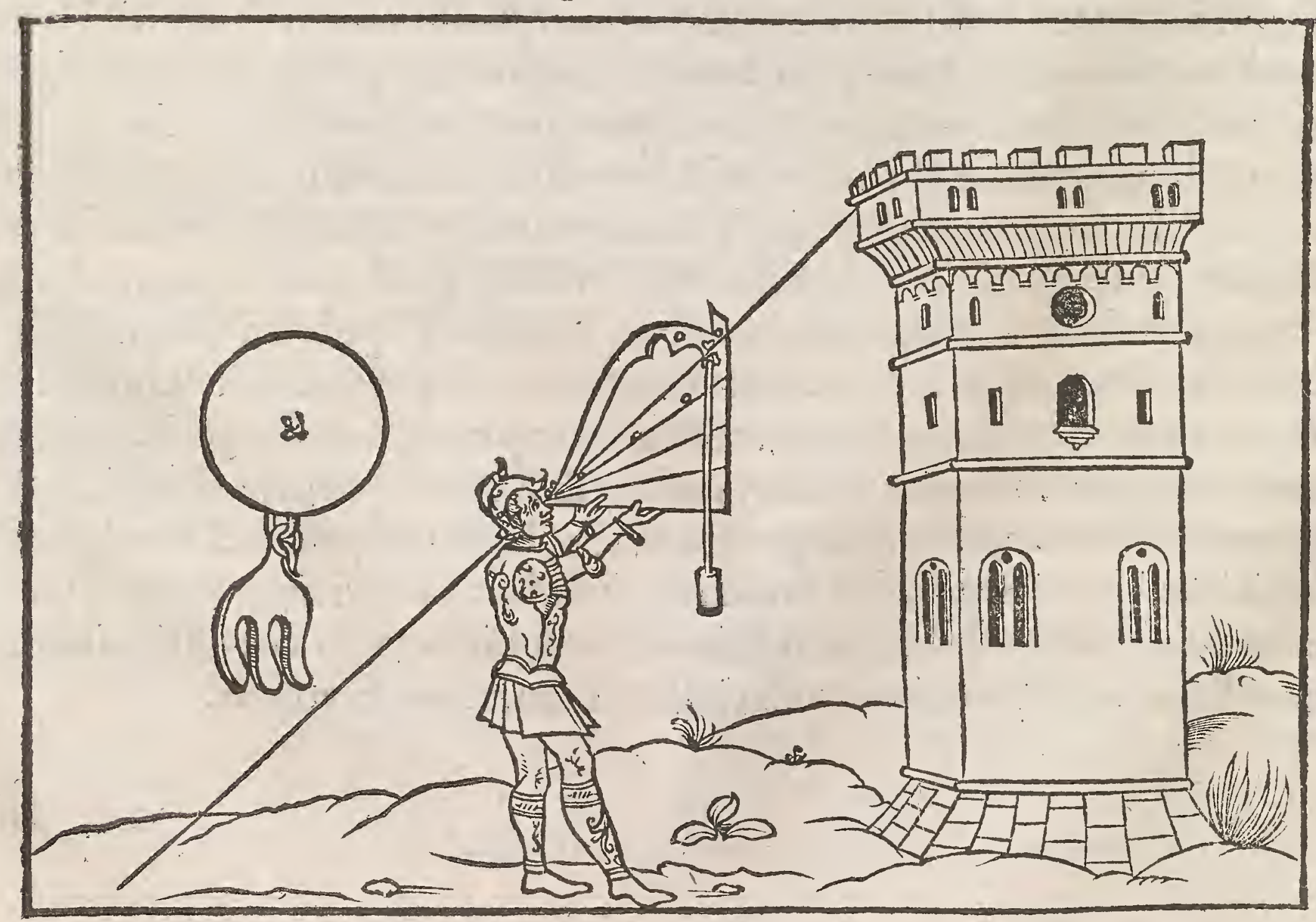




\section{ROBERTI VALTVRII}

A D IL LVSTREM HEROA SIGIS.

mundum Pandulphum, de re militari

Liber Tertius.

De Aftronomia uariäque perquirendorum futurorum arte $f$ q qud eff.

\section{क⿺辶万}

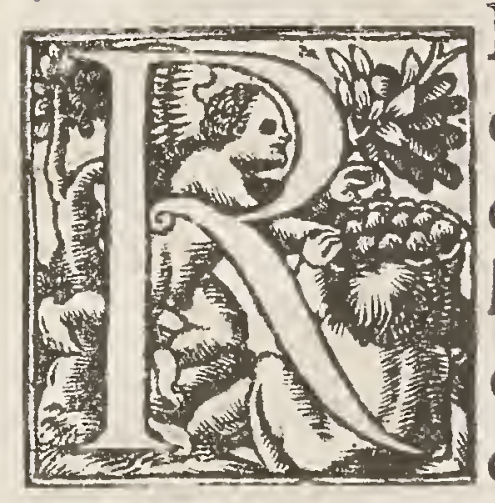

Eftat autem nobis, Sigifmunde Pandulphe,profundiffimam quandam Mathefeos, hoc eft, aftronomicæ rationis tradere difciplinam, quam multi opportunam maxime putãt ad bellorum futurorum euentus denunciandos. Hanc nanque inter cæteros fi non docuit, fectam tamen erroris attigit Lucanus, quum timoré Vrbis defcriberet, bellúmog ciuile neceffariis huus defciplinæ argumēntis ineuitabiliter appropinquante Cælare futurum de nunciaret. Innuit enim poëta doctiflimus, fi tamen poëta dicendus eft qui vera narratione rerum geftarú ad oratores vel hiftoricos magis accedit, Saturni ma litiam quú folus in fui domicilii throno refideret emouendam fore, quú in quit, Quod cladis genus ò fuperi,qua pefte paratis

Sxuitiam? extremi multorum tempus in vnum

Conuenere dies, funmo fi frigida cælo

Stella nocens nigros Saturni accéderet ignes,

Deucalioneos fudiffet Aquarius imbres,

Totág diffufo latuiffet in æquore tellus:

Si fæuum radiis nemaum phøbe leonem

Nunc premeres, toto fluerent incendia mundo,

Succenful'op tuis flagraflet curribus æether,

Hi ceffant ignes, tu qui flagrante minacem

Scorpion incendis cauda cheláfós perüris

Quid tantum Gradiue paras?nam mitis in alto

Iuppiter occafu premitur Venerif'ó falubre

Sidus habet, motúǵ celef Cyllenius hæret,

Et cęlum Mars folus habet,cur figna meatus

Deferuere fuos,mundó obfcura feruntur?

Enfiferi nimium fulget latus orionis

Imminet armorum rabies ferrióp poteltas

Confundet ius omne manu fceleri'g nephando.'

Nomen erit virtus, multol'op exibit in annos

Hic furor.

In hac igitur rerum altiflimarum contemplatione fi quid huiufmodi occurset quo talium curiofi, ftellarum veram poffint affequi pofitionem, vel qualitatem prafcire temporum \& f peculationis fux iocundiflimum fructum capere, tanta 
compleri videntur voluptate vt noftra hęc omnia externa præcipue,ac fortunz munera qux finguli tanti faciunt tanquam exigua $\&$ minima ab eis contem nantur:Ex hac enim reliquáque perquirendorum futurorum arte, fi modoars vlla eft, potiufă vaniffimum cuiufọ ludibrium, clariffimorú philofophorum fummorum'ş virorum conflictari videmus ingenia: nãọ Democriti totius pe nè terrarum orbis peregrinatio fuit, patrimoniíg ampliffimi diflipatio, Platonis Diogenifóp captiuitas \& Pythagoræ longa ad varias gentes peregrinatio. Holtanes verò \& Enpedocles ad rabiem non auiditatem modo eius percipien dx gratia nauigauere, exiliis verius quàm peregrinationibus: hanc reuerfi prædicauere, hanc in archanis habuere: quáquam animaduertam præter hos fummam quog literarum claritatem gloriamóp ex hac ipfa abditarum perueftiga tione rerum antiquitus, \& penè femper fpectatam atọ petitam. Talem dico Milefium Anaxagoram, Clazomenium Xenophanem, Colophoniú Eudoxú,Callifum, Melonem, Philippum, Euchemenonem, A ratum,Hipareú:adde his Socratem,Zenonem, Dicearchum peripateticum, Cratippü, Cleantem, Chryfip pum, Antipatrum, Poflidonium atq̧ Panætium, plurimof'ọ alios quorú voluntaria paupertas, iniuriaru m contumeliarun'ó perpeffio, laborum præterea, itinerum, vigiliarum, algoris, æltus, inediæque fufceptio memoratur: proquibùs eorum aliqui cultus $\&$ honores diuinos vel diuinis pares meruerunt, $\&$ omnes quam femp viui contemplerant, laudem, gloriam $\&$ immortalitatem nominis mortui confecuti funt. Nec verò folos philofophos in hac rerum futurarum cognitione tantum ftudii $\&$ diligentix contuliffe, fed omnes fere nationes, poten cifimas refpub, Imperatores quoog maximos, clariffimos reges $\&$ principes eadem mente $\&$ fententia extitifle, vt his fine quę futura promittút, qux varia mul ciformiâque funt, ad maximas rés gerendas nunğ fibi tutè acced endü putarent. In qua re primi occurrunt Babylonii et Aegyptii,qui quoniam neq domiciliis tegebantur propter aeris qualitatem, negs vilis in ea regione nubibus fubtexitur colum, folis \& lunæ varios curfus, $\&$ meatus fiderum ac effectus folo vfu egregie notauere atç inuenere, quum ea fapius ac liberius caeteris intuerentur. Chaldę deinde vnà cum Affyris diuina coeli obferuatione fümo fudio meditationéq fcientiam creduntur effecifle, qua maximè reliquis antecellerent:dicente Lucano, quis nofcere fibris Fata queat, quis probet aues, quis fulgura cæli Seruet, \& Affyria fcrutetur fidera cura. Arufpicum autem difciplina quo pacto in om nem Cariam diffufa fit peruenerítque ad Telmeffum, religofifmam vrbem, in his $\&$ in aduertendis oftentis curiofam atque diligentem non facile dixerim, nec qualiter tranfierit ad Theffalas vrbes : quan 2 ipfam Britanni tantis cerimoniis obferuaffe dicuntur, vt dediffe Perfis videri poffint, apud quos, Ma gos, doctiffimum hominum genus Aegyptiis antiquiores floruiffe Cicero teItis eft, \& Ariftoteles in primo de philofophia libro. Druides habuit quondam Gallia, religionum fuarum interpretes, qui de fiderum collique $\&$ terræ, mundi\& ambitu \& forma, de immortalium deorum vi, poteftate, \& voluptate differebant, \& auguriis partim ac coniectura quar effent euentura fe fcire profitebanrur, quorum difciplina quanquam in Britannia reperta atg inde in Galliam 
ranflata effe exiftimetur, pòtt tamen qui diligentius eam rem cognofcere voluerunt eò difcendi caufa profecti funt,vbi annos nónullos duo de viginti $\&$ vltrà confumpfiffe memorix proditum eft. Diuinatoribus etiam vtuntur $\mathrm{G}_{a}$ latæ, qui apud eos tum auguriis, tum facrificiis futura pradicunt, quíg plurimi exiftimantur, omni eis obtemperante plebe, quú verò de rebus magnis confulüt, mirabilem incredibilemóg feruant confuetudinem. Iugulât enim enfe homine $\tilde{e}_{3}$ quo decidente,tum ex cafu,tum ex membrorum laceratione,tum etiam ex fan guinis fluxu,ex quadam antiqua rerum obferuatione futura borunt. Gracia ve Iò,omnium bonarum artium nutrix, vt aliquò nullam vnquam coloniä mifit, fic quoq nullum belli genus $a b$ ea, fine fuorum numine deorum coptú aut fú ceptum eft. Quid Hetruria,nónne extorú inuentrix fuit, ac portentorú \& fulg rü interpres, híncque præterea vel à thure et facrificiis, vel à facrufico ritu lingua Græcorú Thufcia cognominata? Phryges prætereo qui auguria inueniffe cre duntur. Cilicum et Arabú,Pifidarú, deinde Pãphilize et Vmbriæ gétê miffam fa cio, huic vni cognitioni femper intentam. Hæc de variis gentium nationibus: Nunc nobilia rerum publicarum fubtexantur exempla imprimilog Athenienfum \& Lacedæmoniorum: hi enim augurem regibus fuis dediffe collegam \& affefforem, illi veró facerdotes quofdá diuinos, quos vt ait Cicero Mantes appel lant,fingul is eorum publicis concionibus prafeciffe dicuntur. Quotiens deinde S.P.Q.R. quum armorum crepitus è cælo auditus, quum prodigiofęlapidum, laterum,ferri,carnis, fanguinisóg pluuix in terram cecidiffent, quum clypei ardentes emicuiffent,cæleftes coronæ arfiffent, quum è forminis mutari in mares, quibus omnibus non minima reip.detrimenta imminere fperabantur, nónne his difciplinis cum Sibyllinis verfibus vfi perhibentur? neque his contenti, omnia quoque, quod omnibus in rebus plurimum conducere poffe arbitraban tur,agendorum fingulorum initiis, quod bonum, fauftum, follix fortunatum effet præfabantur. Calchãtem fcimus tanto honore apud Græcos habitum ob vnam aufpicii difciplinam qua profectò excellebat, licet aliis in rebus multis ef fet inferior, vt petentibus Ilion Graiis, innumerofiflima claffi præfectus memo retur. Amphiaraus verò \& Tireías tam illuftres eodem artificio feruntur, svt primum pro deo colerent, fecundus non modo viuis hominibus præferretur, fed defunctis etiam, Homero dicente, apud inferos Tirefiam folum fapere, vagarique reliquos vmbrarum more. Mopfus \& Amphilochus reges quoque in Gręcia auguriorü fama percogniti. Hic verò mirari polfe aliquos praclare video, vbinam fcilicet vrbis Romanx parentem augurem optimü omiferim: Sed piget reminifci,pudet cogitare vrbem Romam omnium terrarum indubitatum caput,aufpicio conditã et florenté porrò præpotétis populi fortunả auì bus credere maluiffe quàm deo, quú fub regibus\& imperio côfulari multis quidem freculis nihil abfog aulpiciis fieri folitum fit, neque comitia, neque Patrum prouocationes, nec equitum conflia aut peditú defcriptiones, nec tora deniq̧ res militaris. Stupet animus recolens viros illos tam celebres ac magnificos, aurum volatibus garritibúfog fuccubuiffe fallacibus: vbinä Martios dimiferim fratres apud vetuftiflimos romanorum hoc in genere celebratos, fed de his fateor nihil 
preter nomen habere me.Prætereo Caffandrä virginem, Priami regis fliam cuius illultris admodum \& nagnæ rei nuncius furor, Polybú deinde quédan Corinthium de quo eft apud Homerum $q$ multis Achiuorum Troiam peten tibus \& imprimis filio fuo, an furore an aliter incertum eft, morté prænútiauit. Ego autem om ne quod vel fabula eft vel fabulä redolet fciés volensq́g prætereo, Athlantem aftrologize fuiffe peritiffimum, dép fphæra primum inter homi॰ mes difputaffe, qua ex re vifus eft orbem fuis humeris fuftinere: Zoroaltrem ve. rò Bactrianorum regen quem primum magicas artes inueniffe nominatiflimi. teftâtur auctores, nónne vt Hermodorus etiam tradit \& Dion in quinto de phi lofophia libro, \& fui nominis interpretatione aftrorum conftat fuiffe cultorem, mundi principia fiderứg motus curiofiflime fpectaffe?qua curiofa fiderum cognitione atop contemplatione Pericles Athenienfum animos folis obfcuratione territos, eiufce caufis red ditis quas ab Anaxagoræ inftitutione perceperat, vano trepidantes metu liberauit. Alexandro quoo $\$$ Darium infequente quum. lunx defectus matutinis horis incidiffet, Macedones rati numina fibi indignari, tanta feditione commoti funt vt armis abftinere decernerent, nec cos cohibe re potuifet magni ducis imperium, ni Ariftander vates,natura rationes abfoluiffet ficut Dion Syracufanus, turbatis primú militum animis cum grauiflmo \& crudeliflimo tyranno Dionyfio patriam liberaret, Amylta vate docente $\&$ cunctis in medium rationem deficientis fideris reddente, non eft tali cafu deterritus. Arguuntur quoqg diffoni lunæ crepitus, cuius pauoris cauféq ignarus Nicias, Athenienfum imperator, veritus, claffem \& pulcherrimum exercicum portui fubducens perdidit, eorumóp opes afflixit. Nec alitur L . Sulpitius Gallus qui cof.cum M.Marcello fuit,defectum lunę imminenté in L.Pauli exer citu contra Perfem regé militibus metum adimens fore prædixit. Non me præterit, Iulium quoque Cæfarem Aftronomica ratione denos dies obferuationi veterum fuperadieciffe, quòd folis meatum partés ccclxv quibus fol zodiacum luftrat efficerent, vt temporum ratio fluctuans facilius congrueret in annum: quam rationem vnico errore comper to, fuperintercalandis diebus emendauit Aug. \& vt eft fcriptum in Saturnalibus, omnem hunc ordinem æreæ tabulæ ad aternam cuftodiam incifione mandauit. Neronem principem quoque fceleftît imũ ac crudelifimū,alioquin artis eius amãtiflimü fuiffe cótat, qux ex aére eft et frellis, et aqua\& f phæris, lucernis, ac peluibus, in ferorü vmbrarúǵ colloquiis, multif' aliis modis qui diuinationem promittunt, fortuna fua rerum hu manarể fumma geftiente potiffimüqug imperare diis cócupiente: neq̣ fum nef ci us, Adrianum Mathefeos adeò peritu fuiffe, vt de rebus fuis ad fuprenum vfog vitę fua exitum cuncta perfcriberet, dicerétque de vero Helio Virgilianú illud, Oftendêt terris hunc tantú fata nec vltrà Effe frnét. Prætereo Alexandrum Seuerum Mathefeos \& arufpicinæ artis peritifimum, Horof copum quoque fummun Auidum Caffium in his quogs nil omittentem. Taceo Variü Antonium Heliogabalum, qui \& Magorú colloquio vtebatur affiduè. Sunt præter hos qui diuinis numinú præfagitionibus illuftres habétur, neq̧ id mirú quidem, quum Angulis hominibus in lucem editis (falua tamen firmitate fatali) Genios effe quoldam. 
quofdã , eorủ tutelæ, falutíğ aflignatos, velutiactionú fuarú magiftros ac recioresà nónullis, paucis quãä, vi fos,mul ti pliciú virtutú fuarú fplédore cốpicuis, \& Theologi, et Socraticorú, Plat onicorúç lib ri ac auctores celebres, Cenforinus, C.Flaccus,Euclides, A puleius, Trifmegiftus, Anneus Florus, Ammianus Mar. cellinus, led Menãder Comicus imprimis et Homerus docuere, quorũ carminibus illud accepimus, Celeftes deos cú viris fortibus haud qua gä fuiffe locutos,nec affuiffe pugnẫtibus vel iuuiffe, cęterú familiares Genios cü iildê verfatos,quorü adminiculis ac pręcipuis admonitionibus freti plurimi dicütur enituiffe, Socra tes pręcipuè quê fępe dicere folitũ nouimus, diuini quiddâ numinis fecủ effe qd"

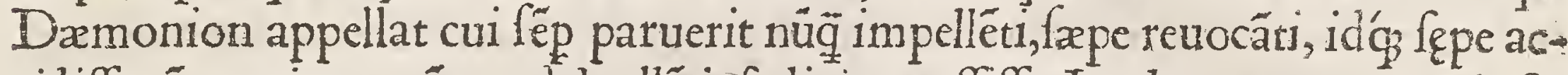

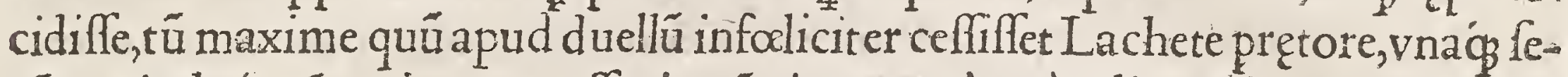
cú proinde fugã arriperet ac effet in cópito,nec eò quò reliqui diuerteret:eius rei caufẩ fcifcitãtibus præmonitū fe ac deterritú à deo dixit:túóp eos q aliò diverterât, in hoftữ incurfiones incidiffe.Nec Socratế folü,vt diximus, in hac divina pre fagione celebrē fuiffe creditũ eft, fed Zalecū et Minoẻm, Cimonë,Zoroaftrem, Lycurgú et Numam,vt Pyrrhi bello Curiü Fabriciü Corruncanú: primo Puni co caratinú duellú, Metellû́ Luctatiú, fecủdo maximú Marcellum, Paulú Garcchü,Catonem fuperiorem Aphricanum, L llium, Syllam, Marium, ac ve nönul li putant,Cęarem quoque Auguftum,multol'ǵ, praterea \& præter hos Romanorum. Refpub. \& Græcorum tulit fingulares viros, quorú neminé nifi iuuante deo talem fuiffe credédum eft. Qux ratio poëtas maximég Homerú impulitvt principibus heroum, Vlyxi, Achilli, Agamemnoni certos deos difcriminú et pe riculorum comites adiungerent. Præterea ipforü deorum aliquando pręfentia quales fuprà commemoraui declarant, $a b$ his fingulis hominibus quibufdam confuli, quod quidem intelligitur etiam fignificationibus rerum futura rum qua tum vigilantibus tum dormientibus portenduntur . Tametfi qui dam talia prorfus tollentes afferant nulli fapientum comparuiffe deum vel genios, verü vecordes quofdã ex imbecillitate homines, in animi horrore aut cora poris intemperie conftitutos, inanes et alienas opiniones attrahere, qui in fe ipfis effe genium, fuperfitionem habent : quibus quidem affentiendum putarem, Epicuri rationibus defenfus, noftri mutatioe atog deceptione innixus, nifi $\mathrm{Di}$ ion atø Brutus,grauifimi viri \& fapientix fudio dediti,nullä p affectioné mor bũve aberrãtes haud facile captabiles ab jpfo ita difpofiti genio fuiffêt vt amicis ac familiaribus retulerint : quare periculofum iter auertes haud facile dixerins vetuftifimis ne auctoribus hunc fermonë comprobantibus affentiendum fit,an huiufmodi homines regna \& exercitus ref́́p̧pub . gubernantes atque regentes, familiares genios ac numina fibi adeffe dicentes, vt infrenes difficilefogh multitus dines caperent nouitate ac magnitudine rei, \& opinionem dei vere commenti fint qux ipfis illis quorum gratia fingebatur faluti effet . Quis itaque, nifí mentis inops quifpiam dicet,non oraculis fidê daret, quum videret non modo fun mos philofophos et humanæ magiftros vite, fed latiffimas nationes, clariffimos populos \& reges apud Delphos et Dodonam \& Ammonem concurrêtes?quis fperneret Sibyllas quas fenatus \& po.ro. in extremis periculis confulebant? quig 
fomnia negligeret quum fciret vt reliquos fileã, Laced $x$ monios ipfos quos thefcio an proximos Romanis fortiffimólque omnium \& praftätiflimos viros iu dicare velim, vígadeo fomniorum curiofos, vt fcribit Cicero, quòd qui eis præerant non contenti vigilantibus curis, in $\mathrm{Pafyph}$ fano, quod eft in agro prope vrbem fomniandi caula excubabant: quia vera in quit quietis oracula ducebãt. Quis deniqg Magos non fufciperet, fine quorum doctrina neminem quantumli bet talibus rebus ornatum ad Perfarum regnũ prouehi poffe cognofceret? His \& aliis eiufmodi vt diximus tunc prouidentix modis agebatur infenfata mortalitas, fidens confultoribus infeftis, nec dum tempus erat ex tá profundis tenebris emergere, profequebatur humanum genus túc diuina vltio,ficque meritum premebat vt(fi dici fas eft) fuperftitionibus humanis caleftis patientia faueret. Nos verò quibus diuinæ gratiæ fplendor illuxit, aliud vitæ genus aliof'ṕp ritus decet amplecti, \& modum omnem vt eft cuique tributa prouincia in prapetibus gubernand is, erudiendis ofcinibus, fpectandis extis, fomniis conformandis, infpirandis vatibus, fulminibus iaculand is, fortibus regendis, cæterífque qui bus futura dignofcimus dęmonum obfequio \& minifterio fieri arbitrandü eft. Etenim deceptionum illudentium plena funt, quibus vt turbent omnia \& erro res humanis pectoribus infundant euenit vt iftis fubdolis $\&$ captiofis præfien tix modis multa futura dicantur, nec aliter ac dicuntur eueniant: quibus impli citi homines curiofiores fiant et fefe magis ac magis inferant multiplicibus la queis perniciofflfimi erroris, quod vt facilius valeant leuiuf́p confequâtur quod in nos intendunt, edunt illa perfape quibus ftupefacti homines fidem commodent fimulachris diuinitatis ac numinis: inde fit vt vitam frepe turbent, fomnos inquietent, membra obtorqueant, valitudinem frangant, morbos laceffant, men téfque aliquando territent: inde eft quòd augure Accio Neuio Tarquinii tempore,lapis nouacula incifus eft, hinc nonnullis regni futuri figna procurantur. Quo fit vt. L. Tarquinio Prifco Romam petenti Aquila pileú fuftulerit $8 \mathrm{c}$ cu alte fubuolaffet, dictu vix credibile,capiti repofuerit . Quo etiam regnante tradunt Creflam virginem reliquias quas ex omni regia néfa percipiebat ad virgines veltales ferre confueuiffe, obtigifféq́ al iquando quum igni facro eas impo neret repéte è foco genitalem cinerem viri infurrexifé ém que que ibi infederat Tanaquilis reginæ ancillam Creflam captiuam confurrexiffe grauidam, Serui umí̧ Tullum natum qui regno fucceffit, cui porrò in regia accubãti puero caput arfife vifum creditumóp laris familiaris filiu, Ouidio in faftis dicente, Nam que pater Tulli Vulcanus Creffáq́ mater Præefignis facie corniculata fuit: Hãc fecum Tanaquil facris de more peractis Iuflit in ornatú fundere vina focum . Hic inter cineres obfconi forma virilis Aut fuit aut vifa, fed fuit illa magis. I uf fa foco captiua fedet conceptus ab illa Seruius à cælo femina gentis habet. Signa dedit genitor tunc quum caput ore corufco Contigit, ingue cona flamme us arfit apex. Hinc quoque $q$ Iuno Vegenfis migrare fefe Romam velle refpondit, quơd Claudix manú nauis fecuta perhibetur, $q$ in facrilegos $\&$ Iuno nuda ta \& Locrenfis Proferpina \& Ceres Milefia vindicauit, Herculesíq de a pio. Nec aliter Hannibali fomnia orbitaté oculi cóninätur. Flaminio extifpicia péricu- 
lum cladis prædicant: vel ferpens, immo verò Dęmoniarches vrbem Ronầ pé Atilentia liberauit Epidauro accerfitus, aut Aeneas oraculorum indicio promifam \& quęfram inuenit Italiam, \& in ea non tâ numinú qu dęmonú nutu fedem ftatuit.Quid aliud agit in fomnis pater Anchifes?Q uid Iupiter \& Apollo qui ambiguitate fudent obnubere oracula, vt cum mendaces aut fallaces inuéti fuerint a liquando rationis vela mine fuam tueri queant fallaciá, fićp perditos per dere \& deprauatis errorem prauitatis infundere ac fallere non definút donec au ditores fuos protrudät in præceps; cui à freculis vatum profuere refponfa? Croæa fone an Pyrrho vel Laio, aut pracedentiü aut fubfequentiun cuiquam? Nónne Crofus opulentiffmus Lydorum rex bellü moturus in Perfas, tali refponfo fer tur illufus, Crofus Alyn penetrans magnã peruerterat opum vim. Quo refpon fo, hoftium fe vim peruerfurum putans peruertit fuam. Vtrum autem accidiffet: corum, verum oraculum fuiffet. Nihilo purius egiffe traditur cum Pyrrho qui bellú Romanis illaturus dumDel hos confulit, hoc refponfú vt ait Ennius accepit, Aio te Aeacida Romanos vincere polfe.Demés Pyrthus fi nó intelligeret $v$ tra pars viciffet verum oraculum videri,fic verfutus artifex texuerat, fic in om nem euentú perfugium veritatis occupauerat, hoc ing a ad cò manifeftam fallaciam præfert vt quang̣ ficut Ennius idẽ ait, femper fuerit ftolidú genus Aeacida. rum,ab eo tamé perpédi abfog difficultate potuerit:illud etiam obfcurius quod Crofum decepit, quod vel Chryfippum potuiffet fallere. Sic enim apud Ciceronem fcriptum eft, cui tamé ad poltremum tota res commétitia videtur et hoe à poéta fictum fulpicatur,illud a b hiftorico,rationes afferés: primum enim latio ne Apollinem nunquâ locutum fuiffe, deinde Pyrrhi temporibus iam iam verfificari defiiffe, $\&$ hoc vltimú vt eodem libro permulta irrifiue dictum arbitror: tamen vtcunç non multum his rationibus moueor, quoniam in latinum tranf ferri $\&$ in carmen inferi potuit ambiguitas oraculi, græcis $\&$ folut is primú verbis edita:nã fi ad linguam refpicio, quxecunģ oraculis dicta fút, latine quidem apud noltros de his græco fonte defcendunt, grace vel ab Apolline prolata vel $\mathrm{ab}$ illis memorix mandata, nec linguarum varietas obfuit veritati. Alia igitur me Ciceronis ratio violentius vrget, ait enim hoc Pyrrho refponfum inauditum græcis, itap fatis credi poteft hoc ab Ennio, fuo quodam iure fictum effe. De Herodoto auteni quem Cicero ipfe patrem hiftorix vocat, quòd fuperioris oraculi fictor extiterit non tam facile crediderim. In dubio igitur vifum eft verúmque attingere, \& Ciceronianam de hac re non præterire fententiam. Illud etiam anceps 8 inopinabile, quod Philippus Macedo ex eodem adyto accepir vt imminens fibi à quadriga periculum prouideret, quo audito rex anxius dif folui currus per omnem Macedoniam imperauit. Quin \& oppidum Bootix cui Quadriga nomen erat vt fatale fibi perpetuo declinauit, vel vt quidam ferunt iuffit euerti, fruftra tamen:aliò nanque minarum fpectabát oraculum.Capulus enim gladii quo eú Paufanias tranffodit quadrigæ cælaturam fertur habuiffe. Itaque Tul.eleganter illudit, Neque enim obfcura tantum fed mendax admonitio, quafi rex capulo \& nó cufpide moriturus effet. Appius Claudius is qui ciuili bello pópeianas partes fecutus eft, de etrentu rerú dubius vicinú caftris

D is qui 
qui iam tunc neglectus obmutuerat retentauit A pollinem. Itaq Perhemonoe quædam templi vates in antrum compulfa folitóg æeltuâs furore fertur in hane fententiam refpódiffe, Magnas huius minas Romane ne timeas: nihil enim ad te, quoniam in pace Eubox cola, vel vt quidam alii,latus euboicum poffidebis. Iucanus, Effugis ingentes tanti difcriminis expers Bellorum Romane minas foluf'\$ quietem Euboici vafta lateris cóualle tenebis : quo ille refponfo velut in fomnis accepto perplexior difceffit inde qu venerat, fed non multo pólt apud lo cum qui Eubor cola dicitur ante fupremum pralium morbo correptus interiit, ita fubtractus bellis \& fepulchro códitus Euboico fidem fecit oraculo. Eodémque modo Laio prædictum eft ab Apolline, Caue vetatos liberum fulcos feras, generatus ille mactabit te impie \& omnis aula refpergetur fanguine. Sed ille quidem vtpote præfcius qux fequerentur fementem iuxta fatum fieri vetabat, fciens in poteftate eius pofitum fi abftinere vellet. Iaius non vt homo nefcius futurorum $a b$ co qui firet quid agendum fibi eflet fcifcitabatur, feuit aue tem non fato eliciente fed victus intemperãtia. Simlliter Argiuis per oraculum quęrentibus an aduerfum Perfas bellum fufcipi conueniret, refponfum eft, Vici nis offenfa deo cariflima plebs armorum cohibe numina, corporis omne difcri men fola capitis tutabitur vmbra. Sciebat enim quid effet deligédum, qóp optio penes hominem: id verò quod fequitur optionem penes factum . Nero Cafar poft hos portendi fibi mutationem ftatus à mathematicis acceperat, qui in hoc concordes in eo difcordabant qux nam fortuna imperio deiectum exciperet: his Neronis animus eger Delphicum oraculum experiri ftatuit, fic enim fibi vifum eft hæfitationem fuam $a b$ humano ad diuinum confilium tranffer ri debere:inde fibi refponfum eft, Annum tertium \& feptuagefimum caueret: quod quum andiffet, homini incófiderato \& vix trigefimum ætatis fuæ annum tranfgreffo, tanta fecuritas incefferat vt iam nihil metuens \& profperitatem \& xtatem fibi integram fponderet, quafi ante prænuntiatum tempus ab Apolline mori non poffet, co deniqg eft infolétiæ raptus vt preciofiffimis quibufdã rebus maritima tempeftate deperditis affirmaret eas ad fe vel pifcium obfequio reuer furas, talibus intumuerat erroribus quú fubito deftitutus ab omnibus \& ad turpiffimam compulfus eft mortem, vtique confiliario dignus A polline, quàmuis vaniffimus ille fpiritus mendaciíp parens ne quid ineptius videretur confuetis ambagibus atç arte prouiderit. Quod ipfe Nero fuprema illa nocte audito clamore militari fuum execrante \& Galbæ nomen celebrante, feró licet, quiuit intelligere, $\&$ ad infoelicitatis fue cumulúauctorem oraculum veridicum appellari. Galba enim fucceffor tertium \& feptuagefimum annú tunc agebat. Admo net nos aliquis obtrectator quibufdam confultorem iftum confulere, quęruntur vtring noftris temporibus facra fibi interdicta cerimonial'óg fublatas, et ob hoc ideo maxime nulla vel perplexa $\&$ inextricabilia omnia talium rerum confultoribus refponfa dari. Cur ergo longe ante imperiü Cafaris ac Chrifti dei faluatoris noftri natiuitatem ficut ipforum auctores atteftantur abolita pene fuerat Pyt hii oraculi fides, abolita auté quia contempta? Porrò autem quare contempta nifi quia vel vana vel falfa vel dubia. Vnde poéta prudéter admonuit in- 
confultiabeunt feden'qg odere Sibyllx. Et ne forte parui id pendant quòd con temptum, abolitú atç antiquatum fuit, hoc effe aut numen aut fedem, A pollo ille Pychius erat quem ferunt magno Pythone ferpente interfecto magnum va tem totiuśg vaticinationis auctorem \& principem hredem fedis \& diumarionis \& nominis extitiffe, ibique eum reddere refponfa elegiffe, vbi orta cú auct ore ipfa diuinatio videbatur, euafiunculas autem quxrentes dicentés $q$ vim fedis ac loci euanuiffe tractu téporis, fic ridet Cicero vt dicat eos non aduertere quod de vi diuiua agitur, qux fi eft vtique æterna eft: Sed perinde loqui quafi de vin aut fallamento qux vim fuam imminuût vetuftate $\&$ paulatim euanefcunt . Itaque hęc profitêtes philofophos fuperftitiofos \& penè phanaticos appellat qui ex cufationes friuolas ineptiis fuis malunt exquirere euanuife fingenies, quàn veritatem ingenue confiteri \& errorem fuú vel ferò cognofcere qui diutiffinhe cir cumuenti für fuper huufcemodi oraculis,partim falfis ve ipfius Tullii verbis vtar,partin cafu veris vt fit in omni oratione fẹpiffime, partim flexiloquis et ob. fcuris vt interpresegeat interprete \& fors ipfa ad fortes referéda fit, partım ambiguis $\&$ perplexis oraculis: hi maxime fallunt quorum prętigias à veritate pro fani intelligere non poffunt.Ideoóg ab ipfis attribui putantet imperia et victori as $\&$ opes $\&$ euentus profperos rerum, denigg cum ipforum nutu fape rempub. conftet periculis imminentibus liberatam, qux pericula $\&$ refponfis denunciauerunt \& facrificiis placati auetterunt, omnia illa mera fallacix funt . Nam quum difpofitiones dei prefentiant quippe qui miniftri eius fuerunt interpo. nunt $\mathrm{fe}$ in his rebus vt quxcunq à deo facta funt vel fiunt ipfi potiffime facere aut feciffe viderêtur. Et quotiens alicui populo vel vrbiduci vel principi fecundum dei ftatutum boni quid impendet, illi fe facturos vel prodigiis vel fomniis vel oraculis vel fortibus cæterif' res \& facrificia tribuantur,quibus datis quum id acciderit quod neceffe ef, fibi fummam pariunt venerationé. Quotiens autem pericula impendét ad aliquam ineptam \& leuem caulam fe profitentur iratos,ficuti vno Varroni quòd formo fum puerú in templo Iouis ad excubias tenendas collocauerat et ob hãc caufam Romanum nomé apud Cannas penè deletum:quód fil luno alterum Ganymedem verebatur, cur iuuétus Romana luit poenas,vel fi dum tantummodo duces vel principes curant cateram multitudinem negligunt? Cur Varro folus euafit qui hoc fecit,\& Paulus qui nihil meruit occifus eft?Itaque fiue periculum quod imminet vitari poteft, videri volunt id placati auertiffe, fue nó poteft id agunt, fićg fibi apud homines qui eos nefciunt auctoritatem pariunt ac timorem, his verfutiis $\&$ his artibus noticiam veri dei trini $\&$ vnius apud onmes gentes inuer terunt. Harum igitur difciplinarum obferuationibus fuperftitiofis, qux ad co gnitionem fiderum coniunguntur focietas dæmonum formidanda atque vi . tanda eft, neque illos $a b$ hoc genere fuperfitionis fegregandos puto, qui ab ip fa Chaldxorum natione profiuxerunt : quod propria eft eorum genealogias ratio vt poffint antea facta futuráque ex ratiocinationibus aftrorum explicas re, hoc eft, quos effectus habent fidera duodecim, ftellæ quinque, fol 8 luna ad humanam rationem conferre: Cuius rei primus Berofus infula \& ciuitate

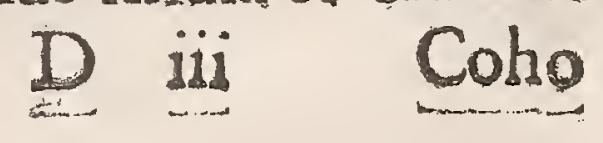


Coho confidens, ibi aperuit difciplinam, poftea fudens Antipater, iterumquê Achinapolus qui etiam non enafentia fed ex conceptione rationes explicatas: reliquit. Hi enim quanquam veram ftellarum pofitionem quum quifo nafcitur confectétur \& aliquando eam perveftigent, per corum inuentas confcriptafóp regulas, tamem $q$ inde conántur vel actus noftros vel mores vel euenta prædice re,nimis errant profecto, nimifque magna dementia detinentur, \& quos.non fo lum chrifianx religionis. inftituta ac fidei noftra lumina,verum multa quoos veterurn poétarum, philofophorum'q illuftrü, clariffimoruníq; ducum 8 imperatorum dicta confutent, ex quibus $\in$ ft illud imprimis facris in literis ad Moy fen annotatum, Quando ingreffus fueris terram quam dominus deus tuus dabit tibi, caue ne imitari velis abominationem illarú gentium, ne inueniatur in te qui luftret flium aut filiam fuam ducens fuper ignem, aut qui ariolos fcifcitetur $\&$ obferuet fomnia atep auguria, ne fis maleficus vel incantator, ne pytho. nes confulas $\&$ diuinos $\&$ ne quæras à mortuis veritate. Omnia hæe enim abominabitur, \& propter huiufmodi fcelera delebit cos in introitu tuo, perfectus eris \&absq macula cum domino deo tuo: gentes ifte quarum poflidebis terram augures \& diuinos audiunt, tu auté à domino deo tuo aliter inftitutus es. Quis ergo dubitet hæc non modo capitalia fed fidei peruerfionem, qux tanta diligentia diuina explodit fententia! Et illud quidem Leuitici,Non augurabimini nee obferuabitis fomnia nec declinetis ad magos nec ab ariolis aliquid fcifcitemini $v$ polluamini per eos: vir enim in eodẽ inquit, fue mulier in quibus pythonicus vel diuinationis fuerit fpiritus morte moriatur, lapidibus obruãt eos $\&$ fan guis corum fit fuper illos. Nec minus ad Romanos apoftolicis verbis expreffum: Quis enim cognouit fenfum domini,auc quis cófiliarius eius fuit? Eft quo que illud divinum ac cælefte confilium, Altiora te ne quxfieris \& fortiora te ne frutatus fueris: Sed quæ præcepit deus tibi illa cogita femper et in pluribusopetibus eius ne fueris curiofus. Non eft enim tibi neceffarium ea qua tibi abfondita funt videre. Non eft veftrum, alibi fcriptum, noffe tempora vel momenta qux in patris poteftate polita funt. Annunciate que futura funt inquit Ifaias, \& fciemus quia dii eftis vos. Simile eft illud Ecclefiaftici, Ignorat homo quod ante fe fuerit $\&$ quod polt futurum quis ei poterit indicare?Quid aliud illud Sapien tiæ afferit? Cogitationes enim mortalium inquit timidx funt $\&$ incertæ prouidentiæ noftræ, corpus quod corrumpitur aggrauat animam $\&$ terrena inhabitatio deprimit fenfum, multa cogitantem: $\&$ difficile exiftimamus qux in terra funt $\&$ que in profpectu funt inuenimus cum labore, qux in colis funt auté quis inueftigabit: lenfum autem tuum quis fciet, nifi tu dederis fapientiam \& miferis fpiritum fanctum tuum de altiflimis? $Q$ fic correptx femitx eorú qui funt in terris $\&$ qux fibi placent didicerüt homines. Atqui tefte Firmiano non hoc idem faciunt philofophi qui difputant in cęlo quid agatur, \& co femper impune id fa cere arbitrantur quia nullus exiftit qui errores eorum coarguat: quòd fi exiftima rent defcenfurum aliquem qui cos delirare $\&$ mentiri doceret, nunquàm quicquam de his rebus quas fcire non poffunt difputarent. Nec tamen ideo forlicior putanda eft corum impudentia $\&$ audacia quia non redarguuntur . Redarguit 
enim deus cui fola veritas nota eft licet conuenire videatur eamop hominum fä pientiam pro fumma fülticia cóputat. Linquo Auguttini \& A mbrofii operofif fimos validiffimośg tractatus ac difputationes lógiflimas quas nec tempis exigit nec recipit locus nec requirit quifquis aliquantulum legendo profecerit, not nempe funt: vnam Auguftini veram nefcio an breuem magis proferam fenten tiam ex co libro qui de dei ciuitate inf cribitur, His omnibus cófideratis inquit, non immerito creditur quum altrologi mirabiliter multa vera refpódent occul to inftinctu fieri fpirituum non bonorum quorum cura eft has falfas $8 \mathrm{r}$ noxias opiniones de altralibus fatis inferere humanis mentibus atque firmare non horofcopi mutati 82 infpecti aliqua arte qux nulla eft. Alteram A mbrofii ipfius exi co libro quem de obitu Satyri fratris nobis luculêta oratione reliquit: eius enim verba funt hæc, De folis curfu cælíg ratione philofophi difputant, \& funt qui putant his credendú quam quid loquantur ignorent, neque calum afcenderunt axem dimenfi,nondum oculis perfcrutati funt : quia nullus eorum cum deo in principio fuit, nullus eorum de deo dixit quum pararet cælum cum ipfo eram \& eram cum eo cuncta componens. A diuinis pręter hæc ad humana defcenden ti permulta fe ingerunt illuftrium poêtarú dicta his fatis cófentanea, è quibus il lud primum antiquiflimum $\&$ acerrimum apud Homerum proferendum: Iup piter inquit non mortalem hominé non è communi grege deum aliquẽ, fed Iunonem illam fuam coniugem ac fororem reginamóp deûm graui comminatio ne deterret ne fecretum fuum intimú auderet inquirere aut fciri poffe præfumeret:poft hunc duo literis demandata funt. Duorum quoque in illa prima xtate poétarum illuftrium, Pacuuius, Nam fi quæ ventura funt præuident æquiparāt Ioui. Rurfum idem poéta iftis qui linguam auiü intelligunt,plúş̧ ex alieno ie. core fapiunt quàm ex fuo, magis audiendum quàm aufcultandum cenfeo. Acci us, Nihil quoque credo auguribus qui aures verbis ditant alienas, fuas vt auro locupletent domos.Quartum his Enniū addiderim qui vetufta illa \& venerabi. li facundia hos ipfos eleganter irridet, vt verbis etian fuis vtar, Qui fui quxftus caufa falfas fufcitant. fentétias. Non enim funt hi aut fcientia aut arte diuini fed fuperftitiofi vates impudentesóg arioli aut inertes aut infani aut quibus egeftas imperet, qui fibi femitam non fapiunt,aliis demonfträt vias: quibus diuitias pol licentur,ab ipfis drachmam ipfi petút. De his diuitiis fibi deducant drachmam, reddãt cætera. Addo quinto loco fpectatæa authoritatis grauitátisóp poéta m doctiflimum Flaccum Horatium dicentem, Prudens futuri temporis exitum cali ginofa nocte præmittit deus, Ridetóp fi mortales vltra fas trepidant necnon illud quod adeft memento componere aquus, \& quid fit futurum cras fuge quærere: Et quem fors dierum quem qux dabit lucro appone. Eft $\&$ illud eiufdem quoge poetrad Léuconoen, Tu ne quafieris fcire nefas, quem mihi quem tibi fine dederint dii Luconoe, nec Babylonios tentaris numeros vt melius quicquid erit pati feu plures hyemes feu tribuit Iuppiter vltimam. Lucanus inter hos fextus his verbis accedit,

Sit lubitum quodcumque paras, fit crea futuri

Mens hominum fati liceat fperare timenti. 
Statium his feptimu aggregauerim, Quid craftina voluerit hora fcire nefas ho: mini. Vltimo in loco fequitur hos Iunius Iumenalis Aquinas \& his verbis,

Spondet amatorem tenerum vel diuitis orbi

Teftamentum ingens calid pulmone columba

Tractato Armenus vel Comagenus Arufpex

Pectora pullorum rimatur \& exta catelli.

Interdum 2 exta pueri faciet quod deterat iple

Chaldæis. Sed maior erit fidutia quicquid

Dixerit aftrologus credent à fronte relatum

Amonis: quoniam delphis oracula ceffant:

Et genus humanum damnat caligo futuri

Hæc religionis noftræ inftituta \& illuftriu dicta poétarkillis fimilia fubfequuntur \& philofophorum fententix, Socratis potifimum qui in hoc calefium fru tino \& caufarum abditarum indagatione ceteris cordatior fuit, quum hæc in telligeret non poffe inueniri, celebre illud ab omnibus probatum in medium no bis attulit, Quod fupra nos nihil ad nos,fić̣ proinde ab omni phyfica quaftione difputationen fufpendens eò fe contulit vt in virtute atque officio omnis eius verfaretur intentio.Itidem Democriti phyficinon ineptus præcæteris contra ta les iocus, quod eft ante pedes nemo fpectat,celi fcrutantur plagas: facetiffimáque illa Cice ronis irrifio temere difputantium, nullaç̧ de re dubitantium tanquàm modo deorum ex concilio defcendentes quid ibi agatur oculis fuis afpexerint auribúfque perceperint. Sanè vt idé inquit Cicero $\&$ in fenectute fua horæ quidem cedunt $\&$ dies $\&$ menfes $\&$ anni nec præteritum tépus vnquàm reuertitur, nec quid fequatur fciri potelt. Sunt \& aliæ contra hæc hominum portenta, philofophorum clarorum fententix, inter quos Fauorini eft illa melius \& vrgencius cateris quos legere potui philofophis futurorum noticiam facillime repudi antis atque dicentis, Nihil enim ab illis audiri poffe dicebat nifi graue atque mo leftum:quoniam aut vera refpondebunt quod rariffime folent: fi quidé mala mi feriam ante tempus afferre \& fuperuacuam folicitudinem: ponta enim illic veri tate, adeft hinc neceflitas. Ita nihil pracife nifi doloré pofcenti reddere libet hoc loco fuftinere, 8 quod communis rerum natura non patitur tentare maior fine offenfione poffit interferi, hoc eft, Fauorini, M. T. cuius hæc fứ, vt omittamus fu periores. M.Craffo putas vtile fuiffe tum quum maximis opibus fortunisq flore bat, fcire fibi interfecto filio Publio exercituque deleto trans Eufraten cum igno minia $\&$ dedecore effe pereúdum? An Cn. Pompeium cenfes tribus fuis confulatibus, tribus triumphis maximarum rerũ gloria lætaturum fuiffe fr fciret fe in folitudine Aegyptiorum trucidatum iri, amiffo exercitu, poft mortem verò ea confecutura quæ fine lachrymis non poffumus dicere? Quid verò $\mathrm{C}$ farem putaffe fr diuinaffet fore vt in eo fenatu qué ex maiori parte ipfe cooptaffet in curia pompeiana ante ipfurs Pompeii fimulachrum tot centurionibus fuis fpectan tibus, ac nobilifimis ciuibus, partin etiam à fe omnibus rebus ornatis trucidatus ita iaceret vt ad eius corpus non modo amicorum fed ne feruorum qui dem quifpiam accederet, quo cruciatu animi vitam acturum fuiffe? \& certe 
ignorantia futurorum malorum vtilior eft quàm fcientia, $\mathrm{H} x \mathrm{Cicero}$. Poffem ego antiquos \& fortunatiffimos ætatis noft ræ viros in huius fentêtię teftimonium vocare, fed nec neceffe, nec locus hic longiorem digreffionem recipit, \& attigiffe videtur ille clariffima: fin auté $v t$ ad Fauorini argumentationé redeat ora: tio, bona pronútiant, duplex incommoditas,expectationis tędium, \& pręcogni ti gaudii extenuatio :quod repentinü, gratius ac cumulatius obueniffet. A ut fal fa dicêt, quod ä familiare \& frequêtiffimú apud eos eft:et fierút infęlicia, angoribus falloóg metu:fi foelicia, inani fpe \& gaudio trifticiáq vbi te delufü fenties torqueberis. In omné igitur euentú hos nugatores fycophătas cótenınendos fo$\mathrm{re}$, ad hanc fere fententiam vt præteream Dicearchum qui expedire omnia no bisfutura nefcire magno volumine conclufit, Anaxarti philolophi ratione cópellor. Is enim quum in Byrfam vrbem trans Eufraten omiffam traieciffet Ale xander, ibi eủ vt antea perfape monuit,vt táquàm falfa \& incerta Magorü præ dicta contēneret:nec ab re. Nam fi fatis inquit ò Alexäder cöftent quẹ prędicun tur, ignota effe mortalibus:fi vero naturæ debeantur, immutabilia quidéeffe. Simile \& illud Demonactis etiam philofophi qui vaté femel intuens publica mer cede tefponfa prabentem, nonne.vides, nnquit,cuius rei mercedé flagites?'Si enim tibi poteftas à Ioue eft eorum quæ fatali lege funt conftituta aliquid commu tandi, quodcunque id eft quod flagitas parum fane eft : fin autem dei nutu 8 voluntate pofita funt omnia, quid tuum nos vaticiniü iuuare poteft?Demofthe nes Grrcorum armisac tanta \& tam prompta virorum potentia confifus,neq mentem adhiberi oraculis,neque vaticinia audiri permifit; E paminundam memorans \& Periclem illa femper formidinis \& ignauix velamenta putaffe. Salus berrimú \& memorabile eft illud omnibus horis Halicarnafei excellettis in aftro logia, $\&$ in regendis fuis ciuibus principis praftatitifimi,totum id quod eft Chal daicum prædicãdi genus repudiantis. Magnus quidam vir ecce fuperuenit,pręmiffis omnibus fide non inferior, Cato ille rigid us qui mirari fe ait $\underline{\text { q non ridet }}$ arufpex arufpicem quum viderit, quod dictum ad omnes qquè augures, fortile gos,coniectores,chaldęosóg \& mathematicos ac totam denique manticen cóuerti poteft. Spectatis enim tot ineptiis quibus credulis homunculisilludunt, occurfus profecto memoriam \& rifuns ex mutua confçientia mouere deberêt . Quàm illud quoque eleganter?quum effet confultus à quodan, monftrum ne effet à foricibus corrofas fibi caligas quum diceret, Refpondit non effe id monftrum, fed verum monftrum habendum fuiffe, fi forices à caligis roderentur. Quod fequitur non minus profecto, fed magnificum ac fucci \& penfi plenum. Nã quú apud Prufiam Hannibali exultanti \& auctori committendi pralii pugnari placeret, ac ille negaret, quòd exta prohiberent, An tu Prufia inquit Hannibal vitulinæe carnis mauis quàm imperatori veteri credere? breue fane atque ampliffimü tantóque principe dignum verbum,vt pote qui Hifpaniam, Galliam, Liguriam, Ita liam denique laceratam in faciem eius effuderit,vnius hoftix viliffim $x$ ac fordidiffima exta tot monumentis ac victoriis rerum praponi indignü ferens. Quid aliud Cæfar quum à maximo augure $\&$ doctiflimo arufpice pręmoneretur ne in Aphricam ante brumam nauigia tranfmitteret, non ne illius dictum nihili fao 
ciens tran miftéguod ni feciffet, omnes aduerfarionü copiæ conueniffent. Econ trario Regulus nónne auguria feruauit \& captus eft? $\&$ Mancinus religionem te nuit \& fub ingum miffus eft? Pullos habuit $P$ aulus, $\&$ apud Cannas tamen cæfus eft. Hæc $\&$ horum fimilia qux confirmädis aufpiciis $\&$ id genus erroribus afferuntur, tam inepta, tam friuola perfape funt vt multis quidem M. Marcelli illius quinquies col probandum fummopere conflium videatur, qui quú effet imperator $\&$ augur optimus, totum hoc militare aufpiciũ omiferit: à quo ne pre pediretur lectica opertus, nec ab re,iter facere folitus: vir enim fortis \& fapies defperabat polfe inulgatam diu $\&$ imbibitam ac oflibus inherentem opinionem aperta fronte difcutere. Non eò vique tamen Marcello affentiendum, nec aufpicia omnino ita repudianda reor vt res magnas nullis vnquàm credam fignis vel aufpiciis præueniri, quum et volatus auiü dirigat deus, vt roftrú lonans, aut prateruolans penna, turbido meatu vel leni,futura præmonftret, vt theologi veteres \& clari quidam auctores teftes funt. Ouidius in faftis,

Non ego te quàmuis properabis vincere Cafar

Si vetat aufpicium figna mouere velins.

Sint tibi Flaminius Trafimenáp̆ littora teftes,

Pervolucres figna multa mouere deos.

Verùm praclare de hoc quogue vt de aliis Cicero, Signa inquit oftendutur ab his rerum futurarum: in his fi quis errauerit, non deorum natura fed hominum coniectura peccauerit. Nec etiam poftremo prater haec rerum futuraru figna eft, quod ratione fignorum vel planetarum certiores bi futurorú nuncii de fingulis quibu fģ polliceri poffint vel audiri: in fepem nâq̧ fideribus de quibus antè dixi mus $\&$ qua ab inceffu vocamus errātia quú errent tamen nulla minus, certę cófi derationis nihil habent nifi lecundú cómune regimé in múdo eis debitú intelli gentia feptuplicé fubftantia extra confiftente virtute fibi coniunctam. Scimus etiam, ne horũ au daciam per fingula pretereamus intactã, eos fateri folitos quòd quifquis aquarii figno in lucem editus fit, pifcatoris minifterium fortiretur. Cxterum pifcatores quum Getulia non habeat, quis eorum dicere aufit, quia nemo illic in ftella aquarii na Ccitur. Rurfum quú plurımos quos nafí figno libræ norint,trapezitas fore prędicent, quos multarum gentium prouincix ignorant, $\mathrm{fa}$ teantur necefle eft aut in eis hoc fignum deeffe, aut effectú fatalem nullo modo haberi. Perfarũ autem ac Laced̨̧moniorú reges guum per genus dominétur, regumóq filii vno eodéćp fidere cum feruis cótinue degentibus nati ad regnú pfici ant, quid rationis habent vt ferui qui fecú iifdé momentis horarúactemporữ fue rant geniti omnino in feruitute comorentur? Homines etia diuerfarum regionum, diuerfarú ætatú, fub variis \& diuerfis fiderü motibus geniti, fi aut oppidoxú expugnationibus, aut collatis fignis, eadé claffe fluctibus obruantur, vel alio quouis modo, eodem tamen genere mortis eodem'́ momento temporis interie runt, vt in Cannéfi pugna contigit, quomodo momenta nafcendi fingulis fecüdum iftos attributa fuas leges habebunt? Aduerfabitur horum iudicis valtitas forfan immenfa alcitudine, difcreta in duo \& feptuaginta figna per rerum aut animarum effigies, in quas digeffere calum peritı. Poffe etiam fieri credibile eft, 
ex infinito ftellarú numeto, vt alia figna pari, maiore, vel minore poteftate frut; fine quibus recta ac perpetua obferuatio perfici non queat : neque cos hominks cernere poffe, neque percipere éxuperantiant vel plendoris vel alritudinis, quuns \& quadam fidera in quibufdam terris confpiciantur,earumóg terrasum hóm.

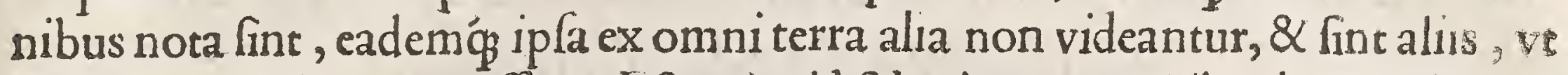
Canopus,omnino ignotiffima. Eft enim id fidus ingens noctibus lucens,clatum $\&$ maxime mirum, cuius fi aliunde fides abeffet $M$. Manilius libro primo aft: 0 nomicon præcellentiffimus teftis accedit: Idcirco inquit, terris non omnbus om nia frgna Confpicimus, nunquam inuenies fulgere Canopum, Donec hiliacas per pontum venerit oras. Quum itaqg cöftet rerum am biguitatem confufioném que dãnofam ex talıü potius diuinationis pranunciatione generari, quàm certan,cổducibile confultoribus cognitioné, quú nihil rite cernant,nihil percıpıãt, nihílqg veniat horum qux ifts lubricis \& fallacıbus cöiecturis delirantesac velut ebrii pollicentur ( niff rarum forte aliquid, aut fortuitum, qualia etiam aliquådo ementiri volentibus elabuntur \& excidunt )nullo pacto,Sigifmunde Pãdulphe, vtendum effe tibi reor iftuf modi fuperftitiofis hominum iudiciis: quorum difciplinas tute optime calles,ftudiis indulges, ingeniis faues, vt argutis apprime delectaris: maxime quum clariffimos quofque atatis viros mathematicos, horo. fcopos fummos \& aftronomos more maiorü domi \& militix ad futura prę fagio enda te femper penes habueris $\&$ habeas. T antorum itaque virorum,tam erudi torum,tam illuftrium exemplis $\&$ auctoritate, ac rationibus fretus, non iniuria dixerim diuinationis artem qua quis de futuris omnibus foli deo cognitits ad interrogata fingula vera refpondeat,aut omnino nullä effe (quod

Socrates \& eum fecuti antigui Academici quos eofdem \& Peri ripateticos nominamus afferunt )aut effe, fed nödum fcitā, aut opinionem quandam, proinde vanam hominum coniecturam atç̧ iudicia quàm maxime fallentem. Finis Tertii. 


\section{ROBERTI VALTVRII}

ADILLVSTREM HEROA SIGIS-

mundum Pandulphum, de re militari

Liber Quartus.

Delegibus $\quad$ cap. I.

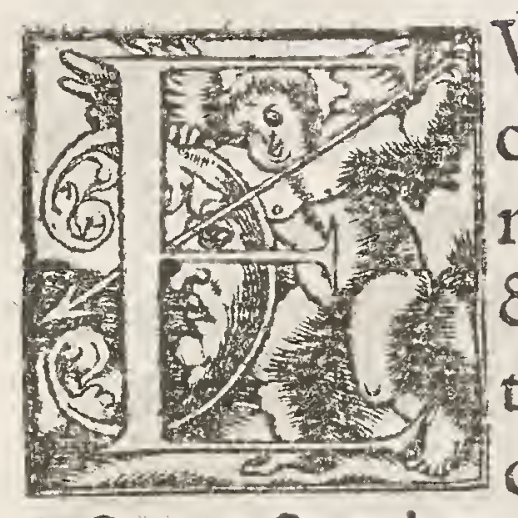

Vm quoque,Sigifmunde Pandulphe,neceffe ext quem aliis du cem $\&$ iniperatorem prafecimus, non harum quaś modo dixi mus bonarum artium inftitutis folum, verum \&' legitimi iuris $\&$ more maiorum, cerimoniarum \& factorú erga deos $\&$ contentionum controuerfiarumóg intèr homines dirimédarú iudi iuf turtum eft,vt in repubinquit Cicero, quod denúciatum 8 indictum, atque hoc ipfum quod aut repetundarum aut propulfandorum hoftiü caufa geratur: legi timi iuris munus etiam dicimus ea iubere qux funt viri fortis, vt non deferere locum in acie,non fugere, non arma abiicere: \& ea qua funt temperätis, vt non committere adulterium, non flagitiu facere: \& ea quę funt manfueti, vt non pul fare, tion iurgia exercere:eodem modo fecundum alias virtutes, \& vitia, has iube re,illa vetare. Effe etiam præter hæc quædam belli iura, vt ineundæ pugnæ folennitatem feruare, decreta publica,foederunı percuffionê, religionem facramêti, militum animaduerfonem, dignitatem, ac præmiorum \& honorum gradun. Quxdam porrò effe quę vit facere ita pati fit fas,vt fata exuri, dirui tecta,prędas hominum pecorumós agi, aliáque id genus qux de fingulis carta funt legibus, in quarum editione funt qui putent Zeleucum, alii R hadamanthum fiue Lycurgum putant:quidam omnium priorem Cererem, qua frumenta, quum antea glande vefcerentur inuenit: molere quoque $\&$ conficere in $A$ ttica, $\&$ alia in Sicilia, ob ibóp dea iudicata, vt Carcinus tragęedus in fuo poẻmate affirmat. Hăc alii gloriam illi gentis hæbreorum duci fummóque philofopho Moyfí tấquam veritati magis confentaneum facile concefferunt. Lycurgus enim \& Zeleucus, omnésque qui apud Grecos mirabiles funt recentes atq̧ nouelli,quantú ad hunc ipfum Moyfen comparatieffe nofcuntur, quoniam necipfum nomen legis,fuiffe olim apud Græcos agnofcitur, \& teit tis Homerus eft, qui nufquàm in diuino eius opere hoc vfus eft nomine. Non enim fecundum legen, fed indiffinitivisfen tentiis \& regum pręceptionibus populus regebatur: vnde etiam multo tempore permanfere tantum moribus vtentes, $\&$ non fcripto, \& multa horum femper fecundum euentum cafuum permittentes. Phoroneus etiam ipfe fecundus Argivorum rex à quo forum forenfég dicédi genus deductum putant,vt Argini certa lege ac iudiciis regerétur, fexcentis ante bellum Troianum ferme annis inter Gracos primusante omnes effecit, fin modo sla qux apud Platonem in Timæo 
Critias ex Solone commemorat de legibus atticis multis annorum milibusante Phoroneum, fabulofa \& commentitia effe credamus . Nec me preterit apud prifcos Græcos Ifidem legiferam appellatam, tanquam primam legum inuentri cem. Aegyptiis auté prima fcriptarum legũ monumenta, Mina rex fiue Trifmegiftus dedit, quem fortafle quifpiâ in philofophorú numero computet, quanquam in deos relatus Mercurii nomine ab Aegyptiis honoretur. Secüdus apud Aegyptios legúlator dicitur, vir prudétia excellens, Safochis, hu nc \&ad deûn religioné cultumón multa prioribus legibus addidiffe perhibent. Tertium Sefoofin regem tradunt, qui ad rem militaré $\&$ belli munera plurima cótulit inftitus tis fuis. Quartus fcribitur rex Buchoris tuliffe leyes fapientia ac vfu rerú exper tus,qui $\&$ vitæ regum leges dederit, \& commercia hominum iudiciáque conft tuerit: polt húc legibus multa addidit Amafus rex,quem tradunt $\&$ de his qua ad monarchas pertinét, déque omni Aegyptiorum œconomia præcepiffe. Minos mare obtinuit $\&$ paulo antè Troiam captam Cretenfibus leges dedit,vt $\mathrm{Pa}$ radius memorat, quod Plato falfum effe conuincit. Spartanis verò qui \& I ace dæmonii funt, Lycurgus primus leges ex A pollinis, vt áiunt, auctoritate cófinxit.Et quanquam leges fcriptas nullas Lycurgus tulerit,vt alii perhibent,vnam tamen ex his qux rhetre appellantur afferam, qux in hoftes militare prohibere ne fape pugnando confuefacti bellicofi redderentur. Qua in re Agefilaum regé maxime pofteriori tempore accufant, vtpote qui continuis $\&$ frequentibus in Bocotiam incurfibus ac pręliis Thebanos refiftere Lacedęmoniis ed ocuerit.Qua re faucium Antalcides quum intueretur, pulchram tuæ doctrinæ merecedem inquit à Thebanis recipis, qui nolentes ipfos neque fcientes pugnandi peritiam docuifti. Huiufmodi fanctiones rhetras libuit appellari, quafi ex deo decretze de ique oracula quædam effent. Epirotis Ariba Epirotarum rex vnus ex pofteris Pyrrhi,Achillis filii,leges, fenatum, magiftratus annuos, \& politice vitæ forma primus infituit. Arianeis Chatharactes, Getis Zamolxis. Pittacus Mitileneis $q$ ad fexcentos elegos verfus, \& carptim de legibus ad ciues confcripfit. Fuit \& al ter Pittacus legifer, cuius \& Fauorinus \& Demetrius meminit. Atheniëfibus ve rò à quibus iura \& leges ortæ atque in omnes terras diftributæ putantur, tulit rigidiffimus Draco, quas \& hoc ipfo mitior Solon,fapiens vnus è feptem, 8 legü fcriptor, propter alperitatem magnitudinémque ponarum abrogädas curauit: vna enim fere omnibus mors poena prædiffinita êrat, vt'etiam qui otii damnati effent capite plecterentur: \& eis qui olera aut fructus furripuiffent, idem fupplici um quod peculatoribus aut homicidis cöftitutum effet.Ob quam caufam illud Demadis à doctis probatur, qui Draconem non atramento fed fanguine leges defcripfiffe dixit. Inter Solonis autéleges quas plures fuiffe cöltat, ac omnes quidé fapiêtiffimè latas, illas præclare ftatuit, quibus athletarum quoç pręmia cafti gata moderatione correxit, \& ei qui Olympia viciflet quingétas drachmas, qui verò in Ifthmo, ei centú dari cóftituit, eadéós ratione in certaminibus $\&$ præliis qui fuccubuiffent præmiis effe illuftrandos, corumque filios publicè enutriendos educādosóp, quo fane animati finguli,fortiter ac ftrenue in bellis dimicabät: fic Polyzeus, fic Cyneagirus, fic Callimachiss, ficomnes qui in Marathonis expu 
gnatione pugnauerunt:fic praterea Armodius, Aroftogiton, Mylciades, infuti: merabiléfque alii: maxime autem Alexis comicus Athenienfes inquit, oportere ideo laudari, quòd omnium Græcorum leges cogunt parentes àliberis ali, Atheniefrum non omnes, nifi eos qui liberos artibus erudilffent. Fuit étiä quandoque in Macedonia lex; eum qui nullum hoftem interfeciffet;capiftro cingi debere. Et apud Scythas, in bello vbi primum quis hominé deieciffet, eius fanguinem bibere, neque aliter participes præda fieri confueuiffe nifi ad regem necatorum omnium capita detuliffent:qux nonnunquam ( horrendum dictu) pur gantes deaurantéfque ad pocula deferebant. Non licere etiam eorum cuiquam folennibus epulis pateram circumlatam accipere, nifi ei qui aliquem ex holtium quoque numero de medio fuftulifet : a pud Gallos fic etiam puberes omnes \& armatos com muni lege cogi ad bellum folere, vt qui ex his nouiffime adueniret, *in confpectu circúfufx multitudinis affectus omni genere cruciatus necaretur. Atque vtab externis ad domeftica alıquádo redeat oratio, quis nefcit Italis leges dediffe Italum quendam Oenotrix regem, à quo mutato nomine pro Oenotris Itali funt vocati, orámque illam maritimam Europæ quæ eft inter Syllaticum \& Lameticum finum Italiz nomé primo cepiffe? Hunc ergo Italum periti quidam tradunt agriculturam Oenotros docuiffe, quum prius effent paftores vagi ac palantes, illisćp comeffationes inftituiffe primum, legeś́p pofuiffe, quas itiden nónulli \& quidem docti non Italum I zalis, fed Saturnum :Romanis verò Quir num. Nam quum agrefti quodam more in Italia etiam viueretur, is genus indo. cile \& difperfum mótibus al tis Compofuit legesóp dedit, Latiúmque vocari $\mathrm{Ma}$ luit his quonia latuiffet tutus in oris. Hic verò quum poft fratrem interemptum, folus potiretur imperio, iura ded it populo, nec re aliqua pręter quàm legibus coalefcere multitudinem vnum in corpus arbitratus eft: populum itaqg Ro.qui no wa tunc paftorum conuenarumíg omnium colluuione collectus erat, Romulus in partes triginta diuifit, quibus quoque additæ funt quinque, eafdém que curias placuit appellari,quòd publicas curas gerebant, quum in illis vniufculul $\$$ partis populi Romani quid gereretur: ita vt in fua quifos curia, facra publica faceret feriálque obferuaret, quibus fingulis curiis, Curiarú nomina virginú impofi ta effe dicuntur, quas virgines quondā Romani de Sabinis rapuerãt: qui verò eis confulerent, ex populo nobilifimo centum fenes delegit, quos ob ętatem Senatores, ob pietatem $\&$ in fimilitudinem curæ Patres nominauit, quorúmque filii Patritii funt a ppellati. Tres equitũ deinde centurias inftituit, quas fuo nomine Ramnes, à T.Tacio Ticienfes, à luci communione Luceres, quãquam huius denominatio auctore Liuio incerta eft, appellauit. Equites item armatos trecétos, qui Celeres vocarentur, tum pace,tum bello fuiad cuftodiam corporis, Tribunum etiam qui ess præerat appellauit. Reliqua verò multitudo regem in bellum eunten fequebatur pedes, vniuerfos autem Milites a ppellabat. Non enim vti po Itea atque in præfentia ornati aureis calcaribus $\&$ aureo cingulo, fed qui erant in exercitu equites \& pedites, vulgò fimul omnes fine difcrimine apud veteres funt milites a militandi confueudine appellati : hunc deinde Romulum fecutus Numa PompiliusPomponii filius, è Curibus Sabinorum oppido accitus 
ad regnum qui Romanum populum vtpote ferreú tcligione mollivit, fidem pà cis ac belli docens, facris pluribus per cum inftitutis: nam Veftæ fecit ædem \& portas Iano gemino ędificauit,augures,flamines tres, Dialem;,Martiale \& Qui. rinalem \& Salios Martis facerdotes: pontificem maximum creauit, leges plutes tulit cerentonias cultumóg deorum omnium immortalium, ob quam tantam iu fticiam \& religionem nemo ei bell um inferre aufus eft. Excipit Numam Pompi lium Tullus Hoftilius Romulo fortior, qui populum iam quieti \& legibus affuetum ad bella $2 \alpha$ arma reduxit: idem omnem militarem difćplinam,artem'́p bel landi condidit,ac debellatis Etrufcis,fellam curulem lictoréf que \& togam pictä atq̧ pratextam,quę infignia magiftratuum Etrufcorũ erant, primus vt Roma haberentur inftituit: huic fucceflit Ancus Martius,Numę Pompilii ex filia nepos, ac religion auite quàm fimilis: hic vt bella geri aliquo ritu,pie ac fancte indici viderêtur,cerimonias lege quadam inftituit,quibus Fecialis \& Pater Patra tus qui effent ad eam rem legat1, hoc eft, ad res repetủdas quum bellü indicerene vterétur. Regnum tenuit poft Ancum Tarquinius Prifcus, qui omnia quibus imperii dignitas eminet decora \& infignia fumpfit ex Tufcia: inde namque au reuset triüphalis curruset equi quatuor, tunice palmate, fafces, trabę, curules, pha lera, anuli ac paludaméta fumpta funt,frequentibus praliis, duodecim Etrurize populis per eum fubactis. Poft hunc Seruius T ull uss, quãquàm quafi precariò regnare coxpiffet, imperium tamen recte miniftrauit,vrbe quadrifariam diuifa,re gionibus collibusç̣ qui incoluntur, \& Tribus eas partes vt ego arbitror à tributto appellauit. A b hoc claffes centurix'́p. conftitute peditum. \& equitum : huius tempore Romanorum ciuium qui arma ferre poffent cenfita effe octoginta mi lia, Fabjus pictor auctor eft: ab eodem cenfus. conftitutus. Diuifit nang ciuitatem non fecundum regiones verum fecundum cenfum, vnum corpus faciens eo rum ciuium qui cenfum habebant fupra centú milia ęris, aliud corpus cenfurm. habentium à centun milibus ad feptuagintaquinque, tertium corum qui à feptuagintaquinque milibus: \& ita defcendens vfque ad quinque milia peruenit, infra eum numerum fine cenfu reliquit, quafi tenues $\&$ impotentes. Ex cenfu au tem qux domi \& militiæ fubeunda forent onera conftituit. Quia verò patrimo nia vel augentur vel minuuntur fingulis quinquenniis, in quinquennium recen feri ftatuit,idǵg quinquennium, Luftrum maiores dixere. Tarquinius cui Super bo ex moribus cognomen inditum eft, poftremus omnium fuit, vir iniquus, crut entus ad reş̧́́ bellicas fortis ac præftans, vtpote qui vrbes euerteret \& turpi arte in deditionem redigetet . Exactis autem regibus,anno feptimo \& quinquagefí mo, ab vrbe verò condita trecentefimo \& vltra, creati funt viri decem ad leges condendas: nouus quidem ac fummi imperii magiftratus, à quibus decem tas bulx primum editx, centuriatis comitiis perlatx funt, fimúlque deinde dux fú peradditz,vt omne ius Quiritum confectú duodecim illis tabulis ad vnguê ab* folıeretur: fiç̧̧à decemuiris leges decenuirales, quibus ta bulis duodecim eft no men, in as fiue ebur incifas in publico propoluerunt, quas táti feciffe Romanun populum memorant vt illis quàmdiu Romę ftetit honor \& innocétia pudicitie contentusfuerit: : Sed cum crefcente improbitate interpretationes prudentum

$$
\text { E is per }
$$


per confuetudinem recepte funt, quas quidem ius ciuile non leges libuit appellare, ex hoc fuerunt actiones, qux ius agendi funt, folenniter inftituta: quibus ficus \& interpretationi collegium pontificum præfidebat. Accefferunt ad hac populi placita,fenatus confulta, fcita plebis,edicta prætorü, refponfa prudentú: 8 trấllata demú in principes lege regia romani populi poteftate, ccepit quod principi placuit, legis habere vigorem. Hoc legú progreffu multi clariffimi romano rum confules tribuni aut cenfores ferendis legibus auctores fuere, 8 à quibus leges denominatæ, vt confulares, tribunicix,iulix, corneliæ. Nam fub Octauiano Cafare fuffecti confules Papius \& Pompeius, legem tulere quxà nominibus eorum appellantur Papia \& Pompeia : fub eodem quoque imperatore Falcidius tribunus plebis,legé fecit ex cuirus nomine lex extat falcidia. Aquilius quoqg legé condidit qux hactenus aquilia nuncupatur, fic Iulia,fic Cornelia, Catoniana regula etiam legibus ab Catonibus inferta quorum nomen quogue adeò clarum, adeo celebre eft vt non folum vrben, fed orbem pene totum fuis téporibus prxfentia, poltea vero memoria fua ac fplendore illuftrarint. Nam vt Prifcú \& Cenforinum illum pręteream,tanta fuit pofterior ille Vticenfis habitus reuerétia, vt eum quum Cærar à fubfelliis in carcerem $i$. aheret, fumma cum mofticia boni ciues vnà cum fenatu taciti atø̧ afflicti omnes fequerentur, vt qux in facris ludif 'G floralibus quibus vulgati corporis metetrices nude more veterum mimarum fungebantur officio, \& in confpectu populi vfque ad fatietatem impudicorum luminum cum impudendis motibus detinebantur,veritus fit populus Ro.folitx lafciuia ludum petere,quoniam fortè tum Cato venerat in theatrum, vnde Mar tialis in epigrammatum fuorum limine inquit, Noffes iocofe dulce cum facrum Florę Feftosóg ludos \& licentiam vulgi Cur in theatrum Cato feuere venifti? An ideo tantum veneras vt exires? legimus enim eum plaudéte populo poltea quàm ex Fauonio familiari \& amico vnà fedente præfentiam fuam fpectaculi confuetudini impedimento effe intellexit, è theatro continuò abiiffe abeuntemóp populum prifcum ludendi morem in fcænam reuocafle, confeflum plus fe honoxis, $\&$ maieftatis, \& reuerêtiæ illi vni deberi quàm fibi vniuerfo védicare. Equeftris autem ordinis \& qui fua literis polteritati demandarent, inter alios, iurifconfultos plurimos fuiffe conftat, $\&$ quidem celeberrimos, quorum fcripta Aufidius Namufa quadraginta \& centum libris complexus eft. Ex his A ufidius \& Nerua ambo doctifimi \& equeftris ord inis a mbo fuere, ex his Furius Sabinus quoque fuit \& publice primus fcripfit. Mitto Tiberium Coruncanum, Labeonem, Trebatium \& Alpheum. Prætereo \& alios innumeros quibus quafi fellis quibufdá leges fulgent; quorumóg cófliis multi fane principum fuum imperium ad maximum felicitatis cumulum prouexere. Adrianus enim Iulio, Celio; Saluio, Iuliano Prifco atque Neratio vfus eft. Antoninus pius Vindio, Vero, Saluio, Valéte; Volu xio,Martiano, VIpio;Marcello \& Iaboleno. M Antonius philofophus Scæuola pracipuo iurifperito: Alexäder Seuerus Fabio, Sabino, Iulio Paulo atque Vlpiano, qué inter cateros tanti feciffe conftat vt Helius Lampridius literis mandauevit, hüc principé ideo fummú impatoré fuiffe, $q$ Vlpiani pręcipue cófliis répub. rexeric.Horü ftudiis fretus $\&$ moribus, iuftifime princeps Sigifmunde, quantum femper 
femper hęc atas noltra tulit, regni tui fummam, regimen, curam ac gubernacio nem tanquàm optimus populorum paftor his hominibus cótulifti qui non callidi,non leditiof, non ad malum idonei, non vircutis hoftes, nö luxu perditi,non cruces, non facinorofi, non fcelerum miniftri,non improbi ac prouincialium ex pilatores, fed fenes, fed fapientes, fed fobrii, feueri, pii, fancti, $\&$ qui habeant illud femper in animo vetus præceptum, Deum fequere, $\&$ qui nihil venderent, nihil mentirentur, nihil fingerent deciperéntque exiftimationem de te bonã tuique mandata, more Perfarum, qui internuncii funt aliud quàm refpondetur à principe fapenumero populis referentes: nec Parthorum regum vfum imitaren tur,quos non poteft quifquam fine munere falutare: \& ne pofteri filentio obruantur quos conflilis tuis huiufmodi præfeceris, quorüdam nomina ac dignitates recenfere non alienum erit. Merito itaque ante omnes pracipuum $\&$ primariú magiftratus huius noftri decus eft Iuftus, ex antiquiffima, \& pręcellentiffima co mitum vrbis Romæ familia, ca vitæ fanctimonia, ea integritate, ea religione,ea iuris ciuilis etiam et pontificii cognitione, ea denique eximia \& materne \& latinæ eloquencia copia, ac fuauitate praditus, vt hac noltra ætate ea non nifi cælitus per eum nobistranfmiffa merito atque optimo iure exiftimari poffit. Effulfit inter hos porrò quafi matutinum quoddam fidus Iacobus Aneftaxius Burgêfis, iuris non folum ciuilis $\&$ pontificii fcientia clarus, cæterum omnium bonarum \& optimarum artiun ftudiis peritifimus, ac in maximis quibusg gerendis te bus quàm aptiffimus, vtpote qui vafra ducum ac principum confilia optime no rit, \& cuius ingenium \& eruditionem ita laudem, vt hac laude cü eo neminem comparem, ita admirer vt magnum nefcio quid portendere in polterum videatur, quum ad quamcunque animo ren fe conferat, in ea facile ac breui fui acis mine ac mobilitate cateris antecellat. Succeflit Deindus, equeftris ordinis, exs primariis Perufr vrbis,vir magni ac præftantis ingenii, multxóp lectionis ac li teraturæ, fic omnibus cófliorū prafidiis, virtutis omnis \& eloquentiæ fplendore confpicuus, vt co non folum vrbs noftra, verum romana etiam, fi prifca illa maiorum gloria maneat, non iniuria gloriari poffit:acceflit quarto loco ex nobia liffuna vicecomitum familia Fräcifcus vicecomes, equeftris $\&$ ipfe ordinis per. paucorum, vir magni penfi magnóque rerum vfu attritus; \& experientia multa perilluftris. Sunt \& alii plures equeltris otdinis \& fpectate nobilitatis viri do. cifin mi, philofophi $\&$ oratores amplifimi ex quibus ad foeliciflimam regni tui diuturnitatem oportuna confilia, litera tx conciones a docta colloquia facillime poffint haberi atque componi.

\section{De Medicisis}

Cap. II.

637 Eque tandem medicine rationem intactam relinquemus, tametfi ma 1. 1 iores noftri virtutú omnium cupidiffimi, minus ä par erat cam cele4 If braffe forfan vif funt. Eft enim,vt doctiffimi auctores tradunt, non 15. folum ob morbum ac vulnerum remedia, quoguo modo corpora de bilitari contingat, verum ficabi diutius habendus elt exercitus, ob falubrem caftris locum deligendum, huius rei habenda cognitio, veterü rationem in haec ipla tepora rewocâdo. In his enim locis quibus fupioris etatis homines aut opp

$$
\text { E iii da }
$$


da,ftatiua, aut caftra cóftituebãt,pecoribus inolatis quę ibi pafcebãtur iecinora infpiciebant, $\&$ fr integram $\&$ folidam eorum naturam inueniebant, ex aqua $\&$ pabulo ibi munitiones conftituebant: fin autem vitiofa, idem in humanis cor poribus ob peltilentem loci cibíq copiam fieri poffecredentes, tranfmigrabant, ac regiones mutạ bant quxrêtes om nibus falubritatem: quã fi propter locorum difcrepantiam terrarumque diffimiles proprietates percipere haudquaquam po terant, \& fama \& incolentium difpofitione corporum, atque eorum colore facile confequebantur. Magna dehinc etiam induftria maiorum inftitutis querendi funt $\&$ deligendi fontes, qui fi nufquá præfto $\&$ in promptu fint, pluref́ç dies caltris im morandum, his fignis híf̣n notis \& rationibus vbinä lateant poterunt internofi. Nanq virentium imprimis herbarum copia, arborum $\$$ proceritas, vicinitatem indicant aquarum: terris enim quibus dulcis humor nó lon ge fubeft, vbertas quorúdü germinum femper arridet, vt iuncus, arundo, rubus, falix, alnus, múltúm que alicui loco pectore incumbens rana. Sunt illa huiufce rei indicia, quim nocte adueniente, loco in altitudinem pedum quinque defoffo, teftáque è figulino opere cruda aut peruncta, pelui ærea cooperta, lucernágs ardente concremata, fine defectu olei reftincta,aut etiam vellus lanæ madidum reperiatur, non dubie promittunt aquas. Addunt, quod certius multo eft, ante or tum folis longius intuentibus, quờd ex edito quidam fpeculantur in colurña fpeciem quandam, nebulofa exhalatione tenuiffimum fumum, qui quanta fuerit altitudine porrectus ad fummum, tanto in imum humorem delitefcere pro fiteatur. Orto etiam fole intuentur loca, talium rerum curiof, \& vbinam fupra terram viderintvolitare fpiffitudiné mufcarum, tunc promittunt facile quod quaritur inueniri. Eft \& peculiaris exiftimatio peritis tantum nota, quá feruentiflimo aftu féquutur dieíg horis ardentiflimis qualis ex quocunque locorum repercuffus fplendeat: ná terra fitiente, humidior eft ille indubitatáque fpe promittitur. Sed tanta oculorum intenfione opus eft; vt indolefcant: quo fugiente, ad alia experimenta decurrunt. Pradicunt etram fapores quarum, vt nec afpera difpendiofo labore debeát quæri, nec dulcis neceffariág inhonora relingui. Aquam enim dulcem argillofa terra, lim ofas exilef"ch fabulum promittit. Glarea incertas venas, fed boni faporis:rubra faxa optimas. Hanc fcientiam fequëribus accuratiflime tradidit a pud latinos Marcellus, inquit enim aquas quæ ad orientem auftrum $\beta$ prorumpunt, dulces atque perfpicuaseffe, $\&$ pro fua leuitate falubres:ad feptentrionem verò atque occidentem quxcunque manant, probari quidem nimis frigidas:fed grauitatis fux crafftudine incommodas. His proinde reperti vt ad humanæ vitæ falubritatem magna diligentia bonæ vtilefóp appetendx, fic non minori cura earum quoque vitia repudianda. Nanque

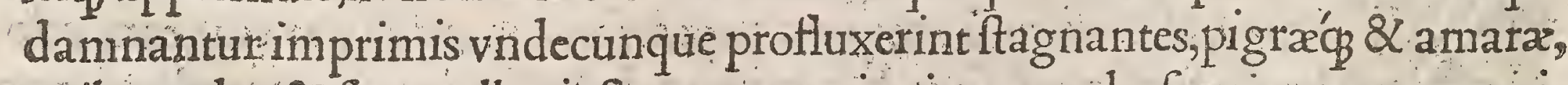
quibus odor \& fapor vllus infit, prater vnius in toto orbe fontis aqux, vt equidem inuenio iocundx,olentífque. In Mefopotamia vtiliores qux profluunt \& excurrunt exiftimantur: curfu enim $\&$ agitatione fua extenuari atque proficere aiunt, éoque miror cifternarum ab aliquibus maxime probari, quum inutiles aluo duritie, ac faucibus conftet. Quód fr rationem afferunt quód leuifina fit imbrium 
imbrium,vt qux fubire in calum potuerit, ac pendere in aére, ideo \& niues prę: feruntur imbribus:leuiores enim his effe,et multo leuiorem aqua glaciem; cuius. ac niuis peftilentiflimos ac infaluberrimos potus predicant. Repudiantur deinde aqux qux conum \& limum faciunt, qux́ǵ corpora inualida, malum colo:; rem, crura vitiofa, lippientes oculos bibentibus reddunt. Culpantur etiam fi vas xre corinthio,vel nobili fparfa infecerint,aut fi legumina tarde percoxerint, de; coctáque craffis obducunt vafa cruftis. Non etiam ipfa aqua qux erit in fonte: fi fuerit limpida 8 lucido calo pfimilis, quòque peruenerit aut profluxerit muf-.

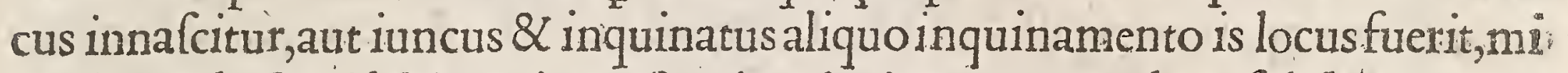
nus improbãda videbitur: intereft enim plurimum vtrum loca fulphure an vitrọ an bitumine plena tranfeat, grauem enim fpiritum caloremóp peftiferü aut nimium rigorem ex loci vitio faporis varietate. concipit, $\&$ füma celeritate corzüpit,quia protınus haufta duratur, nec aliter quàm gypfum fub humore con-. ftringitur 8 alligat vifcera:illinc eft illud de guo Ouidius ait,

Flumen habent Cicones quod potum faxea reddit

Vifcera, quod tactis inducit marmora rebus.

Medicamentum eft etiam, \& eius naturæ habet limum vt corpora conglutines $\&$ induretur, quemadmodum puteolanus puluisfi:aquam attigerit faxum eft: fi econtrario hæc aqua folidun quippram attigerit, hæret $\&$ affigitur. Inde eft quòd res abiectr in eundem locum, lapidę fubinde extrahuntur.Similem vim habent mero illi lacus quos quifque faucibus haufit,vt idem poëta ait,aut furit aut patitur mirum grauitate foporem. Nam quemadmodum ebrietas donecexficcetur dementia eft, $\&$ nimia grauitate defertur in fomnum, fic huius aque vis habet quoddam acrius ex aëre noxio virus, quod mentem aut in furorem mouet aut fopore opprimit.Contingit etiam non folum confectisde induftria venenis plerofg̣n necari, verum aquas qualdam confueto naturalis ordinis curfu, occultiorem in fe peftem feruare. Nanque fertur in Armenia fons cuius pifces in cibo fumpti mortem afferant, in Archadia circa Nonacrina. Styx ab incolis appellata mortifera eft, aduenafóp fallit: quia non colore nec odore notabilis; nec fapore fufpecta eff, qualia funt magnorun artificü venena qux deprehendi nifi morte non poffunt:in eadem regione fontem etiam effe conftat, vt epis gramma indicat,lapide infcriptum, non idoneum ad lauandum, fed inimicums vibus,quòd apud eum Melampus facrificiis purgauiffet rabiem proci filiarun reftituiffetóg earum virginum mentes in priftinam fanitatem. Linus etiam ibi fons eft,qui abortus fieri nó patitur: ediuerfo in Pyrrhea flumen, quod Aphro dixum vocatur fteriles facit. Eft etiâ noxia aqua in Theffalia circa Tempe qua ferá \& pecus omne deuitat,per ferrum $\&$ xs exit, vis illi ineft etiam dura molliendi nec arbufta vlla quidem alit; $\&$ hetbas necat:in:Macedonia non procul ab Euripidis fepulchto dextra ac finiftra monumenti aduenientes duo confluunt rivi,vinum accumbentes viatores tranfre folent propter aqua bonitatem:ad ri num autem qui ex altera parte monumenti, nemo accedit, quood mortiferam aquam dicitur habere. Achaia ex faxo ftillantes frigidiffimos humores habet, quos neque argenteum neque aneum neque ferreum vas, neque vlla alia mate- 
ria quo minus corrodatur potelt futinere, diffilit enim $\&$ diffipatur. coleruare autem eam $8 x$ continere nihil aliud nufi mulina vel afinina, vel. vt alii tradunt: equina vngula poteft, quxe etiam memoratur $a b$ Antipatro in prouincia vbi erat Alexander per Iollam filium perlata effe, \& ab eo ea aqua regem non fine magna Ariftotelis infamia effe necatum. In Bocotia funt duo fontes quorum alter memoriam, alter obliuionem affert:In Cilicia apud oppidum Vifcum, riuus fluit ex quo bibentium fubtiliores fenfus fieri Varro tradit. In Co in fula fontem effe quo hebetes frant. Cidnus etiam Cilicia amnis podagricis medetur, ficut apparet ex epiftola Caffii Parmenfis ad.M. Antonium:in Germania träs Rhenum caltris à Germanico Cafare promotis maritimo tractu fons erat aquax dulcis cuius hauftu infra biennium dentes labefierent decideréntque ac compages in genibus diffoluerétur:villa etiam ab Antonio lacu Campanix Puteolos tendentibus impolita litori celebrata porticu ac nemore quam vocat M.Cicero Academiam ab exemplo Athenarum;exiguo polt obitum ipfius tem pore, Antiftio vetere poffidente, eruperunt fontes calidi,perquàm falubres oculis, celebrati Laurei Tullii qui fuit ex libertis eius, tali carmine,

Quòd tua Romanx vindex clariffima lingue

Sylua loco melius furgere iuffa viret,

Atos Acamedia celebratam nomine villam;

Nunc reparat cultus fub potiore vetus,

Hac etiam apparent lymphæ non antè reperta

Languidáque infuf $x$ lumina rore leuant.

Ninirum locus ipfe fui Ciceronis honori

Hac dedit, hęc fontes quum patefecit ope:

Et quoniam totum legitur fine fine per orbem.

Sunt plures oculis qua medeantur aqua.

In Italix etiam alpibus nultis in locis eft genus a qửx,quä qui potu afliduo hauSerint,turgidis \& prominétibus gutturibus efficiuntur . Scater alibi denique in plurimis terris, alibi frigid al alibi calid $x$, al ibi promifcue auxilia conferétes, \& è cúctis animalibus hominum tantum caufa erüpentes: feruntur alix qux aluos inaniunt, capiti, auribus, oculifque priuatim medentur: neruis alix profunt $\&$ pedibus, alizeluxatis \& fractis adiumêto funt ac vulneta fanant. Eft autem vtilis fulfurata neruis, aluminata paralyticis, aut frmili modo folutis bituminata aut nitrofa, maxime calens. Homerum calidorum fontiü mentionem non feciffe non demiror, quum aliquos lauari calida frequéter induceret, videlicet quia medicina tune non erat hęc qua nunc aquarum profugio vtitur. Caterum quum ad huiu modi humanix infrmitatis remedia aqux prefto femper effe non poffint,atgue alio in loco inter fefe maxime diftantes, neque ad omnia omnes valeant, nunc ad reptilium fugam morfuf' $\&$ reliqua imbecillitatis noftre auxilia ex fimplici medicina vel compofita congeramus: quòd in promptu fit $\&$ inuen tum tam ab ipfa natura quàm a $b$ ipla arte profectum quàm facile: ab ipfa na tura filicem fublterni ville locis fufpectis aiunt, quoniam ferpentem experientia comprobante non recipit, vftáque fugat nidore: experti quoque prodidere, $f_{1}$ fer- 
pens ignibus $\&$ fraxini frondibus concludatur in gyro, in ignem potius quàm in fraxinum fugere: \& quod maius eft,nec maturini quidem occidentisue folis vmbras quamuis longiffimę fint vllo pacto velle cótingere: Verum fi ex arte vt fxpe fit \& Maro inquit fub immotis prefepibus aut mala tactu

Vipera delituit, celumóq exteririta fugit:

Aut tecto affuetus coluber fuccederet vm bræ

Peltisacerba boum, pecoríque afpergere virus

Difce \& odoratam ftabulis accendere cedrum

Galbaneóq́ agitare graues nidore chelidros.

Vel plenius \& vberius vt Pharfalie auctor expreffit,

Vltima caftrorum meditatus circuit ignis

Hic ebulum ftridet peregrináque galbana fudant:

Et larix non lieta comis coáque coltus .

Et Panacea potens \& theffala centaurea

Peucedanumóq fudat flammis ericináque taxus.

Et larices fumoóg grauem ferpentibus vrunt

Abrotanum et longe nafcentis cornua cerui.

Percuflis quorundam hominum tota corpora fue partes profunt, vt Ophiogenes olim in infula Paro, Marfíg alibi in Italia,fue quódam in terra Aphrica, fi modo durét $\mathrm{P}$ filli qui vocãtur à $\mathrm{P}$ fillo rege vt Agarchides tradit dicti. Lucanus, Nam primum tacta defignant membra faliua,

Qux cohibet virus retinétque in vulnere peltem.

Nec Marforum folum ac PGillorum fed ieiunam cuiufque hominis faliuả contra ferpentum ictus pręfidio effe non dubium elt. Silerem in proferendo percufforum remedia, nifi, $M$. Varronem fcirem, lxxx vite annum agentem, Marcúmque Catonem Porcium prodidiffe, afpidum ferpentum ictus; haufta à percuffis vrina, vel Melantio in vini veteris hemina contrito 8 in nares infulo,appofitóque ad morfum ftercore fuillo, efficaciffimè curari: horum etiam $\&$ fcorpionum ictibus ipfi medentur, fi mortui $\&$ attriti ilico fuperimponantur. Viperam etiam ferunt exuftam in cinerem's; dilapfam mederi eiufdem beftix morfui. Ad huiufmodi etiam ferpétum morfus Nigidius de animalibus libro fecun do teltis eft, gallinam quoque apprimum deligi opponíg debere: ex arte quoque ea maxime probantur qua in $æ$ dis Efculapii deilimine contra animalia viru lenta ea, compofitione clariffima fcripta lapide fuiffe inueniuntur, Serpilli videlicet duûm denariorum pondus, opoponacıs ac milii tantüdem fingulorum, trifolii pondus denarii, anethi $\&$ foeniculi feminis $\&$ anef $\&$ op ii duûm denariorum femis ex fingùlis generibus, erui farinæ, xii.que tufa \& cribata ac vino excellenti digefta dari in vini cyathis tribus confueuere. Quo genere antidoti An tiochus magnus rex, aduerfus omnia venenata vfus perhibetur. In fäctuariis $\mathrm{Mi}$ thrydatis, maximi etiam regis inuétam antidoti quoque compofitionem ipfius manu confcriptam legimus, \& à Galeno etiam \& Diofcoride celebratam, è du. abus fcilicet nucibus, ficcis ficis totidem, foliis ruta, xx. fimul tritis, addito falis grano: hoc effectu deniq, vt qui hoc fumereet ieiunus, nullum venen genus pro 
fecto furet illo fibi die nociturum. Porrò vulnerum remedia in prafentiarum attingere, nec abfurdum, nec inutile erit, verum quoniam vulnus nequicquâ con glutinationé admittit fi ferrum intus maneat; infixa \& corpori ad hęrentia quo nammodo abftrahi poflint primum docebinus, prompta \& pauca quadã re media profequentes. Infixa quaque cinis abftrahit hirundinis, in olla combuItx cú aceto. Mus frmiliter diffectus \& fuperimpolitus, farina è femine lini cum radice cucumeris fylueftris, fractis offrbus prefentaneus, maxillarum apricinis, coltis quoque fractis laudatur vnicè caprinus fimus ex vino vetere: aperit enim \& extrahit atọ fanat. Sanguinem porrò ex vulnere fluentem fiftit puluis olibani,cum pilis leporis \& albumine oui facto emplaftro, $\&$ impofito donec cadat. Aloës etiam puluis per fe vel cumaceto vndecunque fluat fanguis eum filtit: vulnera recentia $\& \&$ vetera fi braflic decoctione foueantur; $\&$ ea trita imponancur, mire fanat: vermes qui in ligno, vlcera fanant omnia: vulnera verò recentia terreniadeò cóglutinant, vt neruos quọp præcifos illitu folidare intra feptimú diem Democritus perfuaferit, itaque in melle feruandos cenfuit : inflaturam ex ictu, cicuta trita impofita fanat. Achillea que nillefolium maius vocatur cum aceto bibita ad plurima quum valeat, ad fulpiria precipuè confert pracipitatis ex alto. Eiufmodi remediis clara Efculapii opera fuere troianis temporibus. Podalyrius deinde \& Machaon ex eo genitı fucceffere, qui \& bello troiano duceminclitum Agaménonem fecuti,non mediocrem opem vulneribus tantun medendo commilitonibus fuis attulere. Adhibitos in exercitu fuo à Cyro medicos,Xenophontis tradic hiftoria. Scimus $\&$ Xerxem Perfarum regem à Sothene comitatum effe bello quod Græcis intulit, itemque Alexandrù a Solthene fecundo, nec nifr cura artis huius, ope atque præltantia quä ab inuictiffimis maiorum noltrorú ducibus celebratam nouimus. Hanc enim apud noft ros $M$. Cato magifter primus, folul' $\not$ diu paucis duntaxat attigit,ad armentarios mor bos nedicaminibus haudquaquam omiffis, quæ per alios deniqg diffufius pertractanda funt: polt hüc illuftriư \& clarorum virorum vnus tentauit, C. Eualgius literarum eruditione fpectatus, voluminead D. Cxfarem Augufum de ea edito. Verum enimuerò antè condiderat folus apud noftros vt equidem inuenio Pompeii magni libertus Leucus nomine, quo primum tempore hanc fcien riam ad noftros animaduerfum eft perueniffe. Nanque vt ad externos redeam, qui huius difciplinæ multarú rerum inuentione gloriantur, Mithrydates, maximus fua atate rex $\&$ imperator, quem debellauit Pompeius, omnium ante fe ge nitorum curiofiffinus medicinæ remediorum indagator, tam argumentis $\widetilde{q}$ fama nuncia habitus elt, cui vini cum veneno fepe tentaretur excogitatum, quotidie venenum bibere, prafumptis remediis, vt confuetudine ipfa innoxium red deretur:ficque in hunc vfque diem Antidotum eius nomine celebratiflimum extat, quod Mithrydaticum vocatur:alterú Antidoti genus Zopyrus regi Ptolomæo dicitur compofuiffe, atque Ambrofiam nominafle. Praeter hunc inuenit Iuba rex, $\mathrm{P}$ tolomai pater,ftudiorum claritate admirabilior $\bar{q}$ regni, quàmquam primus vtrique Mauritaniæ imperio præfuerit, euforbiam herbã quam medici fui fratris nomine appellant, edito de ea volumine claro preconio. Cen 
tauréa à Centauro Chirone dicta inuentore, qua curatus Chiron quim Her culis exceptus hofpitio pertractanti arma fagitta excidiffet in pedem. Achillis quoque, Chironis difcipuli Achillea perhibetur inuentum, qua vulneribus mederetur, qux ob id achilleos vocatur: hanc a pud nos millefolium vocant. Alii primum aruginem inuenifle vtiliffrmam in plaftris, ideoós depingitur ex cuf pide decutiens eam gladio in vulnus Telephi . Comperiffe etiam dicitur Teucer eadem ætate 'Teucrion quam quidam germineam vocant. Gentianã quoq reperiffe aiunt Gétium Illyricorun regem vbique nafcentem, Illyrico tamen ad plura praftantiflimam. Sunt \& alia medicamentorum genera quę divino quafi quodá numine tactu ipfo fiant atque leuentur, vt Vefpafiano principi \& Epirotarum regi Pyrrho contigit: illum enim publicè fedentem audiêtég quum è vulgo captus quifpiam luminibus, alter quoque cruris debilitate pariter adi rent,opem implorantes à fe rapide demonftratam illis per quietem, redditurüqu alteri lumen profiteretur fi oculos infpueret, confirmaturumóp alteri crus fi dignaretur calce contingere, quum ridicula tes primum putaretur; nihili pende. returóp , tandem familiarium interuentu et circunftantiú quorundam fuafione vtrunque tentatum eft, nec optatæ falutis am bobus defuit euétus. Hunc auterin lienofis, hoc eft, fplene laborätibus refupinég iacétibus, dextri pedis pollice pref fis medétem accepimus, galli facrificio albi facto, neque quempiam abiectum ab eo fuifle cui huiufmodi genus medicaminis pofcenti abnegaret. Magnä etí am medendo vim verborum ineffe infirmitatibus hominum, animalibus languentibus, claudicantibuf' $\not$ g vel etiam moribundis funt qui putent: \& quanquả literæ id noftræ refpuant \& ad falutis remedium nihil conferre autumét, pro fiuuium tamen fanguinis vulnerato Vlyxé inhibuiffe carmine teftis eft Home rus. Theophraftus etia fciaticis prodidit, Cato luxatis membris, Varro podagris carmen auxiliari.Cæfarem quoque dictatorem poft vehiculi cafum vnú ferune femper vt primú confcendiffet, id quod plerique ea tépeftate facere norant,car mine ter repetito itinerum fecuritatem aucupari folitum. Infinita huiufmodi exmplorum copia fupereft, qux libens ponerem nifi ad gymnafticam \& exercitationem reliquam qux maximum fufcepti muneris officium eft, ac bellicas rationes feftinaret oratio. De bonarum igitur artium ftudiis haec exarata fint, Gymnafticam \& reliquam huiufmodi militarem exercitationem nunc ordine fuo profequemur.

\section{De Gymnaftica equeftrique exercitatione.}

Cap. III: AEterú quum plurima fint exercitationü genera, probanda quiden 3 a 1 folum illa nobis erunt qux fecundú naturæ vim ac ætatis rationem 2. 2 (22) fufcipientur, quo \& valitudo bona feruetur \& ad labores militares 25. 2 ferendos robuftiora deinde membra reddantur.Vtrinque enim primis ab annis non parum referre putandum eft quali quifque alimonix affuefiat, quibúfque exercitiis durioribus vel mitioribus affuefaciendo vrgeatur, veluti ea quę in Lacedæmoniorum ciuitate vel fola vel cum paucis cura à legum la toribus circa educationé $\&$ exercitationem publicè videtur ad hibita: ex ceqteris etiam animalibus $\&$ gentibus apparet, quibus cura eft aflidua bellica habitudi- 
nis, nutrimentum lactis fontiungue aliquorum ad valitudinem roburque maxi me proprium effe corporibus, vt Lucanorum \& aliorum plurimorú:ad vtrunq etiam confert, \& vtile putatur à pueritia frigori affuefacere: $Q$ uapropter ad ami cum fcribens monet Flaccus vt anguftam pauperiem pati robuftus acri militia puer condifcat; $\&$ Parthos feroces vexet eques metuendus hafta vitám $\not$ fub diwo $\&$ trepidis agat in rebus:et quum procliuis puerorum etiam natura fit ad om nia opera $\&$ ad omnes actus, illi ea xtate maxime fufcipiendi funt qui per ludos fiunt. Lu di vero ipfi neque illiberales ne $i_{1}$ illaboriofi effe debent, neque remiffi, fed quales L ycurgum in Spartiatarum filiis inftituifle ferunt: ipfe enim quápri mum feptimum ætatis annum exegiffent affumens diftribuebat in claffes, eófque vnà focios atque contubernales confuefaciebat in vicé finul legere \& fimul exercere, quo per dimicationes mutuas \& promifcuas contétiones difceret quale cuiufque ingenium efiet, qui auderet, neque in certa minibus pugnam detre etaret. Mirides quog Aegypti rex poft ortú filii Sifoofis, ex omni Aegypto om nibus qui eadem die quo filius nati erant infantibus congregatis, nutriri educaríque ac fingulos eadem difciplina exercitióque erudiri fecit, exiftimans hoc pacto fimul educatos atque inftructos meliores in bello fore, hos continuo vfu ad malorum patientiam exercebat: non enim licebat alicui cibum priufquă curfu centumoetoginta ftadia confeciffet capere, quo exercitio vt omnes viri euaferát. \& robufto corpore \& animo præftantes, primum Sefoofis in Arabiam cum eorum qui fimul nutriti erant exercitu à patre miffus afluctúfque venatui, ac cibi potuf́p abftinentix, omnemog eam gétem fubiecit, liberan antea $\&$ feruitio infuetam. Deinde in Libyam profectus maiorem eius partem in deditionem adhuc adolefcentior redegit. Simili modo Alexander xxx . milibus barbarorum puerorü delectis, gręcis eos literis \& Macedonico more armorú exercitationúqúp vibus verfari præcepit, pluribus ad eam rem inftitutis magiftris, fić́ $\not$ præter literas quas pro necelfitate difcebät, reliqua omnis exercitatio et difciplina ad recte obtemperandum armorumóg laborem tolerandum \& prælio vincendú parabatur. Hac in re I acones quoque quum efferatos laboribus perfepe redderent adolefcentes, quafi hoc effet vtile ad fortitudinem, maxime fallebãtur. Nó enim id confequebantur quod intendebant, neque in aliis animalibus, neq in gentibus videmus fortitudinem adefle maxime efferatis, fed potius mäfuetioribus $\&$ leoninis moribus, multxóp funt gentes, quę ad cæedes hominum \& ad eorum co meftioné infuleant,vt circa Pontum Achei \& Agniochi : \& ex mediterraneis alix gentes, que quidem clanculum per infidias latrocinantur,ad bellica tamen opera nihil valent. Omnes enim iftæ feritate liberæ gentes, luporum ritu vt feruire non polfunt, ita nec imperare: non enim humani vim ingenii habent, fed feri $\&$ intractabilis. Lacones praterea fcimus dum ipfi exercebantur præftitiffe cæteris, poftea verò fuiffe aliis inferiores. Non enim ob id folum præftabant $q$ : iuuentutem exercerent, fed quòd ipfi exercitati contra non exercitatos pugnárét. Romana fimiliter legiones nif fuiffent primum affidua exercitatione attritæe (Ab exercendu enim exercitus quòd exercendo fit melior dictus) nullo pacto in pubertate,ante, vel poft pubertatis tempora pedibus agmen præire,fubire pon 
dera,arma deferre,nec preclarum ac memoratu dignum aliquid reddere potuiffent. Huius rei ætatif'ó huius fralia nobis deeffent, Scipionis A phrican fuperioris, \& Aemilii quom Lepidi conftare poteft exemplis:ille enin dum prætextatus elfet,vt Floro placet $\&$ Senece, pubefcens autem vt Livio, eo pi clio quo in Romanos Hannibal ad Ticinum valido ftatim fragore detonuit, pa tre ciuem cófulem bellíģ ducem affectum graui vulnere $\&$ ab holtibus circủuentum per culo mortis exemit,feruatióp parentis cumulatam fuis laudem retulit. Hic vero puểr productus in pugnam, codem congreffu $\&$ hoftem occidit $\&$ ciuem leruauit, in cuius memoriam rei ftatua illi prætextata ex S.C.in capitolio pofita eft, vt \& cxteri exemplo ciufmodi accenderentur. Sed neq \& tu quog hoc in loco nifi tibi tuas laudes inuiderimus, Sigifmunde Pandulphe, filentio obruendus es; aut vilo pacto his duobus inferior habendus, quum tertiumdecimum etatis annü pene agês fub D. fratre tuo Roberto in illa peftifera atg funefta tumultuantium parricidarú conf pirationis eruptione cófternatis tuorum iam onsniü animis, fuborta, de tota Malateftarú familia omniumóp ciuiú ftatu actu m effer, nifi protinus hinc te raptimíg furripiens in legionis vnius numerü,conuocatis vn decunģ fubditorú populorum auxiliis tecum vna die confluentibus, ferro, vi, ar mis cótra quãplurimos, fortiffimos, $\&$ ad fubuerfionem vrbis noftræ inımitiff. mos viros cum maximo capitis tui periculo dimicafles: nifr tu tibi ac fratribus patriam, rerum fortunarúm g fuarum pariter ac tuarum incolumitatem deperditam, \& penè reftinctam vindicaffes, Illa pefte, illo monftro ac portento feditionis auctore ar $q$ flabello à ciuitate reiecto: profligatis cæteris deinde factionis $\$$ tumultus illius primoribus at $\$$ complicibus, 8 qua ad tertium vfo lapidem in corum auxiliü prouenerant, Pifaurienfum copis, plurimis infuper ad cuftodiam,tutelam firmitatemóp ciuitatis noftre per te accitis pręfectifóg cohortibus. Sícque mirabile dictu, in illa perditorum hominum colluuione, vnde veterano, armorum \& equitandi totiúfíg rei militaris peritiff mo euafffe fatis fuiffet, tu id ætatis ob tuam vigilantiam, ingenii viuacitatem, animíque præftantiam, vtriuf que fratris feruati $\&$ patrix, publicæ foilicet ac priuatæ pietatis triplicem meru ift coronam, Clariflimum inuictiffimi futuri ducis initiu. Quid enim fuit prin cipem in fux adolefcentię limine infpicere,tam magnú facinus committere au dere?quid eo ipfo magnific étius, quid fortius, quid gloriofus \& laudabilius?quid in antiquis maiorú tuorü monumentis præclarius? quid famofus tris potulffes pofteris relinquere quàm vina ferè ac omnium voce dici, häc vrbé nobilifímam, vniuerfum populum, ius, xquitatem, leges, mores, per te vno tempore cóferuatos fuiffe? Neque id fane cuiquâ incredibile de te videri debet, qui annos femper tuos longe antecefferis, $\&$ omnes virtutum omnium ab ineunte auo numeros ita colueris, vt in te antè claruerint quàm perfect $x$ intellectęq ab aliis fuerint. Spretis nanque folitis puerilis atat is illecebris, magna vi aftrorum, fortuna tuas res maximas ad imperiü difponente didicifti,non ig nauia, non quiete, nó ocio, non defidia, non voluptate torpere, fed nembra durare, militares labores perferre, vigilare, efurire, fitire, al gere, $x$ ftua re, \& cum vltimis militum \& equitum dura $\&$ afpera quax aggredi. Doctus etiam pra cęteris tui temporis regi pariter $\&$ re- 
gere, exercitus ducere, caftra metari, acies inftrucre, pręidia agitare, hoftes ferire, nachinas erigere, firmare aggeres, pila torquere, haftilia iaculari, clypeisintonare $_{j}$ enfem vibrädo incredibilia penetrare, in fcandéd is equis nó perfico more iuwari, fed inftituto fine fcäfrilis ferri adminiculo, leuiter facilégeos infilire, ac reflexis in tergû́ manibus, velocifimis curfibus ad exemplü ducendi frequéter con citare: nunc item flexis habenis in medio curfu leui mométo pracuertere: nune montes confcédere, nunc foffas faltu traiicere: $\&$ ita demü ad omnia rei militaris munia percallere, vt non facile quíquã poffit elicere miléfne an eques, tribunus vel imperator maior et inftructior accedas vel habearis: pluribus deinde quü adcleueris rerú eiufmodi per vniuerfam Italiam inductoribus accit is, qui neque prusà te dimilli ga in cæeteris quæ modo diximus exercédo, eos aut æquaris glo ria, aut fuperaris, diuiciis plurimis \& honoribus auctos: Alexandrú Seuerũ credo

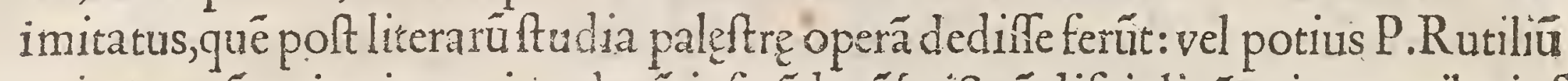
qui armorú agitatione, vitandorũ inferédorǘp ictuú difci linã primus miles iuf fit accipere, $\&$ in caftra penetrare, vt nedú viribus $\&$ audacia quibus antea folis

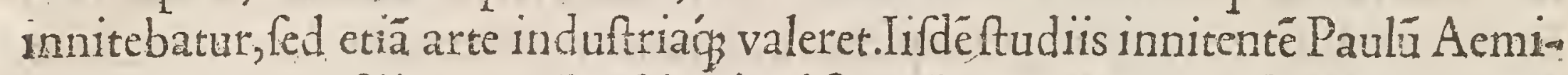
liúlegimus, $q$ \& filios quorü inftitutioni frequéter interetat erudiri céfuit, ac vo luit egregïs taliū rerú felectis preceptoribus cỏ mitri. Mariụ autê iîldé nec dum iuuenis ftudiis, verü quú eflet annis cofectus, $8 \mathrm{~m}$ mlta corporis egritudine grauis - quo filiú militaribus officiis obeüdis per reliquú eqtatis illufré redderet, quotidie cú adolefcétibus foras prodibat in mediü vnà decertans, nó nefcius quãti hoc in pace imaginariæ militiæ genús à teneris annis imbibite, ad maxima pofterorú difcrimna, ac vera belli pręlia ineúda conferret. Et licet hoc militiz genus quod in eiufmodi exercitationibus quaritur longe impar fit ei quod inter bellorú tumultus per indigêtiấ rerũ omniũ omneśq terrores difcitur, mirũ tamé in modũ equitatu facule $\&$ armatura leuiffimú corpus reddit.Idé expeditioné agés, copias fuas affid uis laboribus, curfu $\&$ lógo itinere exercuit,eos' bebat ferre \& vafa \& cibaria illis. in fafciculos coëuntia furcis imponi, fub qbus $\&$ habile onus \& reqes facilis effet, vnde in puerbiü poftea venit, vt $q$ difficultate nulla infractus miles laború eflet patiés, eorúqp nō afpnator, fed ftudiofus ardéśq imperatoris fuiiufla tacitè agés, Marianus mulus appellaretur. Caro etiã Céfori nus flio fuo magitrũ fe prebuit, quippe qui exercêdi corporis, nó modo iaculā-

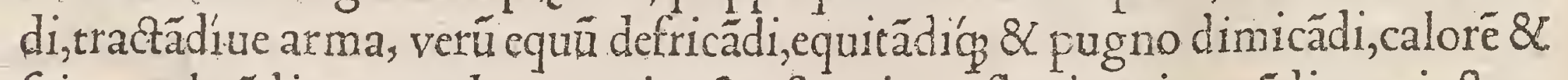
frigus tolerädi, ac xapidos gurgites \& a perrimos fluuios vi tranädi arte inftruxit. Vticenfis autem ille pofterior Cato, in gymnafiis fe exercens, laboris ita pa tiens fuiffe dicitur, vt detecto capite, leu fol, feu imber effet, cum amicis qui vnà iter-faciebant, equífque veherentur, fingulos fape adiens, \& pariter cum fingulis ambulans loqueretur, pedibus ipfe proficifens. Magnim \& pręclarum quoque erat ad animorum fidutiam, maximum ducem afpicere Pompeium, duo de fexaginta annos natum, faltu $\&$ curfu pedites primum, equites armis deinde exercere, nudare enfem, \& currente equo vectum peropportune recondere. In iaculatu praterea, non agitare modo, led pro tempore robur oftendere, qué talibus infdentem, ex iunioribus plerifque haudquaquam facile fuperabant . 
Neque enim ille potuiffet par effe. Sertorio, nif fe militef'op fuos frequentibus exercitiis preparaffet ad pralia, quum ad difficultates ille maximas, ad longas itinerationes, per afpera quxq \& inuia affuefactus,ex quibufcunq locis inuadendi euadendíó ac exercitum ducendi peritiam quandâ \& fummam haberet.Ma Gniffa,Numidarum rex, nonaginta annos natus,præ cæteris hominibus hac in parte admirabilis fuit, adeò quemadmodum Cicero refert, vt nullo vnquam imbre,nullo frigore caput fuum vefte tegeret. Eundem conftat aliquot horis in eodem veftigio perftare folitum,nec antè moto pede $\mathrm{q}$ cófimili labore iuuenesfati gaffet:ac fi quid agi vt frpe folet à fedête oporteret, toto die fępenumero nullam in parté cóuerfo corpore, in folio duraffe : \& quu ingreffus iter pedibus effet, in

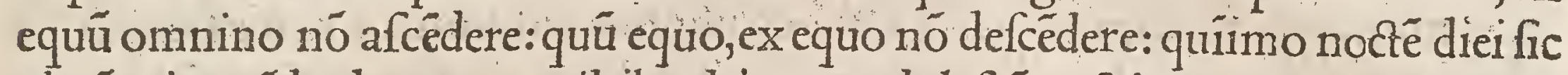
plerüqu iungédo ducere, vt nihil ex his quæ adolefcétes folent, omittere videret̃. P.Scipio côtra Numátiá miffus, corruptú focordia ducés exercitum, exercitatione correxit,cogếs niùes \& frigora pati,vada fluminú pedibus traịcere,timidos fubinde exprobando, \& ignauos,frangendóg dilicatioris lafciuiorif que vitę vfus, \& parum neceffaria expeditioni vafa.Curauit præterea Cyrus vt nunquam milités niff fudore prauio prandium fumerent aut coenam, id'p aut venatione fiebat,aut alio iniuncto opere, quod egens feftinatione fudoré eliceret. Mithrydates rex Ponti per hyemem ocio marcere milites nunquã paffus eft, cos nanqgi aćfe ipfum continuô tectis haud quaquã vrbanis,fed caftrenfibus tenuit: neque verò ludis nifi acerrimis membra indies exercuit, affuetus feras curfu perfequi \& viribus nonnunquả congredi,ne $Z$ ephyro ad bella vocante vires per blandimếta languefcerét. C.quoque $\mathrm{C}$ æáre qué vltrà quàm crédibile cuiquã videatuir laboris patiente fuiffe conftat, ty rones domi per equites peróg etiam fenatores armorum peritos, inftructos legimus, ad eófque fcripfiffe perfape, quo fing gulorum cus ran difciplinámq . fufciperent: nec ty ronibus folum, fed militibus etiam fuis,ac vniuerfo exercitui die noctúg, fubtrahebat, augebátque iter, quo per fegnitiem $\&$ inertiam fubfequentes defatigaret : qua omnia filentibus bellis animaduertếs Probus Aurelius, in negocio verfari milites fuos quàm in ocio ne láguerent, faț us fare duxit, fabricis nunc vrgendo nouis, altas nǘc extruendo turres, nức aquofa deficcando loca, nunc templa qua vetuftate corruffent reftaurando, aut noua \& pulcherrima conftituendo atque colendo. Saltationem quoque domi à La cedęmoniis,admiffam inter exercitationes ad bella viles fuiffe,memorix prodi tur,quam Socrates apud Grecos probat: \& niaiores noftri,nec inhoneftam, fed neceffariam fimili modo putant, quum apud eos faltationem in armis habitan. \& ab ipfo tripudio faltatorios alios denominatos conftet. Et quanquam vno eo demóg tempore tribus nobiliffimis ciuibus, non modo ftudiun faltandi, fed etiam peritian qua gloriarentur fuiffe non dubium fit, Gabinio Fcilicet confulari, $i_{3}$ Cicéronis inimico, quod ei etram Cicero non diffimuláter obiecit, \& M.Cęlio, noto in turbas viro, quem idem Cicero defendit, $\&$ Licinio Craffo, Craffi eius qui apud Parthos extinctus eft filio, Crifpus tamen Saluftius, fpectata veritate hiftoricus, Semproniam, nobiliffimam foeminam reprehendit, non $\Phi$ faltu valeret, fed $q$ eiufce reifingularé quandam peritiam $\&$ eruditioné habuerit 
\& Scipio vt Senecx verbis vtar, co in libro qui de animi tranquillitate inferibitur, triumphale illud \& militare corpus mouet ad numeros non molliter, fed infringens, ve nunc mos ef etiam, incelfu ipfo vltra muliebrem mollitiem fluente. Sed vt illi antiqui viri folebät inter lufum, ac fefta tema pora virilem in modum tripudiare, non facturi detrimetum, etiam fi ab holtibus fuis fpectareritur, nec tibi, $S_{1}$ gifmunde, huius \& allorum faltationis fudium torpitudini fuit,fimili mo do exercere prodiréćp in medium, ac modo aperta fronte, modo perfonata nonnunquam populo effe fpectaculo, hac ratione tua quòd nulla pars corporis in fal tatione, vit frece $\&$ phyfice quidem dicere foles, ociofa fit, fed collum vnà $\&$ crura \& manus exerceâtur exerceríp debeant, per eú qui fit corpus agilius $\&$ ad om nem militarem motum ac celeritatem promptius habiturus. Prater hoc Nembruth, vel vt ali perhibent, A pollinis I ianá́p inuentú, venandi ftudiü fummo pere probare etiam foles, quòd parum tibi quid à iufto differre bello videatur, gnum opus fit feras infequi fugientes, locorum afperitatibus, abruptis $\&$ inuiis moueri, maximos labores capiendi ftudio fubire, abftinere à multis, eftus $\&$ algo res pati,fitim ac inediam tolerare, commoneri deniqganimo quum fint manus conferenda cum feris, cominuf congrediendum, his caufs honeftiflimis, nec ad illecebras tantum $\&$ aniniorum relaxationes, antiquorum plurimos ac quidem grauifimos inhafiffe percelebre eft: nam fixerit ceruam licet, aut Eriman ti nemora plararit victor Alcides, aprum Calydonis regionis vaftatorem ftrawerit Meleager, fuderit auctor romani generis ceruorum corpora, non voluptarifue fed publica vtilitati profpexere. Cyrus fimili modo publicæ vtilitatiș militarisóg difcipline gratia eos ipfos qui aptiores bellis videbantur, venationi affue faciebat, propterea quód id genus exercitii plurimum bellicx rei conducere ad exploranda itinera, $\&$ diucrforum locorum anfractus non dubium fit. Pratereo Alexandrum,Sertoriun, M.Antonium, Alexädrum item Seuerü,Hadrianum, Tacitum, plurefog alios fuperioris temporis imperatores ac duces maximos hoc exercitii genus fummo quodam Itudio profecutos: quos verò fpecies illa venationis oblectat, vt aues auibus infequatur, fr tamé hoc genus aucupii venationi cen feas annectendum, mitiori quidem fudio exercentur, fed non impari leuitate ac yoluptate. Huius autem exercitationis auctorem funt qui Macchabęum,egregi um belli ducem, fuiffe confirment. Ab antiquis auten fecularium hiftoriarum fcriptoribus fidé fumentes, Vlyxem perhibent, qui primus excifa Troia armatas aues attulit Græcix, quas tua vi quadam \& grata intuentium admiratione, duce natura in cognati generis exitrum animauit . Nam quú accipitres pafin auibus infidientur, eal'os rapiant, alii ex terra folum, alii non nifi circa arbores yolitates, alii fedetes in fublimi,aliqui volantes in aperto, in Thracix parte fuper Amphipolin homines 8 accipitres focietate quadá aucupátur. Hi cnim ex fylứs 8 a rüdinet aidunt cü his, traditúmg eft miflas in fublime ibi accipere cos, et quú tépus fit capturz, clágore \& volatus genere inuitare ad occifoné. Pif cationis auté vfus \& modeftior elt, qué nec afpernati funt plures $\&$ qdé magni viri, Auguftus præci. pue \& M. Antonius, qui ob laxandu animü, pilcari fapius hamo foliti ferutur: 
quanquä \& honeltior forte, \& probãda magis illorủ vita füerit, de qua inquit $N$ d Io, Pifcis adhucillis populis fine fraude natabat, Oftreaóp in cóchis tuta fuere fu. is: Nec Latiü norat quam prębet Ionia diues, Nec que pygmeo fanguine gaudet auis. Natand peritia propter maritima etiam bella his ad hibenda videtur, quu $\&$ periculis liberare milites ac duces plerúque foleat, $\&$ ad quęg clarifima facinora audaciores reddere, ideóg̣ maiores noftros cápú marciú Tyberi finitimú delegere quo \& milites tabé onné fudoréó illú Martiú atq̧̧ fqualoren armorú. exercitio cótractú diluerêt ac natádo laborem deponerét. Huius rei peritia Serto rius, Romanis aduerfus Cymbros male pugnãtibus,amiffo equo \& vulnere infuper accepto, R hodanú amné cú thorace \& fcuto per aduerfos fluctus, \& flumi. nis vortices, toto cospore atq omnibus vngulis vt dicitur plurimü innited o traiecit. Simili modo Iulius Cęfar quum Alexandrix circa oppugnationem irrum pentif'p multitudinis impetum preffus fcapham cofcendiflet, mox pondere fequentium preffam ac porrò merfam per ducentos paffus ad nauem, vna manu. elata qualiteras deferebat, natand o peruenit,fićp vt fint qui paludaméto in fluctibus dimiffo enatalle illum dicant : id'́g feu fortuitò, feu confultò, vit holtes in illud fagittis ac lapidibus intentos faceret : fint'q qui paludamentum mordicus: trahentem, ne hanc quidem gloriandi materiam hof tibus reliquiffe confirmêt: hæc tamen vulgatior \& certioribus teftibus fuffulta fententia eft. Nã de co nulla eft cötrouerfia, eleuata illum finiftra manu natauiffe, ne libellos quos ea geftabat,maris aqua perfunderet. Huius difcriminis forte memor Auguftus, ea in re nepotes fuos ita ftuduit erudiri,vt \& ipfe plerunque per fefe doceret. Talia porro exercitia recipienda funt qux ad imitationes eorum qua poltea feriò erunt faci enda, accommodari poffint, nec faciât exercentem habentémque, vilis exercitii operatorem: vile autem exercitium putandum eft quodcunque corpus aut animum, fiue mentem deterius difporyt, vt mercenariorum turba plurima, \& qux fordida nuncupamus: mentem enim non expeditam, nec ad opera bellica vtilem, fed vilibus occupatam reddunt. Illud fimili modo vnü nec pratereundum, tanquam omnium vtliffimum, equos filicet ad equitandum idoneos, fed inexpertos laboris, celeriter confici necarique folere, proinde equitem oportere frequenter eos agitare, \& quoniam frena \& phaleræex loris confecta maxime vfui funt, nunqua fine illis incedere: fićs parua inspenfa permagnum fibi præfidium comparare poterit, $\&$ gloriofius in omni bellico certamine victor euadere

$$
\text { De Osio militari }
$$

cap.

IIII

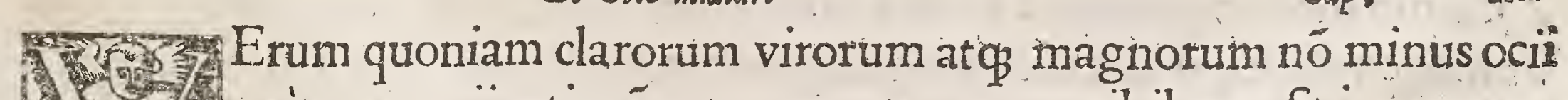
(2) E quàm negocii rationé extare oportet, quum nihil pene fit in opere na I ( ) turx quod non exemplo dierum ac noctium, aliquas vices feriarum The - velit, huic ipfir modum finem'́s præf cribamus. Primum itaq quum permultæ fnt animorum huiufmodi relaxationes qux aliquo tudio feffos leua re poffint,vigorép animi ab omni trifticia \& pertinaci laboris cótinuatione feriatü hilariter difcutere, in ocio \&ceffatione id potiffmú erit, ne quid illiberaliter, ne quia petuläter, ne quid flagitiofe, ne gd obfcene, molliter, impudenter ac improbe fufcipiatur. Sec quicquid id erit, fit vrbanum, fit ingenuum, fit facetum,

E iii 8 
$\&$ eiufmodi denique in quo aliquod probi $\&$ generofi animi lumen eluceat, $v e$ que apophthegmata \& fcomata vocant, quibus Auguftus Cæf. Adrianus aliíg permulti ferociffimi \& bellicofiflimi viri maxime Lacedęmonii vfi perhibêtur. Apud hos enim inter cretera exacte vite inftituta hoc iocandi genus a I y curgo inftitutum eft, vt adolefcentes $\&$ fcommata fine morfu dicere, $\&$ ab aliis in fe dieta perpeti difcerét, vnde fi quis corum in indignationem ob tale delictum prolapfus fuiffet, vlterius ei in alterum dicere non liceret: qua res quantum fit vtilitatis allatura, qui Lycurgi vitam legerit facile inueniet. Licebit etiam variū vitæ genus habere, modo ruri effe, modo in vrbe, fxpius in agro quiefcere ac dean bulare,vt Scipio ille qui primus Aphricani nomê geftis rebus $\&$ virtute meruit. Quippe qui f piritum domitorem gentium, $\&$ aures caftrorum Atrepitu $\&$ tubarum fragoribus oppletas huc referre confueuerat, non vt virtus ocio langueret, fed vt fefe mens varietate negociorum difcreta colligeret. Quamobrem nec fibi vnquam ociofus, neque fibi folus vnquam videbatur. Huius nepos $\&$ ipfe Aphri canus Scipio, ficut laboris $\&$ exercitii fupra fidem patiens, fic ocii $\&$ folitudinis cupidus, folus fxpe cum Lęlio rufticari peregrinarióp folitus, interdum'́p littoribus vagabundus, expugnatricem illam Carthaginis Numantixóp dextram ad marinas conchulas calculófque legendos inclinaffe, éfque, vt Ciceronis verbo vtar, incredibiliter repuerafcere effe folitos, quum rus ex vrbe tãquam è vinculis euolaffent . Q. Mutius Sceuola diuini pariter \& humani iuris illa atate confultiffimus,à procellis fori fugiens in ocium, \& alea, \& calculorum ludo ferturoperam dediffe, éque viciffitudine rerum mole prægrauatum ingenium releuaffe. Quanquam eo in genere probandi forfan magis fint idem Q. Mutius Sceuola augur, \& Lycon philofophus, qui optime pila lufiffe dicuntur, quòd forenfibus caufis interpretandique iuris ac rerum naturalium labore fatigati, ad hoc pracipuum ocii genus recreandarum virium cófirmandorumóg laterum gratia fefe conferebant. Diony frum quoque Syracufium hoc etiam ludo delectari folitum accepimus, \& diuum Auguftum poft finem ciuiliü bellorum a b exercitiis campeftribus ad pilam tranfiffe, $\& \mathrm{M}$. Antonium, Verum, Auguftum, Marcúmque Aureliu Antonium, qui ve de eo Criptum eft, pila quopglufit apprime. Calculo rum quogp lufús quorundam iudicio nec indecens habendus, quum \& pugna bellique fpeciem præferat hoftiliśg certaminis dicente Ouidio,

Difcolor.vt recto graffetur limite miles

Quum medius gemino calculus hofte perit. $\checkmark$ t mage velle fequi fciat $\&$ reuocare priorem,

Necito fugiens incomitatus eat:

Qui ludus proinde $q$ pauculis lignis fit, vagis ac furtim infidiantibus at $\$$ latrocinantibus, Latruncularius ludus apud veteres dicebatur. Vnde Martialis, Infidioforum fi ludi bellalatronum,

Geminus ifte tibi miles \& holtis erit.

Et quanquam probent hoc alii, ex eo quòd ingenii multa meditatione excitare acumen videatur, ex eo mihi quidem videtur magis improbandus, quum nihil It temporis amiflione infoelicius, nihil deterius eo in quo minimú proficias, plu 
rimum cum labores. Poffet enim motus animi, $\&$ mentis agitatio illa qux ibi fruftra diftrahitur, rebus magnis, feriis \& melioribus accommodari : vnde non ab re præter Scæuolam \& Augufú apud maiores noftros hoc ludo ludere quo. que fimias folere,auctore Plinio, nemoria proditum eft. Tabularum verò ludus nec afpernandus nobis videtur, quem Palamedes troiano bello vt Varro tradit, iccirco inueniffe legitur, vt vel hoc negocio milites occupatos teneret, talíg ludo auerteret à feditionibus exercitum . locundum quoque $\&$ fructuofun eft alearú noffe certamen, cuius fimiliter ftudio Claudium Cælarem libro de ipfis edito teneri quondam nouimus. Legimus \& Neronem \& Domitianú, Verú,Commodum,\& Auguftum Cæarem imprimis,tantum huius rei cupidum fuiffe, vt de bello ficulo mordax epigramma huiufmodi inuulgatú fit, Poftquàm bis claffe wicta naues perdidit Aliquando ve vincat ludit affidue alea. Huius etiam voluptate certaminis Ptolomæum \& Alexandrum pluréfque alios grauiores curas nouimus deliniffe, idóp inter ludendum egiffe vt cum laude $\&$ gloria maioribus negociis aptiores poftea redderentur : quod fi aut cupiditatem fequitur, minimeliberale: aut indecenté viro mollienté illan quã Athalus A fiaticus dicitur inueniffe, quanquam $A$ fræ regno excifo inter manubias non fub vna fpecie migrafle ad Gręcos ferunt, damnofum tanquam ac iurgii plenum fugiendum effe, \& leges iubent, $\&$ his verbis $N$ afo non reticet,

Sunt aliis fcriptr quibus alea luditur artes,

Hoc eft ad noftros non leue crimen auos.

Quid valeant tali quo poffes plurima iactu

Figere damnofos effugias ve canes.

Alius verò aleæludus, cum ære quodam pueri denarios in fublime iactantes capita, aut nauium lufu tefte vetuftatis exclamant, quid criminis turpitudinífue in fe habeat nec video neque intelligo. Addit etiam Herodotus Talariü ludum \& fphæræ, Lydos fame oppreffos quafi folatia quadam inueniffe. Altera enim die ludebant, alia epulabantur, atç̧ ita duo de viginti annis feciffe, qux fi non ad voluptatem comparata funt, fimiliter improbanda minime puto. Non igitur ad tam varias huiufmodi ludorum fpecies, atque iocorum, tanta clarorum hominum,ducum, ac principum cupiditas tenderet nifi voluptatem quandam natura infitam, lufus,iocusóp haberent, quum conftet vita $m$ in laxationem \& Atudium diuidi oportere, ob hócque non folum lucubrationes \& vigilias fed etiä fomnos inuentos effe, non turbines $\&$ tempeftates, fed temperies: nec bellum rurfus, fed pacé $\&$ inducias: nec laboriofas femper actiones, fed celebritates quafdam à legum códitoribus inftitutas quibus ad hilaritatem homines publice cogerentur. Finis Quarti. 


\section{ROBERTI VALTVRII}

A D ILLVSTREM HEROA SIGIS.

mundum Pandulphum, de re Militari

Liber Quintus.

De quadruplici uirtutum pecic or earum diftributione, quig.

in bis bellorum duces clarißimi habiti fint.

capi. s.

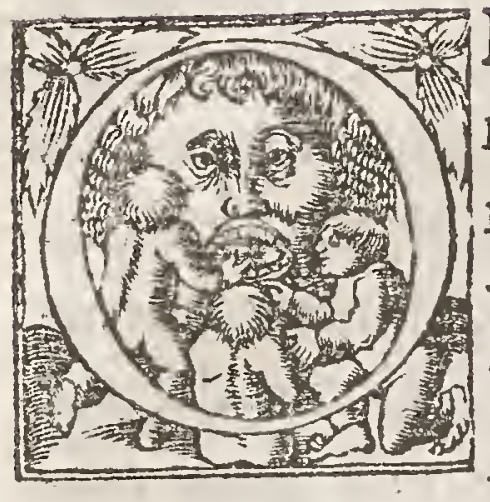

Mnes, Sigifmunde Pandulphe, omnium penè difciplinarum inftitutiones, naturam \& exercitationem, qux fine dubio plus rimú iuuất, in fuperioribus libris attigiffe fatis vifum eft, nune vberiore guadam comprehenfione per omnes quidem fpecies virtutum exemplorúmque ire qui poterunt, magis proficient: maxime fi ducum atque imperatorum quifop confilia, quę Gre ciftratagemata appellant,multáque multorum grauiter,argutè,facetéque dicta, vt ea qux à fene Catone collecta funt, qux vosãt apophthegmata, $\&$ ratione,$\&$ loco, \& tempore vfus diligenter infpiciet. Nam \& omnium quxcüque docemus exempla potentiora \& efficaciora tunt,etiam ipfis qux traduntur artibus. In his enim mirabilem quandam ac variam, illis excogitandi generädíg. fimilia opera noftri duces $\&$ imperatores fument alimoniam, quum nihil ( vt ita dixerim ) ante pralium, in pralio,poft pralium, ftrenuum, memorabile, clarum, vafrum, callidum, continêter, conftäter, benigne, liberaliter,,innocenter,magnifice, fapienter, cum laude \& virtute dictum factímue, quod non hinc legentium animos fa cile poffit irrepere.Non alienum igitur erit,ea primum virtutis exempla petringere,cuius quidé nota omnibus quadripartita diftinctio eft. Nam \& callere ducenn oportet \& quid agendum, non folum in pralio aduer fus hoftem, cæterum vbique, $\&$ cun omnibus induftriú effe: neque enim femper duces pugnant; immo fxpenumero per inducias; aut cafu aliquo pofitis armis,cum amicis aut hoAtibus colloquntur: vbi in eligendis aut reiciendis rebus falli,agrefte, vel fubrufticum aliquid, $\&$ ineptum loqui, imprudentis $\&$ infulf eft . Enimuero ne in id plabamur,nature comitas, affabilitasóp prętabit: in qua primus omniü A phricanus maior, inde A uguftus, Vefpafianus, multíg alii ex noftris,Pompılius rex Romanus, \& Fabius maximus; $\&$ Catones duo clari funt. Adde his Marcủ An tonium, longe prudentiffimum: eum inquam qui Phyficum maluit quàm $\mathrm{C}_{x}$ fareum cognomen : Ex alienigenis Cyri ambo; Ponus Hannibal, \& Ponticus Mithrydates. Et hæc quidéprudétix virtus in tres partes diftributa eff: memoriã enim, intelligentiă, ac prouidentiä affert, qux tres oculos in totidé quoqugtempora, mira rerum diftantium connexione defigunt: memoria qua rerum geftarum, locorum, temporú ac perfonárum meminit, quis pręter cæeteros fuerit infignis haud facile dixerim, permultis gloriam cius adeptis. Diuo lulio $\mathrm{C}_{2}$ fari, hoc imprimis 
imprimis ab hoftibus datum fcio,vt memoria polleret eximia, de quo inquit $\mathrm{C}$ cero $q$ nihil foleret prater iniurias obliuifci,quippe qui huius rei quoq benefi cio, \& legere fimul \& fribere, \& audire, \& epiftolas ex tempore tantarum rerum ¿uobus librariis \& pluribus vt Oppius, vtalius hiftoricus quidem \& orator infi gnis inquit, quaternas, vel vbi nilaliud ageret, feptenas dictare folitus fit.Mirificat profecto res, tam facile fingulis adeffe, tam fideliter omnium reminifci. Nec fum nef́cius huius quoque rei fingularem Q. Fabio Max. laude contigiffe: inter mul ta nimium qua viri illius gloriam extollunt, hoc non in vltimis pofuerim, quod ingenti quadam fuit notitia vetuftatis, de quo eft apud Ciceronem, quod omnia non domeftica folum, fed etiam externa bella memoria complectebatur:itague minime miror, quòd bello punico fecundo dicta eius confiliá̧ tum in populo, tum inter primores patrum pro oraculis habebantur. Vere enim mihi videor dicturus, qui multa fuperioris temporis memoria tenuerit, fore quodam modo futurorü vatem. Sed quum duplex fit memoria, altera rerum, verborum altera; primam qualem in Fabio modo retuli, talem in L. Lucullo, ampliffimo 8 impe ratore \& philofopho admirabiliter viguifle comperio. Alterá atque fecundam habuiffe videtur Scipio. Ex omnibus enim gétibus ac faculis nullum in hac re facile fibi pratulerim, fi modo verum eft quod tradunt, ipfum etiam populo ro. nomina reddidiffe: qua res quidem pené incredibilis eft, nifican permulti clari auctores, inter quos Plinius fecundus in naturali hiftoria, id proprio teftimonio confirmaffent. Fuit et Adrianus ingentis \& mirific memorix, quippe qui \& libros ftatim lectos \& ignotos plurimis memoriter redderet, vnóque tempore con fabularetur, fcriberet, dictaret, audiret. Ab occafu ad orientem verfo, Themiltocles, Graiæ gentis primus occurrit, qui inter grauiffimas occupationes,publicas \& priuatas, cunctorum fuorum ciuium nomina Athenis natus, memoria tenebat, tiupendum profecto negocium, nifi L:Scipionis mentio perfeciffet . Cynea quoque Pyrrhi regis nuncius, clarifimam excellentix huius gloriam confecutus eft:legatus enim fenatui Ro poftero ingreffus eft vrben die, noutus homo \& abea patria alienus, vniuerfum propris fenatum nominibus falutanit. Sune qui equeftrem ordinem, funt qui vrbanam omnem circumfufam fenatui plebé adiiciant. Praclarum fanéfacinus, operofum ac diligens, etiam fi ob aliud $R$ o. nam non veniffet. Cyrus porro, $P$ erfarum rex, et $f$ maximis exercitibus prefeffer, omnium tamen militum nomina meminerat. Mithrydates denique, vt auctor Noctium atticarum, $A$. Gellio, quinque $\&$ viginti: vt Plinio,duarum $\&$ viginti: vt verò nepoti eius, eo libro qui de viris illuftribus infcribitur, quinquaginta ge tium que fub imperio eius, linguatum notitiam habuiffe perhibetur, $\&$ iura cuilibet patrio fermone reddidiffe, $\&$ in concionibus fingularum nationum interterpretem haudquaquam illi fuiffe:que res \& illu militibus, \& hunc populis fuis acceptiffimum ficit. Intelligentia in rerum prafentium cognitione fita eft, hac qui fuerit preditus imperator, non aliena fed vera \& immortali mihi laude probandus videbitur, cui confentaneum illud erit quod Accius Vlyxem probäs in Philccteta fuo, \& in cius tragoedix principio inquit, Inclyte parua pradite pas tria,nomine celebri claróque potés pectore, achiuis claffibus auctor, grauis Dar- 
danis gentibus vltor, Laértiade: nouiflime patrem memorat,verum omnes laudes eius viri non $L$ aértes, nec quifquam alius fibi vendicat, fed virtus eius ducis focia: nec aliud in eodem Vlyxe monet Homerus, qui femper ei comite voluit effe prudentiam, quam poético more Mineruá appellauit, quòd ea comite Vlyxes horrenda quaque fubiit, aduerfisóp omnibus præefuit. Ea nä $\phi_{\beta}$ adiutrice, $\mathrm{Cy}$ clopis antrum introiit, verum egreffus eft, Charybdim \& Scyllam præternauigans nec retentus nec ereptus eft, ad Lotofagos profectus eft nec remanfit, Sirenü cantus audiit, \& Circes nouit pocula, quę fi cum fociis delinitus, ftultus cupidús. que bibiffet, Sub domina meretrice fuiffetturpis \& excors, Vixiffet canis immúdus \& amica luto fus, vt Flaccus inquit . Sic Homeri in cunctis imitator Maro, virum infignem armis \& pietate defcribens, \& quem dignum cenfuit vt patrem faceret Romanorum, in recte gerendis omnibus ei Achatem fociauit, vt circúfpecto duci fic negocia procedant, vt nullis infidiarú dolis praped iatur,\& quafi inuifibilis; gerendorum via non vulgata ad finem intentionis accedat . Eleganter equidem, quum nec res militaris,neć pietatis opus fine folicitudine \& prudëtia exerceri queant, hanc fubdiftinguere vifum eft nobis: eft enim quoddam ho minum genus percipiendis literis quàm aptum, quos præcellenti ingenio, $8 \mathrm{~V}$ vitatiori nomine ingeniofos appellamus, quãquam in actibus humanis hebetiores fint nonnunquam ment is acumine: quum alii econtra ad res gerendas acutifimi,perceptioni literatum inhabiles habeantur, quos vel fagaces, vel cautos, vel folertes, vel aftutos non alienum eft appellare, quibusóp magna pars conuenit cornm qua graco vocabulo ftratagematicon appellant, vbi in re bellica pro ne gocii qualitate præfens fubitò capitur confilium, ad effectúóp perducitur.Quod quia negocio perficitur, dixit quidam romanx lingua difertiffimus auctor, neq illi tamen ad cauendum dolus aut aftutia deerant . Et Crifpus, compertum effe in bello plurimum ingenium polfe. In hac itaog ingenii $\&$ intelligentix parte, fis recte diiudicare voluerimus, nec nofmetip fos amore noftri decipere, iam videbimus manifette tempora noftra haudquaquam antiquis refpondere, nififorte Pyrtho,\& Hannibali,aut Fabio Maximo, aut Marcello, aut lulio Cæfari fxcula nộtra pares aliquot aut cóparandós queant afferre. Eft autem quí in longum tempus confilii effectus extenditur, vbi locum fibi vendicat prouidétia, quętertia prudentiæ pars eft,per quam non tam præfentia quànı ex præfentium \& præ teritorú collatione futura nofcuntur. Sequitur fortitudo, viri fortis maxime propria. Sed hac quoque duplex eft, altera animi, de qua fermo nobis pollt eft habé bendus, altera corporis: fub hac menibrorum robur,agilitas \& quingue integritas fenfuum colligitur: neq enim dux inualidus, quanquam idem doctus, obeúdis muneribus bellicis aptus habebitur: vtilisille confilio,non pugne: domi verbis apıius, ac foelicius, quàm in caftris decertabit. Qux res Aphricani magni fili um virtute animi patri æqualem, doctrina verò etiam altiorem, inhabilem bello fecit. Contra neque praualidus, fi nimia corporis mole grauabitur, repentè poterit variis in locis, vbi res exiget, cohortandis militibus, propulfandıśg periculis adefle, neque rurfum cæcus, vel furdus, vel hoftium, vel fuorum ftatum citcunfpi cere, ex diffonis vocibus clamoreque militum quid in re, quidue futurum, iudi- 
care queat. Huius proprium effe aiunt, exercitus ducere, aliena vaftare, delete vrm bes,oppida excindere, liberos populos aut trucidare aut fubicete ferututi, ex quo plura hominum milia affixerit,fpoliauerit, fubftulerit, cruore cápos inunciauerit, flumináp infecerit, $\&$ maiora quaģ fuerit aggrefla, eo ma gis romen illius illuftrari. In hac prepollentis virtutis parte, apud externos clarum nomen habet Pyrrhus, Hannibal, \& Mafinifla. Ex his veró hominibus qui prodigiola virium oftentatione gloriantur, Polydamas \& Milo omnium certaninum victores, pal mam fecum auferunt:horum enim alter ante oly mpicum certamé; curris filte re currentes, $\&$ manibus, contrà nitentibus iumentis, obnixis retinere folitus \& ft: alter in clypeo vncto perftare, neq folum depelli ab eo villa vi polfe, verum non fecus ac ftatua quxdam plumbo affixa refiftere. Tritanum quendan etiam legimus, qui ludo Samnitum gladiatorio, leui tactu aduerfarios omnes vicit,cius quog filium $\mathrm{Cn}$. Pompeii militem, tam parui feciffe hofem prouocante, vt in ermi eum dextra fuperaxet, $\&$ digito vno correptú in imperatoris fui caftra träfferret. Firmum Saturnium robuftum etiam adeo fuife ferunt, vt Tritanum huius parentem, cuius Elius in prodigiofa fortitudine meminit; viritus fuperaret:nam \& incudem fuperpofitam pectori,conftäter pertulit, quim ipfe recliuis ac refupinus, \& curuatus in manus, \& terga,pëd eret potius quàm iaceret. Ex regibus verò noftris $\&$ ducibus infignes ha bentur T ul. Holtilius, romanus rex, nec non vterç A phricanus \& Marius, Mariúfque ty rannus, lulius Cælar, \& $\mathrm{P}$ apyrius curfor deniģ, ac Maximus, quorum alter nactus ex pedum pernicitate cogno men, alter ex viribus, quum alii Crotoniatem eum Milonem, alis Herculem, Anteum alii vocarent. Nunc fuperef ve de reliqua fortitudinis fpecie differamus, cu ius munera hæc maximè funt, mortis feilicet dolorisóp, \& afperarum terribilitum que rerum contem ptio. Er quanquam hanc multi ducum propriam militaréch vircuten opinentur, quum fit omnium, in bello tamen clarior inter mortes 8 : vulnera emicat. Huius virtutis ante alios inuictum babitaculú Roma fuit, proximum Lacedæmon \& Carthago. Hic ex noftris primus occurrit romane fapientix princeps Cato, cæteris nultorum eruditorum fententia maxime pracel lens, Cleâtem,Chryfippum,Zeńonem, Empedodé fecutus credo, qui omnes, alia licet perfuafione, fponte fua lęto caput obuii obtulere: tametfi nullam in Catone fuiffe, verum onnem potius ceffife fortitudinem afferant alij, praclaro ingenio \& prętanti doctrina viri: \& quü propriú virtutis huius partis fit à fe \& à recto ra tionis tramite non difcedere, nec in rebus a lperis perturbari, ac deiici, $\mathrm{fed}$ perf fere, Fortitudinem afferentes non vmbratilem eam effe, que contra naturä, mon Atr vice nititur, vltráque modum eius egreditur, aut ftupore animi, aut immanitate, aut infania, qualem fuife accepimus ferum quendam in ludo Cefaris gladi atorem, qui guum vulnera eius à medicis execabâtur co fuit habitu oris vit fuperante letitia dolores, ridentis etiam fpeciem prabuerit, fed eam veran 8 probam quam Socrates $\&$ maiores noftri ficintiam effe dixerunt tolerandarú rerum $\&$ non tolerandarum: per quod apparet effe quadam intolerabilia, à quibus fortes viri aut obeundis abhorrent aut fuftinendis. In hac etia ex noftris, lulius $C_{x}$ far, à nobis fape dictus dicend uśás nobis cccurrit, occurrunt Aphricani duo, Pauli 
cotidem, Macedonicus \& Cannenfis, Claudius,Marcellus, Claudius, Nero, Tib.' Cracchus, C. Marius, Drufus \& Germanicus cæfares, Titus \& Traianus principes. Ex vetuftılimis autē,primus et tertius romani reges, necnon ex equeftri or dine Oratius cocles, L.Siccius dentatus, tribunus plebeius, M Sergius, in numerabileśg ali, fi fingulos quofque profequi libeat, quum plures vna gens in quorunque genere eximios tulerit; quàm cæteræ terræ. Externi verò Lacedæmonius Le onidas, Athenienfis Mylciades, fupráp nominati Themifocles atop Epaminú. das; $\alpha$ ex antiquioribus, Liber, Hercules, Thefeus, Achilles, Hector, 'I ydeus, Dio medes, Aiax \& virgilianus Aeneas: Hannibal quoq genitórque Amilchar, \& germanus Hafdrubal, Alexander Macedo, \& huius genitor $\mathrm{T}$ hilippus, \& auun culus Alexãder Epirenfis, \& Pyrthus etiam ipfe E pirotarú rex de quo fuprà diximus. Hebrzorum infuper, \& imprimis Dauid, Iofue deinde \& Iudas porrò. Nec n̉e fallit eam licet virtutë Ariftoteles ipfe pertulerit, quiduldam videri porfe ethicum me virtutum perturbaffe ordinem, non folum prudentiam his annu merando, verum etiam fortitudinem iuftitix præferendo militarem, quum fapenumero iuftitia longe præfulgens, perfectáque virtus ad alium maxime cenfeatur: quod non ab re, fed de induftria quoq̣ factú effe ficito. Eft enim viri pro. pria maxime frtitudo, fola inter cæteras mafcula, plena fpiritus, plena vigoris $\&$ animi: honoratiflimam verò eam effe omnium virtutum, Ariftotelis fentetia ex co patet, non quia optima fit, verum propter ea qua in ea funt optima $\&$ vtilia: quas ob res imperatorum fimulachra defunctorum, militari fere habitu inf gniri,obelifcos,columnas \& pyramides arcus $q$ í triumphales erigi, \& polteritati confecrari videmus, quafi pręc llentiffimú fit, in co genere laud is ac virtutis potiffimum claruiffe, Et quanquam fortitudo hominum cetus maxime protegat, non minus $\&$ iuftitia vna onnium domina $\&$ regina virtutum, etiam ducum propria cenferi potelt, quòd fola hominum cóuentus regit, quòd foedera focietatis humanx cótinet, quòd feruare non anicis modo, fed hoftibus fidem monet. Quúmque nibil fraude vtilius, nec dolo efficacius in his qua in bellis pfperè atque ex fententia gefta funt, qux plurima ac maxima effe comperies, \& quorum gratia aut repudianda imperia funt, aut vnà cum fuis artibus obeunda, funt qui hac Xenophontis fententia fræti, in co libro qui equilum prafectus inf cribi tur, licere fibi exıftiment hofté nedum bello fallere, fed à diis immortalibus ipfis vt pofle contingat precandum,omníque ltudio fraude vel virtute innitendum, iuxta illud Corebi apud Maronem in illa turbulentifima nocte troianæ captiuitatis poft Androgei mortem inquientis,

Mutemus clypeos, Danaûmque infignia nobis

Aptemus: dolus an virtus quis in hofte requirat?

Sint licet qui deteftãdum id omni tempore putent, mutationé illa m clypeorum, \& reliqua non grauifimi poëtx, ed adolefcentis ore dictum cenferi debere afferentes,quod malum \& antiquü et noftri temporis eft, feu illa ignauia eft ducum, feu militum infolentia, auaritieqque rabies, vtraque fentétia militantiü ducumó animis extirpanda eft, vt hoftibus feruetur fides, amicis humanitas, vtrifque iu * titia:vt \& illis nō nif feruato decore noceas, \& his nullo penitus noceas modo. 
Nam quid turpius, aut quid vfquam fceleratius, quàm ñocumento his effe quosum tutelæ ac præfidio euocatus fis, quàm ex cuftode raptorem, ex cane lupum

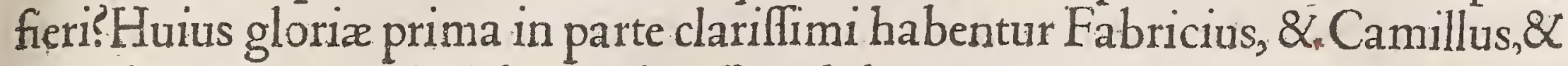
Regulus, quorum primi duo quú poffent dolo vincere, noluerunt: tertius, ne aut damnofus effet patrix, aut infidus holtibus, crudeliffime mori elegit, inter'́g hoAtibus præftitæ fidei Ceruatores, haud prætereundus eft Caffius: in altera auten hi funt quibus modicum fuit à fuorü iniuriis abftinere, nifi vltro pro eis morerentur. Ex his Romæ Curius \& duo Decii, Athenis autem Codrus, Carthagini Philenes fratres fefe ante alios offerunt, quorum primus vt terroré publicum fedaret, lecundi vt victoriam labentem'q́ aciem firmarent, tertius patriam inftanti excidio eriperet, quarti vt fines patrios prorogarent, ad mortem voluntariä funt profecti, vtó ciuibus fuis bene effet,ipfr effe noluerút. In vtraq̧ verò Magnus Pöpeius etfia hunc vnum Cicero omnes bellicas laudes \& quacunque de his quibus egent duces vt fummi frnt aut diximus aut dicturi fumus, cumulatiffimè có parat : iure id quidem meritóque, fed fi cui maxime fuum tribuitur,verè Magni Pompeii laus eft bellica iuftitia fimul'́p. \& cognita inter victorias $\&$ triumphos continêtia, quę ad eam de qua hic aggrediar dicere virtuté referenda eft, fi vnum quod núc ad iuftitiâ fpectat adiecero, effe beneficentiáa liberalitatem pulcherrimas ducum \& imperatorum veftes, quibus indecora plurima tegi poffunt: hac lul. Cæfar prait cunctos gloria,neg. enim quifquam, fi Senecæ verba teneo, libe ralius victoria vfus eft, ex qua nihil nifi difpenfandi poteftatem frbi vindicauit: A pud exteros Alexander primum locum tenet, vt Græci volunt,neog noftri obfant: quanquam Philippus pater in Alexand ro qui largitione beniuolentiam Macedonum fectabatur, profufionem illan pecuniarũ his verbis infecurus eft, Quid te, malum, rationis, inquit, in iftam Ipem induxit, vt eos tibifideles putes quos pecunia corrupiffes?an tu ideo agisvt Macedones non te regem fuum, fed miniftrum \& prębitorem putêt?quod quidem regi fordidum effe non ambigis, \& corruptelam quàm largitionem potius dici: fit enim deterior qui accipit, atque ad idem femper expectandum paratior. Quid autem elt ftultius, quàm quod facias libenter, curare vt id diutius facere non poffis? largitiones immoderatas rapinæ fequuntur, quum enim dando egere coperis; bonis alienis manus cogeris inferre: itaque quum beniuolentiæ comparandx caufa fis prodigus, non tanta ftudia affequeris 'eorum quibus dederis, quanta corum odia quibus exemeris: quamobrem nec ita claudenda eft res familiaris vt cam benignitas aperire non polfit, nec ita referanda vt omnibus pateat, fed vtrinque modus adhibeatur, is'́g referatur ad facultates. Quarta nunc mihi fupereft Modeftia quam temperantiam vocant, cui adiacet ipfa quam paulo antè dicebam continentia, fine qua non dicam dux, fed nec quidem vir bonus vfọ̈ fuit. Quia verò nunc de ducibus fermo eft, quid oratio perita literarumóp cognitio, quid magnanimitas, quidue omnes aliæ imperatoriæ artes profuerint, fi auarita, fi libidinis aut gula imperio dux victus, abiecto freno quo exercitum regat, fe fuáfque legiones precipitet, $\&$ in peftem trahat, quo fepe multi cum omnibus copiis periere? Hac igitur fingularis, $\&$ propria virtus eft Pompeii, in qua fi imitari eư G collega 
collega eius Craffus voluiffet, nunquam ipfe cum filio, \& cum tanta ruina impe rii cecidiffet. Probat hanc romani ducis cótinentiam atọ modeftiam templum: Hicrofolyma opulentifimum, fed ab hoc intactum duce, ab altero fpoliatum: probant $\&$ alia multa, quorum pars in verbis $C$ iceronis apparet qua mox inferamı. Accedit his manfuetudo quęãa, \& fuauitas, facilitasóg animi, in qua Aphri canus \&. Iulius Cæfar excellunt, hac ad conciliandos animos hominú nihil efficacius. Eft huic confinis æquahtas quædam, familiaritas'gp cum exercitu, quęres maxime milites ducũ a mâtiflimos effecit, in qua notus Valerius Coruus \& Mari us ex noftris, ex externis Hannibal: $Q$ ha quidem artes beniuolentia \& amore, $\sqrt{1}$ cut obiectx, feueritas atque imperiofitas exercitum ac fubiectos metu frenant. His artibus Mar.Curius, \& Q. Cincinatus, \& Papyrius curfor, \& Fabius Max. notilimi, fed nullus in ea re Iunio Bruto Manlióg par Torquato, qúorum pri mum publicx libertatis amor impulit vt proprios filiosà fe depulfe tyrannidi fauentes, feruliter virgis cælos, fecuri percufos ad mortem ageret : fecundum vero caftrenfis difciplinę fudium coëgit vt pręclara indole adolefcentem filiun quòd iniuffu eius in hoftem pugnaffet, quanquam vnicum \& v1ctorem necaret. Additur huic feueriffimi facti comes, Pofthumius Tiburtus, cuius ego ne prętermifffe potius, qै vt afferuifle rem tantả videar, mentionem fecerim : apud quofdam enim fcriptorum certa res, apud alios facti eius in ambiguo fama eft. His tan multis \& patientia iungitur éque multiplex, hæc dolores corporis æquanimiter perfert, illa quali quodda mulnus aurium atq animi, contumelias fert verborum,vtraque ducibus $\&$ militaribus curis accommodata : prima quidem fortitudinem, fecunda verò ciuilita té refpicit, atọ modeftiam ipfam de qua fermo eft:in prima Mutius, \& Marius \& Pompeius clari habentur, \& Actilius quidam Cxfaris miles Maftilix fpectatus, \& M. Sergius cum eifdem quibus fuprà comitibus : ex externis verò Cynegirus Athenienfis gracis hiftoriis celebratus: In altera verò ro. imperatores Iulius \& Auguftus ex noltris, ex externis Philippus \& Antigonus Macedonum reges, \& Pyfiltratus Athenienfis tyrannus : denich noftrosatģ externos Magnus ille Pompcius omnes fuperat aut æquat, quo admoneor vt ex oratione que de eius imperio habita eft, ac de imperatorum feu ducum continentia, dêque his qua tuor quue in duce requirimus, M. T. Ciceronis verba paulo antè promiffa fubiiciam, qua clementiffime atç inuictifime prin ceps, vel vfur vel voluptati maxime tibi fore, confido. Neq̧ enim ille, inquit, fole funt virtutes Imperatorize que vulgò exiftimátur, labor in negociis, fortitudo in periculis, induftria in agendo, celeritas in conficiendo, confliú in prouidendo. Et poit hę, Non enim, inquit, bellandi virtus folum in fummo ac perfecto imperatere quęrenda eft, fed multę funt artes eximiq huius ad miniftrę comitéfog virtutis, ac primum quanta innocentia effe debent imperatores, quanta deinde ompibus in rebus temperantia, quanta fide, quanta facilitate, quanto ingenio, quanta humanitate: nec longe polt, Propter hanc auaritiam, inquit, imperatorum,quantas calamitates, quócunque ventum fit noftri exercitus ferant, quis ignorat? itinera qux per hofce annos in Italia, per agros atg oppida ciuium Ro manorum noftrimperatores fecerü recordamini, quum facilius ftatuitis quid 
apud exteras nationes fieri exiftimetis, vtrum plures arbitramini per hofce an nos militum noltrorum armis hoftium vrbes, an hybernis fociorum ciuitates efle deletas? Neque enim poteft exercitú is continere imperator, qui feipfum non continet, neque feuerus in iudicädo qui in le alios feueros cffe iudices non vult. Quibus dictis,ad Pompeil laudes verlus, Et miramur, inquit, hunc hominé tantum excellere cateris, cuius legiones fic in Afram peruenerint vt non modo ma nus tanti exercitus, fed ne veftigium quidem cuiquam pacato nocuife dicatur. Iam verò quemad modum milites hy bernent, quotidie fermo ac litera perferun tur, non modo ve fumptum faciat in militem, nemini vis affertur, fed ne cupicnti cuiquam permittitur: hyemis enim, non auaritia profugitum maiores noftri in fociorú atque amicorum tectis effe voluerunt. A ge vero, cæteris in reb tis qualis fit temperantia confiderate, $v$ nde illam tantam celeritatem, \& tam incredibilem curfum inuentum putatis? Non enim illum eximia vis remigum, aut ars inaudita quadam gubernandi, aut venti aliqui tam celeriter in vltimas terras pertulerunt, fed eum res qux cæteros remorari folent, non retardarunt! non auaritia ab inftituto curfu ad preqdam aliquam deuocauit,non libido ad voluptatem; non amonitas ad delectationem, non nobilitas vrbis ad cognitionem, non deni que labor ipfe ad quietem, poftremo figna tabulas cateráć ornamenta gracorum oppidorum qua creteri tollenda elfe arbitrantur, ea frbi ille ne videnda quidem exiftimauit: itaque omnes quidem nunc in his locis $\mathrm{Cn}$. Pompeium ficute aliquem non ex hac vrbe miffum, fed de cælo lapfum intuentur. Nunc denique incipiunt credere, fuiffe homines romanos hac quōdã abftinentia, quod iam nationibus exteris incredibile ac falfo memorix proditum videbatur: nunc impe rii noftri.fplendor illis gentibus lucet, nunc intelligunt non fine caufa maiores fuos tum cun omni hac temperantia magiftratus habebanus, feruire populo Ro.quàm imperare aliis maluiffe:iấ verỏ ita faciles aditus ad eum priuatorú, ita libere querimonie de aliorú iniuriis effe dicuntur,vt is qui dignitate princjpes ex cellit, facilitate par infimis effe videatur. Iá quátú cóflio, quátü dicédi grauitate $\&$ copia valeat in quo ipfo inelt quxdam dignitas imperatoria, vos Quirites hoc ipfo in loco fape cognofcitis : fidem vero eius inter focios quantam exifimari putatis, quàm hoftes omniú gentium fanctifimam iudicarint? humanitate iam tanta eft, vt difficile dictu fit, vtrum hoftes magis virtutem eins pugnantes timuerint,an manfuetudiné viçi dilexerint; $\mathrm{H}_{x c}$ Cicero, cuius ex officina tanta imperatorum $\&$ ducum monumenta pofuifle velim, quia nefcio an vfquam alibi de bonis \& præclaris eorú moribus luculentius \& vberius feriptü fit. Superelt au ctoritas, qua ex pradictis maxime nafcitur, augetur aute fama nominis, ex opi nione hominú, ex ducü virtutibus $\&$ piperitate cócepta: quo in genere lulius $\mathrm{C} e$. Aphricanus maior, \& Pópeius Magnus opinatiflimi habeț quorü tãta fuit auctoritas, eáq fub iftis militú fidutia vt nó fe ad pręliú, ac difcrimé, fed ad victoriä \& hoftiü prędá duci crederêt, quo nihil vitilius ad votiuos ac pfpeŕos belli euétus $\&$ guos in cótrariü verti folere diffidétia bellatorü,ex leuitate aut inertia ducun orta; fxpe compertủ eft. Poftremo deniqg foelicitas, non folü in militia; fed in vita ế expetêda. Népe huc omnia referuntur, háncque nec dare fibi quifquá poteft, 
nec augere, diuinum fane munus, fed ita duci neceffarium vt quanquã reliquis floreat, li hoc vnum defit,nemo cenfeat eligendum. Nam vt foelicitatem fidutia, fic infoelicitatem ducum, fequitur militum pauor, quo nihil propius exitio eft. In hac quidem quum multi celebres fint, longe tamé Titus, \& Traianus, $\&$ Theodofius, \& Sylla, fue vt fama fert Metellus ille foelix dictus, omnes fupgreditur: etfi iuxta fententiam vere philofophantium, nullus hic foelix fit: fed de folicitate bellica fermo eft, qua foelicem ducem dicimus vincere folitum, infuetum vinci:in hoc numero ex externis Alexander eft Macedo, \& Cyrus Perfarum rex, nifi in Scythiam perrexiffet, \& Carthaginenfuum dux Hannibal, fi aut Matherbalı credidiffet, aut paulo maturius diem obiiffet.

\section{Imperatorum confilia que Greci frategemala appellant, or que ande bellum, in}

bello, or poft bellum fapienter, lepidè, facete ac moderatius dicta funt.

Cap.

II.

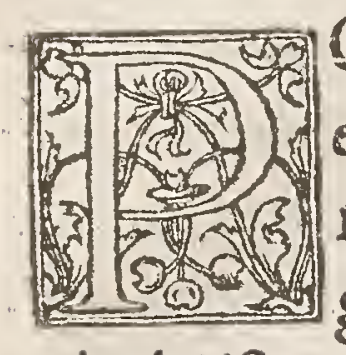

Oit hafce virtutum fpecies \& imperatoria munera, quorú illuftrem effe conftat effectum, vt praclarè factorum; ita dictorum qua ducem moneant, rationes etiam \& exempla promiffa fubiiciemus: quibus egregium primò ac fanè pracellens fit illud quod ab Hefiodo vfurpauit Ariftoteles, ab Hefiodo vel Ariftotele Liuius, dum falutem fuam exercitúfque fui M. Rufus Minutius, beneficio Q.Fabii Max.cognouiffet,eum videlicet optimum \& primum fefe virum qui qua gerenda funt confpicetur 8 cófulat: fequenti autem gradu eum, qui aliorú bene monentiú confilia fequatur:extremi auté ingenii \& penitus inutilis illum effe, qui cófulere nefciat alteri nec parere.

Gymnofophifta quifpiam acri \& perfpicaci ingenio ad fuccincte refponden dum,ab Alexandro interrogatus, quonã pacto quis late imperitans, magnam fr bi bẻniuolentiam comparare poffet, $\mathrm{Ne}$ fit terribilis inquit. $\mathrm{Ab}$ eodé interrogatus item, quomodo mortalis quifpiam $\mathrm{fe}$ in deorum numerum reciperet, $\mathrm{Si}$ humañis, fubiunxit,maiora viribus opera gefferit.

Agis rex, quú Atticus quidã in Laconicos enfes cauillaretur $q$ parui effent, dicerétọ facile eos abforberi à circulatoribus in theatris poffe : Et tamé vix nos ingt attingimur hoftiú gladiis lógioribus. Ego verò \& laconicá orationem intu eor,qua breuis videtur effe,maximas res cóplecti, \& auditorum mété attingere. Cyrus confpecto Centurione prope fe difcumbente, graui turpíq corpore, iocãdi gratia adolefcentem ne ponè affidentem ob pulchritudinem more græco fecum duceret rogauit,annuente illo dicétég fe afpectu cius oblectari admodum, coniicere in eum oculos qui vnà conabant, vifág viri inhonefta nimium facie, rifere omnes, fubinde quęrétes, qua fibi in re vfui talis vir effet: is Céturio quotiens die noctúg ab fe appellarế, ait nulla vnä excufatione viú, citò femp obtëperafle: quú quid ei denıâdaffet, núqu abfq̣ fudore mädata executú, reddidifle quoq̣ cómilitones fuo exêplo folicitos. Idé quog ad impii magnitudinem hoc adiecit inuêtú, vt quicquid etiä in remotiffimis a geretur locis quprimú fciret. Cognito nă \$ quantü die noctúq eques itineris cóficere polfet, difpofitis in loco equitibus, vt recés literis receptis fuccederet feffo, velociter qd vbiq accideret noui pcipiebat, puidebátq put neceffariü effe videbat́: hęcóg caufa extitit, quis procul abfit à ve ro, vi velocius ä grues iter facere putarétur, idọ́ ppter velocitaté eútiú creditú eft. 


\section{DEREMILITARI: LIB. T.}

Aefchylus in Ifthmo certame fpectans, vbi altero vulnerato theatrum exclamad uit, Ionem Chium tangens; Vidésne inquit quid exercitatio fit? vulneratus enim tacet, ,pectantes verò clamant.

A gefilaus interrogatus quid facturi Lacedæmonii victores effent, Si prudenriffinus, inquit, imperator rem gereret. Hoc item práente duce, quũu quifpiấ $\mathrm{L}$ a cedæmoniuis muros deeffe queftus eflet,Dic, inquit, meliora:ciuitas eninm jpfa nơ Atre vrbis munitiffima moenia funt:par fiquide eft, nö lignis aut lateribus, fed virture patriä,deos penates, aras, focos, parentes, cóituges,liberos, tueri àtģ defendere.

Brafidas quu in caricis murem cóprehédiffet, mor fus eum dimifít: deinde ad aftantes conuerfus, inquit, $\mathrm{O}$ Hercules,nihil eft tam paruú negg tam imbecillum; quod fraufit vlcifci, \& inuadentibus repugnare, non fe incolumem feruet.

Chabridas dicere conlueuit,formidabiliusefie ceruorü agmen ductu leonis: quàm leonú ceruo duce. Idem eos dicebat pulcherrime officio imperatoris fun gi,qui res hoftium maxime nofcerent.

Sefoftris Aegyptiorum rex, quum eos qui iuxta mare rubrü funt homines claffe fubdidiffet, $\mathrm{X}$ in Aegyptum rediens per terram; omnes gentes quę fibi imm pediméo erát expugnaflet, harú quẹcurqq f fibi fortis \& libertatis cupida vifa eft, in eorum regione colünas erigens, in eis \& nomen eius, \& patrix hominifop veréda incidit, \& vt fua fotếtia cos vicerat: quos auté fine pralio \& facile fupctaf fet, ibi colúnis pofitis ea feripfit nomina, addens ad ea mulieris pudibúda incifa.

Q. Mutius legatus à romanis ad Ponos, duabus tefferis pofitis, altera pacis; altera belli,optione fibi collata vtrá S.P.Q.R.referri mallet,vtraque fublata, $\mathrm{Pok}$ norum, inquit, non Romanorum vtram vellent effe debere.

Q. Fabius, Romanorum imperator econtra,fimili modo ad Carthaginen fes mifit epiftolam, in qua vtriufque populi fententia par vigor amplitudó́g quon dam fuiffe deprehendi foteft:ibi enim fcriptum quum effet,po.ro.miffife ad eos haftam et caduceũ,figna duo belli aut pacis,ex quis vtrum vellent eligerét, quód: que elegiffent, vt vnü id effe miffum exiftimarent, Carthaginenfes refronderunt fefe neutrum velle eligere, fed poffe cogitare qui attuliffent,vtrum mallent relinguere: quod'q̣ reliquiffent, íd fibi profectò gratư futurum: hæc tametfi ab elegãtiffimis rerum geftarum fcriptoribus dicta fint, $M$. tamé Varro,certiffimus auctor, non haftam ip fam, neque ipfum caduceum miffa dicit,verum duas tefferu las, in quarum altera caducei, in altera haft $x$ fimulachra fuerint incifa.

Carthaginenfes quia fpartum $\&$ nerui deficiebant ad fagittas emittểdas; ton farum crinibus mulierum ad funes efficiend os vf funt,quod aliquâdo \& apud Maffilienfes, \& R hodios, \& A quilegienfes, \& Romanos in capitolio obfeffos vi' be à Gallis occupata faclü eft:vade \& in honorem matronarum, templum Vej neri caluæ fenatus decreuit.

Tarquininus Prifcus, Quiritibus,operis tædiư periculúóg fugientibus,nouñ $\&$ incxcogitatú antea, pofteáṕ, remediü inuenit. Sex enim hominú vita defunctorü figere crucibus corpora fpectãda ciuibus, fimul à feris volucribuf̣́́ lacerãda iuf fit,quäobré pudor tomani nominis, qui prius res fępe perditas feruauit in prẹliis

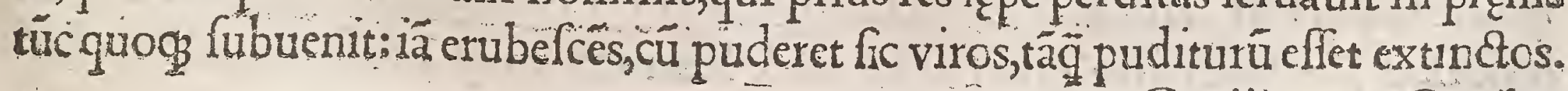


Cacilius Metellus Pius proconful, Trebiam vrbem Hifpanix primariam quum fubigere nequiret, ac vagantem fluctuantémque exercitum duceret, hóqque mo. do adoriretur, modoad illos fe tran fierret, \& iunior quidam tribunus militum quid fibi vellet tam crebra locorum nutario petert. Si hanc refpondit interiorem tunicam exiftimarem mentis mex conlciam effe, exutus eam, in ignem con tinuo mitterem : frcó, foelıcibus cop is poft tam longa itinera, tam varia peragrata municipia ad Trebiam inopinatam denuò conuerfus eã oppreflit, 8 non dine omnium admitatione, voti fur compos factus eft.

Scipiocui primum A phricano cognomentum extitit, vt Valerio Maximo, vel Fabius, vt Senecæ placet, Turpiffimam aiebat $\&$ ignauix plenam imperatori excufationem effe, Non putaui: confultè enim quæ armis geruntur tractari de bere opinabatur, quum prætenıa præcipitatáq magis reprehendi,quàm reuorari vlla vi humana, vel ratione in integ rü reftitui corrigiue poffint. Is etiam Scipio quum à re militari atque vrbana ftudium ad literas conuerteret, dicebat quum ociofus effet.plura tunc negocia à fe geri. Inde vbi Carthaginem in deditionem vi accepiffet,ac milites quidem quam cepiffent captiuam praftanti forma virginem adueherent, atque illi darent, Libenter, inquit, acciperem, fr priuatus, haudquaquam imperat or cffem. De eodem itidem licet inuulgatú fit, in aciem nunquam defcendere imperatoré debere nifi aut occafione fe prabëte,aut neceffitate impullente, ex Sempronii tamen. Afellionis veterisfcriptoris quarto hiftoriarú libro de P.A phricano, Paul filio ita proditum ef, Se patrem luum audiffe dice re, L. Aemilium Pau.nimis bonum imperatorem, fignis collatis non decertare, nifi lumma r eceffitudo, aut fumma ei occafro data effet: \& fapienter quidé vtrūque. Nam a t totius exercitus falubritatem nibil efficacius quàm quòd viri $\&$ du cis eft, non deefle fortunæ præbenti fe, fed oblato cafu ad confliü flectere : nibil pernicioffus quàm in anguftiam rei bellice compulfum, imbellem fieri:quod nec euentus modo docet qui ftultorü ma gifer eft, fed eadem ratio qux fxpenumero fuic futuráque cit.

Auguftus quum decimum oftauum annum agens hoftiliter vrbem inuaderet,ex ipfius exercit us legatis qui fibi eius nomine confulatum expofcerent, cunctante lenatu, Cornelius Centurio legationis princeps reiecto fagulo,enfis capulum detegens, haudquaquam dubitauit in curia dicere, Hic faciet, fi vos non feceritis. Idẽ Auguftus faxo in expeditione percuffum, ac notabili cicatrice in fróce deformem nimiú, tamen fua opera iactanté, fic leuiter caltigauit, At tu cū fug ies, inqt, nunḡ poft te refpexeris. Ad cum itē veteranus quifpiã,quü die fibi dicto piclitarế, acceflit in publicü rogavitós vt fibi adeflet, Auguftus aduocatú quéex comitatu fuo elegerat frne mora dedit,cómédauitó ci litigatoré: exclamauit ingenti voce veteranus, At nö ego, Cęfar, piclitãte te Actiaco bello vicariü quęfrui, fed pro te ipfe pugnaui, detexitóp impreflas cicatrices, gbus erubuit Cęfar venitóg in aduocationê, vt qui vereretur ne fupbus tantü, fed etiã ingra tus videri polfet. Imperatori quog bono inluper neq̧ quicquá minus quàm temeritaté congrucre arbitratus eft, fatiśg celeriter fieri quicquid commode gereretut, quod à $\mathrm{Ca}$ tone licet prius dictú fit , crebro tamen \& familiari tanquá fú folitus erat vfur- 
pare fermone.Occurrit illud eiufdem Auguft.Cær.poftremo, qui quum Alexati drigeffet $\&$ antrum vbi Aegypti regum cineres preciofis pyxidibus feruabantur ingreffus effet, ,orpus quidem Alexandri Macedonis libenter afpexit, interio gatus verò num \& Ptolomæi reliquias vellet infpicere, Reges fe inquit velle videre, non mortuos: atqui rex fuerat $P$ tolomæus,fed quantum inter veros reges,éof que quos regum nomine vulgus appellat interfit, breui diffinire voluit elogio fapientiffimus imperator.

Scipio iunior Yolybii præceptum obferuans ftudebat non prius èforo abire quàm aliqueni ex abeuntibus faniliarem fibi atọ amicú quouis pacto effeciffet. İdem quum pulcherrime ornatú quifpiam fcutum cfétaret, Heus,inquit,adolefcens,fcutum certe pulchrü eft, verum decet tomanum virum in dextra potius fpes fuas quàm in finiftra collocet.

Scilurus quü relictis maribus filis octoginta, dië effet obiturus, haftarü fafcể cuiqg oftendés, vt illú confringeret iubebat : id autem fingulis fe poffe negãtibus, figillatim haftas eductas, facile omnes confregit: ita docés illos,vbi vna efle perfe uerarent,firmos ac potentes fore: imbecillos verò, fi fepararentur ac diffiderent.

Tigranes vrbanum, facetúmque quippiam in Romanorum exercitum afferre cupiens, vulgatiffimum illud dixiffe fertur, Eos fil legati venirent, fatis multos quidem: fi verò pugnaturi,perpaucos admodum effe.

A mafis Aegyptiorum rex, quum contemneretur ab Aegyptiis qnòd oblcuro loco natus,\& paulo antè regno potitus, vas aureum quod habebat lauảdi gra tia ad turpéfque vfus; fregit,deióp fimulachrum ex eo confecit, ídque in celeberri mo rrbis loco ftatuit, quumq́ religiofe coleretur ab Aegyptiis, huius rei certior factus eos cónocaurit,rémque docuit, vt ex eo vafe fimulachrum erat in quod pri us Aegyptii vomebant,meiebántque, \& pedes lauabant: nunc verò venerabãtur, codem fibi modo cueniffe, fiquidem prius plebeius erat, nunc corum rex, proinde fibi honores haberi iuffit,fic Aegyptios induxit ad fui venerationem.

Agathocles figulifuit filius,qui Sicilix dominationé adeptus, réxque appellatus, fictilia pocula confueuit inter aurea ponere eáque iunioribus oftendens dỉ cere, Ego quum huiufmodi pocula confueffem, in prefentiarum quoniam diligentix ac fortitudini fuduerim, hæc facio . Infuper quum vrbem obfideret 8 quidam è moenibus per conuicium dicerent, O figule, quo pacto militibus ftipe folues, manfuete is atç fubrideñs ait, Quum hanc cepero : quum auté viribus in fuam redegiffer ditionem, captiuos venundabat, inquiens, Si conuicio me rurfus affeceritis, querar apud dominos veftros.

Antigonus quum milites quofdam effet intuitus qui thoracibus \& galeisad pilam luderent gauifus eff,eorumọ́ duces accerfuit quos laudarct:vt autem audiuit eos bibere, illorum ducatus militibus dedit . Is etiam pofteàquàm longam xgrotationê euafffet cóualefceretó, nihil ait deterius accidat: hęc enim aduerfa valitudo nos monuit,vehementius nobis efferendum non effe, quoniä mortales fumus.Idem nocte quadam quum nonnullos ex militibus fuis exaudiffet omnia mala imprecantes regi qui ipfos in illud iter inextricabilép lutum deduxiffet, acceffit ad eos qui maxime laborabant, \& quum ignorantes à quo adiuuarétur expli 
explicuiffet, Nunc, inquit, maledicite Antigono, cuiris vitio in has miferias incidiftis:ei autem bene optate, qui vos ex hac voragine eduxit. Infuper tam miti animo hoftium maledicta quàm ciuiu talit . Itaque quum in paruulo quodam caftello Graci obfiderentur \& fiducia loci contemnentes hoftem, multa in deformitatem Antigoni iocarentur, \& nune ftaturam humilem, nunc nafum cola lifum deriderent, cú gaudio inquit, Bene frero, fi in caftris meis flentiü habeo: quum hos dicaces fame domuiffet, captis fic vfus eft vt cos qui militie vtiles erã in cohortes delcriberet, cæeteros praconi fubiiceret, id's fe negauit facturum fuiffe rifi expediret his dominum habere, qui tam petulantem linguam haberent: Rurfus quum fequa tempeltate iactaretur, ac in eadem naui fecu fuos omnes ha buifet, precepiffe liberis dicitur, vt $\&$ ipfi meminiffent, $\&$ ita pofteris proderent, ne quis cum tota gente fimul in rebus dubiis periclitari auderet . Cuius præcepti memor Philippus, quum duos fimul filios fecum haberet, ambos fe non com mifturú in aleam eius qui preponeretur cafus: \& quoniā maiorem filium fecum duceret, minoré ad fubfidia f́cei, \& cuftodiā regni remiffurūin Macedoniá eflé.

Dum Antagoras poèta congrú elixaret idemọ́ patellã quateret, Antigonus qui poft cum ftaret, Homerũ ne, ait, putas Antagora quum Agamemnonis res geftas 1 criberet, congrum elixaffe? $\&$ Antagoras, Tu auté rex, ait, exiftimas Aga memnonem quum illas res gereret, currofum adco cxtitiff, fi quis in caftris congrum elixaret.

Lamachus quum manipularem præfectú quendã reprehenderet, quoniā delia quiffet, iśǵp diceret núgä fore vt id amplius faceret, bello enim bis errare nó licet.

Memnon qui cótra Alexandrú pro rege Dario bellú gereret, quendá qui fub Ce merens multa de Alexãdro maledicè,petulanterọ́ loqueretur, vbi lancea percuffiffet, Ego te, inquit, alo vt pugnes, non vt Alexandro maledicas.

Dum Med is irruentibus Perfarum acies pulfata in fugam ageretur,ac omni no deficiens, nec victorem a picere auderet, matreffamilias corum \& vxores paffim obuiam fugientibus occurrerunt, $8 \mathrm{earum}$ denfata acie orant $v t$, ciufce fuge notam haudquaquam fubeant, fed fortiter in pralium reuertantur: nolentibus fublata vefte obfcoena corporis oftendunt, rogantes ne in vteros matrü vel vxorum velint refugere: hac repreffi caftigatione, in pralium redeunt, \& facta im preffione quos fugiebant fugere compulerunt.

Themiftocles adhac iuuenis, quum Marathonis victoriam \& Milciadis imperium animo celebratum repeteret atque verfaret, infomnés que noctes proin de duceret $\&$ folita ref pueret conuiuia, interrogantibus ad mirãtibusọ́ vitę mutationen, eum dicere folitum ferunt, quod Milciadis victoria fibi fomnos eriperet.Interrogatus etiam, vtrum Achilles mallet an Homerus effe, Tu autem ipfe inquit, vtrum victor in Oly mpia effe malles, an victorum præco? R urfus quum Adimanthus qui nauale prælium formidaret diceret aduerfus eú qui ad id Græ cos adbortaretur fuadendóque incitaret, o Themiftocles, cos qui in certaminibus primiirruperint cedunt femper, Ita eft inquit, Adimanthe, verum cos qui manferint haud coronant. Quum item ad interfectorum cadauera ad mare viLenda fe contuliffet, vt armillas pafing \& torques abiectas afpexit,preteriens ipfe 
amico qui eum fequebatur, Collige tibi, inquit, tu enim nequaquam Themifto cles es. Eundem etiam dicere folitum ferunt, fe neque honoribus ab Athenien. Gibus affici,neque apud eos in admiratione effe, fed procella vexatos,imminente periculo, fe veluti platanum fubterfugere: reddita autem ferenitate, euellere ata que deiicere.

Cum Antiochus rex, pofteaquàm Romani aduerfus eum traieciffent in $\mathrm{Afr}$ am, pro foluendo bello ad Scipionem miffflet,eiufmodi refpófum accepiffe fertur, Prius enim oportuit, non nunc quum frenum $\&$ fefforem fufceperis. Idem cum ingenti exercita Gręciam petiturus effet, cunctis ob militǘ multitudinem \& armorum varietaté, qux paulo antè iactabantur perterritis, huiufcemodi ad Achros dictione eft vfus, Quum enim apud Calchidenfem, bonum quidem ho fpitem \& fcitum conuiuatorem folftitiali tempore comiter accepti miraremur vnde illi eo tempore anni tam varia $\&$ multa venatio, homo gloriofus ridês varietatem,ait illam fpeciem ferinæ carnis,ex manfueto manfuefactam, fed condi mentis \& apparatibus folú differre : Proinde nec vos vlla teneat admiratio circa hæc varia nomina gentium inauditarum,Dacas, \& Cadufios, \&Elimęos \& multa genera armorum, haftatos, cataphractos \& pezeteros, hoc eft, pedeftres fo cios,cumó pedeftribus fagittarios auditis: nam homines omnes effe,armis inuicem differentes, aut paulo mancipiorum melius propter feruilia ingenia quàm militum genus.

Lucullus in Armenia, quum cataphractos Tygranis maxime milites fui metuerent, bono animo effe iuffit: futurum enim plus laboris in illis fpoliandis, quàm in vincendis.

Lucius Sylla qui Prænefte obfidebantur occiforum in prælio ducum capita haftis infixa oftendit,atg ita obftinatorum peruicaciam fregit. Sylla item cognomëto fęlix, inter fuas maximas foelicitates duas exiftimabat, $\mathrm{Pii}$ Metelli ami citiam, \& quòd vrbem Athenarum non æquaffet folo,fed feruaffet potius.

Eumenes quum in caftra reuertetetur, $\&$ epiftolx paffim in ipfis caftris abieetx inuenirentur quibus his qui eius caput ad Antigonum detuliffent magna præmia diffinirentur,vocatis ad concionem militibus,gratias primò egit,quòd nemo inuentus effet qui fpem cruenti præmii fidei facramentis anteponeret, tî deinde fubiecit callide confictas has à fe literas ad experiendos fuorum animos effe,caterum falutem fuam in omnium poteltate effe,nềc Antigonum nec quéquam ducum fic velle vincere vt ipfe in fe peffimum exemplum ftatuat: hoc facto in pręfentilabantiũ animos coërcuit, $\mathcal{Q}$ in futurũ prouidit, $v t$ fi quid fimile accidiffet,non fe ab hofte corrüpi, fed à duce tentari milites arbitrarentur. Infuper quum intelligeret fi copix fux cognofcerent aduerfus quos ducerentur, non modo non ituras,fed fimul cum nuncio dilapfuras, hoc eius fuiffe prudentiffimü fertur vt deuiis itineribus milites duceret, in quibus vera audire non poffent, $8<$ his perfuaderet fe contra quofdam barbaros proficifci : itaque tenuit hoc propofitum, \& prius in aciem exercitum duxit praliumó commifit, quàm milites fui fcirent cum quibus arma conferrent . Effecit etiam illud locorum præoccupatione, vt equitatu potius dimicaret quo plus valebat, quàm peditatu quo erat 
deterior. Hunc item Eumenem perfequens Antigonus, cum omni genere copiarum fxpe abundaret,neque vnquâ ad manus accedere liceret nif his locis quibus pauci multis poffent referre, extremo tempore cum confilio capi nó polfet, multitudine circuitus eft: hinc tamen multis fuis amiffis, fe expediuit, \& in ca feellum Phrygix quod Nora appellatur confugit,vbi cum videret fe fortunam obfidionis fubiturum, maioren exercitus partem dimifit, ne aut confenfu multitudinis hofti traderetur, aut obfidio ip a multitud ine grauaretur, in hif $\mathrm{p}$ qui remanferant quú vereretur ne vno loco manens equos militares perderet, quod fpatium non eflet agitandi, callidum fuit eius inuentum, quémad modum ftans ium entum concalefieri exerceriç poffet, quo libentius $\&$ cibo vteretur $\&$ à cor poris motu remoueretur: fubftringebat caput loro altius quàm vt prioribuspe dibus planè terram poflet attingere, deinde pofterioribus cogebat exultare, 86 calces remittere: qui motus non modo minus fudorem excutiebat, quàm fi fpatio decurreret: quo factü eft, quod omnibus mirabile eft vifum, vt xquè iumenta nitida ex caftello educeret quum complures menfes in obfidione fuiflent, ac fi in campeitribus ea locis is habuiflet. Demades pofteaquá ex hac luce migraffet, Alexander aiebat videre fe Macedonum exercitum excæcato Cyclopi perfimilem, quoniam tali principe effet orbatus. Artaxerxes quum aliquädo fugiens, cómeatu impedimentil" direptis ficcis ficis vefceretur ac pane ordeaceo, Cuius modi, inquit, voluptatis rudis eram?

Aurelianum imperatorem, ne vti ftatuerat in vrbem Tyanam defauiret placauit Apollonius, maximx famx \& auctoritatis homo: "quippe fi vis o imperator, inquit, vincere, nibil eft cur fruias in ciues iftos: fi vis impera re, abftineas à cruore innocentum oportet: fi vis viuere, cleméter age. Idem $\mathrm{Ty}$ anam quidem rebellem vrbem obfidens iurauit fe neque cané in ea vllum fi caperet relicturum,ac probe id quidê: ea nanque res militibus prædæa auidis fpem dedit, $\&$ animum capiendi,obfeffis veró defperationem fecit : at verò vi capta vrbe, quum milites iuxta illud dictum quo canem fe relicturum apud $T$ yanzos negarat, euerfionem rrbis expofcerent, refpondit his, Canem, inquit, negaui in hac vrbe me relicturum, canes ergo omnes occidite: quod dictú quo prada negabatur ciuitáfque feruabatur, totus exercitus quafi dietaretur accepit. Infuper Manlio Chiloni cuipiam forfan iurganti hominé ab eo de medio fublatü, quo peruadèdæ vrbis fuæ confliario vfus maxime fuerat, in hunc modum refpondiffe fertur, Occidi paffus fum,cuius quafi beneficio Tyanam recepi : ego verò proditorem a mare non potui: \& libenter tuli quòd eum milites occiderunt, neque enim mihi fidem feruare potuiffet,qui patrix non pepercit.

Exercitum ducens in Perfas Iulianus apoftata, quem occuparat ponté quum tranfffent copiz omnes, igne combuffit vt pugnaretur fortius, militéfque in ho fium terra aut mori aut vincere oportere.

Iacedæmonii magna bellicæ rei gloria cæteris præftantes,natorumfuorum verberibus publice admotis experiebantur indolem, exhortabantúrque ut flagellorum ictus fortiter ferrent, $\&$ laceros $\&$ femianimes rogabant perfeueranter vulnera prabere vulneribus. Nec aliter matres pugnam inituros filios admone- 
bant quàm vt eam minus detrectantes, aut fuperftites atmatíg coram reuerterentur,aut exanimes vnà cũ armis teferrentur:vt enim eorú epigramma oftendit, $\&$ viuendum libenter $\&$ moriendum, fed vtranque cum virtute, cenfebant. Lacedæmoniorum etiam quifpiam quum præfens hoftis inter loquendum glo riabundus affereret, folem telorum copia fuorum \& fagittarú multitudine Spar tiatas non vifuros in vmbra,immo inquit melius pugnabimus.

Cymbrorum probanda etiam ac Celtiberorum animi praftátia qui inter arma, fanguinem, $\&$ vulnera exultabant tanquam beati vitam relicturi:egrè ferebant,vt cateri mottalium, aliquo morbi genere confici, tanquam turpiffimum id effet 8 miferix plenum. Hi etiam ignominix non parux effe putabant,praliis fupereffe, quum is oppetiffet, pro cuius falute fe deuouiffent : proinde, quod mirú dictu eft, lati ferebant vulnera,enumerabant cicatrices, $\&$ telis traiecti mo rientesetian amabant pro quo caderent imperatorem.

Alexander animo femper ingenti, quànquam matris legiffet epiftolă qua admonebatur vt à veneno Philippi medici precaueret,acceptã potioné tamé bibit nổ deterritus: \& quia plus fibi de a nico fuo credidit, dignus fuit $q$ innocétể haberet, dignus $q$ faceret. Is etiẫ inftructo exercitu, quû̉ milité quêdádá intueretur qui iaculü a métaret,ex acie vt inutilem repulit:quippe qui nunc inftrueretur, quü ið̃ armis vtendum effet. Infuper quum ad Arbelas aduerfus decies centena hominum milia de fumma rerum, acie dimicaturus effet, \& anici eum adirêt qui mi lites fubaccufarent quòd intra tabernacula inter loquendum pacifcerentur, vt nihil omnino fpoliorum in regiam telaturi forent, fed fibi ipfis comparaturi,at ille fubridens, Bona, inquit, nunciatis omnia: audio enim his viris vincendi,non fugiendi confultationes effe. Sagittæ quoque ictu in crure vulneratus, vt eorum multi concurriffent qui eum appellare deum confueffent, læata hilariộ facie, Hie quidem fanguis eft, ait, vt videt is, \& non cruor cælicolæ qualem diui mifére flu entem. Idem, præceptorem fuum crédo fecutus Ariftotelem, ænea concha fuppofita, brachio extra cubile protento pilam tenebat argenteam, vt quum neriorum vigorem foporllaxaffet infufus, geftaminis lapfr tinnitus fomnum abrumperet. Rur fus qui inter Indos optimus arcu videretur,diceretur $q$ p per anulum fa gittam emittere,eum quum haberet captiuú vt id oftenderet iuflit: quod quum ille nollet,iratus Alexander hominem imperauit interimi: ille verò quum agere tur, vbi ad eos à quibus agebatur cóuerfusdiceret, multos fe dies ei rei non ftudu iffe,proptereáq ne aberraret timuiffe: id poftquam Alexander audiffet, $\&$ mira tum effe, \& muneribus donatum hominem liberaffe. Laboranti item ob fitim, Macèdonum manus aquam vtribus ferés, impletã galex aquam obtulit, quam accipiens fitienten'p exercitum circunfpiciés, demiffo capite $\&$ frxis in potum oculis inguftatam hifce probandis verbis reddidie, Si bibero, inquit, hos meror inftigabit:quo audito, milites adeffe eum cernentes, magna cum voce ingétíg fpe certatim acclamauere. Non enim laborem perferre, non morti fe obnoxios putare, donec talem eis regem ac ducem adeffe contingeret. Cuidam etiam ciui tati, partem agrorum ac dimidium omnium rerum pollicenti,Eo,inquit, Alexander, propofito in Afram veni,vt no id acciperem quod dediffetis, fed ve id has 
beretis quod reliquifem. Illud etiam eiufdem regis, dictu fane ac factu memorabile, qui quum Darii filias captiuas haberet, $\&$ mirum in modum forma preftantes, nec afpicere quidem voluit, indignú ac turpe regi ac duci effe ratus, eos qui viros vincerent, à mulieribus vinci. Hoc loco denzque non videtur prætereundum, Sigifmunde, confiliú tuum, Alexandri conflilo quàmfimilimú, qui non folum vltro oblatas hoftium epiftolas Cæáris more nö combuffit, fed fuorum callide perquifuit: quanquam quid Alexandrum té́p nomino, quum omnium penè hominú confilia hac de re paria, \& Alexädrea Sigifmüdeág potius quàm Cæefarea vel Pompeiana efle confpiciantur?

Caius Pompilıus, vt ferè omnes tradunt,vt Plinius, P. Octauius cof. legatus a Romanis miffus ad Antiochum regem, qui abftinere illú Aegypti, \& ab Alexandria difcederet quam obfidebat, ne Ptolomæi filiorum qui pupilli effent regnum occuparet,aut fi iam cepiffet excedere iuberet, quum in Aegypto Pompilium per caftra aduenientem eminus Ántiochus quàm humaniffime falutaffet,ofculumóg ei poftea rex obtuliffet, non feruata falutandi vice (nam coluerat inter cæteros Antiochus multum Pompilium, quum obfes Romę fuiffet)tum Pompilius faceffere interim priuatam amicitiam iubet, quum mandata patrix intercedant, prolatóg fenatus decreto, $\&$ tradito ac perlecto, quum rex dixiffet cófultaturum daturúóp refponfú, Pompilius rege in gyrum virga circüfcripto, 4. Hic ergo ftans, inquit, confulta \& refponde. Cunctis autem viri grauitate atque animi magnitudiné admirantibus ftupentibúfq \& Antiochus fe fenatui pariturü refpödit, \& ita Pompilius \& falutauit eü, \& gratiflimis vinis cóplexus eft.

Hadrianus qui réges omnes muneribns fuis penè vicit, quum quodam tempore veteranum quempiam notúfibi in militia, dorfum $Q$ reliquú corporis in balneis vidiflet atterere, percunctatus cur fe marmoribus detergédum daret, vbi audiuit hoc id circo fieri, $q$ ferum non haberet, $\&$ feruis eum donauit $\&$ fum ptibus: verum poltridie quum plures fenes ad prouocandam liberalitatem prin cipis parietife fimili modo attererent, euocari eos iuffit, \& alium ab alio inuicem defricari.Idem familiaribus quibufdam facilitateri comitatem q $_{\text {fuam ni- }}$ miam in omnes obiurgantibus, eiufmodi fubiecit, Imperatorem fingulis effe de bere,cuiufmodi effe fibi fingulos imperator optaret.

Fauorinus philofophus quum pro verbo quopiam quod elegantifime protulerat ab Hadriano inepte reprehenderetur atque ceffiffet, arguentibus ac egre ferentibus ob id illum familiaribus fuis, fubridens, Non rectè quidem fuadetis,

4 inquit, quinó patimini me illü doctioré on nibus credere $q$ habet $x x x$, legiones.

Antonius poft Mutinéfem obfidionem fugiens, feu $q$ naturali more fui corporis laboribus exhauftis creberrine bibebat, $v$ bi bibédi facultas afforet, per fin gulosíg paffus fubfiftebat, ê veftigio deinde fugä præcipiti confternatione reaffumebat, interrogatus ex familiaribus eius quilpiam quid ná Antonius ageret, fublecit, Quod canis in Aegypto,bibit enim \& fugit: memorie enim pditú eft canes agy ptiacos crocodilorú contactu anxios ato lunaticos, bibere $\&$ fugere.

Theocritus ille nô Syracufius, fed Chius, ad infenfum fibi regé Antigonum altero captú oculo quú traheretur, fpé prę bétibus fuis fore vt quú ad oculos regis perueniffer 
perueniffet mifericordiam inueniret, refpódit, Impollibilis ergo eft ifta códitio, actum eft, perii. Verumenimuero hac intempeftiua mordacitas, \& Theocrito mortis, \& Antigono homicidii fimul ac periuri caufa fuit: iurauerat enim fibi parcere, fed ioci afperitate motus non pepercit.

Mithridates Pont i rex, Ariaracti regi Capadocum fub fimulatione colloguit infidias tendens, gladiü fub fafciis abdiderat, crudelis licet adolefcens, $\&$ ad in teritú deftinatus, regio tamen illorum more temporum, fcrutatoré permifit : qui dư Mithridati curiofius manü in fecretiores partes corporis immittit, iccabundusille, Caue,ait,ne aliud telum quàm quod quæris inuenias: eóģ modo fufficione detracta iocis texit infidias, euocatum' regem ab amicis velut ad fecretum fermonem, vtroque infpectante peremit exercitu.

Cicero quum diutius ad caftra Pompeii adueniffet, in primordio ciuilis belli reprehendentibus amicis $q$ nimis difuliffet, Minime, inquit, ferius adueni: nan nitil hic paratum video, Pompeii tarditatem in apparatibus bellorum ludens. Iden Cicero cum poft Pharfalicum pralium, fugiente Pompeio Nonius quifpi am dixiffer, adhuc a quilas feptem apud ipfos effe, $\&$ ob id vt bono animo effet hortaretur, Recte, inquit, moneres, fi cum graculis nobis pugnancum effet.

M.Craffus perquirenti cuipiam quo tempore moturus effet exercitum, refpon dit, Vereris ne tubam non audias?

P.autem Licinius Craffus coff.\& pon.max. aduerfus Ariftonicû Athali fratrem cum inftructiffimo miffus exercitu, maximis infuper copiis \& regum prafidiis fultus, conferto tamen bello victus eft, iśǵ ne feruiret barbaro victori, virgam qua vfus fuerat ad equum regendum impegit ad oculum Thracis cuiufp am, vt iplum in necem fuam iritaret: quo ita fibi adueniente, morte fua dignitatem reipub.\& libertatem fiam feruauit.

Pelopidas domum egrediens, lac hrymante vxore 8 exhortante ac rogâte feipfum faluum redderet, inquit, $O$ mulser priuatorum femper eft admonere, ducum autem acimperatorum alios faluos facere. Idem cum primum cognitum eft per difficilia arcáç loca iter babiruros effe aduerfarios, \& accelerans quidam o Pclopida,inquit, incidimus in hoftes, Quid, air, in illos nos magis incidmus, in nosilli?quibus dictis tanquam futuri belli praludium,equam à cauda impel li iuftịt.Rurfus quú in Pharfalú veniffent aduerfus Alexädrü, dicêti cuidã tyran num cum ingentibus copiis aduentare, Eo melius, inquit:nam plurium victoria nobis aderit.

M. Porcius Cato coff.quum Celtiberos domuiffet compertúmque háberet experientia rexum magiftra \& illufrium auctorum fententiss, eam gentem locorum natura $\&$ hominum ingeniis ad rebelládum non folum omnibus alis provinciis, fed ipfa etian Italia aptrorem effe, quoninus id facere poffet, Iteras. ad fingulas ciuitates dedit, vt muros diruerent: quod praceptum tam immite, ad rebellionem hortari potuiffet potius, guàm ad cam fedandam, fi generale id quidé effe cognouifent: verú quum qualibet fibi foli imperari, non aliis putaret, metu omnes imperii paruere. Hẹc \& Flinii\& hiftoricorü penè omnü habet affercio, apud hiftorie autem Romane patrem T. Liuium couocafle Catoné con- 
ftat omnium vrbium legatos, atque eis oftendife, eorum rebelliones Romanis quàm laboriofas, Hifpanis difcriminú plenas, feftiferas, atque funeltas effe: hor tatum deinde vt rebellionibus abftinerent, vt'́g quonam id modo fieri melius quiret in commune confulerent : nil refpondentibus illis, aliquot dierum fpaci um dediffe, quo exacto, reuocatis iterumóp filentibus, iplum confilio quod ab illis quafiuerat in fe affumpto mififfe per vniuerfum orbem nuncios edictáque $v t$ vno die Romanis qui in vrbium præfidiis erant muri onines euerterétur: quo facto, ipfus ilico ad eos qui adhuc rebellarét cú exercitu fé conferens, omnes ferme metu territos in deditionem accepit. Idem quum Eumenes rex Romam profectus effet $\&$ à fenatu comiter \& honorifice fufceptus, \& clariffimorum cir ca eum ciuium frequentia certatim verfaretur, Cato non obfcure tantum erga regem ftudium fufpectum habens, eum declinabat, verùm quum ipfi dicere. cur, Eumenem frugi virum, amiciffimo animo in rempub. Romam veniffe, Efto,inquit, cæeteru hæc ipfa Belua, $R$ ex fcilicet, natura vorax canis eft. $R$ uifus quum animaduertiffet in Hifpania potiri fe quodam oppido poffe, frinopinatos inuaderet, quatridui iter biduo per confrag ofa \& deferta emenfus nihil tale metuétes oppreffit hoftes: victoribus deinde fuis caufam tá facilis euentus reqrentibus, dixit, tum illos victoriam adeptos quú quatridui iter biduo cófeciffet.

Epaminundas vxorem quum nunquam nouiffet reprehendereturóp quòd liberos non relinqueret à Pelopida qui filum haberet infamem, malẹ́ eum in eo patria confulere diceret, $V$ ide, inquit, ne tu peius confulas qui ralem ex te natum relicturus fis. Neque verò ftirps potelt mihi deeffe:namque ex me natam relinquo pugnam Leuctricam, qua non modo mihi fuperltes, fed etiam immor talis fir neceffe eft.

Pomponius, vir infignis, cum in Romanorum cỏgreflu acceptis vulneribus ad Mithridatem ductus fuiffet rogareturgue ab co fi curatus fibi foret amicus, $\mathrm{Si}$ tu, inquit Pomponius, Romanis amicus fueris : fin auté, me quog inimicum habebis. Mithridates clariffimam viri conftantiam admiratus, ab omni peni tus in eum iniuria temperauit.

Lycurgi exemplis huiufmodiad ciues refponfa feruntur,quonam pacto hofti um impetus repellere poffent poftulantes, Si pauperes, inquit, manferitis \& contemptiones mutuas omileritis. Et rurfum de muris, nequaquam ea vrbs minus circundata muro fuerit, fi quis eam viris fortibus non lateribus cinxerit.

Paulus Aemilius col. quú in Lucanis iuxta littus angufto itinere exercitum duceret, \& Tarentini agnen eius forpionibus adorirentur, captiuis eunitum latera prætexuit, quorum prætextu hoftes tela inhibuere. Idem nocturnas excubias iuffit fine hafta \& fine enfe afferuarent, quò defperantes qui hoftibus re pugnarent magis fomno reffterent.

Tyberius Gracchus L ufitanis afferentibus in decenne tempus alimoniam fe habere, 2 obfidionis incómoda non reformidare, Vndecimo, inquit, anno vos capiam: quo dicto perterriti Lufitani tametfi commeatu muniti fe dediderunt.

Ly ander poftquam incumbentibus Corinthiis monia prætergrediens, languidiores ad inuadendum Lacedamonios cernit, \& interim lepus foram tran- 
Gilire vifus effet, Non pudet vos, ait, eius generis hoftes pertimefcere, quorum monibus per fecordiam lepores indormiunt?

Pompeius Luculli facta detractans, illum dicebat tragicum \& vmbratile quoddam bellum cum regibus geffiffe : fibi verò certam atque frobriam hofti um vim ad expugnationem referuatam effe, quú Mithridates ad enfes $\&$ equos confugiffet. Ad qux Lucullus, fimulachra \& vimbras belli immo Pomperum acceffiffe expugnatum aiebat, fuetum veluti volucrem alieno cadauerı celerem aduentare, reliquilfque bellorum infurgere. Sic enim Sertorio \& I e epido \& Spartanis infurrexiffe eum dicebat, quum illa Craffus, alia Metellus, alia Lepidus bella ftrenue geffiffet. Ad hac Sertorii fcripturis in Hiberia potitus, inter quas erant multorum ducum epiftolæ quibus ad nutandam perturbandám que rempub. Sertorium Romam accerfebant, illas omnes concremauit, facultatem his quidem prabens vt mali ad fanitatem redirent ac meliores fierent. Idem quop Pompeius quum omnes factiones fux vno pene ore, tanquam diuino quoda $m$ oraculo moniti, ad furentem Cxaris inuafonem pronunciarent nulla ratione poffe concipere quo fe modo tueri poffet, cum tâta veniente belli tempeftate delectum ad refiftendum neque haberet vllum, neque pararet, refpondiffe fertur, fore quum Italix folum pede quateret, vt pedeftres copix equeftréfque fcatcrent: paulo verò pòlt, fama increbrefénte $\&$ nuntiis, quum percepiffet R ubiconem flumen tranfuiffe Cælarem Ariminúmque egregiam tunc \& amplam vrbem ilico fubegiffe, ac palam magífque ac magis in dies increbefceret rumor. $C_{2-}$ farem iratum \& infenfum Pompeio \& patribus effe, atque co animo aduentare vi confulatum aut fponte datum acciperet, aut negatum, vi, armis arriperet, proindéque copias qua Picenum, qua $\mathrm{Vmbrum}$, quæ Hetrufcum agrum occuparent, omnémque exercitum fuum Romam traicere (quanquam id fallum erar, quum maiorem non haberet manum quàm trecentorũ equitun $\&$ quinque milium peditum)metu tumultúque huiufmodi prequio qual is nunquam antè vrbem inuaferat ita funt Pomperanæ factionis omnium deterriti animi, vt ci uitas tota trepidaret,nec venire ad vrbem Iul. Cefar $R_{0}$. ciuis ac legiones romanæ, fed Pcenus ille ferulque holtis Hannibal, ac omnis barbaries videretur: fu turus quidem fi vinceret $C æ$ far nec Cinna clementior in principum cæde, nec Sylla moderatior in diripiendis expilandífque locupletum fortunis, coniectura \&opinione omnium putabatur.

Aulo Torquato gracam vrbem oppugnanti quum diceretur, iuaentutem ibi iaculis ac fagittis ftudiofe exerceri, Pluris eam,inquit,vendam.

Iugurtha Numidarum rex corrupta muneribus fenatus parte atgauro victis belli ducibus, fepe votorum iniquilfimorum compos, quum tandem pecuria $\&$ artibus fuis fidens R omam fub fide publica veniffet, ato inde prater fpem verecundia vincente cupidinem iuffus excederet, portas vrbis egreffus crebróq taci maturè perituram, fi emptorem inuenerit: quod verbum ab holte prolatum, dictu mirum eft quàm late ad infamian $R$ omanorum inuulgatum eft.

Philippus Alexandri pater quum munitifimum caftellum quoddam capere H. ii vellet 
vellet, vbi exploratores retuliffent quàm difficilimum effe $\&$ nullo modo $\mathrm{cr}$ poffe, rogauit itáne difficile effet, quo ne afinus qdē auro onuftus quiret accedere.

Cleomenes Athentenfis trecentos qui prafidium Craterium tenebant aggref fus, tela quædam in quibus fcriptum erat veniffe fe ad liberandum eorum rem publicam inter muros iecit, \& eodem tempore captiuos quofdam conciliatos fibi remifit, quorum conflio feditione inteftina apud obfeffos conciliata, admo to exercitu, ciuitate potitus eft. Idem quum quis fe Gallos ei daturum polliceretur qui pugnando interirent, Iftos mihi des, inquit, nolim, fed illos potius qui pugnandointerimant.

Lycenes Sicyonius ductum aquarum in oppidum Chryfeorum labêtem ru pit, mox factis fuis reltituit aquam elleboro corruptã, qua vtentes profluuio ven tris correptos cepit.

Pyrrhus quum ex Antigona quidem Ptolomaum, ex Ianoffa verò Alexandrü,ex Tircenna Helenú filios fúfcepiffet, omnes manu próptos $\&$ bello feroces, itatim à pueritia adhoc ipfum innutritos, diciť cuidã ex filiis puero patré rogã ti cuinā regnú relinqueret, refpódiffe, ei ex vobis qui gladiú acutioré ha bebit.Sed hoc nihil differt ab illa tragica deteftatione, Acuto ferro diuidant fratres domú.Idé ex A mbrachia vt quendá maledicum pelleret precantibus refpondit,Po tius apud paucos illic manens, quàm currens apud multos de nobis obloquatur.

Darius vt Scy thas difceffu falleret, afinos canésqg in caftris reliquit, quos quu rudentes latrantéqque holtes audirent, remanere Darium credidere. Eodem mo do Ligures per diuerfa loca buculas laqueis ad arbores alligauere, qui diducti, frequentiore mugitu fpeciem remanentium præbuierunt hoftium.

Leonidas rex intempeftiue quodam de rebus militaribus verba faciẽte, $\mathrm{O}$ ho fpes,inquit, non opportune quod oportet vteris. Eius quoq ducis contra Perfarum exercitum quàm fortiter commilitones fuos hortantis elogium eft, vt non aliter pranderent quàm $f_{1}$ apud inferos conaturi effent. Mirum dictu,non in ore creuit cibus, non hęfit faucibus; non elapfus eft manibus, cæterum alacres $\&$ ad, prandium illi promiferunt, $\&$ ad conam.

Periandri confiliü Thrafybulo datú eft, fupereminétes fpicas decerpere,tãquä opportunú fuerit eminentiores ciuium de medio tollere. Itidem Tarquinius Superbus pater, apud noftros Sabinorum principes necandos cenfuit.

Theopompi regis dictum probari etiam folet, qui dicente quodam eo feruari Spartam quòd reges imperare didicerint, Quin propterea,inquit, potius quòd ci ues imperio parent:non enim parere illis patiuntur, qui nefciunt imperare, fed fubiectorum obedientia difciplina eft principis: nam qui recte ducit,vt recte fequätur efficit. Atqui ficut equeftris artis eft, manfuetum praftare \& obfequentem equum:fic \& regix difciplinæ munus, obedientes efficere.

Helius Cómodus Cęf.curforibus fuis exëplo cupidinú alas frequéter appofuit, cośq̣à ventorü nominibus fępe vocitauit, Boreã, Notú aliü, \& itê Aquiloné aut Circiū cęterisóg numinibus appellás, $\&$ indefefle ato̧ in cíeméter faciè curfitare.

M.Sertorius acie decertáté barbarú qui ei núciauerat Hyrculegiú periiffe pugione traiecit,ne in aliorú notitiâ pueniret, $\&$ ob hoc animi fuoru infirmaretur. 
Antoninus. Pius pacem eoufque dilexit vt Scipionis fententiam vfurpare fre pe folitus Gat,qua ille profitebatur, malle fe vnum feruare ciué quàm mille hoftes occidere.

Hannibalem venientem in Italiam cum tria milia Carpentanorum relinque rent, callidiffimo ille aftu ne \& cæteri mouerentur edixir, a fe efle dimiffos $\&$ infuper in fidem eius rei paucos leuiffimæ operæ domú remifrt. Eiufdé quog̣ ducis clementiflimum fane falubrég in fuos conflium : nam quum milites eius gelu ac frigore torperent, ignibus ante tentoria factis vt epularentur edixit, oleum'́p per manipulos in partiendum vt vngerentur molliréntó artus mifit : \& fcitèid quidem ac fapienter. Nam vt phyficis placet, oleo nihil ficorporibus exterius admoueatur falutarius : fri interius, nihil perniciofius eft . Rurfus quú apud $\mathrm{Au}$ fiảum, fluuium prope Cannas caftra haberet \& orto die extemplo belli fignum extuliffet (Nam erat rubra quædam veftis fupra confulis tentorium protenfa) Carthaginen fes profpecta impetatoris Romani audacia, \& copiarum hoftilium multitudine, quum ipfi haud medium numerum attingerent, principio, ingenti trepidatione perculfi funt : Hannibal iubens exercitum arma capere, eques iple cum paucis ex quodam humili tumulo hoftes qui iam legiones in acies ftruxerant; fpeculatur, quúmq quidam ex his qui circa ipfum erant, vir haud inglorius Gifgo diceret admirabilem fibi hoftium multitudinem videri, contrahens faciem Ha nnibal,inquit, Alternm te vidiffe puto hoc ad mirabilius, quod è memoria tua excidit: interrogante Gifgone quidna m illud effet, refpondit Hannibal,quòd inter hos tot homines, nemo preter te fit qui Gifgo appelletur: hæc fcó mata præter opinionem accidentia, omnes in rifun milites coniecerunt, \& qui ex colle digrediebantur, \& qui circa eum erant: quare quum Carthaginéfes profpicerent imperatorem corum in periculo iocari, \& rem parui facere, in conferendo bello audentiores facti funt.

Claudius Nero victis Ponis quos Haldrubale duce in Italiam ex Hifpania traiicientes exceperat, caput Hafdrubalis in caftra Hannibalis eiecit : quo factum eft vt Hannibal ( nam frater occifus erat ) exercitus defperatione aduentätis prafidii affigeretur.

Camillus difceptätibus Romanis obfeffis cú Gallis de pecunia pédenda intera ueniens, cú optimatibus aurú arripiens, miniftris dedit,trutinā reddidit hoftibus, abire iubens, proprium inquiens effe Romanis ferro non auro patriam feruare.

Domitius Corbulo quum Cretam obfideret \& Armeni pertinaciter videren cur tolerare obfidionem in Vaduadum ex megiftanis quos coeperat animaduex tit,caputọ́ eius in balifta excuffum intra munimenta hoftium mifit: id fortè de cidit in medium concilium quod tum maxime habebant barbari,ad cuius con fpectum velut oftento confternati ad deditionem feftinauerunt.

Gallorum equites pectoribus equorum ad terrorem fufpenfa Romanorum geftarunt capita , $\&$ lanceis infixa, ouantéfque moris fui carmine : quanquam fint qui $\mathrm{Vmbros}$ fuiffe non Gallos tradant.

Appius Claudius, in on i fermóe negociü Romanorū ocio pręerre folitus fert: atq nemo tá demés eft q ocii dulcediné, negociorú curis, fr fecuritas cú ocio con-

H iii tingas 
tingat nó præferendá cenfeat: fed in anteriora profpiciens vir cautifimus, videbat id qd" exitus ap pbauit, Romanã virtuté negotiis ali, fegniciég marcelcere.

Q. Metellus bello punico fecundo, pulfo tädem ex Italia Hannibale ac fuba cta Carthagine, cunctis gaudio exultantibus folus in fenatu graui ac circumfpe cta fententia vfus eft, Ignorare fe afferens ea victoriáne lætabilior an formidabilior effet reipub.Sicut enim Hannibal Alpes ingentiftrepitu tranfgreflus, concuffa Italia dormitantem populum Ro.excitaffet, fecurus torpor opprimeret.

Scipio Nafica vir optimus à fenatu iudicatus, tertio bello punico dum à fen tentia Catonis Cenforii,qui vir omniú fapientiflimus habebatur acerrime conftanteróg diffenfit, \& illo cenfente inexorabiliter delédam effe Carthaginem aduerfatus eft,non quòd vrbem infeftiffimâ parcius odiffet, led quòd patriam diligeret cuius morespræuidere fe dicebat in luxuriam abituros amoto emule vrbis ftimulo. Atg vtinam eius tunc confilium valuiffet, longioris equi forfan Romana folicitas fuiffet, nec vitiis propellentibus corruiffet, pace bellorum gloriã inquinâte, a tọ orben domirum vindicante luxuria.

Melanthus Athenienfium dux quum prouocatus à rege hoftiú $X$ antho Bo étio, defcendiffet ad pugnā,vt primum cominus ftetit, Inique, inquit, Xanthe $\&$ contra pactum pacis,aduerfus enim vnum cum altero proceflifti: quum'́padmi ratus ille, quifnam fe concomıtaretur refpexit,a dortus hominé vno ictu cófecit.

Dionyfius fenior cum forte concionatores pro literarum ordine traherentur, vbi,D litera forte ipfi obueniffet,ad eum qui dixiffet deliras Dionyfi,dominabi tur immo refpondit, atç vbi concionem habuiffet, continuò à Syracufanis pre tor defignatus eft: accufantibus veró quibufdam, hominem à fe honorari $\&$ ad dignitatem prouehi,qui $\&$ improbus foret $\&$ moleftus ciuibus, At volo, inquit, eum effe quem magis quàm me oderint.

Leon Byzantius, gibbolo,fibi oculorum vitium obiicienti, Humanú,inquit, malum reprehendis, quum ipfe tergo fupplicium luas.

Hermucrates Syracu anus fuperatis acie Carthaginenfibus, veritus ne captiui quorum ingentem manum in poteftatem redegerat, parum diligenter cuftodirentur, quia veritas euentus dimicationis in epulas, in fecuritatem'́g compellere victores poterat, finxit proxima nocte equitatum hoftlem venturum: qua expe cta tione affecutus eft, vt folito attentius accuratiusóp vigilix agerentur.

Caius Pontius Samnitum imp.ambos coff.atque omnem exercitum ro.forte præruptis \& anguftis locis incluferat, miferabile fpectaculum, tot fortifimos viros, adépta pugnæcopia, \& armatos frmul \& captiuos cernere: quum interuentus noctis animos ab operibus in curas traduxiflet, nec minus lętitia victoribus, quàm inclufis dolor conflium ademiffet, vifum eft Herenniü Victoris patrem, virum \& xtate \& fapientia prouectum confulere, (Neque enim aberat)fenex au dito rerum ftatu confilium dedit vt abire permitteret,infuper honorificis verbis \& omni obfequiorum genere prolequeretur: quod vbi in confilio caftrenfiapud feroces animos iuuenum agitari coepit, nimis molle ac prorfus fenile conflium de tam infeftis hoftibus, \& indignum omnibus videri : proinde iuffus nuncius reuerti,ac virilius refponfum petere. At ille omnes ad vnum occidendos cenfuit 
Romanos: enimuero tum cuncti,præcipue imperator delirare iam fenem arbitrati funt,quippe qui de eadem re tam:pugnantia fuaderet:quia tamen fama hominis preclara erat , placuit rurfum exquirere, fi quod forte medium confilium baberet : tum verò fenior ftratis fefe iuflit attolli, \& vehiculo impofitum fe ad caftra filii perferri, cuius aduentum circüfufis omnibus, Nihil, inquit, noui conflii daturus venio, fed eorum qux dedi dicturus rationem: Primú quidem eft,Romanos bello clariffimos \& optimos mortaliü viros, grandi \& infperato beneficio aftrictos ex inimicitiis ad amicitiam attrahere, $\&$ vobis ac pofteris veftris tam valid $x$ gentis præfidium promereri:quonam enin modo vnquam odiffe poterunt,aut eos aut corum fobolé qui ab eis nafcentur per quos fe meminerint vita ac libertate donatos? Secundum, fi hoc vobis difplicet, reor vti pręenti fortunà, \& gentem inimicam extirpare funditus placeat : fic enim in longum non tantum vobis confulitis, fed natorum nat is, $\&$ qui nafcentur $a b$ illis. Tertium fane quod ex me petiftis conflium nullum eft: nam quos, inquit, in manibus habetis dimittere contumeliis affectos, ea demum fumma dementia eft, quæ nec hoftem tollit nec amicum parat: verumtamen cæcus $\&$ infolens victoris animus vtroç côfilio defpecto, tertiü quod ille dânauerat amplexus, exercitum \& confules exarmatos \& fub iugum actos relaxauit,armis etiam veftimé tisóg fublatis,tantum fingulis vilioribus operimentis ob pudibunda corporis tegenda conceffit, quod quurm nunciatum effet Herennio, vt audiuit eos moeftiffimos abire, nec amicum, nec hoftem poffe à quoquam romano verbú extorque$\mathrm{re}$, Ei, inguit, mifero quàm graues minæ fub hoc filentio premuntur : id quoque quàm vere prodiderit fubfecuta Samnitũ Atrage duce Papyrio Curfore repofitumóg ingum Pontio \& legionibus teftatur. Eiufdem etiam Caii Pontii Samni tum imperatoris dictum illud memorabile fuiffe aiunt, Vtinam, inquit,ad id têpus me fata referuaffent quo Romani dona accipere copiffent : non effem pafs fus eos diutius regnare. Sapienter id quidem hoft is optabat: videbat enim impe rium donis corruptibile,duturnum effe non poffe.

Xerxi quum exercitus fui magnitudine multa vndique iactarentur qux hominem nimia exiftimatione fui furentem concitarent, aliuśg diceret Gracos quibus bellum illaturus effet,non laturos nuncium belli, $\&$ ad primam aduentus famam terga verfuros, alius nihil effe dubii quin illa multitudine non vinci folum Græciam, fed obrui poffe,alins vix illi rerum naturam fufficere, angufta effe claffibus maria, militi caftra, explicandis equeftribuscopiis campeftria vix patere,cellumọ́ haud fatis ad emittenda omniú manu tela multaq́p in hunc modum,Demaratus Lacedæmonius folus dixit, I pfam illam quæ fibi placeret mul titudinem indigeftam $\&$ grauem metuendam effe ducenti: non enim vires ha: bere,fed pondus: verum'̧́ effe quod diceretur,maiorem belli apparatú effe ğ qui recipi ab his regionibus poffit,quas oppugnare conftituiffet : qux res contra te eft,ob hoc ipfum te Græcia vincet, quia non capiet,\& vti toto te nó poterit. Pręterea quæ vna rebus falus eft, occurrere ad primos rerum impetus \& inclinatis opem ferre non poteris, nec fulcire aut firmare labentia, multò antè vinceris $\tilde{q}$ victum effe te fentias: fic denique vt Demaratus predixerat, ftratus per totam 
paffim Graciam Xerxes intellexit quantum ab exercitu turba diftaret.

Hanno Carthaginenfis, vir apud fuos fpectatæ prouidentię perferuidú Han: nibalis ingeniu ab infantia contemplatus, femper luafit continendum domi fub legibus, docendú ex equo cú ciuibus fuis viuere, abftrahêd um ab exercitibus ne intempeftiuo affuefactus imperio, poftquá ceruicem dediffet,ty rannum ageret: id fulubriter ne præmoneret declarauit exitus:Quanta enim cum Aphrice, Hif paniæáp \& Italiæ ruina, quantóp populorum cum gemitu ac fanguine imperitandi dulcedinem femel deguftatam perpetwam reddere puer ille nixus fit, tam notum eft $v t$ commemoratione non egeat.

Periclen Athenienfum ducem, quem virum cautifimum fuiffe conftabat, Ariftophanes comicus ab inferis reuertëtem finxit, conciues furos monentem, non oportere in ciuitate leonem educari: verum fi educatus fuerit, obfequi opor tere: perfuadere volens hoc figmento, adolefcentibus generofis ac præferocibus habenas fubftringi debere : poltquam laxatæ fnt, ferò contrahi,immodica frenum recufante licentia.Poffe igitur inimicúlibertati nimium fauorem petentibusnegare, confecutis verò eripi non poffe. Idem Pericles cum à Themiftocle vehementer diffideret, multę́ inter ipfos \& graues effent, \& diffonæ contentiones, dicere in concione folitus fertur, nunquã falntem Athenienfum rebus fore, nifi fe ac Themiftoclem in barathrum coniicerent.

Cimon Athenienfis, Peloponefiaci belli téporibus qui fuiffe dicitur,inhumanas admodum \& hominum congreffus fugiens, $\&$ colloguia omnia prater vni us Alcybiadis qui ea tempeftate adolefcenserat, \& præftanti forma, \& lingua maxime promptus, quum eum libentiffime amplecteretur ofculareturó gatus ab Epemanto quid ita fáceret, ideo fe adolefcentem a mare refpódit quòd intelligeret illum multorum malorum caufam Athenienfibus fore.

Iulıus Cęar ciuili victoria clementiffime vfus,quú fcrinia deprehendiffet epiAtolarum ad Pompeium miffarum ab his qui videbantur aut in diuerfis,aut in neutris fuiffe partibus, igni tradidit, \& quàmuis moderatè foleret irafci, maluit tamen non poffe: maximum putauit genus venix, nefcire quid quifque peccaffet: fatiul'q elfe ratus, in quibuldam rebus decipi,quàm fallaciffimis fufpicionis \& coniecturæ intamentis polfe decipere. Idem Pomponio oftendéti vulnus ore exceptum in feditione Sulpitiana, quod ipfe paffum pro eo pugnante gloriabatur, Nunquam fugiens refpexeris, inquit. Huius paterni verbi etiam poftea forte memor Augultus, in que mpiam fimili modo iactitantep, \& cicatrices oftentantem inuectus eft.

Antigonus fecundus, Demetrii filius, quum bello nauali aduerfus P tolomai prætores pugnaturus effet, gubernatoró dixiffet hoftiú naues multo plures effe, At me, inquit, prælentem aduerfus quot naues opponis ? Inuadentibus verò hoftibus, quum aliquando cefliffet, ait nequaquam fe fugere, fed ipfum vtile quod retro pofitum effer infequi.

Alcybiades canem quum haberet optimum quem nummunm feptém mili. bus emerat, ei caudam abfcidit, dicentibúque id vile incly ti ducis minifterium fuife, Hoc ideo feci, inquit, quò Athenien les hac de re loquentes, de me aliud 
nihil curiofus quaritēnt.

Thy moleon quú Demenatus in concione populi de rebus geftis eius detra he re coepiffet, ac nónulla inueheretur in eum, dixit núc demum fe vori factú compotem, nanque hoc à diis immortalibus femper precatum vt talem libertaté reftitueret Syracufanis in qua cuivis liceret de quo vellet, impune dicere.

M. Bruto quum fe penè tota Lufitania dedidiffet ac fola gentis huius Citania ciuitas pertinaciter inftaret, tentata redemptione propemodum vno ore legatus eius refpondit,ferrum videlicet fibi à maioribus quo vrbem tuerêtur, non aurum quo libertatem ab imperatore auaro emerent relítum.

Timotheus fortunatus imperator quum putaretur, atque qui ei inuiderent pingerent vrbes qua illo dormiente ad rete vltro fe implicarent, I taque dicebat Timotheus, fi huiufmodi vrbes capio dormiens, quid me facturum arbitramini"quum vigilauero? Ad hæc quum ex audacibus prætóribus quidam A thenienfibus vulnus oftenderet, At me,inquit, puduit quòd me pratore veftro in Samo catapulta propè concidit.

Iyfimachus in Thracia fuperatus à Dromachea, quum \& fefe,et exercitum fuum præfidi dedidiffet, vbi bibiffet in captiuitate pofitus, $\mathrm{O}$ dii,,inquit, vt parux voluptatis gratia memet feruum ex rege feci.

P. Syllanus quum maxima apud hoftes dignitate ac potentia præftans, $\mathrm{Ma}-$ rio in bello ciuili foffa circundato \& obfeffo occafionem \& tempus operiens dixiffet, O Mari,fi magnus imperator es, defcende in aciem \& pugna, refpondiffe Marium ferunt, At tu fi clarus imperator es, certare me nolentem coge. Iterum quum aliguando hoftes fibi congrediendi prabuiffent caufam Romanúfque certamen detrectauiffet, vt abiere, vtring militibus in concione habitis, A mbigo, inquit, an hoftes, an vos magis eneruatos appellem: non enim veftra illi, neé vos eorum terga intueri poteftis.

Laberius quum vitam omnem honefta militia exegiffet, fexagefimum vitx annum agens,ad extremum Iul.Cæfaris blanditiis ac precibus quæ de ore prin cipum armatx prodeunt productus in fcenam, de Romano equite factus eft mi nimus: quam iniuriam ipfe quidem non tacitus tulit, immo multis $\&$ inter $c x-$ tera his queftus eft verbis, Ego bis tricenis annis actis fine nota, eques Romanus lare egreffus meo domum reuertar,minimúfque nimirum hó die vno plus vixi quàm mihi viuendum fuit . Idem diu antè clariffimus \& inuietus,tandem à Publio victus extitit, quippe à quo éa tempeftate nemo non victus extitit, quod

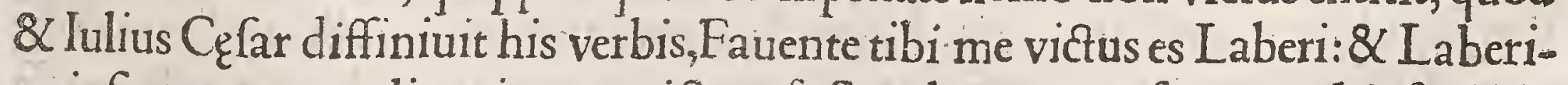
us ipfe tam æquo tulit animo ve victum fe fine altercatione fateretur, his fapiétiæ plenis \& memoratu dignis verfibus, Non poffunt primi effe omnes omni in tempore, Summum ad gradum quum claritatis veneris Confiftes egre \& citius quàm defcendas Decides,cecidi ego,cadet qui fequitur, Laus eft publica.

Athenodorus fingularis $\&$ vita $\&$ doctrina philofophus, guum aliquandiu in inftruendo Augufto dediffet operam \& vrgente fenectute facultatem in patriam redeundi ab imperatore oraret, ac tandem impetraret, difceffurus vt àliquod quafi pignus \& perpetuum fui receffus monumentum relinqueret, in ex- 
uremo abeundi gratificandíque officio quum irafci, inquit, Cafar, tibi contigerit, nihil prius dixeris fecerífue quàm quatuor \& viginti literas mente per curras : quod à philofopho fưmmo inuentum proinde puto, quiò concitatio Illa vehemens anini aliò traducta, parui temporis momento languefceret: fapiens profectò preceptoris dictum. Non minus beni gnum illud Octauiani Cæfaris factum: apprehenfa enim Ahenodori dextra, Tua mihi \& adhuc opus eft præfentia dixit, hominem'́s apud fe annum poltea tenuit,præfatus taciturnitatis, quia fine periculo fit,tutum, nec mediocre præmium fore.

\section{ROBERTI VALTVRII} AD I L LVSTREM HEROA.SIGIS. mundum Pandulphum, de re Militari Liber Sextus.

Belli gerendi indicendiğ, sut feriendi fockeris antiquorum rationes:

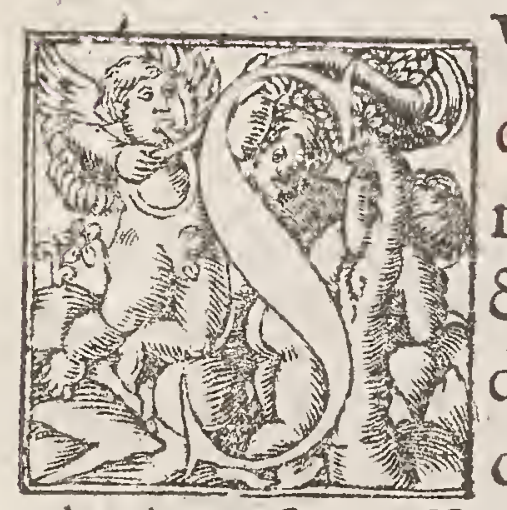

Vnt alix bellorum rationes at@ conflia permulta, Sigifmundè Pandulphe, qua tradere, ardua res quidem erit $\&$ operofa nimis, quoniam quod vtile quif $\$$ probat dux $\&$ imperator id \& fequitur : \& quanquą nouis ingeniorum inuentis occurrere difficillimum etiam fit, quum non præmeditata fepenumero calus afferat, dabimus tamen operam ex his que prioribus ad gloriam fuccefferit viã aperire pofteris, vt ex fimilibus elicere finilia queant con filia:inftituti nanque veteris ac probati quàmdiu fuiffe legimus nullum bellum geri,neque indici debere, neque folere, nifi quicquam prius hoftibus à facerdoti. bus foccialibus denuntiatum effet, apud quos belli æquitas pacífque fanctiffimo Ro.populi iure perfcripta erat. Formula autem indicendi belli aut feriendi foe deris per foecialem huiufmodi erat: \& qua nulla, vt Liuio placet, vetuftior effe memoratur, Focialis inquit,regem Tullium ita rogauit, Iubésne me, rex cú patre patrato populi Albani fodus ferire? iubente rege, Sagmin, inquit à te rex pof co.Rex ait, puram tollito: Focialis ex arce graminis herbam puram attulit, poItea regem ita rogauit, $R$ ex facis ne me tu regium nuncium populi Romani,vos comitef'os meos, Rex refpódit, quod fine fraude mea populique Romani Quiritum fiat facio,multif' id $_{\text {id }}$ verbis que longo effata carmine non opera precium eft referre, peragit:legibus deinde recitatis; Audi inquit' Iupiter,audi Paterpa- 
trate populi Albani,audi tr popule Albune, vt illa palam prima poftremáue ex illis tabulis ceraue recitata funt fine dolo'nalo, vtiog ea hic hodie rectiflime intellecta funtillis legibus populus Romanus prior non deficiet . Si prior defecerit,confilio publico, dolo malo, tu illo die lupiter populum Romanum fic ferito, vt ego hunc por cum hodie feriam, tantóque magis ferito quanto ma gis potes polléfque:id vbi dixit, porcum faxo filice percuffit. Sua item carmina AIbani fúmique iufiurandum per fuum dicta torem fer facerdotes peregerunt. Ancus aute Martius Numæ Pompili ex filia nepos, æquitate ac religione aui perfimilis, qui Latinos bello domuit, ius foeciale quo legati ad res repetédas vterentur ab Equiculis tranftulit, quod prius Hefus fertur excogitafle. Patrispatrati vfus eodem tempore quo Focialis apud Ro.prodiit. Nam $\&$ in feriendis à foc cialibus forderibus, Patrispatrati opera auctoritáfque exigebatur. Legatus igi-

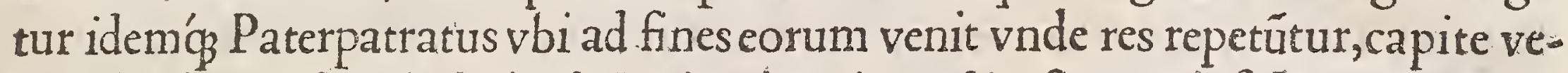
la to filo, lanę velamé eft, A udi Iupiter, inquit, audite fines cuiufcúğ gentis funt; numina audiât fas, Ego fum publicus núcius populi R omani,iufte piéç legatus venio verbif'ch meis fides fit. Peragit deinde poftulata, inde louem teftem facit, Si ego iniufte impiệ illos homines illáfque res dederit, populo Romano mi híg expofco vt patrix compotem nunquàm me finas effe : hæc quum finit fuprà fcandit. Hrc quicunque primus vir ei obuius fuerit, hre portam ingrediens, hæc forum ingreflus, paucis verbis carminis concipiendióp iurifiurädi mutatis peragit. Si non deduntur qua expofcit,diebus tribus \& triginta (tot enim folennes funt) peractis bellum ita indicit, Audi lupiter, \& tu Iuno, Quirine, dii omnes cęleftes, vófóp terreftres voĺọ inferni audite, E go vos teftor, populú illú, qui cunque eft nominat,iniuftum elfe neque ivs perfoluere. Sed de iftis rebus in pa tria maiores natu confulemus, quo pacto ius noltrum adipifcamur. Quum is nuncius Romam ad confulem rediit, confeftim rex ex his ferme verbis Patres confulebat, quarum rerum, litıum,caufarum, códixit $P$ aterpatratus po.ro.Quiritium Patripatrato prif orum latinorum, hominibul'́B prifcis latinis, quas res dari,fieri, folui oportuit, quas res non dederunt, nec foluerunt, nec fecerunt, Dic inquit ei qui primum fentétiam rogabat, Quid cenfes? Tum ille,Puro pióğ duello quxerendas cenfeo, itaque cófentio, confiftóque, indég ordine alii rogaban tur. Quandóque pars maior eorum qui aderant in eandem fententiam ibat, belo lum erat confenfu fieri folitum, vt Focialis haftam ferratam aut fudem prauItam ad fines eorum ferret, \& non minus tribus puberibus præfentibus diceret, quòd populi prifcorú Latinorum, hominésue prifci Latini aduerfus populum Romanum Quiritium fecerunt, deliqueruntó,, Po. Ro. Quiritium bellum cum

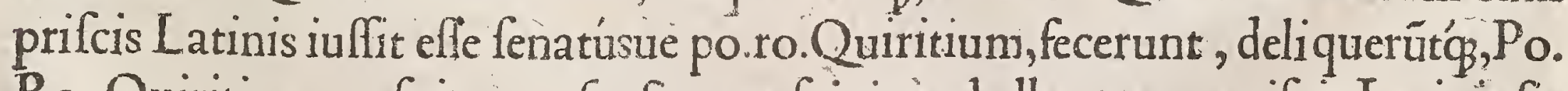
Ro. Quiritium cenfuit, confenfit, confiuit ve bellum cum prifcis I atinis fie ret ob eam rem: Ego populul' $\$$ Romanus, populis prifcorum I atinorum hominibúque prifcis Latinis bellum indico, facióque: id vbi clara voce denunciaffet, clarigationem quafi claram actionem veteres dixere, haftä in fines corum emittebat, quę fic denique miffa, belli principirim erat: quod nec diffimulaffe vifus eft Maro, quum inquit, Et iaculum torqués emittit in auras principium pu- 
gnę erat. Erat \& ante Bellona templú, Bellica(colünę id nomen eft) fupra quam haftam etiam iaciebant bellú indicturi. Ouidius in faftis, Prof picit à tergo fummum breuis area circum Eft vbi non parux parua columna not . Huc folet hafta manu belli prænuncia mitti, In regem $\&$ gentes quum placet arma capi. Hoc itaque tum modo repetite primum res à $R$ manis ac bellum indictum, mo rémque eum pofteri \& fi abfoleuerit acceperunt.

De euocationitis deruotionis formula.

Cap. II:

Elebres deinde auctores habemus, qux vel vi vel arte excogitari ac machinari poffunt ad capiendú opprimédúmque hoftem,nutu deorum \& auficio fieri folere, vt his propitis \& auctoribus ars efficacior effet . Simili modo in oppugnationibus vrbium ante omnua folitum à Romanis facerdotibus euocari deum conftat, in cuius tutela id oppidum fit,promittiógilli eundem aut ampliorem honorem apud Romanos cultúmue, quòd haud aliter vrbé capi poffe non crederent:aut etiā fi poffe, néfas exiftimarent deos habere captiuos. Propterea durauit in pontificum difciplina quãdiu id facrum, contátque ideo occultum \& multis faculis ignotú vrbis latinú nomen tutelarifue dei. Sed Dei quidé nomen nonnullis antiquorú inter fe diffidentium libris infitum eft. Alii cnim louem crediderunt,alii lunam,alii opem confciniam: \& horum quidem fides firmior videtur quibufdam. Sút qui Angeronam: inter antiquiflimas fane religiones, huius dex facellum colitur, cui facrificatur ante diem xii, Kal.ianuarii, que Diua praful flentii ipfrus, pręnexo ore, digitógs ad id admoto fimulacrum habet, quod filentium denüciat. I prus deinde verum vrbis nomem $\&$ vnde deductum fit, inter doctifimos non fatis cöftat. Vt enim Varroni placet $\&$ Liuio, potito imperio Romulo fue Remo condita vrbs eft, $\&$ conditoris fui appellatione nominata. Ali funt qui videri velint $R$ oma vo cabulum ab Euádro primum datum quum oppidum vbi fita nunc vrbs eft,ibi offendiffet, quod extructum antea latino nomine Valentia dicebatur, cuius vocabulum Arcades vertentes in gracum, iuxta prioris verbi fignificationem ¡wulta pro Valentia vocauere. Heraclidiplacet, Trcia capta quofdá ex Achiuis in ea loca per Tyberim deueniffe, deinde fuadête Roma,nobilifima captiuarum que his comes erat, incenfis nauibus pofuiffe fedes, ftruxiffe monia, \& op pidum ab eius nomine vocauife. Agathocles fcribir Romam non captiuam fuiffe, fed Afcanio natam Aenex neptem ciufce denominationis caufam extitiffe tradit, \& Rom $x$ nomen verum, vetitú tamé publicari quò minus annúciaretur cerimoniatum arcana, neque quod fape aduerfus vrbes hoftium feciffe $f_{e}$ nouerant, idem ipfi quog hofrili euocatione paterentur. Sed videndum ne quod nonnulli exiftimauerunt, nos quoq̧ confundat opinátes vno carmine $\&$ euocari ex vrbe aliqua deos, $\alpha$ ipfan deuóä fieri ciuitatem. Eft autécarmé huiufmodi quo dii euocantur quum oppugnatione aliqua ciuitas cingitur, Si deus, fi dea eft, cui populus ciuitáfóp Carthaginenfiseft in tutela, tép maxime qui vrbis huius populíg tutelam recepifti precor, veneror'q,veniamíg à vobis reto, vt vos populu ciuitateníg Carthaginenfrum deferatis, loca,templa, facra, vrté co rum relinquatis, abfque his abeatis, eíg populo, ciuitati, metum, formid incm, 


\section{DERE MILITARI LIB. VI. s?}

obliujonem iniciatis, proditíg Romam ad me meol'ps veniatis, noftráq vobis loca,tepla, facra,vrbs acceptiora probatiorág frnt: mihi quoop populóp Romano militibúfog meis prapofiti fitis, vt fciamus, intelligamúfog : fi ita feceritis, voueo vobis templa ludol $\left.\right|_{q}$ facturu. In eade verba hofias fieri oportet, auctoritatémq videri extorum, vt ea pronittât futura: vrbes verò exercitúf ņ numinibus lam euocatis, his verbis fic deuouétur, Dis pater veiouis, manes, fiue quo alio no mine fas eft nominare, oro vt omnes illá vrbé Carthaginem exercitúg qué ego me fentio dicere, fuga, formidine, terrore cópleatis: quíg aduerfus legiones exercitúǵ, noftrum arma, teláq ferent, vtì vos eũ exercitú,cos hoftes, eólç homines; vrbes, agróf $q$. eorum \& qui in his locis regionibuf'q; agris, vrbibifíp habitant: abducaris, lumine fupero priuetis, exercitúq, hoftum, vrbes agrólqz corum quos: me fentio dicere, vti vos eas vrbes agróíg, capita, ætatéfq eorú deuotas cófecra : talog habeatis, illis legibus quibus quando ơ funt naxime holtes deuoti, eófque ego vicarios pro mea fide magiftratúg meo po. ro. exercicibus legionibúfque

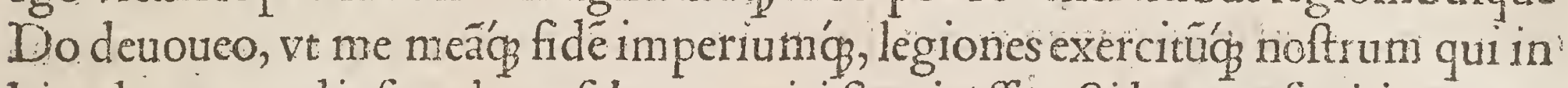
his rebus gerendis funt, bene faluos nos irifinetis effe. Si hac ita faxitis, vt ego fciam, fentiam; intelligấp, tum quifquis votü hoc faxit, vt vibi faxit, recte factum efto, ouibus atris, Tellus mater, teó 1 Iupiter obteftor, quum Tellurem dicit, mani: bus terram tangit: quü louem dicit, manus ad calum tollit: quum votum recipere dicit,manibus pectus tangit. Hęc eft euocationis, deuotionífó forma ex libro rerü reconditarum v. Sámonici Serravi vtrüq̧ carmể hoc cótinentis, quod etra ille in cuiufdá Furii vetuftifimo libro fe reperiffe pfeflus eft. Lituius autem libro octauo ab vrbe cödita trepidationem Decii conful is fe deuouentis, alia de uorionis forma his verbis expreflit, A gedum pontifex publicus populi to: prei verba quibus me pro legionibus deuouean: Pontifex eú togam pratextan fumere iuflit, et velato capite manu fubter togam ad métun exerta, fuper telü fubiectum pedibus ftäten fic dicere, Iane, Iupiter, Mars, pater Quirine, Bellona, lares: diui,numen fimiles dii indigetes, Diui quorum eft poteftas noftrorü hoftiun' diigh manes, vos precor, veneror, veniam peto feróg ve Po.Ro. Quiritium vim

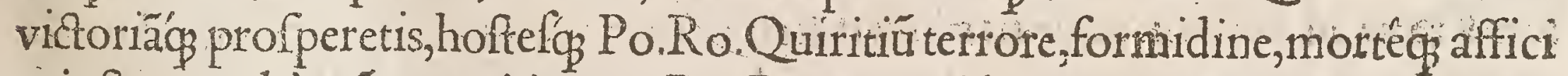
atis, frcut verbis núcupaui, ita pro Ro.Po.Quiritiú exercitü,legionibus, ausiliis Po.Romani Quiritiü,legiones, auxiliág hoftium mecú diis manibus telluríque deuroueo. Hęc ita precatus, lictores ire ad T.Mâliú iubet, maturéó collega fe deuotum pro exercitu nunciare, ipfe incinctus cinctíng gabino armatus in equuni infilitt, ac fe in medios hoftes immifit; côfpectus ab vtraq̧ acie aliquâto auguftior humano vifu, ficut à celo miflus piaculü omnis deorum iræ qui peftem à fuis aduerfam in hoftes ferret:ita omnis terror pauórqu cú illo latus, frgna prima La tinorũ turbauit, deinde in totâ penitus aciem puafit, euidétiflimü id fuit $q$ quồ cung equo inuectus eft, ibi haud fecus qu peftifero fidere icti pauebant, vbi vero corruit obrutus telis, inde iam haud dubie coffernatæ cohortes Latinorum fugam ac vaftitatem late fecerunt.lllud etiam adiiciendum videtur, licere Confuli Dictatoríg \& prætori quum legiones hoftium deuouerit, non vitique fe, fed quen velit ex legione Romana fripta ciuem deuouere. 
(2) Eque etiam fermo ille quem de Zaleuci, Minois, I ycurgi, Numæ aliorumóg fimilium virorum religione deorum narrant hiftorix, in -

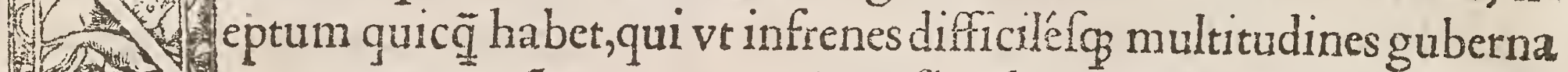
通得. rent, deorum opinionem comméti funt,quæ ipfis illis quorum gratia fingeban tur faluti effent: in qua re prater hos quos modo diximus, nec externorum, nec noftrorum fimilium virorú defunt exempla. Nanque Epaminundas ille Thebanus, non aliter aduerfus Lacedæmonios quàm religione fidutiam fuorum adiuuandam cenfuit, è veftigio enim arma quæ in tem pli ornamentis affixa erante nocte fubtraxit,perfuafitóg militibus deos iter fuum fequi, et praliantibus ipfis adiumento fore. Pericles Athenienfum quog dux initurus pręlium, quum animaduertiffet locum ex quo vtraó acies confpici poterat denfiflum opacitatis; vaftum alioquin \& Diti patri facrum, ingentis illic ftaturę hominem altiflimis cothurnis \& vefte purpurea venerabilem in curru conftituit, qui dato pugna figno proueheretur, $\&$ voce Periclem nomine appellans cohortaretur eum, diceretq́p deos Athenienfes adeffe:quare fubitò demiffis ac confternatis animis, hoftes in fugam verf funt. Thymoleon Corinthius, magnus etiam omnium iudi cio vir \& dux, humanarum rerum nihil quod fauftum, foelix, fortunatumg effet fine deorum numine geri poffe putabat: proinde fue domi facellum conftituerat id́p̧ fanctiffimè colebat. Ad hanc quoq̧ hominis excellenté probitatem $\&$ religionem, mirabiles accefferant cafus: nam prelia maxima natali fuo die fecie omnia, quo factum eft vt eius diem natalem feftum haberet vniuerfa Sicilia. Sy rus nomine quifpiā Eunus, fanatico furore fimulato, dū Syrię dę comas iactaret,ad libertaté et arma feruos quafí numinú imperio cócitauit,idq̧ vt diuinitus fieri probaret, in ore abdita nuce quam fulphure \& igne ftipauerar leuiter infpi râs, fiãmam inter verba fundebat, hoc miraculú primo, II.M. ex obulis, mox iure belli refractis ergaftulis, $\mathrm{l} x$. amplius miliu fecit exercitum: regiis, ne quid malis deeffet, decoratus infignibus, caftella, vicos, oppidáç miferabili direptione valta uit. V tque ad noftros, vnde paululú difceffit, redeat oratio, Scipio maior clariflimum hac in re pre cęteris fibi locum védicat, quippe qui ab adolefcentia fuprà quàm credi poffet mira quadam arte in oftétationé virtutis ac fanctimoniç in ftrucus erat: percrebuerat cnim fama, feu cófultò, f́ u temere, incertú, nó huma na fed diuina eú ftirpe progenitum,cui quidé in tali re vfu euenit, \& fabularum ambages aderảt,vifum ferpétê infuetx magnitudinis in lecto matris, fibi infan ti draconé circüfufum nihil nocuiffe, multa id genus, in vulgus indoctú matura: Hanc de fe opinioné hominú tali ingenio nutriuit ve de origine quidé fua nihil fpóte loqueretur, \& interrogatus an vera effent qua paffim ferebätur, nec affirmaret ne quả exinde vanitatis notam incurreret, nec negaret quod credi ab omnibus gratulabatur: hac taciturnitate plus affecutus, $\vec{q}$ fi palàm louis fe filiü prędicaffet. Addidit etiā aliud religionis genus, per frngulos dies antequả quicquá publici priuatiog muneris ageret, in capitoliú afcédens, cellã louis folus intra bat, ibíq aliquádiu perftans, veluti divino colloquio frueretur, quod vulgo per- 
fuaferat,inde fpéi plenus ad gerendas res digrediebatur, íd $d \not$ in multis bellis,repletis fuperftitione ac f́pe militum animis, quafiè cæalo promiffis prof peris euëtibus ad victoriam eis contuliffe certú eft. L. Sylla quò paratiorem militem ad pugnådum haberet, prædici fibi à diis futura fịmulauit. Poftremò etiä in confpectu exercitus priufquâ in aciem defcéderet, fignum amplitudinis quod D el phis fuftulerat orabat,petebátq promifan victoriá maturaret.C. Marius mulierem quandam Syram,nomine Martam habuit,vaticinii (vt dicebatur)gnatam, quã lecticx incubãtem compófitè ornatéǵg circunducebat,à qua fe dimica tionum euentum predifcere infmulabat. Q.Sertorius cum barbato $\&$ rationis \& cófilii experti exercitu, in religioné tamé prono vteretur,ceruâ cãdidi coloris per Lufitaniam ducebat,tanquã donum id eflet Dianæ fibi tranfmiffum, \& ab ea qux agenda qúxve vitâda erant pernofcere fe affeuera bat: nam quotiens ho. Plium copias fines ingreffos, aut oppidum aliquod cepiffe occultè perfenferat, in fomnis fibi dictum à cetua infimulabat, vt fuos in armis haberet. Rurfum verò, fi victoria aliqua ducú fuorũ deferebatur, occultato núcio ceruam coronabat, fî

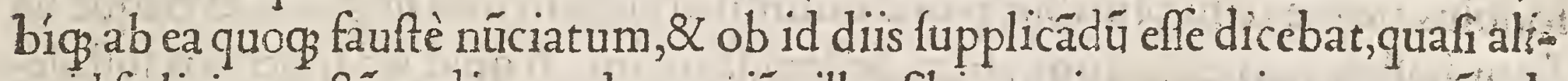
quid focliciter gefú audituros: hac ratióe illos fibi magis ac magis parere côpellebat, veluti nô hominis alienigene, fed dei cóflilis ac religiỏe fum ma ducerétur. Poft hos deniqg intueri fi libet, $M$. Furium Camillum, virum religione pace ac bello verè vnicú, caterólog Romanorú et exterarũ gétiú illuftres, ab ætatis zooftrę memoria remotos, maximarú pfectó victoriarum et optatę glorię cópotes fuiffe eos femp inuenies, $q$ res præ cæteris exactifflimo deorú cultu aufpiciọ́g geffffent.

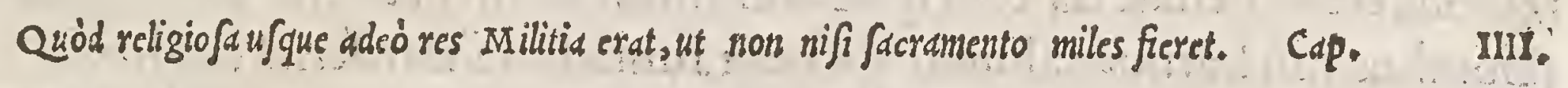
12. T. Sque etiam adeò religiofa res Militia fuit, vt non nifr facraméto fie-

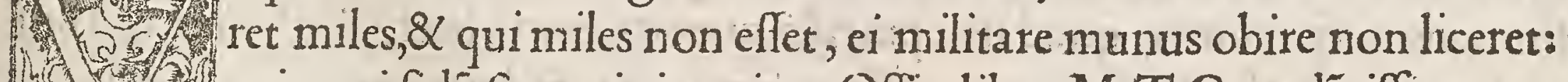
2. 2 . cuius rei fidê fi quęris, in primo Offic.libro M.T.C.opulêtiffimus te12.2. - Ptis ef, Pompilius inquit imperator tenebat prouintiä, in cuius exercitu Catonis filius tyro militauit: quum autê Pompilio videretur vnam dimittere legionem, Catonis quog filium qui in eadem legione militabat dimifit: $\mathrm{fed}$. quum amore pugnãdi in exercitu remanfiffet, Cato ad Pompilium fcripfit, vt.fi eum pateretur in exercitu remanere, fecúdò obligaret militix facramento, quia priore amiffo iure,cú hoftibus pugnare nó poterat . M.quooģ Catonis fenis ad M.filium extat epiftola, in qua fcribit fe audiffe, eú dimiffum effe à cófule quum in Macedonia bello Perfico miles effet, monet igitur vit caueat ne prẹlium ineat: negat enim ius effe cum hofte pugnare, quafi miles non fit:ecce $q$ vir fapiétiffimus militem non credebat, nifi eum qui facramento ad militiam effet adactus.

Quando ex uolumario inter ip fos milties foedere militare facranentum ad tribunos ac legtio mam iarifurandi adactionem tranflatum fit, quidǵ; iurarent fe facturos. Cap.

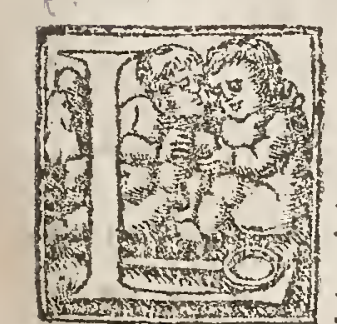

Vcio etiam Flac.\&C. Varrone coff. milites primo iureiurädo facti funt:anté enim factaméto tantúmodo à tribunis rogábátur, ipfíg. inter fe cöiurabãt ducis aut tribuni parere edicto, milituã nô deferere, - Atrenue pugnare, defendere figna, no vitare morté, tenere pugnädo lo cí, ếdēẹg inter eúdü feruare, fuccurrere feflis, pregere faucios, die in lcripto adeffe, 
\& citanti imperatori refpondere: guod \& Liuium, xxii.ab vrbe cỏdita minime præterit,Delectum, inquit, profecto cof.paucos morati dies, dum focii ab nomine latino venirent, nunquä quod antê factum erat, iureiurando à tribunis militum adacti milites, iuffu cor. contrenturos neque iniuffu abituros. Nam ad eam diem nihil præter iuramentū fuerat, \& vbi ad decuriatum \& centuriatú conueniffent, fua voluntate ipfi fe equites, decuriati, céturiati, pedites, coniurabât fefe fự ga atque formidinis caufa non abituros, neque ex ordine non receffuros, nifi teli. fumendi aut petendi, aut hoftes feriendi, aut ciuis feruandi caufa, $i d$ ex voluntario inter ip fos foedere ad tribunos a c legitımä iurifiurãdi adactionē tráflatú.

Tribuni Militaris uerba cum delectus antiquus fieret.

Cap. VI:

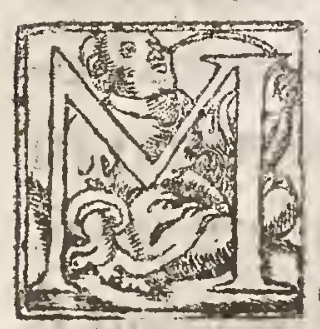

incius verò de re Militari quú delectus antiquus fieret \& milites fcribetentur, iufurandum eos tribunus militum adigebat in verba hę, in magiftratu verba hac, C. Lelii,C.F.col. L. Cornelii, P. F.cof.in exercitu decémque milia paffuum propè,furtum nó facies dolo malo, folus,neque cum pluribus pluris nummi argétei in dies fingulos, extráque ha ftam, haftile,pompabulum, vtrem, follem, faculam, fi quid ibi inueneris fuftulerílue quod tuiu non erit, quod pluris argentei nummi erit, vti tu ad C. Lelium, C.F.cof, L.ue Cornelium,P.F.coffrue ad quem virum eorum iufferit proferes, aut profiteberis in triduo proximo quicquid inueneris fuftulerifue in dolo malo, aut domino fuo cuium id céfebis, red des, vri quod recte factun effe voles. Mi litibus aute foriptis tempus præfiniebatur quo die adeffent, $\&$ vt citanti confuli refponderent:deinde ita concipiebatur iufiurâdum vt adeffet, his additis excepuonbus, nif harunce aliqua caufa erit, funus familiare, feriæ vindemiales, qux non eius rei caula in eum die collata funt, quo is eo die minus ibi efet, morbus fonticus,auf piciúmve, quod fine piaculo præterire non licet, facrificiúmve anni uerfarium, quod recte fieri non follet nifi iplo die. Si harunce aliqua caufa erit, tum poftridie licebit: quum autem miles die qux prędicta erat aberat, neque ex cufa tus erat, cxterum infrequens dabatur: iurabät autem milites tefte Flinio per Jouem Marteniog.

Quót imperium belli habentibus, fceptri eleuatio iufiurandun erdt.

Cap.

VII!

Mperium autem belli habentes apud veteres, de controuerfis iudica$\left[\begin{array}{c}0 \\ 5\end{array}\right]$ bant,atque hoc alii iureiurando, alii fine. Erat autem illis iufiurand $\overline{\mathbf{u}}$ per freptri eleuationem, vt Ariftoteles auctor eft. Et hæc de militaris ac imperatorii forma iuramenti dikta funt.

Gentium diverfarun ratio in deligetdis milttibus.

Cap.

VIII

Vum autem duo fint qux militem efficiunt, delectus folicet $\&$ fa1. - cramétum, de facramétóg dictú fatis fuperóg fit, de al tero nobis diffe1. 100 rèdum fupereft:in hoc itaos militum delectu, primo cuius gétis fint, L - ipfius deinde regionis fpectáda natura, quú $\&$ vario $\&$ diuerfo terra rum fitu cellíg a fectu, \& facies hominum, \& voces, $\&$ colores, \& corporü lineameta, $\&$ qualitates, animorüq́p diuerfitates prodeât: nec dubiü fir efforminari ani mos, locorum a monitate nimia,aliquid'ş ad dandū animis vigoré corrúpédũóp polle regioné. Hinc enim Aegyptios effe fuapte natura leues, ventolos, pédulos; furibundos, 
furibundos, iactantes, iniuriofos, nouarú rermm cupidos, \& ad omnia famę momenta volitãtes, Romanos graues, Græcos fuperbos, auaros, \& leues, expeditiore ingenio Atheniefes, callidos Ponos et verfipelles, infenfat os Galatas, Q $G$ Diodoro credimus molles, minaces, detractores, opinionéó inflatos, acutos ingenio, \& à doctrina minime alienos, mobiles \& infidos Numidas, Seres, Perfas \& Allobroges, horridos Hifpanos, furentes Cymbros, animofos Germanos \& feroces procero corpore, animón magno magis ğ firmo Gallos, quorum Iulio Cel.belli gallici libro tertio auctore, vt ad bella fúcipienda alacer nó folum fed próptus eft animus, fic mollis ac minime refiftés ad calamitates perferëdas mens corum eft,vtó in quit romana pater hiftoriæ, Horum etiá quidé corpora intolerantiff-

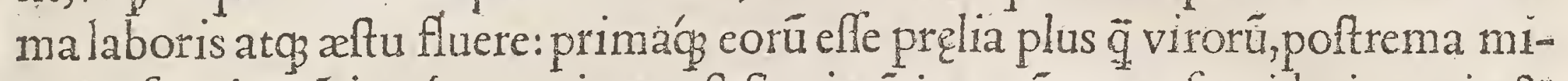
nus q̄ forminarú, iamóg cognitum eft fi primú impetú quem feruido ingenio \& ç̨ca ira effundunt fuftinueris, fluút fudore \& laflitudine membra, labãt arma, mollia corpora, molles vbi ira confedit animos, Sol, puluis, fitis, vt ferrüron admoueas,profternüt. Quid de nónullis Afræ partibus, Phrygia Carráqg dixerim? nónne fi Ciceroni credimus, \& veteri prouerbio, Phryges plagis fieri folere meli ores?quid de tota Caria?nóne prouerbio etiā increbuit, fr quid cum periculo ex perire velis, in Care potifimú id effe faciédü? quid porrò de Cretenfibus dicana quos Epimenidis poétę fententia quá poftea Callimachus vfurpauit, \& menda $\rightarrow$ ces,et malas beftias,et vétres pig ros femper fuiffe côftat?deniqg qui proximi funt ad axem meridianú fubiectiợ folis curfui, vel ad oriêtis plagas vergunt, breuroribus corporibus funt,ob cęlíg tenuitaté ex acuto feruore ad cófiliorü bellicorú cogitationes incredibili folertia expeditius celeriul' $q$ q ceteri mouétur, at $\$$ vt in genii $\&$ artis plurimú,ita \& animi parú hạbét. Propter fẩguinis enim exiguitatê, folis calore exhauftá,ferro refiftere formidolofiores fint cólequés eft.Lucanus, Quicquid ad coos tractus mundíg teporem

Labitur,emollit gentes clementia cali.

Illic $\&$ laxas veftes $\&$ fluxa virorum

Velamenta vides.

Sub feptêtrionibus auté quę nutriütur gêtes ac nationes, immanibus corporibus \& fanguine plutimo ab humoris plenitudine \& craffitudine celi perfufi hebetes ac tardas vt habét métes, ita $\&$ animo quidé magno funt $\&$ elato, proinde ad ar morú vehementiam procliuiores funt: fanguinis enim copia,fine timore in ferrum ruunt, \& vulnera. Quod fi in dubium cuipiã forte veniat, ardétiffimus duo bus in locis teltis Lucanus accedit, in altero quidem his verbis,

Certe populi quos defpicit arctos

Folices errore fuo quos ille timorum

Maximus haud vrget lati metus: inde rtiendi In ferrum mens prona viris animǽ́g capaces Mortis \& ignauum eft redituræ parcere vitæ: Omnis in arctois populis quicunque pruinis Nafcitur indomitus bellis \& Martis a mator.

Alpina etiam corpora humecto calo educata,fimile quidpiam niuibus fuis ha I isi bents 
bêt, fuóg. fimilima cęlo vîutur vt ait poéta. Quü enim mox pugna incaluerine, ftatim in fudoré eunt,et leui motu quafi fudore laxãtur.Quú igit acutiores et ad motú pniores efficiat calidus aêr hominü mentes, refrigeratus auté cötrà tardio res, os pigrú cótractưóg elt frigus, vt in ferpétibus eft videre, quę folis incendio explola humoris refrigeratione, curfu et corporü dimicatione mouétur acerrime: hyberno autë têpore ab humectatione cęli refrigerate, immobiles æpemodú fiüt atç. ftupentes, ex his itaq̧ qui mediã quandã locorú regionumóq qualitaté ab ori gine nacti erút, eligétur, $q$ vtriufque naturæ participes fint, ad cędem mortifque contemptum, ad intelligentiá vigorem'́p animi, dimicationibus impartiendum idonei-Adde quòd falubris hęc vtring mixtura, ad omnes actus, ritus, mores, fen fus focunda efficit ingenia, imperii omnis totiusóp naturæ capacia, vt Italorum omnium qui contra barbarorum virtutes, forti manu: confilis verò contra meridianorum cogitationes, orbis terrarum imperio potiti inuictas $\&$ immortales laudes confecuti funt: quas etiam inter hos vt facile confequamur, adhibendi erunt præftanti ingenio viri, militaris difciplinæ gnari, quos fumma cura $\&$ dili gentia niti decet ne quis militú ętate minor, aut quàm virtus pofcat, aut maior $\tilde{q}$ patiatur humanitas, contra morem veterem deligatur: xtatis autem huiufmodi initium ad finem Tubero in hiftoriarum primo fcripfit, Seruium Tullum pru dentifimum Ro. Po.regem à XVII. ad annum vfque quadragefimumfexcum milites fcripfffe, quòd idoneos tunc effe populos Ro. arbitraretur.Similiter fena tum triumuiros binos creare in hoc militum delectu folitum accepimus : alte ros qui citra, alteros qui vitra quinquagefimum lapidem in plateis, foris $\&$ conciliabulis omnem copiam ingenuorum infpicerent: $\&$ fi qui roboris fatisad ferenda arma habere viderentur,etiam fi nondum militari xtate effent, milites $f a$ cerent:tribuni plebis, Ir his videretur ad populum ferrent, vt qui minores feptem $\&$ decé annis facramento ad dixiffent, his perinde fitipendia procederent, ac fr feptem \& decem annorum aut maiores milites facti effent. Nec aliter Dictator ex auctoritate patrum dictus, Iunius $\&$ T. Sempronius magifter equitum, delectu edicto, iuniores ab annis decem \& feptem \& quoldam pretextatos fcriplere, qua tuor ex his legiones \& mille equites efficientes. Macedonú regum Philippus pri mo, ac mox Alexander non pratextatos $\&$ impuberes, nec fpectati roboris iuue nes tantum fed veteranos etiam qui fuperiori tempore fxpe ac diu in caftris ver fati effent ad exercitum deligédos cenfuit, quólque non tam milites quàm in nilitum præfectos $\&$ tribunos virtutis veneratione $\&$ fapientiæ magnitudine delectos iure diceres. Proceritate funt deinde qui in hoc delectu fpectari debere maxime putent, fortitudinem nan $\$$ \& virium magnitudinem confiftere quemad. modum form xulchritudinem in magno corpore aiunt. Non ab re igitur delectori fuo Pyrrho dixifle ferunt, Tu grandes elige, ego eos fortes reddă. Nec multú tamen id refert, fi catera probitatis infignia coéant, proceríne fint an fatura bre uiore. Præftat enim virium quàm fature rationé habere,vnde equites ro. binûm fuiffe cubitorum, ${ }_{9}$ lari nec defunt auctores, vt C.Marium quum facultatem haberet deligédi exercitus ex duobus q fub Rutilio quíq̧ fub Metello, ac poftea fub re ipfo meruerant, Rutilianum quempiam minorem, quoniam certior is difcipli 
næarbitrabatur, militem praptafle. Idem Marius declaratus col militüagens delectum, capite cenfos militix affcripfit, quod genus homıñ ab imperatoribus cateris antea nüquàm receptum fuerat: arma enim veteresilli, non nificum ingenuis hominibus, cuiufdamó cenfus \& benemeritis partiri foliti funt, iudicantes cenfum adres bene gerédas vt pignus effe:id auté ab C. Mario prater legem morémque maiorum, alii per ambitionem confulis, alii bonorúinopia factum memorant: veritus autem poftea, hanc militum electionem in fui nominis fugillationem verti polle, \& veluti capite cenfum imperatorem compellari, einfcemodi militix genus obliterandum duxit: \& quanquam ad hunc vfque dien ca pite cenfum militem etiam nobilem romana res publica deligendun egre tulil. fet, calis tamen ferullibus è paftorum cafulis, mancipiorum, vt ita dixerm, colluuionem quandam deligere \& tanquam validiflimü robur legicnibus fuis adiicere coacta ef. Bello etiam punico fecundo quum deeflent qui fcriberentur, fer ui pro dominis pugnaturos fe polliciti in ciuitaté recepti funt: \& Volones, guia fponte hec voluerun, appellati. Eiufdem etram belli punici tempore, infolicibus quibufam pralion m fuccellibus confedis, imminutifque Romanorum legionibus, fenatus cenfuit, vt publice ferui emerentur : proinde quatuor \& viginti milia feruorum empta fuife cóftar, hófque iureiurando adactos, fortiter frenueque quoad Poni vexarent Italiam laturos arma in caftra tranfmifit. Ad Cänas quoque victis Roma nis, fimilem formam noui delectus inopia liberorum capitum ac neceflitas dedit: octo milia nang iuuenum validorum ex feruitis, prius fcifcitantes fingulos vellentne militare empta publicè armauerunt, quumóq fex milia Romanorum qua in caftris Hannibalis captiua erant, minoris redimi polfent, maluit fe res publica feruis in tanta tempeftate cómittere, in qua \& pretextatorum plurimos arma tuliffe $\&$ abdicatorum, \& vitimo fupplicio plectendorum fex milia etiam cöfcripa fuifle memorant. Sed poft calamitaté apud T ra fmenú nozte cladis acceptam, libertini quog in factamêtũ vocati funt: bello fociali cohortum XII.milia ex libertinis confcriptarum opera memorabilis virtu tis a pparuit aduerfus Gallos.L. Furio duce quú Latini qui à Romanis fubiugati erant milites preftare nollent, ex Romanis tátum tyrones delecti funt factá, legiones decem, qui modus LX. vel co amplius armatorum milia paruis ad huc rebus Romanis efficiebat. Cafarem quum milites in amifforum locum fubftitueret, feruos guog, ab amicis accepiffe $\&$ eorum forti opera vfum effe comperimus. Cxar Augufus in Germanis \& Illyrico cohortes libertinorum complures legit, quas voluntarias appellauit. Ac ne putes hac tantü contigifle reipub. nofræx, Boriftenidæ oppugnante Zopyrione feruis liberatis datáque ciuitate pe regrinis \& factis tabulis nouis hoften fuftinere potuerunt. Cleomenes Lacedx. monius quum mille quingenti foli Lacedamonii qui arma ferre follent fuperfuiflent, ex feruis manumiflis bellatorum nouem milia confcripfit. Athenienfes confumptis publicis opibus, fervis libertatem dederunt. Cato Cenforius eo item milite quifquis ille effet frbi opus non effe aiebat, qui vt inter eundum manus, ita inter pugnandum pedes agitaret, quiog in ftertendo holtibus quàm in cla mando longius fentiretur. Rurfus hic feiuuenibus dicebat magis oblectari qui rubefce- 
rent quàm qui pallore perfunderentur.Idem in pinguem quendam acerbe maledictis inuectus, quibus enim in rebus huiufmodi corpus ciuitati fructuofum fore putas interrogauit, cuius inter guttur $\&$ inguem cuncta fub ventris ditione pofita effent. Neque aliter magnis atç prepinguibus dux ille Thebanus Epaminundas infeftum fe præbebat, quippe qui $\&$ talem quempiam amouit exercitu, inquiens, vix tribus quatuórve cly peis tegi eius ventré, cuius magnitudine fuam ipfius mentulam ne videre quidem poffet. Nimis fimiliter pingui homini $\alpha$ cor pulento militi cenfores quondã equos adimere folitos legimus, minus idoneum filicet ratos effe eum tanti corporis pondere ad equitis munus obeundum. Cæa far militem neq à morum vrbanitate neq à formæ dignitate, neque ab externorum bonorum copia, fed à viribus corporis tantum deligédum probat, maiores fuos credo fecutus : vera enim illa Ronzuli proles agris villisóg exercitata vt firmiflimis perualida corporibus, fic ad militiam quum opus effet femper fortiffimos viros \& milites ftrenuifimos ex ruftica plebe deligens præpofuit vrbanæ, vtọ́ omnem villam ortü vetēres appellant quòd ibi qui arma capere poffent orirentur, fic finitis quoog bellorum operibus, augend x reipub.caufa vrbes inflituerunt, quas victoribus militibus pro eorum meritis aflignarent, $\&$ ab incolendo Colonos appellauere. Hinc etiá ciuitates à maioribus ciuitatibus veluti populorum examinibus conditx, Coloniæ nuncupantur. Sic Iulius Cæáar militem à colendo rure deductum intra Atipendiaria merita detinuit,veteranosóp in coloni as dimifit. Diuus æque Augu exercitus qui fub Antonio aut Lepido militauerant, pariter \& fuorum legionú milites, colonos fecit, alios in Italia, alios in proninciis quibufdam, deletis hoftum ciuitatibus nouas vrbes conftituit, quofdam à veteribus oppidis deduxit $\&$ colonos nominauit. Illas quoog vrbes qux deletre à regibus aut dictatoribus fuerant, quafíg ciulium bellorum interuentus exhau ferat, dato iterum colonix nomine numero ciuium ampliauit. Romana quoque refpib - quum neceffaria admodum effet militia in vrbe ad vim vi hoftü propellendam vixóp fieri poflet quo idem femper militix munus obirent, rem vt on nibus conducibile in vrbe retinuit : munus aute huiufnodi pro cuiulģ hominis códitione, intercapedine, ac viciflitudine quadá curauit. Quapropter \& agri cola quum viciffitudo $\&$ reipub neceflitas aderat, relictis agris ad arma proficifcebatur, omifíque agricolationis artificio quafi alius factus militabat, rurfusç ad artificiú redibat, non wt miles vel belli dux, fed vt artifex: Nec erat illis pudor, depofitis armis anguftia rei familiaris coactis, a greftem vitam repetere: ea nanq. xtate ciuitatis proceres in agris verfabantur, 8 quum conflium publicum fieri folitum erat a villis accer febantur in fenatum, quod vque adeò verü effe conftat vt Attilium Serranum imperium populi Ro. fufcepturum, dati honores ferenten inuenerint, vnde \& cognomentum poftea. Aranti etiam illa quatuor fua iugera in Vaticano qux prius prata Quintia dicebâtur P. Quintio Cincinnato viator attulit dictaturam, ex qua obfefli confulis \& exercitus liberator, depofitis fafcibus rurfus ad eofdem boues rediit bubfequín g $_{3}$ denuo factus eft.C. item Fabritius \& Curius Dentatus, alter Pyrrho finibus Italix pulfo, domitis alter Sabinis $s_{2}$ ó minori induftria agros coluit quàm ftrenue ac fortiter armis holtes que 
fuit. Nec aliud de M. Furio Camillo multíque aliis Romani generis memorabilibus ducibus ad hoc ferriper duplex ftudium vel defendêdi vel colendi patrios quxitósve fines incunabetibus coniectarilicet, refte Lucano quum inquit, Paupertas fugitur totóg arcelfitur orbe, Quo gens quarque petit nunc longos iungere fines

Agrorum, \& quondam duris fulcata Camilli Vomere, et antiquos Curionum paffa ligones Longa fed ignotis extendere rura colonis? Quum diftinctio honófque ciuitatis ipfius non aliude effet, nec prima maiorum cognomina: non alitinde enin Fabios quàmab agrorum folfione Fodios qui dan non incelebres primum dictos putãt, nututífque geminis literis Fabios de inde cognominatos, vel à fabarum exactifimo cultu. Fabiorum enim, Lentulorum, Ciceronúmøg cognominationem ad mittebant, vt quifque aliquid optime getus fereret. Sic luniorum familiam bubulcum nominarunt, qui bobus vtebatur, nec folum femina ac boues, fed fcrofam etiam \& afinam viris non mediocribus Tremelio \& principi Cornelire gentis ceterífue Corneliis \& Scipionibus cognomenta prebuifle non eft obfcurum. Syluius deniqgà quo omnès Albanorum reges Syluil funt vocati, non ăliunde quàm quòd fyluis \& rure fuerat educatus, hoc fibi apud latinam gentem nomen afciuit: \& quoniam rufticæ tribus laudatifima corum qui rura haberent, vrbanæ verò in quas tranfferri ignominia effet defidix probro, ea porróratione vt ex agricolis milites deligerentur factun efle rèor: quónia minime nale cogitantes duratis ad omnen malorum tolerantiam menibris, \& ętum, \& puluerem, \& frigora, \& niues pati,vada flumi num trailcere,celeribúque plantis montes fuperare aptiffimi funt. Adde $q$ delitiarun omnium ac voluptatum contéptores iure vidétur non multifacere opor tere in bello, cú tot laboribus tantífque malis affecti libetentur. Nefcio enim quo pacto fit vt is morten minus reformidet, qui laute minus vixerit. Neq tame inficiandum reor, fortiflimos ac optimos Greccorum Romanorumo milites cum laude $\&$ dignitate ex vrbibus ad militiam fuiffe delectos, veru quia hi tunc non otic, nô läguore, non defidia, non luxu, nó vmbris, nô delitiis, cẹterisọ́ voluptatibus infringebantur pericula fubire foliti,ex infamix pudore \& gloriæ cupiditate, quales Homerus aliquot ex ciuibus etiam facit,vt Hectoré, \& Diomedem Ro.reipub.regníç illius a m pliffimi falus ac fundamentum erât. Noltra autem etatis milites vrbani $\&$ vernæ, fplendido apparatu, vncti $\&$ nitidi ac vrbium illecebris heliniti, cum loci difciplina feuerior firmet ingenium, aptumóp magnis conatibus reddat, fr manus conferere debeant, quum in leui armatura parum ha beant fidutix, in graui minimum alacritatis, crebrò non tam ducibus fuis con ferre ad victoriam quàm holtes iritare ad prædă folent: vnde \& Hânibal quum apud regé A ntiochü profugii caufa diuertiffet, faceriflime cauillatus eft, eaque cauillatio huiufmodi fuit, Oftendebat ei Antiochus exercitum ingentem quem bellum Po. Ro: facturus comparauerat, purpura, infignibus auri $\&$ argenti, for tunæ apparatibus florentem : inducebat etiả falcatos currus, \& elephátos cum turribus, equitatúmque cum frenis, monilibus, falerífque præfulgentem, atque 
vbi rex contêplatione tanti ac tam ornati exercitus gloriabundus Hannibalem afpicit, Putasne, inquit, conferri poffe, ac fatis effe credis Romanis hæc omnia? tum Ponusilludens ignauiam imbelliámque militú eius preciofè armatorum, Plane fatis effe credo, ait, Romanis hac omnia, etiä fiauarifimi funt:nihil pror fus,nec tam lepide, nec tam acerbe dici poterat. Rex enim de numero exercitus fui, ac de exiftimanda xquiparatione quxfuerat, refpondit Hannibal de pręda, tanquam ad eam huiufmodi homines expofiti foleant efle. Doctus enim erat Ponus horridum militem ferro $\&$ armis fretum effe debere, non cælatum purpura, auro, atọg argento, illúm que infignium armorum apparatum prædam verius quàm arma effe, vt' $\not$ nitentia ante rem, fic deformia inter fanguinem \& vul nera virtutémque efle militis decus, $\&$ omnia illa victoriam fequi, $\&$ ditê holtem quàmuis pauperis victoris præmium effe : eos fi denique milites $\mathrm{Nafo}$ à militari re lua, nedum arcet,fed efle procul tanquam peftem \&labem quädam iubet, quis cos credet ad robuftá militiam admittendos, nififorte cum Dario vel Thrafone potius ad imitationem expugnandæ Thaidis,lenonum, mulierú ac fpadonum agmine cæterorum'q qui miniftri funt voluptatum, \& ford idi quętus, ac viliffimarum artium, Veneri militiam fuam deuouerit, Marte contempto non folum contra Hannibalis, fed Catonis quog ac veteris militix inftitutum? quod Lucanus breui quodam praconio his verbis expreflit,

Hirtam membra cuius Romani more quiritis

Incluaffe togam:

Hoc profecto tantus auctor haudquaquam extuliffet, nifi durioris etiam toga vfus de quiritum confuetudine proceffiffet. T ales denique ex omni genere homi num đeligi debent, qui non vti Sánites vibrent haltas ante pugná quibus in pugnando nihil vtantur, fed qui ipfis qbus pręluferint pugnare poffint $8 \mathrm{valeant.}$

\section{De delectu Equorum.}

Cap. IX.

F Vnc quoniam de militum delectuabüde fatis dictum eft, equorum 1. 1 ad pugnam deligendorum rationem \& frgna inea mus, per qua mi 37. Litix incumbentes excellentis equi notas intelligant, ne fallätur em-

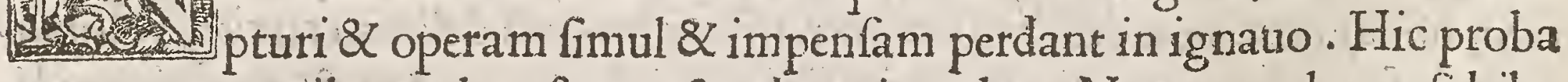
tur natura, moribus, colore, forma, $\&$ educationis loco. Natura probatur fi hilaris, filafciuus, \& alacer, fi intrepidus, fi noux rei haudquaquam terretur afpectu. Ex moribus, qui ex placido \& concitato mitifimus fit, quíg ex fumma quite facile commoueatur, vel excitatus feftinatione non difficili teneatur, hoc eft honoris appetens cum temperantia ac pudore, promptus, cohortatione folum 8 ratione regatur. Alter econtra improbandus qui intortus \& multiplex,inglorius, $\&$ contumax vix flagello ftimuliś̨́ obtemperás,nec habenis nec verberibus coërceri poteft, fed inter equitandnm calcitrat, ac domitisfrenis ne regi poffit, violentia equitem aurigámque fuum mordet $\&$ in præceps quo per fe timuifet defcendere,proturbat \& rapit: quo fit vt fi quando holtibus obuiam fit eũdum, neceffe fit equites aut poftremos in agmine confequi, aut eorum malignitate inuriles reddi. Colores inter nultiplices eorum mixtas facies hi duo tantum reuera potiflimum f́pectandi,Candidus quadam nitéti luce perfufus, ex omni quogs 
parte niger intermixtus: albus deinde nigris punctis interuenientibus, \& fpadix glaucúfque, hoc eft, exuperantia \& fplend ore ruboris, quales funt fructus palma arboris non admodú lole incocti: vnde fpadici phonicei nomen eft. Forma deligetur, vt fit arguto \& breui capite \& ficco, pelle propenodum offibus a dharente, ceruice ardua \& erecta, aurib us breuibus \& acutis, oculis magnis \& prom $\$$ nentibus nigrifque, fiue fellineis, id elt, quafi quodam fplendore perfufis, naribus patulis, duobus vtrinque foraminibus quibus auras captare yberius faciliuqque reciprocare animam poffint, coma denfa $\alpha$ in dextrum latus protendéte, pectore lato, ventre fubftricto, paribus \& exiguis teftibus: rotundis clunibus, promil fa cauda, mollibus altis erectífque cruribus, pedibus' $\not$, ficcis, altis, concauis,atque rotundis, vniuerfo corpore compofito, articulatim diftineto, grandi, fublimi, erecto, $\&$ in afpero loco( $v$ : Xenophonti placet)educato, vt autem Satyra inquit, Nempe volucrem

Sic laudamus equum, facili cui plurima palma

Feruet, \& exultat rauco viktoria circo.

Nobilis hic quocunque venit de gramine, cuius Clara fuga ante alios \& primus in equore puluis.

cap. $x_{0}$

Electis militibus \& equis ad pugnam idoneis, quis potiflimum illis (1) praficiendus fit dux quarimus, voluntates \& gentium fudia in his 1.2. declarantes. Iudxis alienigenam lex præfici vetat, ne auctoritas im- perio religionis fur cultú inuertat, in aliis duces $\&$ imperatores externi,patria \& natione nobiliffimi reperti funt, vnde $\&$ ex oraculo Aegyptiis di ctum eft vt auxiliatore Hebręo contra Aethiopas vterentur. Carthaginenfes in fracti bellis \& cladibus multis exinaniti, Xantippum Lacedæmoniorú regem cum auxiliis ducem bello præfecerúnt, qui fortiter ac ftrenue pugnantes Romanos euerterunt. Tarentini Gilippo duce \& ipfo Lacedæmonio Athenienfes vicere. Galli Brëno duce Britanno Italiam cepere, Roma infuper incenfa. Romanos tamen quos labore $\&$ induftria armis quogz ac bellicis inftitutis cateris nationibus, Græcorum pace dixerim, præfloruiffe conttat, multi opinione ducen-

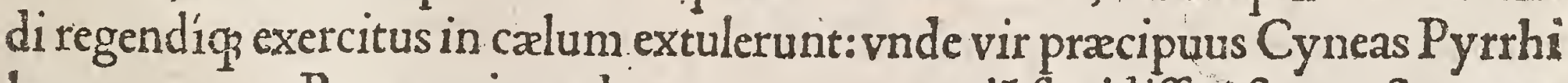
legatus, quum Romam iugrederetur, regum patriá fe vidiffe teftatus eft: quam fententiam vidco poëtico illi nimium conuenire,

Excudent alii fpirantia mollius æra,

Credo equidem viuos ducent de marmore vultus,

Orabunt caufas melius calíg meatus

Defcribent radio \& furgentia fidera dicent,

'Tu regere imperio populos Romane memento,

Hæ tibi erunt artes,paciśg imponere mores:

Parcere fubiectis \& debellare fuperbos.

Caterú in hac ipfa lentétia præ fe ne ipfi Romani fauiffe vlli reperti funt, quando externos quorum virtute romanam creuiffe conftat, in fupremos dignitatum gradus admifere. Sunt qui aftruät folas diuitias effe quae ducum \& impera. 
torum gloriam concomitentur \& illuftrent, quibus deficientibus volunt ac prę. dicant nihil arduum, nihil magnificú \&l excellens geri polfe; fic Perfas, fic Gra$\cos$, fic Romanos non fine diuitiarum copia orbis terrarum potitos efle. Alii putane ad laureas $\&$ triumphos habendos; fcelices duntaxat, fortunatófque ducés femper præfici debere. Aiunt enim, qux diuitix vel copia gentiun Romanos fere fubactos aduerfus Hannibalem erexiffent, nifi Cornelium Scipionem, fortu natiflimum imperatorem, qui illum apud Carthaginé relicta I talia folus fudit, habuiffent?Quid profuiffent,inquiunt alii, Carthaginéfibus thefauri exuberantiffimi aut exercitus ampliffini ad oppugnandam diruédám que tot ännos Italiam, nifi ipfum Hannibalem callidiffimum audentiflimumóp belli ducem gen tibus fuis præfeciffent? Sic Epaminundam Thebani, Leonidam Lacedæmonii, Themiftodem Athenienfes, fortifimos duces fortiti fant. Alii \& gui tecum rectius fentiunt, Sigifmunde, non diuitiis affluentibus, non fortunatis, non callidis $\&$ audentibus ducibus tantum, cæterum ingenio ato animi virtute præditis decernenda imperia, fummos credédos magiftratus effe putant:Parum enim, ait Cicero, funt fortia arma, niffenfilium fit domi:neque fortuna, aut viribus, aut velocitatibus, aut celeritate corporú, aut excurfione, aut faltu, aut eminus haftis, aut cominus gladiis tantū res magnę gerútur, fed cöflio magis, fed ratione, fentétia, auctoritate atç fciétia. Que omnia fue deorú feu naturę munere quüm in te effe omnes: intelligant, prædicent, admirêtur, quid mirú, fi te ducéad omnes bellorum euentus \& magnifica quxque conficienda, vniuerfa hinc inde delegit: Italia? Quod de te autem reformident finguli,refelleréque palam audeant, vnum hoc êt, Aiüt enim qd" tamen Epaminúdę, quod Sertorii,quod Cęaris, quod Au gatti, aliorúmp plurium \& maximorum ducum proprium fuifelegimus, frenut militis officio fungi, fortitudinis opera manu propria edere, ac fine vlla te. exceptione: periculis nimis ingèrere : quod quàm gloriofum fit quámque per-i niciofum ad maxima \& plurima bellorum munera obeunda, quum cóflio pol leas, viribus preftes, 2 cunctis tam ducibus quàm militibus in vtriuflibet officiis antecellas; tuo prudétiffimo iudicio exiftimandum relinquo. Rariffimum quidem decus; $\&$ quod inquit Crifpus de Iugurtha, de te imperatorú noftri aur glo-: ria, om nium confenfu dici poteft. At fane; inquit ille, quod difficillimum impri $\rightarrow$ mis eft, \& in praho ftrenuus erat \& bonus confilio: \& quoniam alterum ex prouidentia timorem, alterum ex audacia temeritatem afferre plerunque folet, glo. riofum nomen tuum non tam fortuna $\&$ opinio, quàm virtus, 8 conflium circunferat periculifque obiiciat Eaue itaque oro, ac ducis $\&$ militis officia diftinguas obfecro. Tu enim longe melius nofti qux fint ducis partes, \& qua mi litum fortitudo atç profeflio debet, qua feorfum à duce exigenda, praftandá́ non funt nifi forte cum fumma:neceffitas incumbit. Legimus fortifimum ducum Marium prouocáti ipfum ad fingulare certamen refpondiffe, fe frmori voluifet multoties fufpendio potuiffe, \& fapientem non quarere pugnam; fed porus cogitare victoriam. Ecce virum glorix cupidiffimum \& romanum difcernentem quid inter ducis $\&$ militis officium intereffet, $\&$ reputanten frepius ducen fine exercitu falum euafifle quàm exercitum fine duce. Vides, inclyte dux, 
Marium declinauiffe fingularem cógreffum quem nullum ferme militum legimus recufaffe, vt eius exemplo difcas que funt militis fpernere, Z Q qux imperato rix maieftati conducant adimplere: $q$ fi te parum mouet ob fanguinis ignobilitatem Marius,audi de gente Cornelia Scipionem, non quêlibet, fed illum qui virtutibus fuis Aphricani cognomé adeptus. Hic enim quum à quodam $q$ parum pugnax foret argueretur ignauix, crimé lepida refponfione fubmouit: inquit etenim, Recolo matrem me imperatorem peperiffe non militem.Metellum quoque quum multi clamarent vt ipfe fingulari certamine cum Sertorio prouo cante dimicaret,dux cum duce, $\&$ romanus cum romano, detrectantem verò pù gnam vt ignauum afpernabatur:fed ipfe Metellus hæc dicentes merito cótemnebat. Ducem etenim vt inquit Theophraftus,non militis,fed ducis obire mortem decet. Nec te moueat, dux præcellentiffime Sigifmunde, $q$, Alexandrú $\mathrm{Ma}$ gnum legamus \& imperatoris \& militis impleuiffe munus, led memêto quòd à principe rei militaris peritifimo at $q_{p}$ probatiffimo laudatus fit folum, $q$ parua manu aduerfus maximos exercitus fteterit viceríto̧, $\&$ in extremas mundi partes peruenerit pugnäs vltra fpem,exiftımationêmq̧̣ mentium humanarū. Nam quód manu promptus \& pugnaciffimus fuerit,quum \& gregarii militis laus fit, glorix illi principi non affcripfit:tantus iudex ac teftis, quantus Hannibal cum Scipione conferens fuit.Neq Catilinam peffimæ factionis tibi imitandum proponas velim, de quo Saluftius fcriptum reliquit,Interea Catilina cum expeditis in prima acie verfari,laborantibus fuccurrere, integros pro fauciis accerfere, om nia prouidere: \& pręter hæc imperatoris officia quod militis eft fubdit,multum ipfe pugnare, fxpe hoftem ferire, ftrennui militis \& boni imperatoris officia fimul exequebatur. Alia quidem ratio eft eius quod fieri debet,alia eius quod ille faciebat:pugnabat enim def peratione plenus, poftqua m, vt ille ait, videt montibus atque copiis hoftium fefe claufum, in vrbe res aduerfas, neque fugæ neque prafidii effe fibi vllam fpem, optimum factu ratus in tali re fortunam belli tentare ftatuit. Promittebat enim cuncta fibi, fi vinceret: $\&$ defperabat omnia, $f_{i}$ vis hoftium preualeret. Nam nec ego velim te penitus non pugnare, fed tunc te manum conferere probo, quum de fumma rerú agetur, quum cuncta ficut optimú ducé decet prouideris, quú neceflitas tulerit, quú cuipiam ingenti periculo vt fępe foles, videris occurrendũ. Audi Craterũ Alexandrũ fuum admonentem, Quãtalibet,inquit ille, vis omnium gentiú côfpiret in nos,impleat armis virisọ́ totum orbé, claffibus mare cófternat,inufitatas beluas inducat, tu nos praftabis inuictos: \& fubdit,fed quis deorü hoc Macedoniæ columen accitus diuturnum fore polliceri poteft, quú tam auidè corpus periculis offeras, oblitus tunc tot ciuium animas trahere te incaffum?ac poft plura,quòcúque iufferis ibimus, obfcus ra pericula, \& ignobiles pugnas nobis depofcimus, temetipfum ad ea ferua que magnitudiné tuam capiunt,citò gloria abfolefcit in fordidis hoftibus. Vidésne qua regula ducis pugna limitetur, et vbi coueniat imperatorem manus iniicere? Et qd,putásne fị quotidie te periculis obiicies,nó ali quädo fortunã inuenire tuâ?? Tragicum eft, iniqua rarò maximis virtutibusfortuna parcit. Nemo fe tutò diu periculis offerre tam crebris poteft, quem frpe tranfit cafus aliquando inuenit. 
Noli itach in paruis ac minimis experiri fortunam, fatis enim periculo tuo,immo noftro quantum ad gloriam attinet, Sigifmunde, te pluribus oftendifti, fatis Picentibus, fatis Etrufcis, fatis Infubribus, fatis Latinis ac Barbaris ducibus, fa tis amicis, fatis denigh hoftibus te mortis omnif'p periculi contemptorem, manu ac corpore ftrenuum $\&$ ad horrenda omnia quifquis cafus immineat expeditum. Fauir deus, nunc exhibendum prudentic temperamentum, $\&$ cautionis modus, vt qux geffifti conflio \& animi magnitudine, non impetu, non temere geffiffe videare. Deniqg corporis habitudo \& integritas, formáq dignitas, non munditiis culta, fed virilis \& pene militaris, vt Liuius inquit,non nihil etiam du cibus folet conferre, qux fi defit, non vfquequaque tamen expetenda eft, vel quo minus militent alísve praficiătur omnino repudianda, modo animo præftent 8 harum rerum quas modo diximus cognitione ornentur. Iure etiam diui Tra iani fententia militabãt qui aliqua corporis parte debilitati vel minuti funt, idós in multis fane vrbis Rom exterarum' ${ }^{\prime}$ gentium ducibus eft intelligere. Nanque præter Marium, praclatum ducem, varicibus laborantë, legimus \& Camillum quum Præneftinos \& Tyrrhenos pralio vicit, fenem pariter \& $x$ grotum, 8Ululium cæafarem dictatorem femel atque iterum inter res gerendas comitiali morbo correptum.Q.quog Ciceronem, magni Ciceronis fratré,tenuiffimę valitudinis, multa, \& grauia bella fub hoc duce in Gallia prudenter ac perftrenue adminiftrantem. Apud Lacedamonios nec minus Lyfandrum, frepenumero vi morbi ac magnitudine, mentis viribus \& corporis deftitutú. A gefilaum quoque eorum quỏ dam regem claudum, proinde fummę an eum rei præficerét, diu multumóg deliberafle, deniq̧ ftatuerüt fatius effe ingreffu regem quàm imperio regnum claudicare. V' tó Scyllam \& Cottam, nó obfcuros fane duces, eo habitu fuiffe naturæ perhibent, quòd vno tantum tefticulo nati memorentur, fic Serto. rium; Oratium Coclitem, Philippum, Antigonum, \& Ponorum ducem Hannibalem, qui onines maxime bellacifimi fuere, altero non tefticulo caruiffe, fed oculo alię fideles tradüt hiftorix. Quod auté ad forme dignitatem Spectat, Scipio Aphricanus \& Iul. Cax.etfi procero corpore fuerint, breui tamé Antigonus, Alexander Macedo, \&2. Auguftus, nec tamen eorum magnitudini breuitas, nec breuitati nagnitudo obfuit, nec detraxit famæ. Et ad tumulum Archemori dü ludos folênes Gręcia celebraret, Tydeũ Capaneo pręftitiffe poético pręconio percelebre eft, à quo humili admodú ftatura \& exigua Thebanos omnes certaminibus lóge fuperatos fuifle traditur. Gerëda igitur huius rei dignitas \& fum. ma meritòillis tradetur, quibus explorata fint omnia, quíg cóflii, auctoritatis, fciẽtiæ, multarüǵg rerum geftarú titulis illuftrati præfentes non modo prouocen ad victoriam, fed eorum commemoratione pofteros initatione fuccendant.

Agminis fiue incedentis excrcitus ordo fecundum grecam romanamóg difciplinam Cap. IXI. V pereft nunc agminis, hoc eft, incedét is exercitus ordo, circa quem (1) fumma imperatorum ac ducum verfanda confideratio eft, quum fit

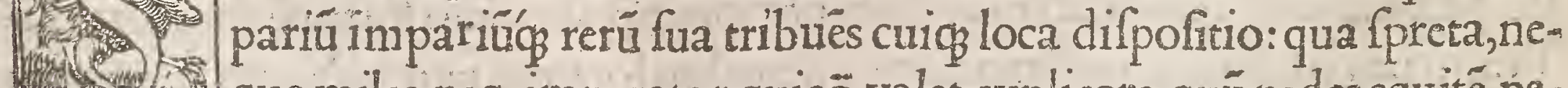

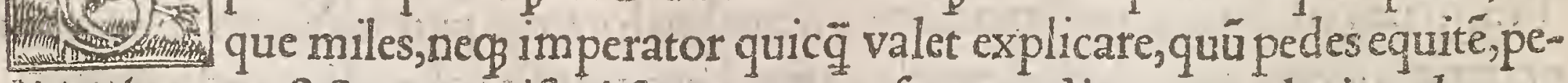
diteni'g eques, fi fint promifcui, fapenumero fe prapediant, ac veluti ex theatro confufe 
confufe abèuntes, fe inuicếafflictent atog opprimant. Econtrario verò, vbi fit ri te difpofitú ag men, fuóg quid $\$$; ordine locatú, fine trepidatione Impera tor victoriam ab omnibus optatã promittet. De hoc itą̧ jpfo breuiter à nobis fecúdum gręcam rationem primò differédum eft, ab Romana traditione deinde fu mentibus.Quum igitur ciuitas in Tribus diftributa fit, ex his Decuriones primùm, de cuius tribuni fententia ex ipfo iuuétutis flore deligédi funt: ex his qui xtate \& prudentia,qui pulchrú aliquid \& gerendi \& audied i ftudio flagrêt, hos anteire oportet. Poft hæc totidem deligédi funt ex his qui ærate \& prudétia ma xime antecedant, qui poftremi in ipfis céturiis collocabútur. Decurionum veró ordo ob has præcipue caufas probatur, $q$ qui priori loco collocati funt, omnes principes fiút: quúmq in dignıtate funt magis ququú priuati, impofitú fibi effe exiftimant præclari alicuius facinoris gloriam quærere. Deinde quú quidpiam

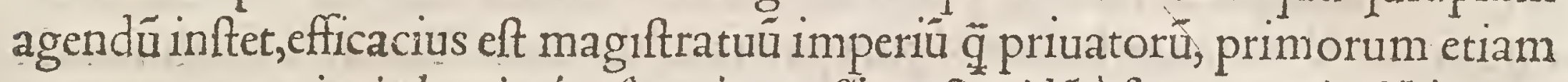
manus promptiori alacrioríg fe animo offert, fiquidéà fronte periculú ingruat, quú eam minime lateat,eú locú fux virtuti credıtum effe. Et poftrema, fi qua à tergo maior vis premat, quú eam haudquaquã etiā fugiat, deferere ordiné turpiffimum effe: qui etiā poftremum agmen ducit, hunc omni laude cumulatû virum effe cóuenit.Si enim pręláti virtute erit, quú tempus inftabit,iubens in hoAtem inuadere prioribus virès adiiciet: In rurfus pedé referre opus erit, prudẽter abducens fuos profecto magis feruabit incolumes : $\&$ hic fecundú Græcorum rationé agminis ordo. Secüdum Romaná autem eiufmodi erat, Nanq auxiliá-

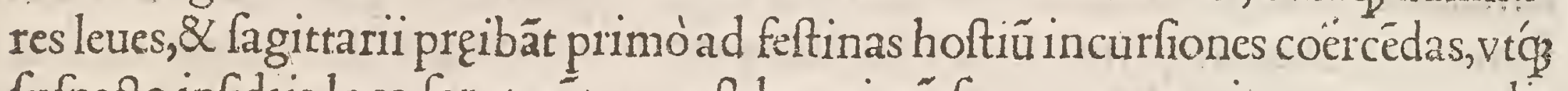
fufpecta infidiis loca fcrutaretur: polt hos viarú fcrutatores, qui aggerum maligna corrigerét, fyluásç præciderent,ne pplexo itinere fatigaretur exercitus, deinde fua fuperiorǘp fibi rectorü impedimenta ferétes, \& defenfionis ergo plurimi cû his equitum, pott quos princeps ipfe equitatus peditatus'qg hos poftea fequebätur, qui remouédis vrbibus' machinarū ac reliquorum tormëtorum genera deferebãt. Chiliarchi deinde atọ præfecti, \& polt hos circa Aquilä cætera frgna militaria, púftọ́ ferui fingulorú ordinú cú peditatu erant,agminis poftrema multitudo mercenaria quá armorú factores fequebãtur, \& armati equites peditésф̧ non pauci. Caterum pro têpore $\&$ caufis occurrêtibus, Iul.Cęfar octo legiones hac ratione et ordine inter eundú difponebat, quú hofté cominus fentiret, fex legiones expeditas preponebat, polt has totius exercitus impediméta, inde du as legiones quę minus firma ad dimicãdú putabãtur, vt agmê clauderét præfidióó impedimétis effent: minoribus auté expeditionibus tres legiones expeditas pręmittebat,deinde imped iméta, nouifîme legioné vnã quę agmé clauderet. Ita quadrato ferè agmine incedere, vbi hoftis ab omni parte fư pectus effet. Et hæc de agminis difpofitione fecundum vtranque difciplinam dicta funt.

Acierum inftruendarum uaria ratio.

Cap. XII.

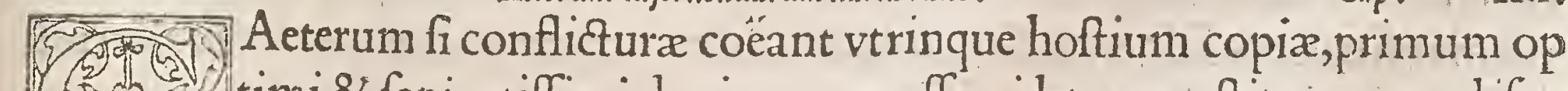
timi \& fapientiffimi ducis munus effe videtur, conftituere atog difpo nere qui prudenter,fideliter, ftrenue ac viriliter hofté inuadãt. Quod fi omner ciuium equitatum celeriter ad mille equitum numerú com

$$
K \text { ii pleri }
$$


pleri neceffe fit,ad ducentos,præterea peregrini conftituendi funt equites, $8 \mathrm{in}$ ter ciues collocâdi: hi enim adiuncti vidêtur mihi, \& firmioré vniuerfum equitatum praftare: \& magis emulatione quadam ad laudis \& glorix cupiditatem incendere, vt certatim fe inuicem virtute fuperare nitantur. Nec vero'me prate rit Lacedæmonios, rei militaris peritiffimos bellicofiflimof f $^{\prime}$, tum primü eque ftri gloria maxime clarere coepiffe, quü peregrinos equites af ciuerint. Et in aliis quoq bellorum euentibus diuerfíf $p$ nationibus conftat, peregrinas copias magnum fibi \& praclarum nomen peperiffe, vfus enim ad promptitudinem plur mum confert: Videtur præterea peditatus equitibus adiunctus ad rem gerédam efficaciffimus effe, maxime $\mathrm{fi}$ his hominibus conftituatur qui hoftibus infenfiffini fint. Sunt qui putent pro ratione acierú illud Neftoris apud Homerum effe, qui iubebat per tribus atop partes corum, cohortes aciel'op Grxcorum coordinari, vt $\&$ tribus tribubus $\&$ pars parti auxiliaretur. Satius $\&$ falubrius alii cenfent, a matorem iuxta amatum collocari debere: nam ordo fecundum tribus non multú rationis in periculis habet,verum fi cuncus ex amicis inter fe amantrbus exiftit, indiffolubilis \& infeparabilis ad perferendos inferendólop ictus effi citur;quum hi amatorum mirabili amore, ferrea et adamantina,vt ita dixerim, cathena teneantur, \& facram, vt aiunt, cohortem efficiant; quéadmodum Sefoo. fis in Arabiam,vt antè diximus,cum eorú qui eadem dıe geniti qua ipfe fimúlque nutriti erant exercitu à patre miffus. Atop in hoc quog ad primos ictus fuftunendos funt qui fuos cohortentur, \& eo iplo fuperiores fe putét quòd non inferiores in occurfu primo reperiutur. Hac arte fiue ratione vfus Pompeius Phar falicis in campis: acies enim ab equo animaduertens, vt hoftes nouit cum flen* tio congerdiendi tempus ex ordine expectare, fuúmg exercitú fine frepitu non effe: immo turbulentum \& imperitia tumultuanté,extimuit, ne in ipfo pugna initio penitus diffolueretur:vnde quum vtrino concurrendi figna danda effent, acierum primos monuit vt in locis fuis frarent, $\&$ denfa confertáq manentes $f_{e}$ rie hoftilem incurfum donec intra pili iactum effent folidiffime exciperent.Qua quide in re fi L ucano creditur, fteterit licet ordine certo infoelix acies, Cæfar tamen erraffe Pompeium afferit.Plagarum enim ictus impetu curfúg illatos fubfiftend o reftingui in quit, feriêdo enim \& initio confligêdo, magnas vires impetu $\&$ curfibus adiici, $\&$ animos perinde ac flatibus excitatos omni ex parte fuccendi.Cæfar itaqg quum finiftrü Pompeii cornu confpexiffet, tot munitú equiti bus, timens armaturæ fplendorem, quing fiue $\mathrm{ex}, \mathrm{v}$ ali ferunt, obliquas poft $\mathrm{f}$ gna cohortes, quibus cum orbem terrarum congreffus eft è legionibus eductas legioni decima à tergo locauit;iuffitop eas quietem agere, hoftibúfó ignotas effe. Sed quum irrueret,equites ad monuit, quòd neq vt folitum effet iacerent pila, feftinaréntque quemadmodum robuftiffimiad perftringendos enfes, fed ferire eos altius iuffit, oculófque, frontéfque hoftium ad vulnera impetere. Non enim permanfuros eos fulgentes floridófque infultatores, inquit, neque contra ferrum infpecturos in oculos illatum, illos iuuenes parum bellis ac vulneribus affuetos. Hoc itaģ impetu, hac acierum ferie, ratione $\&$ ordine inftruitur vtring acies. Pompeius oftoginta \& octo cohortes triplici ordine locauit, fuerunt auté pedi. 
tum, xl.milia, equites in finiftro cornu, DC. in dextro D. praterea reges multi, fenatores, equitefóp ro.plurimi abfque leuis armaturæ magna copia. Cæfar fimi liter octoginta cohortes triplici ordine difpofuit, cui fuerunt minus xl.M.peditum,equites mille. His explicitis obfecrátibúfọ militibus Cæfar pugnæ fignun dedit. Erat forte in exercitu eius, C. Craftinus, qui priori tempore honefto gradu fub Cæfare militaffet, tunc verò non militiæ facramento quo folitus erat, fed iure quodá a micitix euocatus a derat, vir bellica fortitudine memorabilis. Cæéaris nanqg concione intellecta, $Q$ vt ab his vtrilog figna dari vidit, alacri vultu è Cæa faris phatáge procurrens, Sequimini me inquit manipulares olim mei, \& imperatori noftro quã debetis operá exhibete, vltimú hoc prælium eft, quo peracto ille fuam dignitaté, nos noltram recuperabimus libertaté. Dehinc verfus in $\mathrm{C}_{\mathcal{E}}$ farem, Faciam, inquit, hodie imperator, vnde vel viuo mihi vel mortuo gratias agas: hęc dicés in hoftes irrupit,eumọ́, delecti milites circiter cétunjuigınti fua fponte profecuti funt.Erat nempe vt aliqui tradidere, nec diffimile veri eft, quidam vtring in ipfo pugnæ principio pius torpor,qui ftrictos iam gladios contineret, quum germani fuos fratres ab aduerfa acie, patres filios, \& parentes filii viderent,donec Craffinus hic pracipitanti rabie vocem tolleret,pllumqs torque ret itágp pralium coeptun eft, quòd nifi huius faror hominis acies mnlicuiflet,po terat fortaffe ducibus ipfis parientibus,circa R omani imperii humanióp generis excidiư mutua pietate cóponi. Sed proh dolor, inuentus eft qui Cęfare iplo dif ferente properaret,imperium q́ $_{\text {f }}$ upremú irrepa rabili clade protereret. Steterunt enim acies antè magno ordine vtring, \& bello copto,quu maliquádiu equis vitribus hine inde dimicaretur, $\&$ Pompeius"multitudine fifus ad circúueniendum Cæarem equitatú effunderet, $a b$ vtrog cornu $C æ f_{a} r$ fuis equitibus quos intentos in hanc rem fecerat fubito fignú dedir:qui dicto citius in effu fos facto impe tu, vere illos effuderunt ac dare terga coëgerunt, $\&$ fecuta eft equitatum ardëtifli malegionum, adeò cóglobata vt quafi vna manus omnium videretur. Acceffic 8 magni inftar exercitus Cælar ipfe vbique prælens, vtrung frmul exhibens, \& fortiffimi milit is $\&$ fummi ducis officium, $\&$ feriens, $\&$ exhortans. Dux ex om nibus illius per omnia difcurrétis voces annotatæliterífque mandatæ: ferox altera,fed ad vincendum vtilis, Miles ficiem feri : altera autem pia, 8 hanc li. cet ad iactationem Cafaris compofitam in hunc modum Florus dicat, Miles parce iam ciuibus, Pompeio tamen inter hortandú tribuit Eutropius. Illa enim ve Floro affenciar, Cæfaris vincere fatagentis, hæc eiufdem vincentis, feu iam vi ctoris miferétis, vox fuit : illa in medio prælii ardore, ac iam victis $\&$ in fugam verfis holtibus vfus eft. Ille etiam pix non conlentaneus actus fuit quòd cuilibet fuorum vni, hoftium quem optaffet vitam dare permifit. Nec mi m nus ille, quòd in tanto conflictu nullus inuentus eft nıfi armatus in acie cecidiffe. Pompeius turbatis ac territis fuorum ordinibus tantæ ruinæ molem nec fufferre valens nec attollere, tanquàm infano attonitóg tantum fimilisabiecit pondus imperii, feque in caftra recepit,nimis illi quod de alio eft carmini cóue niês, Iupiter ipfe pater currus exterruit altos Aiacis, tetit ille a més cly peǘğ rumentē Tergore fepteno poft terga immania iecit, Huncó oculos volues moeftus 
fe auertit ab armis. Hæc vbi ingreflus eft caftra, tamdiu fecum tacitus perfitit quamdiu confligendo plurimi cum fugientibus fimul in cæedem corruiffent, rupróque filentio tandem vocem hanc vnicam emifit, Ergo ad congreffum, aliúdque nihil locutus, furgit, vẹttég fumpta, præfenti cladi accommodata caftra exceffit, féque fugx credidit, non tam viuere cupiens quàm metués mori,ne fecum reliqux legiones incaffum traherentur: quo fubmoto, nemo amplius in acie ftetit, fićóp vniuerfus Pompeii fugit exercitus, cladéfque in caftris permagna facta miniftrorum, eorumque qui contubernia defenderent: $\&$ quanquam facta cæe forum ratione, milites tantu ad fex milia cecidiffe clariffimus teftis fit Afinius Pollio qui tunc cum Crefare militauit,compertum eft tamen per alios nobilifimos auctores de legionibus \& equitatu Pompeii XV.M. cecidiffe : nam exterarum gentium $\&$ auxiliorum qua ex magna orbis parte confluxerant, innumerabilis ftrages fuit, $\&$ eorum qui vag1, \& inermes nullo ordinead fatietatem cędentium funt oppreffi. Eorum verò qui deditione in poteftaté Cælaris venerât numerum XXHII.M.\& eo amplius fuiffe literis traditum eft,figna militaria centum octoginta \&LXXX. aquila. Inter cefos fuit Craftinus vt dictum eft ardentifime di micans, qué Cæfar eo prælio mira virtute rem geffiffe $\&$ de fe optime meritum prædicauit, atq̧ ita vt prædixerat vel mortuo gratias egit . Pompeianorū enim multos quum ftrauifet, in confertiffimam aciem inuectus, vnius gladio per ora illi ad oppofitum latus adacto perfoffus occubuit, notatúmque oris vulnere, oris impetum punitum, vltione iuftiffima. Periit Domitius is qui ad confiniū captus fuerat ac dimiflus: ex his qui Cxaras partes fecuti non nif ducenti milites funt defiderati.Céturiones XXX.viri excellétes. Mirú dictu, Romanis ab vtraq̧ parte pugnantibus, ea fuiffe cladis imparitatem: (ed puto diis placuiffe vt Pópeium fua illa vetus fortuna relinqueret. Pyrrhus in inftruenda acie apud Afculum, Homerici verfus fententiam infecutus fertur, quo equidé minus bellicofi in medio collocantur,elephantos \& equitatú omné in fubfidiis efle iubens . Xantippus Lacedæmoniorū rex in auxiliü aliquando euocatus à Carthaginéfibus quos Ro mani fepenumero protriuerant, infpectis Ponorum copiis atq̣ in campum deductis, quum in percunctando quemadmodum Romani fecum pugnando femper fuperiores euafffent percepiffet, ac errata fubinde quibus res eorum fubuerfa forent quafi difciplinam quandam aperiens edocuiffet, in inftruenda acie, fic equitum, fic peditum, fic elephantorum ordinem difciplinä́p digeffit, vt qui mo do ne confpectum quidem Romani exercitus fuftinere poffent, vltro iam poftularent vt ad hoftes ducerentur. Cognito igitur militum ardore Carthaginéfium fortunam pralii ratus Xantippus, aduerfus Romanos Carthaginéfium acies fic inftruxit. Prima enin fronte elephantos conftituit,paulo pòft vibaná multitudi ném dextro ac laùo cotnu, deinde mercenarium militem veteranorumóp robur diftribuens, expeditos quo fo $\mathrm{g}$ ac celeres vtrinque inter equitum alas certare iuflit. Econtra vt folidam Romanorum aciem perfpexiflet, qui aduerfus elephátos ex omni exercitu expeditos \& delectos oppofuerant, nultiplicíg fubfidio firmauerunt, equitatu in vtróg cornu diuifo ne ab elephantis perrüpi agmé poffet,Xantippus quo Romanorum aciem labefastaret, circumire equitatum ac extremos à 
tergo laceflere iuflit: hoc quu pluribusin locis faceret, ac legiones Romana neceffario extra equites conuerfæ illisrefifterent ac propellerent, interim rarefacta acies ac diliuncta, ab elephantis perrum pitur confligiturop : quo in conflictu XXX.Romanorum milia cecidere. Regulus dux eorum cum quingentis interceptus, \& duo milia in Clypeam vrbem fugata funt. Hannibal imperator maxi mus, directa acie ad Cannas milites fortiores bellicoforésque in extremitatibus difponens,ipfe cum debilioribus medium, vbi multi ex fortibus \& ftrenuis viris præerant,tenuit: fexcentos deinde equites Numidas tranffugere iuflit, qui ad fidem faciendam gladios \& fcuta Romanis tradiderunt, \& in vltimum agmen recepti,vbi primum cócurri coepit, ftrictis minoribus quos occultauerằt gladiis, fcutis iacentium affumpt is Romanorum aciem cecidere. Ad hoc etiam mifcen darum acierum difcrimen, Scipio aduerfus Hannibale in terra Aphrica quum ordinaret exercitum, haftatos prima fronte locauit : principum deinde cohortem, quam quidem triaris deniq̧̧ claufit, nec dèfas fuorú aciés inftruxit, fed quodam interuallo diftantes, quò elephanti recepti abfque vlla fuorum permixtione ac ordinis perturbatione tranfmitti quirent. Velitum etiam plurimi præftò erant, iuffi in ipfo beluarum impetu eorum terga dextrum laúnque latus telis confodere: equites deinde diftinxit in cornua, \& cú italis equitibus I ęlium ab læuo,Mafiniffam verò Numidis inftructum dextro cornu oppoluit,quæ ordina tio magnam fibi peperit victorix laudem. Hannibal verò econtra cum decernendum fibi neceffario effet, \& ad illud fupremum glorix certamen quo nullum vnquam perniciofius, nullum magis terribile vel memorandum quoque, quum vel omnium gentium imperium, vel perpetuum feruitutis iugum fuis fore videret, ex Scipionis hoftis fui fententia omniúmque qui armorum vel militarium rerü gnari erant, id laudis affecutus, vt fuorum cohortes mirabili aftu \& diuina potius quàm humana ratione difponeret : elephantos enim octoginta trementes in terga turres, militibúfque refertos, habentes, in profpectu Romanorum exercitus præfepfit,vt inde fuo terrore, impetu ato̧ vi, holtium ad fuos táquam clypeus \& murus a heneus acceffum prohiberent, auxiliaribus, Gallis, Ly guribus, Mauris atç Balearibus ante Ponorum fuorum'q ciuium cohortem deinde fublequentibus, ne mercenariis diuerfarum nationum militibus, quos non fides, non patrix pietas vlla fortes ac ftrenuos redderet, fugiendi facultas daretur : vióp primo poft elephan tos loco pofiti pugna impetum admittentes extiǹguerét tum fuorü ac Macedonum multitudinem, vt integri cumfeffis holtibus pugnando victores euaderent. Italicos verò \& Brutios, tãquam infidos, $q$ moeft $i$ coactíg magna ex parte terra Itala excedere, imperium ducis \& caftra fequeren tur, in poftremam fummouit aciem:ad fuos poftea quum ambo fe duces vtrinque recepiffent, hortarentúrque varie \& ignauiæ notas \& pręmia militibus præ ponerent,interim ad initium pugnæ claffica Romanorum cecinere, tanto quidem omnium clamore, vt elephanti quos primo agmine anxia tanti ducis cura in præfidium locauerat, fortuna confilium peruertente, in fuas acies redirent, impetúg fưo loco adeò turbarent vt equitibus in fugam verfis primam tátæa ru inæ tantæóg ftragis caufam præbuiffent. Equitibus enim imminuta Ponorum 
acies, pedes in hoftes concurrit, primóque nixu loco moueri contigit : hos vt motos Romani fenfere, partim fefe ad fuos recipientes ac terga dantes, Carthaginenfum aciem adorti funt. Re autem bene ac foeliciter gefta, tot iam fugatis equitibus, tot elephãtibus fufis,primífque ordinibus in fecundos iam pulfis, inter pugnandum Lxlius ac Mafiniffa qui pauloante pedem referentes aliquantifper profugos infecuti fuerant opportune redeuntes, \& quidem equites hoftilis exercitus quotquot fupererant à tergo incurfant, if $q$ quafi inopinatus impetus holtilem aciem tanta compleuit formidine vt ancipiti vndique pugna circumuenti funderentur cæederentur'́, nullo pudore,nulla reuerentia tanti ducis valête fugam filtere. Et quanquàm fane ab vtroque ipforum ducum, \&ab aliis fxpenumero maiores alibi ftrages ædite fint, grande tamen prælium in primis meritóg feu ducum claritate, leu gentium potentia, feu militü virtute, feu ancipiti cæforum difcrimine, feu denique victoriæ effectu inter illuftria referendum, quum auctore etiam Floro nó fuerit maior fub imperio Ro. dies quàm ille quo hęc gefta funt. Ex Carthaginéfibus \& fociis xx.M.\& co amplius hac in pugna cecidere,totidem fere capti,fignáq militaria c.xxxii.cum elephantis xi.intercepta. Romanis vero qui fuperiores euafere, nec incruenta victoria fuit: decé nanque milia periere. Dux autem ipfe Hannibal moltus, \& equitibus paucis admo dum comitatus, Hafdrumetum, id oppidi nomen eft, fuga fe contulit, fingula tam ante pręlium quàm in pręlio qua quemlibet magnanimum principem decent priufquam inde abiret expertus. Carthaginem patriam deinde fuam profe Etus vil reuocatus, coram primoribus \& fummatibus vr bis fe non pralii modo, fed belli vniuerfi gloria inferioré euaffle, \& à Scipione viêu \& fuperatum effe non iuit inficias. Cornelius Scipio cognomento Aphricanus, aduerfus Hafdru

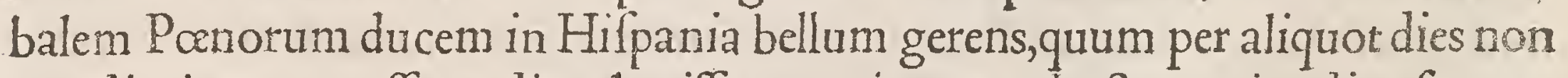
quo dimicaturus effet ordine duxiffet exercitum, ac hoftes pari ordine feruato proficicerentur, codem die quo manus conferere inftituerat inftructionis mutauit ordinem, \& quibus ipfe prequalebat infirmiffimas hoftium partes vna acie aggreffus facile fudit. Theogenes Athenienfis, quum exercitum Megaram duceret petentibus acierum ordinem refpondit, ibi fe daturum: deinde clam equites præmifit, eóf $\not \beta$ hoftium fpecie impetum in focios retorquere iuflit: quo facto tanquam ad hoftium occurfum præpararétur, permifit ita acies ordinari vt quo quif g loco voluiffet confifteret, vt inertiffimus quog quifog retro fe dediffer, ftre nui autem in fronte profiliffent, vt quemque inuenerat ftantem ita ad ordinem milites prouexit. Adderem his ego Arcturi regis placita,cuius apud nos nefcio q verax,fed noua vtiq, \& ob id ipfum fufpecta mihi elt fama; et quáquá hiftori is mifcere fabulas nihil ft aliud $\ddot{q}$ mêdacio veri fide imminuere,eius tamen hac in re gefta; vel qua geri potuerüt,códucibilia plurimü,nó filuiffe equide qu affirmafle maluerim. Hic enim in acie,vt aiunt, inftituéda peditatü quidem omnem per fe ponebat,equitatum quoqs : quumq́p pedites pugnam iniiffent, equites fuperuenientes aduerfam aciem diffipabant. Præter hos autem feorfum quofdam manipulos militares collocabat, qui pręlio feruefcéte fuperuęiétẹs, hoftes impeterent. Ita cum feffi integris à tergo vrgerentur, fuo commento nunquam nö vi 
ctor in omni pralio fuit Alexander, peditatum in mediam aciem equites à dextro læuóg cornu difponens. Idem aduerfus Archelaum quum hoftium copias multitudinem tem fpectantem ordinauit, vt circumuentis vndig pugnandi facultas effet. Hic idem al liquando omnibus ad pugnam ftructis, quum pratores militum interrogaffent, ad hac aliúdne quicquá iuberet,Nihil,refpödit,nifi vt barbæ Macedonú abraderentur. Parmenone verò admirante, an ignoras, inquit,anfam in pralio nullam effe quàm barbe meliorem? M. Antonius aduerfus Parthos qui infinita multitudine fagittarum exercitum eius obruebant fubfidere fuos $\&$ teftudinem facere iuffit, fupra quam tranfmiffis fagittis fine militum noxa exhauftus elt ho ftis . Quòd fi holtilis acies infolubilis frt,vt plerifg mos eft, fcutorü teftudine cisneos infolubiles efficere inuenti funt aliquando iuuenes militie Roman̨ qui fupra infilirent \& fcuta manibus euellentes defuper vulnerarent. Scipio Aemilianus ad Numantiam non cohortibus tantum, fed centuriis fagittarios $\&$ funditores interpofuit . Fuit \& mirabilis Romanorum aduerfus Lätinos Latinotǘp aduerfus Romanos in omnibus penè par in inftruéda acie ratio,cum qquis ante omnia vtrinq viribus, codem animorum ardore, iifdem militaribus inftitutis, codem armorum genere congruentes, milites militibus, centuriones centurionibus, tribunos tribunis cöpares collegiffent: quüóp in vnum manipuli plures coiffent, plures haftati, \& fcutati, \& principes, antepilarii,vexillarii, triarii, rorarii \& accéfin hiśǵ omnibus quũ munitus effet exercitus, haftati omniú primi pralium inceptarunt: qui fi hoftibus pugnando inferiores reddebantur, ipfi fefe ad fuos recipientes à principibus excipiebantur,tuncóp principes qui dicti funt decernebant, \& fublequebantur haftati: $q$ frà principibus quoog infoeliciter dimicatum effet, ad Triarios qui poftremos claudebant pedetentim referebantur: qui quü in acie tertio ordine extremis fubfidio locarentur cófurgentes, hoftes inceffebant: hi quanquam fpei nihil fuis pòtt relinquerent, holtibus tamen formidinis plurimum afferebant, quum velut fufos profligatosíp hoftes infecuti,\& victorię com potes, inopinatam extemplo aciem fcutis $\&$ haftis horridam munitamque $\&$ mi litum numero auctam intuerentur. Inftructis ita que, ficut antè dictum eft,ordinibus, aduerfus Lacinos Romani in aciē proceffere, \& Manlius \& Decius eorü dextro ac læuo cornu præfuere. Adiectü eft aliquid $R$ omana difciplina per $Q$. Neuium centurionem in exercitu Fuluii Flacci procof.contra Campanorü mul titudinem ad inftruendam aciem præter eam qux eft ex equitibus peditibúfque pugnã : lecti nang agilitate corporis iuvenes, leuibus armis tecti galeiculis gladiffque ac feptenis haftis quaternorü circiter pedum armati,polt terga equitum infidebant, \& cum ad hoftem ventum erat equis defilientes hoftem ex improuifo confodiebant, Velites ipfi huiufmodi pugnatores appellant. Samnites præter ceteros belli apparatus, vt acies fua fulgeret nouis armorum infignibus fecerüt: duo nanque illis exercitus erant, \& fcuta alterius auro, alterius argéto cęlata, fpo gia pectori tegmentum, et finiftrum crus ocrea tectum, galeaque criftatx que fpe ciem magnitudinis corporum adderent, tunicæ auratis militibus verficolores, ar gentatis lintex quibus apparatibus formidinis plurimú \& terroris aduerfe parti redde 
redderetur. Fidenates, \& Falifci, Veientes item et Tarquinienfes quia pares armisnon erant ad terrorem in acies hoftiles mouendum, cum plurimis fuorum noua acie irrumpente, $\&$ inaudita $\&$ ante id tempus inufitata, in habitu facro facerdotibus faces $\&$ angues fanatico velut inftructa curfu pręferétibus, $R$ omanorum pari modo aciem exterruere. Scythicx gentis A mazones exercitum ad pugnam ingreffuræ tegmenta corporum pro armis habuere, ferpentú magnorum coria, quorum \& quidem prater fidem ingentium copia in Libya fupereft:vtebantur longis enfibus, hafta $\&$ arcu, quo non folum exaduerfum pugantes vulnerabantur, led fugiendo feriebant infequentes. Aduerfus Carolum quog in Hifpaniị Arabes mirabili arte in inftruéda acie vfi perhibétur: equitatu nâque in acie directo, Arabes contrà laruarum infuetam faciem obiicientes, fimul \& tympanorum Atrepitus concitantes, equis pauefactis equitatum omnem pepulerunt : nec fuit refiftendi facultas, donec equorum facie velata auribusóg obturatis milites rigidis perfonarü fimulachris repugnarent . Baleares tribus fundis quig in praliis armantur, vna caput cingunt, altera ventrem, tertia in manibus geftatur: in prælio multo maiores lapides quàm reliqui ita iactãt robufte, vt ab aliquo tormento lapis videatur emiffus, in vrbium expugnatione lapidum iactu eos qui defuper ex propugnaculis tuentur monia vulnerant, in pugna vero fcuta, galeas, omnéç armorum genus confringunt, tantáque vis ac peritia his eft vt creberrime grandinis modo in aduerfam partem \& propinquanté iam terre claffem effufa intrare portum finant neminem: quod cúque enim volunt lapide miffili facile contingunt. Nec eft quod gentis huius quifpiam certiffimos miretur ictus, quum hæc fola gentis arma fint id'ó vnum ab infantia fudium : nam cibum puer à matre non accipit,nifi quem ipfa monftrante, funda percuffit. Tro glodyte A ethiopum gens tantę velocitatis quum fint vt feras curfu pedum aftequantur, in aciem arma hęc ferunt hi, fcutum ex corio crudo bouis rotundum, \& ferratam clauam: arcus alii lanceáfque,nec vt Græci ob irã aut ambitionem, fed pabuli gratia belligerantur inuicem. In eorum concertationibus primú iactis lapidibus quoad aliqui vulnerentur concertant,cum arcu quo admodum exercitati funt pugnantes, mutuis vulneribus cadunt,eorúm $\$$ certamina dirimũt quæ atate præcedant forminæ, quibus nullo periculo in medium prodeuntibus (nefas eft enim has villo pacto lędere)extéplo à certamine ceffant. Macæ qui circa Syrtes habitant inter cæteros Libyos quum fint corporibus etiam agiles, patria veró vt plurimum plana, neq̧ enfe,neqg galeis,neq̧ aliis armis inter pugnandum vtuntur,tantum ferunt haftas, lapidesóg in vafis ex corio factis delatos, cum his certantes, tum in congreffu, tum etiam abeundo primo hoftem ferire conan tur, ad curfum \& lapides recte iaciendos longo vfu edocti, ergáp. externos nullữ ius, nullam omnino fidem feruant. Germani acies fuas rhed is circundare foliti funt ne cui fpes in fuga relinquatur, hiśg impediméta imponút. Iidem equeftre aciem fic fruunt, equitum quot milia lectifima funt, totidem numero pedites velociflimi \& fortiffimi, quos ex omnibus copiis finguli in fingulos falutis fuze caufa delegerint: cü his in pręliis verfantur et ad eos fe equites recipiüt, hi fi quid fit durius, concurrunt: fi quis grauiori vulnere admiffo equo deciderit, circunfr-o 
ftunt: fi quò fit longius aut celerius recipiendum, prodeundi tanta eft celeritas, horum exercitatione vt iubis equorum fubleuati corum curfum adęquent. Celtiberorum quidem fcutis leuibus certant, alii rotund is vmbonibus magnitudine clypei cruribus ocreas ex pilis factas inuoluunt, galeas ferunt æneas criftatas plumis,gladios infuper ex ferro puro ad palmæ menfuram : qui in conferta pugna ferrum fuo moread conficienda arma præparantes (nam ferreas laminas in terra abfcondentes ibi tam diu effe finút quoad debiliore parte ferrugine abfumpta validior fuperfit)ex co tum enfes fortiffimos, tú catera ad belli vium arma neceffaria componunt: hoc pacto fabricata adeò cædunt omnia vt neque fcutum, neque galea, neque aliud quid eis obfiftat: duobus gladiis fulti cun eque Itri certamine fuperiores euaferunt, ex equis defiliunt pedeftremóp adiuuant pugnam. Sueuorum gens qua longe maxima $\&$ bellicofiffima Germanorum omnium eft, equeftribus pręliis fẹpe $\&$ equis defliunt ac pedibus pręliantur,equosọ́ codem remanere veftigio affuefaciunt, ad quos fe celeriter quum vfus fert recipiunt. Galli equitü aciem inftructuri, inter equites raros fagittarios expeditośq leuis armaturę interponunt, qui fuis auxilio fint,atq impetum equitum fuftineant: pedites autem pugnaturi nudabantur, vel nudi fuper vmbilicum vaftis fcutis $\&$ prælongis gladiis accincti in pugna perfiftebant. Adhæc cantus inchoantium pralium \& vlulatus, \& tripudia, \& quatientium fcuta in patrium guendam modum, horrendos armorum crepitus, omnia de induftria cópofita ad terrorem : verùm hęc quibus infolita ato infueta erant aduerfus Gręcos, \& Phry ges \& Cares multi ad victoriã momenti erant: aduerfus autê Romanos quibus gallici tumultus vanitates notæ erãt, nullius vel quàm parui. Nam tametfifemel atç iterum ad Cremeram et ad Alliam olim fuderint maiores noftros, in deteri us tamen eorum quotidie data res eft, quü ex eo tempore per ducentos iam annos pecorum in modum confternati,cæef, fugatióg fint: ac plures quoog de Gallis victorix quàm de toto orbe terrarum per Romanos habite, ac literarum cufto. dix tradita memorentur. Galatæ in pugna iugis vtuntur qua rhedarius $\&$ affeffor ducunt, in bellis obuium hoftern iaculo ex curru primum appetunt, tum relicto curru pedités enfibus certant. Quidam adeò mortem contemnunt,vt pu gnent nudi: cultodes corporis ex liberis hominibus pauperes eligunt, qui \& pro aurigis in pugna feruiant, \& ferant fcutum: inftructa acie praire confueuerunt, \& ad fingulare certamen hoftium fortifimos prouocare, arma vt hoftem terreant quatientes, capita hoftium in acie cadentium abfciffa equorum alligant col lo, hoftium fpolia fanguine perfufa famulis tradunt, in foribus domorum cum cantu atgh hymnis affigenda, quemadmodü feras folent venatu captas : hoftiü nobilionu capita aromatibus vncta in terris condunt, fumma diligentia oftendentes ea hofpitibus, nullóque precio ea vel parentibus vel aliis reddunt. Britannis vel Belgis Gallix populis fua cura hæc inuenta etiam funt, effedis \& carris apud ipfos primú repertis ftruunt genus pugnæx, quod eiufmodi eft, Equis enim huiufmodi curribus iunctis $\&$ bellatoribus impofitis, omnes primò partes perequitant, inter media equitum agmina tela iacietes, atqg ipfo terrore equorum \& Itrepitu rotarum fuperftans hoftis, infolitus'ç eius tumultus, nónúquam Roma- 
norum conterruit equos aliorum' $\$$ ordines plerunque perturbauit. Caterum hi quum fe inter turmas immiferint,effedis defiliunt \& pedites praliantur. Interea aurigæ paululum è prælio excedentes, ita fe locãt vt fi ab holtibus fuis premantur, tutum receptum ad eos habeant:ita mobilitatem equitum, peditum ftabilitatem in præliis præftant,vfu quotidiano \& exercitatione inftructi, vt \& decliui $\&$ pracipiti loco equos fiftere, moderari,ac flectere per temonem, percurrere \& iugo infiftere, 8 in currus quàm ociffime fe recipere confueuerint . Quod genus pugnæab orientalibus fumptum puto, qui curribus falcatis vtuntur in preliis, ex quibus eft pugna haud diffimilis. Multa in his fpes orientalibus fuit . Filiiloleph multo tempore ab hæreditate prohibiti funt curruum falcatorum metu. Sifara noningentos in expeditione contra Ifrahelitas produxerat . Darius eam fpeciem obiecit Alexandro, quos ille laxis ordinibus fuos iuffit excipe$\mathrm{re}, \&$ non impune vagari.Hos in bellis \& rex Mithridates, \& rex Antiochus, aliiqg plurimi nobiliffimi duces habuerunt. Ex equo acies vbi armis ad pugnam inftruere Theffali prius docuere, hos poftea omnes pene fecutæ nationes, equis ad certamina vfr funt, ac in dies magis magífque vtũtur : verum Scythæ non equos pro bello, fed equas malunt: quoniam vrinant curfu non impedito. Colophonii \& Caftaboléfes canibus in bella ductis primas acies inftruebãt, tutifíma ac fidiffıma hominum auxilia, non eris alienæóp ftipis indiga, nec dominorum fidem detreckantia. Dominos enim conftat canum auxilio à craffatoribus fape defenfos, \& pugnaffe eos aduerfus hoftes pro dominis Garamátum regis exemplo quem ducentorum canũ acies obiicientes fefe contra refiftêtes propter bella, ab co quo detinebantur exilio reduxere. Seianus perfidus miles, acerrimos canes vt fibi vni mäluetos \& mites, holtibus verò in acie feros \& immanes habere poffet, fanguine pafcebat humano: Bactros,credo, fecutus, qui canibus humana car ne nutritis obiiciunt fenes: quod quum Alexandri præfectus Siafanor emendare voluiffet, pene amifit prouintiam. Aduerfus Amilcarem Hifpani, non canes, fed boues vehiculis a diunctos in prima fronte locarunt, vehiculáque rhefinæ, ful phuris, ac fæpi plena, vbi æneatores pugnæ frgnum dedere incéderunt:actis deinde \& exagitatis fic bobus, confternatam ac diffipatam hoftü aciem reliquere: neq enim ludibriis precipitióp furore, fed alta conflii meditatione his inuen tis maiores bella tractabant, deferta quogg requirentes, vt elephantos ac terrificas feras etiam ad pugnam cogerent. Equidem de natura elephantorum non operofe tractandum, quoniam in remotis orbis partibus reperiuntur:quę autem ad bellorum vfum attinent, his inftandum. Capti quàm ociffime mitıficantur order fucco, truncos gratiffino in cibatu habent: palmas quoģ celfiores fróte profternunt, atque ita latentium fructum affumunt mandúntque: \& fi pabulum in præfepio pofitúattingi cótingat à mure qué maxime animaliú odere, faftidiüt: in potu quoo haufta hirudine, quam Sanguifugam vulgo appellât, cruciatum maximum fentiunt: \& quod ad docilitatê attinet, minimi Aethiopis iuflu difcunt fubfidere in genua, ambulare per funem, militare, turres armatorú in dor fis ferre, magna ex parte Perfarum $\&$ orientalium regum bella conficientes. Ad acuendos verò cos in praliü, linteú vuæ vel mori fanguine tinctum eis oftẻdūt: 
\& profternant licet acies, proterant armatos, fuis tamen \& muris animantis exigui ftridore ac vifu( tanta eft rerum natura)terrent ur, territi vulneratíque retro femper cedunt, haud minore quandoque fuarum partium pernitie. Semiramis bellum Indis motura, inferior illis elephantorum apparatu,rem excogitauit qua terreret Indos cogitantes nequaquam extra Indiam elephantos effe. Occifis igitur ccc. boum milibus, carnes operariis diftribuens, coria infui fecit elephantorum inftar,quæ poltmodum fơno referta veri elephanti fpecié præ fe ferebant: intus hominem, camelum que fuper quo fedens formam belux duceret, inclufit, hac in loco femoto occultóque acta, ne qua exterius emanare poffent, vtọ́ inde improuifa re perculf, veras beftias exiftimarent: his biennio confectis, tertio in Bactris coëgit. Fuerunt præter aliam infinitam multitudinem currus ad milia centum, erant totidem numero homines fupra camelos cum gladiis cubitorum quatuor:aflefecit auté equos ne eis fimulachris terrerentur,quod \& Perfeus $\mathrm{Ma}$ cedonum rex multis pòft annis in eo bello imitatus. Verum neque illi in bello, neque Semiramidi profuerunt : audita enim rex Indorum tum exercitus magnitudine, tum ingenti apparatu belli, conatus eft excedere Semiramidis vires, accit is maioribus quàm qux erant Semiramidis copiis, elephantorumque fylue ftrium venatione facta, plurimos ad bellum inftruxit, vt verum terrorem quem intulerunt a ficientibus inicerent. Pyrrhi bellis hi primum in Italia viff fuerunt, quippe qui vique ad id temporis inuifos Romanis, numero xx. in Italiam primus inuexit. L. Metellus pontifex victoria de Pœenis captosílii.vt quidã clx. tranfulit ratibus, quas doliorum confertis ordinibus impoluerat. Antiocho regi, A ntipatroauctore, duo fuere celebres in bellicis rebus, cognominibus fuis appellati argue diftincti:etenım nouere ea. Certe Cato quum in peratorum nomina annalibus defcriberet, cum qui in acie punica fortifime prelliatus eft, Sutrum tradidit appellatum, altéro dente mutilato . Antiocho vadum fluminis eis aliguando renuit experienti: Aiax,aliquando dux agninis femper.tum pronuntiatum eft cius fore principatü qui tranfiffet, a afúmque Patroclum, ob id phaleris argëteis, quibus maxime gaudent, \& reliquo omni primatu donauit, ille qui notabatur inedia vitam finiens, mortem ignominix prætulit . Mirus nang his pudor eft, victíg vocem fugiunt victorum,terrámque ac verbenas porrigunt $\mathrm{pu}$ dore. I dem rex quum in præalti fluminis tranfitum elephantos compellere non poffet,nec navium copiam haberet, iuffit ferociffimum elephantú fub aure vul nerari, \& eum qui vulneraffet ftatim tranfnato flumine procurrere, elephantus exalperatus ad fequendun doloris fui auctorem tranauit amnem, reliquif'p idem audendi fecit exemplum. Antiochus quem Eupatorem dixerunt xxxii. in acie contra ludxos produxit, in fubfidiu cuiufque beftix quingentis equitibus deputatis, in fingulis turribus fuere pugnatores xxxii. electi. Hannibal aduerfus Scipionem in Aphrica quum exercitum dirigeret, elephantos octoginta in prima fronte locauit vt auxiliares Gallos \& Lygures, Mauros \& Baleares $P_{\text {oxnis à tergo ftantibus à fuga arcerent, hoftín }}$ que a ciem terrore peruerterent. Cęfare dictatore, tertio confulatu fuo viginti etiâ elephãti cótra pedites quingen tos pugnauere,itemíg totidem turriti cum fexagenis propugnatoribus codé quo 
priores numero peditum \& pari equitum ex aduerfo dimicante, prima inter regem Pyrrhú $\&$ Leuinum confulem apud Heracleam Campanie vrbem, fluuiumóp Lyrim pugna commiffa, introducti inter concurrentia agmina elephan ti forma truces, odore graues, mole terribiles, vt videre Romani, nouo pugnandi genere circunuenti,\& territi,equis maxime pauitantibus diffugerút:fed poftquã Minutius Cencurio quartæ legionis primus haftatus protenfam in fe, haud improprie belluæ manú appellatam gladio defecuit atgi in fuos fruire coégit, cius immoderato difcurfu perturbari ac permifceri ordines copere, finisóp pugnæ beneficio etiam noctis impolitus eft. Secunda inter Pyrrhü eundem \& Ro manos pugna fuit P.Sulpitio, Decio Murena confulibus,vbi elepháti qui prima pugna vulnerari ato in fugam poffe cogi deprehenfi fuerant, fubiectis inter poRteriora \& molliora ignibus exagitati, ardentes infuper machinas furore trepidi circunferentes exitio fuis fuere. Tertia inter Pyrrhú \& R omanos pugna fuit Curio Dentato confule, vbi elephantibus in fubfidium miflis Romani affueti iam pugnare cum belluis, cum malleolos ftuppa inuolutos ac pice oblitos infuper aculeis tenaces praparauiffent,eośǵ flagrantes in terga belluarum turréfque vibraffent, non difficile furentes, ardentes'́p belluas in eorum excidium quorum fubfidio fuerant retorferunt: Eofdem aliquando Velites à volitando dicti vel à græco $b_{\alpha}^{\prime} \lambda \lambda d u$, id eft,iaciëdo, quod genus militiæ paulo antè repertum fuerat, $\mathrm{fa}_{2}$ brili fcalpro.inter aures adacto, retrò agebant, $\&$ quúà fuis regi non poffent, necabantur. Id genus occidendx bellux cum opus effet, $\mathrm{Hafdrubal} \mathrm{Hannibalis} \mathrm{fra-}$ ter primus inuenit, vnumg tis per oculú recepto : ipfi tela cæteráq́ quæ hæferint corpori, olei potu decutiunt. Contra bos diuerfa refiftendi ratio fuit,bini equi cataphracti ad currú iungebantur; quibus infidentes longiffimas fariffas in elephantos dirigebant: muniti enim ferro, nec à fagittariis quos elephanti vehebant lædebãtur, $\mathcal{Q}$ ipforum impetum equorum incurfatione vitabát. Cataphractos alii mittebãr milites,ita tamen vt aculei ferrei vndecunque in eorum armis prominerent, ne venientem in fe militem fine vulnere elephanti poffent excipere. Alii velitum aciem his obiecere, dato eis præcepto vt quàm primum elephanti ab hoftibus acti fpatio intermiffo reciperentur, ad elephantorum impetum vel retrò, vel pòrt, vel ad la tus contunderent équitatum. Permulti quoq quo nihil tutius erat, eminus fundis cos per quos regebantur elidebant, fićp in fuos plerunque lapidibus adacta bellux, \& a miffis rectoribus fruire cogebantur. Venientibus nonnulli quafi terrore quaterentur, continuas detrahebant cohortes: manipulifque inter fe diftan tibus fpatium dabant, cumque agminis medium attigiffent, circunfufa militum multitudine obruebantur, illafíque vnà cum rectoribus aliquando intercipiebantur. Camelos Vitelliani in terra Aphrica, \& aliquot clari etiam duces in aci em produxere, qui ante legiones pofiti, aut cum legionariis mixti,cum cominus pugnarecur, hoftiü fxpe acies puertere. Crofus numerofo ac præpotêti hoftium equitatui eos obiecit, quorum nouitate afpectus, odore, atque horrore trépidan tes equi,nedum equitum, verum etiā peditú fuorú acies peruerterunt,vincédosóp hoftes prębuerunt. Cameli ité cư Scipióne Antiochü deuicere, $8 \mathrm{cum}$ Archelao 
item ad Orchomenum \& Cheroniả conferuiffe camelos memoriæ proditum eft. Horum qui in pugna præettent nonnulli gibbum duplicé in dorfo habent, duos quogs in bello in certamen fagittarios ferunt dorfo, inuicem contrarie refi dentes:alterum à fronte ver fus holtem, alterum contra perfequentem pugnátes. Tentarunt etiam Poni,vt Lucretius inquit, tauros in munere belli, Expertíg fues fcxuos funt mittere in holtes, Et validos partim præ fe mifere leones, Cum ductoribus armatis fcæuif'o magiftris, Qui moderarier his poffent vinclífque tenere. Nequicquàm quoniam permixta cæde ruentes Turbabant fcæui nullo difcrimine turmas Terrificas capitis quatientes vndique criftas: Nec poterant equites fremitu perterriti equorum Pectora mulcere \& franis conuertere in hoftes

\section{ROBERTI VALTVRII}

A D I L L T T E M HER OA SIGIS-

mundum Pandulphum, de re Militari

Liber Septimus.

है)

De Religiofis, hoc eft, infauftis uel infamibus menfium quorundam diebus ac tempore ad bellum idoneo

Capi it

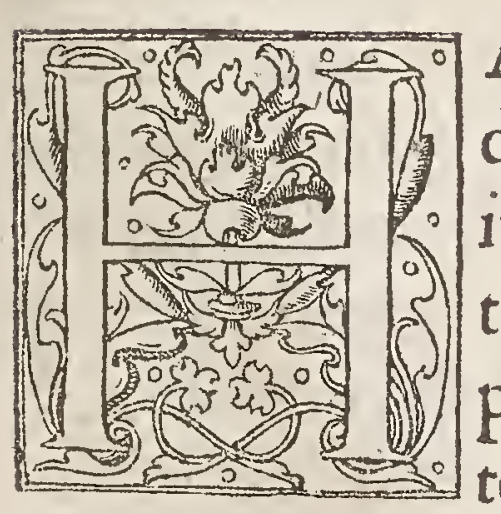

Actenus, Sigifnunde Pandulfe, de inftruenda acie fecundum diuerfos ducum altus, varrálque rationes de impugnatione hu iufmodi atque expug natione, fi quando vfus tulerit, ad præfen tiú ac pofterûm inftructioné dicta fint : deinceps vt erat propofitum, de religiofi temporis diebus ac menfibus pręfenti ma teriæ fubiacentibus, quos infames, atros, vel infauftos in xi.cómentariorum grammaticorum Nigidius appellauit, pauca memorare exempla forfan nó incongruú erit, feu recte feu perperam id fiat. Menfis itaque octobris pridie nonas Romanos primo quidem à Cymbris fub Scipione exercitu priuatos fuiffe conftat, poftea verò imperatore Lucullo Armenios \& Tygranem vicifle. Lucullus enim in Armenia cum decem milibus peditum \& mille equitum aduer us Tigranem qui centum quinquaginta milia hominum in expeditione haberet hoc die profectus cú effet quo Scipionis copiæ confumptæ funt à Cym bris, \& quidam dixiffet Romanis illum diem infaftum effe atque formidabilem; Pugnemus igitur, in quit, hodie impigre, quo hunc quoog Romanis diem ex atro 
\& trifti hilarem iocundúm $q$ reddanus: ato quum pugnaffet illófque fugaffe Romanos quinque leto interceptos amifit, hoftium verò fupra centum milia oc cidit: Menfis nouembris clades Barbaris magnas euidenter intulit: hoc nang menfe Alexandri regis ductoresad Granicum vicit, \& Carthaginenfes feptima \& vigefima die apud Siciliam à Thy meleóte victi funt, fub quam diem llion cat ptú videtur ficuti Ephorus, \& Callifthenes, \& Damafches, \& Philarchus perhi bent. Bcootiis quidem contigit menfis Ianuarii quinta die binas præclaras $\&$ infignes victorias coepiffe, vtpote quibus Græciælibertatem reftituerent. Februarius Graecis haudquaquam æquus extitit, huius feptimo die pugna cũ Crano$n e, a b$ Antipatro victi funditus periere, $\&$ in Cheronia âtea aduerfus Philippum haud foeliciter pugnauere. Hac eadem die februarii eodemóp anno qui cum Archidamo tranfiere in Italiam, ab illius loci Barbaris foede confumpti funt. Vige fimamnonam Carthaginenfes obferuant, vt qux plurimas eis \& maximas cala mitates intulerit.Menfis Martii fexta quidem die Marathone, tertia vero in Pla tæis frmul \& apud Michalem Perfæà Græcis deuicti funt: quinta vero \& vige fima die, Arbelis Athenienfes nauali pugna circa Naxon victores fuere, fub ipfam præterea eiufdem menfis vigefimam diem Macedonum Athenienfes præfidium cepiffe, quo die myfticoluftrant Baccho. Apud Romanos praliares ctiam dies funt,quiab iuftis non fegregantur: frquidem iuft funt cótinui $x x x$. dies, quibus exercitui imperato vexillum rufi coloris in arce pofitum eft : præliares autem omnes, quibus fas eft res repetere, vel hoftë laceffere : eligendi enim ad pugnandum diem Romanis tunc fuiffe licentiam conftat, fi ipfr inferrent bel lum. At cum exciperent, nullum obftitiffe diem quo minus vel falutem fuam, vel publicam defenderent dignitatem : vitabant $\&$ ad viros vocandos dies qui effent notati rebus aduerfis. Dies auté qui funt poftridie Kal. nonas, idus, quánquã ad ré fane militaré nihil attinere notet Varro, fed ad folas actiones relpicere priuatas, ad omnia tamen maiores noftri cauendos putauerunt : quos etia m atros, velut infaufta appellatione da mnarunt: ob hanc caufam dictos habitośg atros Seruius Flaccus fcribit, quòd vrbe à Gallis Senonibus recuperata L. Actilius in fenatu verba fecit, $Q$. Sulpitium tribunum militum ad Alliam aduerfus Gallos pugnaturum, rem diuinam dimicandi gratia poftridie feciffe, cum exercitu populi Romani occifum . Item a pud Cremeran multíque aliis temporibus $\&$ locis polt facrificium die poltero celebratum male ceflife conflictum, \& poft diem tertium eius diei vrbem præter capitolium ca ptam fuiffe, quàm plu. résque alii fenatores recordari fe dixerunt, quotiens belli gerendi gratia res diuina poltridie Kal. nonas, idus populi Romani facta eflet, eius belli proximo deinceps pralio rempublicam male geftam effe, túmque ea re per fenatum in pontifices reiecta vt ipfi quid videretur ftatuerent, pontifices decreuerunt $v t$ hi dies negs pręliares, neqp puri,neg comitiales effent, nullǘp his diebus facrificium recte futurü: quod nec doctiflimú poétáa Ouidiú pręterit, primo Faftorú dicéten, Vendicat aufonias. I unonis cura Calendas.

Idibus alba loui grandior agna cadit. Nonarum tutela adeò caret omnibus iftis. 
Ne fallare caue proximus ater erit.

Omen ab euentu eft illis : nam Roma diebus

Damna fub aduerfo triftia marte tulit.

Hac tibi dicta femel totis hærentia faltis,

Ne feriem rerum fcindere cogar erunt.

Ante diem tertium nonas octobris $\&$ ante diem fextum idus nouembris nihil in repub. maiores noftri geri voluerút.Itą̧ per hos dies nó cú hofte manus con ferebantur, non aliud quodcung in repub.non exercitus fcribebantur, non comitia habebantur, non aliud agebatur, nifi quod vltima neceffitas exegiffet adminiftrabatur. Ante diem quoq quartum Kal. vel nonas, vel idus,tanquam inominabilem diem plerigg vitant, cuius obferuationis an religio vlla fit,memorie proditum nihil inuenio, nifi quòd Claudius a nnaliú quinto, cladem illá pugnae Cannenfis vaftiflimam factam dicit ante diem quartum nonas fextiles. Ante di em infuper xv. Kal. fextiles à Romanis. haud procul fluuio qui Allia nuncupatur ac xi. milibus paffuum via Sabbaria ab vrbe diftat, inftantibus Gallis male pugnatum eft, fufáp extemplo Romana acies, ad ripam fluminis quo finiftrum cornu defugerat à Celtis tâta ftrages facta vt vrbi fubito fubfecuta ruina, \& patrữ cædes, atọ capitolinæ arcis obfidio. Eorum fuga verò nocturna fuit, eo tem pore quo commiffa eft, pugnatumóp elt circa xftatis finem circáq plenilunium, quo die ingens \& antea clades in Fabios ad Cremeram flumen inter vrbé \& Ve ios acciderat : fex \& trecenti nanque patritii,milites omnes ex eodem genere eademọ́ familia vna die à Veientibus carf funt. Pompeius etiam fugienté Mithridatem ad prælium compellere cupiens, noctis tempore expugnationem fieriftatuit: quem Pompeius infecutus, vt luna tunc orta à tergo Romanis erat, Mithri dates exercitus longitudine vmbrarum, proximitatem hoftium ratus, cuncta in irritum tela fudit: illi inermes aggrefl, fine labore certaminis vicerunt, \& caftra ceperunt. Hannibal apud Cannas hac militari temporis ratione $\&$ aftutia vfus non noctis tempore, fed orto iam fole aduerfus Romanos dimicaturus; ita fuos ad pugnam ftruxit vt contra folem orientem exercitum romanum pugnare co geret, contráque Eurum ventum quem noftri Vulturnum vocant: nam in morem ardentis fulminis mane more fuo perflare folitus tunc flabat, rapidúmque puluerem ex patentibus torridisọ́g campis eleuabat, \& fupra Carthaginenfium phalanges ad ora Romanorum impellebatur : fićg cum Euri vel Vulturni véti adiutorio, ac fulgoris oculos hoftium perftringentis, Hannibal illam memorabilem \& immortalem Cannenfis pugnæ gloriam fibi adeptus: vbi ipfe quum effet crudeliffimus Romanífue infętiflimus, tanta tamen inimicorum atrociffimorum cæde fatiatus, parci iuffifle perhibetur. Par poftea ratio Romanos iuuit. Marius enim \& Catullus coff . contra Gallos pugnaturi, virtuti dolum addiderunt: primum nebulofum nacti diem vt hoft $i$ inopinanti occurrerent, tum ventofum quoque vt puluis in oculos oráque ferretur; tum acie conuerfa in orientem, vt, quod ex captiuis mox cognitum eft, ex fplendore galearú ac repercuffu ex aduerfo vifum eorum puluis oppleret, $\&$ fplendor hebetaret, totam terribilem Gallorú multitudiné minima Romanorü clade profligauere. Eft etiam 
preterea fua fabbatifni ratio Iudxis, qua quum eis nefandum fit quicọ feriæ rei facere, Diuus auguftus Vefpafranus adortus eos fuperauit. Fofdem alia ato huic diffimili ratione fubegit Antiochus: is enim quam Hierofolymam obfide ret, Iudxis ad maxima illa folennia petentibus dierum feptem inducias, non eas modo dedit, lèd etiam tauris auratis cornibus odoribusóg a pigmentis affatim preparatis, ad portas vfque pompam egit, atque facrificio illorum facerdotibus tradito,ipfe in caftra rediit: Iudæi verò ad mirati,continuò fefe poft folénitatem dedidere. Eft \& aliis gétibus alia quog temporis ratio. Nam Mylciades quum Perfas triduane religionis ocio teneri didiciffet,improuifos inuafit $\&$ obtinuit. Athenien les quum fubinde à Lacedæmoniis infeftarentur, diebus feftis quos fa cros Minerux extra vrbem celebrabát, armis vefte celatis, peracto ritu fuo,non ftatim reuerfi Athenas, fed potius inde raptim acto Lacedæmonem verfus agmine,eo tempore quo minime timebatur,agros holtium quibus fubinde prade fuerant vltro depopulati funt. At heniefes fimili modo vbi aduentare $D$ arium compererunt, quanquàm auxilium à Lacedxmonis popof ciffent, tamen quum detineri Perfas quatriduanæ religionis ocio compertum haberent, fpem religionis occafione fumentes, inftructis tantum decem milibus ciuium $\&$ Plateen fibus auxiliaribus mille, aduerfus fexcenta milia holtium campis Marathoniis perruperunt, Mylciade eius belli duce, qui celeritate magis $q$ virtute fretus, alacri latis expeditione prius hofti cominus hęfit, quàm poffet expedito fagittarü ictu propulfari. Tanta in co bello diuerfitas certádi fuit,vt ex alia parte viri ad occidendum parati, ex alia pecudes ad moriendum praparatæ putarentur. Du centa enim milia Perfarum apud campos Marathonios ea tempeftatececiderunt. Germanorum etiam animos quum fortilegarum vaticinia mulierum obtunderent, ve puta qux fluuiorum curfus, vortices, ftrepitúǵp coniectantes futura prædicerent affererentóp frue Ariouifti eorum regis inftituto, fiue lege non effe fis fuperari eos fi ante lunam noua m contenderent, Cæfar fatius effe duxit cir ca tempus inuadere, quàm idoneum illis tempus expectando cedere: facto itac in eorum munitiones \& tumulos impetu, non antea ftimulare ac inceffere defti tit quàm ira deducti pugnam capefferent. His hac de re denique in fugam verfis, Cxfar ftadiis cccc. ad R henum vfque perfequens, terram omnem cadaueribus fpoliisóg referfit. Ariouitus cum paucis præueniés, R henúm traiecit: cęforum numerum $\mathrm{xxx}$. milia fuiffe perhibent.

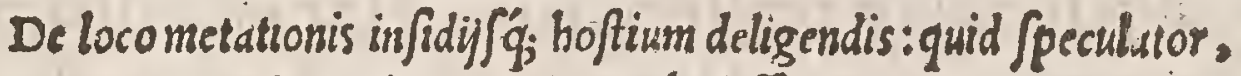 or quid explorutor, in quoó; differant}

Cap.

II.

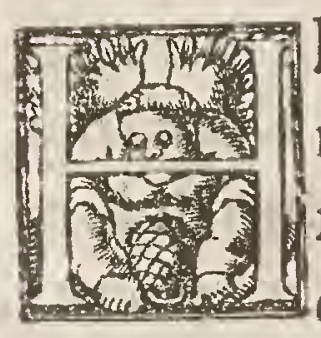

Ic deinde locus caftris idoneus deligatur neceffe eft: ea enim res maxi me rationis eft bellica, vt hoftis hoftem ri petierit è fublimi repelli non poffit, aut fane collectis viribus excipi: fue igitur ex itinere qui12. efcendum fit, frue caftra caftris obiicienda, in deligendo loco hanc ra tionem haberi oportet, vt locus arte vel natura munitus fit, \& necelfariis fuffici ens: arte, veluri foffa, vallo,vel aggere:natura munit us, vt funt tumuli afcéfu dif ficiles,colles ardui,locáq, edita \& afpera qua verrucas Cato appellauit, vt loca fluminibus vel paludibus cincta, neceffaris fufficiens, vt materies, aqua, frumen 
tumǿ̧̣ de proximo peti poffint. Quòd fi \& horú cōparatio habénda fit, loca mit nita $\tilde{q}$ opuléta viros illuftres quęfiffe magis inuenio, quod \& Mario venit in fuc ceffum. Is enim tertio cófulatu fuo, bello Cy mbrico quú collé occupaffet qui cá: po \& fluuio imminebat, vbi hoftes fe diffuderant, quúmque aqua exercitui deeffet ad potandum, querelifque omnium coargueretur, aquam in profpectu effe refpondit, led eam ferro vindicandam. Primis itaque calonibus in pugnam cum clamore ruentibus, fublecutus exercitus, mox iufto certamine compoftis agminibus, bellum geftum eft, \& vicere Romani . Iulius Cæfar loca eminentia in omnibus approbauit, qua fi negaffet facultas, irrigua praferebat. In uenitur etiam Gallicis expeditionibus aliquandoiuxta fluuium Axonam caftra pofuifie, qux res \& latus vnum caftrorum ripis fluminis muniebat, $\&$ poft cum qux crant, tuta ab hoftibus reddebat, \& commeatus vt à proximis ciuitatibus fine periculo aduehi poffent, efficiebat.Cn. Pompeius in Capadocia locum delegit caftris ponendis editum, ab imo paulatim procliué: vnde adiuuante procliui impetum militum, facile iplo decurfu Mithridatem fuperauit.Q. Metellus in Hifpania citeriore in caftra hoftiü humili loco pofita ex fuperiori parte flumen immifit, \& fubita inundatione turbatos per difpofitos infidiatores cecidit. Tanto itaq locus vilior iudica bitur, quanto fuerit editior: in fubiectos enim ve hementius tela torquentur, maioríque impetu pars editior obnitétes propulfat, 2 impellit, quum hi qui humili funt loco caltrametati,duplex fubeant cum loco primum, deinde cum holte certamen.

De oppofitiloci pofitione, multitudine, uoluntate, ftudijs, ac confilijs.

cap. ill. T quoniam pracellents eft ducis munus, tum pace,tum maxime bel 1. 10 lo holtiun regionem exploratam planég cognitã habere, ne omncs 1) ordines temere vagari errarég contingat, confiderandum quoqs op- pofita ipfus regionis qua fit naturalis pofitio, rupibus ne inuia aut fluminibus cincta,vel paludibus impedita: inhabitantium preterea multitudines quantæ, qux voluntates, quæ ftudia; quæ confilia perquirédum: firmis, an infirmis, natura vel arte munitis prefidiis contineantur: qua fingula in ducis con fiderationem deducta, fi minus per fe præetare queant, alios quorumcunque locorum peritifimos adiungere oportet. Hæc autem tutè ac commode poterit, fi ex vtrorumq amicis ciuitatibus atq mercatoribus futuri funt qui explorent. $\mathrm{Ci}$ uitates enim, omnes qui importent aliquid quàm liberaliter femper accipiunt. Sunt qui hac per hoftes, aut per fuos, vel etiam per feipfos imperatores quidan fcrutati funt.M. Cato in Hifpania, quia ad hoftium conflia alio ingenio peruenire nó poterat, iuflit trecétos milites fimul impetum facere in ftationem holtium raptumós vnum ex his in caltra perferre incolumem, tortúfque ille, om nium fuorum archana confeflus eft. Iulius Cæefar miffis equitibus his quos in agris reperiffet, hoftium res $\&$ confilia fcrutabatur : \& vt concordi corú fententia reperiffet, quid agendum in confultatione deliberabat, \& fcitè ac fapienter id quidem. Speculatores deinde exploratoreśǵp de fuis mittere vniuerforum ducü in. ftitutum effe: \& quanquam duo hæc vfus fape confundat, difcernit tamen ratio, \& doetifimorum hominum auctoritas, vt fpeculator is fit qui hoftilia filen- 
rio perfpiciat, quú explorator clamore peccata cognofcat . Explorare enim anciguos pro exclamare legimus vfos, fed poftea profpicere, \& certum cognofcere copit fignificare. Per fe quog nullo extrinfecus adminiculo, explorandi modus quidam eft, quo \& ipfi duces vfi fæpe perhibétur, ficut Aemilius conf. bello Etru fco: hic enim dux apud oppidum Coloniam, multitudinem auium procul contemplatus citatiori volatu ex fylua confurrexiffe, intellexit illic aligd infidiarum delitefcere, quòd \& turbatx aues \& plures fimul euolarent. Pramiffis igitur exploratoribus, decem milia Coloniorum comperit, excipiendo ibi Romanorum agmen in itinere,eaq́q alio quàm expectabatur itinere latenter miffis legionibus circumfudit. Thianicus Horeftis filius fimiliter quum audiffet iugum ab holtibus munitum, præmifit fci citaturos quid rei foret, referentibusó non effe verum quod opinarentur, ingreffus iter vt ex co loco vidit magnam vim auium fimul euolaffe, arbitratus eft ibi hoftium agmen refidere, itaq; circunducto exercitu illufit infidiatores. Per fefe aute hoftium res fcrutati funt Alexander, Sertorius, $M$. Volufus, ædilis plebis \& Maximianus quóq qui cum Diocletiano poltea imperauit, $\&$ mutaro habitu quidem. Iulium verò $C æ$ farem $\&$ habitus mutatione \& per alium, \& per fefe etiam exploraffe conftat. Nam quum Britanniam expu gnare illi mens effet, \& infulæ ftatum moréfque hominum percunctari, explorafle per C. Volufenú, vt cómunis habet hiftoria, funt tamé non ignobiles auctores qui Cæfarem per feipfum portum \& nauigationem, \& acceffum ad infulam exploraffe confirment: \& quanquả illi fortunam fuam experti forte probauerint, omnino tamen audacia \& temeritatis mihi maxime efle videtur, con filium \& fubfidium totius exercitus periculis obiicere, quum hi omnes aut vitæ fue, aut aliene necis cupidi fint, qui huiufmodi vel ipf fuftinuer int, vel alios perpeti coëgerint: maxime quä id quod Scipio et Valerius Lauinus coff. \& Xerxes pro fua nobilitate memorabile pofteris reliquerüt exemplum, non lępe fed pertarò contingat. Ille enim captus tres Hannibalis exploratores circumduci per caftra iuflit,oftéditóg his totum exercitum nihil de hoftibus percunctatus: mox

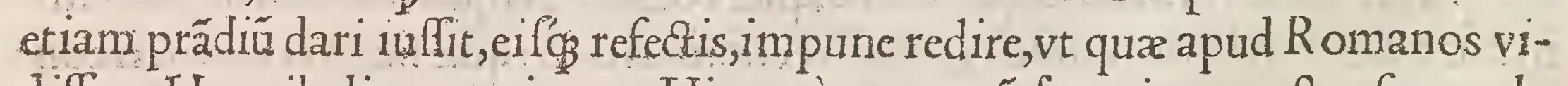
diffent Hannibali renunciarent. Hic verò quum nô fecus intra caftra fua explo tatorem holtium deprehendiflet, magnámque copiarum fuarum fiduciam haberet, circunduci eum iuffit, terrendíg holtis caufa exercitum fpeculatoribus co rum quotiens voluiffet patere. Poftremo Xerxes fimiliter Darii filius quos in ca Itris f peculatores Græcorú deprehendiffet nullo affecit fupplicio, quin vbi iuffiffent eos circunduci, vt audacter intuerentur exercitum cuius gratia venerant, libere quód voluerunt dimifit incolumes. Præterea non vfquequaque etiam obuiis $\&$ tranffugis quibufque credendam falutem fuam plurimorú periculis edo cemur. Babylon enim ingens, quam exercitus capere nulla vi poterat, Zopyri arte capta eft: fe nanq plagis affici, auribus'g ac naribus mutilari confulto iuffit, ac deformis veluti tranlfuga vrbem ingreffus, fe cum omnium audientium intuentium lum cohortatus forti animo vt eflet, ac monia tueretur patereturóg fe vnà cum fuis recentiore ira \& iniuria laceffitum, bellum contra Darium inire. His nan- 
que $\&$ aliis huiufmodi Babylonii decepti fraudibus, fummam gerendarum rerum omnium curan \& poteftatem liberam Zopyro tandem omnium tranffugio tribuerunt: augendam verò ad fidem fxpe is profligauit hoftes,ac poftremo creditam multitudinem in hoftum manus duxit : fic vrbs Babylonia, qux vi non poterat, fraude capta eft. Quum autem Darius poftea punicum malú quod dam, $\&$ id quidem permagnum aperuiffet, quærenti cuidam quidnam tantum habere vellet, quanta effet granorü multitudo, Zopyros fe velle refpondit. Erat autem Zopyrus non modo comes illi, verùm vir tum probus, tum amicus,qui vbi fefe iple cecidiffet,narémque \& aures obtruncaffet, \& ita creditus Babyloni os fefelliffet ac Dario tradidiffer vrbem, fxpe dicebat,Darius,Zopyrum malle integrum quàm centunı capere Babylonias. Iulianus quoque in Parthos expeditionem agens, quum in defertum primo captiuorum habuiffet ductorem,poftea quidam fenior tranffuga fub fchemate proditoris ei fe compendiofum iter oftendere pollicitus, quum triduò ambulantes ad maiores fol itudines perueniffent, in infidias inciderunt: \& mox quidem illum fenem fuftibus occidere,confitentem fe hoc pro patrix libertate feciffe, \& libenter afpera quxque pati velle: in quo bello imperator concidit, \& exercitus in conditionem adductus eft. $\mathrm{Va}$ lerianus item Auguftus doctrina \& eloquentia clarus, ingêtem exercitũ in Perfas agens; $\&$ incaute quidem fuorum ac aliorum ductu à Sapore Perfarum rege captus, ignominioła apud Perfas feruitute confenuit,donec damnationê fortitus vt ipfe accliuis humi, regem afcenfurum equum non manu, fed dorfo fem per attolleret. Ad poftremum quum nulla præda hoftibus pulchrior nec præftantior quàm exploratorum, vel fpeculatorum, fic capi eos contıngat,quod fape fit,quum perfequantur quodcunque fe illis peruium obtulerit, non vfque ita fides habêda illis vt cuftodia negligatur, fed inftructa femper omnia et parata effe oportet, æxque ac fi hoftem inftare vel imminere nunciatum fit.

\section{Caftrorum forma officiorum'; caftrenfium ritus}

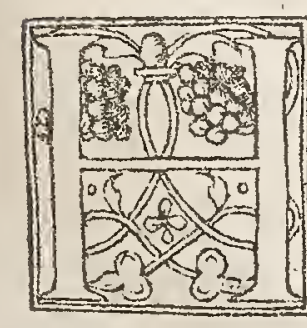
Is pro loci qualitate hinc inde rite peractis,caftrorum formam fecun dum maiorum difciplinam officiorứó caftrenfum ordinem, ritus, ac rationes ex reliquo profequamur,quattuor nanque anguliseorun dimenfio defignabatur.Nam \& fabrorum multitudo \& ferramentorum copia quæ vfus extructionis pofcit fequitur exercitum, $\&$ interior quidem pars caftrorum tabernaculis diftribuitur, ambitus autem eorú extrinfecus muri faciem praferebat,ordinatis etiam turribus pari fpatio difpofitis, quarum interualla telis atque baliftis alijfog machinis faxa torquentibus, omnıbúfque inftrumentis miffilium complent, vt cuncta fcilicet iaculorum genera in promptu fint. Ex omni denique muri parte, quattuor portas ædificant, tam iumentis aditu faciles, quàm ipfis fi quid vrgeat intro currentibus latas. Intus autem caftra vici fpatis interpofitss dirimunt, mediáque caftrorum tabernacula collocant, $\&$ inter hæc imperatoris ac ducis maximi mediü templo fimilimum,vt quafi repen tina quxdam ciuitas exiftat, forúm que $\mathcal{Q}$ opificum ftationes, $\&$ fedes militum, primatibus ordinúm que principibus, vbi fr qua fit inter illos ambiguitas iudicet: ipfe vero ambitus, $\&$ omnia qux in eo funt, multitudine fimul $\&$ fcientia, $\&$ 
fabricantium opinione quum opus eft dicto citius communitur, qui fi res vrge at, folla extrinfecus cingitur depreffa cubitis quattuor,paríque fpatio lata. CaArs erian fic munitis aut muniend is armata cuftodia deefle non debet. Numerus cohortis extimatione nunquam inferior, per fingulas portas fi pericula immineat ducis arbitrio augetur, híg per vic es quaternis horis die noctúg fibi fuc cedunt. Horarum autem difcretionem veteres aqua $\&$ vmbra denunciarunt, $\&$ ad pofteros in hunc modú nofcenda tranfiniferunt. Duo nanq illis vafa erant ænea, fue vt Clefbius Alexandrınus primum inftituit ex auro perforata,aut ex géma terebrata: ea enim nec terútur percuffu aquę,nec fordes recipiunt vt obtu rentur. Non vbique tamen ea vlui : nam alibi alterifundus erat in modum cleply rę foratus, et quod erat integrū vacuú fubiecerūt, pleno aque altero fuperpo fito : alıbi luperioris vafis vacui fundus erat fimili modo perforatus, alterü quod fubicce üt integrum ac aquæ plenum, altero fuperadditc $\&$ aquam contingente. fed aqux meatu antè hinc inde munito, quæ vbi primum cœpit furfum vel decrlum emergere, vel effluere, vel influere, mox munitione fubducta pmiferunt influere vel eftluere, fluxitque in noctis ipfus $\&$ fequentis ipfus drei finem, atque id $v f \$$ ad principium noot is fecundę: fic fibi menfura temporis in aqua de ill fluxu lucepte quantitate pofuerunt, ac in partes quas xii. fub fida dimenfione diuifa decreuerunt in ipfo ciclo conftituere, \& diuifionibus annotauere, vt cerri effent horarum numeri, in quos eas ingredi, morari \& egredi nunciarent. Tuncóp poft Aegyptiorum retrò maiores quos cóftat primos om nium cælum $\&$ temporis momenta fcrutari $\&$ aufos metiri, fue Horus ille fuerit quem folem appellant, \& vnde horæ dicł funt, fue quòd Horus A pollo fit qui præ cæteris horas inueniffe perbibetur, Scipio Nafica collega Lenati priø

mus apud noftros aqua diuifit eas æqua noctiu ar dierum idģ horologium in hunc modum fub tecto dicauit Anno vrbis quingentefjmo quadragefimoquinto. 


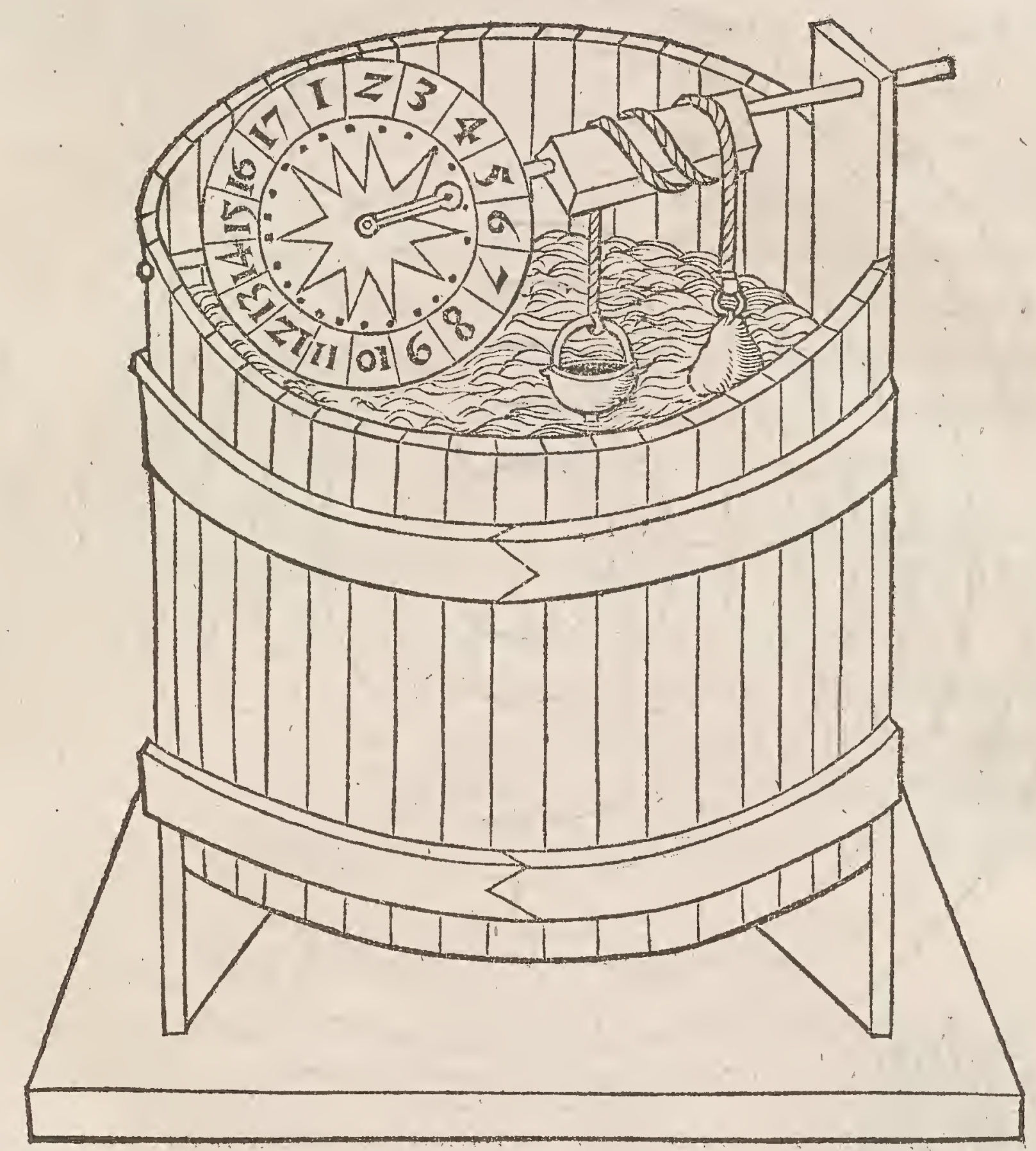

T. प. Mbrarum autem rationé apud Græcos Anaximenes Milefius Tha10.5 letis difcipulus inuenit,primusóp horologium Laced æmoniis often19. dit: hęc ipfa ratio interdiu, modo horofcopi inftitutio die nubilo nö

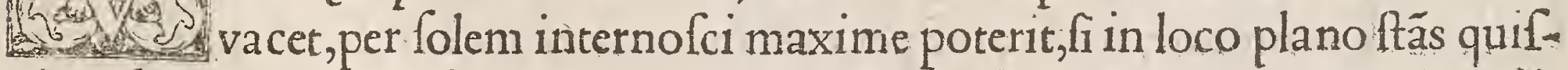
piam dorfum contra folis rectitudinem pofuerit, fuíg vmbram corporis pedibus metietur à xxilii. die menfis decembris cum ianuario inchoando, in quo eft numerus in fua hora prima, $\&$ in decima pedum xxix . Nam decébrem cum ia unario in horis caufa difpar adiúxit, cum linea fimili alter augeatur, alter vero decrefcat. Nouem brem \& februarium ratio temporis per horas duxit equaliter. October martium concordibus vmbris afciuit, \& parem fibi fecit : feptembris $\&$ aprilis dies horis fimilibus conferuntur, auguftú niaio par folis curfus æquabit, iunius \& iulius horarum fibi æqua fpatia contulerunt, vt de fingulis menfibus in huiufmodi circunfcripta numerorum defcriptione continetur. 

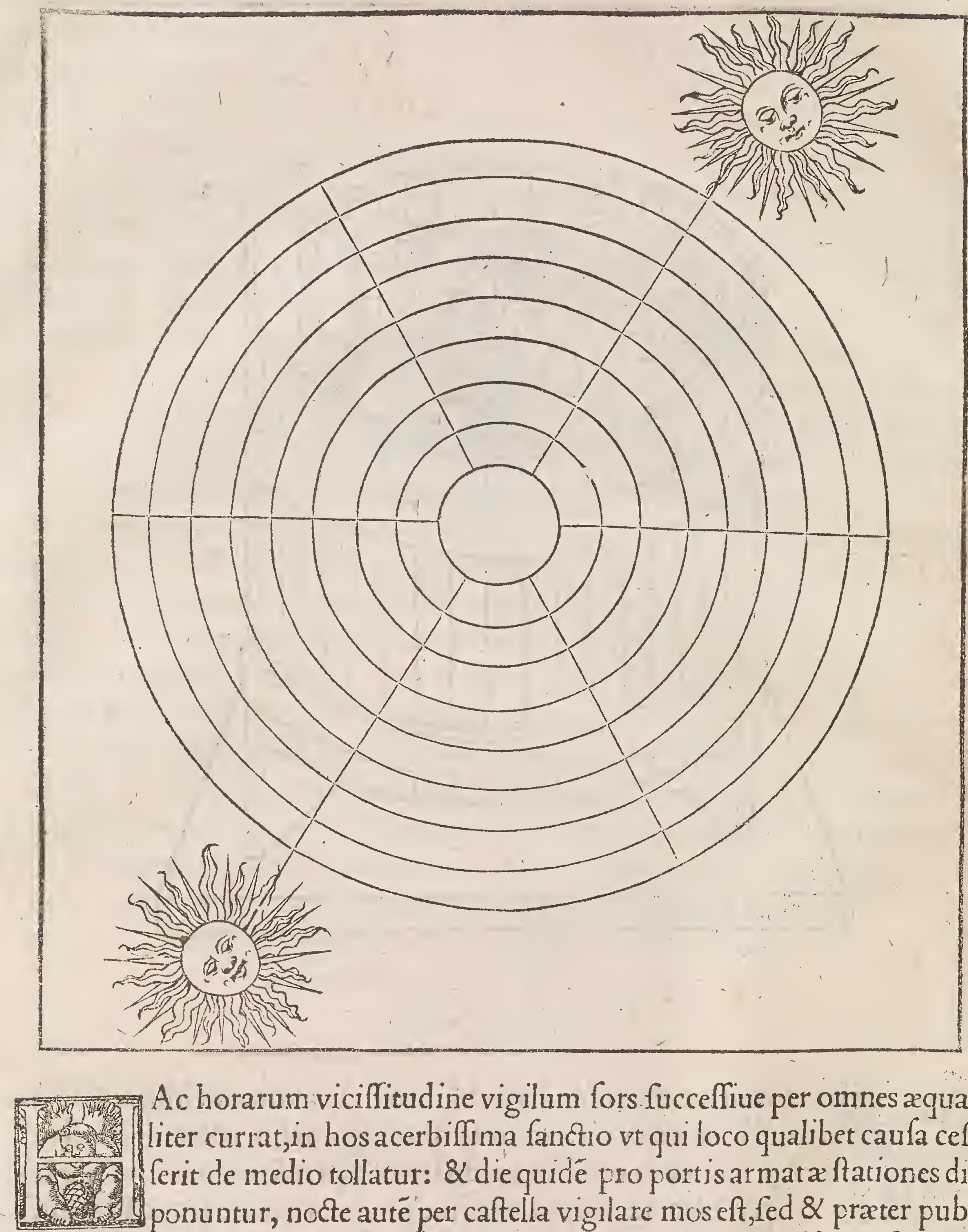

Ac horarum viciffitudine vigilum fors fuccefliue per omnes aqualiter currat, in hos acerbiffina fanctio vt qui loco qualibet caufa cefferit de medio tollatur: \& die quidé pro portis armat 2 ftationes dif

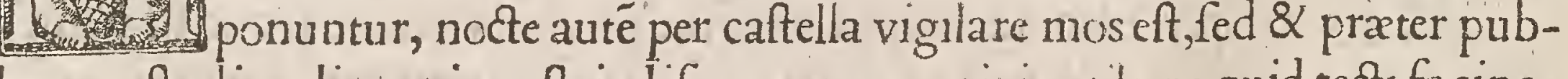
licas cuftodias aliquot in caftris difponere, non erit iputile, ne quid tect facinoris admittatur. Brutus enim ex captiuitate Grxcorum quam pernotos fibi vigiles euocaffet totum exercitum fnú in caftra Græcorum induxit, hoftélque cófecit: ideo prudétioribus confuetü fuit vt circitores caltris præficerét, quos olim circuitores appellabant, qui vigilias circuirent ac renunciarent, li quos immerfe ritculpa vel aliquando per fe vigiles reuilere. Titus Hierofoly morum obfidione primam vigiliam noctis per caftra \& caftellorum fpacia circués explorabat: fecundã lecüdo à fe principi Alexandro permiferat, tertiam agminum ducibus. Alcybiades Athenienfis ciuibus fuis à Lacedæmoniis obfeflis, veritus negligentiam vigilü, his qui in ftationibus erant denúciauit, vt lumem obferuarét quod 
nocte oftenfurus effet ex arce, \& ad confpectum eius ipfi quoque lumen attollerent, quo munere qui ceffaffet, ponam paffurum : dum folicite itaque expectaretur fignum ducis, peruigilatum ab omnibus $\&$ furpecta noctis periculum euitatum eft. Iphycrates A thenienfum dux, quum fubaduentu hofiu ipfe vigilias circuiret, vigilem quem dormientem viderat teli cufpide perfodit, quod inclemêtius factum nonnull is increpantibus, Qualem inueni,inquit, talem reliqui. His itaque omnibus frmul fomnum \& excubiarum \& vigiliarum tempora buccinæ fignificêt, nec quicä præter ordinem fine ducis geratur edicto: funmo manè officiis p religione celebratis, mox milites ad centuriones, ad chiliarchos illi veniant,cum quibus ad fummum omnium ducem vniuerforum ordinum principes,quibus ille figna det, aliáp̧ pro regotio præcepta perferéda fubiectis, quæ cum in acie fuerint recognofcant: $v t$ fi res exigat incurfibus, item' $q$ reuoca tionibus vniuerfi oblecundent $\&$ pareant. Signum ab imperatore dandú quod deferant fubiectis, quod nemo non fciat in ordine conftitutus, nemo fciat externus,eiufmodi eft, quum quid memoriter tenédum indicitur, vti in bcllo Marii, Bardeus:in Syllæ, Apollo Delphicus in Cæraris, Venus genitrix : Græcorum Chrittianorum Kyrieleefon \& alia atque alia, prout cuique vifum eft:id enim quo fe holtibus difcernant, maximi v fus in bellis eft, fue in luce pugnetur, frue in tenebris. Nam fi hoft is in armis domefticis latere velit, fignum interrogatus focium vel hoftem illico fe prodit: id alii fymbolum vocant, prabati auctores Liuius \& Maro tefferam.

Legationes cum boftibus fi agende funt, quales effe debeant.

Cap. $\quad V_{0}$

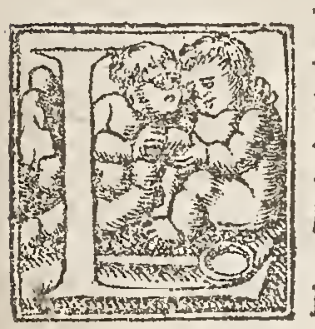

Egationes cum hoftibus fi agend $x$ fint, illud animaduertendum, vt hi mittantur qui aftu vel multarum rerum cognitione holtium latebras atque conflia metiri queant. Scipio enim Aphricanus occafione mittendx ad Syphacem legationis capto cum I alio feruorũ habitu, tribunos \& centuriones electiffimos ire iuffit, quibus cura effet regios viros infpicere: qui vt liberius caftrorū pofitionem fcrutarentur, equü de indufria dimilfum tanquá fugiétem profecuti, maximam parté circuierunt munitorum: qux quum nunciaffent, incend io confectum eft bellum.ltidem Carthaginenfes mifere qui per fpeciem legatorum Romæ morarentur, exciperent confilia Romanorum Cato autem Cenforius poftquä tres in Bithyniam legati Romæ de. lecti quorum articulari morbo \& podagra vnus, capite alter vulneribus confoffo,terius vecordia laborare videbatur, ridens, Populus romanus, in quit, legatio nem mittit, qux nec pedes, nec caput,nec cor habet. A pud eú populum auten? legati fi quando incogniti venire núciabãtur, primò quid vellet ab exploratoribus requirebãt, poftea ad eos egrediebãtur magiftratus minores, \& tunc demum fenatus extra vrbem poftulata nofcebat: \& ita, fi vifum fuiffet, admittebantur,

Qua cautione confultationes cum hofibus habende.

Cap. vị.

DI I I utem confultationes hoftiū admittenda funt, qua cautione id fieri debeat, Cefaris \& A riouifti Germanorum regis nonemur exem. plo. Hi enim quum occurriffet dies colloquii vtriufque confenfu indicta, placuit equitatu tantum arma to conuenire. Cxar quum falu- 
tem fuam non omnibus committere vellet, Gallis auxiliaribus equis fubtractis, milites eis legionarios decimæ legionis, cui maxime propter virtutem confide bat,impofuit, hos ducentis paffibus ab Ariouifti pręfidiis in tumulo collocans, vt ex equis colloquerentur, pari quog interuallo aberant equites Ariouifti:vbi verò inter loquédum, Cæfari nuntiatur Germanos adequitare lapideśq̣ \& tela in fuos coniicere, loquendi finem fecit, fég ad fuos recepit. Nam \& fi fine vllo pe riculo decimæ legionis præftantia hoftes fuperari videret, à fuis tamen pręliom committendú non putauit, ne poffet dici pullis hoftibusà fe per fidem in colloquio circüuentos. Caftris item \& loco et manu munitis, fi ex confultatione fimi liter cum hoftibus agendum, fapientis ducis effe ftatuo, ne fe incaute illis ingerat ad loquédum. Agrippa enim rex cú Gamaléfibus de traditione loqueretur, Vef pafrano iubente, ad dextrum cubitú lapide ictus agre de medio fublatus eft. 'Titus quoq̧ad Hierufalem, quú putaret Iudęos hominis gentilis oratione poffe flecti, lofephum mifit oraturum, qui grauiter in capite ab eis faucius, nifr mature ab iplo Cafare in caftra fubreptus fuiffet, oppetiiffet.

Armorum ho filitiun ratio babenda.

cap.

VII.

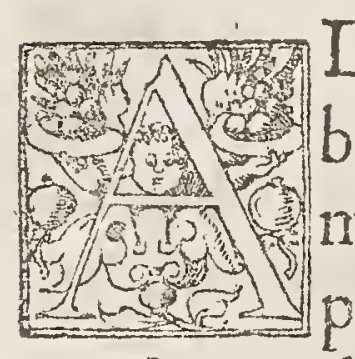

Dhuc armorum habenda ratio:eorum enim habitus plerifog gentibus alio atģ alio tépore noxius eft, vti Numidis haftilia telorum, qua manu fine amentis intorqueri folent, pluuiis ingruentibuslubrica ac per hoc inutilia fiunt. Scut ta etiam quę elephâtorum corio extêto atque durato habilia \& tuta geftabát, quorum ea natura eft vt acceptú imbré tan quá fpongia ebibant, ac per hoc intractabilia repétino pódere fiant, quia circun ferri nó poterant, defendere nequiuerunt. Orientales qui maxime fagitis bella cóficiunt, oderunt ventos \& imbres, qui inter illos pace effe cogunt: proinde $P$. Scipio in Lydia quú die ac nocte imbre cótinuo vexatú exercitú Antiochi videret, nec homines tantú aut equos deficere, verú arcus quoģ manantibus neruis inhabilesfactos, cohortatus elt fuos vt fubfequéti, quã quã religiofo, die committerent pralium, quam fententiam fecuta extemplo victoria eft.

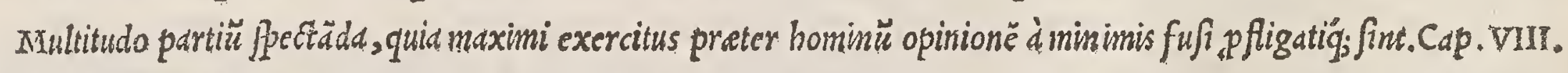
7 Vrfus in multitudine partiü difciplinæ ftudium vel ratio vtring ani 1 . 1 maduertéda,ne pugnantibus \& difciplinæ tenacionis militibus, rudé 1. 2 indoctam multitudinem mifceas, putãs in vniuerfo exercitu, Xer2. 1 xis exemplo, belli robur cöfiftere. Hic enim pręclarus Afiæ rex cú armatorum feptingenta milia Perfarum,trecentág de auxiliaribus pręter claffem maximam vixóg credibile habuifle narretur, meritóque inopinato exercitui vix ad potum flumina, vix terra ad ingreffum, vix maria ad curfum, calum ipfum vix patere fagittis putaretur, huic tẫ incredibili téporibus noftris agmini,cuius numerũ nunc difficilius eft aftrui qu túc fuit vinci, Leonidas rex Spartanorú cú quatuor milibus hominü in anguftiis Thermopylarum obftitit, triduo cótinuo manú conferens : quatriduo deinde cum iugi bello videret hofté vndiq̧̧ircúfundi, dimiffis fociis auxiliaribus vt ad meliora fe tempora referuarent, hortatus Spartanos fuos admonet de gloria plurimum, de vita nihil fperädum,neø expectandum, vel hoftem, vel die, fed occafione noctis perrumpenda caftra, com miféda 
mifcenda arma, conturbäda a gmina fore, núquã qu victores honeftius $q$ qu in caftris hoftium effe perituros.Perfuafit igitur plus fe patrix debere quàm vitæ, ac mori malle cum gloria $\bar{q}$ fupereffe fine. Mirum dictu, fexcenti viri caftra fexcétórum militum irruperunt. Poftremo inter ftragem $\&$ cadauerü aceruos, inedia, vigiliis, \& labore longx cædis fefli,cú duce fuo multo cruore graues inuicti gterna vi uentes gloria cecidere. Xerxes verò eo tumultu terreftri ac perturbatione territus, \& à Themiftocle naurbus quibus omne mare compleuerat fpoliatus, incognitus \& faucius fugit: nec aliter fane, vt Saty rus in quit, $\ddot{q}$ vna naue cruétis fluctibus,ac tarda per denfa cadauera prora. Xerxes itidem à trecentes Lacedamo niorum ad Thermopylas vexatus, cum vix cos confeciffet, hoc le deceptum aiebat, $q$ multos quidem homines habebat, viros autem difciplinæ tenaces nullos, vel óp pauciores: a xiiii.milibus Græcorú, qui numerus in auxiliis Cyriaduerfus Artaxarxem fuit,centum milia barbarorú fuperata funt . Cyrus bello aduerfus Perfas, xiiii.milibus armatorú immenfas diffịcultates fuperauit. Alexãder $\mathrm{Ma}$ cedo, xl. milia hominum iam inde à Philippo patre tanta difciplinæ affuefecit, ve terrarú orbem aggreffus, innumeras hoftium copias fuperarit. Primo nanģ, cæteris omiffis, Alexandri cum Dario rege congreffu, fexcenta milia Perfarum In acie fuere, qux non minus arte Alexand ri fuperata, quàm virtute Macedonü terga verterunt. In excrcitum Alexandri cxx.equites,et ix.tantũ pedites defuere, Secundo prælioà Dario cum cccc. milibus peditú \& centum milibus equitum in Alexandrum pugna cómittisur, quoad Darius fugeret \& Perfarum cæades fe cuta: ibi enim tunc peditú octingéta millia, equitum x. milia cæfa funt, capta au tem xl.milia fuere: ex Macedonibus verò cecidere pedires cxxx. equites cl.inter captiuos caltrorú, mater \& vxor,eadéóg foror, \& filix dux. Darili fuere, quatum redemptionem Darius tum etiam oblata regni dimidia parte non impetraffet. Tertio cunctis Perfarum viribus fociorum' rat fpe pacis amiffa, 8 cccc.milia peditum $\&$ c. milia equitú A lexandro ab Aegypto reuertéti apud Tharfum bello opponit:fed Darius poft anceps diu preli um cum vinci luos videret, mori in bello paratus, perfuafu fuorum fugere compulfus eft: quo prælio Afre vires \& regna ceciderunt, totuśq oriens in poteftate Maced onum efle copit imperii : atọ̧ ita attrita eft in hoc bello Perfarú omnis fidutia, vt poft hoc rebellare aufus fit nullus, xquóg a nimo Perfaz poft imperiư tot annorum, iugum feruitutis acceperunt:in tanta malorum multitudine dif-

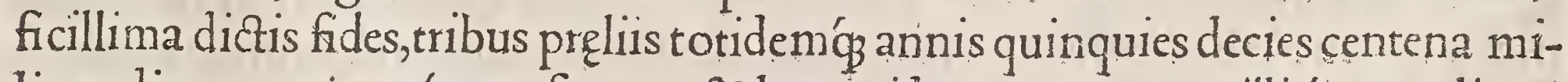
lia peditum equitumọ́ confumpta, $\&$ hęc quidem ex co regno illiś́p populis vn de iã ante annos nó multos plures decies nouies centena milia profligata referútur. Epaminúdas Thebanorü dux quatuor milibús hominú, ex quibus quadrin genti equites erant, Lacedæmoniorum exercitum vigintiquatuor milium peditum, equitum mille fexcétorum, vicit. Mylciades A thenienfum dux in paucis fuorum omnibus Perfarum copiis occurrens, prius hofti cominus hrfit quàm poffet fagittarum ictibus propulfari: itaque in xi. nuilibus fuorum, ducenta milia Perfarum occidit . Lucullus in Armenia cum decem milibus peditum \& mille equitum aduerfum Tygranem, qui centum quinquaginta

$M$ ii milia 
milia hominum in expeditione haberet, nemine illorum fuorum impetum fufinente dum illos fugat, Romanos quinç lato interceptos amifit, holtium verò fupra cêtum milia occidit. Idé Lucullus träfgreffus Eufratem \& Tygrim cum Mithridate \& Tygrane cögreffus minina fuorum nuanu magnum numerum hoftium occidit,triginta milia holtiú in eo bello caifa referuntur. Tygranes vix cü cl.equitibus aufugit, diademate ne agnofceretur abiecto.Fabio Maximo,De cio Murena coff.quatuor fortiflimi florétiffimíg Italie populi, Etrufci, $\mathrm{Vmbri}$, Samnites \& Galli in vnum agmẽ foedusóṕ, confpirantes Romanos delere conati funt.Cumọ̧ cú Samnitibus \& Gallis bellú inirent, \& in eo bello Gallorú impetu Romani premerentur,Decius conf.occifus eft.Fabius cum magna Deciane partis ftrage vicit,eo prælio xl.milia Samnitum \& Gallorũ cæfa.Romanorú ve rò feptem milia,ex Decii tátummodo parte qui occifus eft referütur. Fuiffe auté abfọ Etrufcis \&V mbris quos aftu Romani bello auocauerüt Gallorü \& Samnitum peditum cxl. milia $\& \operatorname{cccxxx}$. equitum verò $x I$ vii. nilia Livius refert, $\&$ carpentarios mille in armis cötra aciem ftetiffe Romanan. A Romanis aduerfus Mithridatis exercitum in minore Armenia quadraginta milia hominú cæa fa vel capta füt, Romani vulnerati mille, vix autë quadraginta interfecti. A Ro manis item penes Metaurum flumen victus eft Hafdrubal capútque eius ante Hannibalis caftra proiectum, dép exercitu fuo fex \& quinquaginta milia occifa:capta autem quing milia \& quadraginta cum ab exercitu Romanorum fociorumóg octo fermè milia cecidiffent. Cum Teuthones \& Cymbri Italix plana peruafiflent, Marius \& Catulus aduerfus eos miffi ita pugnarunt, vt tanta táque terribilis multitudo minima Romanorú clade, fua autế vltima internitur. tıone cæderetur, cl.milia eorú tunc in bello cęfa, quadraginta milia ca pta dicúL. Aemilio Catullo, C . Accilio Regulo coff. formidine magna confternatus fenatus defectione cifalpine gallix, cum etiam ex vlteriore gallia ingens aduentare exercitus nunciaretur maxime Gerfatorú, quod nomé non gentis fed mercenariorum gallorum eft, ita permoti confules totius Italia ad præfidium impe rii cótraxere vires, quo facto vtriufque cófulis in exercitu octoginta milia armatorum fuifle referuntur, ficut Fabius hiftoricus qui eo bello interfuit memoria demandauit, qua nec faltem tanta quanta cos terrere debuit, cæfa fui parte, fugerunt, nam tria milia eorum tunc interempta hiftorici tradiderüt, quod ideo ignominiofius turpius'g̣ eft tam paucis amiflis tanta agmina diffugiffe . Sylla poft partam Athenienfium vrbem cum Archelao conflixit.cx.milia cæfa,vix decem milia fuperfuiffereferuntur, hac comperta clade Mithridates leciffima fe ptuaginta milia militum in fubfidiú Archelao mifit ex A fra. Secundo pralio fexaginta milia ex his interfecta funt. Tertio bello omnes copie quas Archelaus habebat extinctę funt,nam viginti milia militú eius in paludépulfa quú Syl la fidé implorarent infatiabili victoris ira interfecta funt,totidéǵp alia in flumé coacta ac necata, reliqui miferorú trucidati funt.Pra fodes Perfa dux belli exercitum maximü ad cc.milia hominú coẹgit, caftrifó in finibus Cadufiorú poftis Arfeum Medorum ducem fe aduerfus cum octingentis milibus hominum profectum pugna inita fuperauit, ad quingenta milia interfectis, reliquos extra 
Cadufiorủ fines abigës hac victoria infignis à Cadufiis rex creatus in Mediam tranfit,omnióp prouincia vaftata magnã gloriam affecutus eft. Crotonienfes Ita lix quôdam poteriffimi populi, bello funt à Locréfibus fufi, quãä militum illis centüuiginti milia, his nô milia xv. modo effent. Heraclianus cui imméfam \& fatis incredibile claffem nauiü fuiffe perhibent, quippe qui tüc tria milia feptin gentas haberet, qué numerum apud Alexandrum magnú vel quenquã alium regem pręter Xerxé fuiffe hiftoriæ nó ferút,finul vt cum agmine militiú ad væbem pergës littore egreffus eft,occurfu comitis marini territus, \& in fugam verfus, arrepta naui folus Carthaginem redit, atque ibi conto militari interem ptuseft.

Obfefforum exploranda ftudid.

Cap. IX.

\%क्र Nobfeffis item ftudia multitudinis exploranda, fi enim diffenforum 1. 6. partes intercidant auditus, aperitur viro forti,dum trepidant, ait ille, 13. nullo firmatze robore partes Tolle moras femp nocuit differre para I. Tis. Titus proinde dú Taricheas bello fugaffet in ciuitatem, regreflus aduenas cum indigenis diffidétes audiens, mox armato milite ciuitatem ingreffus obtinuit.Itidem fi ad deditionem offeratur affenfus,cauendum ne fententia plurimorum in dolo obtineat,P. Licinii proconfulis exemplo: nam quum pa gos fub fpecie deditionis oblatos accepiffet, qui in poftrema recepti acie collo. cati funt, Romanorum terga ceciderưt: proinde Cærär nunquã dedititiis credidit , nifi armis obfidibusóg traditis, \& ipfis ex nobilioribus lectis veluti filiis ac fratribus principum, numero pro amplitudine loci plerunque ad quingentos, quo \& fidutiam hoftibus adimeret \& fibi munimenta conquireret.

Quid agendun fi oppugndri caftra contingdt.

cap. X.

7 I I oppugnari caftra varia forte plerumç cót ingat,qua id ratione fiat 1. 1. horú monemur exêplis. Scipio A phricanus aggreffus hyberna Poe1.1. norum, caftra atque munitiones nocte cócubia fecit incédi,Poni tre12. - pidi quum cafu ignem accidiffe vel affuiffe putarent, inermes ad extinguendum aduolarunt,qui facile $a b$ armatis oppreffi funt, in vtrifque caftris xl.milia hominư igni ferróque confumpta, capta quinque milia, duces ipfí miferabiliter adufti agre effugerunt. Craffus ex ducibus $C$ farris hoftium caftra hac arte expugnauit, Ipfe in Aquitania res gerens, quum aduetteret hoftes confuetudine rei publica,loca capere, caftra munire, cômeatus fuosinncludere, non Gunctãdum ęftimauit quin pugna decerneret: hac re ad confilium delata, quum omnes idem fentirent,pofterú diem pugnix conftituit: prima luce productis copiis auxilia in mediam aciem coniectauit,fić,' acie inftituta, quid hoftes conflii caperent expectabat : illi etfí multitudine fua \& Romanorum paucitate tutò fe dimicaturos arbitrarétur, tutius taméeffe rati funt,obfeffis viis, cómeatu interclu fo, fine vulnere victoria potiri: quòd $f_{i}$ fe Romani recipere coepiffent,firmiori ani mo fub farcinis adoriri cogitabãt. Hac re pcepta, Craffuscum hoftü cunctatione fuos alacriores effeciffet,ad hoftium caftra contendit : vbi quum alii foffas complerent, alii telis coniectis hoftes repellerent, auxiliares quibus non multum confidebat, lapidibus telífque fubminiftrandis $\&$ ad aggerem cefpitibus

$M$ iii "deferendis 
deferendis conftituit, quum his intenderet, equitesóg Craffo renunciarent, nö eadem diligétia ab decumana porta caftra munita, illi Craffo iubéte, eductis quatuor cohortibus, qux præfidio caftris erant, in hoftium caftra peruenerür:quúm que bellum anceps effet, \& vltro citróque ferirentur, hoftéfque per munitiones eiiciêtes fugam peterent, equitatus eos apertis campis confectatus ex hominum milibus quinquaginta vix quartam partem reliquit. Propter huiufmodi cafus, animaduerto Cæfarem fatis cauiffe, ne caftrorum munitionibus ampliores vnquam latitudines includeret, quàm fuis copiis implere fufficeret. Eidé vna con fuetudo etiam fuit, nunquam caltra deferenda effe, nifi cum munitionibus effractis, hoftes vallo prohibere non poffent: aft eruptio quãdo neceffaria fit, Gal ba eiufdem Cæfaris dux, documentum nobis fit. Hic enim quú ad radices Alpi um hy berna caftra locaffet, \& commeatus caufa plurima pars fuorum abeffet, Galli fubito Alpium culmina occupare coperunt: Rebus cognitis, Galba concilio conuocato perquirit, placet interim rei euentum experiri,\&caltra defendere. Tunc figno dato, holtes ex omnibus partibus concurrunt: hi quum primo integri viribus, \& qua parte caftra nudata defenforibus erant, concurrentes auxi lium ferrent, tandem hoftium multitudine, \& fuorum paucitate, languidiores effecti funt:vallum hoftes. fcindere, foffam complere coperunt, vt res ad extremum cafum perduci vifa fit. Primorum ordinum principes ad Galbam conue nientes, experiri extremum remedium fuadent, atque eruptione pugnare:principes fuos fubiectos centuriones faciunt vt paulifper miffa tela excipientes, fefe ex labore reficiant: poftea verò figno dato, atque ommibus portis cruptione faata, nulla fui colligendi facultas hoftibus fuit: led circunuéti omnes, fufíg funt. Romani verò fe incolumes receperunt. Aemilius fimiliter Paulus vniuerfis Lyguribus ex improuifo adortis caftra eius, frmulato timore diu militém continuit: fatigato deinde iam hofte, à quatuor portis eruptione eueftigio facta, ftrauit, cepitóp Lygures. Titurius quogs Sabinus aduerfus amplum Gallorum exercitum continendo militem intra muniméta, $\phi$ metuerit, fufpicionem eis prafitit: cuius augendi caufa per fugam, mifit qui affirmaret exercitum Romanorum in defperatione effe, ac non nifi de fuga cogitare. Barbari oblata victoria fpe concitati, lignis onulti, quibus folfas implerent, ingéti curfu Romanorum caftra petierunt. Vnde in eos Titurius vniuerfas immifit copias: multísque Gal lorum cæefis, plurimos in deditionem accepit.

Quòd rebus bellicis quifquis finis obuenerit, nunquam negligendus.

Cap. XI.

D hac rebus bellicis quifquis finis obuenerit, nunquam is negligen(1) 0 dus. Si enim pari forte difceffum eft, paribus animis repetere licet: Si 3 . 3 aute hoftilis pars fuperior fit, rebus labentibus, $\&$ in fugam verfis, ma [2. 2 turo confilio fuccurrendú eft. Sertorius enim à Q. Metello Pio acie pulfus, quum neque fugam fibi tutam arbitraretur, milites difperfos abire iuffit, admonitos in quem locum vellet cöuenire. Viriatus dux Lufitanorum Romanorum copias, locorumque iniquitatem euafit, eadê qua Sertorius ratione f par fo exercitu primò, deinde collecto. Tryphon autem Syrix rex victus, per totum iter fugiens pecuniam fparfit: éimque fectantes Antiochi equites morando effu 
git. Rex item callidus Mithridates, Romanx'́g auaritix gnarus, quũ fequentes moraretur, Ypargi frmiliter à fugientibus farcinas \& pecunias iuffit. M. Marcellus cof .quum in manus Gallorữ incidiffet, omniáque infefta videret, in medios hoftium irrupit:quibus inopinata audacia exterritis, regem eorum occidit,atq vbi fpes falutis vix fuerat inde maxima fpolia reportauit.

Quid agendum $f i$ bello pulfi munitionibus receptif fint.

Cap. XII.

Vollo follo pulf munitionibus receptifint, vbi deliberatioe opus eft, (1.7. - nunquam animus dimittendus: nanque Carthaginenfes quum Syra 1. 1. cufanos graues infertófque paterentur, ab Athenienfibus auxilia im$D-2$ petrauere. Athenienfes magna claffe inftructa L y fra \& La macho du cibus, tantis viribus Siciliā petunt, vt fuffragia fua ipfit timerent: duobus preliis fecundis fucceffibus factis hoftes in vrbem concludunt, $\&$ obiecta claffe terra mariog cingunt. Syracufani fractis feffiśǵg rebus, auxilia à Lacedemononis pe tunt, à quibus mittitur Gylippus folus quidem fed in quo omniü prafidiorum inftas praferebatur, qui veniens vt audiuit inclinatum iam belli ftatü, auxiliis contractis opportuna bello præoccupauit loca: deinde duobus praliis victus, in tertio Lamachum congreffu occidit, hoftes in fugam vertit, focios ab obfidione liberauit. Athenienfes nauali certamine congredi parant. Gylippus claffem inftructam a Lacedæmoniis accerfit, auxiliáǵ fociorum. Atheniéfes prima cógreffione vincuntur, caftra cum omni pecunia pablica vel priuata amittút. Sic Gylippus optimus dux licet bis victus, nec animo tamen confternatus, nec fractus, in ftatũ optimú res reduxit: \& fi quidê viribus diffipatis, nulla manus bello fuperfit, hoc ipfum fociis rei gerendx oscafionem offert. Arifonicus Afre rex Licinium Craffum cum multis auxiliorum copiis bello obtinuit. Huic Craffo Perpenna col.fucceffor veniens Ariftonicum recenti victoria exultanté, improuifo bello adortus,nudatum omnibus copiis in fugã vertit.Cum'óg Stratonicen vrbem ad quam ille confugerat obfidione cinxiffet, cruciatum fame ad deditionem coégit.

\section{Quid agendum fi hofers bello fine munitionibus pulfi.}

Cap. XIII.

T.5. Erum fi hoftes bello fine munitionibus pulf fuerint, omnino inftan1. (50. dum erit ad reliquias copti pralii confumendas, vti Marius qui deui 1.2. F- L -2 rat, continuis fubinde circunfedens clamoribus, perpaucis fuorủ perterruit, infomnémque hofédetinuit, ex eo affecutus vt poftero die irrequiet um facilius hoftilem debellaret exercitum: infinita hac negligentibus damna cötigere. Ethius cof.Romanus dum Hunnorum cétum octoginta milia vnius diei quota parte proftrauiffet, facillimúm que fibi foret reliquos conficere, bellú confilio nimis imprudenti diremit, actotius Gallix excidium hofte impunite reli quit. Par huic Pompeio contigit, quo fili ipfi morte confciuit. Nam cum $\mathrm{C}_{x-}$ far Torquatum eius legatum, legionemóg vnam vt expugnaret aggreffus eft, hoc periculo fociorum Pompeius cognito, omnes eò copias contraxit,in quas fe illico $C_{x}$ far omiffa obfidione conuertit. Torquatus autem è veftigio prorüpens auerfum infecutus eft: ita Cæfaris milites ancipiti pericülo territi, ipfo Cæfare fruftra 
fruftra obfidente fugerunt,euafit tamen $\mathrm{C}$ far, quia nocte interueniente Pompeius profequentem reuocauit exercitú, qui $C$ afaris teftimonio victor tunc crat, cum diceret, Erat hodie profectó victoria apud hoftes, féque tantum ea die ab eis potuiffe fuperari,fivincendi gnarum ducem habuiffent: deniqg dilapfus con tractis copiis cum Pompeium Pharfalicis campis viciffet, fugientem infecutus eft, protinúque obtinuit. In omnibus bellorum negociis femper in confummationem intendebat, nil actum credens cum quid fupereffet agendum:ipfe nanģ cum Heluetiorum trecenta quinquagintaocto milia bello cecidiffet,centum triginta milia que fuperfuerant nulla noctis parte itinere intermiffo, die quarto in fines Lingonum peruenerunt, cum Romani propter vulnera \& occiforú fepulturam triduo remorati fuiffent, Cęfar ad Lingonas literas nunciumque mifit ne cömeatu, né ve alia re adiuméto illis effent: qui fr iuuiffent, fe cos hoftiüloco habiturum. Ipfe autera triduo intermiffo, cum omnibus copiis infecutus eft. Helue tii rerum inopia adducti, deditionem fui obtulerunt, at $\not$ ad pedes Cxfaris obortis lachrymis prouoluti pacem petiere: quibus cum oblides armáque tradere præcepiffet, dum ea conquiruntur nocte intermiffa fex milia diffugerunt, quos ille infecutus hoftium numero habuit, reliquos in deditioné accepit ac fuis locis reftituit. Idem cum Belgas bello fugaffet, illi in finibus fuis pugnaturi domú reuerti fatuerunt:quibus fecunda vigilia profectionem parantibus, Cæfar veritus infidias, quòd caufam nondum cognouerat, exercitú cótinuit. Prima luce re ab exploratoribus confirmata, equitatum præmifit qui nouifinum agmen moraretur, ipfe cum inftructis legionibus infecutus, tantam multitudinem interemit, quantum diei fpacium fufficit. Mox antequam hoftes fe ex fuga reciperent in fines eorum progreflus, fine difficultate vlla munitiones eorum obtinuit . Omni Gallia deuicta cum quædam ciuitates belli conflia renouare nuntiarentur, in eorum fines exercitum traduxit, repentino eius aduétu accidit vt prius ab equi-" tatu opprimerentur quàm diffugere in oppida poffent. Nam \& illud incurfionis fignum quod incendiis ædificiorum fit, Cafar edicto fieri vetuit, tum ne præcaueri non poffet, ac ne pabuli frumentique copia deficeret. Itaque Cæfar omnibus holtium confliis, magnis itineribus aduolando contendens, occurrebat, nec dabat vlli ciuitati fpacium de aliena potius quàm de domeftica falute cogitandi: hac celeritate $\&$ fideles amicos retinebat, $\&$ dubitantes terrore ad conditiones pacis adducebat.

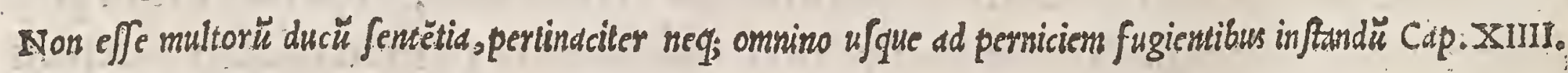
Contra verò non effe etia m pertinaciter neque omnino vfog ad perni $\sqrt{25}$ tiem hoftibus inftandum, multorum ducum fententia perfpicuú eft. Nanọ M. Licinius fufo Hafdrubale, hortãtibus eú quibufdã vt ho2 s. ftem ad interemptionem vfos profequeretur, refpondit, Aliqui vt fu perfnt qui de victoria noftra holtibus nuntient neceffe eft . Scipio A phricanus dicere folitus eft, holti non folum dandan viam, fed etiam munienda. Pyrrhus quog Epirotarum rex inter cæetera præcepta imperatoria memorix prodidit non effe pertinaciter neo $v$ fo ad perniciem fugieribus inftaturos victores, quod ftratagematis genus $\&$ ab ipfo, 8 ab aliis etiä plerifog clariflimis ducibus in exs 
in expugnandis quouis modo hoftibus obferuatum inuenio: ipfe enim cum ciuitatem quandam accepiffet claufisque portis ex vltima neceflitate fortitex dimicantes eos qui inclufi erant animaduertiflet, viam illis ad fugam dedit . Hannibal cum inclufr Germani ad Trafimenum acerrime pugnarent, deductis fuorum ordinibus abeundi facultatem reliquit, abeuntesóp fine fuorum cæde $\&$ fanguine ftrauit. Agefilaus Lacedæmonius aduerfus Thebanos cum acie confligeret intellexiffet'q hoftes locorum conditione claufos ob defperationem fortius dimicare, fuorum ordinibus aperta Thebanis ad euadendum via,rurfus in abeuntes cótraxit aciem, \& fine iactura fuorum cecidit. Aduerfos ob defperatinem fortius dimicare fuos ponte irrumpere prohibuit, cum docuiffet fatius effe eum expelli ab Europa quàm cogi ex neceffitate pugnare, mifitóg idem ad eum qui indicaret quo in difcrimine fua res fita effet, nifif fugam maturaret . Antigonus Macedonix rex ex Aetolis qui in obfidione ab eo compulfifame vrgebantur ftatuerántque eruptione facta commori,viam fugx dedit, atque ita fracto im petu eorú infecutus aduerfarios fudit. Titus eques romanus $\&$ cui duobus Scipionibus occifis exercitus imperium detulit, cum circúuenti ab eo Poni ne mul ti morerentur acrius pugnarent, laffatis manipulis ex conceffo fugx fpatio diffi patos fine periculo fuorum trucidauit.C.Cæfar Germanos inclufos ex defperatione fortius pugnantes emitti iuflit fugientêfque aggreflus eft.C. Manlius côf. cum ex acie reuerfus capta ab Etrufcis Romana caftra inueniflet, omnibus por tis ftatione circúdatis inclufos hoftes in eam rabié efferauit vt ipfe in prelio caderet:quod animaduertétes leg ati cius, ab vna parte remota ftatione exitú Etrufcis dederunt, \& effufos perfecuti occurrente altero confule ceciderunt.

Dolabra hoftem effe uincendum nullámque rem fummo duci magis conuenire quàm moram cunctationë qै;s mullam minus qudm feftinationem ac temeritatem.

Cap. XV.

1. AN Ccedit ad hęc Domitii etiam Corbulonis confliü, qui Dolabra ho2. E. Hem dicebat effe vincendum, quod mult is non fecus præclaris ducto 25 Gribus id feruantibus in fucceffum \& nominis fui gloriã venit, \& Fa2 2.e. 1 bio maximo imprimis. Nam cum aduerfus Hannibalé miffus nollet cum eo acie confligere, fed cunctando exercitum eius terere, qui tum pecunixe tum annonæ premeretur inopia, per fumma montiü inga $\&$ abditos nemorum faltus caftra ponés. Hannibalem fequebatut, \& fefe è latere egreffus opponebat: cúmque à multitudine rideretur, $8 \mathrm{H}$ Hannibal is vocaretur pedagogus, id minimi pendens cogitatibus fuis ato cebat,eum fibi timid iorê videri qui caullationes conuitiág timeret, quàm qui hoftéfugeret. Infuper cú de collega Minutio quoniã hoftes aliquot proftraffet magnus rumor effet, quafi vir effet romano nomine digniffimus, Magis fe ingt fecundam Minutii fortuná quàm aduerfam pertimefcere, paulóg poft cum in infrdias incidiffet Minutius \& frmul cum exercitu periret, vbi ipfe auxiliü tulit, tum magnum hoftium numerum perdidit, tum illum feruauit,vnde \& $\mathrm{Hanni}$ bal victus $\&$ impetu fuo fractus ad fuos \& amicos dixiffe fertur, Nunquid non dixi vobis fore aliquando $v t$ hæc montana nubes maxima nos in campo vi tem peftatis obrueret? Eodem modo aduerfus Philippü Sertorius cum trans Hibe- 
rum amnem ad eum conflueret vndique multitudo, $\&$ barbara turba qux feritate \& fuperbia fua cuncta turbaret, nec ducis iulfum expectaret fed temeritate in hoftes ferretur, primùm rationibus \& verbis inftruere eos conatus eft, deinde vt vidit eos nihilominus temere properantes, ftatuit fic eos obiicere hofti $v t$ non omnino frangerentur fed vulnera acciperent, fperans per hæc ipfis in reliquum tempus manfuetioribus vfurum. Gefta itaque re vt ipfe cogitanerat,op portune affuit, \& fugientes fufcepit reduxitó in caftra, ac paucis pòft diebus vt eorum mentes erigeret confola retur qp$_{\text {, }}$, duocata totius exercitus concione, duos equos in medium adduci iuffit: alterum macie feniógue confectum, alterum for tem $\&$ nitidum, ${ }_{3}$ caudamóp promiflam habentem: aftabat autem iuxta gracilem illum vir magnus \& robuftus admodum, iuxta nitidü \& præpotentem vir paruus $\&$ imbecillis: dato autem figno vir ille magnus vt ei mãdatum erat caudam vniuerfam gracilis equi ambabus manibus captam auellere temere ac vno cona tu adnixus eft, paruus etiá vir prapotétis equi caudam paulatim depilabat: tan dem verò ille fruftra frmul totam caudā trahens, fibi quidem moleftias inanes, circunftantibus verò rifum præbens defeffus eft: \& ille paruus euellendo paulatim fetas, caudam equi fortis Spatio perbreui nudauit. Tunc affurgens Sertorius, $V$ idetis, inquit,commilitones ingenium plus poffe quàm vires, multáque qua vno impetu fuperari non poffunt, fenfim paulatimque fuperari? Scipio iunior cú effrenatã hoftium demếtiã effet intuitus, dicebat tépore fecuritatë emi . Nam boni imperatoris veluti medici officium effe vt ferri curatione vtatur ad poftre mum. Veruntamen tempeftiue adortus Numantinos, in fugam vertit: cumque victos grauiter feniores ferrent, exprobrätes quid eos fugiffent quos toties fugaffent, Numantinum quempiam dixiffe fertur, Pecudes quops ea idem nunc effe, at paftorem alium. Proinde nullam rem fummo duci magis conuenire quàm mo ram $\&$ cunctationé, nullam minus quàm fettinationem temeritatem $q$ : his duabus maxime contrariis rebus omnes qui diuturno bellorũ vlu peritiffimi hoc tempore iudicantur, magnis, imo ingentibus te, Sigifmunde Pandulphe, laudibus in calum tollunt : vtpote qui duos florentifimos potentiflimólque regios apparatus mora ac celeritate protriueris. Alphonfum enim clariffmu $\&$ illu ftrifimum Taraconenfum regem cum plurimum vigeret, $\&$ Francifci Sphortie foceri tui copias primo perlequeretur, tu pil filii functus officio, focerum gen téfque eius omnes intra munitiones phani fortunæ \& monia politis caftris reci piens, id mora cunctandóque affecutus es, quànqua m holtes portas vrbis fapenu mero excurrerent, obfelfoque frmilis viderére, vt $\&$ foceri tutela fieris, $\&$ huiufmodi vires regis conatumve omné fapiétia tua \& animi magnitudine faciliter eluferis, \& irruptione tandem in eum facta, ex Piceni finibus exegeris : eundég quinquennio pòft Regem, Populonia expeditione, löga \& graui illius metatione aggreffus, non a rmis $\&$ gentibus, fed armorum vmbra potius, ignium nocturna fignificatione illucefcentium, tranffugarúmque crebro rumore nuntiâtium, auxiliorú populorüóp totius Hetruriæ tecú, ne id oppidủ ded eretur, cófluentiū, forti denique $\&$ animofa repentinágg tuorum militum eruptione muros haben tem exultantég iamiam $\&$ poliantem, vno, vt fic dixerim, non toto incurfu, 
more fulminis obtriuifti, quòd vno codemíg momêto adiuifti, perculfifti, ab ficef fift : nec vana de te predicatio eft, regem abs te antè victum effe, quàm vifum: fićp,quod paucis vnquam ducibus conduxiffe accepimus, Faneftrium, Sphortientiumque expugnatione ad agendum cunctatione, Populonia ad tuendum fuccurrendimque aud acia, irruptione, ac feftinatione vfus es.

Cauendum ne fucceffu rei quifpiam elatus, in periculum perniciemque trabatur.

Cap. Xvir.

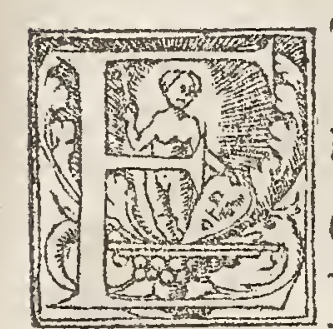

T quanquam audentes deus ipfe iuuat, vt Nafo inquit, \& vfu fape numero comprobetur, illud tamen fummopere cauendú elt, ne fucceflu rei quifquam elatus, in periculü fuorum pernitiem que trahatur. Hoc quidam imperatores conflium minime feruantes dum andacter magis quàm cautê feruntur in holtes, in magnam fe ac fuos ruinam clademós propè miferabilé iniecerunt: quod fin non aliunde conftaret, Cyri potentif fimi 2 preclariffimi Imp. ac Afrorü monemur exemplis. Cyro enim Scythiam ingreffo, Thomiris regina qua genti praerat, tranfitum Araxis fluminis cum poffet prohibere, tranfire permifit:primo, propter fidutiam fui, deinde propter opportunitatem obiect fluminis \& hoftis incluf. Mitt it igitur tertiam partem copiarum cum filio ad infequédum holtem. Cyrus caftra inftructa vino epulifq deferuit, quafi territus refugiffet. Barbari quafi ad epulas inuitati, primò ebrietate vincuntur, mox reuertente Cyro vniuerfi obtrúcantur. Thomiris exercitu ac filio amiffo, vel matris vel reginæ dolorem fanguine hoftium diluere potius quàm fuis lachrymis parat. Diffidentia igitur diffimulata defperatione cladis illatx, paulatim cedendo fuperbum holtem in infidias vocat, cui cú inter montium anguftias occurriffet, ducêta milia Perfarum cum ipfo rege deleuit, addita fuper omnia illius rei admiratione, $q$ nec nuntius quidem tante cladis fuperfuit. Aduerfus Afros rebellantes Hannibal à Carthaginenfibus nịfus cü fciret gentem auidam effe vini, vinum quod illi erat in caftris mậdragora permilcuit, cuius inter venenum \& foporé media quædam vis eft: tunc prælio lecui cómifro, ex indufria ceflit: nocte deinde intempefta, relictis intra caftra quibufdam farcinis, $\&$ omni vino infecto fugam fimulauit : cumq $B$ Barbari occupat is caftris in gaudium effufi medicatum vinum haufiffent $\&$ in modum defunctorum ftrati iacerent, reuerfus cepit eos $\&$ trucidauit . Idem cum fciret fua $\&$ Romanorum caftra in eis locis effe que lignis deficiebãtur, ex induftria, regione deferta, plurimos armentorum greges intra vallum reliquit, quibus velut præda Romani potiti in fummis lignationis anguftis infalubribúfque fe cibis onerauerunt Hannibal autem reducto nocte exercitu, fubitò oppreffit . Hiftri cum fequerentur Aetolos qui bellantes eos nuper adiuuerát, initia pugnæx profpera hofti fuerunt,eadémóp exitii caufa. Nam cum Cn. Manilii caftra cepiffent optimæós pręd $x$ incubarent, epulantes $\&$ ludibundos plerolque ac vbi effent nefcientes præ poculis Appius pulcher inuadit: fic cum fanguine \& fpiritu male partam reuo muere victoriâ:iple rex epulo, equo impofitus, cum fumma fubinde crapula \& capitis errore laffaretur, captú fefe vix \& egre poltquam experrectus eft didicit. 
De Conuiuiorum apparatu in caferis uilando.

CAp. zovII.

A Ccurationes proinde couniujorum \& apparatus, nobiliffimi duces ca (3) frenfibus prohibuere. Sic Mafiniffa m po. Ro.amicum centefimum 195.5. vita annum agentem, ftantem vel ambulantem meridie ante taber2R. 3 naculum folitü cibos fumere nouimus. Hannibal ne quam diei partem intermitteret,nö nifi crepufculo cœnabat. Scipionem \& Alexand rum fimplici pane in itinere cum amicis contentos fuiffe tradüt. V rius fortifimus dux romanus, qui validiffimam Italiæ gêtem, qui ditiff mum Græciæ regem vicit, vt de eo fcriptum eft, Paruo quæ legerat orto, ipfe focis breuibus ponebat olufcula. Eadem leguminũ ratio permultis placuit, quibus Seuerum principé inter tot diuitias vti folitum accepimus, fingulas etiam delitias faftidretem Seuerum Septimium nobilem ducem legimus cum effet in caftris. Nam cum vinum iuffaffet in expeditione neminem bibere, fed aceto vniuer fos effe contentos, piftoresíg fequi câtra prohibuifet, buccellato iubens omnem militarem turbấ contentam effe, ante omnes ipfe communi \& militari cibo vfus, corámq $\&$ ante papilionem, nec fibi vnquam vel contra folem, vel imbres, tecti quxfiuit fuffragia. Pompeius vero cum aduerfa valitudine laboraret, \& vt turdo vefceretur medicus iuberet, illumóg fui fruftra tunc quærerent( (erat enim præter anni tempus) dicerétgquidam fore vt apud Lucullum turdi quem penes annum integrum nutrirentur inuenirentur, Ergo, inquit, ni Lucullus ftuderet deliciis, viuere f'ompeius non poffet,ac dimiffo medico parat u, facillimis vilibúsqg cibis vfus eft. Iu lio Cæári facilitas circa victum tanta fuit vt cum appofitis a fparagis pro oleo vnguentum inftillaretur, idóp quamprimu m animaduertiffet facile commanducaffet, increpuifletợ qui id molefte tuliffet. Milites eius radicem cuiufdam herbx euellentes, ea lacke commixta vefcebantur, factúmos ex ea panem intra haltium fationes præcurrentes iaciebant, addebántọ fe quamdiu herbam huiufmodi terra nutriret, obfidionem Pompeii haudquaquam deferturos. Eum autem panem eumóp fermonem, ne hofium patientia ac pertinacia fuorum animi fran gerentur, afpoztari in mediumpp proferri vetuit Pompeius. Augufto etiá quem minimi cibifuiffe conftat, \& ferè vulgaris, fecundarium panem, pifciculos, cale um manu preffum ficúsq; biferas $\&$ virides placuiffe legimus. Trans R henum criam Tyberiü, id vitæ genus obtinuiffe ferunt, vt fedens in cefpite nudo cibum ceperit, fine tentorio pernoctarit. Diuus Adrianus cibis caftrenfibus, cafeo \& la rido in propatulo libenter eft vfus, Scipionis Aemiliani, Metelli \& auctoris fui Traiani frætus exemplo. Cambyfi non prouifis commeatibus, non exploratis itineribus, per inuia $\&$ arentia fuum trahenti exercitú, cum deeffent neceffaria, nec quicquam fubminiftraret fterilis \& inculta humanóp veftigio deftituta regio, tenerrima primò frondium cacumina, deinde coria igne mollita necelfitas cibú fecit: poftea cü inter harenas,radices quoq̧ $\&$ herbæ defeciflêt, a pparuiffetọ́ inops etiä animalium lolitudo, decimú quenque fortiti alimentum babuerunt: cúmog partem exercitus a mifffet, parte comediffet, timuiffet'̣́ ne vocaretur ad fortem, proind ég tunc demum fignum receptui dedıffet, feruabantur interim generof $x$ illi aues $\&$ inftrumenta epularum camelis vehebãtur, cum fortirentur 
Illos milites eius, qui male perirent peiusóg viuerent. Illud der ique, Sigifnunde Pandulphe, nó filuerim, inter hæc fumma ducum \& imperatorü vit $x$ ot namen ta tantâ videri in te limilitudinem ac cófonantra m yt nihil excogitari polfit fi milius, nibil maius dici, cú omue genus hoc hominû, ducum et imperatorum, la borum patiés, vigiliarú, fitis, inediæ et omnis anguftiæ, innitädo aut xquaris aut excefferis.Quis.n.nefcit cú per onnem vitá nullum viliffmi cibi genus afperna tus fis, vnà cum tuis militibus Populonia expeditione, non fecundo, iftorü more,non cibario tátum pane te vfum, fed atro, fed duro faxi inftar virentióq qua dam lanugine atọg mucore, quẹ canes aninalia ad cibú femper prona,ac iumé ta fingula faftidirent? Prætereo glâdes è fubere quæ tibi tuisóg militibus in tanta fa mis acerbitate,tanquá fapore \& cōdiméto quodam immixto,opes regia vi debãtur, taceo ftagnantiú fontiū calentes ac fulphureas aquas: \& quan g̈ vini habendi facultasomnis abeffet, ac eiufmodi aquę nauleam prius quandä afferret, quàm fitim reftinguerét, nihil tamé tibi ac tuis cum omniú ad miratione incolentium, vifum eft vnqua illis aquis bibiffe iocüdius. Maxime igitur rationis eft bellicx fefe deliciis continere, maxime rurfus in pradam leui momento non ru ere, ambitiofa licet ac certa videatur: fepenumero enim fit vt dum deliciis, dum exuuiis holtium, dum q́p fpoliis miles occupatur, hoftem in fe reuocet,fićp quàm multos præclaros duces cum ingentia prælia maximosóg exercitus cöfeciffent, huiufmodi rerum voluptate fubactos confectólque fuiffe.

Qu ufui uideătur utrinq; ad danda uel euocanda fubfidia, fi exercitum noftrum caftris aut locis munitis obfideri contigerit aut allos obfidere, deqúp notis militaribus quóue tempore qui notarij app:llancur denominationem acceperint.

Cap.

XVIII:

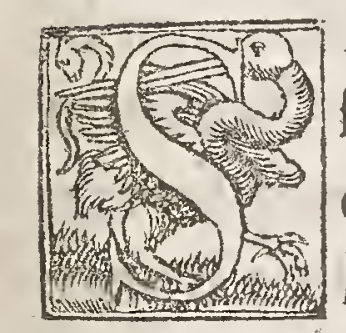

Ane polt hafce quas modo diximus bellorü rationes, fi exercitún noftrum caftris aut locis munitis obfideri contigerit, aut alios obfidere, qux vfui videãtur vtring ad dáda vel euocanda fubfidia, vel certe ad inutile fcire, \& maiorú exēplis euoluere. Cicero Cefaris dux caftris hybernis ob feffus, nuncios atrétius deftatu rerú fignificare cupiens, mittit ad Cafaré, et cum aliqui in hoftiú manus lapfi et fub oculis fuorú crudelibus fuppliciis affecti, reli quos merito terrore cópleuerint, inuétus eft tamen feruus vnus ex Gallia qui libertate et magnis præmiis \& pollicitationibus literas iaculi a méto in fertas, quia gallus et gallis minime fufpectus, tulit ad Caxfaré.Illius ergo folicitus Cefar,gal luns equité quendã pmiffis ingétibus impellit, vt literas fuas ad Cic,rcferat, \& in caftra ingredi nequeat,alligatas iaculo intra vallú iaciat: paret ille, $\&$ ad caftra cum veniffet,arcedere metués, vt iuffus erat literas iaculatur, qux cafu quandã in turrim inciderủt, neq̧à quoquả ante diem tertiū vife funt. T unc cófpectx à quo dam milite detrahuntur et ad ipfum cui infcriptæ erất Ciceroné perlatæa atọ in concilio militú recitatæ, magna on nes fiducia \& gaudio tepleuere. Erat autem perbreuis epiftola, ne à barbaris poffet intelligi, literis gracis in hanc fentétiam perfcripta. Ego iam cum legionibus iter arripui, confeftimág a dero : tu virtutem tuam priftinam vt retineas quxfo. Vale.

Iofephus velleribus ouiư nútios tegés, multo tẹpore vigiles Romanorú fefellit, N ppecie 
fpecie canum deceptos. Fuerune qui inflatis vtribus literas intus infutas habentibus per nunciü mitterent, qui cruribus velut gubernaculis curfum dirigentibus, procul afpiciétes qui in caftris erant maxime fpecie bellux deciperét. Arpa gus occafione vindicandx iniuriz querens, literas Cyro nepoti apud Medos in exilio demoräiti, exenterato lepore per feruú mifit, rete guoq deferre iuffit, quo fufpicioné viarú cuftodibus vmbra venatus auferret, factüg eft vt fecrete hinc inde miffis epiftolịs,Cyrus auú Altyagé regno \& Cyro \& Medo priuaret. Non nulli vaginarủ interiora fcripferüt, arưdine alii dolonibusve $\&$ baltheo, alii clãdeftinis nütri fui corporis iumentorǘg fuorum partibus circüplicatam mittunt epittolã. Columbre quog internuncir in magnis rebus fuere, epiftolas annexas collo vel earü pedibus, obfidione Mutinenfi Hyrcia cófule ad Decium Brutum: ac Decio Bruto rurfus ad Hyrciü mittente, vi difpolito cibo quibufdả eminen tifimis locis, colübas tenebris prius inclufas \& fame plurima affectas illinc inde volare inftituerāt.Cæacilius Volateranus equeftris ordinis, hirüdines côprehêfas in vrbé fecú afferens, victoria nuncios amicis mittebat in eundé nidú remeantes. Tradit Fabius Pietor cú obfideretur pręidiú Romanorum,à Lygurtinis ạd. fe allatis lino ad pedes alligato nodis fignificare, quo die adueniéte auxilio eruptio fieri deberec. Eft literarú græcarũ vfus inter Latinos, Latinorũ \& aliorum inter Gręcos. Gręcis.n.literis friptas epiftolas Symmachus Dionyfo regi mie tens, parefacit Carthaginenfes duce Hannone ad beliú arma parare,ob quā rem infidris cognitis, Carthaginéfes edicto publico vetuere ne quis fuorum gręcè lo queretur aut fcriberet. Eft Aegyptiorü quogs vfus, atç qui hunc fequutur, vari as animaliú fpecies pro literis notant eorú more. Non enim fyllabarú compofiti one aut literis verba eorủ exprimútur, fed imaginū huiufmodi forma, éarum fignificatione vfư memorix hominá tradita. Nam vt Lucanus inquit, Nondum flumineos mệphis contexere biblos Nouerat , \& faxis tãtum volucresóp feræóp, Sculptágg feruabant magicas animalia linguas: $v t ~ \&$ in obelifcisadhuc Romæe Rantibus eft videre. Per vulturë nang naruræ vocabulü indicant. Nam mares nullos poffe inter huiufmodi volucres inueniri phyfici tradüt: ac per fpeciem et figuram apis mella cöficientes regem, aculeośq:peraccipitrem ré denotant cito factâ, qưoniam hæc aliarú rermè omnium auis fit velociffima, tranfferturque hac notatio ad domefticas res que velociter fiant. Crocodilus malú frgnificat: dracone auté caudã fuã mordente et in fefe recurrêtc, a nnus per coldem indicatur, fịcut apud noftros clauum indicé annorum numeri fuiffe, diligés taliü modo numerorú auctor Cincius affirmat.Leonis etiam capite apud cos móftratur præfens tépus, quia conditio cius inter pręteritú futurum qu acu præfenti valida feruenş̧́ eft: fed præzeritủ tempus lupi capite fignatur, q memoria rerú tranfactarum rapitur 2 aufertur. Canis ité blandientis effigies futuri têporis defignat euẹtum, de quo nobis fpes licet incerta blanditur. Terram infuper Aegyptii frgnificare cum volunt, bouis figurả ponút. Ofrim cum folé effe afferüt, fceptrum fculpür inóg eo fpeciem oculi exprimunt: \& hoc figno Ofrrim möltrant; frgnifi cantes hunc deũ folem effe, regalióp poteftate fublime cuncta defpicere, quia folem louis oculap appell aur antiquitas. Oculus itê iufticix feruatur, \& totius cor- 
poris interpretatur cuftos : reliquarum corporibus partiü dextra manus dgitis paffıs liberalitaté defignat, finiftra verò cópreffis tenacitatem atọ auaritiá : codem modo \& cxteraru corporis partium figuræ ato infrumenta aliquid certü notabãr, que memoria hominú longa ac meditatione obferuata, è vefrigio quid ea exprimerent internofcebất. Sunt $\&$ iuris militaris notæ, de quibus dicere neceffarium effe duximus: in breuiculis enim quibus militú nomina infcripta cótinebantur apud veteres, quo inficerétur quanti ex militibus fupereffent, quantíg in bello oppetiffent: T. litera in capite verficuli pofita fuperftité defignabat, Thita verò defunctú vnde illud, O primú ante alias infoelix litera Thita. Cum autem imperitia frgnificare vellent, huiufmodi nota, $A$, vfi perhibëtur: cum verò filétio quid agendú,S. Notas etiam literarü inter le veteres factitabant imperatores ac magiftratus, vt qcquid occulce inuicem in fcripturis fignificare vellent, mutuò fcriberét, cęteris ignorátibus quidnã eiufmodi fibi literarum vellet ordo: huius rei teftes funt libri epiftolarum C.Cæfaris ad C. Oppiü, \& Balbum Cornelium, quibus rerủ gerendarú eius in renotis pręentiã exhibere cura erat. In eiufmodi.n. epiftolis inuenire erat literas abfque vllo fyllabarum coniugio, cum occulto tamen ipfarú literarum permutationis ordine, vt in feriptura quidem alterius altera \& fitum \& nomê occuparet, vt in Bartus \& Felipo vocabulis, his ad cuiuf $q_{\beta}$ notädi nominis integritatem literis qux deeffent ex reliquo ele mentorum numero fuperadditis, aliis'g pro feribentiư arbitrio nihil fignifican tibus. Iulius ite Cefar in his qux aperta non om nibus effe voluit,per notas fcripfit, atq̣ eo elementorú fitu vt dictio nulla cóponi quiret. Hû́c verò literarú ordi nê fr quis imitatione dignú cenfeat, $\mathrm{D}$ pro $\mathrm{A}$, et fic deinde reliquis cómutabit $\&$ trâfferet. Super eodé Augufti quoç̧ Cęfaris ad filiñ extat epiftola in húc modũ: Quoniam quidem innumerabilia affidue que fcribi alterutrú oporteat, et ea fẹcreta habeamus inter nos notas, fi vis, tales vt cú nobis aliquid fcribendü erit, pro vna quaqulitera feribamus fequêtem hoc modo, B pro $A$. C pro $B$, ac deinceps eade ratione ceteras, pro Z, litera redeundum ad duplex A A.Sed \& ip fa charta in ratione eft: Ea enim fi fucco crex infcribatur, igni oppofita reddit literas. Tichy malli quoqg quã noltri lactariam herbã,alii lactucam capriná vocant,albifimo fucco inf cripto corpore cum inaruerit, fi cinis fpargitur apparere literas, $\mathbb{Q}$ eis quidẽ alloqui maluiffe veteres quàm codicillis. Simili modo alii alios fallunt, lacte recenti chartis infcriptis, fathifcentibus deinde literis, afperfe carbo nis puluifculo, quales apud ingeniofum poëta in fua re militari dicentem inuenies: Cum poflit cruri chartas celare ligatas, Et iuncto blâdas fub pede ferre no tas, Caurit hæc cuftos, pro charta confcia tergum Prabeat inque fuo corpore verba ferat. Tuta quoog eft fallitós oculos è lacte recent 1 Litera carbonis puluere tange leges. Fallit et humiduli qux fiet acumine lini, Efferet occultas pura tabella notas. Chartam alii callidifimo aftu nullius mométi verbis de rebus feriis ac familiaribus atraméto primú infcribunt, cú alia que cupiút efle fecreta vrina notét: quę deficcata ve intuentiü oculos fallit, cum literarư perfpicue etiá intuen tibus nihil cofpiciatureff fic igne calefcat, literas oboriri vndiq ac legi poffe non dubiư eft. Legimus quog Demaratú lacedęmonio regno pulfum et apud Per 
fas degentem, paratum exercitum contra Gręciam à Xerxe Perfarú rège Lace dęmoniis callido ftudio patefeciffe; fcriptas nấg, tabellas fuperducta recéti cera texit, eafdémque per feruum nefciú facti mifíc: delatæ auté magiftratibusftupo rem attulerunt: fcriptum enim videntes, nihil quàm delufionem effe putabant: alii mittentis ingenium fufpicati funt,ac eo rem maiorem quo effet occultior as bitrati funt, demum rem omnibus dubiam Leonida regis foror aperuit : cera enim tegmine abrafo et fublato, literas occultas inuenit, ac Xerxem vii milia tre centaćp de auxiliis regno armaffe. Nec aliter Ponorum quifpiả à Carthaginenfibus miffus ad confilia hoftium exploranda, fingés fe patria pulfum militemóg fe expeditionis offerens, pugilla ribus vacuis noua defuper illita cera ciuibus fuis omnia perfcribebat. Quidam barbarica calliditate \& aftu plusğ punico vf, abrafa hominum capita infcribunt,domíg quàmdiu capilli frutificent eos obferuant, qui tandem ad amicum fecreti illius confcium miffi abrafíģ, delitefcétes crinibus literas produnt. Lacedæmonii autem \& Ephori cú reipib. fecreta nó omnibus effe communia, literis publicis aut ad claffis prafectos aut ad imperatores fuos miflis volebant, ne fi in manus holtium inciderent, arcana publica proderentur, ea hoc modo in fcripta mittebant, Haftilia duo teretia erant eadem longitudine, pari craflamento, ornatúque confimili, adeò ve vicifim coniuncta cógruerent: ex his alterum cum domi fibi referuent, alterũ tribuant prafecto vel imperatori in bellum defcendenti, cum arcanum quic $\&$ arduum infcribere cupiunt, chartam lori inftar prolixam $\&$ anguftam haltili fuo circumplicant $\&$ inuoluunt,nullum oris cohęrentibus facientes interuallum, haftilis fu perficiem vndique charta occupáte: quod vbi factú eft, in circumplicata charta per tranfuerfum iuncturarum, verfibus à fummo ad imum proficifentibus, defcribunt : dempto dehinc codicillo ad prafectum vel imperatorem commenti illius confcium abfque ligno fcripta nittunt: quac cum is accepit \& lectione mihil valeat, literis truncis $\&$ mutilis $\&$ ita vndique hinc deinde fparfis $\& \alpha$ diffipatis, ve nullius prorfus fenfus coniecturá habeãt, fuo quod penes fe habet fumpto haftili,codıcillum fic pracifum à fummo ad imú, vt fieri debere fciebat, circumplicatum inuoluit, adeò vt eiufmodi curcunductione fimilem in feriem con ftituta verborum continuatio reperiatur. Eft \& circa perfcribendas voces, vel paucioribus literis notandas ftudium neceffarium: quod partim prout cuiq $\mathrm{vi-}$ fum eft fit, partim pro vfu publico \& obferuatione communi. Nanque apud ve teres cum vfus notarum nullus effet propter fcribédi facilitatem, maxime in fenatu,vt hi qui fcribendo aderãt celeriter dicta comprehenderent; quadam literis notabant, \& fingulæ literæ quid fignificarent in próptu erat. Hoc modo vni cam Catonis orationem vt de coniuratis fupplicium fumeretur feruatam, \& literis demandatam ferunt Cicerone confule velocifimos fcriptores difponente, atque docente vt per figna quædam breueśq notas huiufmodi multarum literarum vim habentes dicta colligerent, quo tempore nondum reperti erant hi qui notarii appellabantur: Fed tunc primum huius rei veftigia ferunt extitiffe, aucto réque ad Lucilium Seneca, vilifímorum niancipiorum comméta fuiffe hanc. Itaque publicam et occultam literarum fignificationé quẹ in monumentis ve- 
terum curiarum, tribuum, comitiorum, poteftatum, magiftratuum, præfecture, facrorum ludorun, rerum vrbanarum, rerum militarium, collegiorum, decuriarum, faftorum, numerorum, menfurarum, hiftoricorum denique $\&$ oratorum libris fparfim reperitur, qui latius $\&$ vberius fcire volet, Probi Valerii grammatici, Tullii Tyronis, Ciceronis Liberti, Philargii Samii, L. Annei Sene ca, \& Petri Diaconi commentarios de ea re fatis curiofe confcriptos inquirat. Sunt $\&$ aliæ quædam digitorum note, \& oculorum, aliarumve partium quibus fecum taciti, procul'́p diftantes colloquuntur: ficut militaris etiam mos eft, vt quotiens confentit exercitus, quia voce nó poteft, manu promittat. Alii quia vo ce non poffunt, gladiorum motu faltant. Ennius de quadam impudica, Quafi in choro pila ludens, datatim dat fefe, $\&$. communem facit, alium tenet, alii nutat, alibi manus eft occupata, alii peruell it pedem, alii dat anulú, alium inuocat, cum alio cantat, attamen aliis dat digito literas. Ouidius fimiliter more maiorum apud quos hoc loquendi genus frequentifimum fuife comperio, impudicam aliã \& amicã fuã his notis \& nutibus monet in virum,

Cum premit,inquit, ille thorum vulku,comes ipfa modefto

Ibis vt accunbas, clam mihi tange pedem.

Me fpecta nutuśg meos vultúmque loquacem,

Excipe furtiuas \& refer ipfa notas.

Verba fuperciliis fne voce loquentia dicam,

Verba leges digitis, terba notata mero.

Cum tibi fuccurritveneris la fciuia noftre

Purpureas tenero pollice tange genas.

Si quid erit de me tacita quod mente loquaris,

Pendeat extrema mollis ab aure manus.

Cum tibi qux faciam, mea lux, dicámve placebunt,

Verfetur digitis annulus vque tuis.

Tange manu menfam, tangunt quo more precantes,

Optabis merito cum mala multa viro.

Idem poêta la ciuifimus alibi \&.impudicá aliam \& amicả ab alio corruptam, Ipfe mifer vidi cum me dormire putares

Sobrius appofito crimina veftra mero.

Multa fupercilio vidi vibrante loquentes,

Nutibus in veftris pars bona vocis erat.

Non oculi tacuere tui, confcriptáp vino

Menfa, nec in digitis litera nulla fuit.

Sermonem agnoui quod non videatur,agentem,

Verbáq́ pro certis vifa valere notis.

Finis.

N iii 


\title{
ROBERTI VALTVRII
}

\section{A D I L V S T RM HEROA SIGIS-}

\author{
mundum Pandulphum, de re Militari
}

Liber Octauus.

Vocabula rei Millitaris, publici honoris prifca dique preclara.

Cap. I.

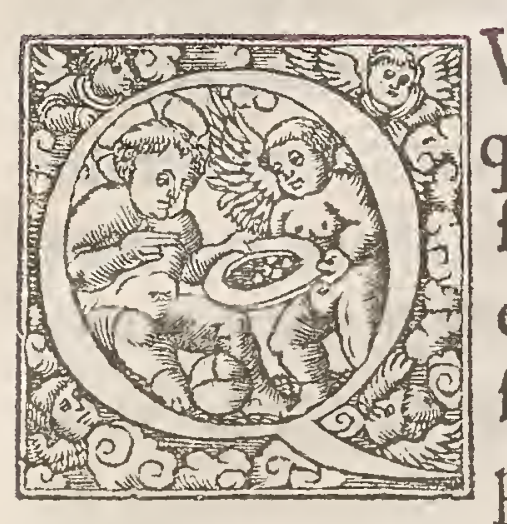

Vanto ingenio ac ftudio, Sigifmúde Pandulphe, apud plerofque fparfim publici honoris rei militaris principatuum magiAtratuumque mentio habita fit, tanto labore fum profecutus eorum vocabula, origines, 8 officia, locis permultis fic diffufa in vnum hunc fequentémque librum, quafi vnum in corpus redigens, ne quid tuæ cognitioni profeffioníque deeflet, quod dignum feientia videretur . Et quoniam regia quidem dignitas ex augurali familia primùm conftituta, fuprema eft omnium dignitatum humana. rum, poétæ veteres Iouem non imperatorem appellant fed regem, tribuentes deo id nomen quod eft apud homines maximum atos amplifimum. Refpub. ciuitates, \& gêtes, tanquã omnium fupremi ac dii quidam inter homines excellentes bonitate, fapientia, \& virtute reges rexerunt: fićóp reges à regendo \& recto, quod reges maximè decet dicti, non vt quorundá temeritas vfurpauit à regnando.Horum plura funt genera,nec eft regú omniú modus vnus poteftatis. In Lacedæmoniorum enim repub. videtur effe maximè fecundum leges, neque enim poteftatem habet omnium, fed cum egreditur extra regionem, imperium habet eorum, qux pertinét ad bellum, præterea facrificia deorumog cerimoniæ ei commiffa funt. Hæc igitur regia poteftas, eft quafi auctoritatem belli perpetuam ha bere: vita enim necifque alicuius non habet poteftatem, nifi dum bellum gerit, vt ëtiam apud antiquos fuiffe videtur, quod oftédit Homerus. Nam Agamemnon in concionibus maledictis $\&$ iurgiis vexabatur, fed cum à concione digref fus in pralio erat,occidendi habebat poteftatem. Eft alia infuper fpecies regni, qualia funt apud quoldã Barbaros regna vim habétia proximã tyrannidi, licet fint legitima \& fecundum morem patrix : ob id enim quia magis aptæ funt ad feruiendum nationes Barbarorum, quàm Gręcorum: \& eorú qui incolunt Afram, quàm eorũ qui Europã, perferūt feruile iugum aquo animo. Tertia eft fpeci es vt antiquitus in Græcia fuere, quios vocabant Efegetas : eft enim hac vt fimpliciter dicamus electiua tyrannis, differens à Barbarica,non eo quòd legitimx, fed eo quòd non confueta: poteftas autem huiufmodi aut viuente durabat, aut tempore aut rebus geltis finiebatur, qualem elegerunt quandoque Mitilenei $P_{\text {it }}$ tacum aduerfus exules fuos. Quarta fpecies eft quales erant heroicis temporibus fpontanex, \& fecundum morem \& legem: propter beneficia enim à primis collata in populos,vel per partes,vel per bellum, vel per congregationem in vnum, vel per acquifitionem regionis, delatú fuit eis regnum de populorum voluntate, 
\& fuccefforibus,id erat fecundum patrię morem ( fecundum patrium etiam mo rem apud Taprobanem,alterum terrarum diu exiltimatum orbem, eligi regem à populo, lenecta, clementiáque infigni, liberis carentem folere, cæterum fi poftea gignat abdicari, ne fiat hæreditarium regnum:rectores quinetian ei dari à populo xxx,nec nifi plurium fententia quenquam capite damnari: fic quog appel lationem effe ad populú,, $\mathrm{xx}$ iudices dari, fi libertus: fi rex,amplius triginta. Ex Aphricæ quadam etiam parte funt, qui fecundum morem canem pro rege habent,motu eius impia augurätes. Primo autem regia poteftas fuit apud Cretam tefte Ariftotele,Diodoro licet vbinam coperit incompertum fit, cum nulli omnino hiftorici eam tradant. Illam poftea fuftulerút imperio in bello ad Cofmos tranflato: ad alias deinde atqu alias nationes defluxit, inter fe habitu, cultúg diItantes, vt ad Perfas,à quorum regibus mos erat thiaram geri, in cuius fummitate gemma erat permagna \& lucens in auro illigata. Aegyptios verò apud reges mos erat, aut leonis, aut tauri, aut draconis priorem partem in capite ferre, infignia principatus: quandog verò arborem, aliquando ignem, quandog redo lentia fupra caput vnguenta. Aethiopum reges fceptrum in aratri formam gerunt, ac pileos oblongos circa finem, vmbilicum habêtes ferpentibus, quos afpidas vocant circumuolutum, monumentum infigne, eos qui contra reges infurgere audeant, mortiferis morfibus fubeffe. A pud Romanos autem infignia erát Sella currulis \& Trabea: iuxta maroneum illud, Et Sellam regni Trabeámque infignia noftri.

Nam diadema vt aliarum gentium reges,primó non habebãt: creterum haftis, quas Graci fceptra dixere, pro diademate vfi perhibentur: atqp hacc apud excellentiffimü quoq̣ vatem Homerú non omnes reges à loue fumebant, fed folum qui bonum \& qui fummum ftudium adhiberent ve fubditi quàm beatiffimi ef fent. Hæc diuerfa regum infignia,tum ad decorem fpectabant,atģ or natú, tum ftuporem ac fuperftitionem quandã alpicientibus iniciebant. Ad poftremum, quoniam rex in tyrannú, regni tranfgreffione prolabitur, tyrānus'ọ \& rex non nomine fed factis diftant auctore Seneca, fit vt regis appellatio quand oque in ty rannum cadat, tyranníg in regem:

Quo potuit ciuem populus perducere liber:

Afcendi, fupráq́ nihil nifr regna reliqui: \&illud,

Spes míhi pacis erat dextram tetigiffe tyranni.

Interregnum deinde appellatum id tempus quo regia vacabat fedes: nam cum primùm initum eft poft Romulü regem vita functum, totus ille annus per quinos dies cétum fenatoribus deputatus eft, decem decuriis factis finguliṣ́́ in fingulas decurias creatis, qui fummæ rerum pręeffent, ne aliquis fub equali dignita te romani expers remaneret imperii: decem itaq imperitabant, \& vnus dütaxat qui \& lictores haberet, dicédíque iuris poteftatê, ac regis \& imperii infignia, id' $\$$ imperium quinque dierum fpacio finiebatur, ac per omnes in or bem ibat, annuumque interuallum regni fuit $i d, a b$ re quod nunc tenet nomen interregnum appellatum. Huc accedit quòd etiam fub confulibus praditi imperio confulari fr quando interregnum initum eft,interreges fuerüt, nec unquam ita vacua 
fuit hoc nomine respub. vt nullus interrex biduo falté triduóve crearctur . Video mihi hoc in loco poffe obiici currules magiftratus apud maiores noftros quadrienniú in repub.non fuiffe, fed erant tribuni plebis cú tribunitia poteftate que pars maxima regalis imperii eft, tamen nó eft proditú interreges eo tépore non fuifle, quin etiam verioribus hiftoricis referétibus declaratú eft,confules ab interregibus procreatos qui haberent reliquorum comitia magiftratuú. In hoc autem regis delectu decreuerunt vt cum populus regem iuffiflet, id fic ratú effet fi patres auctores fierent: tum interrex cócione vocata, Quod bonum, fauftum, foelixóp fit,inquit, Quirites regem create, ita patribus vifum eft : patres deinde fi dignum qui fecundus à Romulo numeretur crearitis auctores fient. Dictator Etrufco more creatus, tremédus profectò ma giftratus ato̧ feuerus fummx́ćp po teltatis erat; quippe quòd cęteros omnes magiftratus diffolueret pręter tribunitiam poteftatem, auctore Plutarcho, quodóp dicto eius parèndum effet, nec ab co ad populum vti à confule prouocare liceret : infignia erant huic confularia omnia, ac fpeciem quodammodo regix poteftatis præferebat: verùm rege exiftente coff.præxtores ac cęteri magiftratus in repub. manere nó poterant. Dictatura au tem fimulac inducta fuerat in rempub. cæteri magiftratus omnes interibant, $\&$ abrogati per creationé dictatoris præter tribunos plebis cenfebantur: $\&$ in hoc differebat dictatura à rege, quòd rege regnante tribunitia poteftaś́p plebis aucto ritas omnis omnino foluebatur: dictatore manente, plebis plebeíp magiftratus vim auctoritatémque fuam retinebant. Dictator idem nec alio quidem pacto creari confueuit fue ad bellum defignari, quàm cum vis aliqua maior de impro uifo oborta, ingentem vrbi cladem minitare videretur,fićóp duos quondam vno tempore in vrbe fuifle dictatores, quòd im moderata fors, neceffitas, \& tempus ef fecerunt xxiii. vrbis códitæ, auctor eft Liuius. Huic equitare fas non erat. fed ve. teri lege prohibitum, frue quod maiores vires inefle pedes manum conferere debentibus arbitrarêtur, fiue propter hoc imperatore in phalange permanere opor tere nec locum deferere, frue quòd ad alia etiam ty rannica magnáq fit principa tus potentia. Fabius autem dictator defignatus ma giftrum equitum, L. Minuti um primùm à fenatu petiit,vt equo vti fibi dictatori liceret. Præterea eum quem nos dictatorem diximus, in hiftoriis ita nominari,legimus apud antiquos magi ftratum populi vocatum, pofteáque in auguralibus libris ac in bonorü finibus fcriptum effe, \& Cicero, \& Seneca ad Lucilium clari teftes non defunt, teftimouium'́s eft quòd qui ab illo nominatur, magifter equitum eft, quem vti volebat ipfe dicebat. Non autem poft reges exactos anno dignitas hac fiue poteftas pro tempore maior quàm confulatus, cum magiftro equitum qui ci obfequeretur creata eft, \& apud patres effe copit nec amplius quàm femeftri tempore duratura, nifi fi qui forte illam potentiam adepti per vim diutius tenuerint, vt $\mathrm{L}$. Sylla,\& C.Cafar qui perpetui dictatores, tyrannidis odiofum atque infame no men vitare volentes rempub. oppreffere. Quis autem primum dictator creatus fit non fatis conftat auctore Liuio, apud vetuftiffimos tamé auctores frqua eidem auctori fides elt, \& Eufebio Cæfarienfi, T.Largium dickatorem primü,Sp.Caffrum magiftrum equitum, creatos inuenio : quòd autem vel futuros dictare hic magiftratus 
magiftratus folitus fit, vel à confule diceretur,cui dicto obedientes omnes effent, M. Varrone tefte dictatorem appellatú conftat: vel vt inquit Plutarchus in vita M.Marcelli, cum dictator à populo aut à fenatu deligi non polfit, verùm alter confulum aut imperator progreffus ad populum quem cenfeat dictatorem dicit, \& quia dictus fit dictatorem appellant. Nonnulli ab eo dicta torem dictum aiunt, quòd non populi fuffragio aut affenfu, verum quòd is cenfeat, imperat frquidem iuffa magiftratuum qux Græci só qu $\alpha$, Romani vocant edicta: $\&$ im periofffimi duodecim fafces licet fuerint vtpote penes quos fenatus \& equeftris ordinis $\&$ vniuerfa plebis fummum decus effet, quorimgue nutu Latium ac to tius Italix vires regerentur, contufi tamen ato fracti dictatorix huic fe animaduerfioni perfxpe fubftrauerunt:ac ne multa foret lafa gloria militaris,cóful delicti omnis vindex à dictatore nonnunquam punitus eft.

Magifter equitũ dictus, quòd vt eft fumma populi dictator̂, fic fumma huius poteftas in equites \& accéfos, frue quòd in bello equeftres ipfe copias duceret: qui verò dictator effet et fr praeffet omnibus, legiones tamen folú pedeftres more maiorü ducendas haberet. Reliqui quidem minores quàm hi magiftri dicti magiItratus,vt ab albo albatus.

Magifri appellantur quibus præcipua cura rerum incumbit, quí $\not$ magis $q$ cæteri obligantur. Nec folum doctores artium fed etiam pagorum, focietatum, vicorum, collegiorum, equitum, magiftri dicuntur, quia omnes hi magis cæateris obligantur \& poffunt, quinetiam \& ipfi magiftratus qui per imperia potentiores funt quàm priuati, per deriuationem à magiftris cognominationé afcifcút. Eft enim magiftratus poteftas vni vel pluribus hominibus à populo vel à principe commiffa. Vnde prætores, procoff. Tribunos plebis, $\&$ xdiles currules, \& pręfectos ãnonæa aliófque qui maiorü, vt diximus, arbitrio puincias regunt, non principatú dicimus habere, fed magiftratú. His enim datú eft deliberare de quibufdã $\&$ ftatuere, $\&$ iubere, $\&$ intelligere fe gerere perfonam ciuitatis, deberéque eius dignitate $\&$ decus fuftinere, feruare leges, ịura defcribere, $\&$ ea fuę fidei com miffa meminiffe. Ad hos palatii quog pertinet difciplina,per quá infoletiú mores pcellofi, multorúnque ordine moderatione fua fine aliqua confufione cóponuntur,per eoslegatorum, quanquam feftinantium, prænuntiatur euentus, his poteftatem eam decernit antiquitas vt nemo iudicium per prouincias fafces af fumeret nifi hoc $\&$ ipfi fieri decreuiffent, tantág eorú officium auctoritate deco ratur,vt militiæ perfunctus muneribus ornetur nomine principatus, miróg mo do inter pretorias cohortes $\&$ vrbanæ prafecture milites primatú inueniffe videantur. Principatus auté maior eft quędam fupereminentia cui cæteræ omnes poteftates parent,fic Oetauianum, Claudium, \& Vefpafianü principes fuife dicimus: Senecam verò qui col. fuit temporibus Neronis, nemo principem appellaffet. Erat enim Nero princeps non Seneca,neque confulatus Senecæ principatus erat, $\mathrm{fed}$ magiftratus: \& neque imperium Neronis magiftratus dicebatur fed principatus. Cum veró quidam magiftratuum $\&$ non omnes pertractent multa negociorum publicorum, necefle eft effe alium magiftratum qui rationes repe. tat ato corrigat,ipfe veró nihil tractet: vocant vero hos alii correptores, alii ra- 
tionales, alii fcrutatores, alii procuratores: pręter verò hos omnes magiftratus vnus eft maximè principaliffimus omniü: idé enim plerüğ habet finê et introdu ctionem, qui prafidet multitudini vbi populus dominatur: oportet auté id quod cogit fumman habere in repub auctoritaté. Appellat verò quibufdam in locis præconfultores, ex eo quia ante deliberant: vbi vero multitudo elt, conflium ma gis. Ciuitatum igitur magiftratus tot aliqui funt. Nec id præterea fubticendum Marci. Varronis lententia libro rerum humanarum vigefimoprimo, In magiftratibus, inquit, habent alii vocationem vt confules \& cateri qui habent imperium, alii prefronem vt tribu. plebis, et alii qui habent viatorem, alii neq vocationem neque prenfonem, vt queftores \& cxteri qui neç lictorem habent neque viatorem. Qui vocationem habent iidem prendere, tenere, adducere poffunt: $\&$ hxc omnia fue adfunt quos vocant, fue acciri iufferint. Tribuni plebis vocationem habent nullam, neç minus multi imperiti perinde at ${ }^{2}$ haberent ea funt vfi. Huius ergo iuris quod M. Varro tradit Labeonem arbitror vna tunc fidutia cum priuatus effet vocatú à tribuno non iffe. Sed quarentibus quam ob cau fam tribuni qui haberent fummam coërcendi poteftatem ius vocandi non habuerint, facile eft refpódere: quòd tribuni plebis antiquitus creati videntur, non iuridicendo, nec caufs querelisg' de ablentibus nofcendis, fed interceflionibus fa ciendis: quibus qui pręensfuifet, vt iniuria qua coram fieret arcerctur, ac propterea ius aduocandi ademptum, quoniam ve vim ficri vetarent affiduitate horum \& præientium oculis opuserat. Moris porrò erat magiftratum petentibus, prehenfos dextra ciues benignis orare verbis, $\&$ ablog interiore tunica in forum opertos vefte defcendere, frue vt eo habitu ad fupplicádum humiliores accede. rent, fue vt qui cicatrices haberent manifefte figna fortitudinis a perirent : hæc cum plura ofenderent, quæ affidue multos per annos egregii bellatores exceperant,vniuerfillorum virtutem tacita.veneratione profeguebãtur, magiftratum deniqg vltra quing dies nifr qui iuraffent in leges non licebat gerere. Legati tefte Varrone funt qui leçi publicè quorum opera cóflióque vteretur peregre magiftratus, quíve nuntii fenatus aut populi effent.

Imperatores femper multi quotannis re bene atog foliciter gefta aduerfus ho fes à militibus honoris caufa appellabantur, vnde \& inter cateros atatis fue du ces $\&$ imperatores cum circumfufa multitudo Hilpanorum $\&$ antè deditorum, \&' pridie captorum regem Scipionem ingenti plaufu ac confenfu appellaffent: tum Scipio filentio per praconem facto, fibi maximum nomen imperatoris effe dixit quo fe milites fui appellaflent, regiumíg nomen alibi magnum, Roma exofum $\&$ intolerabile effe, regalem animü in fe efle, fri id honoris ingenio ampliffi mum ducerent, taciri iudicarent vocis vfurpatione abftinerent. Inter principes etiam ciuitatis M.T.Cicero procol dum Parthos tripartico exercitu hoftesinua deret;ac polt magnam eorun cæedem Amanum eius gétis caput, Sepiram item \& caftella cóplura vi cepiffet, ab exercitu imperator appellatus eft. I ulius autem Cęar cum fapius poft partam victoriam effec imperator ab exercitu appellatus, non imperatorum aut regum, fed dictatoris nonen vfurpauit, tantum odium fibi regis nomen in vrbe contraxerat. Cum autem regis nomen cuperet, vereretúrque 
eirque populi indignationem, molitus expeditionem in Parthos, afferens in libris fatidicis cótineri, non nifi à rege Parthos fuperari poffe,fe regem dici procurauit, qui maturädx mortis fux caufam prabuit coniutationi. Nullus autem fequentium Cxlarum fe regé Romanorum dicere aufus eft. Imperatoris autem appellatio perpetua Cafarum non erat, ficuti nec confulis, nec pretoris, nec tri buni plebis: pam \& priores illos vario numero, quofdá fepties, quofdam maiori, quofdam minori numero inuenimus appellatos imperatores, fic coff fic tribunos plebis: dignitatis enim, non officii id nomé fuit. Nam re profperè aduerfus hoftes gefta, fic erat a maioribus inftitutum, ac repu. libera perpetuo cuftoditum ve cof.procol. prætor, fiue quis alius fuerit Romanus qui hoftiú numesú quàm maximum cxderet, aut pernagna contra hoftes victuria potiretur, is quodam: præexcellenti honore ad virtutis teftimonium vel decus; imperator ab exercitu vocaretur. Nondú erat qui núc viget mos, vt quen Romanorum imperatorem gentes vniuerfe vocant, is fit vnus orbis princeps, \& poteftate fumma rerum dominus videatur: id enim dú S.P.Q.R.cóflio pub.rempub.gubernarunt, ducibus non honoris pro victoria parta, non poteftatis fuit : A quo aucem primum hace noua imperatoris noftri temporis coronandi ornandíp cófuetudo veliabu fio potius defluxerit, non fatis intelligo, maxime cum romanum Cafarem antiquis illis temporibus coronatum fuiffe, nullum vnquam audierim aut legerin. Non enim Iulius Cafar, non Auguftus, non Tyberius, non Caligula,non Nero, Q. erant hi duo potifimum extremi intolerand $x$ fuperbix ac luxuriæ, coronan imperii vnquam fufcepit, aut habuit, aut vfus fertur, nifi forte laurea cum triumphaffet: aut quapiam alia ciuica, vel caltrenfi, qux non Cxfarum erant magis $s_{2}$ quàm quorumcunque triumphantium aut vincentium. Exiftimo autem hoc å Barbaris deriuañ, qui cum prifcas hiftorias ignorarêt, neque verborum vim imperatoris $\&$ regịs probè nolcerent, effetque frequens a pud eos regis nomen, vtpote fub regı bus viuentes, imperatorem yerò rarum viderent, id excellentius ar bitrati funt quod rarius ac infuetius confpiciebant: vtcunque tamen hoc adole uerit, id planè conftat vel à Barbariş, vi antè diximus, non fcitèjaut à doctis parư modeftè hanc fublimem imperatoris, id eft, dei appellationem, vt inquit Cicero, magis quàm regiam poft coronationem vfurpatam, $\&$ à polterioribus introductam effe regibuśśg côceffam. Prinum autem apud maiores noftros inperatorem appellatum, vtpote cui armorum exercirú que ad tutandam augendámog rempub.commiffa fit auctoritas, Lucium Lucullum fuife, in defcriptione temporum teftis eft Eufebius.

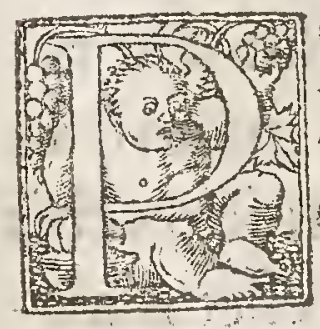

Ontifices aliquiauctore Plutarcho dictos putant, quoniam deos co lunt,potentes ac omnium dominos:alii veró inquiunt nomen confi ctum effe ad potentum profligationen, tanquam iubente legunilato re, facerdotes obire potentia facra debeant: pontifices verò ve Varro inquit, Q. Mutius Scruola dicere folebat à polfe \& facere appellatos elfe, fed ea defcripio a Varrone non fatis probatur: nam à ponte \& facio potius dictos exitimat, $q$ ab his primum pons Sublicius factus, \& fape reltitutus Ge: Secundum 
alios à fanctiffimis \& vetuftifimis facrificiis, qux ad pontem fierent. Pontifices quatuor ex gente patritia, totidémq plebcia à Romanis primùm creati, quorum ordinem \& conftitutionem Numæ tribuunt: Maximus veròappellatus $q$ \& minores pontifices effent, Liuius. L. Cantilius Scriba pontificis, quos nunc mi nores pontifices appellant, qui cum Floronia ftuprum fecerat, à pontifice maximo coulog virgis in comitio cæu erat; vt inter verbera expiraret. Hic Maximus ex pontificibus, veluti interpretis $\&$ prænuntiantis, quin hierofantæ potius ordinem et locum teriet,qui quidem non folum res qux publica funt curat, fed eti am priuatim facrificantes obferuat:impedimentóque eft re quis legitima tranfgrediatur,docétq qua quifpiam rẹ ad venerationem deorum,vel ad poftulandá veniam indigeret. Erat \& facrarum virginum cultos quas Veftales appellant, \& iudex, $\&$ punitor facrilegii.Habebat etiam penes fe idem pontifex facra omnia, dèfignabatóq quibus hoftiis, quibus diebus, ad quxtempla facra fieri deberent: cuiufmodi diuinis in rebus, \& vnde erogand a pecunia fumptus fieri deberet . Pontificibus etiam permiffa eft poteftas memoriam rerum geftarum in tabulas conferendi \& hos annales appellant, equidem maximos quafi à pontificibus ma ximis factos. Proinde maiores noftri antiquiffimi, prafertim terum geftarum memoria delectati, hanc diligentiam habuerunt, $q$ hiftoriam fcribere auderet nemo,qui munus id datú fịbi de publico non haberet, id verò daretur nulli, nifi effet vir probitate fidei;fingularíque virtute aliqua præditus, ac dignitate cæeteris anteiret. Hebræo nanque populo,vt ab illis initium fumam qui vetuftate generis,qui magnitudine rerum, qui dignitate hiftoria fe cęteris praponunit, hanc legem fuiffe cóperimus, vt qua ab his gefta pace vel bello effent, nili qui propheta effet: prophetam cum is populus habere defiit, tum naximum ad pontıfice qui auctoritate, honore, dignitate præftaret, hanc ipfam fcribendi curam $\&$ officium detulerunt. Hunc inorem à vetuftiffimis traditum, perdiu $\&$ eos vique dies quibus eft Hierufalem excidium fuum paffa, diligentiflime cuftoditum, Iofephus in Appionem fcribens tradit. Chaldxi quoque, \& Aegyptii, \& qui oriundi funt ab illis Phonices, Syriæ nobilifimi populi, fum mo fudio $\&$ diligentia afferuarunt, $v$ t qui magno facerdotio potiretur, hic nodo populi fui gefta perfcriberet. Plato ité philofophus, \& Ariftotelis preceptor, fuo in Timæo adducit facerdotem xgyptium, hominem apud fuos venerabilem, $\&$ multarum rerum notitia excellentem, gui Soloni interroganti de geftis, $\&$ vetuftate gentis ægyptiæ refponderet. A pud Grecos,qui militari difciplina, qui imperio,qui fapientix ftudio plurimum floruerunt,ea lex perdiu manfit, quòd deli geretur de publico vir bonus atop doctus quilpiam, qui co pacto, \& dicta, \& facta omnia memoraret, vt nihil infereret quod aut ipfe oculis nó vidiffet fuis,aut ve. rủ effe certo \& indubitato teítimonio nố haberet : Romanis verò \& maioribus noftris, qui orbis tandem imperium vendicarunt, hoc inftitutum ab initio vrbis ad multos annôs fuiffe memorant Cicero \& Liưuis, vt qui pontifex effet maximus, facra püblica ab Numa inftituta, frue res omnes fingulorü annorú mandaré literis, eáro in albun refêrét, at $\phi$ dom praponeret in publico tabulas, vt po pulo effet poteftas cognofendi, nihil gratia, nihilog odio fcriptum effelllud nec minus 
minus prætereundum, quòd fi maiorum religiones $\&$ eorum monumenta reuolueris, inuenies apud illos non humilibus $\&$ inopibus, fed opulentis hominibus et principibus ciuitatis fummum facerdotium mãdari folitum effe . Imprimis, primi cum fe ingerant, Perfarum facerdotes qui erāt \& dicebantur Magi: Aegyptiorum deinde, Affyriorum, aliarumóg nationú quantis diuitiis opibúfque prapollerent his, qui aliquam rerum geftaru notitiam habuerint, fat is conftare potelt: quòd fi parum ifta te mouent, $q$ externa \& peregrina funt,maximé que à noftris legibus abhorrent, repetantur fummi hebræorum facerdotes, quorum vetuftifimi, Aaron, Eleazar, Phinees, Heli, Abiathar,fic omni copiarum genere abundarüt, vt dictu incredibile cuiquá videatur: fr deniq̧ad Romanos redeo,vnde coeperat oratio, M. Fabiü primú ex patribus lectũ, Luciumọ́ pòft Me tellum, praclarũ virum, pontificem factum maximum duośg eum et xx.annos ei facerdotio præfuiffe conttat. Cæfares quog legimus \& plerosóp alios qui Ro. mæ téporibus illis gloria rerum geftarú, opibus \& potentia plurinum præetare putabantur, fummos fepe facerdotes fuiffe. Hanc dignitatem pontificum, augu rum, qua Romulo regnante nulla erat, Numam Pompilium à rege ad alios detuliffe accepimus, ne quâdo rege bellicis rebus occupato diuinus cult ưs intermit teretur. Pontifices deniqg veteres, vt in tertio de Oratore teft is eft Cicero, propter fácrificiorü multitudinê tres viros epulones effe voluerunt, cü effët ipfí à Numa vt etiâ illud ludorum ac epulare facrificium facerent, inftituti . Epulones, Fefto tefte, dicebãt antiqui quos nũc epulones dicimus, da tứq his nomé $q$ epulas indi cendi loui cæeteriśg diis poteftatem haberent: de his ctiam Lucanus in primo, Virque epulis feptem Feftus Titiis'́p fodales.

Caterum cum aliqua fpecies curationis fie circa rem diuinam, ceu facerdotes $\&$ æditui circa templa vt conferuentur quæ funt, $\&$ erigantur ruinofa ædificia; \& cetera omnia qux pertinét ad divinum cultum, euenit alicubi curam hanc ef fe vnam,vt in paruis ciuitatibus:alibi verò feperatis à facerdotio, vt facrificuli, xditui,\& cuftodes fâcrarú pecuniarú. Huic confequens eft cura illa qua eft circa facrificia publica quxcunq, qux ex facerdotibus lex non cómittit, fed ex pu blico funt. Vocant autem eos qui iftis prafunt, alii reges facrorum, alii pótifices maximos. Maiorum enim confuetudo tunc erat, vt rex effet etiam facerdos vel pontifex,fic poltea vel reges vel imperatores pontifices dictos, Maro nullius religionis expers his verbis oftendit, Rex Anius, rex idẽ hominú Phoebiọ́ facerdos. Fociales quorum pater patratus princeps erat, facerdotes dicebantur qui faciendis pręerant foederibus: hi vt Pomponio placet à ferendo dicti, vt M. Varro mi à fide et faciendo, vt aliis, foeciales quafi fordiales, à foederibus faciendis, quorü ius ab Equiculis ad Romanos tranflatum effe non dubium eft.

Caduceatores,pacis legati dicútur: ficut enim per foeciales bell a indicebãtur, ita pax per caduceatores. E凡t auten caduceum verbena $\&$ pacis fignum, quod nó ab re Mercurii virgã poffumus exiftimare. Mercurius enim orationis deus dicitur,ct interpres deorü: vnde ficut virga ferpétes diuidit, hoc eft venenum, ita bellantes interueniente oratione fedantur, bellumíg cadit atóg dirimitur. Aediles quidam publicis ludis ac egdibus pręerät, nomen ab adibus huic ma 
giftratui datum ve Fefro placer, Varroni \& Paulo quod adium non tam facrarum quàm priuatarü etian cura haberent, ac illis praffent, in quibus fcita omnia fua plebs deferret: duo quidem primum \& ex plebe conftituti ac proinde ple bei appellati,exactisóg regibus anno propemodum feptimodecimo cum plebs à patribus feceffifet, tribunos fibi in monte facro creauit, qui effent plebei magiAratus, deinde cum vellet ex fuo quogue corpore colf. creare \& patres recufarét, facum ef ve tribuni militum crearentur, tum ex plebe, tum ex patribus confulari poteftate, paulópoft cum placuiffet creari ex plebe confules, ceperüt ex vtroque corpore conftitui, tunc vt aliqui pluris patres haberét, placuit duos ex numeto patrum conftitui : $\&$ ita facti funt $x$ diles currules, vnde ortum vt adiles alii plebei, alii currules appellarentur. Sella enin quafi feda à fedendo dicta eft. R e* gia quidem fedes erat currulis, à curuitate pedú ipfus fella, in qua fedetur fic di cta : vel quod in ea qui effent reges cum veherentur curru ad eminentiam vtetẹtur. Poftea verò cum regibus libera Roma fuiffet, Magiftratus maiores, vt confules, dictatores \& plerigg ali, regio more fella curruli vectabantur:vnde magiftratus hi funt currules, cæteri vero plebei feu pedanei, guod pedibus irent appellati,nec curru negg fella curruli veherentur: quod autem duo fuerint çdiles, his verbis in Pifonem ofendir Ciccro, Mecum, inquit, guatore imprimis adilem priorcm,pratorem primum cuncis fufragiis populus faciebat, edilem prioren dixit quod duo erant tantum $x$ diles, ficut duo confules. Huius rei fi quis fidem polulet, bini femper adiles in argumentis comodiarum nominantur a Terentio. Hi etiam fue plebci, fue currules ludos faciebant inftaurabátóg. Liuius belli Macedonicilibro primo: Iudi Romani f anici co anno magnificè apparatéq factiab xdilibus currulibus. Idem in codem paulópont, \& plebeiludi ter tots infauratiab ædilbus plebis: adilum enim partes in ludis inftituendis, quantum impenf 2 in quibus fpectaculis fierent haudquaquam minima fuere. Id etiam erat potifmum adilitatis munus ve fua quifg xdilis impenfa ludos pro modo patrimonil ac dignitatis fux celebrand os curaret. Huius inftitut $M$. T. Cicero in officialibus, cum fux \& $\mathrm{Cn}$. Pompcii xdilitatis meminit tefis eft. Alconius etiam Pedianus Pompeium ædilem Gacum theatrú quod fumma impenfa ædificauerat magnificentifimis ludis in quos currus cum elephantis induxit,edificaffe afferit: Valerius ité Maximus in libris dictorum factorúmq memorabili um fripfit Attilium Seranum \&L. Scribonium ædiles, fenatus plebífque loca fecreuife: Quod fi Vlpiano auctore mancipium fugitium erronémque aut iumentum morbo aut vitio aliquo affectum quifpiam pro fano venundederit, do lis ac fallaciis vendentium occurrendo ædilium edicto emptori fuccurritur tedhibeturóp: Porro vt vrbis cloacæ, aque ductus, \& xdificia qux $q$ publica \& pri uata, munda, lota, integra, expeditág, afferuarentur ad adilium officium pertinere non dubium eft, vt Cicero nofter cum factus effet edilis, actione in Verrem feptima, cateris more fuo longè verius ac melius atteftatur: Nunc fum, inquit, defignatus adilis, habeo rationem quod a populo Romano acceperim mihiludos farítiffimos maxima cú cerimonia Cereri, Libero,liberég faciendos, mihi Floram matrem populo plebíque Romano:ludorú celebritate placảdam, mihi ludos 
ludos antiquifimos, qui primi Romani funt nominati maxima cum dignitate ac religione loui, I unoni, Miueruxép efle faciêdos, mihi facrarum ędium pro curationem, mihi totam vrbem tuendam efle commiffam, ob earum rerú laborem \& folicitudinem fructus illos datos, antiquiorem in fenatu fententix dicen dælocum,togam pretextam, fellam currulem, ius, imagines ad memoriam poRteritatem'́p prodendã. Sunt præter hos ædiles plebeios \& currules, duo alii qui frumento preerant, \& quorum creandorum auctor fuit C.Iulius $C x$. híque, vt inquit Pompeius, à Cerere cereales dicti. Aeditui preterea appellatione eqdiles intelligimus: eft enim edituus idem op æilis, cuftos facra fcilicet $x$ dis vel templi, quafi ædem tuens vel adis tutor; dictus is enim elt cui facrari cuftodiar commif fa erat, vbi ftatuæ feruabantur et fmulacra deorú gentilium, quę opus erat exorare,fi quis optaffet aliquid apud illa deprecari et impetrare, quod multi factita bant credentes exaudiri, fi verba fua fimulacrorum auribus inftillaffent, Seneca epiftol.li.v. Non funt ad celum eleuande manus, nec exorandus adituus, vt nos ad aure frmulacri,quafi magis axandiri poffimus, admittat. Aeditimus quog idem quod edituus: fed. M. Varro in fecundo libro ad Marcellum de latino fer mone, æditimum dici oportere cenfet magis quàm ędituum: quod alterú recéti nouitate fictum, alterú antiqua origine incorruptum: Lauinius in Prothefliao Clauftrinú dixit qui clauftris ianuæ præeffet, eadem.f.figura æedicinú dici inbe bat,qui ædibus præelt: in Verrem. M. Tul.in exemplaribus fidelifimis ita in ueuiri fcriptum, aditimi cuftodéfque maturè fentiunt. In libris autem his vulgaribus ęditiui fcriptú eft, Pomponii fabula Atheliana eft, quę ita infcripta ef, Aeditinus, in qua hic verfus eft, Qui poftä tibi appareo atque eqditimo in templo tuo: T.autem Lucretius in carmine fuo pro ædituis adituentes appellat.

Flamines permultos fuiffe comperio, \& tot deniqg quot deos colerêt, vfos vete res romanos, M. Vartro in his libris quos de origine lingue latinæ fcripfit teftis eft,vt Dialem, Martialem, Quirinalem, Volcanalem, caterośg eiulmodi, verum flaminem Dialem Numa Pompilius Romæ rex creauit, cú antea reges pontificum ac regú munera promifue gererent, vt de Priamo \& Aenea apud Maronem, \& à minoribus tandem, vt à C.Cæe.diuo Augufto, multisg aliis principibus, quos maxime pontificatus titulis infignitos in multis qux adhuc extât monumentis cernimus obferuatú effe. Cæterú Numa plures in vrbe Romuli qu fui fimiles reges fore ratus, qui relicta religionis cura, bellorú negotilis implicaretur, facerdotes quos flamines appellant, quión rei diuinæ iugiter adactieffent, multis deorum inftituit, flaminem vnum loui infigni vefte $\&$ curruli regia fella adornatum, quem Dialé rocant, huic duos flamines adiecit Marti vnum, Quirino alterü: dicti autem primo fiamines ve Plutarcho placet, ab his qui circum calua ria lunt pileis, quibus ad tegédum capita vtuntur, quafi pileamines quidã eflènt. Lucanus in primo: Et tollens apicem generofo vertice flamé :vel vt Varro inquit, quòd in Latio capite vela to erant, $\&$ caput filo lanæ pracinctú habebant, à quo flamines quafi filamines vocabãtur. Dialis verò à dio, à quo vita dari putabatur hominibus:vel à Toue quod eft iuuâs deus . Cæateri enim quig̣ cui præfunt, numinis eius titulo decorätur: hic folus, vt Varro ait, lib.1i.rerü diuinarum
$O$ ii
album 
Album habet galerú, vel eo $q$ maximus eft, vel eo quód loui immolari alba ho ftia opus fit. Multiplices etiam cerimonix fiunt, quas in libris qui de facerdotibus publicis compofiti funt, item in Fabii pictoris librorú primo fcriptas legimus, vade has fermè funt qux cómeninimus:equo enim dialem flaminem ve hi religioeft, item iurare dialem fas nunquam eft, ignem è flamine,id eft, flami nis dialis domo nif facrum efferri ius non eft, vinctum fi ades eius introiret folui neceffe eft, $\&$ vincula per impluuium in tegulas fubduci atog inde foras in viam dimitti, hederam neq tangere neg nominare fas erat, pro eo quòd hedera vincit ad quodcunq fe applicat: fed neanulum quidé gerere eilicebat folidum, aut aliquem in fe neque in a pice neque in cinctu neque alia in parte nodum habere, fi quis ad verberandú ducatur, fi ad pedes eius fupplex procubuerit eo die verberari piaculú eft. Capillum dialis nifi qui liber homo eft non tonfet,capram $\&$ carnem incoctam \& fabam neq tangere diali mos eft neque nominare, procinctam claffem, id eft, paratam ad bellum militú multitudine dialiflamini videre non licet, propagnnes è vitibus altius pratentis non fuccidet, pedes lecti in quo cubat luto tenui circunlitos etiam oportet, vnguis dialis \& capilli fegmenta fubter arborem ilicé terra operientur. Dialis quotidie feftatus eft fine apice, fub dio autem effe licitum non elt , fub tecto vtiliter $\&$ non priden à pontificibus conftitutum. Manfurius Sabinus f cripfit \& alia cerimoniarú genera in húc modum, frinam fermento imbutam attingere ei fas non erat, neq̣ tunicam intimam nifi in locis tectis exuiffe, fub cælo tanquá fub oculis louis nudus ne fit, fuper flaminen dialem in conuiuio, nifi rex facrificulus, haudquaquã alius accumbit, vxorem fi amiferit flaminio decedit, flaminis matrimoniü nifi morte dirimi non eft ius, locum in quo bufum eft nunquam ingreditur, mortuú nunqua mattingit, funus tamen exequi non eft religio.

Salii facerdotii genus quod ex huiufmodi caufa inftitutum dicitur, nam annum iam octauú regnante Numa morbus peftifer, Italiam occupans, Romam quoque inuaferat : : morentibus verò cunctis traditur peltam æneam è cælo delapram in Nume manus decidiffe $\&$ in ea mirabilia quędá dixiffe regem, fed ex Egeria Mufs'ćp audiffe, ac peltã in vrbis falutem miffam,oporterép eam obleruare,aliis vndecim ad illius figuram magnitudinem'ç et formá effectis quo du bium furi ob fimlitudinem fit cæleftis illius adipifcendx. Peltam itaç ex eius auctoritate atog imperio effingere artifices cum certaflent, diffidentibus ac defperäribus cæteris, Vecturiū Ma murium vnú ex furm mis opificibus vfø̧ adeo fimilitudiné effinxiffe ftruxifféq omnes fimiles, vt neq3 Numa iam ipfe dignofceret: harum aute cuftodes ac miniftros conftituiffe dicitur falios facerdotes: Salii veró vocati funt, non, vt quidam fabulantur, à viro Samothrace feu Mantiacho Salo nomine, qui faltationem qux in a rmis dicitur edocuerit,cũ eam re vera tefte Plinio vi.natufalis hifto. Dardanus inftituerit, fed ab ipfo tripudio faltatorio. Ouidius iii.faftorum: Iam dederat falie à faltu nomina dicta, quod nec vehementius robuftiusóp per vrbem currétes faltarent, tum ad menfem Martium facras peltas fufciperent, induti puniceis tunicis, reneis balt heis latisóp fuccindi, Aeneas capitum galeas portantes $\&$ aneú fuper tunicam pectori tegmen , par- 
uiśǵg gladiis arma pulfantes. Reliquum verò faltationis pedú eft opus: mouentur enim fuauiter, conuerfones ac mutationes in celeri ac crebro numero robu ftè ac leuiter red dentes: Mamurio autem artis illius fux mercedem fuife perhibent njemoriam quandá per faliorum carmen fimul cum pyrrichio modulo ab folutum. Alìi verò Vecturium Manurium qui canebatur fuiffe aiunt.

Senatoriam dignitatem à Romulo inftitutam fuiffe nemo a mbigit. Romulus enim vrbem conditurus paftores inter quos adoleuerat conuocauit, cum'q is numerus condenda vrbi parum idoneus videretur, conftituit, A fylü quo paffin confugerent ex finitimis locis peflimi quiqg fine vllo códitionis difcrimine, ex hiş́ omnibus populum conflauit, legitóp in fenatu eos qui æxate anteibant, \& patres appellauit, quorum conflio geteret omnia. De hoc etiam fenatu Propertius elegiarú fcriptor hæc loquitur: Buccina cogebat prifos ad bella quirites, Centú illi in pratis fxpe fenatıs erat. Curia prectexto nực qua inter alta fena tu Pellitos habuit ruftica corda patres. A tqui vt apud Lacedamonios fenes frue feniores appellari eos, qui fummum quendam magiftratú gerunt Cịcero auctor ef, fic nili confilium, ratio, fententia fenibusineffent, non fun mum confilium maiores noftri fenatum appellaffent. Quod \& Ouidius in faftis non reticet dicens: Magna fuit quondả capitis reuerentia cani, In'qu fuo pretio ruga fenilis erat. Martis opus iuuenes, animofág, bella gerebãt, Et pro diis aderãt in ftatione fuis. Viribus illa minor, nec habendis vtilis armis, Conflio patrix fxpe ferebat opem. Nec nifi poft annos patuit tunc curia feros, Nomen \& ætatis miræ fenatus erat. Iura dabat populo fenior, finitáp certis Legibus eft ætas, vnde petatur honos. A b hono e ergo patres, a brate lena tores appellati. Alii lenatores à finé do quòd faculatem darent, dictos putant, vel o agrorum partes tenuioribus ac liberis propriis attribuebant. Huic centum lenat orü numero plures ac diuerfis temporibus additos inuenio: Brutus enim quo plus virium in fenatu etiafrequentia ordinis faceret, diminutum parum numerú primoribus equêtris gradus electis ad trecentorum fummam expleuit, traditum óp inde fertur vt in fenatum vocarentur, qui patres quíque adlecti atque confcripti effent patres, vt diximus, vocati, vel quòd funt patritii generis adlecti, quòd propter inopiá ex equeftri ordine in fenatorum funt numero affumpti,confcripti autem quod in fenatu quẽ nouü effecerunt funt fcripti: Verum poft Cęfaris obitum cxcrefcenté húc numerü defurmi incódita ac indigniflijma turba, mille enim excefferat, \& nonnulli per gratiam, nonnulli præmi electi, qui abortiui vulgo appellabātur, Auguftus ad modú priftinú \& fplëdorem redegit. Prater hac fenatorum nomina funt qui pedarios fenatores opinentur appellatos, quòd fententia in fenatu non verbis dicerent, fed in alienam fententiam pedibus irent,tanquam fententie dictione carentes, aliorum dicta confirmarent, et quafi pedibus in alienam fententiam defcenderent. Alii verò quafí differentia quadam, quód effent pleriqg qui magiftratus currules adepti, fll a curruli honoris gratia in fenatum veherentur: qui verò iter pedibus facerêt, pedarii appellabãtur. Marcus autem Varro equites quofdam dicit pedarios appellatos, videtúrque eos fignificare qui nondum à cenforibus in fenatu lecti quidem erât, fed honoribus populi vfi in fenatum ve-

O iii niebát 
niebant \& fententiam eius habebant. Nam \& currulibus magiftratibus fun cti, qui nondum à cenforibus in fenatum lecti erant fenatores non erant: etiam quia in poftremis fcripti erant, non rogabantur, fed quas principes dixerant in eas fententias defcendebant. De more autem habendi fenatus Marcus Varro rogatu Pompeii librum edidit,cum ille cof.primum M. Craffo fuiffe defignatus creditur: quia foris militix́g ad eam xtatem occupatus ciuilis cófuetudinis expers effet, vellétque cateris non indoctior videri :in hoc libro id genus mul. ta fcribere Varronem Gellius atteftatur, primímg illud fuiffe per quas perfonas haberi fenatum liceret, nominans dictatorem,cófules, prætores, tribunos plebis, interregem, prafectum vrbis, neq alii prater hos ius fuiffe dixit facere fenatufconfultú, quotiéfque vfu veniffet vt omnes ifti magiftratus eodem tempore Romæeffent, tum quoque fupra ordinem fripti effent, qui corum prior aliis effet, ei potiffimú fenatus confulendi ius fuiffe. Addit deinde extra ordinaria in re tri bunos militares qui pro confulibus effent, decemuiros item quibus tum imperium confulare effet, item triumuiros teip . conftituenda creatos, ius confulendi fenatú habuiffe. De loco autem habendi fenatus aut fenatufcófulti rogãdi nifi in locis per augures conftitutis qux tem pla appellantur, haberi rogarive potuiffe negabat. Moris etiá erat vt eo in loco fenatus iniufus a fidua ftatione cogeretur, qui fenatulum appellabatur, vnde accitus deinde quàmprimú in curiam proficifceretur. De tempore autem habendi fenatus ita diferuit, ante exortú inquit folem aut polt eius occafum fenatưfconfultum irritum, opus etiá cenforiú fuiffe,per quos et quo tempore factü fenatufconfultum effet excutere. De atate autem fenatoria ne cui paucioribus $x x v$. annis nato, fenatum ingredi liceret, $v t$ in vita magni Pompei auctore Plutarcho conftitutú eft, cæterum minoris æta tis fenatum aliquando ing redi moris fuiffe vetera legentibus non dubiú eft, veluti M. Valerio Coruino contigiffe nouimus, cui tertium \& vigefimú annum in greffo confulatum largiti funt. Quò minus autem fenatum introirent cum prętextatis filiis fenatores, vt moris antea fuerat, decretú poftea factú eft, Papyriíg pratextati factum in caufa fuit: qui etiam fenatum habiturus effet aufpicari pri mò atọ immolare hoftiam debere idem Varro céfebat. Docuit etiam de diui nis rebus prius $\ddot{q}$ de humanis ad fenatum effe referendum:idem fenatufconfultum duobus modis fieri, aut per difceffionem fi confentiretur, aut fi res dubia effet per fingulorum fententiam, de pignore quoọ capiendo déóp multa irrogáda fenatori, qui quo tempore venire in fenatũ debuit, non venit. In quo $\&$ illud animaduertendum de more, quòd ficut lex à quinquagefimo anno militem non regit, ita à fexagefimo fenatorem non citat. Hunc etiä moréapud veteres neceffi ta tes publicæ reperierút, $v t$ f forte aliqua vis ab holtibus immineret, que cogeret vel humilia captare confilia, vel aliqua conftituere, quæ non prius oporteret dici quàm effici,vel fi nollent ad amicos aliqua permeare fenatufconfultum tacitum fieret, ita vt non fcribe,non ferui publici,non céfuales illis actibus intereffent, fenatoréfue exciperent omnium officia cenfualium fcribarímque complerent . Horum \& ars erat de irato facere beniuoluñn, de fufpecto placatum, de auftero mitem, de aduerfante propitium. Et quanquâ,vt diçum eft, fenio confecti armis 
minus valerent, binos tamen fenatores fingulis cohortantibus prapofitos tertio $\mathrm{ab}$ vrbe condita libro teftis eft Liuius. Patriciorum familia loui nofcitur fuiffe dicata, fr origine dignitatum antiquitatis ordinem perfcrutemur, quo fummi dei ficut putauere cultura locum primariú poffideret, patriciatuśg nomen ipfum vt quidam veridicorum à patribus dictum effe voluerunț.

Confularem exactis regibus dignitatem regii nominis fafum declinantem, cum plenam pené eorum inftar adminiftrandx reip. facultatem haberent accer frtam fuiffe antiquitatis monumenta declarant: Duo hi erant pro vno rege creati,vt fi alter malus effe voluiffet, ab altero fimilé poteftatê habente cohiberetur. His primú omnia iura ex regia poteftate erãt, omnia deinde eiufmodi infignia pomparúmg fercula \& officii fui orna menta. Nam ambobus fafces erant coff. quatuor \& viginti lictores, totiden cum fecuribus qux proinde tantæ poteftati cathenarum nexibus preceptæ funt alligari, vt cum tardius foluerentur, moram deliberationis acciperent: maxime fi de cade aut hominis nece aliquid cenfuiffent. Cunctator enim effe debet, qui iudicat de falute. Alia enim fententia corrigi poteft, de vita hominis haudquaquam, arma quinetiam ifta iuris funt non fu roris, \& contra noxios fic inftituta, vt plus terror corrigat quàm pona cólumat. Ciuilis eft etiam pauor ifte magis $\mathrm{g}$ bellicus, vtpote quem abactores timęant,reformident fures, latronës exhorreant, innocentia tantú leta refpiciat:inftitutúmque eft etiả vt ne duplicatus terror videretur, vt eorú tãtum alter fafces haberet, non ambo,ifque penes quem fafces effent maior conful diceretur: vel is qui prior factus elt pretor, aut maior vrbanus minores, ceteri quibus, quod plerung in maximis vrbibus folet, fenatus decreuit vt darent operä ne quid refp.detrimenti caperet: permifit'q corum alterum vel ambos cum opus effet exercitum parare,bellú gerere, coërcere omnibus mod is fubditos atq̣ ciues, domi militix́g imperium ac iudicium fummum capitis dicere, fed ciuis non Romani, quem folum cohibere \& in publicam cuftodiam duci iubere illis fas erat: Sella Curru li pro fui magnitudine vtebantur multis gradibus innixi,vtibilocati nihil abie ctum nihilóp humile meditarétur, vtọ́ in ocio fubiecti mererêtur, quod alii polt maximos labores affumunt imperatores: Manus porrò victoriali Scipioni munita erat, quo Romana reip. viri fort is dextra tueretur fortunas omnium, ac li beros, in augmentum etiam publicæ gloriæ famulos folueret iugo feruili,calceis auratis praterea prodibant in publicum, tanquam auri materiā quam mens ad inane volans tanti putat, paruifacere non folum, fed peffum etiä dare viderétur. Inter cęteras etiam reip.dignitates foli meruerunt pictos habere humeros, vario colore palmatæ veltis, quam foelicitas dabat pręnio vincentium. Quòd au té candidis veftibus induti procedebant, candidati appellabantur, quód deniqg populo confulerent, \& patrix, cum omnia eorum traderentur arbitrio, ne infolefcerent animo à confulendo confules dicti funt, nifi illinc potius, vnde Actius ait in Bruto, Qui recte confulit conful ciatur, vel vt Quintilianus, conful frt à confulendo, vel à iudicando, nam $\&$ hoc confulere veteres appellauere: Magiftratus huius imperium annum erat, quo ne diuturna po teftate infolentes facilius in errorem aliquem prolaberentur fe cuftodirent: 
hi quanquam breuis effet eorum magiftratus, ni hilominus tamen fi haud eflent idonei infra annum amouebantur: illud quogg de more fuit confulatum petentibus vt per fe ipfis comitiis intereffent, nullíg xxy . annis minores, qux fenatoria ætas erat, a dmitterentur.

Suffes conful etiam ponorum lingua dictus eft, auctore Calidio. Liuius belli Macedonici libro quarto, Poftero die cum fuffetes ad ius dicendum confediffent, confpectx tabellx demptróq \& lecte. Alii à fufficio quod elt fubminiftro vel in alterius locum fubftituo, fuffectos dictos putant, quafi fub alio factos. $\mathrm{Li}$ uius xxxi. M. Aurelius cotta decemuir facrorum mortuus, in eius locum $M$. Attilius Glabrio fuffectus. Cicero pro Murena Vnus erit col, $\&$ is nó in adminiftrando bello, fed in fufficiend o collega occupatus, Illud denique nec prætereundum, nam cum dux res poffint eodem auctore prouehere homines in hunc ampliffimun cófularis dignitatis gradum, \& honorum populi finem, vna iuris, alcera militis, non dubium eft quin ad eam adipifcendam multo plus conferat res militaris quàm iuris ciuilis gloria : vigilat enim alter nocte, vt fuis confultoribus refpondeat, alter quò intendit, mat urè cú exercitu perueniat: illum gallorû, hunc buccinarú cantus exufcitat: ille actionê inftituit, hịc aciem inftruit: ille cauet ne cófultores, hic ne vrbes aut caftra capiâtátille vt aquę pluuię arceant fcit, hic fcit et timet ne holtiư copię: ille in regédis, hic in ppagãdis finịbus exercitať.

Proconfularis dignitatis creandæ morem ac necellitaté induxit imperii Ro. amplitudo, guòd nec adeffet vbique ad bella geréda nec omnes obire prouintias confules, qui modo effent duo poffent, his confularia infignia cętera pręterquàm o fex duntaxat lictores relicti fuere conceffa funt: numerus autem proconfulum definicus erat nullus, vtọ́ pręifium nomen generale quod \& proconfules $\&$ om nes prouintias regentes fenatores licet effent,prefides appellabantur, fic proconfulum appellatio fpecialis ett, qui denique quòd confulum iuribus fungerentur proconfules nominati funt.

Lịtor crudelitatis minifter confulis, proconfulis, prętorum qui fafcem virgarum alligatum cum fecuri portat. Sunt quilictores confules xii : aliorum autem feni, Lictorem Valgius Rufus in fecundolibrorum quos infripfit de rebus per epiftolam quarfitis, dicit à ligando appellatum effe, quòd cum magiftratus popu li Romani quempiam verberari iuffiffet, crura eius \& manus ligari vinciriog à viatore folita fint, $1 f_{\mathrm{B}}$ qui ex collegio viatorum officium ligandi haberet, lictor fit appellatus, vtituróp ad eã rem teftimonio $M$. T.verbáque eius refert ex oratione que dicta eft $p$ C.Rabirio, Lictor inqt colliga manus. Liu. li. viii. Lictor deli ga ad palú hæc ita à ligádo Valgius Rufus, M.T. Liuius, Fefus ac omnis antiquitas putat \& nos fane cü illis fentimus, fed Tiro Tul.M.Tullii. C.Libertus lictorem vel à lino yel à licio dictü foripfrt:licio enim tráfuerfo quod linú appellaturà veteribus qui magîl tratibus inquị pręminiftrabẩt cinctị erẩ, ad reorü manus ligãdas, \& crura vt diximus vinciéda. Male ita $\$$ \& infcitè qui lictoréà litan do dičū putant. C. interpofita quia rem lictat $\&$ interficit, illídq inepte addunt quafil legis ictoré dici q iciat, id eft, percutiat reü,iuxta legis mandatú quod anti quitas non approbat,colorata licet ratio videatur. Numero autem duodecim li ctores 
Crores fumptos à Romulo: alii à numero vulturú qui regnum fibi ptëderant au gurio: Alii putät \& melius ab Hetrufcis finitimis, vnde fella currulis, vnde toga pretexta fumpta eft ad imitationem regum fuorum, quòd duodecim ex populis creato regi fingulum finguli populi lictorem darent.

Quæltura in qua effe debet fcientia iuris fumma, literarum gloria, cautela fer monis, firmitas animi, continentiæ domicilium \& virtutum omniü fedes, Actione in Verrem ii. auctore Cicerone primus eft gradus honoris, dignitatúmque om nium genitrix, Varro lib.vi.tefte Caffi. Officiú autem eius et origo perquàm vetus eft $\&$ pene ante omnes magiftratus, quiorundam \& quidem eruditorü fententia. Gratianus Iunius lib. vii.de poteftatibus apud iplum Romulum $\& \mathrm{Nu}-$ mam Pompilium binos queftores fuiffe auctor eft. Pomponius hunc magiftratum coepiffe tunc afferit cum zrarium po . Ro.arctius $\&$ cumulatius effe copiffet, vt effent qui illi præeffent, quod Romuli tépore fuiffe, cú res tenues \& perexigux tunc effent, haudquaquam putandum eft. Cæterum ficut in dubium venit an $R$ omulo \& Numa regibus quæitor fuerit, ita etiam Tullo Holtilio rege à quo cenfus in ciuitate $\&$ defcriptio centuria rum \& claffium; quxe prius non erant eft facta, quxftores fuiffe, ac tunc initium habuiffe veri magis fimile eft, $\&$ fanè crebrior apud maiores opinio eft, Tullum Hoftilium primum in remp . induxiffe quaftores: hos autem à quarendo quaftores initio dictos Pomponius \& I unius \& Trebatius \& Feneftella \& Varro lcribüt : verum quia de capite civis Romani,iniuffu populi non erat lege permiffum confulibus ius dicere, propterea que ftores conftituti funt à populo qui capitalıbus rebus pręeffent, quax triumuiri po ftea capitales perquifuere, híg appellabãtur quętrores parici Fefto tefte, vel Pon ponio parricidii quorum meminit lex xii.tabu.dicai : quoniam parricida non vtique hi, qui parentem occidrffent, fed qualemcunque hominem dicebantur. Idem etiam fuiffe indicat lex Numæ Pompilii in his compolita verbis, Si quis. hominem liberum morte fciens eluit, parricida elt. Horum officio iniunctum erat vt prouincias ex fenatufconfulto fortirentur, vt'̣́ extra vrbem adueniêtibus regibus obuiam irent, $\&$ haftr fubiectos captiuos venderent. Erant $\&$ candidati principis quxftores alii qui libris duntaxat in fenatu legédis operam darent, quíp literas eius in fenatu legerent.

Prætores initio erant,quorundam iudicio, qui poftea confules, $\&$ hi bella adminiftabant: proinde fic dicti quòd præirent $\&$ anteirent iure in exercitu. Au Etore etiam Pomponio tunc creati, cum confules bellis finitimis auocarentur, neque effet qui in ciuitate ius reddere poffet. Numerum autem pratorum habuit Roma protempore varium, primum quidem vrbanum, deinde poft aliquot annos, eo non lufficiente peregrinum, fic dictos quódius alter peregrinis, alter ciuibus diceret. Deinde vero plures augendo numerum, ad octo vfque creatos inuenio. Vnde Cicero pro Milone, Septem pratores, octo tribuni plebis, illius aduerfarii, defenfores mei, captis prouintiis, totidem pretores quot prouincix in deditionem venerant creati funt : partim çui vrbanis rebus;partim qui prouintialibus præeffent, horum autem pretorum infignia fex fuiffe fecures, Plutarchus in vita Pauli Aemilii auctor eft: Ad hoc enim bellum inquit Aemilius miffus, 
Acmilius, miffus non cum fex vt cæteri pratores, fed cum duodecim fecuribus ita ve dignitas confularis imperio eius ineffet.

Cenfores ad cuius cenfionem, id eft, arbitrium cenferetur populus, vel ab re ipfa quòd praeffent faciendo cenfui appellati, vel quòd rem fuam quifque tanti. aftimare folitus fit, quantum illi cenluerint, vel quod cenfere pro arbitrari veteres cognatione quadam focia ac fimili effe voluerint: funt qui à céfendo, id eft, conftituendo \& præcipiendo, vnde etiam dicere folemus cenfeo hoc facias, \& fenatum aliquid cenfuiffe, inde Modeftino auctore cenforis nomé videtur effe tra ctum. Hoc munus inftituiffe primum Seruius Tullius legitur, poftea verò ve funt reges exacti,ius omne faciendi cenfus \& catera qua regix maiefta tis huius fuerant ad confules delatú erat:creandi verò nou magiftratus huius dedit caufam,quòd bellis vrgétibus neọ populus fine céfu effe, nec qui effent cófules nauare operam commode céfui faciédo poffent: res quidé vt parui admodú momen ti prius vifa, quòd nihil iuris haberet ni cenfendi modo populum, ita illuftris magiftratus hic maxime omnium reuerentie plurim xóp poteftatis ac feueritatis porna fuit . Eo autem venit vt haudquaquam de opibus modo, verum de militari difciplina moribúfque cenferet.Mos nanque Roma apud equeftres erat auctore Plutarcho,cum per legitimum tempus à quoquam militatum effet, equum per mediun forum duci coram uiris duobus publicè pręfidétibus, quos cenfores nuncupauit, illifque quemlibet ducum ac imperatorum fub quibus militatum fit recenferi, deinde cenforum iudicio fubigi, qui iuxta cuiufque meritum vel laudem vel infamiam tribuunt. Huic prefecti curæ tancerant viri dignitate or natique infignes, ad hos fella curruli infidentes, equites fubituri iudicium ritu cum prodirent, cenforum alter qui fenior erat interrogabat, fi militias omnes iuxta difciplinam militarem abfoluiffet, omnéfque fub imperatore meruiffet, quòd fi non fecus ac dixerat foret inuentum, ingentı laticia plaudentibuśq amicis domu millum ad mittebant: fin minus cenforia eum inurebant nota, $q$ ex tenuifimis caufis licebat illis, quifla gitiofe ac intemperanter degerent ac loquerentur, equum adimere $\&$ exercitu demouere. Horum etiam erat vectigalia populi $R$ omani augere minueréque, luftrum completo quinquennio concedere, \& foli taurilia facrificia de fue, oue, tauro facere, de nuptiis, de liberorú procreatione, de viuendi ratione, de conuiuiis diligenter inquirere, ne quis patriam ac confuetam viuendi difciplinam tranfgrederetur : ad hxc etiam munera duo cum effent, alter patritius, alter verò plebeius, eis licebat fenatus principem defcribere, immeritos fenatu quoque amouere, vt C. Fabricium feciffe ferunt, qui P. Cornelium Ruffinum patritium virum, quòd decem argenti facti pondo in conuiuium adduxiffet, fenatu amouit: frue vt $M$ : Catonem cenforem, quem $C$ : Flaminium, T. Flaminei fratrem, quòd exhortatus à Puello quem deperibat tefte Plutarcho, vel à fcorto aliorum fententia, cum effer conful in Gallia, vt aliquë ex his,qui vt in vinculis rei capitalis dãnati erant, fecuri percuteret, obtéperauit, fenatu eiecit. Valerius Antias non ad pueri, fed ad mulieris cuius anore teneretur, arbitrium id ab L.perpetratũ affirmat. Liuius auté fcriptú in oratio-

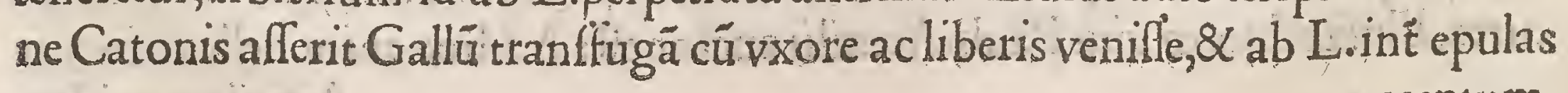
exceptum, 
exceptum mox vt forto, guod ardebat, oblequetetur, ab eo propria manu cons fofum. Hoc ad exacerbanda Luci crimina iure dictum à Ca tonecredidẹin, ip fum aute occifum minime tranffugâa, verùm ex damnatis vnú in vincula conie ctum extitiffe, cum alii quàm plures, tü verò teftes funt $V$ alerius $M a x$.et Cicinn co qui eft de fenecturelibro,vbi omnem Catoni fermone $\&$ ipfins rei narrationem tribuit: ipfi deinde cenfores facrificiorum pretia cura bant 8 \& deforiptionis genera, \& reipub. officia diflinguebant. Cenfionem enim facere dicebantur, cu mul cam equiti irrogabant, cêfióg haftaria dicebatur, cum militi mulçx nomine ob delictum militare quod haftas daret, dicebatur. Multas praterea poteftates hic magiftratus habet, quas ponit Iulius Capitolinus in vita Valeriani, Sulcipe, iuquit,cenfuram quam tibi detulit Romana refpub.quam folus mereris,iudicaturus de moribus hominum, iudicaturus de moribus noftuis. Tu æatimabis qui manere in curia debeant, tu equeftrem ordinem in antiquum ftatum rediges, tu' cenfibus modum pones, tu vectigalia firmabis, diuides fatum, resp.recenfebis, tibi legum fcribendarum auctoritas dabitur, tibi de ordinibus militú iudicandum eft, tu arma refpicies, tu de noftro palatio, tu de indicibus, tu de prafectis

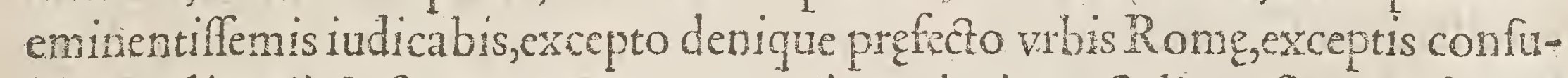
libus ordinariis \& facrorum rege, ac maxima virgine veftalium, fr tamen incorxupta permanferit,de omnibus fententias feres. Illud denique non prętereũdum, cum alios magittratus annuos fuiffe conftet, quinquennalem quondam cenfuram extitife, quod quia per tot annos graue, diuturnum infolénfque nimis vifum eff, tre plus $\ddot{q}$ annua ac femeftris cenfura effet, confenfu ingenti populi facum eft, atg hoc tefte A f conio tam trife euerímque nomen po. ro.fic oderat, vt intermiffum effer nonnunquam per plurimos annos, nonnunquam propter infamiam corruptorú iudicũ , pleben ipram quod ante recufauerat popofcrfe.

Tribunos celerum prinus Romulus creaffe fertur . Nam cum eodem tempore in tres tribus tota ciuitas diuifa eflet, $\mathrm{R}$ amnenfes à nomine fuo, à Tatio $\mathrm{Ta}$ tienfes, tertix autem tribus homines Luceres dicti à luco Afyli, in quem multi fuga delati cinitate donati funt, $v t$ Plutarchus inquit $\&$ Plinius teftis eft, no ua. Quanquam tertix huius denominatio auctore Livio incerta fit. Tribus au tem ipfas tres fuife numero nomen ipfum declarat; quibúlque qui praerant, tribunos vocitabant, quòd terni tribus ex tribubus olim ad exercitum mittebantur. Celerum autem tribunum proinde appellari quidam opinati funt, quòd vel celeriter occurrerent, fr quando corum opera refpub . indigeret, cum equitibus ille præeffet $\mathcal{E}$ veluti fecundum locum tefte Pomponio à regibus obti neret, vel à celere Remi interfectore, quòd ccletes antiqui dixerunt, quos nunc equites dicinus. Horum tribunorun militarium, ve inguit. Q. Afconius Pedianus, duo funt genera, primum qui $R$ uffuli vocentur, $8 \mathrm{hi}$ quidem in exercints creari folent à cófule non à populo, de quorum iure,vt Feftusetiam inquit, quòd Rucilius $R$ ufuslegem tulerit, Rufuli ac poftea rutuli funt vocati. Alii funt comitiati, qui comitiis defignantur ad gubernandam rempublicam côfulum loco, aliquando fub confulibus vt effent in exercieu ad ordines ducendos inftituti. Horü officiü, vel corum qui exercitui pręfunt, in libro de rę militari Marcello tefte? 
tefte, milites in caltris cótinere, ad exercitationem producere, claues portarum fufcipere, vigilia interdum circuire, frumentationibus commilitonum intereffe, frumentum pbare, menfurę fraudê coêrcere, delicta fecundū fuam auctoritatem his mod is caftigare, principins frequenter intereffe, querelas commilitonum audire, valitudinarios infpicere. Flauius Vopifcus in vita Aureliani in epiftola ad vicarium fuum permulta his adicit, ad tribuni officium maximè fpectantia.Si vis, inquit, tribunus effe, imò fi vis viuere, manum militum cótine, nemo pullum alienum rapiat, ouem nemo contingat, vuam nullus auferat, fegetem nemo deterat,oleum, falem, lignum nemo exigat,annona fua contentus fit, de præda hoftis non de latrocinis prouintialium habeat, arma terfa fint,ferramenta fa miata,calciaméra fortia, veltis noua veftem veterem excludat,ftipendium in baltheo non in popina habeat, torquem brachialé annulú apponat, equũ \& faginarium defricet, alter alteri quafi feruus obfequatur, à medicis gratis curentur, arufpicibus nihil dent, in hofpitils caftè fe agant, qui litem fecerint vapulent. Tribunis autem plebis creandis initium fuit feceffio plebis à patribus, in facrum montem facta,vbi Menenii Agrippæopera pace inita cóuenit vt plebeios magiftratus in vrbe baberét, fićng duos tribunos tum habere plebs coepit à Virginio \&. T. Vetu fio coff. Alia poftmodú feceffione tres additi Appio Claudio \& T.Q.coff.mox quings alii coff:Q. Minutio \& M. Oratio Puluino. Hoc pacto x.tribunis in ple bem Ro.funt iurifdictio, fićp plebi concelfum eft conditiones inire cócordię,vt plebs fuos magiftratus haberet facrofanctos, quibus auxiliis latio aduerfus confules efiet, néve cui patrum capere eum magiftratum liceret. Tribunorum tandem tantum in modum creuit auctoritas, vt quicquid fenatus decreuiffet, ita denum ratü haberetur, fi tribuni approbaffent. Sta bant autem hi in veftibulo curiæ, vbi habebatur fenatus: nam templú fue curiam ingredi nó licebat, \& quæcunģ fenatores decreuilfent, tribunis prefferebãtur, vt qux è repub. fore viderentur,a pprobarent,cætera ad arbitrium reiicerentur:tum quæ fenatufconfulta ap probaffent.t.literam in tergo adiciebant, haud aliter rati iudicatum iri. De po teftate autem tribunitia Labeonis Antiftii iuris peritiffimi extat fentétia, cuius verba quemadmodum foripta apud Gellium offendi, ita illa ipla fcripf: In epiftola inquit Athei Capitonis fcriptú legimus, Labeonem Antiftium legum atq̧ morum \& P.iurifque ciuilis doctum apprimè fuiffe. fed agitabat inquit hominem libertas quædam vecors vfgg eò, vt diuo Augulto iam principe $\&$ rempub. obtinente, ratum penfumgs nihil haberet: nifi quod iufum fanctumgne effe in Romanis antiquitatibus legiffet : ac deinde narrat quid idem Labeo per viatorem à tribuno plebis vocatus refponderit : Iuffit enim eum qui miffus erat redire, \& tribunis dicere ius eos non habere, neque fe neqg alium vocandi, quòd mo ribus maiorum tribuni pręhenfionem haberent,vocationem non haberét: poffe igitur cos venire \& pręhendi iubere, fed vocandi ablentem ius non habere, idóp etiam apud Varronem in libris rerũ humanarũ fcriptum afferit A. Gellius:qui quidẽ Varro cũ triumuir effet, afferit fe à tribunis plebis vocatú nó effe, \& cum tribunus plebis effet vocari neminem fecifle. Ea etiä tribunis plebis auctore Plu tarcho poteftas eft, vt fi prafens fit dictator, lecunda fit ${ }_{2}$ fin autem adfit, prima ac 
ferme fola. Huic pręterea magiftratui nullum integrum diem abeffe Roma lice re ius erat,ius etiâ huius tribunitia poteftatis magis ad impediédú eft qa ad agédum, quippe quæ cæteris omnibus collegis volétibus \& fi plures fint, vnus qui no lit \& le opponat, plus pofflit. Fuit etiam,vt aiunt, tribunitia poteftas prius apud Romanos publice dignitatis infigne, poftmodú quog iudicialis ordinis obtinu it rationem. Inde nanq̧ \& decretum illud fenatus, vt Auguftus Cafar morum legunịp regimini ac rque in perpetuú tribunitia pręeflet poteftati. Vnde apud cos tribunus dictus eft, $q$ tribus pręeffet ordinibus patritio, equeftri, \& plebeio, dicti etiam fimili modo tribuni plebis à tribu, $q$ vel tribunú fuffragio crearetur, vel quòd in tres partes populus diuifus effet, cum plebs à patribus feceffiffer, \& ex fingulis finguli crearétur: tribuni auté xrarii à tribuẽdo ęre funt appellati,quod ærarium fanè populus Romanus in æde Saturni habuit.

Scriba à fcribendo nomen accepit, officiü exprimens vocabuli qualitate. $L_{i}$ uius $a b$ vrbe con. li.ii. I bi cum ftipendiú forte militibus daretur, $\&$ fcriba cum rege fedens pariferè ornatu multa ageret, cum milites vulgo adirent, timens fci fcitari, vtrú Porfena effet,ne ignorando regem femet ipfe aperiret quis effet, quò temere traxit fortuna facinus? Scribã pro rege obtruncat. Probus Aemilius de excel. du. exter.gen.in vita Agefilai, Itage eum habuit ad manum fcriba loco, quod multo apud Graios honorificétius eft quàm apud Romanos.Nanq̧ apud nos re vera ficut funt, mercenarii fcribx exiftimantur: \&. apud illos econtrario nemo ad id officium admittitur, nifi honefto loco \& fide \& induftria cognita, quòd neceffe eft omniü confiliorú eum effe participem. Cicero in Verrem actione.v.Sxpe enim noftri imperatores fuperatis hoftibus optime rep. gefta, fcribas fuos annulis in cótione donarunt. A b epiftolis vel à fecretis etra is intelligi dicitur, cuius fecreta fcribit vel epiftolas. Suetonius in vita Claudii, Sed ante omnes Narciflum ab epiftolis $\&$ Pallantem à rationibus, quos decreto quoque fenatus non præmiis modo ingétibus, fed quętoris prætoriisq́g ornamentis ornarilibés paffus eft. Flauius Vopifcus in vita Carini, Quorü vitã fngulis libris Claudius. Eufthenius qui Diocletiano ab epiftolis fuit, fcripfit. Notarius item fecretorum fcribitur, Flauius Vopifcus in vita Aureliani, Incidit autem, vt fe res fataliter agunt,vt Mnefteú,quếdam qué pro notario fecretorü habuerat, libertum, vt quidã dicunt, fuum infenfrore fibi minando redderet. Caf.primo, hift. Pater enim Candidat i fub Valentino principe geffit tribuni \& notarii laudabiliter dignitatem, qui honor tunc dabatur egregiis, cum ad imperiale fecretu tales conftet eligi, in quibus reprehenfronis vitium nequeat inueniri.

Cancellarius vel à câcello ala palatii fic dictus, $q$ olim ibi officiü fuum exerce ret juxta thefaurú imperatoris, cuius frbi cura demãdata erat, vel à cácello fecun dum eã fignificationê, qua dicitur interftitiú à Paleftina regióe tractũ, vbi tecta cacuminata nó erant, fed iacebant in planú proftrata. Interftitia igitur illa inter propugna cula fita, parietibus hinc inde erectis, câcelli proprie dicûtur:Qui vero epiftolas miffas recitare volebãt populo, in dicta regione fuper tecta afcédebant \&. de câcellis recitabant, vnde inoleuit vfus paucorủ tamen eruditorü, vt qui populo literas principis habent miffás exponere, cancellarii appellatione nominen, 
tur. Ce.li.xi.Var.Refpice quo nomine nuncuperis,latere non poteft quod inter cancellos egeris, tenes quidé lucidas fores, claultra patentia, feneftras, ianuas, $\mathbb{Q}$ quàmuis ftudiofe claudis, necelfe eft vt te cũctis aperias. Nã f̂ foris fteteris, in eis non emendaris obtutibus, fingrediaris, obferuãtium nó potes declinare confpe ctus, vide quò te voluerit collocari antiquitas, vndiģ cófpiceris, qui in illa clarita te verfaris. Flauius Vopifcus in vita Carini, A micos optimos quofog relegitaut tenuit, prefectum vrbi vnú ex cancellariis fuis fecir, qúfo foedius nec cogitari po. tuit aliquando nec dici.

Populares \& optimates inter fe differunt. Nam populares telte Prifciano lib. artis gaãmatica.v. hi funt, qui defédunt populü,optimates qui defendút fenatores. Cicero pro P. Sexitio, Duo genera femper in hac ciuitate fuerunt, corü qui verfari in rep.atco in ea fe excelletius gerereftuduerunt, alteri populares fe, alteri optimates \& haberi \& effe voluerüt:Qui ea qux faciebät, qux'́p dicebant multi tudini iocunda effe volebát,populares: qui ita fe gerebāt vt fua conflia optimo cuiģ probarétur, optimates habebantur. Iden in eadé, Onnes optimates funt, qui neq⿳⺈ nocétes funt, neq̧ natura improbi, nec furiofi, nec malis domefticis impediti. Idé in eadé, Quod ert prętátiffinú maximéğ optabile fanis, bonis, \& bea tis, \& cú dignitate otiú hoc qui volüt omnes optimates, qui efficiunt fummi viri et cóferuatores ciuitacis putätur. Ariftoteles li.v.ethi. Ex dignitate quóq id apparet, iufũ enim illud, quod in diftribuêdo cófiftit fecundü dignita té quádā elfe oportere omnes fatétur:ipfam verò dignitaté non eandem onnẹs effe aiunt, fed populares quidể libertaté, potentes verò opulentiâ aut genus, optimates auté vir tuêe dicunt. Idem !i.iii.poli. Vocare auté confueuimus cú vnus ad vtiliraté com muné tefpiciens gubernat regiá poteftaté: cum verò pauci gubernãt, plures tamen vno,optimatú gubernationế, vel ex co quia optimi præfunt, vel ex eo quia ad optimum publicú adminiftrât. Idem in quarto, Videtur auté optimatú effe maximè honores tribuere fecundú virtuté, finis enim optimatú virtus: paucorü verò gubernationis diuitix, popularis auté libertas. Idem in codê, Quo enim ab optimis viris fimpliciter per virtuté effet gubernatio reip. 8 non ad fuppofitionem quidem bonorum virorum, eam folam iufum eft optimatem appellari.

Proceres tefte Varrone principes ciuitatis, quia eminêt in ea ficut in æedificiis mutili quidã, id eft, capita trabium que pceres nominâtur, quafi pcedes. Hinc fa cta tranllatio eft ad quofdã vt proceres dicâtur q ante omnes honore præcedút. Sunt qui pceres, quafi procul à carie, hoc eft, putredine ac vitiorú corruptione, di ctos putent, quod tametfi principibus cóuenit maxime propter excellétiam \& egregiam, qua præditi effe debent, probitaté,falluntur tame inf citia literarum, nec tam $q$ eft, $\ddot{q} q$ effe debet, autumärt, huius fingularé numerú raro eft inuenire. Iuue:lib.iii. Agnofco pcerê, falue Getulice, feu tu Syllanus, quocüqpalio de fanguine rarus. In plurali frequétiflimú eft. Liuius ab vrbe cond. li.iii. Et nos, vt decet pceres, vt Fábio nomini eft nō indignū, pugnạdo porius ä adhortädo accen danıs militú a nimos. Luca. in v. Fata vocét pcerú mot us hæc cúcta fequútur.

Primores ficut hi proceres, vel primates vel qui inter reliquos maioris potefta is \& digniores in populo. Liu. in primo, Ipfe ad primores Ronulus peruolat. 
Summates viri potentes. Satyrus in comodia pifatoria, Summates virifin plices facti funt ganei: Macrobius li.i.de fomno Scipionis, Sed fummatibus tan tum viris fapientia interprete veri arcani confcils contenti fint: reliquiad venerationem figuris defendentibus à vilitate fecretum.

Pręfidum nomine omnes prouincias regétes, licet fenatores fint, appellantur: iure pręes is dicitur, qui maius in prouincia habet imperiú poft principé. Hinc prafidium dicfú auxilium principale: ficut fubfidiú id quod in auxiliú fuccedit dicitur,et milites qui in aliorú tutelâ militü,oppidi vel caftelli,frmiliǘǵ, collocati

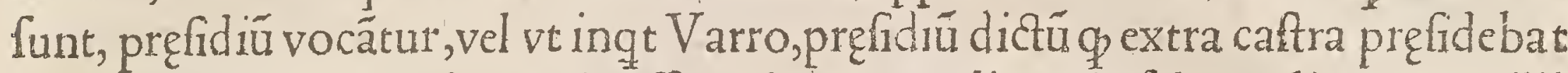
in loco aliquo, quo tutior regio efret, vel $\phi$ pro vtslitate $\&$ falute, alicuius auxilii gratia pręponiť: ficut fubfidiú, quod poltpofitú eft ad fubueniédü laborantibus. Satrapes vel Satrapa is eft, g locorü pręfectus defignatur. Plutarchus in vita Eu menis, Tú capto Ariarate rege, \& regione in poteftaté redacta, fatrapes, hoc eft, locorü prafectus defignatur. Kegum libro primo, Et non inueni in te quicquả mali ex die qua venifti ad me vigh ad diem hanc, fed fatrapis non places. Idem in eoden, Reuertere ergo \& vade in pace et non offendas oculos fatraparum.

Princeps ordinis nomen eft, dictus $q$ primus capiat : ficut municeps ab eo $g$ munera capiat:idem \& dignitatis, cui hac tuenda ex officio, \& capitis periculo defendéda, religiones, anfípicia, poteftates, magiftratus, fenatus auctoritas, leges, mos maiorü,iudicia, iurifdictio, fides, proumtix, focii imperii, laus rei militaris,

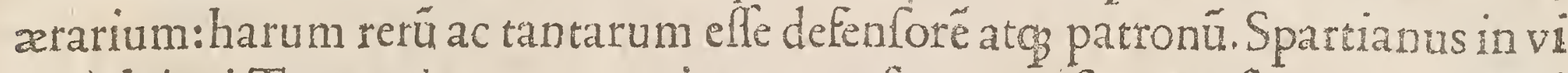
ta Adriani, Tunc enim mos, vt princeps caulas cognof ceret, et fenatores \& equi tes Romanos in confiliú vocaret, \& Centétiam ex omni deliberatione proferret. Caff.ii.hifor. Vocabulũ principis nulla forde maculafti, feruâs dignitatem no minis exercitatione virtutis. Ouidius de Romulo \& Cælare fecundo faftorum, Tu rapis his caftas duce fe iubet effe maritas, Tu recipis luco, reppulit itle nefas, V is tibi grata fuit,florent fub Crefare leges, Tu domini nomen, princiois ille tenet. Te Remus incufat, vetriá dedit hoftibus ille, Calefté fecit te pater ille paré.

Domini verò appellationé pràclariffimos in rep. principes er duces inuenio declinaffe: nam et Scipio iple prius I talia Hifpanizós recuperata,cum A fricám quoog fubegiffet, Hannibale pulfo, nullo tamen fucceflu dominú fe paffus eft ap. pellari nifi à Ponis, qui p equas códitiones toties rupto foedere fraudulenter iugü abiecerant, nó obtemperâtes, milicia a biecit, quâfi reipub hoftes infa mia notäs: Auguftus quoque Romani decus imperii nec ferio nec ioco fe paftus eft à quoquá tali nomine appellari. Tertullianus in apologetico cótra gëtes, Auguntus imperii formator, nec dominú quidé dici fe volebat. Et hoc enim dei eft cogno men. Dicá planè imperatoré dominum, fed more communi. Sed quãdo non co gar,dominú dei vice dicá. Hoc cú declinaret Auguftus, meruit profecto patris patrix cognomen, quod vniuerfi repétino maximóg confenfu ei detulerunt, $q$ gratius effet pietatis nomen quàm poteftatis, vt'q́) fciret datã fibi poteftatem patrix, qux temperâtiffima elt, liberis confulens. Quid auté inter patrem et doninú in terfic, of tédit probè Terétianus ille Mitio, hoc patriü eft, inqt, potius rófuefacere filiü fua fpöte recte facere, $\vec{q}$ alieno metu, hoc pater hoc dominus inteft. 
Duxà ducendo dictus, effe enim debet præc cæteris dux in ducendo a gmine præcipue folers, vbi iter quópiam fecerit, $\&^{\prime}$ cum ad difficilem tranfitu faltú venerit, contemplari fecum animo ab omni parte loci naturá,comites deinde vete ranos fi quos habet, quęrere \& percunctari fi hoftes eo loco, quid fi à fróte, quid fi à latere, quid fi à tergo adorirentur capiendum conflih foret, vtrú ne pergeret qua occopiffet ire viä,an eã qua veniffet repetere fatius effet. Caftris auté deligen dis quãtum muniméto loci cóplexurus, quà opportuna aquatio, quà pabuli lignorǘṕ copia, quà comeatus expedire;quo tépore pugnam inire, aciem ftruere, fubfidiis firmare, magnifice adhortari, perterritos milites à metu reuocare, nec verbis tantum ferocem \& Atrenuum effe, fed operum militarium haudquaquam expertem, quị $\&$ ipfe, cú opus fit, tela tractare, procedere ante figna, verfari in media mole pugne fciat, fciat quoque confilia fua celare, tacere, diffimulare, infidiari, ab infidiis pręcauere, hoftú cogitationes pręripere, peculari \& explorare corú vbi copix fint, quâtx quóve genere armorum, plurimum enim intereffe vfuris, qux deinde turba inermis, que leuis armaturæ, que impedimenta, quanto ea aut quali præfidio cuftodiant, deinde dicta nó tam quàm facta milites fequi iubere, nec difciplinam modo fed exéplum. Quod diligentix genus reçtiffima fortaffe ratione probabitur, quoties licebit: verum fi mutabitur natura loci, fi mons oc curret,fi flumé obftabit, fr collibus, fyluis,af peritatég alia phibebitur, mutabit hoftiú genus imminentis conditio difcriminis, \& nunc acie directa, nunc cune is,nunc auxiliis, nunc legione pugnabitur. Ad hæc infuper intueri $\&$ feire quo aufpicio ineunda pugna fit, nec deeffe fortune præbenti fed oblata cafu flectere ad confilium debet.lllud ad poftremum pre cęteris in animis ducü habendum, nihil in bello debere contemni, neọ fine caufa dici,matrë timidi flere non folére. Horú igitur omniü qui funt memores \& vfu \& experientia cópotes, eos du • ces dixerim, cæteris iure prætulerim modo à populo non à militibus creati fint.

Comes,focius, fodalis, comiśǵp \& collega in quo conueniant, quóve differant, auctorum fententiis illuftrium ex his accipe. Comitem dicere debemus auctore

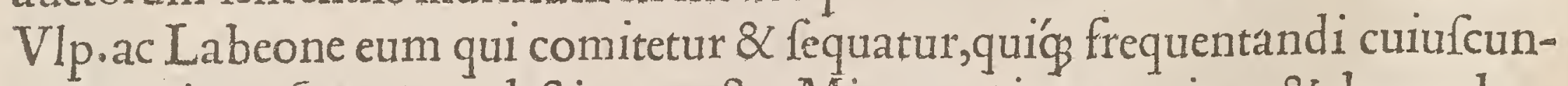
que gratia vt fequeretur deftinatus eft. Minores etiam comitem $\&$ ducem ha bent, vt Cicero non comite fe, inquit, fed ducem præbuit, \& alibi: Neq̧ princeps tunc ad falutê effe potuiffem, fi effe alii comites voluiffent: Socius verò nó minor fed par eft, ideoóp duces in bello quoties milites alloquútur conciliandæ beniuolentix gratia, non ferè appellant comites fed focios, cómunicâtes quodammodo corú dignitatem cû illis,vt ediuerfo, cum eofdé commilitones vocát,com municantes eorum cöditioné at ô fortem cum ipfis: nẹg enim dux cómilito eft militum, fed milites inter fe cómilitones, vt apud Virgiliú Aeneas de militibus fuis, $\mathrm{O}$ focii, auctor ipfe in fua perfona loquens de Achimenide Comes infoelicis Vlyffi, 8 iterü, vno graditur comitatus Achate. Neqp fcite dixiffet de Vlyffe \& Aenea hunc effe comitem Achatæ, illum Achimenidis, idem tamen ait, Arma deosóg parant comites, et iterum, Sacra deośq́ tibi commendat Troia pena tes. Hos cape fatorü comites Nunquid dii erant comites Gręcorú atф̧ Aeneæ, an duces? Certe dii penates comites erant confeflione tum Aenex, tum ipfo- 
rum quoque deorum: nam lib.i. Aeneas ait, victos qui ab hofte penates clafo fe veho mecum: \& in iii, Dii aiunt, Nos te Dardania incenfa tuáque arma fecuti. Nos tumidü fub te permenfi claffibus æquor, fub te, id eft, te duce, et te fecus ti fumus, id eft, tui comites fuimus. Idem de Gracis quidem dicêdū $\&$ de eorum deis.Idem etiá de Sibylla \& Aenea, quanquâ modo hic modo ille dux erat aut comes, quia fequebatur Aenę voluntaté Sibylla, et quafi miniftram fe præbuit, comes erat: quia verò ducebat præmonftrans iter $\&$ declarans ea quæ ille ignorabat, dux eadem dicitur, tamet fr aliquádo comitem pro focio dicimus, vt Cice ro in rhetoricis, de viatore qui cum ante lucen furrexiffet comitem, inquit, fuum inclamauit, $\&$ femel fępius cum de eodem antea dixiffet in itinere quidé pro ficifcétem ad mercatum quendã, \& fecum aliquãrum nummorum ferentem eft comitatus, id eft, fecutus.Quare in pręfatione artis gram matice Prifcianus monitus in primis aliosóg monés, monédus tamen plurimú in hac verba ad lulia nú fcribés, Tibi ergo hoc opus deuoueo, omnis eloquétia praful, vt quátúcunģ mihi deus annuerit, fulcepti laboris gloria te comite quafi fole quodã dilucidius crefcat: Sed quid magis delirü ablürdumọ́,qu quem dicas tuum folé,eundem appellare comité tuú, hoc ipfo $q$ fol eft. Eft praterea alia inter comitë et focium differentia, quôd comes eft quicúqg fequitur alterius ductum, focius plerung; in negotijs feriisq̧́ rebus $\&$ fortunæ arbitrio fubiectis. Cæfar in cómétàriis, Ita $\$$ Androfthenes prætor Theffalix cum fe viciorix Pompeì comité effe mallet $\tilde{q}$ focium Cęaris in rebus aduerlis, om nem agris multitudinem ferworü ac libero rum in oppidú coëgit. Verū huiufmodi differétia apertior inter fociū et fodalem eft, fodalis enim propriè in rebus leuioribus ac fape voluptuofis. Quintilianus, Quo tädem patereris animo, fi delicatus adolefés, præfertim fplendidis opibùs, vel ex atate mores vel ex fortuna traxiffem, \& tempcitiua cóniuia \& puigiles io cosad vocata fodaliū turba folutus atog aftlués ageré. MI.T.Epulabor modicè cú fodalibus, fodalitates enim me quętore funt inftitute. I dẽ alibi, Ego Plautiü La terenfen \& ipfum gratiofum dico \& habuiffe in peritione multos cupidos fui gratiolos, quos tu fi fodales vocas, officiolam amicitiánomine inquinas vitiofo. Caius auté fodales, inquit, funt, q eiufdé collegii funt, quos græci cu2lórcus vocant à quo nö fane difcordat M. Antonius qui Norbanū quaftorem fuum appellat fodalem:at collegarú appellatione hi continentui qui eiufdem poteftatis funt. Comis verò benignus eft homo \& facilis, qui aliis non æegre inferuit.

Chiliarcheq qui fingulis militú milibus præerât: Curt. hift.iiii. His ingutcoopo fitis, in regioné quæ Satrapone vocatur puenit, fertilis terra, copia rerü et omni cómeatu abundans:itaqg diutius ibi fubftitit, ac ne defides otio dimitteret animos,iudices dedit, præmiáp propofuit de virtute militari certantibus: nouem fortiffimi iudicati cú elfent fingulis militum milibus præfuturi, Chiliarchos vo cabant, tunc primum in husc numerum copiis diftributis, nanq antea quinge naria cohortes fuerant, nec fortitudinis premia geflerant.

Centurio is erat,vt inquit Liuius. vii.ab vrbe cond -quem nunc primipilum appellät, \& auctore Fefto qui nüc céturio antea cêturionus dicebatur,à centü dìctus, vt inquit Varro, qécenarius eius iuftus fit numerus. Quintilianus libro pri 
mo infti. Diu deinde referuatú ne confonantibus a fpirarent,vt in Graccis et in triumpis erupit breui tempore nimius vfus, vt choronæ chenturiones adhuc quibufdam infcriptionibus maneant.

Succenturiati milites funt non qui in prima fed qui in fecunda céturia funt, vt fi prima defecerit ifti quos fubefle diximus, laborantibus primis fubueniant, vnde ad infidiandum ponitur fuccenturiatus quafi armis dolofis inftructus. Terentius in eunucho, Ego in fubfidiis ero fuccenturiatus.

Decuriones funt, qui denis prefunt equitibus, quidã dictos aiunt ex co quòd in initio cum coloniz deducerentur decima pars eorum qui ducerentur, cofflii publici gratia fcribi folita fit. Alii proinde dictos putát, quòd fint de ordine cus rix cuius officium adminiftrarent. Decurix pluribus diftinct $x$ nominibus fuere tribunorum $\&$ iudicum, propter hoc nongenti vocabantur, ex omnibus felecti à cuftodiedo fuffragiorum fcita in comitiis, $\&$ diuifus hic quog ordo erat fuperba appellatione nominum, cum alius fe nongêtun, alius felectum, alius tri bunum appellaret.

Quaterniones à quatuor militũ quibus præerant numero dici. A Auum apo ftolorum.xii.tradens eum quatuor quaternionibus militum cuftodiendum.

Milites-dicti quia mille erant ánte in numero, quos Romulus primus ex populo fumpfit \& milites appellauit.vt in lib - primo hiftoriarum inquit Eutropius. Varro milites dictos afferit quòd trium milium legio primo fiebat atque frngula tribus Tatienfum Ramnenfum Lucerumóg milia militü mittebant. Vlpianus a pud Iuftinianum li. xxvii. Militem inquic quafi millefimum quemque dictum, hoc eft, omnem qui ex millenario numero, fne licet nonnulli noftri temporis iuris periti, latini fermonis ignari, qui dictum putât ex mille maxime ftrenuum. Alii inter idoneos rerum fcriptores ve Helius à mollicie per antiphra fim diçum putant,eo quod nihil molle fed potius afperum quid gerat, ficut ludum dicimus in quo minime luditur, vel à graco verbo quod duritiem fonat. Vnde Maro, Durum à ftirpe genus natos a dlumina primú Déferimus, fruoque gelı duramus $\&$ vndis. Álii à multitudine vel à malo arcendo militem, $\mathrm{m}$. litiámque quafi malitiam, vel multiciam dictam rectè arbitrantur,cum eius mu* neris fit multitudine malum malitiámque hoftium arcere, tueríg ciuil is potentix partes ac iura, ne quid mali ab illis ciuibus fuis inferatur: fićpille nó folum militat qui in acie ftat $\&$ cornu dextrú læúumve defendit, fed qui portas tuetur $\&$ ftatione minus periculofa, nō otiofa tamen fungitur,vigiliáfque feruat,et armamento præeft: qux minifteria quamuis incruenta fint, in numerum itipendi orum tamen veniunt. Illud nec obruendum filentio, vniuerfos qui erant in exercitu qui pedibus $\&$ equo mererent, fine difcrimine veteres appellaffe milites, $\&$ communi genere protuliffe nonnunquam: quanquả qui equo non milites modo fed equeftri gradu $\&$ honore preftarent: cuius rei fidem facit, quód milites dicimus etia non fatis honelto exercitio preditos, vt qui reos cuftodiunt $\&$ qui ad fupplicium ducunt.Valerius Max. lib.ix. Cn. Carbo magnæe verecundize eft latinis annalibus tertio in confulatu fuo iuffu Pompeii in Siciliam ad fuppliciú ductus, petiit à militibus demiffè $\&$ flebiliter fibi aluum leuare prius quàm expi- 
raret liceret, quo miferrimę lucis vfu diutius frueretur. Vnde \& illud etiam, mili tem $\&$ reum eadem ftringit cathena : quare apud omnes propemodú inuulgatum videmus vt miles peditem defignet,eques autem cum honore dicatur.

Tumultuarii milites dicti à tumultu id eft Italico bellovel Gallico, quando vicinum periculum $\&$ fubitum, $\&$ improui fum bellum ingruit $\&$ non eft fati um nec têpus cóflii, quod fingulos iurare patiatur, vt inter Fabios fuit,fed princeps patratus fue conful intrat templü \& arripit vexillú \& inquit, Qui remp. fal uam vult me fequatur . Euocati milites non funt,verú pro milite củ ingruit neceflitas et proprię vires non fuppetunt, aliunde euocátur. De his Crifpus, Ne quis miles, neu quis pro milite $\&$ ab his alibi omnes euocatos $\&$ centuriones.

Auxiliares dicuntur in bello focii Romanorum externarnm nationum, dicti ex graco vocabulo quod nos dicimus rerum crefcentium auctionem.

Sacramento rogati hi funt,qui plenam militiam habent $\&$ xxv.annis in mi litia tenebantur,quique in temp.iurant $f e$ non redire, nifi pręcepto confulis polt completa ftipendia,id eft, militix tempora,

Legimus apud Iul.Cęfarem aliud militix genus in Gallia fuiffe pecunia con ductum, Solidurios ipfi vocant, qui neqg nuncibi neçalibi vfquam funt: horum conditio eiufmodi erat, ve cum his quorum amicitix fe deuouffent onnem fubire fortunam, \& ad vltimum etiam mori vellent,nec poft ipfos vitam villam pa ti poffent,quin fi aliter mori non daretur,mortem fibi manu propria confcifcerent.Mirum genus militum, his noftris temporibus aduerfum, neq quifquam ex eo numero inuentus à fecul is ferebatur, qui hoc ficere renuiffet,

Mercenarii à mercede dicti, vt hi quos anno ab vrbe cond.circiter,d.xl: Sempronio Graccho Fabióó Maximo cófulibus Scipionis fratres res in Hifpaniis gerêtes, ex Celtiberis militibus pecunia folicitatis ab hoftium focietate in fua ca ftra traduxere. Quo primum têpore externa manus in caftris $R$ omanorum copit haberi: quòd Celtiberum iunentutem eadê mercede, quæ facta cú Carthaginenfibus erat, imperatores Romani ad fe perduxerunt \& nobilifimos $\mathrm{Hif}$ panos fupra trecen tos inde in Italiam ad folicitådos populares qui inter auxilia Hannibalis erant, miferunt: id modo cius anni in Hifpania ad memoriam infigne eft, quòd mercenarium militem in caftris neminem antequam tum Celiberos Romani habuerunt.

Equites dicti quòd eis in legationes ituris equi dabantur de publico, vel cum militandum foret, vt non pedites ipfr,quemad modum plebs fordida reliqua, fed digniori militix genere maioríque honore regé ac imperatorem in bellum euntem equites fequerent ur. Liuius, hac vbi inter figna peditum dicta dedit, aduolat deinde ad equites,agite iuuenes, inquit, praftate virtute pedite, vt honore at $q$ ordine preftatis. In his quog qui ad equitatum tra hebantur, nomen fape variatum inuenio, Prius enim fub Romulo regibusóg appellati funt celeres, vel à cele ritate vel à duce Celere, qui dicitur Remum occidiffe, in cuius gratix vicem à Romulo fieri tribunus militum meruit: híque trecétifuere, quos $R$ omulus tum bello tum pace ad fui cuftodiam corporis habuit: hi deinde flexumenes dicti, po 
ftea Trofuli, cum Trofulum oppidú in Tufcis citra Vulfnos fine vllo peditum auxilio cepiffent, huius'g nominis appellatio durauit vltra C. Gracchum: I unius poftea qui ob amicitiam eius Gracchianus eft appellatus, fcriptum reliquit his verbis, $Q$ uod ad equeftrem ordinem fpectat, anter Trofulos, nüc equites vocant,ideóque quia non intelligunt trofulus nomé quid valeat, multos pudet tro fulos vocari. Quo autem honore equefter locus vel gradus apud maiores fuerit oftendit M. T.Cicero in oratione ad iudices pro Plancio, Video inquit quid di cam, hic familia côfulari eft, ille prętoria, reliquos video effe in equeftri loco, funt omnes fine macula, funt æquè boni viri atque integri, fed feruari neceffe eft gradum, cedat confulari generi prætorium, nec contendat cum pretorio equefter lo cus: idem Cicero, Demum equeftre nomen in cófulatu ftabiliuit fuo Catilianis rebus ex eo fe ordine profectũ effe celebrans, quo tempore hoc.iii.corpus in rep. Itatutum factumóp eft,cœpitq̧́ adiici fenatui populóq̣ Romano \& equefter ordo.

Defultor is eft $q$ de vno equo ad aliü fe tranffert. Liuius ii.belli pu.lib.iii, Nee omnes Numidx in dextro locati cornu, fed quibus defultorú in modum binos trahentibus equos, inter acerrimam fape pugnam in recentem equum ex feffo armatis tranfultare mos erat, táta velocitas i pfis, tám que docile equorum genus, cum hoc modo inftructiftarent.

Procurfatores à procurrendo dicti . Livius belli punici fecundi lib.ix. Velites fubfidio mifit, à quibus vbi per procurfa tores commiffa pugna miffa effet, Lelium cum equitatu impetum ex occul to facere jubet.

Pedites quòd pedibus non equis inniterentur dicti, horú nomen femel tantum variatum inuenio, \& ab I phicrate Athenienle, qui multa in re militari noua atculit, multáģ meliora fecir: nanq̧ pedeftria ille arma mutauit, \& cum ante illum imperatores maximis clypeis, breuibus haftis, minutis gladiis vterentur, è conrario ille peltam pro parma fecit, à quo poftea Peltafta pedites funt appellati,vt ad morus concurfúsque efferit leuiores.

Accenfus, Q. Alconio tefte, nomen eft ordinis \& promotionis in militia, vt nunc dicitur princeps \& cornicularius. Accenfos Cato adminiftratores effe fcri bit: ali accenfos militiz genus effe adminiftrantibus preximú perhibét. Varro, vt coff.vt pratores, qui fequuntur in caftra accenfi dicti, quòd ad necelfarias res fapius acciantur velut accerfiti, quos nunc dicimus deputatos: vel accenfi dicebantur qui in locum mortuorum militum fubito fubrogabantur, ita dicti quòd ad cenfum adiiciebantur.

Adfcriptitii veluti quidam fcript idicebantur, qui fupplendis legionibus adfcribebantur:hos et accen! os dicebant, quòd ad legionum cenfum effent adfcripti, vel quód olim inermes armatis militibus adfcribebantur, qui fuccederent fir quis eorum deperiflet.

Leuis armatura fueleues, viii. ab vrbe condita tefte Livio, qui hątam tantum geffàque gererent, vocabantur.

Expediti $\&$ impediti ab eodem denominationem fibivendicåt, aut ex folutis militibus aut illigatis. Sifenna hiftor. lib.iii. Inermes armat impeditos expediti fine vllo fuorum vulnere cunctos interficiunt, vel expediti $\&$ impediti dicti, quòd 
milites ac bellatores expeditos curis \& domefticis affectibus abfolutos effe opor tet $\&$ impeditos ac ligatos.

Ferentarii qui leui funt armatura milites inftructi ad bellum, vt fund is \& lapidibus, enfe, telis $\&$ his armis qux feruntur non qux tenentur: Saluftius in Cati linario, Pofteaquam eò ventum eft vt à Ferentariis pręlium committi poffet, ma ximo clamore cum infeftis fignis concurrunt, pila emittunt $\&$ gladiis res geri tur: hos Varro à ferendo etiam dictos putat, verú codem tefte equites dicti funt ferentarii, qui eo modo habebant arma qua feruntur, vt iaculum, eiufmodíque equites pictos vidife inquit fe in Aefculapii æde vetere, \& ferétarios affcriptos: Cato autem eos referentarios dixit, quòd tela ac potiones militibus pugnantibus miniftrabant.

Pygmęos montana Indiç incolentes quibus eft vicinus oceanus exiguę adeó proceritatis homines effe quidam auctores non leues tradidere, vt cubitalé men furam non excedant, belligeros tamen: hos enim aiunt arietum caprarúmgg dor fis armatos infidentes continuum bellum gerere cum gruibus. Iuuenalis,

Ad fubitas Thracum volucres nubémque fonoram,

Pygmæus paruis currit bellator in armis

Moxóp impar hofti,raptusóg per aéra curuis

Vnguibus a faua fertur grue, fi videas hoc

Gentibus in noftris rifu quatiere: fed illic

Quanquam eadem affidue gerantur pralia,ridet

Nemo,vbi tota cohors pede non eft altior vno.

Arimafpi hominú in Ponto genừ vno oculo in fronte media cum gryphis aurum cuftodiétibus affidue bella gerentiü, quośģ fama eft non incelebris Pom peii contra Cęfarem Philippicis in campis partes ac figna fecutos fuiffe, Vnde Lucanus in tertio,

Hinc \& Sydonize gentes, auroóp ligatas

Subftringens Arimafpe comas.

Amazones Scy thic mulieres bellicofiflimæ quę excidio coniugum $\&$ pace tum arm is quęfita ne genus interiret concubitum finitimorum ineant, fi qui ma res nafcantur interimant,virgines in eundem ipfis morem non otio neque lanificio, vt cæteræ mulieres, fed armis, equis, venationibus exerceant, inuftis infantium dextris mammillis,ne fagittarü iactus impedirentur. Vnde \& à Græcis eo quòd mammis careant Amazones appellantur. Curtius lib.quarto, veftis non toto Amazonú obducitur corpori:nam læua pars ad pectus eft nuda,cętera deinde velantur: nec tamen finus veftis modo colligunt, infra genua defcédit, alterna papilla intacta feruatur, qua muliebres fexus alant, aduritur dextra vt arcus facilius iñtendant \& tela vibrent: nam vt poèta meminit, Pulfant \& pictis bellantur Amazones armis.

Argyrafpides ob arma deargentata fic dicti milites, qui fub Alexandro militabant . Orofus tertio hiftoriarum, Quare vltimo confilio Argyrafpidas ob arma argentea fic dictos, hoc eft, milites qui fub Alexandro militauerant in aus xilium rogat. Iuftinus in epitome Trogi Pompeii.xii.cui glorix vt etiam exer- 
citus ornamenta cóuenirent, phaleras equorum $\&$ arma militum argento inducit, exercitúnque fuum ab argêteis clypeis A rgyrafpides appellauit. Liuius ab vrbe códita xxxvii. A b eadem parte paulumi prorupto cornu regia cohors erat, argyrafpides à genere armorum appellabantur.

Capitecenfi milites vocabantur, qui nullo vel qui g̈paruo ære cenfebantur: hi nanģ nifi in tumultu maxirio \& afperis reip.temporibus, cum iuuétutis ino pia effet,in militianı tumultuarianı legebantur,armág his fumptu pub. præbebantur, \& non capitis céfrone, fed profperiore vocabulo à munere officióq prolis edendę, proletarii appellatı funt, quòd cum re familiari parua haudquaquam polfent remp.iuuare, fobolis tamen gignend $x$ copia ciuitatem frequentaret. Ca pitecélos primus C.Marius, vt quidam ferunt, bello Cymbrico, vel potius, vt inquit Crifpus bello Iugurthino milites fcripfiffe traditur, cú factum antè in nùlla memoria extaret.

Cataphracti equites hi dicuntur, qui \& ferro muniti funt, \& equos fimiliter mu nitos habent. Liuius $x x x v$. ab vrbe côdita, His, vt plerique quos opes alunt, vaniloquiis maria terráfque inani fonitu verborum compleuit, equitum innumerabilé vim traiici Hellefponto in Europã,partim loricatos quos cataphractos vocant. dem xxxvii, Pręter rectorem quaterni armati ad latus dextrum phalangitarum mille \& quingentos Gallogreccorum pedites oppofuit: his tria milia peditum loricatorum, quos cataphractos ipfi appellant,adiunxit.

Geloni,vt inquit Pom. Mela Cof.lib.ii. Non loricis fed hoftiü cutibus equos fég velabant, illos reliqui corporis, fe ca pitum.

Cetrati à cetris, hoc eft, breui cutorum genere muniti \& armati milites dicti. Liuius ab vrbe condita xxxv, Nauigia parua in fationem occultam agri Argiui contraxit, in ea expeditos milites cetratos plerof que cum. fundis $\&$ iaculis $\&$ alio leui genere armaturæ imponút. Idem in codem, Cetrati itaq quantum latitudo vallis patiebatur inftructi federent, vt facile per interualla ordinum fugien tes fuos acciperent.

Pilani teite Varrone dicti quòd pilis à principio pugnarent, fòft comnutata re militari minus illuftres facti- Ouidius .iii. faftorum,

Inde patres centum denos fecreuit in orbes,

Romulus haltatos infituito decem:

Et totidem princeps, to:idem pilanus habebat,

Corpora legitimo quilog merebat equo.

Velites expediti \& leui armatura milites à volitando ob celeritatem dicti,tefte Orofio libro quarto hiftoriarum: vel à gręco Bázlep, id eft,iaciêdo, hi tripedalem parmam habent $\&$ in dextra haftas quibus eminus vtuntur gladio Hilpanenfi accincti, cum armis fuis poft terga equitum confidebant, continuóque pedites ipfi ex alia parte equitibus per quos aduecti fuerant dimicátibus, holtem pertur a babant:Quod fi pede collato pugnandum fibi érat,tranflatis in læuã haftis, gladium ftringebant, vt velites ctiam in legionibus effent. Auctorem peditum equitibus immifcendorũ cêturioné QNeuium ferunt co bello primũ, quo Capuam nobiliffimả ac potentiffina quondam vrbé Fuluius Flaccus imperator obfedit. 
Velatos appellant veftitos $\&$ inermes milites, qui exercitum fequebantur quíç in mottuorum militum locum fubftituebantur.

Volones dicti funt milites qui poft Cannenfem plagã vfğ ad octo milia,cum effent ferui, voluntariè fe ad militiam obtulerunt, \& cum fponte hi vellent, volones appellati.

Tituli milites proinde fic appellantur, quòd patriam tuerentur, vnde \& Titi prænomen ortun eft. Titulum autem dici ait Numa Pompilius de pontificalibus fcribés pallium quo facerdotes caput tutabant, cum ad facrificium acceffiffent,ficut \& Virgilius,

Et caput ante aras phrygio velamus amictu.

Rorarii milites qui leui armatura primi pralium committebant, quòd vt ros ante imbrem, fic illi ante grauem armaturam prodibant, Rorarii dicti.

Beneficiarii dicebantur milites, $q$ vacabant muneris beneficio,ficut côtrà mu nifices vocabantur qui non vacabant, $f$ ed munus reip.faciebant, vel beneficiarii militú genus qui ex eo ita appellantur quia promouentur ad honores beneficio tribunorum, vt inquit Vegetius,ídq confirmatur auctore Cæfare in commenta riis fuis, cuius verba hæc funt, $\mathrm{H} x$ c erant milia xlv. euocatorú circiter duo, quæ ex beneficiariis fuperiorú exercituú ad eú côuenerất, qux tota acie difperfa erât

Dupliciarii milites dicti, vt Varro inquit, quibus ob virtutem duplicia cibaria vt darentur inftitutum eft.

Latrones conducti milites vocantur: Moris enim erat vt hos imperator circa fe haberet, \& primò mitteret ad omne difcrimen, et quanquam gracum eft nomen, Varro tamé dicit hoc poffe habere etiam latinam etymologiam, vt latrones dieti fint, quòd circa latera erant regi quafil laterones, atç ad latera habebaat ferrum, quos poftea à ftipatione Stipatores adpellarunt, $\propto$ quia conducebantur, \& ea merces dicitur mwis ab ea veteres poëtæ nonnunquam milites mercenarios appellant latrones, aut quòd latrocinari militare eft mercede, aut I latent ad infidias faciendas, quos nunc Satellites vocant:

Sicarii latrocinantium genus ficas $\&$ gladios fub vefte deferentium. Iofephus bello iudaico libro ii. Sic enim regione purgata aliud genus latrocinantium in Hierofolymis oriebatur, hi autem ficarii vocabãtur; die claro \& in media ciuitate paffim quofque interficientes, potiffimum verò diebus feftiuis mifcebantur vulgo, \& ficas fub vefte geftantes his diuerfos quofque interficiebant, ac deinde collapfis hominibus, illi inter reliquos de fcelere quarebant, qua fraude extra futfpicionem manebant.Idem in eodem, Inter infirmiorem autem vulgum multi irrumpétes ficariorum, fic enim vocant latrones, gladios in finibns gerentes, auldaciffime vtebantur opere quod adorti erant.

Defiderati milites fecundum confuetudinem deperditi vel qui perię̧unt, vel fecundum rationem dictos puto, quòd abfentium rerum necdum inuentarum fint defiderium. Cicero pro A.Cluentio, Afrnius verò breui illo tempore quafi in hortulos iret,in harenarias quafdam extra portam Efquilinam perductus occiditur, qui cum vnú iam $\&$ alterü diem defideraretur,negg in his locis in qbus ex

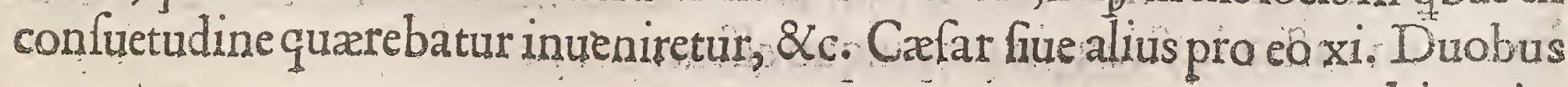


his vnius diei præliis Cæaris defiderati funt milites.dcccclx. Idé li.xii. Eodém que die Lariffam peruenit, in eo pralio non amplius trecentos milites defiderauit. Q. Curtius quarto, Cecidere Perfarum quorum numerum victores finire po tuerunt milia xl. Macedonum minus trecenti defiderati funt. Idem in tranfitu Tigris, Nec quicquam præter pancas farcinas difideratum eft.

Triarii milites tefte Varrone fic dicti,quòd in acie tertio ordine extremis fub fidio ponebantur, quódque hi fubfidebant ab eo fubfidiú dictum. Plautus, Agite nunc fubfidite omnes triariis. Liuius ad vrbe condita xxxvii, Haftatorū prima figna,deinde principú erant, triarii poftremos claudebant. Idem in octauo, Triarii fub vexillis confidebät finiftro crure porrecto, fcuta innixa humeris, haftas furrecta cufpide in terrā fixas, haud fecus quàm qux vallo fepta acies inhorreret tenentes : fi apùd principes quoģ haud fatis profperê effet pugnatú, à prima acie ad triarios rediiffe,cum laboratur, prouer bio increbuic.

Retiarii nomé ab armaturæe genere ortum perhibetur: contra enim pugnantem Mirmillonem retiarius ferebat occulte rete, quod iaculum appellatur,vt ads uerfarium cufpide infiftentem operiret, implicitum'g viribus fuperaret:huic retiario pugnanti aduerfus Mirmilloné, cantabatur non te peto, pifcem peto, quid me fugis galle: quia mirmillonicum genus armature gallicum eft, ipfíp Mirmillones antè Galli appellabantur, in quorú galeis pifcis effigies inerat: quod genus pugnę inftitutum eft à Pittaco ex fepté fapientibus vno, \& exercitus imperatore, qui aduerfus Phrynonem Atheniéfum ducem qui pancratiaftes et olympioni ces fuerat dimicaturus, propter controuerfias finium qux erant inter Atticos $\&$ Mitilenos, rete fub clypeo occulte lato impediuit Phrynonen, \& dum non cauit inuoluit.

Gregarii humilis militix ac vulgatx milites qui ex minoribus \& extraordinariis funt, cú alii maiores $\&$ ordinarii dicantur. Iuftinus epit. trog . Pomp.xiii。 Prima P tolomæo Aegyptus. Aphricæ Arabię́g pars forte venit, quem ex Gregario milite Alexander virtutis caufa prouexerat. Idcm xxxviii, His auditis An tiochus occupandum bellum ratus, exercitum quem multis finitimorum bellis indurauerat aduerfus Parthos ducit, led luxurię non minor apparat us quàm mi litia fuit: quippe octoginta nilia armatorum fecuta funt trecenta lixarū ex quibus coquorum, piftorum, fcortorumóg numerus fuerit maior: argéti certe auríg tantum,vt etiam Gregarii milites auro caligas fingerent proculcarent'ó materi am,cuius amore populi ferro dimicant.

Optiones appellantur hi milites quos dècurio aut centurio optat fibi rerum priuatarum miniftros, quo facilius obeat publica officia:optiones autem dicti $q$ fint electi, nã optare, eft eligere: ficut eft illud, Optauítģ locú regno, id eft, elegite

Optices quoque ab optãdo appellati eò quòd antecedentibus agritudine prxpeditis tanquam adoptati eorum ato vicarii, folent vniuerfa curare.

Excubitores dicti pro eo quòd excubias femper agunt, funt enim ex numero militum.

Procubitores autem dictuntur, qui noctu cuftodia caufa ante caftra excubabant,cum caftra hoftium in propinquo eflent.

Strenuus, 
Strenuus, efficax, gnauus, vigilans, fortis fic dictus, quòd fternendo aduerfa re nuat. Liuius viii.ab vrbe códita, Cn. Cornelio C.Lentulo. P. Philone iterü colt. Palapolim ad res repetendas miffis, cum relatú effet à gręcis, gente lingua magis ftrenua quàm factis ferox refpófum. Iuftinus epi. Trog.Pomp.xii. Nam \& ma nu ftrenuus, $Q$ in concionibus perfacundus habebatur.

Tranffuga, Vlpiano tefte, no eft folus accipiendus, qui ad hoftes in bello träffugit, fed et qui per induciarum tempus, ad eos cum quibus nulla amicitia eft, fide fufpecta, tranlfugit.

Fugıtiuus, vt Ofilius inquit, is eft qui extra domini domú fugæcaufa,vt fe à domino celaret, máfit. Cęlius auté fugitiuum effe ait eum, qui ea mente difcedat, ne ad dominú redeat, tametfí muta to confilio ad eú reuertatur. Nemo enim talị peccate inquit poenitétia fua nocés effe definic. Caffius quocp foribit fugitiuum effe q certo propofito domú relinquit. A pud Iul . item relatü eft fugitiuú ferè ab affectu animi intelligendũ effe: nô vtio̧ à fuga. Nam eú qui hoftem aut incendium, latronë, ruinámve effugeret quàmuis fugiffe eft verü, nô tamé fugitiuũ effe. Apud Labeonem \& Cæliü quæritur,fi quis in A fylum cófugerit aut cò fe con ferat quò folent venire qui fe vanales poltulát, an fugitiuus fit? Ego puto nó effe eum fugitiuư, qui fecit id quod publice facere licere arbitratur, nec eũ quidem qui ad ftatuam Cefaris confugit, fugitiuum arbiror, nö enim fugiendi animo hoc fecit. Idem puto et in eum qui in Afylú vel quid aliud finnle confugit, quia non fugiendi animo hocfecit: fi tamé ante é ugit, \& poftea fe contulit, non idco magis fugitiuus effe definit. Item Calius fribit placere eum quoq̧ fugitiuum ef fe, qui cò le conferat vnde eum dominus recuperare non poffit, multóg magis illum fugitiuum efle qui eó fe conferat, vnde abduci non poffit.

Tyrones dicuntur fortes pueri, qui ad militia deliguntur atque armis geren dis habiles exifunt, vnde et Tyrones dici. Ty ro etiam rudé \& ignarum fignificat. Proinde Cæár Tyrones neque in ludo negs planiftas, fed in domibus per equites romanos atque etiam per fenatores armorum peritos erudjebat: hi enim antea probantur, ficut mos fuit Rome puberes exercere ąmis, \& fub cuftodibus effe, poftea milirare, de quibus poëta nobiliffimus, Ft primo flore iuuentus. Inde Tyrunculus per diminutionem paruus Tyro dicitur.

Veterani legionarii dicuntur,quíque iam in vfu prelii non funt, fóf que mul tos militix labores quiet is fuffragium confequuntur. Veteranus etiam Modefino auctore effe creditur, non folum legionarius, fed omnis qui qualitercungs militauerit, \& honeftè eft iple abfolutus.

Emeriti dicütur foluti militia; \& quia merere militare dicitur ob ftipendia.f: quæ merentur, ficut emeriti ftipendii, vel emeritæ miliria qui militia perfuncti funt nominätur: qui extra meritú ftipendii \& militie pofiti,ficut miles olim poft lx.vel lxx. annum quià labore folutus nó cogebatur militare, a gro vel villa donatus: Nonnullarü enim rerü publicarum hic mos ef, vt fort fexagefimü ad mi litiā nemo cogatur, in pluribus detur remiffio iufta poft lxx. Inftinus epi, Trog: Pomp.lib.xi. Alexander cú contra Perfarum tam periculofum bellú, exercitum legeret, nó iuuenes robuftos, nec primum florem ætatis, fed veteranos, plerofque 
etiam emeritos militiæ, qui cu m patre \& patruis militauerant,elegit.Quintilianus, Emeritis hinc bello ftipendiis: \& per tranflationem à poéta præclaro emeri ti boues dicuntur in georgicis quoque.

Armiger eft qui tela gerit, \& arma tantum domini fui, vt fcutum, pilum,arcum,cæterág id genus, vt quidā perhibent, qui cos imperitiæ quogs arguút,qui armigerú vocant armatú equitê, quod à clariffị is rerum geftarum foriptoribus haudquaq̈ obferuatú inuenio, Liuius ab vrbe cond.xxii. Donec infuper eques cui Ducario nomen erat, facié́, nofcitans cof.inquit, hic eft cum popularibus fuis qui legiones noftras cecídit, a grośg \& vrbem eft depopulatus, iam ego hảc victimam manibus peremptorum foedè ciuiü dabo, fubditisó̧ calcaribus equo, per confertiffimam holtium ururbá ımpetum fecit,obtruncató prius armigero qui fe infêto venienti obuiam obiecerat, cófulem lancea tranffixit, fpoliare cupientem \&.c. Curtius, Atarras antè cum trecétis armatis intrauerat tegiam, huic decem fatellites traduntur, quorum fingulos deni armigeri fequebãtur, hi ad alios coniuratos comprehendendos diftributi. Seneca tragicus in Hippolyto de Amazonibus, Et prorfus ifte gétis armigerę furor odiffe Veneris foedera, \& caItum diu vulgare populis corpus. Suetonius in vita Octauiani, C xterum nume. rum partim in vrbis, partim ad fuam cuftodiam adlegit, dimiffa Calliguritanorum manu, quam vfós ad deuictum Antonium, item Germanorum, quá vf̨̣ ad cladem Variam inter armigeros circa fe habuerat.

Lixa qui exercitum fequuntur quęfus gratia, dicti quòd extra ordinem mili tie funt,eisóp liceat qued libuit. Ali eos a Lixa appellatos dicunt $q$ \& ille Hercule frt fecurus, vel quò: lixæ militibus aquã ad caftra vel tentoria folerent ferre, quam lixam veteres dixere, quam'q́ coctam, elixam dicimus: quidáa liguriendo Qux oppofita; vt paucitatem maxime fpernent ibus Ponis, ingêtis repente exercitus fpeciem fecerit . Calones Nonio tefte militü ferui, dicti quod ligna militibus lubminitrent, fiue ligneas ferant clauas.

Cacula etiam militis feruus. Plautus, Video caculam militarem: \& dicitur à græco xúxan quòd fultibus clauífque ligneis ad tutelá dominorum armari foliti funt, íque qui huiulmodi claua \& teli genere vtitur, Clauator appellatur..

Auctoratus miles is dicitur, qui obligatus \& fubiectus eft. Sueto.lib. iii. De le gendo velauctorãdo milite ac legionum et auxiliorú defcriptione: ex quo fit au doramentum, guod quafi obligatio eft rernm, vel ftipendium quoddam, vel pre cium cuiufdam militıx ac pugnæactionífque.

Exauctoratus infignibus militaribus amoitus : exauctorare enim eft infignia militaria detrahere, auctore Vlp.Si enim Iuliano acced imus, fi quis milité exauctorauit, inter infames effecit, licet nó addidiffet ignominię caufa eú exauctoraf fe:exauctorare quog,s, I liani pace dixerim, eft non folú infamem milité reddere, verum duce ab imperio fuo dimittere, vel miffum milité fa cere, illumóg honefta miffione militix plerüg donare. Liưius ab vrbe cond lib.xxix. Vbi ex his vnus aufus eft dicere fe prfus fi fibi vtrügg velit liberú effe, nolle militare, tú Scipio, Ex quo igitur adolefcés quid fentires nô diflimulafti, vicariư tibi expedi iã cui tu 
arma equüóg et inde cæetera inftruméta militiæ tradas, \& tecú hinc extéplo domum ducas, exerceas, docendum cures, equo armisq̣ lęto conditioné accipienti vni ex ccc.quos inermes habebat tradidit: vbi hoc modo exauctoratú equitem cú gratia imperatoris cęteri viderüt, fe quif ${ }_{\not B}$ excufare \& vicariũ accipere. Iulius Frontinus Itratag.quarto, Diuus Auguftus Vefpafianus cú quendá adolefcenté honeftè natü, militię inhabilë, anguftiarú rei familiaris gratia eductum, ad longiorē ordinéerexifiet, cenfu cóftituto honefta miffione exauctorauit. lam hucuśg perductus liber ifte claudendus eft, eiuśg prolixitatis modus ad hibendus: verum quia nonnulla etiam mihi in hoc adhuc video ponenda effe, qua fint illa proximus liber cómodius indicabit,ne hunc tam prolixum vlterius onerenus.

\section{ROBERTI VALTVRII}

A D I L V S T E M HER OA SIGIS-

mundum Pandulphum, de re Militari

Liber Nonus.

然

Quid quoluplexig; bellum, or unde catera bellici exercitus nocabuld; acierum, fingularumq́; denominationum caufa.

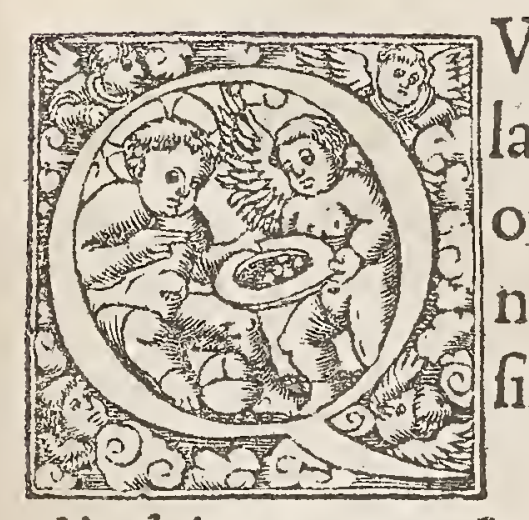

Voniam fuperiori volumine, Sigifmunde Pandulphe, vocabu la militaris ac publici honoris prifa et praclara parias corú origines $\&$ officia monftrauimus, bellici núc exercitus intactũ ne quid aliorum relinquatur is lequés liber patefacict, caufasóg fingulorum ac denominationes feorfum aperiet et explicabit. Bellum quod eft mulciplex, fuisóg dıftinctũ nominibus,cum aliud internum fit, aliud externum, aliud feruile vel fociale vel py raticum, vt an tè diximus, dictum à belluis quòd belluarú fit pernitiola diffentio, vel vt Seruio placet,ficut à lucendo lucus dictus eft, fic à nulla re bella bellum, cò quơd contrà fit horridum et peffimun, vnde bella horrida bella:alii à Belo qui primum gladium ferreú produxit.Caffi. primo hift. Poftea Belus ferreum gladium primus produxit,à quo bellum placuit denominari: \& eft bellum tempus omne quo pre paratur aliquid pugnæ neceffarium illis quo pugnetur, vel bellum eft totü tempus quo in militia fumus, quod indocti noftri temporis Guerram vocant, vt bel lum Gallicum, bellum Punicum, bellum Macedonicum.

Duellum bellum videlicet, quòd duabus partibus de victoria contendentibus dimicatur, vt inquit Feftus. Bellum enim ante duellú vocat um, vt alii perhibent, eò quòd duæ fint partes dimicantium, vel quòd altera faciat victorem, altera viEtum: poltea verò mutata \& detracta litera dictú eft bellum. Horat .prim.epift. Græcia Barbariz lento collifa duello, Stultorum regum \& populorum continet æltum. Ouidius vi.faltorum, 
Hac facrata die tufco Bellona duello, Dicitur, \& latio profpera femper adeft. Liuius primo ab vrbe condita, Dic, inquit, ei qué primum fententiam rogabat, quid cenfes? Tum ille puro pióg duello quęrendas cenfeo.Idem.xxxvi.Si duellum, quod cum rege Antiocho fumi populus iuffit, id ex fententia fenatus, po pulique Romani confectum erit, tum tibi Iupiter Populus Rom. Iudos magnos dies decem continuo faciet.

Tumultus grauius vrget quàm bellú: poteft enim tefte Cicerone effe bellum fine tumultu, tumultus effe fine bello non poteft. Quid eft enim tumultus nifi per turbatio tanta, vt maior timor oriatur: vnde etiam nomé eft dịctum tumultus. Itag maiores noftri tumultú Italicum, quơd erat domefticus, tumultú Gállicum quòd erat Italię finitimus, præterea nullû cumultum nominabãt: grauius autem tumultum effe quàm bellum hinc intelligi licet, quod bello Gallico vacationes valent, tumultu non valent, ita fit quemadmodum dixi, vt bellum fine tumultu effe poflit, tumultus fine bello effe non poffit.

Turbam appellari Labeo ait,ex genere tumultus,id'q̣ verbũ ex græco cótractum: turbá autem ex quo numero admittimus, fi duo rixam cómiferint vique non accepimus in turba id factü, quia duo turba nö propriè dicuntur:enimue ro fi plures fuerint decé aut quindecim homines turba dicetur: quid ergo fi tres aut quatuor?turba vtigh nó erit, \& rectiffimè Labeo inter turbã et rixá multum intereft, ait nanque turbam multitudinis hominum effe perturbationem $\& \mathrm{c} x$ tum, fed rixam duorum.

Prælia congrefliones armatorú,certamina belli pugnę́g partes dicútur. Lu * cilius.xxvii. Ro. po.victus vi \& fuperatus præliis fape eft multis, bello verò non vnquã. Liuius ab vrbe cond.ix. Quantalibet magnitudo hominis cócipiaturanimo, vnius tamé ea magnitudo hominis erit collecra paulò plus decé annorum foelicitate, quam qui eo extollunt, quòd po.ro. \& fi nullo bello, multis tamen præ. liis victus eft. Dicitur auté pralium ab imprimédo hoftes, vnde prala ligna qui bus vua premitur vel à preludendo, bellú enim quafi præludendo incoetabant.

Pugna à bello differt \& prælio: eft enim vnius diei $\alpha$ belli pars, vt Cannenfis, Cremerenfis, multág continet pralia, cú aliud in cornibus, aliud in media, aliud in extrema acie geritur, \& à pugnis dicta, vel quòd ab initio vius fuiffet in bello pugnis cótendere, $Q$ primo bellü pugnis incoptabant. Lucretius li.iii.rerum na. Arma antiqua manus, vngues, détesóg fuerunt: Caflio li.i.hift. Inter ipfos quoque aduer farios, vt fcitis, nô erant plus armata certamina, fed pugnis fe feruida quęlibet laceffebat intentio, vnde \& pugna nomen accepit. Pugnare ctiấ eft manus cóferere,expugnare verò pugnando vincere, expugnare naué fimiliter, tefte Calliftrato,eft eã aut fpoliare, aut mergere, aut diffoluere, aut pertüdere, aut funes eius excidere, aut vela cófcindere, aut anchoras inuoluere de mari, quo equidem miror illud Pfalmographi Sepe expugnauerunt me àiuuentute mea, dicat nune Ifrahel,etenim non potuerüt mihi, pro co quod eft oppugnauerunt fiue impugnauerũt: fi enim nô potüerút mihi, profecto nó expugnauerüt fed oppugnaue rüt: graxcè auté magis eft oppugnauerunt fue impugnauerunt g̃ expugnauerüt, pro eo fignificato accepit incerpres, nifi librariorum vitio ita fcriptum fit.

Gymnicum 
Gymnicủ certamen velocitatis eft ac viriú gloria,cuius locus gymnafú dicitur, vbi exercétur Athletæ, \& curforú volocitas cöprobatur, hoc alii veterü Pentathlum, ahi Quinquertum dixerút:id autem genus exercitationis in his quing artibus conftat,iactu difci,curfu, faltu, iaculatione, lucta. Ouidius in faftis, Ceftibus $\&$. iaculis et miffo pondere faxi Brachia per lufusexperiend a dabant. Luctatio laterum complexus, quibus cominus certantes v tuntur.

Exercitum militum copiã dicimus nó vnã cohorté tâtum, neq̧ vnam alam, fed numeros multos militum, legionum vel legiones cú fuis auxilis continentem: nomen autem exercitus ab exercitatione traxit, vel vt Varroni vifum eft, exercitus quòd exercitando melior fit.

Copias plurali tâtum numero de exercitu: copiam verò aliarú dici rerùm teftis eft Seruius cóment.ii.xneid. in hoc tamé numero cótra Seruium vfus venit eruditorú. Saluftius in Catili. Poltremo ex omni copia Catilinæ, nequ in pręlio, neog in fuga quifẫ ciuis ingenuus captus eft. Idem in eodé, Dum ea Rome gerūtur Catilina ex omni copia,quã \& ipfe adduxerat \& Manlius habuerat, duas legiones inftruit.Idem in eodé, Sed ex omni copia erat quarta pars inftructa nili taribus armis. Liuius bel. Mace. li.v. Ipfe paucos poft dies lex milia fuorum mi litum, ex ea copia qux Lamiæ repéte colligi potuit, non ita multos A etholos du cir. Statsus. vii. Theb. Premit indigefta ruêtes copia, \& quę fit mecú,tefte Virgi. copia luftro. Teren.in eunucho tefte Donato in cóment. fex homines copias du cit militern fcilicet, Parafitum, Doracé, Sirifcum, Simalionem, Sangam,cum in quit, militem fecum ad te quantas copias adducere.

Expeditio dicta quod milites ac bellatores expeditos curis \& domefticis affectibus abfolutos effe oportet.

Legionis proprietaté vt ab eligédo vel ab electione militü maximè \& Seruius \&.V arro de vita patrúlibro tertio diçá,interpretâtur, ita circa eius numerū om nes penè variãt. Seruius in primis nobilis grammaticus, variis in locis Virgilii menté interpretádo. Nam in legione, inquit,ñó nificcc.equites exant. Virgi.in feptimo, Equos numero pater eligit omni, Stabät trecenti nitid in pręlepibus al tis. Vnde \& alibi, Trecéti fcutati omnes noti, Idẽ Legiones propriè peditú funt, turmæ verò equitú. Virgilius in nono, Cætera tú legio cápis inftructa moratur. Varro de lingua latina, milites dicti quòd triū miliü primo legio fiebat, atọ fingulæ tribus Tacienfiú, Ramnéfium, Lucerú milia militú mittebant. Cintius autem de te militarı libro fexto auctore Gellio no.atti.xvii. ita fcriptú reliquit, In legione funt céturię fexaginta, manipuli triginta, cohortes decem. Flauius Vege tius.ii.de re militari,Macedones, Gręci,Dardani phalanges habuerüt, in vnáq̧̣ phalãge nouê milia armatorú cenfebãtur, Galli Celtıberi pluresóg barbaræ nationes cateruis vtebãtur, in quibus fena milia armatorum erãt. Romani legiones habent quibus fingulis fena milia \& eo amplius, interdum eo minus céfuerunt effe. Plutarchus in vita Romuli, Legiones fingulæ fex miliü peditủ \& fexcentorum equitum coplebant numerum. Liuius li.xxxviii.ab vrbe cond. Cum eas le giones quatuordecim fcripfffent, quòd plus q̆ quinq̧ milia peditũ trecéti equites in fingulis legionibus effent. Idem in eodem, Ob ea nouos exercitus confcribi

$Q$ iis placuit? 
placuit quatuor legiones in Ligures, vti fingule quina milia \& ducentos pedites ccc. haberet equites, fociorú item Latini nominis quindecim milia peditú addita $\&$ octingéti equites. Idem trigefimofexto, Romana acies vnius propè formà \& hominum \& armorum genere, dure legiones Romanæ, duæ fociùm ac latini nominis erant, quina milia $\&$ quadrigenos fingulæ habebant. Idem lib. octauo, Scribebantur quatuor ferè legiones quinis milibus peditum, equitibus in fingulas legiones trecentis.Idem lib.xl, Et pręterea fupplemento adductá quo amplius duabus legionibus, quàm.x.M.\& quadringenti pedites fexcenti equites effent, $\&$. focium latini nominis duodecim milia fexcenti equites, quorum forti opera du obus aduerfus Celtiberos præliis vfus Q. Fuluius effet, quos fi videretur lecü deportaret. Legionem autem fex milium \& ducentorum hominú primus C. $\mathrm{Ma}=$ rius, Pomp. Fefto tefte delcripfit, cum antea quatuor milium fuiffet, vnde etiam vocabatur Quadrata . Eufebius in ecclefiaftica hiftoria, Noftrorú verò \& Tertullianus hæc memorat, $\&$ a pud Gręcos A pollinaris, qui etiam ipfam legionem pro infignis facti miraculo mutato nomine vocitatam dicit ad imperatorefulmineam. Tertullianus verò $M$. im pe epiftolas nunc etiam haberi dicit, quibus de his apertius indicadit. Vnde autem tanta inter doctiffimos rerum geftarum fcriptores varietas oborta fit, Seruius in comment.xi.lib çnei.à feiplo penè diffen ties his verbis oftendit, Legio auté habebat ducdecim cohortes, fexaginta céturias, licet in his rebus acceffu temporis, ducum varietas femper immutauerit militix difciplinam. Vnde Liuius belli Punici libro fecundo, Numero peditú equitumóp legiones auctas, milibus peditum \& cétenis equitibus in fingulas adiectis .

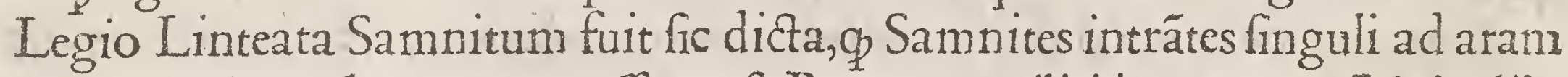
velis linteis circundatam, non ceffuros fe Romano militi iurauerunt. Liuius lib. decimo, Primoribus Samnitum ea deftinatione obftrictis, decem nominatis ab imperatore eis dictum vt ius vifum legerent, donec xvi. M. numerú confeciffent, có legio linteata ab integmento confepta, quo facrata nouitas appellata eft.

Phalanx lingua Macedonum legio eft, tefte Seruio in comment.lib.ii. Aenei. Liuius ab vrb.cōd.xxxii, Et cohortes inuicé fub frgniffọ cuneú Macedonú, Pha langem ipfi vocant, fi poffent vi perrumperent, emittebant.Idem xxxvii. Decem \& fex milia peditum more Macedonú armati fuere, qui Phalangitę appellantur.

Agmen ordinata propriè multitudo dicitur, vt eft ambulantis exercitus ab agendo, id eft, eundo dictum: neģ enim in vno loco ftans agmen vocatur, aut fi inuentum fuerit, v furpatum eft.

Cohors, in quit Varro, quòd vt in villa pluribus tectis cöiungitur, ac quiddam fit vnum, fic ex manipulis pluribus copulatur cohors; à cohærendo quòd cohęreat cunda quę interius funt, vt in villa quòd circa eum locú pecus cogeretur, vel $\phi$ coérceat obrectu fuo extraneos, \& a dire prohibeat: huius numerum varium effe inuenio. Plutarchus in vita Pelopidx, Primus Gorgias ex quadringentis electis viris, quibus ciuitas exercitationé dietam ${ }^{\prime}$ in arce Thebana militantibus prabuit, facram cohortem, vt ferunt, ordinauit, \& propter hoc cohortem ex ciuitate vocauerunt:Ephorus autem cohortem quingétos effe viros affirmat: Callifthe nes verò feptingétos, quidam alii quod Polybius fenfit, nonaginta milium ido. 
neum numerü perhibent,alii aliter.Iofephus belli Iudaici lib.iii, Decem autem cohortum fingulæ mille pedites habebat: in cæteris verò xiii. fexcenti pedites, $\&$ centeni viceni equites erant.

Cohors prętoria eft dicta,quòd à prętore non difcedebat:Scipio enim Aphri canus primus fortiflimú quemque delegit qui ab eo in eo bello non difcederet, $\&$ cætero munere militiæ vacaret, \& fexquiplex ftipendium acciperet.

Manipulus ducentorum militum eft, \& militum parua quog manus fex vel feptem in vnú collecti viri qui vnú fignum fequuntur, fic diçi fiue $q$ bellum primo manu incoptant, vel quòd antequâ figna effent,manipulos, id eft, fafciculos alicuius herbę p fignis habebãt, à quibus Manipulares milites poftea dicti funt.

Globus,vt inquit Vegetius tertio de re militari, is dicitur, qui à fua acie fupera tus vago fuperuétu incurfat inimicos, cótra quéalter populófior vel fortior mittitur globus.Liuius lib.ii.ab vrbe cond. In eum hac gloriantem cun globoferociffimorum iuuenum Romulus impetum fecit.Idem lib. xxi. Alii fugientes pugnantium globo illati hęrebant, alios redeuntes in pugnam auertebant fugientium agmen.

Cuneus eft collecta in vnum militú multitudo : vnde propter quòd in vnum coit huiufmodi coitio in vnum, cuneus quafi coneus, quôd in vnum omnes cöé-

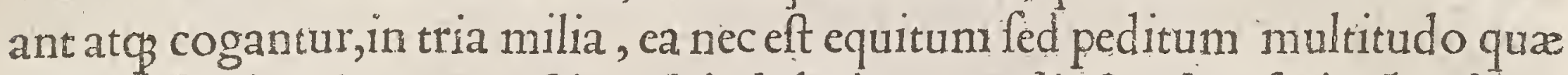
iuncta cú acie primo anguftior, deinde latior procedit, $\&$ aduerfariorú ordines prorumpit: quia à pluribus in vnum locum tela mittuntur, nec eft cunei deterninatus militum numerus, fed ordinatio acierum in modum cunei.

Cuniculum autem foramen dicimus fubterraneum occultể, aut à cuneorum fimilitudine omnem materiam nodofam quam fubintrant fcindentium, aut po tius ab animali quod eft lepori perfimile appellatum, quod fub terra folfa latere folitum eft.

Gaudet in effolfis habitare cuniculus antris, Martialis:

Monftrauit tacitas hoftibus ille vias.

Sunt qui non cuniculum fed cuniculos plurali tantum dici numero debere arbi trentur, quod à quodá noftrę huius etatis aliàs doctiffimo hiftoriarú fuarum libris, contra multorum v fum eruditorum depromptum admiror.Vegetius, Inuentum eft remedium, per noctem fub fundamentis muri cuniculum fodi. Item alibi, Aliud genus expugnationis eft fubterraneum atø̧ fecretum, quod cuniculum vocant, à leporibus qui cauernas fub terris fodiunt, ibique conduntur. Sic \& Cæfar fcriptor elegantiffimus. De tertia vigilia animaduerfum eft aggeré fumare, quem cuniculo holtes fuccenderant. Sic Liưuis belli Macedonici lib.viil. Ibi commiffis operibus cum è foffa cuniculum patèret iter. Sic Curtius, Vlirima peftis vrbis fuit cuniculo fubruptus murus, per cuius ruinas hoftis intrauit: $Q d^{3}$ $v t$ nequeat; A pollonia nobilis quondam ciuitas documento nobis fit. Nam cum ingentiadmodum obfideretur exercitu, \& cuniculis milites minus ambigerent intra monia penetrare, id cum A polloniatibus per fpeculatores denúciatü effet, eiufmodi nuncio perturbati, confternatióp funt omnes, quòd nec tempus nec locum fcire pofle videbätur, quo emerfuri forêt hoftes: tunc verò Try pho Alexan 
drinus qui ibi fuerat ingenio fummo intra murum plures fpecus defignauit, 82 fodiendo terram, progrediebatur extra murum dútaxat per fagittæ emiffionem, $\&$ in omnibus vafa æenea fufpendit; ex his in vna foffura qua contra hoftü fpe-, cus fuerat vafa pendentia a d plagas ferramentorum fonare coperunt, ita ex eo tumultu intellectum eft, qua vrbis parte aduerfarii cuniculos agentes intrà penetrare cogitabant, fic liniatione cognita temperauit ænea feruentis aquæ $\&$ picis, defuper \& ftercoris humani \& arenæ coctæ candêtis, deinde noctu pertudit crebra foramina, \& per ea repente perfundendo qui in eo opere fuerunt holtes onnes necauit. Maffilienfes fimili modo per cuniculos obfeffi cum numero fupra triginta fpeculatum mifffent, ab his co percepto loco quo cuniculi agebantur, intra muru m baratrum amplifima longitudine $\&$ amplitudine vti pifcinam fe cerunt,eamóp è puteis \& è portu impleuerunt, ita cum fpecus effet repente naribus apercis, vehemens aque vis immiffa fupplâtauit fulturas, quíg intra fuerant $\&$ ab aqux multitudine \& à ruina fpecus funt oppreffi. Ambrachienfes pauidi ne eciam fubrutis muris facta in vrbem via per cuniculú effet, filentio facto pluribus locis aure ad mota fonitum fodientium captabant, quem vbi acceperunt aperuere reçam in cuniculü viań, nouáque haud magni operis aduerfus hoftes qui in cuniculo erant excogitata res eft. Doliú enim ferreum à fundo pertufum quo fiftula modica \& ferrea inferi poffet,operculúm pluribus locis perforatum fecerunt, tenúque pluma completum ore in cuniculum verfo poluerunt per oculique foramina prelongæ haftæa ad fubmouendos hoftes eminebant, fcintillam leuam ignis plumæ inditam folle fabrili ad caput fiftule impofito flando accenderunt, inde non folum magna vis fumi, fed acrior ctiam foed o quodam odore ex adufta pluma cum totum cuniculum adimplef fent, haud durare confinterég quifquam intus potuerat.

Forficem ordinationem militarem vocant cunco oppofitam, nam ex lectiffi. mis militibus in . $v$. literam ordo cóponit, \& illum cuneum excipit atọ ex vtraque parte concludit, frons dicła quòd aduerfus hoftes fectat, hæc in pugna publica fi fapienter difponitur plurimum iuat: fi impertè quanquam optimi bellatores lunt mala ordinatione franguntur.

Serra pręliari dicitur cum aflidue acceditur receditúṭue neque vllo tempore confifticur, dictáo proinde ferra: hæc à ftrenuis direpta ante frontem opponitur holtibus, vt turbata acies reparetur.

Alx exercitus ordines qui circum legiones dextra finiftáque tanquam alæ in auium corporibus locabantur, $V_{t}$ lib.vi.de re militari a pud Cintium fcriptũ eft, Vir.iii.ænied.Dum trepidant alæ faltusóp indagine cingunt. Livius ab vrbe condita xxviii. Siniftra ala ab Romanis $\&$ cohotes qux admife rant figna in prima acie pugnabät, $\&$ funt alæ xxx. equites in exercitu, fint licet qui pluribus quàm xxx.equitibus alam côtitui cenfeant. Liuius ab vrbe cond. xxxviii. His ala mille fermè equitum, hoc gemmam vocapt.

Turma tefte Fefto \& Varrone quafi terna, e in v abiit,quód terni eqtes ex tribus tribubus Ticienfiü, Ramnenfiú \& Lucerú fiebant. R omani enim equites in vna tribu trecenti fuere. De fingul is enim céturiis decem dabantur, \& fiebat tur 
DE RE MILITARI LI B. IX. 189

ma, itaģ fi Pomponio credimus frngularú decuriarü decuriones dicti: quidám volunt, quorú eft Fronto decurionem effe turma, que conftat ex duobus \& xxx. equitibus . Cyaxares autem primus, Herodoto tefte, A fianos dicitur per turmas diuifffe: iufifféq fagittarios ab equitibus, aliólq ab aliis feorfum effe, antea cun permixti \& confufi effent.

Nodus propriè eft denfa peditum multitudo,ficut turma equitü, vt lectum eft in difciplina militari,fic dictus pro difficultate quòd vix poffit refolui.

Acus exercitus inftructio dicitur, quôd ea pars militum vehementiflima eft ad hoftem vulnerandum acumine telorum.

Acies exercitus inftructus dicta, quòd ferro armata fit, $\&$ acumine telorum.

Claffes equites dicebãtur, ob diuifionem exercitus, qui poftea Manipuli dicti, vel pro turmis equeftribus à quibufdam clafficis qua habent, vnde non ab reà nobili poéta dictú, Claffibus hic locus eft.Claffes etiam partes populi. Liuius pri mo ab vrde condita, Tum claffes centuriáfque $\&$ hunc ordinem ex cénfu de. fcripfit, vel paci decorum vel bello, ex his qui centum milia æris aut maiorem cen fum haberent.lxxx̀, fecit centurias quadragenas feniorum ac iuniorú:prima ${ }^{\circ}$ claffis omnes appellati, feniores ad vrbis cuftodiam vt prafto effent, iuuenes vt foris bella gererent. Claffici, vt inquit Gellius vii.noct. Atti. dicebantur non om nes qui in claffibus erant, fed prima tantum claffis homines, qui centum $\mathrm{xxv} \cdot \mathrm{mi}$ lia æris ampliffimè cenfi erant, infra claffem auté appellabantur, fecundæ claflis cæterarumóg hominum qui minore fumma æris quàm fupra dixi cenfebantur. Columella, claffes non maiotes quàm denum hominum faciunde, quas Decurie appellant antiqui. Quintilianus primo infti. Non inutilem fcio feruatum effe à præceptoribus meis morem, qui cum pueros in claffes diftribuerent,ordinem di cendi fecundum vires ingenii dabant. Claffes nauium poftea fubiere, vetuftiusq́g fuit, Pomp auctore, multitudinem hominú quàm nauiü claffem appellari: Diodoro enim tefte, ab ipfo orbis primordio animätia omnia effe generata,eodémque modo $\&$ homines à principio genitos dicunt, in agris paftum quærétés fyl ueftri \& incondita vita vixiffe, quibus herbæ $\&$ arborum fructus vltro victum praberent: belluas infuper his fuiffe infenfas, quibus vt obfifterent, claffes $\&$ cotus hominú ob timorem factos aiunt communis vilitatis gratia , auxiliáq inuicé prebita, \& loca habitaculis quęfita. Claffes clypeatas antiqui dixere, quas nunc Exercitus vocamus, claflis verô pcincta exercitus inftructus $\&$ paratus ad bellü maximè cú exercitus cinctus erat Gabino ritu fue cinctu, cófeftim pugnaturus.

Caftra pro exercitu tantum pluraliter. Liuius punici bellilib.v. Valerius Ancias vna caltra Magonis capta tradit. Idem in eodem, Exuitur caftris atque ita nocte ac die bina caftra hoftiũ oppugnata, bina proinde non duo caftra dixit. Idem lib.ix. Sed cum vna caftra in fines,altera in finitima terra Hetruria prope in confpectu habebant, caftra autem quafi cafta ob hoc dicta quód illic caftra retur libido. Quòd fr ab ea origine ortum traxerit,apud noftros inane nomé effe quis dubitat? Quotus enim inter hos homines inuenitur, qui pudorem pudicitis am caftitatemóp colat, qui non prorfus cupiditatibus cuncta irrideat atque contemnat?quotus qui non proftibulo congredi malit, quàm cum hofte manus con 
ferere? quotus qui non libentius de expugnanda adolefrétulorü pudicitia, de virginibus violandis, de vi inferenda ingenuis, de fuis ftupris, fceleribus, flagitiis fer monem conferat, quàm de hoftibus inuadendis, de excipied is vulneribus, de mor te pro dignitate a ppetenda, de ignominia fugienda, de gloria comparanda; de to lerantia,de patientia, \& de labore? Quòd fi quando forte cótigit,vt te, quifquis es lector, in horum hominum caltra vel potius luftra conferas, videbis ibi fuper leetulis non continétiffimos duces Fabricium, Aemilios, Scipiones, Hannibalem, Alexandrum, fed militares homines, \& eos qui cæteris dignitate excellunt, iuxta meretrices exoletas, fcorta, $\&$ pueros meritorios accubantes, mollifimimis verbis $\&$ flagitiofiffinis, \& ad concitandam Venerem nedum caftrandam accommodatis, inter fe colloquentes: $\mathrm{Vbi}$ autem calere iam res coeperit, hic alius ructet, $\&$ vo mat: mingat alius \& pedat: ibi luditur, hic bibitur, atog vt ex huiufmodi euenire folet fxpenumero rixa exorta eft. Nullus, vt funmatim reliqua cóplectar, pudor in eorú verbis,nulla in rebus temperantia, nulla religio, nulla modeftia,nullü con uiuio maiorú dignú filentiü, fed fumma obfconitas, blaf phemię, clamor,cöfufro, perturbatióp rerum omnium: quod veterum díciplina nefas quidem erat, aut delicatum, aut parú pudicum inferre fermonem, ibi nó modo verbis non abftinent turpibus, fed cętera etiam faciunt quę à verecüdo homine dici non poflunt.

Metari caftra diuidere, \& loca militibus in caftris affignare, vel ponere caftra, vel mutare. Lucanus in primo,

Audax Hefperios veniam metator in agros.

Taberne appellatio, VIpiano telte, declarat omnè vtile ad habitandum eqdifici um, non ex eo quòd tabulis claudatur, inde tabernacula \& contubernales. Tabernam etiam domicili genus antiquifimum Romanis fuifle, teftimonio funt exteræ gentes, quæ adhuc tabulatis habitant ædificiis: vnde etiam tecta caltrenfra, milicumóp tentoria quibus folis ardores tempeftatesóg imbriü, ac frigoris iniu. rias vitant, quàmuis pellibus tegerentur, tabernacula dicta funt. Liuius belli $\mathrm{Ma}$ cedonici lib.iii. Tabernaculum regium pro vallo in confpecto maximè tumulo $v$ terrorem hoft act. vii. Nam in ipfo aditu atg; ore portus, vbi primum ex alto finus ad vrbem ab littore inflectitur, tabernacula carbafeis intenta velis collocant.

Tentoria pro eo dicta, quòd tendantur funibus at $\$$ palis, vnde \& hodie prætendere dicitur vt olim. Ouidius in Heroi.

Illic Aeacides, illic tendebat Achilles.

Virgilius in primo æneidos, Nec procul hinc Refi niueis tentoria velis

Agnofcit lachrymas.

Papyliones tentoria dicuntur, auiculæ prouolantis fimilitudine. Helius Spar tianus in vita Seueri feptimi, Idem in omnium expeditione ante omnes milita* rem cibum fumplit ante papylionem. 


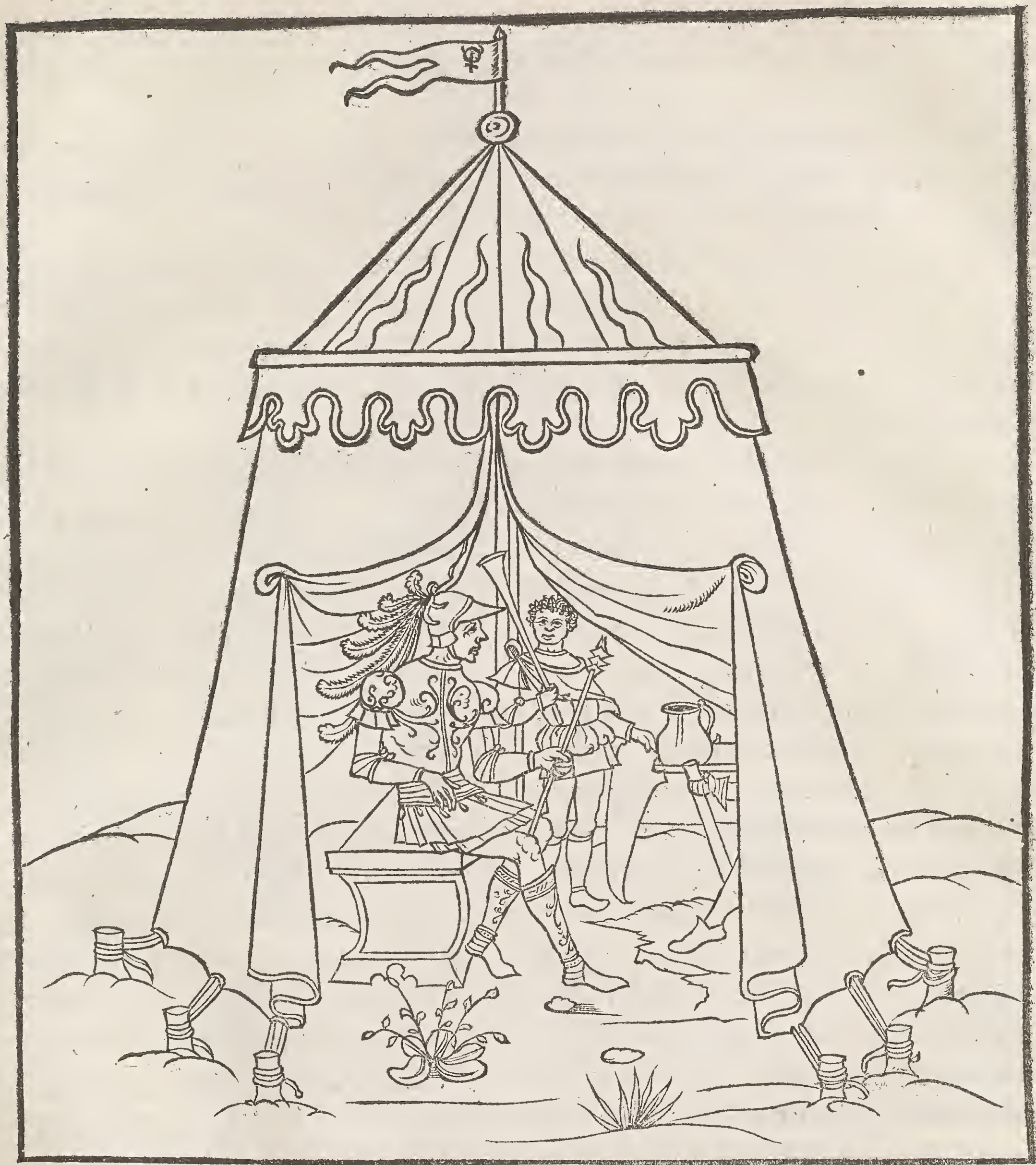

Hybernacula caftrenfia ad obfidionem potius quàm ad oppugnationem hy emando ædificia. Liuius libro quinto ab vrbe condita, Cum fpes maior imperatoribus Romanis in obfidione quam in expugnatione effet, hy bernacula et res noua militi romano ędificari coepta, cófliúg, erat hyemádo cótinuare beilä.

Impedimenta caftrenfem fupellectile dixere: impedire enim quafí irretire eft, $\&$ in pedicam trahere. Liuus vigefimonono, Interim Romani impedimentis quoq̧ omnibus traductis contractiş́́ in vnú locum, quia ia m moueri videbant hoftem, nec fpatium erat caftra communiendi, aciem inftruxerunt. Idem vigefimotertio, Lixæ caloneş́́ \& alia turba cuftodiæ impedimentorum oppofita.

Commeatus pro cibaris ad alimoniá reipublicx, aut exercitus, aut alicuius multitudinis commeantis dicimus. Liuius trigefjmolexto ab vrbe cỏdita, $\mathrm{Cúm}$ exercitibus cómeatus quog omnis generis ex A fía venturos in præfentia curæ effe Aetolis debere, vt copia frumenti fuis \& annona tolerabilis rerum aliarum fuppeditentur.Cómeatus priuatim etiam dicitur. Cicero prolege Manilia, Iam cómeatu $\&$ priuato $\&$ publico prohibemur. Ab imperatore etiam militibu 
commeatus dari dicitur, id eft, tempus quo ire \& redire commodè poflint, vel facultas ad tempus à militia recedendi eundique quò velint,ad pręfcriptum diem reuerfuri.

Munimenta munitiones funt caftrorum cæterarúmọ rèrum quæ contra aduentum hoftium muniunt, fiue vallo \& foffa, fiue alio quouis modo quo fint milites $a b$ hoftium, vt dixi, a duentu vel incurfu muniti.

Monumenta i mutata in $\mathrm{v} \& \mathrm{v}$ in $\mathrm{o}$, fepulchra, ttatuæ, tituli,libri,cæterápque nos alicuius rei præterita moneant recordari : nam quòd de futuro quidam volunt ideo fepulchra appellari monumenta, quòd noftrx mortis moneant fallum arbitror : in honoren enim mortui illa tantummodo fiunt, non in publicam praceptionem.

Athleta vir fortis venatórque qui perũcta corporis flexibilitate cú beftia dentata luctatur, vt motibus fuis fpectantibus placeat, \& fanguine fuo voluptatem populo præftet. Liuius belli punici lib.xî. A thletarú quo certamé tum primo Romanis fpectaculo fuit, $\&$ venatio data leonum \& pätherarum, \& prope huius faculi copia ac varietate ludicrum celebratum eft. Sabinusautem \& Caffius $\&$ generaliter omnes, artem ludicram non facere A thletas opinantur. Horum fpectaculum fabricis tam clarum \& actione tan tetrum, in honorem Scythice Di anx qux languinis effufione gaudebat, ab Athenierfibus repertum eft,damnofa profecto publicè priuatimgue nocens delectatio, quod facile colligi poteft fi in mentem venerit ex hiftoriis rei huius initium progreflufque, apud noftros quáto publici cenfus impendio, quantáque infania proxima dictu cura, quâto demum populi ftudio, plaufu ac labore conftiterit, tot milibus fimul gladiatorum paribus,tanto elephãtorum precio, tigrydum'śp \& leonum ac pardorum gregibus, onagrorum quog, equorum ferocium atọ a nimaliü dinerfi generis è toto orbe terrarum omnium tranfmiffis, fyluis omniumque gentium venatibus romano famulantibus theatro: adde illam ædificandi luxuriem cunctas terra pelagóque marmoreas columnas in ludorum vfum $\&$ artificum fummis ingeniis expolitas, cuius princeps infaniz haud conticendus eft Scaurus is qui adilis in theatri fcanam opus dierum paucorú, \& quod paucis lignis ac funibus attolli poterat, fuffecurü oculis populi talibus gaudentis, trecentarú fexaginta talium monftra columnarum intulit, fecitóp opus, vt friptum eft, maximum omnium quæ vnä fuere humana manu facta. Curioné quoç ex fuperioris æui monumentis accepimus, qui ciuili bello pro Cæfaris partibus in Aphrica occubuit, vt Scaurum quem opibus equare non poterat fuperarit ingenio; non marmoreum vt ille, fed ligneum theatrum, duplex tamen ac penfile meditatus, populum victorem gentium, ludis victum \& periculis plaudentem fuis mira arte fufpendit, vt ridentes interius ftupentésque ipfi exercitus fpectatoribus rifui fierent \& ftupori . Iam inde ab exordio primus regum noftrorum Romulus fuit, omnem qui in his rigidam, tetricamóp illam Sabinorum pudicitiam circumuenit, inde porrò Titi potentia, principali diuitiarum perfufo flumine cogitauit ædificium fieri,vnde caput vrbium cerni potuiffet, cum theatrum quiod eft hemifpharium gracè di-

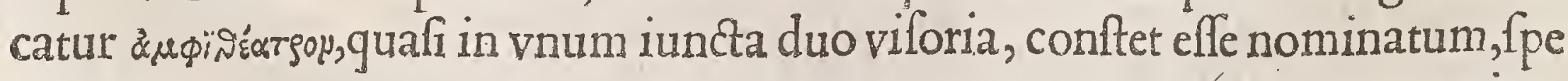


ciem eius area concludens, vt $\&$ currentibus aptum daretur fpatium, \& fpectantes omnia facilius intuerentur, dum quadam prolixa rotunditas vniner la colligeret : qux autem latini certamina, Agones alii vocant, a b à quod fine fonat 8 revíx angulus, quia, vt Fefto placet, locus in quo huiufmodi ioci facti funt fine an gulo fint. A li aliter atog aliter dici putant. Ouidius primo faftorum,

Nominis effe poteft fuccinctus caufa minifter,

Holtia celitibus quo feriente cadit.

Qui calido ftrictos tincturus fanguine cultros,

Semper agat ne roget, nec nifi tuffus agat.

Pars quia non veniant pecudes, fed aguntur $\mathrm{ab}$ actur

Nomen agonalem credit habcre diem.

Pars putat hocteftum prifcis agonalia dictum,

Vna fit vt proprio littera dempta loco.

An quia præuifos in aqua videt holtia cultros,

An pecoris lux eft ipfa notata metu.

Fas etiam fieri folitis ætate priorum

Nomina de ludis græca tulife diem:

Et prius antiquus dicebat agonia fermo,

Veráque iudicio eft vltima caufa meo.

Beliona Martis foror \& bellorum dea cui proprio fanguine facerdotes facrifi cabant, Lactantius atç Lucanus teftes funt,tunc quo fectis Bellona lacertis frua mouet cecinere deos : $\&$ eft dicta à bello Bellona, quæ nunc duellona à duello vt inquit Varro.

Minerua virtutum præful quam principem $\&$ inuentricem belli ferunt, dicta quòd bene moneat: hanc enim pagani pro lapientia ponebant. Cornificius verò quòd figuretur pingatúrq̣ minitans armis eandem dictam putat, galeatá enim haftam tenet $\&$ clypeum: alii nónulli vel quòd minueret vel minueretur dictam putant:quamobrem eadem Capta fiue capita dicta fit, incertum elt. Varige enim funt huius nominis caufre. Ouidius tertio faftorum,

Cælius ex alto qua mons defcendat in eqqum,

Hic vbi non plana eft fed propè plana via eft.

Parua licet videas Captæ delubra Mineruę,

Quar dea natali coepit habere fuo.

Nominis in dubio caufa eft, Capitale vocamus

Ingenium folers,ingeniofa dea eft,

An quia de capitis fertur fine matre paterni,

Verrice cum clypeo profliiffe fuo?

Aut quia per donitis ad nos captiua Falificis

Venit 8 hoc fignofyllaba prima docet:

Aut quòd habent legem capitis qux pendere poenas

Exilio iubeat furta reperta fuo.

A quacunque trahas ratione vocabula, Pallas

Pro ducibus noftris ægida femper habet. 
Hæc cadem \& tritonia dićta eft, quòd téporibus Ogygis ad lacú vel ripam Tritonis fluminis in virginali fertur apparuiffe habitu.

Pallas autem fecundum Victorinum à Pallene infula Thracix, vel à gigante quem occidit dicta eft: \& fanè duo hæc Antonomafia fine proprio funt nomine nonnunquam à poëtis prolata. Virgi.ii.æneid. Tritonia refpice Pallas Infedit nymbo effulgens \& Gorgone frua.

Mars ab eo quod maribus praeft in bello,ve Varroni placet, licet tria fint gənera confuetudinú, ficut apud I axamathas Tanais fluminis hoftio proximos, vbi eafdem artes foem inæ quas viri exercent, adeò vt ne militiæ quidem vacent: viri enim ped bus inhęrent, fagittífque depugnant: illæ equeftre pręlium ineunt, nec ferro dimicant, fed quos laqueis intercepere trahendo conficiunt : vel apud A mazones vbi fola fomina, vel a pud Romanos aliasóp gentes multas vbi foli mares dimicant : vel Mars dictus quòd Sabinis arreptus vbi \& Mamers idé eft ofca lingua quod Mars: etenim cum fruit, gradiuus dicitur: cum tráquillus eft, dicitur effe Quirinus. Huius in vrbe duo erant templa, vnum Quirini intra vrbem quafi cultodis, id eft, tranquilli:alterú in Appia via extra vrbem propè portam, quafi bellatoris, id eft, gradiui: in bello enim gradum inferunt qui pugnant, aut impigrè gradiuntur. Ac ficut Epaminūdas B cotium agrum Martis Orche Aram, \& Xenophon Ephefum belli officinam appellat, fic Romani tunc bellige ri templum Mart is quem ferocifimum omnes deum \& armigerum dicunt, \& ob id bellis armiś́ pręeffe, hunc \& Liberú vnú eundemíg demú arbitrãtur nonnulli, Romaníg vtrunque patris appellatione venerantur : alterú Liberum patrem, alterü Marfpitrem, id eft, Martë patrem cognominantes. Hinc etiam Liber pater bellorum potens probatur, quòd eum primum edidenút auctorem trium phi: hoc etiam apud Lacedęmonios fimulachrú eius hafta infigne non thyrfo demonftrat, fed cum thyrfum tenet quid aliud g latens telum gerit, cuius mucro hædera lambente protegitur? quod oftendit vinculo quodam patientix obli gand os impetus belli. Habet etiam hædera vinciendi obligandíque naturam, nec non $\&$ calor vini cuius Liber pater eft auctor, homines ad furorem bellicum vque propellit: propter cognatum ergo vtriufque effectus calorem, Martem ac Liberum vnum eundem' $\not$ deum effe voluerunt.

Mauors figuratū eft vt induperator, auçore Seruio in cómento primi ænei: $a b$ aliis quòd magna vertat fic dictus.

Gradiuus mars frue mauors dictus eft, à gradiendo, co quòd in bello gradum inferant qui pugnant,aut impigrè gradiâtur: vel à gradiédo in bella vltro citróg, fue $a b$ vibratione haftę qd' Grecci dicüt upas céva: vel ut alii, qa gramine fit ortus, qd' interpretant quia corona graminea in re militari maxime eft honorationis.

Feretrius iupiter dictuseft à ferendo, quòd pacem ferre putaretur, ex cuius templo fumebant fceptrum per quod iurarent, $\&$ lapidem flicem quo foedus ferirent. Alii cum Acron Cecinenfium rex à Romulo victus \& infefto telo traiectus effet, eiuśq́ fpolia, Toui votis nuncupatis, Ronuulus ad vrbem reuerfus dica ret, hoc tropheun Ioui ftatutum cognomen deo addidit feretrio loui a feriendo hoftem:eft $\&$ à ferendo vt antè diximus. Propertius, 
Nunc fpolia in templo tua condita caufa Feretri

Omine quòd certo dux ferit enfe ducem.

Seu quis victa fuis humeris hæc arnia ferebat,

Hinc feretri dicta eft ara fuperba Iouis.

lanus faciendis foederibus præelt. Nam poltquam Romulus \&, T. Tatius in foedera conuenerunt, Iano fimulachrum duplicis frontis effectum eft, quafi ad imaginem duorum fopulorum. Ganius Baffus in eo libro quem de dïis compa fuir, lanú bifrontë fingi ait, qualı fuperü atọ inferum ianitorem.

Ouidius in faltis,

Quicquid vbiog vides, colum, mare, nubila, terras,

Omnia funt claufa noftra patentóp manu.

Me penes eft vnum vafti cuftodia mundi,

Et ius yertendi cardinis omne meum.

Omnis habet geminas hinc atop hinc ianua frontěs,

Equibus hæc populum fpectat \& ille larem.

V tóp ledet vefter primi quoọ limina tecti,

lanitor egreffus introitusíg videt.

Sic ego profpicio coleftis ianitor aulx,

Eoas partes hefperiasóp fimul.

Eundem quadrifrótem legimus, quafi uniuerfa climata maieftate complexum:

Nec mirunx fanè apud aliquos bifrontem, quadrifrontem apud alios ellé : nan alii prater hæc eum dici deum volunt, in quo ortus eft \& occafus. Horatius, Matutine pater, feu lane libentius audis.

Alii anni totius deum, quem in quatuor tempora conftat effe diuifum:anniaus tem effe deú illa res probat, quòd ab eo prima pars anni nunc nominatur: Hunc chaos, Patulicum \& Claufum eriam appellauit antiquitas. Ouidius in faftis, Me chaos antiqui,nam fum res prifca,vocabant.

Nomina ridebis modo nanque Patulicus, idem

Et modo facrifico Claufius ore vocor.

Horum duorum nominum ratio hre eft, quia bello valux eius patent, pace clau dütur. Huius etiä rei hęc caufa narratur, cú bello Sabino quod virginü raptarü gratia commiffum eft, Romani portam qux fub radicibus collis viminalis erat, qux poftea ex euentu lanualis vocata eft, claudere feftinarent quia in ipfam hoftes irruebant, poftquá eft claufa mox fponte patefacta eft: cumíģ iterú ac tertio idem contigiffet, arnati plurimı prolimine quia claudere néquibât cuftodes fteterunt,cumó ex alia parte acerrimo prælio certaretur, fubito fama pertulit fufos à Tatio Romanos,quan ob caufam qui aditum tuebantur territi profugerunt, cum'q́ Sabini per portam patentem irrupturi effent,fertur ex æde lani per hanc portam magnam vim torrentium vndis fcatentibus erupiffe, multáfque per duellum cateruas aut exuras feruenti, aut deuoratas rapida voragine deperiffe: ea re placitum vt belli tempore velut ad vrbis auxilium profecto deo, fores referarentur. Ianualis porta ve aii perhibent ab Jano dicta, ideóque ibi fofrum iam fignum, \& ius inftitutum à Pompilio, vt fcribit in annalibus Pifo, 
vt fit aperta femper, nif cum bellum fit: nufquam tamen traditum eft memoric, vt inquit Varro, Pompilio regefuiffe apertam, fed poft eius regnum, tefte Liuio, T.Manlio cof. bello Carthaginéfi primo cófecto, bello ité Actiaco finito ab im peratore Cxfare augufto, pace terra maríque parta. Hunc auté apud nos lanum. omnibus præeffe ianuis nomen oftendit:quod eft verifimile, nam \& cum claui \& virga figuratur, quafi \& rector viarum \& omnium portarum cuftos: belli licet geminæ fint. Virgilius in primo æneid.

Sunt geminx portx belli fic nomine dicunt

Relligione facra \& frui formidine Martis.

Centum ærei claudunt vectes æternáque ferri

Robora, nec cuftos abfiftit limine Ianus.

Has vbi certa fedit patribus fententia pugna,

Ipfe quirinali trabea cinctúque gabino

Infignis referat ftridentia limina conful,

Ipfe vocat pugnas, fequitur tum catera pubes,

Aereaque affenfu confpirant cornua rauco.

Hæc \& tum æneadis indicere bella Latinis

More videbatur triftesóp recludere portas.

Pactum à pactione dictum auctore Vlpiano, inde \& pacis nomen appellatum eft : fed eft pactum duorum cófenfus a tọ conuentio, pactio verò duorum pluriúmve in vnum placitum atọ confenfus. Liuius libro fexto ab vrbe condita, $\mathrm{Cu}$ ius fipei moram pati cum fortuna obfefforum non potuiffet, confectáque pauciras oppidanorü, opere, vigiliis, vulneribúfog femper eofdẽ vrgebat, per pactionem vrbe boltibus tradita, inermes cum fingulis emiffi veftimentis, miferabili agmine penates reliquerant.

Pax fignificationis notam habet.

Pars mihi pacis erat dextram tetigiffe tyráni. Pax venia, Idem in iii.æne. Sed votis precibusóp iubent expofcere pacem.

Pax propiciatio.Idem in eodem, Exorant pacem diuúm. Pax beniuolétia.Idem in iii. Paceñog per aras exquirunt. Pax quog tefte Prifciano lib.v.tam fingulariter quàm pluraliter prolata idem poteft fignificare, fed pluraliter non vtimur, quia auctoritas deficit : quod à grammaticorú principe dictum non parum admiror, maximè cum a pud nonnullos \& quidem probatos \& fumma auctoritate praacellentes latina lingua viros, pluraliter prolatú inueniam.L ucretius rerum naturalium libro quinto, Ventorum pauidis paces animasóp fecundas.

Varro de vita patrú lib.iii. Animaduertendú primú quibus de caufis \& quéad. modú conftituerunt paces, fecundú qua fide $\&$ iufticia eas coluerint. Hor.i.epi. Bella queis $\&$ paces longum diffudit in æuum. Idem lib.ii.

Hoc paces habuere bonæ ventique fecundi.

Hoc de pacis vocabulo et cius vfu dictum fatis fit imprefentiarum. Effectus au tem funt,vt in ea populi proficiant,vtilitas gentiü cuftodiatur:vt hae bonarem artiú decora fit mater, hęc eadẻ mortaliü genus reparabili fucceffione multiplicans,facultates ptendat, mores excolat, tätum go boni in fe cötineat vt terrenis in 
rebas nihil gratius foleat concupifci,nihil defiderabilius, nihil poft remò melius poflit inueniri : proinde non ab re poft triumphos \& Romani imperii firmiffimum tatum, D. Vefpafianus tranquillitatis, pacis \& concordix templum ędificare decreuit, in quo ea diuitiarum largitate vfus vt omnia in illud phanum collecta effent, quorũ vifendorú ftudio per orbé totú $q$ ante eú fuerant vagabantur.

Foedus lex, nonnunquam pax quæ fit inter diffidentes, fic dictum vel $q$ inter foedera interponatur fides:vnde $V$ arro, Per hos etiam núc fit foed us quafi fidus. Ennius fcribit dictum in re militari vel à foccialibus, id eft, facerdotibus per quios fiunt foedera, vel ab hyrco vel hoedo, filitera addita quod veteres in graui fignificatione ponebant,vt, Sanguine foedantem quos ipfe facrauerat ignes: vel à porca foede \& crudeliter occifa lapidibus, cuius mors optabatur ei qui à pace refiliffet: vnde poétarum doctiflimus:

Pòft inter fele polito certamine reges

Armati louis ante aram paterasóg tenentes,

Stabant \& cæa iungebant foedera porca.

Arabum in huiufmodi iungendis foederibus non porcam fed interiore manus

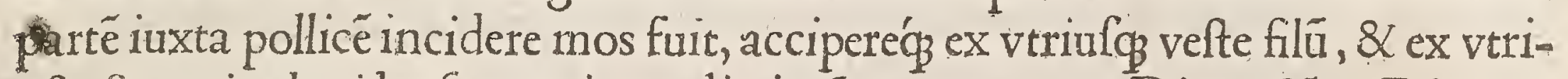

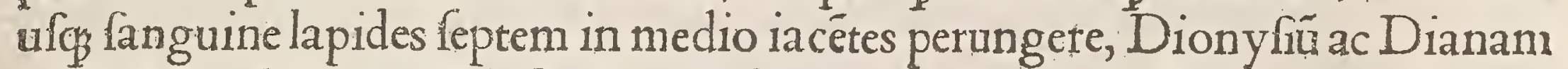
inuocantes, hisćp peractis denique hof pites eos vel amicos nuntiare. Scythæ \& Lydi in huiufmodi fimiliter, Herodoto tefte, fe fauciant hauftúque mutuo fanguinis foedus fülciunt, non fuo tantú more fed. Mod orum quoqu v furpata difci plina: belloenim quod geftú eft anno polt llion captú fexcentefimoquarto inter Illyricem Lydum \& Aftiagem Medię regem, hoc pacto confirmata funt foedera. Romanis autem cum Aetolis his legibus foedus ictum eft, Imperium maieftatémque populi romani genus Aetolorú conferuato fine dolo malo, ne quem exercitum qui aduerfus focios a micófque corum ducet per fines fuos tranfire frnito, néve vlla ope iuuato, holtes eofdè habeto quos populus Ro. armáq in eos ferto, bellum'q pariter gerito, perfugas fugitiuos, captiuos red dito romanis fociifque, praterg̈ fiqui capti cú domos rediiffent iterú capti funt, aut fiqui eo tëpore ex his capti funt qui tũ hoftes erant Romanis cũ inter præfidia romana Aetoli effent:aliorú qui cóparebüt intra dies centũ Corcy ræeorú magiftratibus fine dolo malo tradâtur. Qui non cóparebüt, quando quifọ primus eorú inuétus erit reddatur. Obfides $x$ l.arbitratu cófulis romani dato, ne minores duodecim annorum neu maiores $x \mathrm{l}$. Obfes ne efto prætor, præfectus equitú, fcriba publicus, neur quis qui antè obfes fuerit apud Romanos. Cephalania extra pacis leges efto. De pecunia fumma quam péderent penfionibusóg eius nịil ex eo quod cú confule cóuenerat mutatü: pro argento fi aurú dare mällent, dare couenit:dü pro argenteis decê, a ureus vnus valeret. Quæ vrbes, qui agri,qui homines Aetolorü iuris aliquád do fuerüt, qui eorú, T.Quintio, Cn. Domitio coff. pòłt eos coff.aut armis fubacti, aut volútate in ditioné populi ro.venerưt, ne qua eorũ A etoli recepiffét vel in Aetolia decê vrbes agrosó, A carnanú funto. Alia etiã infigni foederis for ma, auctore Liuio,ex decé legatorú fentêtia in hac verba cú Antiocho cófcripta eft, Amicitia Regi cü populo Romano his legibus \& cỏditionibus efto, ne quem 
exercitum qui củ populo Romano focísve bellü gefturus erit Rex p fines regni, corúmve qui fub ditione eius erunt tranfire finito, ne cómeatu, neu qua alia ope iuuato.Idem Romani focíque Antiocho \& his qui fub imperio eius erunt pre Itent, belli gerendi ius Antiocho ne efto cum illis qui infulas colunt,néve in Eu ropã tranfeúdi gratia exced ito vrbibus, agris,vicis, caftellis. Cis Taurü montem vlog ad Tanaim amnê, et à valle Taurivi qua arma efferto: ex his oppidis,agris, caftelliśs q gus excedat,fi qua extulit; quax quóg oportebit reçe reftituito, nec militể neu quẽ aliú ex regno Eumenis recipi to, fi qui earú vrbiú ciuéf̧ abfcedút reg no cú rege Antiocho vltrà ä fines regni eius funt, A pameã omnes ante diē certã redeant: qex regno Antiochi apudRo manos fociólque funt, his ius abeundi manendíque efto, feruos fugitiuos, feu bel lo captos, feu quis liber, captus, aut tranffuga erit reddito. Romanis focífop elephantos tradito omnes, neque alios parato: tradito \& naues longas armamentá que earum, neu plures quàm decem naues, nec vllam qua plus quàm triginta remis agatur habeto,néve minorem ea: belli caufa quod iple illaturus erit,ne naui gato citra Calicandrum, neu Sarpidonium promontoria, extra qua fi qua nauis pecuniam, ftipendium, aut legatos, aut obfides portabit, milites mercede con ducendi ex his gentibus qua fub ditione populi Ro. funt Antiocho regi ius ne efto, ne voluntarios quidé recipiendi, \& $R$ hodiorum fociorúmve quæ ædes ædi ficiáque intra fines regni Antiochi funt, quo iure ante bellum fuerüt, co $R$ hodi orum fociorúmve finito: fi que pecunie debentur, carum exactio efto: fi quid ablatum eft, id conquirendi,cognofcendi, repetendíque jdem ius efto: fi quas vrbes quas tradi oportet hi tenent quibus Antiochus dedit, et ex bis prefidia deducito vtíque recte tradantur curato, argenti probi talenta attica xii. milia dato intra duodecim annos péfionibus equis, talentú néve minus pódo lxxx. Romanis pöderibus pédat, \& triticixl.milia modiûm Eumeni regi,taléta cçclintra quin quennium dato, \& pro frumento quod aftimatione fit, talenta cxxvii, obfides ro manis xx. dato, \& triennio mutato, ne minores oftodenúm annoxim, neu maiores quàm quadragenúm: fi qui fociorum populi Romani vltro bellum inferrent Antiocho,vim vi arcendi ius efto, dum ne quam vrbem aut belli iure teneat, aut in a micitiá accipiat: controuerfias inter fe iure ac iudicio difceptét: aut fr vtrifop placebi, bello: de Hannibale Pono \& Aetolo, Thoante, \& Miluna, Sy mmacho,\& Acarnane,\& Chalcidérbus Eubolida \& Philippomene dedendis, in hoc quoque foedere confcriptum eft, ve fi quid poltea add i immutarive placuiffet, vt id laluo foedere fieret. Effe etiam tria foederum gênera quibus integrè pacifcerentur anicitias ciuitates regéfque, apud probatiflimos auctores inuenio. Vnum cum bello yictis dicerentur leges: vbi enim onnia ei gui armis plus pof fet dedita effent, que ex his habere victor quibúfo̧ mulctari cos velit, ipfius ius atque arbitrium effe. Alterum cum pares bello equo foedere in pacem atque amici tiam yenirent: tunc enim repeti reddíg per conuentionem res, \& fi quarum tur bata bello poffeffio fit, eas aut iuris antiqui, aut partis vtriufque commodo componi. Tertium eft genus cum qui nunquàm hoftes fuerint ad amicitiam facciali fodere integrè iungendã coéant, os neque dicere, neque accipere leges, id enim victoris 
victoris \& victi efle : \& quanquam auctore Liuio, nulla vetuftior foederis memo ria fit, quàm eius quod inter Albanos Romanófque ictum eft, Thefeun tamen primo foedera inueniffe. vi.natur hiftor lib.teftis eft Plinius.

Sancta propriè dicimus auctore VIpiano qua nec facra neç prophana funt, fed fanctione quadam funt confirmata, vt fanctx leges, fanctione enim quadam fubnixx funt : quod enim tanctione quadam fubnixum eft, id fanctum eft, etfi deo non fit confecratum.

Sanctum, tefte Martiano, eft quod ab iniuria hominum defenfum atque mu nitum eft. Liuius belli maced. lib.ix. Iam ne à legatis quidem qui iure gentium fancti funt violandis abltinere infidias pofitas eundi ad T. Quintium: fanctum autem dictum eft à fanguinibus.

Sagmina autem dicebant her bas verbenas quexex loco fancto carpebantur, legatis proficifcentibus ad foedus faciendum, bellumíg indicendum. Liuius lib. - i. ab vrbe cond. Iubente rege, fagmina, inquir, te rex pofco. R ex ait, purä tollito: focialis ex arce graminis herba puram attulit. Idem belli punicilib.x. Fociales cum in Aphricam ad foedus feriendum ire iuberentur, ipfis poftulantrbus fena tus confultum in hæc verba factum eft, vt primos lapides filiquos primaśg ver benas fecum ferrent, vt vti Po. Ro.his imperatet ita fudus tei irent: illi prætorem fagmina pofcerent, herbæid genus ex arce fumptum dari foecialibus fo'et. Has etiam herbas legati Po.Ro. lolebant ferre,vt ab his defenf atque muniti ef fent, ne quis eos violaret: ficut legati Gręcorú ca fierebant quę Ceritia vocabãtur.

Obfides a b obfidio, quia propriè ab obfeffis dantur : vel oblides pro obfides, quòd ob fidem patrix praftandã dantur, tefte Fefto. Vasidem quod obles à va do dictus, quia dato vade licet abire $\&$ vadere $:$ inde vadatus dicitur obftrictus vel fub fider iufione ambulans, ficut Feneftella ait, Penes quem vadatus amicitix nodulo tenebatur.

Hoftis apud antiquos peregrinus dicebatur, \& qui nüc hoftis perduellio. Var ro, Hoftis antè eo verbo dicebãt pereg rinum qui luis legibus vterentur: nǘc dicunt eum quem tunc dicebät perduellem. Cicer o primo officiorum, Ex quoictiam illud animaduerto $q$ qui proprio nomine perduellis effet, is hoft is vocaretur, verbi lenitate rei triftitiam mitigante: hoftis enim apud maiores noftros is dicebatur quem nunc peregrinum dicimus, indicant duodecim tabula, aut ftatutus dies cum bofte, itemg aduerfus hoftem xterna auctoritas, guid ad hane manfuetudinem addi potelt, eum quo cum bellum geras, tam molli nomine ap pellare?quanquam id nomé durius efficit iam vetuftas: à peregrino enim receffit, \& propriè in co qui arma contrà ferret remanfit. Caius de verborum fignifica tione, Quos nos, inquit, holtes apfellamus cos veteres perduelliones apfella bát, per eam adiectionem indicantes cum quibus eflet bellum. Vlpianus vero vbiad legem Iuliam maieftatis, Plane quifquis, inquit, lege Iulia maieftatis reus eft, ho fili animo aduerfum rempub, vel principem animatus eft: hoftes etiam dicun tur $\&$ funt qui nobis, aut quibus nos publicé bellü decretimus, cæteri prædones aut latrones appellantur. Hoftire æquare eft, hoftimentum aquanicntum, vnde $\&$ hoftes dicti funt quia ex æqua caufa pugnam adeunt.

Hecatombe 
Hecatombe Iul. capitol.tefte, Sacrificium eiufmodi eft, Centum arę vno loco cefpititie extruntur, $\&$ ad eas centum fues centumóp aues mactabantur.Iam $\&$ imperatorum facrificium fit, centum boues, centum aquilæ, fi cetera huiufmodi animalia centena feriuntur, quod quidem etiam Græci quondan feciffe dicuntur cum peftilentia laborarent.

Hoftix facrificia dicutur qux antè $a b$ his fiunt qui in hoftem pergunt, dicta ab eo quòd \& hoftire elt ferire. Harum gratia Trebatius lib.i. de religionibus docet effe duo, alterum in quo voluntas dei per exta difquiritur, alterum in quo fola anima deo facratur, vnde $\&$ arufpices animales hoftias vocant, vtrunq ho. ftiarum genus diuino carmine fuo Virgil. oftendit, \& primò quidem id quo vo luntas numinum per exta monftratur, Mactat, inquit, lectas de more bidentes: \& mox,pecudumóp reclufs Peçtoribus inhians fpirantia confulit exta. Alterum id eft, in quo hoftra animalis dicitur quo his tantú anima facratur oftendit, cum facit Entellum victorem Erici mactare taurum, Nam vt exploret animalis ho. ftix caufas, ip fo vfus eft nomine, Häc tibi Erix meliorem animá pro morte $\mathrm{Da}$ retis, \& ve nücupata vota fignificaret, ait, perfoluo, quod de voto propriè dicitur: víģ oftenderet perfolutú diis, frg nificauit dicens, Sternitur, exanimifó tremens procumbic humi bos. Idem circa hoftiam animalem, Sanguine placaftis ventos \& virgine cafa Cum primum Iliacas Danai veniftis ad oras, Sanguine querendi redıtus animáque litandum argolica. Nam cum animam, id eft, holtię nomen pofuit, \& licare, fignificat facrificio facto placaffe numen.

Victim verò facrificia qux poft victoriam fune dictx funt, vel quòd vincta ad aras ducebantur, vel quòd ictu percuflæ victriciog dextra cadebant: de hoc, fu periorég voca bulo licenter plerúg cöfidit auctoritas. Ouidius primo faftorum, Victima quę dextra cecidit vicunice vocatur, Hoft ibus à domitis holtia nomẽ ha bet. De altero tantum. Liuius ab vrbe códita xxii, Donec infuper eques cui $\mathrm{Du}$ cario nomen erat faciég nofcitans cófule, inquit, Hic êt cú popularibus fuis qui legiones noftras cecidit, agróqque $\&$ vrbem eft depopulatus: iam égo hanc victimath manibus peremptorum foede ciuium dabo.

Poftliminium Scruola.P. filius iunctum effe putat verbú, $v t$ fit in eo \& poft \&limen, vt qua à nobis aliena funt cum ad hoftem peruenerint, 8 ex fuo tang limine exierint hinc cü redierint, pòtt ad idé limé poftliminio redilfé videantur.

Præda tefte Varrone ab hoftibus capta, quòd manu capta,dicta quafi parida.

Manubir, vt $Q_{i}$ A fconio Pediano placet, funt preda imperatoris pro portione de hoftibus capta: manubias autem à præda, vt in libris rerum verborumq́ veterum fcriptum ef, in hoc diftare exiftimauerunt, vt fit prada ipfa rerum que captæ funt, Mianubiæ veró appellatæe fint non præda fed pecunia per quęftorem Po.Ro.ex præda vendita, contracta: per quæftorẽ autem, quod dictum eft,oportuit pręfectum ærarii fignificari, nã cura æraria à quęforibus ad pręfectos tranflata eft. Liuius ab vrbe cōd.xxxvi.P. Cornelius Scipio Galliã puintiá fortitus, priufquam ad bellum qtod cum Bois gerendum erat proficifceretur, poftulauit à fenatu vt pecunia fibi decerneretur ad ludos, quos prætor in Hifpa mia quum effet inter ipfum difcrimęn pugux vouifet, nouum $\&$ iniquum po- 
ftulare eft vifus. Cenfuerunt ergo quos ludos inconfulto fenatu ex fua vnius fen tentia vouiffet, $e$ os vt idem manubiis fi quam pecuniam ad id referuaffet vel fua ipfe impenfa faceret. Eft tamen nonnunquä inuenire ita fripfiffe quofdam non ignobiles fcriptores, vt aut temere aut incuriofe prędam pro manubiis, et manu bias pro pręda pofuerint:aut tropica quadä figura mutatione vocabuli fecerint, quod facere conceffum eft, fcitè id peritéóp facientibus: fed qui propriè atque Ǵgnatè locuti funt, ficuti plures, \& M. T.auctor diligentiffimus in oratione quam dixit de lege Agraria, manubias pecuniam dixerunt . In libris quoç Etrufcorum lectum eft iactus fulminum manubias dici. Manubies denique dicuntur ornamenta regum, vnde \& Petronius Arbiter, Tot regum manubies penes fugitiuum repertæ.

Refignatum æs dicitur militi,cum ob delictú aliqưod iuffu tribuni militum, neftipendium ei detur in tabulas refertur : fignare enim dicebant pro fcribere. Aerarii milites ab ære dicti, tefte Varrone, quòd ftipendia facerent: hinc up. fum ftipendium à tipe dictum, quòd xs quoque ftipem dicebant: $\&$ milites ftipendiarii ideo quòd eam ftipem pendebant. A b eo etiam Ennius, Poni ftipendia pendent: ftipem autem effe nummum fignatum teftimonio eft, 8 pro eo $\$$ datur in ftipendium militi, et quòd fpondetur pecunia, quod ftipulari dicitur.

Pecunia quam belli neruos effe rion dubium eft, vt inquit Cic.tefte Varrone dicta, quòd in pecore cum paftoribus confiftebat. Plinius natur.hif. xxxiii. Ser uius primus frgnauit æs, fignatúm que nota pecudum, vnde \& pecunia appellata.Caffr. li.vii.Pecunia á pecudis tergo nominata, Gallis auctoribus fine aliquo adhuc figno ad metalla tranfacta.

Aes alienum miles etiam habere dicitur, \& qui aureos debet, \& qui corinm forma publica pèrcuffum, quale apud Lacedæmonios fuit quod vfum numera. tx pecunia prętabat,vt de beneficis libro quinto in quit Seneca.

Denarii quafi deni, tefte Varrone, quòd denos æris valebät, ficut quinarii qui quinos. Victruuius Archi. lib.iii.Noftri autem primo fecerunt antiquum num mum, \& in denario denos æreos conftituerunt, \& ea re compofitio nominis ad hodiernum diem denarium retinet. Didymusautéà decima libella dictum putat.Plinius nat. hifto.xxxiii. Et placuit denarius pro decem libriseris, quinarius pro quinque, feftèrtium pro dipödio \& femiffe: libræa autem pondus ęris im mimutum bello Punico primo cum impenfis refpub.non fufficeret, conftitutumg vt affes feltario pondere ferirentur: ita quinta parte facta lucri,diffolutumg $x$ alienum. Nota aris fuit ex altera parte lanus geminus, ex altera roftrum nauis: in triente verò \& quadrante as, quadrans antè triuncis vocatus à tribus vnciis. Poftea Hannibale vrgente, Q. Fabio Maximo dictatore, affes vnciales facti,placuit'̣ denarium xvi affibus permutari, \& quinarium octonis, feftertium quaternis, ita respub. dimidium lucrata eft: in militari tamen ftipendio femper denarius pro decem affibus datus. Nota auté argenti fuerunt bigæ at $\not$ quadrig $x, \&$ inde bigati quadrigatió dicti:paulò pôft lege $P$ apyriana hemiüciales affes facti. Licinius Drufus in tribunatu plebis octauä partem ęris argento immícuit, qui nunc Victorianus appellatur, lege Clodia percuffus elt: antea enim hic numnus ex Illyrico 
ex Illyrico aduectus mercis lo co habebatur:eft autem fignatús victoria, 8 inde nomen Aureus nummus poft annum fexagefimumfecundum argenteus, aucto re incerto, percuflus elt, $q$ anno vrbis quingentifimo octuagefimoquinto; $Q$.Fa bio col. quinque annis ante bellum punicum fignatus eft, éque $P o$. Ro.ne quidem ante Pyrrhum regem deuictum vfus fertur fuifle. Etiam aurei nummi, \& argentei, \& $x$ rei apud alias gétes vfum $\&$ originé $L$ ucanus his verbis expreffit. Primus Theffaliz rector telluris Ionis

In formam calide percuffit pondera maffx,

Fudit $\&$ argentum flammis aurúmque moneta

Fregit, \& immenfis coxit forracibus æra.

Numimus, non à numero, nec à Numa Pomp.dictus, led à nomen quód prin cipum nominibus prifco more effigietur, vel potius, Ariftotele. v. Ethi.tefte, ob hoc vocatur, quòd non à natura, fed à lege quax vón

Seftertius tefte Prif.de figuris numerorum $\&$ ponderibus, Nummus eft duarum femis librarum, vnde feftertius dicitur quafi femiftertius: de quo Aruntius, Seltertius olim dupödius \& femis quafi femiltertius, quo tempore denarius decuffis precium valebat. Varro de lingua la tina lib.v. Seftertius quod femis tertius, dupondius enim \& femis antiquus feftertius eft . Victruuius lib.iii . archi. Quod efficiebatur ex duobis affibus \& tertio femiffe, feftertium vocauere. Plini us natur. hift.xxxiiii. Et placuit denarius p decélibris ęris, quinarius $p$ quing, feftertius pro dupondio ac femiffe. Plutarchus in vita M. Antoninixxv. Milia romani decies feftertiùm appellät. Helius Spartianus in vita Heliogabali,Idem nunquam minus centum fefter tiis conauit, hoc elt, argenti libris triginta.

Talentum quanti fit quia de eo variant fcriptores, neceffarium exiftinaui di uerforum auctorum dicta fubiicere. Liuius.xxxiiii.ab vrbe códita, Ingens nu * merus bello Punico captiuorú, quorum Hannibal cum ab fuis nó redimerétur vænundederat, multitudinis eorum argumétum eft quòd Poly bius fcribit centum talentis eam rem Achæis ftetiffe, cum quingentos denarios precium in capita quot redderentur dominis. ftatuiffent: 商ille enim ducétos ea ratione Acha ia habuit captiuos I talicos. Adiice nunc pro portione quot verifimile fit Gręciam totam habuiffe, qua ratione oftenditur fex milia denariorum habere valentum:nam quinquageni denarii pro mille ducentis captivis dati, colligütur fexcenta milia denariorum, centum ea oftendit fuiffe taléta: centefima autem pars fexcentorum milium, fex milia inueniütur: denarii autem illo tempore nummi argentei erant, quod in eodem oftendit Liuius, Signati, inquit, argenti lxxxiii. milia fuere Atticorú Tetradrachma vocant: trium verò denariorum argenti in fingulis elt pondus. Idem Liuius xxxvii. Oftenditur magnum talêtum atticum lxxx . habere libras \& paulò plus, cum fupradictorum computatio manifeftet Ixxxiiii. libras \& quatuor vncias habere talentum, quod eft fex milia denariorum, Liuius, Talentum ne minus pondo $\mathrm{xxx}$. Romanis ponderibus pendebat. Simili modo Aegyptium, vt Varro \& Plinius inquit xxxiii.natur.hift.ldem Li uius, Sic decreuit fenatus vt non plufquàm ternæ libræ \& quaternæ vnciæ fingulis defint talentis : \& fciendum fecundum Liuii computationem, quòd centum Mina 
tum Minæ atticæ quarum fingulælxxxv . drachmas habent, faciunt talentun magnum: nam minas lx. habet fecundum Dardanum: quòd auté eft magnum \& minus oftendit Terentius in Phormione, Si quis daret talentú magnum. Seneca in $x . e p i f t . x x i i i i$. feftertia, id eft, talent um atticum paruum. Prifianus de pöderibus, Talentum Athenienfe paruum,minælx:Magnum, minæ lxxxii1.\& vncix quatuor. A. Gelius noct. att. lib.iii. Ariftotelem quog traditur libros pau culos Speufippi philofophi poft mortem eius emiffe talétis atticis tribus: ea tum ma fit númi noftri feftertia duo \& feptuaginta milia .Idem libro quinto, Equus Alexandrı regis \& capite $\&$ nomine bucephalus fuit: emptü Cares fcripfit, talen tis.xiii.et regi philippo donatum, æris noftri fumma eft leftertia.ccc xii.Seruius autem in comento.v.æneid. Talentum fecundú varias gentes variü pondus eft. Apud Romanos eft feptuaginta librarum, ficut Plautus oftëdit in Muftel.qui ait duo talenta effe.cxl. libras. Legimus etiam talentum efle paululum:nam Ho merus in ludis funebribus Patrocli vltima pręmia dicit duo talenta, quod cogit nos aliquid minimum intelligere: nam ficut primus victor bouem accepit, confequens non eft vt dicamus quòd vltimus magnum accepit.

Pondo fingulari numero caret tefte Foca. Dicimus tamen duo pondo, tria pondo, non bina pondo, aut terna. Quintilia lib.primo inftit. Qund guòd quędam fingula proculdubio vitiofa funt, iuncta fine reprehéfrone dicuntur: nam duo,tres, $\&$ pondo diverforum generum funt. Barbarifmi autem duo pondo, $\&$ tripondo vfque ad noftram ætatem ab omnibus dictum eft, $\&$ recte dici Meffa. la confirmat, \& idem eft dux, tres, quatuor libræ quod duo tria \& quatuor pondo,vt quida m volunt, \&' ex multis colligitur, quod quidam auctores non vfquequaque probant. Liuius.xxii.lib. A rgenti pondo bina \& fex libras in militem praftaret. Idem libro tertio, Dictator corona m auream libra pondo ex publica pecunia populi iuffu in capitolio loui donum dedit.

Spolia cum propriè ea tantum fint quibus hoftis fpoliari poteft, ve lorica,vel veftis, a bufiue tamen poliú dicitur quicquid ab hoftıbus tollitur. L iuius, Marcellus captis Syracufanis cum catera in Sicilia tanta fide \& integritate compo fuifet ve non modo fuam gloriam, fed etiam maieftatem Po.Ro.augeret,orna menta, figna vrbis, tabuláfque quibus abundant Syracufe R omam deuexit, hoftium quidem illa lpolia \& parta belli iure,cæterum inde primum initium mirandi græcarum artium opera, licentiæç hinc facra prophanáque omnia vulgo fpoliandi,factum eft.

Opima fpolia funt qux dux duci detrahit, dicta ab ope, vt inquit Varro, vel ab opere vt alı ferunt, \& quidem doctıffimi, cum fit opus egregium \&. clariffimum, bell ducem parem fibi ductorem fuperare.

Exuuias, \& f polia, \& hominum tegmina, aut veftes dici poffe, Virg.autor eft, Exuuias,inquit, indutus Achilli: \& cum de ferpente in Geor.fmili modo, Com pofitis nouus exuuiis nitidág inuenta luucluit. Nam fape illorum fpolis volitantibus auctus.

Excubix diurnę funt, vigilix autem nocturnę; quas primo Palamedes Tro. iano bello auctore Pli.natur. hifto.vi.inueniffe traditur, 
Inducia quid fint duobus modis M. Varro in libro hiftoriarũ qui eft de bello \& pace diffinit, Inducieg,inquit, funt pax caftrenfis paucorum dierum. Idem alio in loco, Inducix, inquit, funt belli ferıæ fed lepid ma mis atque iocundę breuita tis. Vtraque diffinitio quàm plana aut approbata effe videtut: nam neque pax eft inducix, bellum nanque manet, pugna ceffat, nec in folis caftris, nec paucorum tantum dierum inducix funt. Quid enim dicenius, fi induciis immenfum aliquid factis caltris concedatur, nónne ideo inducia non funt? aut rurfus quid effe id dicemus quod in primo annali Quadrigarii fcriptum,Cn.Pótium Sam nitem à dictatore romano fex horarum inducias poftulafle? Quid effe id dicemus quod à Liuio ab vrbe cond. $x$. fcribitur, Tres validifima vrbes Etruria capte, Vol fcum, Perufia, Àretium pacem petiere, \& veftimentis militum frumétoóg pacti cum cófule ve nitti Romam oratores liceret, inducias in quadraginta annos impetrauerunt?Quid illud quog eiufdé libro primo, Eág̣ clade haud minus quàm aduerfa pugna fubacti Veientes, pacem petitum oratores R omam mittunt,agri parte mulatatis in centum annos inducię datæ, fr inducię tantum paucorum dierum appellâdæ funt? Gręci autem fignificantius confignantiuṣ́ ceffationem illam pugnæ dixerunt: nam quòd eo tempore non pugnetur $\&$ ma

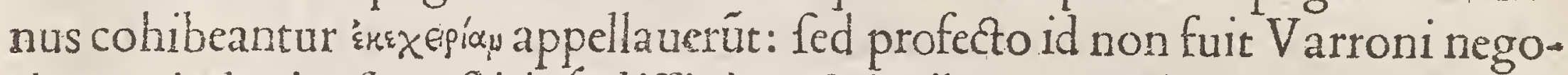
tium vr inducias fuperftitiofe diffiniret, \& legibus rationibus'̧ on nibus diffinitionum inferuiret. Inducrarú autem vocabulú qua fit ratione factum, ex multis qua iam legimus, probablius id quod dicam videtur, Inducias fic dictas arbitror quafi tu dicas indicta ocia, vt in diem certum, vel in certum tempus non pugnetur nihilq $\$$ incommodi detur, at que is dies, idve tempus vbi venit, inde vti iam pugnetur, idcirco ex his quibus dixi vocibus, quafi per quédam coitum $\& 2$ copulam nomen induciarum connexum eft. Aurdius autem Opilius mufarum lib.i. Inducia dicuntur,inquit, cum hoftes inter fefe vtring alteri ad alteros impunè \& fine pugna ineunt: inde ab eo inquit nomen effe factum videtur, quafi inix. Has Lycaonem inueniffe Troia no bello auctor eft Plinius.vi.natur. hifto.

Suppetix illa funt auxilia quæ maxime petuntur ab aliis, quæ præcipuè dan tur iis qui fub aliorum detinentui poteftate. Suppetias etiam, auctore Fabio Pla ciade, auxilium vel adauxilium dicimus. Meuius in tragoedia Herculis, Ferte in quit fuppetias optimi milites. Suetonius de Vefpafiano, Legatum infuper Syrie confularem fuppetias ferenté rapta aquila fugauerút. Plautus in Epid. Sed memento fi quid fruiunt fenes, fuppetias mihi non forori ferre. L. Apuleius libro fexto metam . Et occipit ftatim clamans vlulatibus auxilium validioris manus implorare, fed fruftra fletibus tumultum commouebat: quippe cum nullus afforet qui fuppetias ei ferre poffet, nifi folla virgo illa captiua. Auguftinus. viii.de ciuitate dei.Qui huic deferunt petitiones noftras, inde referunt deorum fuppetias ad auxilium. Cxf.xii.commen. Et nunciabantur auxilia magna equitatus oppidanis fuppetias venire.Idem in eodē, Suis'́g rebus timens elephantis'́p.xxx. relictis fuis finibus oppidifop fuppetias profectus eft. Idem quoog in codem, Atque fuis fugientibus fuppetias ire contendit.

Stringa caftrenfe vocabulum, interuallum turmarú in quo equi fringuntur: 
vel ftringx appellantur ordines rerum inter fe continuatæ collocatæọ́̂a à frrin. gendo dicte, vnde \& Atrigofi nominantur,vt aiunt,corpore macilenti, vel ftrigo* fus apud veteres morbus dicitur iumentorũ,qui corpora ftringit, aut fame, auß alterius vitii caufa quafiftringofus. Mafurius Sabinus lib.xxvii. Cêfores, inquit, P. Scipio Nafica,\& M. Pompilius cum equitú céfum agerent, equum nimis ftrigofum \& male habıtú,fed equitem eius vberrimú \& habiliffimum viderunt. Li uius.xxvii. Moram pugnæa attulit, $\underline{\text { H }}$ Hafdrubal prouectus ante figna cum pau cis equitibus fcuta vetera hoftium notauit, qux antè nó viderat, \& ftrigofiores equos,multitudoóg maior folito vifa ef. Stringere in re militari etiã nudare eft, vinde enfem ftrictû, id eft,nudatum dicimus. Liuius ab vrbe cond.vii.Pilóg̨ pofreo,ftricto gladio in hoftẻ imperú facit. Idem in nono, Fluctuantemóģ \& inftabilem aciem reddéte grato clamore,ftrictis gladiis haftati, \& principes inua dāt. Suetonius de Cæxare, Vtóg animaduertit vndique fe ftrictis pugionibus peti, toga caputobuoluit .

Defendere \& offendere non ex vulgari confuetudine, fed admodú propriè \& latine accipienda: \& eorú altetû fignificat incurrere in aliquid \& incidere, alterú eft auertere atq̧ depellere:quod hoc in loco à Quinto Claudio dicitur, Cum à Poenis,inquit, hoftes defendebãt facillime. Cernere dicebant antiqui củ aliqui pugnarent inter fefe de re aliqua quá qui (ọg fuã diceret, Virg . Ingentis genitos diuerfis partibus orbis Inier fe coilife viros, $\&$ cernere ferro: quod nunc clarifsimo tefte ad Luciliü Seneca, Decernere dicimus,fimplicis illius verbi vfu amiffo.

Recipere recuperare vel periculo liberare. Cicero in Catone, Nã nifi tuã amififfes, ego nunḡ recepiffem. Virg. Frugéfğ receptas, \& torrere parant flãmis. Receptus is dicitur quò fe exercitus recipit,vnde \& figna receptui canere dicun tur. Liuius. xxxvii.ab vrbe cond. Coactus ergo periculo militú prætor,receptui cani iufsit, ne obiiceret in autos furentibus defperatione ac rabie.

Prandium tametfi ex græco elt duçû,,cũ meridranû cibum connã vocarents negare nỏ poffum aliüde à plerifọ̧ dici, \& à parấdo maximè, quafi parâdium, quòd nilites fiue bellatores ad bellú vel pugnam paret: huic rei argumentum eft præater auctorem comprobatú vetus illud Leonidx elogiü : Hic enim Lacedxmoniorú dux clarifsimus củ effet in bello aduerfus Xerxem,quod fupremú fibi atç hoft ibus fuit,cú fexcentis fuis famofífsima illa incitamenta dixit, Prandete commilitones tanğ apud inferos coenaturi. Cato in quinto orig . Exercitũ fuum pranfum, paratum cohortatus eduxit foras atçinftruxit.

Sub pileis feruos vęnum folitos ire, quorü nomine venditor nihil pręfaret, Cellius Sabinus fcriptum reliquit.Cuius rei caufam effe ait,guòd eiufnodi conditionis mancipia infignita effe in vendendo deberêt, vt emptores errare $\&$ capi non poffent: neq̨̣ lex vendêdi operienda effet,fed oculis iam perciperét quodnam effet iam mancipiorũ genus, ficutt, inquit, antiquitus mancipiouñu iure belli capita coronis induta veniebât, $\&$ iccirco dicebãtur fub coronis vęnire: nam qu vt ea corona fignum erat captiuorú vænaliun, ita pileus impofitus denronftrabat eiufmodi feruos vænundari,quorum nomine emptori venditor nihil pręftaret. Eft etiam alia rationis opinio cur dici folitum frt, Captiuos fub corona vænun 
dari, quòa milites cuftodiæ caufa captiuorum vanalium greges circundarent, eáque circunftatio militum, Corona appellata fit: enimuero id magis verum eft quod fupradixi, quod Cato in libro quem compofuit de re militari docet. Catonis verba hęc funt, $\mathrm{V} t$ populus fua opera potius ob rem bene geftam coronatus fupplicatum eat, quàm re male gefta coronatus væneat.luftinus epit. Trog. Pomp.xxxiiii. Vrbs ipfa Corinthus diruitur, populus omnis fub corona vendi tur, ne hoc exemplo cæteris ciuita tibus metus nouarum rerum incuteretur, ferui ex eo deinde appellati de hominum ftatu Floro auctore, quòd imperatores ca ptiuos vendere iuberent, \& per hoc feruare neq occidere folerent. Auguftinus ciuitatis dei libro vndeuigefimo, Origo autem vocabuli feruorum in latina lin gua inde creditur ducta, quòd hi qui iure belli poffent occidi à victoribus conferuabantur, feruiós fiebant à feruando appellati, fub hafta captiui væniebant, haftæóg fubiiciebantur ea qux publice vænundabant. Liuius ab vrbe cond.iiii. Hoftes præter fenatores omnes vænundati funt,ptędæ pars fua cognofcentibus Latinis atque Hernicis reddita, partem fub hafta dictator vendidit. Sub iugum mitti dicuntur hoftes, cum duabus haftis in terrá defixis tertiág fuperligata inermes, difcinctis pectoribus terrá tenus fub ea tranfire coguntur.Lưuius ab vrbe cond.ix. Siquidem etiam quod quibufdam in annalibus inuenio, Pontius $\mathrm{He}-$ rennius Samnitum imperator ve expiaret confulis ignominiam, fub iugú cum cæteris eft miffus. Sub vitem præliari dicuntur milites, cum fub vinea militari pugnant. Lucilius, Neque prodire in altum, præliari procul fub vité. Sub vitem haftas iacere elt, cum eas fub manu miles furfum mittit . Lucilius, Vt veles bonus fub vitem qui fubmifit haftas. Sub vineam iacere dicuntur milites, cum cen turionibus aftantibus iacere coguntur fudes.

Deditio eft quando victi hoftibus fe tradunt. Spontanea traditio, in qua rex fi Liuio credimus, interrogabat, Eftísne vos legati oratoréfque miffi à populo Collatino, vt vos populímg Collatinum dederetis? illis annuentibus, tum rex, Eftne populus Collatinus in fua poteftate?ita effe illis denuò refpondétíbus, fubiungebat rex, Deditísne vos populumó Collatinum, vrben, agros, aquam,terminos, delubra, vtenfilia, diuina humana ọ́ omnia in mean populiós Ro.deditionem? cum omnia hæc illi dederent, tunc ille demum, At ego recipio: $\&$ hæc fecundum veteres in re militari deditionis formula.

Victoria dicta, $q$ vi,id eft, virtute adipifcatur: nam victoria dolo quxefita tur pis eft, \& a pud veteres maximi habebatur. Iuftinus epit. Trog. Pom.xv. Et vt apparet, nó odii fed dignitatis gloria accenfos, donis, muneribuśg inter ipla bel la contendebant: tanto honeftius tunc bella gerebant, quàm nunc amicitiæ co. luntur. Hanc quoque victoriam \& virginem \& deam communem cum Bellona \& Marte finxit antiquitas, $\phi$ hi in bello vtriç parti poffent fauere: Claudianus; Ipra duci facras victoria panderet alas,

Et palma viridi gaudens \& amica tropheis,

Cuftos imperii virgo qua fola mederis

Vulneribus nullum'ó doces fentire laborem.

Tibullus elegiarum fcriptor, 
Ecce fuper feffas volitat victoria puppes,

Tandem ad Troianos diua fuperba venit.

Ouidius viii. metamorph.

Et pendebat adhuc belli fortuna diứç

Inter vtrumque volat dubiis victoria pennis.

A rmiluftrum tefte Varrone ab ambitu luftri, locus, id eft,circus maximus, dictus $q$ circú fpectaculis ędificatus ibi ludi fierent, \& quỏd ibi circum metas ferre tur pompa \& equi currerent \& ludentes ancilibus armati: luftrú autem, vt idem inquit,nominatum tempus quinquennale, à ludendo, id eft, foluendo, quòd quin toquog anno vectigalia, $\&$ vitro tributa per cenfores perfoluebantur.

Armamentarium,vbi tormenta, $\&$ arma, $\&$ tela quxcunque fint illa, ponútur ac feruantur. Liuius xxxi. Aucto etiam tumultu, quòd circa forum ignis tectis iniectus erat, conflagrauerunt, $\&$ tota regia $\&$ armamentariú cü ingenti appara tu machinarú, $\&$ tormentorum. Idê vigefimonono, Tormêta machinasẹ́ aduexerat fecum, \& ex Sicilia miffa cum cómeatu erant, \& noua in armamentario multis talium operum de induftria inclufis, fiebant.

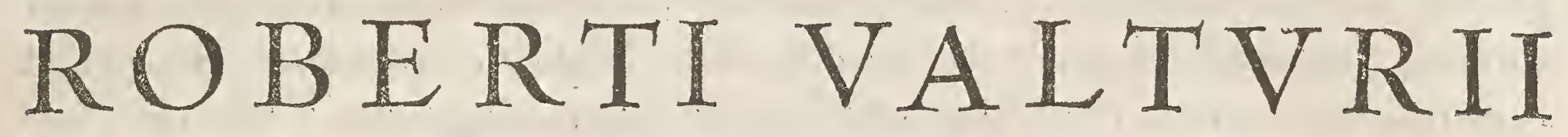

A D I L L V T R E H ER O A S G IS. mundum Pandulphum, de re Militari

Liber Decimus.

(2)

De Militari cultu qui pro confuetudine gĕtium er inuentu hominum uarius reperitur, Cap. I.

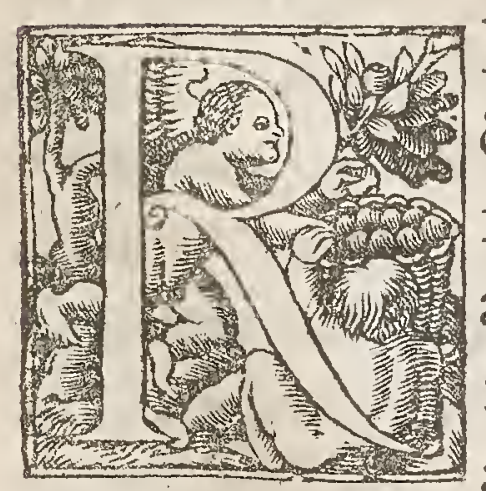

Elatis in militiam honore pub.dignis, Sigifnůde Pandulphe, \& $p$ virili mea corum ac totius exercitus muneribus expreffis, fui finguli cultus ornamenta reddemus, \& primo quidem qua à maioribus circa hoc tradita funt ornamentorum genera, armorum deinde, tormentorum, machinarumiọp rationes, materias, genera, fpecies, \& formas: figna porro cognofcendi in bellis quę fuperiori etiam tempore in vfu fuere, $\&$ intellectum \& fignificationê quampiam videãtur habere. Gradus igitur honorum ordinum $q$, ac magitratuum diuifiones habitus ipfe fecernit, qui pro confuetudine gentium $\&$ hominum inuentus varius reperitur. Apud Romanos toga veftis erat qua primum fexus om nis $\&$ omni tempore interdiu \& noctu vteretur, fue ficut in confuetudine habebatur quia in foro amicirentur, \& à tegendo dicta quòd exterior ac longa veftes alias tegeret. Eius forma rotúda erat $\&$ fufiore $\&$ quafi inundâte finu, $\&$ fub dex tro veniens fuper humerum finiftrum obuoluta ponebatur, vt in operimentis fimulachrorum Romæe eft af picere, vtóg à Valerio Maximo de Scipione Nafica in Mutium Scxuolam literis traditum eft, Quoniam, inquit, conful dum iuris ordi 
nem fequitur, id agitur vt cum omnibus legibus romanum imperium corruat, egomet me prinatus voluntati veftræ ducem offero: ac deinde læuam nanum apertæ togæ circundedit, fublatáq dextra proclamauit, Qui rempublicam faluam effe vult,me fequatur.

Toga candida eademọ́ cretata, in qua câdidati,ideft, magiftratum petentes a mbiebät, addita creta quo candidior infignior'ós eflet, vt'̣́ magiftratuú huiufmodi cópetitores innocentes viderétur ex habitu $\&$ nô per ambitioné velle magiftratus expofcere. Gabinus cinctus eft toga fic reiecta vt vna eius lacinia reuocata hominé cingat. Hoc autem veftimenti genere vtebatur conful bella indicturus, ideo quia quum Gabii Cápanię ciuitas facris operaretur bellum fubitó euenit, tunc ciues cincti togis fuis ab aris ad bella profecti victoriam adepti funt:vnde is ortus eft mos. Virgilius, Iple quirinali trabea cinctúque gabino Infrgnis referat ftridentia limina conful.

Toga palmata ea dicebatur qua triumphãtes \& qui palmã meruerüt vteban tur: vocatur $\&$ toga picta eo $q$ victorias cum palmis intextas haberet. Hanc pal matam tunicã \& togam pictam, vtinquit Iulius Capitolinus, Gordianus fenor primus Romanorü priuatus fuam propriam habuit, cum fuperiori tempore eti am imperatores de capitolio acciperent, vel de palatio. Prætexta \& toga picta qux infignia quondā magiftratuum Etrufcorum erant, primus Tullus Hoftilius rex Romanorú tertius, debellat is Etrufcis vt Rom $x$ haberentur inftituit, fed prætextam illo fxculo puerilis non vfurpabat ætas: erat enim, vt cætera que enu meraui, honoris habitus, led poftea Tarquinius Demarathi exulis Corinthii filius Prifcus, qué quidàm Lucinoné vocatú ferunt, rex tertius ab Holtilio,quintus à Romulo, de Sabinis egit triumphú, quo bello filiú fuum annos xiiii. natú quòd holtem manu percufferat, \& pro concione laudauit, \& bulla aurea præte xtág donauit,infigniens puerü vltra a nnos fortem præmiis virilitat is $\&$ honoris. Alii putât eúdem Prıf́cum, cum is ftatum ciuiu folertia prouidi principis or dinaret, cultú quog̣ingenuorú puerorum inter præcipua duxiffe, inftituiffég vt Patritii bulla aurea cû toga cui purpura prętexitur vterétur, dütaxat illi quorum patres currule gefferát magiftratũ, cęteris auté vt prętexta tantü vterêtur indultú, fed vlog ad eos quorú parêtes equo ftipédia iufta meruiffent: libertinis verò nullo iure vti pretextis licebat, ac multo minus peregrinis quibus nulla effet cü Ro manis necelfitudo, fed poltea libertinorú quoog filiis prętexta cócelfa eft ex cau fa tali,quá M. Lalius augur refert, $q$ bello punico fecüdo duumuiros dicit ex fenatufcofulto propter multa prodigia libros Sibyllinos adiiffe,et in fiectis his nú

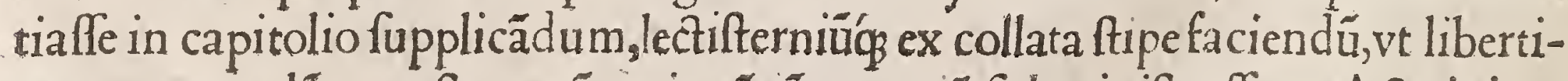
næ quoq quę löga vefte vterétur in eã rê pecuniã fubminiftraffent. Acta igitur obfecratio pueris ingenuis, itéóp libertinis, led et virginibus, patrinis matrinifóg pnüciätibus carmé, ex quo conceflum vt libertinorú quo q̧ filii q ex iulta dútaxat matrefamilias nati fuiffent, togã pregrextã \& lorũ in collo $p$ bullę decore ge Itarét. Valerius Flaccusait, Cü Po. R o.peftiléria laboraret, eflétọs refpófum, id ac cidere $q$ dii refpicerêt anxià vrbem fuiffe ob nó intellectum oraculum, eueniffetos vt in Circenfum die puer de conaculo pompá fuperne difpiceret \& patri 
referret quo ordine fecteta facrotum in arca Pilentia cópolita vidiffet: qui quề rem geftam fenatui nuntiaffet,placuiffe velari loca ea qua pompa veheretur, at ita pefte fedata puerü qui ambiguitatem fort is abfoluerat, toge prætextæ vifum impetraffe. Vetuftatis peritiffimi referút in raptu Sabinarum vnam mulierem nomine Herfiliả dũ ad hęreret filię fimul raptam, quam quữ Romulus Ofco cuidam ex agro latino qui in afylü cius confugerat virtute confpicuo vxoré dedif fet,natum ex co puerum antequam vlla alia Sabinarum partum ederet, cumóg quòd primus effet in hoftico procreatus, Ofcum Hoftlium à matre vocitatum, \& eundem à Romulo bulla aurea ac pratextæ infignibus honoratum: is quum raptas ad cófultandú vocaflet, fpopondiffe fertur le eius infanti qua prima fibi ciuem romanú effet enixa, illuftre munus daturum. Nonnulli credunt ingenuis pueris attributum vt cordis figuram in bulla ante pectus annecterent, quẫ inf cientes, ita demum fe homines cogitarent fí corde pręfarent, togấç prætextam his additam vt ex purpuræ rubore, ingenuitatis rubore tegerentur.

Paludamêtum veftis quæ nunc chlamis dicitur infigneóp pallium ducum \& imperatorum, albo vel colore fanguineo purpureum $\&$ auro diftinctum. Ho: belli tempore imperatores indui mos erat, proinde tefte Varrone fic dictú quòd co indutus palàm faceret bellú futurú. Paludati armati et etiam ornati, on nia enim militaria ornamenta paludamenta vocabant.

Trabex veftes regia: harum tria effe genera Suetonius in libro de genere veftium auctor eft, vnü puriffima purpura, tãtum diis facratü:aliud regiü, quod eft purpureum, habet tamen albi quippiam: tertium augurale,crocto \& purpura.

Lana veltimentủ militare quod fuper omnia veftiméta fumitur, \& $\propto$ de lana fit, tefte Varrone, fic dicitur: quidã Thulcè appellatả exiftimãt, quidä gręcè, quã chlenam dicunt: obbas non lęnas, fed chlenas effe ait: cuivufmodi enim veftis ge wus, quóve colore fit oftendit his verbis Maro, Tyrióp ardebat murice lęna.

Sagum, fagam, frue fagulum, veftem breuem \& idoneam bello conftat ac mi litia. Liuius lib.cetauo ab vrbe cond. Non omnia fagulo regali amictus, centurionibus item manipulariú militum habitu ductis,ne ducé circumuenire hoftes notarét perluftrauit . Liui.xxi.de Hannibale, Multi fæpe, inquit, militari fagulo. opertun humi iacentem inter cultodias ftationesóg militum cöfpexere, veftitus nibil inter xquales excellens, arma atque equi confpiciebantur. Sunt \& qui militare pallium quadratú, \& à Gallorum lagacitate cótra aéris intemperiem in * nentum fic dictum appellant.

Penulam militare pallium, pendentibus cuni fimbriis, fic dictam quidam vo Iunt, quòd à Ponis initium habuerit qui rali vefte maximè vtebantur. Seneca ad liberalem de benefi.lib.v. Meminifti quidem fub quadam arbore minimum vmbræ fpargente quum velles refidere feruentifimo tole, et effet afperrimus locus in quo è rupibus acut is vnica illa arbor eruperat, quendam ex commilitoni bus, psnulam fuam fubftrauiffe. Spartianus in vita Adriani, Penulis vti tribu ni plebis pluuia tempore folebant, imperatores autem nunquam: vnde impera. tores fine penulis a togatis videntur. Helius Lampridius in vita Alexandri Seueri, Penulis intra vrbem frigoris caufa vt fenes vterentur permifit, quum $S$ iii idvelti 
id veltimenti genus femper itinerarium aut pluuiale fuiffet.Iuuenalis in primo, Scilicet hoc fuerat, propter quod fxpe relicta

Coniuge per montem aduerfum gelidaśg cucurri

Exquilias,fremeret faua cum grandine vernus

Iuppiter \& multo ftillaret penula nymbo.

Lacerna pallium fimbriatum quo olim foli milites vtebãtur, vnde in diffinguéda caftrenfivrbanáqg turba hos togatos, illos lacernatos vocabãt, indeóp lacernę quafi amputatis fimbriarum capitibus dictæ.

Maftruca, vt Confentius inquit,eft Sardorum veftis que fit ex pellibus ferinis, fic dicta, vt quidam volunt, quafi monftruofa: quia quifquis ea induitur, quafi fera monftratur. Cic.pro Scauro, Quem purpura regalis non commouit, eum Sardorum maftruca mutauit ex induftria: quod fardum illudens $\mathrm{Cic}$. maftrucam dixit tefte Quintiliano.

Stragulas veftes pellicias nonnulli licet habeant,veluti etiam Sarmatarum popu li qui pellibus teguntur, nec dubium fit, vt Labeo inquit, quin ftragula veftis fit omne palliü, magnopere me mouet Pomponii \& Caffii multorumq auctoritas, $v t$ ftragula veftis fit nec fordida quidem fed preciofa, vt Liuius bel. macedonici . libro iii, Quum tibi, inquit, viro liceat purpura in vefte ftragula vti.Idem in eodem lib.ix. Luxurię peregrinæ origo ab exercitu Afratico inuecta in vrbé eft, lectos auratos, veftem ftragulam preciofam. Cicero in Verrem actione iiii. Dice bat fcyphorum paria complura, hydrias argéteas, preciofam veftem ftragulañ. Valerius maximus lib.iiii. Age, fi quis hoc freculo vir illuftris pellibus pro ftragulis vtatur. Horat.fecundo fermonum

Vnumdeoctoginta annos cui ftragula veftis.

Rectius tamẽ \& propriè magis arbitror, Varrone opulentiffimo tefte, vbi de cul citra loquitur, in lingua latina, quicquid infternebant â fternendo ftragulum ap pellari.Seneca lib.epifto.xv. Culcitra in terra iacet,ego in culcitra:ex duabus pe nulis altera ftragulum, altera opertoriú facta eft. Val. Martialis in apophoretis, Stragula purpureis lucent villofa tapetis.

Stragulas etiam \& Bafionica, qux equis infterni folët puto veftes effe. Eft fua eti am apud Lacedæmonios tunica quã nonnulli Puniceam dicunt,nonnulli $\mathrm{Coc}$ cineam. Hanc $a b$ his repertam conftat ad celandum coloris frmilitudine fangui nem, quotiens quis in acie vulneraretur, ne contemplanti aduerfario animus augefceret. Hac fub confulibus Romani vf funt. $V$ nde folebat etiam pridie quàm dimicandum effet ante principia preponi, quafi ad monitio \& indicium futuræ pugnæe eflet, quod ita effe Plutarchus in vita Fabii Maximi auctor eft, Hanni bali,inquit,quum apud Aufidum fluuiú caltra haberet prope Cannas, orto die extemplo belli fignum extulit:nam erat rubra quędam veftis fupra confulis tentorium protenfa,quare Carthaginenfes profpecta imperatoris romani $\&$ audacia \& copiarum multitudine, quum ipfi haud ad medium numerum attingerët, principiò ingenti trepidatione perculfi funt.Idem in vita Pompeii, Tum Cafar exoptatum inquiens adueniffe diem in qua cum viris non cum inedia, non cum egeltate pugnandum eflet, extemplo coram contubernio tunicam rubram 


\section{DERE MILITAR I}

poni iuffit: hoc enim Romanis pugnæ fignum erat.

De armis or unde dicta fint,

Cap.

II.

E ipfa, nunc graui labore monemur armorum fpecies vniuerfas, infrumentorum, tormentorun'q́ nuuralium ignorätibus circum fcri1. Wu pte monftrare: \& quonıam fua cuiqg gentiú placita fụnt, \& artificum 1. - . virili noftra profequemur, nufquam ingeniis hominum præfcribentes, quin lice at cuique $\&$ referre qux viderit, \& fuis inuentis gratulari. Arma vt inquit $\mathrm{Cic}$. tufcula.lib.primo, membra militis effe dicuntur: quæ quidem ita gerútur aptè vt fiv vus foret, abiectis oneribus, expeditis armis vt mébris pugnare poflint. Lucretius libro quinto de rerum natura.

Arma antiqua, manus, vngues, dentes'́p fuere,

Et lapides, \& item fyluarum fragmina rami,

Et flammæógignes,poftquam funt cognita primùm.

Polterius ferri vis eft ærisóp reperta,

Et prior ęris erat quàm ferri cognitus vfus.

Arma, V Ipiano tefe, funt omnia tela, hoc eft, fuftes \& lapides, no folum gladii, hafte, $\&$ framex, id eft, romphex. Caius de verborum fignificatione, armorum appellatio non vtique fcuta \& gladios fignificat, fed fuftes \& lapides: \& quoniam his arceri poteft hoftis, arma ab arcendo dicta cenferi poffunt: vel arma di cuntur $a b$ armis propriè,id eff, humeris dependentia,vt fcutum, gladius, pugio, fica,cū ea quibus pcul præliamur tela dicâtur. Cic.pro Au.Cecinna, Armatos, filatine loq volumius quos appellare vere poffimus? opinor eos qui fcutis teliś́g parati armatió fint. Quid igitur? fi glebis, aut faxis,aut fuftibus aliquem defun do precipitem egeris, iuffufque fis quem hominibus armatis deieceris reftituere, reftituiffe te dices? Verba fi valent, fi caufę non ratione fed vocibus pöderantur, me auctore dicito, vinces profectò non fuiffe armatos eos qui faxa iacerent, qua de terra ipfi tollerent, non effe arma cefpites neq̧ glebas, non fuiffe armatos eos qui pretereuntes ramum defringerent arboris, arma effe fuis nominibus, alia ad nocendú,alia ađ̆ tegendum, qux qui non habuerint, eos inermes fuiffe vinces. De armis quibus tegimur.

Cap. III.

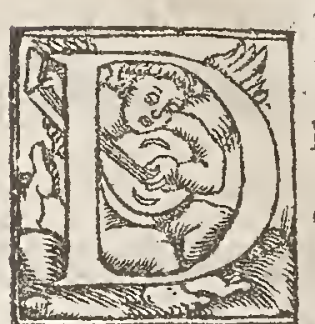

E his igitur quibus tegimur primo dicendü, nec temerariú fuperioris temporis patrium quendam Gallorum morem túm eft imitari, qui corporis viribus fidentes, tanquam gloriofius dimicaturi, nung̈ nifi in pugna nudabantur, nudíg ver labấtur in acie, vnde multa pe ricula probatiffimis contigerunt. Arma igitur quibus tegimur funt caffides,tunicæ varii generis, clypei \& id genus plurima. Ferrum autem in arma cóuertere, $\mathbb{Q}$ armis corpus tegere, funt qui Minerux, funt qui louis, Theffaliz regis ferant inuentum.

Silæx galeę dictę funt à frmilitudine Sili: Silus enim, vt Fefto placet, nafus appel laturfurfum verfus atque repandus. Eft autem galea, quam Curetes reperiffe perhibent, tefte Diodoro, crifta capitis de corio, quû́ fit calfis de lamina: dictáq galea, vt inquit Varro, à galero quo multi antiquorum vfi funt: conum curua- 
turam galex quæ in ea præeminet dicimus, fuper qua criftę funt. Virg.iii.æneid. Etconum infignis galeæ, criftasóg comantes.

Fuccula galex pars eft. Iuuenalis in iii.

Et tracta de caflide buccula pendens.

Comanté autem galeã quoğ legimus aut criftatam, q de caudis animaliü habeant criftas: vt, Criftaq́p hirfutus equina: aut comas habenté. Statius, Non ergo in terga comantes Abätiadas: \& ibi deinde, Comante Androgei galeam. Simili modo qui fe de velocitate iactabãt,pinnas in galea fua ponebant, in fignum velocitat is, quas deuictis hoftibus auferentes, collo fuo in fignum victorię fufpélas ferebant, maiorémq illis rapiendo profeffi velocitatë, Pinnirapi appellati funt. Iuuenalis in primo, Inter Pinnirapi iuuenes, iuuenéfque lanift

Torques colli induuias \& ornamenta, tam ma culino genere quàm fomineo idóneos quofdam, \& præ cæeteris illuftres latinæ lingux auctores protuliffe inuenimus. Ouidius primo faftorum, Ex vno quidam celebres, aut torquis adempti.

Tul.ni.officiornm, Atq T.Manlius is eft qui ad A nienem galli quē ab co prouocatus occiderat, torque detracto, cognomen inuenit. Liuius libro vii .ab vrbe condira, lacens inde corpus ab omni alia vexatione intactum, vno torque fpoliauit quem refperfum cruore, fuo collo circunded it. A. Gellius noct. atti.lib.ix. Vbi eum euertit, caput pręcidit, torquem detraxit, eam fanguinolentam fibi in collum imponit. Hieronymus in expofitione Danielis.ii. Kem quidem facio ri diculam, vr in expofitione prophetarum de verború generibus quafi grammaticus difputem: fed quia à quodam nihil fciente, 8 omnia follicente reprehéfus fum, quare torquem foemineo genere tranftulerim, breuiter an notabo quòd $\mathrm{Cic}$. in Mario Torqué genere formineo, Titus Liuius malculino dixerunt.

Armillas ex armo quas viri nilitares ab imperatoribus donati gerüt, dictas effe exiftimant $q$ antiqui humeros cum brachis vocabát armos, vnde arma ab his dependentia funt vocata: \& funt armilla humeralia fiue ornamenta brachi-

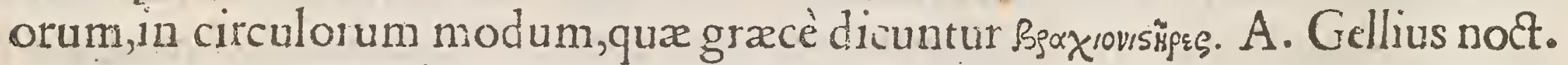
atti.lib.nono, Quos inter gailus quidam nudus, prater futum \& gladios duos, torque atqg armillis decoratus proceffit. T. Liuius, Additur fabula quòd vulgo Sabini aureas armillas magni ponderis brachio læuo gemmatośp annulos ha buerunt pepigiffe eam $\phi$ in finifris manibus haberent . Ouidius ii . faftorum, Fregerat armillas non illa ad brachia factas.

Caftus quú pugilum arma fignificat et quartxe elt form $x$, coriú elt cú plübo infuto rigentíg ferro, quo manus fuas \& brachia pugiles muniunt \& vinciunt, \& apud plurimas nationes, maximè Sauromatas, le inuicem pugnädo cædunt, vnde $\&$ caltus nomen ind itum. Cicer.ii. Tufculan. Pugiles etia m quum feriune aduerfarium, in lactandis cælt ibus ingemifcunt, non quòd doleant animóg fuc cumbant, fed quia in profundenda voce,omne corpus incendicur, venítos plaga vehementior. Virgi.in quinto, Sic deinde locutus,

In ned io geminos immani pondere caltus

Iroiecit quibus acer Erix in pralia luetus 
Ferre manum, duríque intendere brachia tergo.

Obftupuere animi, tantorum ingentia feptem

Terga boum plumbo infuto ferróque rigebant.

Ante omnes ftupet ipfe Dares, longéq́ recufat,

Magnanimúfque Anchifiades \& pondus, \& ipfa,

Huc illuc vinclorum inmenfa volumina verfat.

Tum fatus Anchifa caftus pater extulit æquos,

Et paribus palmas amborum innexuit armis.

Idem in eodem,

Conftitit in digitos extemplo arrectus vterq;?

Brachiáque ad fuperas intentus extulit auras.

Adduxere retro longe capita ardua ab içtu,

Immifcéntque manus manibus pugnámque laceffunt.

Idem in eodem, Durófque reducta,

Librauit dextra media inter cornua cæeftus,

Arduus effractóque illifit in offa cerebro.

Et didici quonam Poni arma rotatu,

Quo maflagetæ fua bella cient, quo turbine cæftum

Sauromatæ.

Ifculponeas etiam dici voluerunt cæft us plumbo illigatos,vt \& Neuius in Phi lēporo comoedia, I fculponeis bactuéda huic funt latera plübo. Plautus in Caffina, fimili modo ait, Melius Ifcul poneis qus bactuatur tibi os fenex nequiffime.

Pectorale ferreum pectoris tegimen. Pli.na.hift.xxxiiii. Fecit \& Spurius Camillus Iouem qui eft in capitolio, victis Samnitibus facrata lege pugnantibus, pectoralibus eorum ocreifque \& galeis,

Thorax humanum pectus propriè, vel eius eminentior parseft. Plinius.xxvi. na. hifto. Hyffopi quinque rami cum duobus rute \& ficis tribus decoctis thora cem purgant.Cęterun! pro eo quod ferreum eft, $\&$ quo velatur pectus $\&$ corpus, nonnunquam ponitur.Plutarchus in vita Luculli, Erat ipfe thoracem ferreum indutus, fplendidum atq̧ fquamofum, quo fuper punicá geitabat epheftridem.

Tunicas quibus nudú tegitur corpus pro vfu \& exiftimatione plerigg varias habent, ferico vel by ffo plurimis plicaturis impenetrabiles audio.Alii fpumam ferri folutam in puluerê, \& plicaturis iniectâ,omné ferri aciem repellere dicunt: nonnulli thuris puluerem probant,eo modo congeftum:corium apud alios cer uinum fucco maceratum, probari maxime comperio. Lanas denique aceto coctas ferro refiftere in naturali hiftoria auctor eft Plinius. Proinde milites nullum pręfidium habêtes in gladio, totum fubfridium in huiufmodi tegimine ponunt, laminis ferreis $\&$ loricis vniuerfum corpus tegentibus confifi.

Phalerx \& ephippia, equorum fiue hominum vel bellorum munimenta fiue ornamenta. Virgil. in quinto.

Primus equum phaleris infignem victor habeto.

Saluftius in Iugurtha, Ac fir repoftulet haftas, vexillum, phaleras, \& alia militaria arma. Virgilin decimo Cur tales phaleras damnetis $\&$ aurea bullis, Cingnla. 
Iutenalis in quinto

Vt lati phaleris omnes \& torquibus omnes.

Horatius in epiftolis

Optat ephippia bos, piger optat arare caballus.

Lorica quam Mydas Meffenus reperiffe dicitur, eft propriè tegmẻ de loro fa ctum, quo maiores dolo vti confueuerant. Varro de lingua latina,lorica quòd è loris de corio crudo pectoralia faciebant : poftea fuccedit Chalybs ferro fub id vocabulum,ex annulisóg ferream tunicam fecere,qux tantum pectora apud ma iores tegebat, poftea vniuerfum corpus: vnde,

Triplici feruantur pectora ferro.

Nam tergo tunc nullus erat metus. \& Lucánus vii.

Quærit iter quo torta graues lorica catenas

Oppofuit,totoóp latet fub tegmine pectus.

Hæ pro diuitiis, materia vel opere pretiof $x$, vt Maximiani adolefcentis, \& Ptolomæorum regum aureæ, quædẩ æneæ, \& communes ferreæ. Simplices quidam habent bilices ac trilices, alii loricas fquammatas inncturis adopertis, fiue plumatas alii probant,illíque teguntur. Crifpus, Equis paria operimenta erãt, quę lintheo ferreis laminis in modum plumæ annexa erant, Virgil.quoo,

Spumantémque agitabat equum quem pellisaënes

In plumam fquammis auro conferta tegebat.

Iuftinus epit. Trog.Pompe. lib.xli. Munimentum ipfis equífque loricæ plumatex funt, qux vtrumque toto corpore tegebant.

Baltheus eft non tantum militare cingulü,fue cingulus militaris quo cingun tur milites, fed etiam à quo arma dependent: nec ad humilicatem folum, verum ad infultationem nonnunquam \& iactantiam, vt Turnum habuiffe conftat.

Virgil.in xii. Infolix humero quum apparuit alto

Baltheus $\&$ notis fulferunt cingula bullis,

Pallantis pueri victum quem vulnere' $T$ urnus

Strauerat ato humeris inimicum infigne gerebat.

Clypei peditum tegmina funt, fcuta verò equitum.Virgil.in ix.

Et clypeum fupèr intonat ingens:

aut, Ip fe ingens clypeum fupra ipfum. Lectum eft autem et hoc clypeum, vt pro bat Caper, quod magis debemus accipere,nam Homerum imitatus eft : neutro nãg genere et mafculino à doctiffimis artiú fcriptoribus vfurpatú inuenimus. Trabellius Pollio, llli clypeus aureus, vel vt grammatici loquuntur, clypeum aureum, fenatus totius iudicio in romana curia collocatus eft. Neutro quoque $\mathrm{Li}$ uius xxxv.ab vrbe cond. Aedilitas infignis eo anno fuit $M$. A emilii Lepidi, \& P.Aemilii Pauli,multos pecuniarios damnarunt, ex ea pecunia clypea inaurata. in faftigio Iouis ædis pofuerunt. Idem xxxviii. Et duodecim clypeaaurata ab æảilibus currulibus P.Claudio, \& P. Sulpitio Galbæ funt pofita ex pecunia qua frumentarios ad annoná comprehenfam damnauerant. Pacuuius, Clypea currum reliquit chlamide côtorta. Appellarút quoģ clypeum antiqui ob rotundita tem \& corium bouis in quo foedus Gabinorum fuerat defcriptum cum Romanis. A pud maiores enim fortium virorum picta erant fcuta, ecötra inertium\& tyronum pura erant: vnde eft, parmáque inglorius alba, id eft 
etiã qualibus apud Troiam pugnatum eft, auctore Plinio natu. hifto. xxxv, continebantur imagines, vnde \& nomé habuere clypeorum, non vt peruetfa grammaticorum fubtilitas voluit à cluendo: cluere enim antiqui pugnare dicebant. Clypei maiora fcuta fecüdum Seruium ab eo dicta, quòd celent corpus, à græco

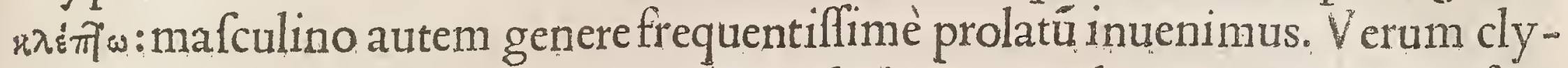
pea, vt alii volunt, neutro ad imaginem, vel picturam, vel ornamentum: mafculino verò genere ad fcuta referuntur. Clypeos Protus \& Atrius inter fe bellätes, fue Calthus Athamantis filius inueniffe prodütur. Cares quogs fuiffe tradit $\mathrm{He}$ rodotus qui primi fcutis figna fecerunt, $\&$ anfas quibus fcuta tenétur, quum antea fine illis, vterentur loris ex corio ad collum $\&$ ad finiftum humerum appendentibus. Horum autem materia com mendatur ex forma. Pœni ex aurofactita uere. M. Aufidius docuit maiores fuos argenteos clypeos habuiffe. Alexander rex Iudęorum octo milia pugnatorü Ptolomæo oppofuit, quos. Hecatómachos appellabat, hoc eft, contra centú pugnantes, cò $q$ clypeis æneis v térétur. Numidx coriis elphantorum fcuta fecife traduntur, impenetrabilia quidem iaculis, fed ea cafu inutilia fiunt: corii nanģ ea natura eft, vt imbrem fpógiæ modo ebibat, quo pondere preffa circüferri non poffunt. Ligneis faciendis preftant ligna fri gida, aquis innutrita, ac leuia, quorü plaga contrahit fe,protinúfog claudit fuum vulnus, $\&$ ob id contumacius tranfmittit ferrum : in quo funt genere fici, falix, tilia,fambucus, populus: leuiffima falix, ideo vtilior . Sed formæ placito fingulis ceffere: oblonga funt peditibus, nonnullis recurua teftudinéfque vocant:aliis ro, tunda, vt cæetra,pelta,vel parma.

Catra fcutum breue loreum, quo vtuntur Afri 8 Hifpani.

V1rgilius, Lauascatra tegit.

Pelta fcuti genus breuiffimi in modú lunæ iam medię, cætræ haud diffimile: vnde Maro, Ducit Amazonidum lunatis agmina peltis.

Parma fcutum breue, etiam fic dictum, tefte Varrone, quòd è medio in omnes partes fit par.

Ancile fcutum breue, cęlo, reganante Nuna Pompilio, delapfum, fic dictú propter figuram: circulus enim non eft, neq veluti pelta circunferentiam reddit, fed excifuram habet linex helicoidis, curus a pices curuaturam habétes, $\&$ denfitate in fe conuerfi,ancili- figuram faciunt. Ancile etiam frutum breue, inquit Feftus, quod ideo fic appellatur, quia ex vtrog latere erat recilum, vt fummum infimüóg eius latus medio pateret: vel dictú aincile ab ambecifu, tefte Varrone, q ea arma. ab vtraque parte vt thoracum incifa funt: vel vt Seruio placet in commento lib. viii æneid. Ancile fcutum breue atque rotundum, fic dictum, vel quòd vndique

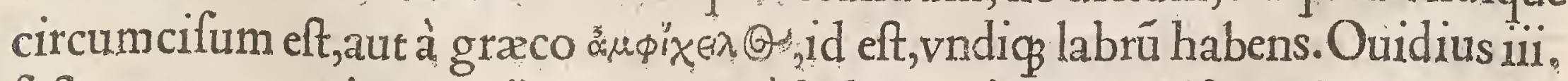
faftorum, Atgancile vocant quòd ab omni parte recifum eft, Quòd'g motis oculis angulus omnis a beft

Alii ex an quod eft circum, \& neni $\omega$, voluo dictum putant,aut propter \& \& eft,cubitum ad quem circumferunt: hoc enim lobbas inquit, cupiens nomen à greco deducere, Poffet primú hoc cognomé ab eo vel motu vel impetu defcédere

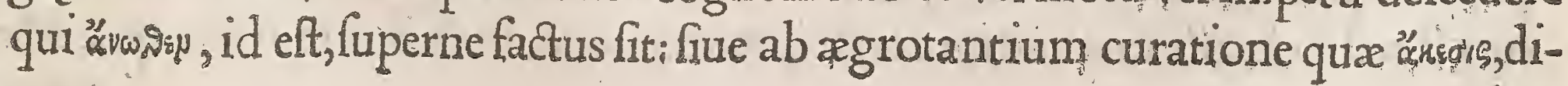




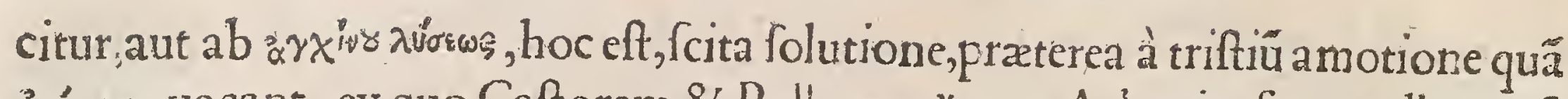

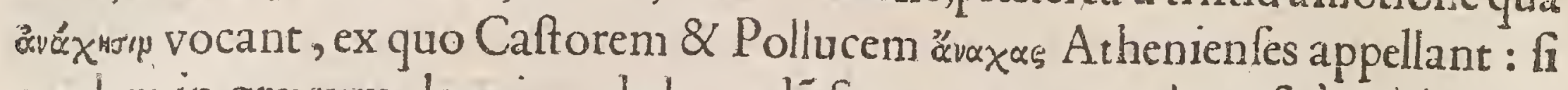

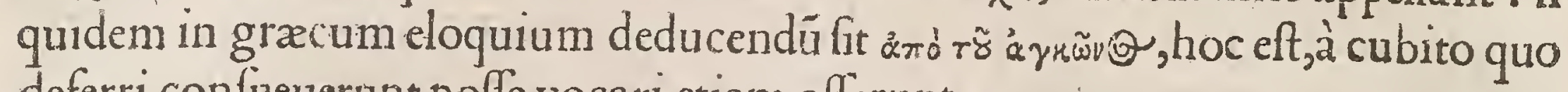
deferri confueuerunt poffe vocari etiam alferunt.

Sariffa dypeus' neus. Q. Curtius libro ix, ingens hic militum multitudo,inter quos erant Græci qui Dyofippo ftudebant: Macedo iufta arma fumpferat,eneum clypeum, quen Sariflam vocant, laua tenens, dextra lanceam, gladióque cin ctus veluti cum pluribus dimicaturus. જód $\Theta$ græcum eft, $\&$ proprie veluti fcutü breue quod in medio tecto eft, in quo trabes coèunt, $\&$ ad quod dona fufpédi cófueuerant. Statius fecundo Thebaid.

Hic ego nuaiorum pugnas vultusíg tremendos,

Magnanimûm affigam regum, figamque fuperbis

Arma tholis quáç iple modo quxfita reuexi

Sanguine,quxóp dabis captis Tritonia Thebis.

Vmbo fcuti pars media quafí vmbilicus: vmbo etiā fcutû fxpe fignificat. Nam à parte totum intelligimus. Virgilıs in decimo

Inde aliud fupérque aliud figít que volatóp,

Ingenti gyro fe fuftinet aureus vmbo.

Ocrę crurum regnina, quòd opponebãtur ob crus dif̊x. Liuius ix.ab vrbe con dita,Et finiftum crus ocrea tectum, galex'óg criftatæ qux fpeciem magnitudini corporum adderent. Eas verò \& criftas galearum feruntur Cares tradidiffe, fed galeam Lacedæmonii inuenerunt.

Péto rufticum calciamentü, à Graciæ more vbi hoc armorum fuerat genus tractum, \& Hernicis à poéta nobiliffımo affignatum vnde ifti trälierant: proinde funt in lib.vii. Vurgilii illi verfus, quibus Hernici populi \& cormm nobilifimivt tunc erat ciuitas Anagnia,enumerantur:

Quos diues Anagnia palcit,

Quos Amafene pater,non illis omnibus arma,

Nec clypei currúsve fonant, pars maxima glandes.

Liuentis plumbi f pargit,pars fpicula geftat

Bina manu,fuluólque lupi de pelle galeros

Tegmen habent capiti,veftigia nuda finitri

Inftituere pedis, crudus tegit alcera pero.

Hunc moréin ltalia fuiffe vt vno pede calciato, \& altero nudo iretur ad bellum, nufquam adhuc, quod fciam, reperi, fed eam Gręcorü nonnullis cófuetudınem fuiffe, locupleti auctoritate iam palam faciam: in qua quidem re imitari eft po exæ inclyti occultifimam diligentiam, qui quum legiffet Hernicos quorum eft A nagnia à Pelafgis oriundos, appellatosóg ita à Felafgo quoda m duce fuo gui Hernicus nominabatur, more quem de A etolia legerat Hernicis affignauit, qui funt vetus colonia Pelafgorum. Et Hernicum quidem, hominem pelafgum, du cem Hernicis fuiffe, Iulius Higinus in libro lecundo vrbium non paucis verbis probat: Morem veró Aetolis furffe, vno tantummodo pede calciato in bellum are, oftendit clarifimus Euripides fcriptor tragicus, in cuius tragoedia qua. Me- 
leager infcribitur,nuncius inducitur defcribens quo quifog habitu fuerit ex du cibus qui ad aprum capiendum conuenerant, in qua animaduertitis, diligentiffimè verba Euripidis à Marone feruata: ait enim ille, \& eúdem pedem nudum. Virgilius quoque dixit, Veftigia nuda finiftri Inftituere ped is.In qua quidem re quo nobis ftudium noftrum magis comprobetur, non reticebimus rem pauciffimis notam, reprehenfum Euripidem ab A riftotele fecûdo de poêtis libro,qui ignorãtiam iftiufnodi Euripidis fuiffe contendit: Aetolos enim non læu um pe dem nudum habere, fed dextrun: quod ne affirmem potius quàm probem, Ari ftotelis verba funt in eo libro,quem de poểtis fecundo fcriptum reliquit, in quo de Euripide ea locutum inuenies. Hæc quum ita fint, Virgilium tamen Euripide auctore, quàm Ariftotele vti maluiffe conftat: nam vt hæc ignorauerit vir tam anxie doctus,minime crediderim. Iure autem prætulit Euripidế: eft enimi ingens ei curn græcarum tragodiarum fcriptoribus familiaritas, quod ex multisdictis eius licet opinari.

Scanfilis ferri in equos vfum, adminiculum apud veteres tam Græcorum $\tilde{q}$ Latinorum fuiffe haud inuenio.V irgilius in duodecimo,

Infrænant alii currus, aut corpora faltu

Subiiciunt in equos, $\&$ diftrictis enfibus adfunt.

Idem in eodem,

Turnus vt Aeneam cedentem ex agmine vidit,

Turbatosóg duces fubita fpe feruidus ardet,

Pofcit equos atq̧ arma fimul faltuóg fuperbus,

Emicat in currum $\&$ manibus molitur habenas.

Vegetius lib.prim. Non tâtum à tyronibus, fed etiam à ftipendiariis militibus falitio equo diftricte eft feniper éxacta, que vfum vfoß ad hanc xtatem licet iam cum diffimulatione perueniffe manifeftü eft. Equi lignei fub tecto hyeme, xftate ponebantur in campo, fuper hos tyrones primo inermes dum côfuetudinem perficerent,deinde armati cogebantur afcendere, tantaóg cura erat vt nó folum à dextris fed etiam à finiftris partibus $\&$ infilire $\&$ defilire condifcerent, euaginatos etiam gladios vel contos tenentes, hoc enim affidua meditatione faciebât, fcilicet vt in tumultu pralii fine mora afcénderent, qui tam ftudiofe exercebantur in pace. Liuius fecundi belli punici lib.iii. Nec omnes Numidax in dextro lo cati cornu, fed quibus defultorum in modú binos trahencibus equios inter acerrimam fxpe pugnam in recenten equum ex feffo armatis tranfultare mos erat: tanta velocitas ipfis táf́p docile equorum genus. Xenophon Socraticus in eo libro qui equitum prafectus infcribitur, Poftquã verò equites quales effe oporteat dictum eft,qua nam parte equites optimi comparentur hoc in medium cona bor exponere. Ex his igitur iuniores impellere atque adhortari debemus, vi in equos infilire difcant. Huius autem rei magiftrum pręceptoremọ́ qui adhibuerit,iure laudabitur: natu aute grandiores affuefacere vt in fcandendis equis perfico more fe inuicem adiuuent. Plutarchus in vita Gracchorü, Dimenfo præterea viarum fpatio fingulis miliariis(eft autem miliariú paulo minus $\mathrm{q}$ octo ftadia)columnas lapideas fpatii figna proferentes conftitutas:alios infuper lapides 
parum inter fe diffantes ex vtraqg viarum parte difpofuit, vt ex illis faciliter \& fine faltu in equos effet a cendere. Huius rei præter hæc teftes $\&$ indices funteti am arcus in vrbe romana trium phales, ac æneus apud̊ Lateranum equus abfq huiufmodi fcandendi adminiculo cum equite \& feffore fuo.

Calcar,agitandi cócitandióp equi ftimulus eft, à calce denominationem afcifcens. Ouidius,

Non nocet admiffo fubdere calcar equo.

In eo autem quod vi. anei. fcribitur, Seu quúpedes iret in hoftem, Seu fpumantis equi foderet calcaribus armos, fpeciem pro genere pofuit Maro, hoc eft,equi armos pro equo, quú nó poffint armi calcaribus fodi: vtộ hoc ad concitandú, fic virga ad regendum equum diuerfarum gentium inftitutum fuiffe prodicur. Valerius Maxi.lib.tertio de.P. Craffo, Inter Eleã,inquit,et Smyrnã exceptus, ne in deditioné cius pueniret, dedecus arceffita ratione mortis effugit. Virgã enim qua ad regendú equum vfus fuerat in vnius barbari oculú direxit, qui vi doloris accenfus, latus Craffi fica confodit. Lucanus in quarto,

Et gens qua nudo refidens maffilia dorfo

Ora leui flectit frenorum nefcia virga.

Que arma ad nocerdum apta, inftrumentág; bellica quibus nominibus explicentur.

Cap. IIII.

Var fuis nominibus ad tegendum funt arma dixiffe videmur, nunc 1. 1 ad nocendum que funt reliqua profequamur. A cinacis, gladius mili 1. 1. 2. cet poni poffit.Q.Curtius lib.vi. Sed pręter clypeum eius putrem, \& arcus duos Scythicos \& acinacé nihil reperit. Hieronymus lib.i.cótra louinia num, Strato regulus Sidonis manu propria fe volens cófodere ne immirétibus Perfis ludibrio foret, gladü qué arripuerat circúfpectans, holium pauidus ex fpe ctabat aduentum, quem iam iámque capiendum vxor intelligens, extorfit acina cem è manu, \& latus eius tranfuerbetauit.

Enfis \& gladius huius naturæ funt,auctore Qunitiliano infti.libro ix. vt idê pluribus vocibus declarent, ita vt nihil fignificationis quo potius vtaris interfit. Macrobius.i de fomnio Scipionis, Nunc videamus que fint hæc duo nomina quorum pariter meminit cum dicit, Qux fidera \& iftellas vocatis, neogenim hic res vna gemina appellatione monftratur, vt enfis $\&$ gladius.

Gladius, quem auctore Plinio.vi.natur. hifto. à Lacedęmoniis cóftat inuétú, tefte Varrone, c in g cömutato à clade dicitur, $q$ fit ob hoftü cladê, vtóp dupödii nomé quod dicitur à multis duobus modis, hic dupódius $\& 2$ hoc dupödium, fic hoc gladium \& hic gladius. Quintilianus lib.i.infti. Et gladia qui dixerunt,ge nere exciderunt: fed hoc quoque notare contentus fum, ne arti quorundam culpa peruicacium perplexæ videar $\&$ ipfe quxftionem addidifle.

Spatha, enfis, fue gladius, nomina funt omnibus penè nota. Liuius trigefimonono, $\mathrm{Vbi}$ omnia fuga completa, vidit, Cato ipfe ad fecundam legionem qua in fubfidio pofita erat reuehitur, \& figna præ feferri plenóg gradu ad caAtra holtium oppugnanda fuccedere iubet, fi quis extra ordinem auidius procurrit, \& iple inter equites f patha percutit, \& tribunos centurionéfque caftigarê iubet. 
jubet. Hoc vocabulum in veterum etiam libris feriptüinuenies, 8 apud A. Gellium noctium fuarum libro decino.

Harpe falcatus enfis quo vfus eft Perfeus in occifone Gorgonis. Lucanus in ix. Harpen alterius monftri iam cade rubentem. Idem in eoden,

Perfeos aduerfi cyllenida dirigit harpen,

I.ata colubriferi rumpens confinia colli.

Maro in feptimo, Læua fceptra tenet falcati cominus enfes.

Linguam veteres dixere gladiolum oblögum in fpeciem lingux factum, cus aus meminit Neuius in tragoedia Ixione.

Machæra gladius longus exaltera parte acutus,à grecco: nam Gręci waxis" lon gum vocant. Cx́ar.ii. commen. Ad multam noctem etiam ad impediméta pu gnatum eft, propterea quòd pro vallo carros obiecerát, \& è fuperiore in noftros venientes tela coniiciebant:nonnulli inter carros rotasø̧ machæras \& ftragulas fubiiciebant noftrófque vulnerabant. Seneca libro quinto de benefi.ad Liberalem, Nec galea m illam fi videris agnofces: machæra enim hifpana divifa eft .

Dolones gladii funt. Plutarchus in vita Gracchi, Nec fecus paratis clàm percufforibus, necem Tyberio machinabantur: ille verò palàm gladium quem dolonem vocant accinctus ambulabat. Dolones aliorum fententia, flagella funt intra quorum virgam pugiones latent: aut fecundum Varronem ingens contus cum ferro breuiffimo, à dolo vel à fallendo dicti, quòd decipiant ferro, quum fpeciem praferant ligni. Sunt \& qui velint perteretes mucrones, dolones dici: \& Maro inquit,

Pila manu lruosóp gerunt in bella dolones.

Sica à fecando dicta, eft enim gladius breuis quo maxime vtuntur qui apud Italos latrocinia exercent, à quo \& Sicarii dicti:quanquam auctore Quintiliano libro nono inftitutionum, per abufionem Sicarios omnes vocamus, qui cædem telo quocung commiferint.

Pugio gladius breuis \& bis acutus lateri adhęrens, fic dictus Fefto tefte, quòd co punetim pugnetur: eft \& pugio fecundum Varroné ingens contus cû ferro. Clunadum cultrum fanguinarium dictum eft, vel quód ad clunes depédet, vel quòd clunes beftiarum diuidit.

Secefpitam cultrum fer reum dicunt oblongum, manubrio éburneo rotundo folido, iuncto ad capulum argéto a uróg, fixo clauis æneis are cyprio, quo pon tifices flamineśǵg ad facrificia v́tebátur,à fecando lecefpita dicta : alii fecurim, alii dolabram æneam efle putant.

Mucro,enfis \& gladius idem funt. Prifcianus artis grammaticæ lib.ii. Syno. nyma tam propria quàm appellatiua inuenuntur, ficut en fis, gladius, mucro, vnủ atq ide fignificãt: ficut P. Cornelius Scipio A phricanus, vnum atque idem fignificát. Boêtius de trinitate, In rerum enım numero nô facit pluralitatem vni tatum repetitio: vt fi de codem dicam gladius vnus, mucro vnus, enfis vnus. Poteft enim vnus tot vocabulis gladius agnofci. Hxc enim vnitatum iteratio potius eft, non numeratio: veluti fi ita dicamus, enfrs, mucro, gladius, repetitio quaedã eiưldé non numeratio diuerforú: velut fi dicâ, fol, fol, fol, vnus fol, nó tres 
foles effecerim, fed denuo totiens predicauerim. Idem in eodem, Recte repetitio magis de eodem quàm enumeratio diuerfi videtur effe, quum dicitur, Deus pater, deus filius, deus fpiritus fanctus, at $\$$ hac trinitas vnus deus: vel enfis, ato $\mathrm{g}$ mu cro, vnus gladius: veluti fol, $\mathrm{fol}$, $\mathrm{fol}$, vnus fol.Idem paulo infrà in codem, Non veró ita dicitur filius ac firitus fanctus quaf multiuocum quiddam: nã mucro enfis ipfe eft \& idem, pater verò ac filius \& fpiritus fanctus idé quidé eft, nó verò ipfe. Liuius lib.vii.ab vrbe cond. Gallus velut moles fuperne eminens proiecto læua fcuto, in aduenientis arma hoftis vanum cæefm cum ingenti fonitu enfem deiecit, Romanus mucrone furrepto quum feutum feuto percuffiffent. Mucro,enfis quog vel gladii vel cuiuflibet rei acumé dicitur. Liuius ab vrbe cond.xxii. Gal lis Hifpanifque fcuta eiuldẽ formæ erant, ferè difpares \& diffimiles gladii.Gallis prælongi ac fine mucronibus. Hifpano punctim magis quàm cæfim affueto petere hoftem breuitate habiles cum mucronibus. Seneca ad Lucil. lib.xi. Gladium bonum dicere non cui auratus eft baltheus, nec cuius vagina genus diftin guit,fed cui $\&$ ad lecandum fubtilis acies eft, $\&$ mucro munimentum omne rupturus.Macrobius lib.i.de fomno Scip. Nam \& Dionyfus aulę fidereæ inclemé tiffimus incubator, familiari fuo cuidam folam beatam exiftimanti vitam tyranni volens quàm perpetuo metu miferam, quámq impendentium femper periculorum plenam oftendere, gladium vagina raptum $\&$ capulo de filo tenui pendentê mucrone demiffo iuffit familiaris illius capiti imminere inter epulas: vnde etiam à poéta clariffimo dictum eft in xii.

Illa manu moriens telum trahit, offa fed inter

Ferreus ad coftas alto ftat vulnere mucro.

Omnes hæ denicg gladiorum fpecies vaginis abduntur.

Aclides, auctore Seruio, tela funt quadam antiqua adeò vt nequicquam com memorentur in bello. Legitur tamen quod claue, cubito femis eminentibus hinc \& hinc acuminibus in holtes ita iaciuntur religatæ loro vel lino, vt peractis vul neribus polfint redire : putantur tamen effe teli genus quod in flagello immerfum iaci poteft dicente Marone,

Teretes funt aclides illi

Tela,fed hac lento moseft aptare flagello.

Telum vulgo id appellatur quod ab arcu mittitur manu,vtlapis, lignä, fuftis,

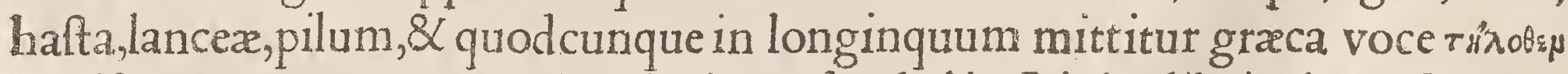
fignificatum, quanquam etiam legimus de gladio. Liuius lib.i. Arma his imperata, galea, clypeus, ocreæ, lorica, omnia ex ære: hæc vt tegimenta corporis effent, tela in hoftem haftáģ \& gladius. Seneca lib.xv. epift. de diuitiisloqués,lllx, inquit, neminem lædunt, nec fua cuiquam nocet fulticia aut aliena nequitia: fic quemad modum gladius neminem occidit, $\&$ occidentes telum eft. Virgilius, At non hoc telum mea quod vi dextera verfat Effugies.

Verutum telum breue \& anguftum, Nonio tefte. T. Liuius ab vrbe cód. deci mo, Quibus plerifg in fcuta verutis, in corpora ipfa fixis,fternitur cuneus. Idem in primo, Arma mutata,nihil præter haftam $\&$ verutum datum. Vegetius lib. fecúdo quú de miffilibus loqueretur \& de vno ac maiore dixiffet, Aliud, inquit, 
minus ferro vnciarum quinque, haftili pedum totidem \& femis, quod tunc verutulum nunc verutum dicitur.

Fuftes funt quos palos ruftici vocant, quíg inter prima humani generis arma fuere. Baculus à Baccho fecundum Rabanum \& plerofque alios repertus \& appellatus, vfu communi mafculinum eft, fignificationem habens notifimam. Liuius lib.primo, Augur ad lauam eius capite vela to fedem cepit, dextera manu baculum fine nodo aduncum tenens, quem lituum appellarut: diminutiuum tamen neutro genere bacillum habet. Cicero ii. de fin.bono. Bacillum aliud in. flexum, aliud ita natum. Primitiuum etiam quod eft baculus, baculum neutro genere prolatum inuenimus. Apuleius magiz lib primo, Veruntamen hoc $\mathrm{Di}$. ogeni \& Antiftheni pera \& baculum, quod regibus diadema, quod imperatoribus paludamentum, quod pontificıbus galerum, quod lituus auguribus.

Ouidius xv.metam. Effe folet, baculúmqne tenens agrefte finitra.

Vindicta virga prætoris qua ferui percuffiliberantur $\&$ libertatem acquirunt, vendico dicta, quia per eam vendicent libertatem. Perfius,

Ad dominum ignoras nifi quem vindicta relaxat.

Liuius lib.ii.ab vrbe cond.llle primum dicitur vindicta liberatus. Quidam vin dicta quoque nomen traçum ab illo putant, cui Viridatio nomen fuiffet, poft illum obleruatur vt qui ita liberati efent in ciuitatem accepti viderentur.

Verbera pro verberatione licet nonnunquam accipiantur, rem tamen corpo ream propriè fignificant, vt flagella qux funt propriè farmentorum fummitates.Quintilianus, Ignes ex proximo raptos, \& verbera qux cafus obtulerat.Iuftinus epit. Trog.Pomp lib.ii. Ad monentur Scythæ mutare genus pugnæ, memo res non cum hoftibus, fed cum feruis præliandú: nec armorü, fed dominorü iure vincendos: verbera, non arma in acié afferenda, omiflóg ferro virgas \& fiagella cækeráq leruilis metus inftrumenta paranda. Haftas Lacedæmonios inueniffe dicitur. Fraxinus obediẹntiflima, corilus melior, forbus lentior: ea Homeri praconio Achillis hat ta nobilitata eft. Haftilia minores lãcę funt ferro płoducto $\&$ quas manu iacere ars eft. Conti haft longiores funt $\&$ robuft $x$, fine ferro fed acuta cufpide. Iuuenalis,

Nocte iter ingreffus gladium contum que timebis.

Lancea quam Aetolos inueniffe vi.na. hifto. teftis eft Plinius, vt hafta manifeftam habet fignificationem, latinúlicet nomen non fit, fcriptumóp eft in libro M, Varronis rerum divinarum xxiii, quo in loco Varro quum de pectorico dixiffet effe id verbum gallicum, lanceam quoque dixit non latinum fed hifpanicum verbum effe: alii à græco dictum putant, quod Græci zórx le vocant,

Pilum Panthefilex licet inuentum, hafta romana, vt gefa Gallorum,\& lariffa Macedonú,id auctores dicút maximi, vfus in bellis, quòd huiufmodi hafta amen to equa lance fi pédeat \& ponderata vibretur, vbi excuffo lacerto valide intorta fuerit, vix armatura inuenitur qux vibrantis ictum fuftineat, eminus intortum vbi armis hæferit agitatione $\&$ motu continuo penetrare contẻdit, nec fubitum euitari poteft aut repelli, fed nec euelli holte premente. His Britanni maximè vf \& circumiacentes etiam infulae. Gefa Gallorum tela, frue viriles haftr. Nam 
\& vifos fortes Galli Gefos vocant: Liuius ix. Tere paftorali habitu,agreftibus telis, falcibus, gefiśǵ binis armati : funt qui à cędendo cæfa dici rectius putant. Ruma pilú,rumata pilata, tumex telum; fparo gallico quàm fimile. laculum quod cum amento Aetolum Martis frlium inueniffe ferunt telum etiam, quòd vi iaciatur fit, tefte Varrone, dictú. Spara,Pomp.telte, minimi generis iacula agreftia \& ruftica, à fpargendo dicta. Aemilius de excellentibus ducibus extera rum gentium, Epaminundam pugnantem \& f paro eminus percuffum concide re viderunt. Lucilius, Tum fpara, tum murices portantur ftragula porrò. Sparos maf.etiâ genere legimus. Saluftius in Catil. Sed ex omni copia quarta pars erat militaribus armis inftructa, cateri vt quofog cafus armauerat, fparos \& lanceas,alii præacutas fudes portare. Sariffa, ut Póp.placet,tefte Seruio eft hafta macedonica. Liuius ab vrbe cond. lib.ix. A rma clypeus, fariffx'g illis, id eft, ha ftx.Idem xxxvii. Ibi fimul perturbari ordines, \& impeditus intercurfu fuorum vfus prelongarum haftarum, fariffas Macedones vocant,intulere figna romanæ legiones. Idem xxxviii . Per oculi foramina prælongæ haftæ, quas fariffas vocant, ad fubmouendos hoftes emittebantur.Q. Curtius lib.vii. Prior Barbarus emifrt haftam, quam exiguus modica capitis declinatione vitauit,atque ipfe infeltam fariffam equo calcaribus concito in medio barbari gutture ita fixit, vt per ceruicem enineret, pręcipitatus ex equo barbarus adhuc tamen repugnabat, fed ille extractam ex vulnere haftam rurfus in eos dirigit.

Gibinam appeliant Illyrici telum venabulo finile. Ennius, Illyrici reftât fro cis Gibinífque fodentes. Securis quafi femicuris vel femiquiris, quod eft haAta: vel à gręco roís $\alpha \vartheta$ qui règé fignificat: cöftat autem Romanos Gręcosfuiffe, $\&$ erant fecures figna qux ante confulem ferebantur. Tragula eft hafta ferro præacuta, \& vt Varro inquit,à traiiciendo dicta,vt Pomp.teli genus, dictú quòd fcuto infixum trahatur. Cæfar lib.v.commentariorú,Monet vt tragulam cum epiftola ad amentum deligata intra munitioné caftrorum abiiciat. Liuius $\mathrm{xxv}$. Ibi fignis collatis pugnatum per quatuor fermè horas, egregién vincétibus Romanis fignum receptui eft datum, quòd $\mathrm{Cn}$. Scipionis ferrum tragula confixum crat. Claua teli genus quo Hercules vtebatur, fic dicta $q$ fit cla uis ferreis inuicem religata: claua enim, \& leonis pell is antiquo Herculi conueniunt, quo tempore arma nondũ erát a dinuéta, fed fuftibus homines iniurias propulfabant, ac ferarum pellibus tegebant pro arm is corpora. Hanc quidam Catheiam, quam \& Horatius Caiam vocat, dictam etiam putant,éfto Catheia gallici teli genus, quod fi ab artifice mittatur,rurfus venit ad eum qui mittit. Huius Virgilius me minit, Theutonico ritu folitos torquere catheias: Theutonico ritu dixit, quia Theutonici Galliæ comatx funt populi. Bipeninis dicitur, qu ex vtraque parte acutam habet aciem, quafi duas pennas: penum autem antiqui acutu dicebant: vnde \& auium pénę quafí acutæ. Quintili. lib.i.inf́titu. Quare difcat puer quid in literis proprium, quid commune, qux cum quibus cognatio: nec miretur cur ex Lcamno fiat fcabellum; aut à pinna, quod eft acutum, fecuris vtrinq habens acie bipennis, ne illorũ fequatur errorem, qui quia à pennis duabus hoc effe nomé exiltimant,pınnas auiú dici volút. Dolabra quafí duo labra, $q$ duo habe- 
at labra,ad dolandum, \& delendum, demoliendumóg. Liuius belli punicilib.ii. Tunc Hannibal occafionem ratus, quingentos ferme A phros cum dolabris ad fubruendum ab imo murum mittit.Idem in eodem, libro quarto, Dolabræ calonibus dividuntur ad vallum proruendum, foffá $f^{\prime}$ implendas, intra munimen ta inftruit acies. Idem in eodem, libro octauo, Eadem bem illata, $\&$ aliis partibus fecuribus dolabrifque cædebantur portæ. Iuvenalis libro tertio, Nodofam poft hæc frangebat vertice vitem

Si.lentus nigra muniret caftra dolabra.

Falarica genus teli miflilis, quo vtuntur ex falis, id eft, ex locis extructis dimican tes, vt Seruio placet, ingens telum tornofactum, ferrum habenscubitale, $\&$ rotun ditatem de plumbo in modũ fphære in ipfa fumnitate, dicitur 8 ignem habere affixū, hoc autem telo pugnatur de turribus quas falas dici manifeftú eft: A falis dicta falarica, ficut a muro muralis: fane falaricam Lucanus dixit neruis mitti tortilibus ex quadam machina,

Hunc aut tortilibus vibrata falarica neruis

Obruit,aut vafti muralia pondera faxi.

Virgilius verò in nono,fic ait Turnum manu iaculari potuiffe, quod à poéta vel poétice, vel in laudem \& virtutem Turni forte dictum eft, qui talem haftam ma nu iaculatus eft. Liuius ab vrde códita.xxii. Libro, Falarica erat Saguntinis mif file telum haftili ab ligneo, \& cætera tereti præterquam ad extremum vnde ferrum extabat, id ficut in pilo quadratũ fuppa circúligabät liniebantós pice. Fer rum autem tres in longü habet pedes, vt cú armis tranffigere corpus polfet: fed id maxime,fi hęfffet in lcuto,nec penetraffet in corpus, pauorem faciebat,quod quum medium accenfum mitteretur conceptúmque ipfo motu multo maiorem ignem ferret,arma admitti cogebat,nudumóp nilitem ad infequentes ictus prębebat. 


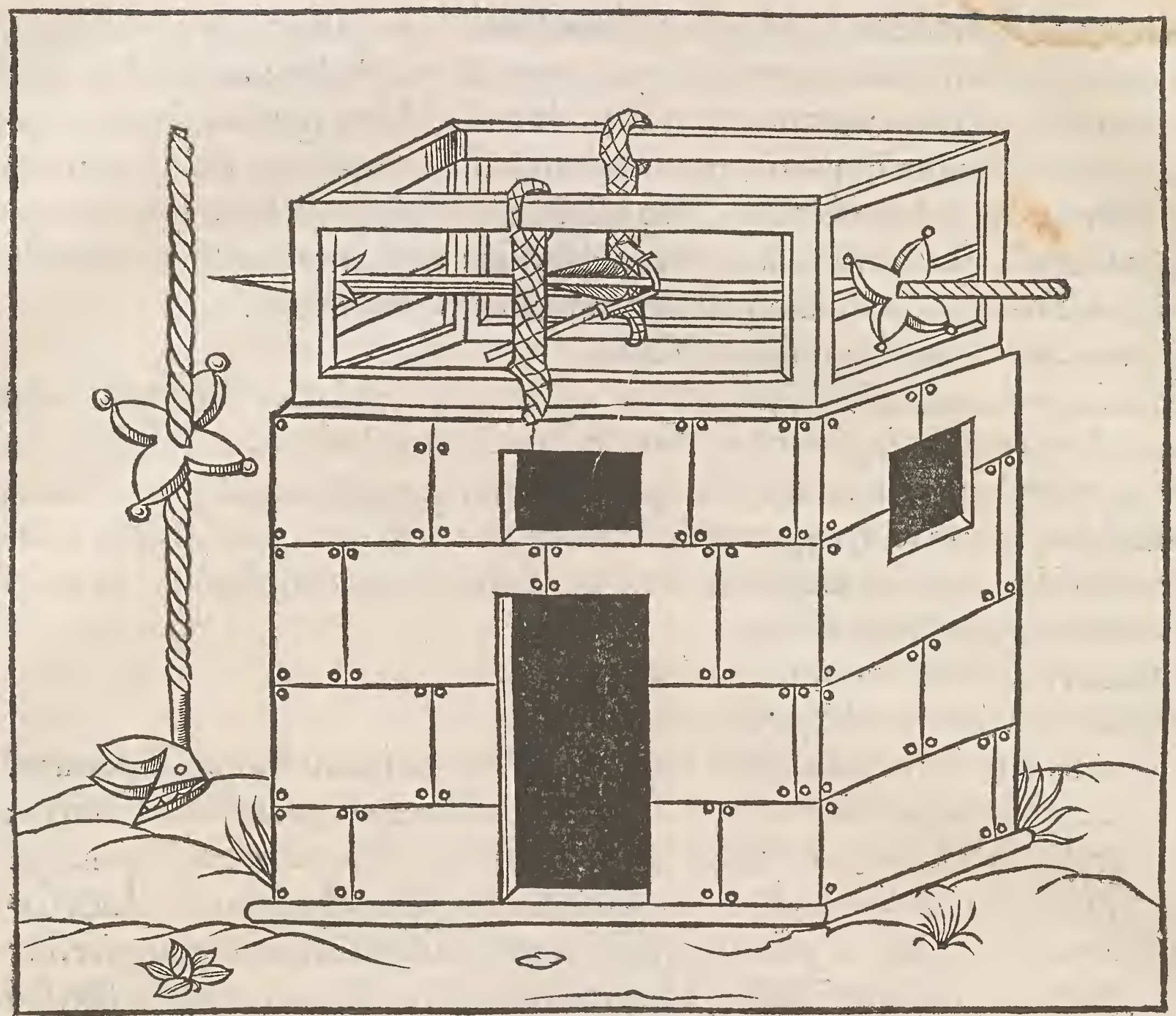

Malleoli tela funt in muliebris coli formam. Ammianus Marcellinus.xxiiii. rum geftarum, Malleoli autem teli genus figuratur hac fpecie, Sagitta eft cảnea inter Ipiculum \& arundinem multifido ferro coagmétata, qux in muliebris co li formam quo nentur lintea ftamina concauatur, ventre fubtiliter \& plurifariam patens, atque in alueo ipfo ignem cum aliquo fufcipit alimento, \& fic emiffa lentius arcu inualido: arcus ictu enim rapidiore extinguitur aftus incendiorum,nec remedio vllo quàm fuperiecto puluere vel amurca confopitur. Liuius xxxviii.ab urbe condita, Alii cum ardentibus facibus, alii ftuppam picémque \& malleolos ferentes tota collucente flammis acie aduenere. In huiuf́nodi autem malleoli concauo glutinum ignífque fomentum eft inextinguibile ex colophonio, fulphure, fale quẻ nitrum appellant, omnibus in lauri oleo liquefactis: fecundum alios, oleo, petreleo, adipe anatis, medulla cannæ ferulæ, fulphure: vt aliis vifum eft,ex olee oliuo, fepo, colophonia,camphora, refina,ftuppa. Hanc veteres compofitionem bellatores Incendiarium appellant. 


\section{DE RE MILITARI LIB. X.}

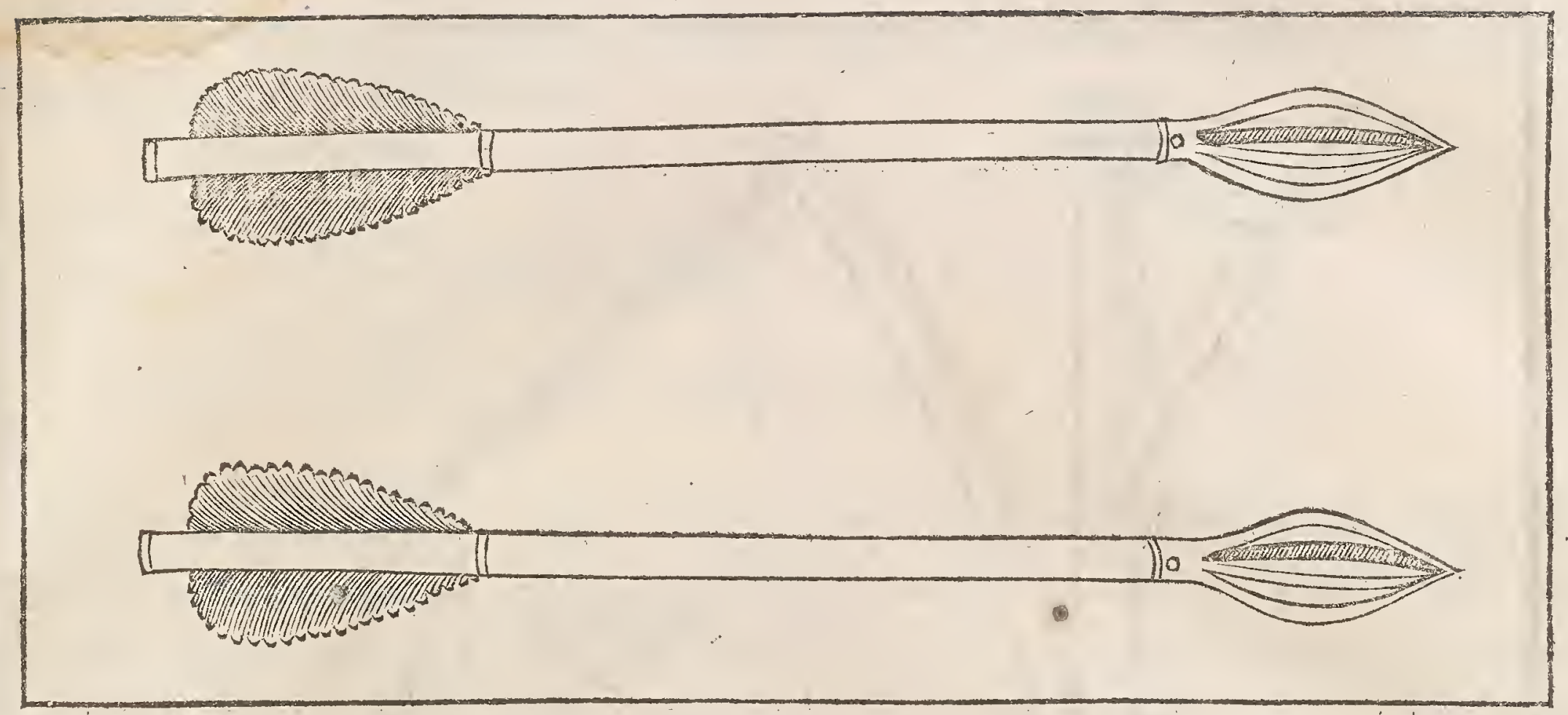

Miffilia haftilia,tela à mittendo dicta . Liuius, xxxii. Magna tormentorum etiam vis, vt miffilibus procul arcerent hoftem. Catapulta quam Plinius vi. natur. hifto. Cretes inueniffe perhibet, iaculum eft celer, vel fagitta, vt Nonius inquit.Cæfar,fiue alius pro eo commentariorum $\mathrm{x}$.Centonéfque infuper iniecerunt,ne vt tela tormentis miffa tabulationem perftringerent, aut faxa \& catapulta lateritium difcuterent. Liuius belli punici lib.i.Collatífque eò catapultis, fagittis, baliftífque vt caftellum in ipfa vrbe velut arcem imminentem haberet, muro circundant. Plautus in Gurgulione, A tque ita te neruo torquebo vt catapultrx folent.Idem in Captiuis,Nam meus eft balifta pugnus, cubitus catapulta, humerus aries. Catapultam etiam organum, bellicúmog inftrumêtum quo tricubitalia tela iaciútur, vfu doctiffimorum comprobatur auctorum. Pom. Trifax,teulm longitudinis trium cubitorum, quod catapulta mittitur. Victruuius libro decimo, Ex ratione grauitatis proportiones fumuntur, quemadmodum catapultis de longitudinibus fagittarum. Liuius belli punici libro primo, Ip fe Hannibal qua turris mobilis omnia munimenta vrbis fuperans altitudine agebatur,hortator aderat, qux quum admota, catapultis baliffífque per omnia tabulata difpofitis,muros defenforibus nudaffet.

Pars catapultz qux fune trahitur debet effe ex chalybe. 


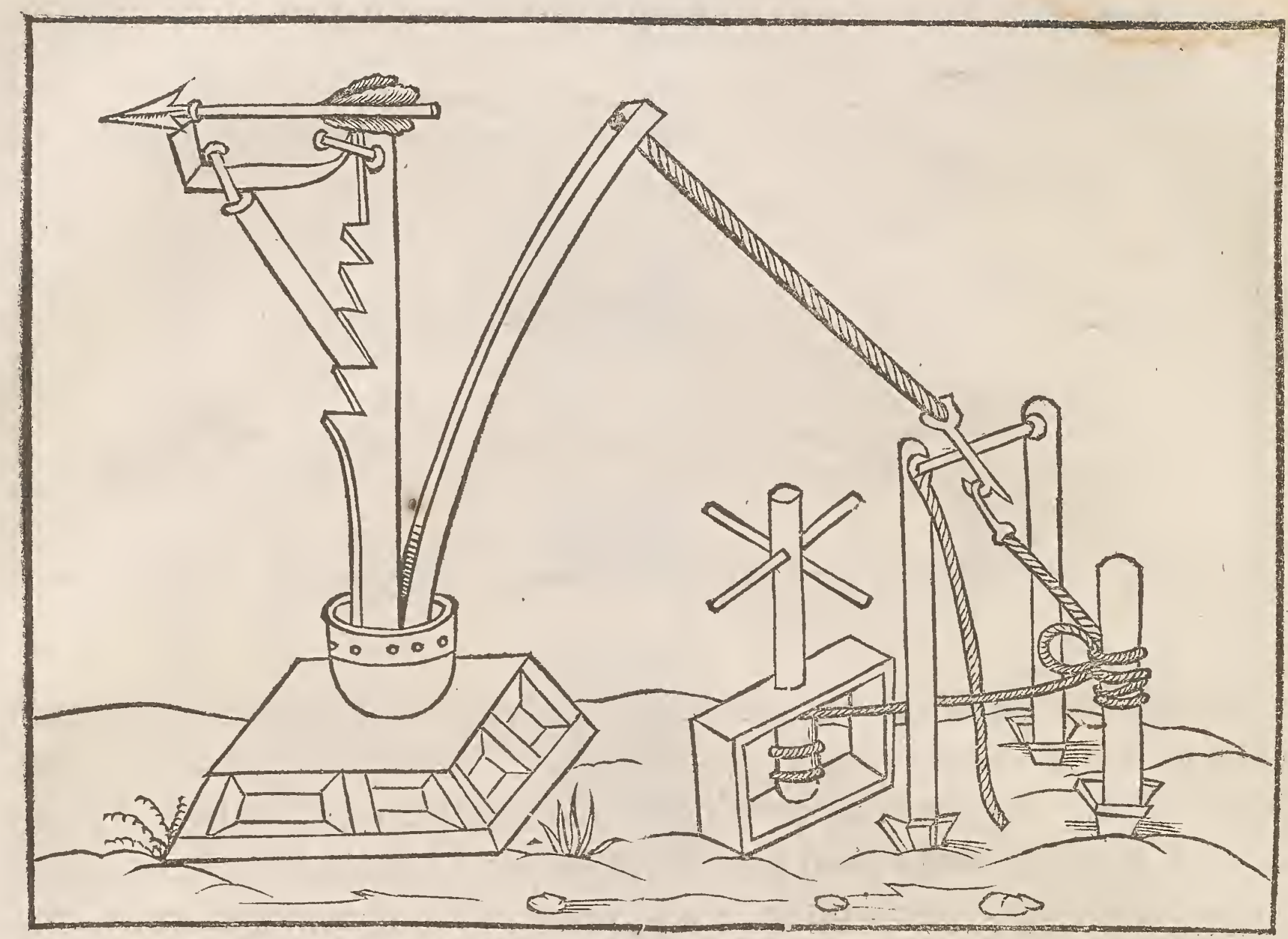

Romphæa, tefte A. Gellio noct. atti.lib. ix. genus teli eft thracæ nationis: apud alios frameam fpatham \& gladium licet fonet. Hoc vocabulum in Q. En nii annalium xiii. pofitum inuenies. Liuius ab vrbe condita xxxi. Thracas quo que romphæe ingentis \& ipfæ longitudinis inter obiectos vndique Romanos impediebant. Arcus quarte formæ ad iaciendas fagittas bellica inftrumenta, $\&$ veluti ances qux partes vrbis excelfæ atque munitæ funt:ab arcëdo bofte dieti,quanquam quantum ad arces fpectat fint, cum quibus eft Seruius, qui quòd arcana fecreta dicuntur, arces dictas putent quafi res fecretas: vel fint aliilicet, tefte Solino libro primo memorabilium, qui videri velint, quum Arcades in excelfa parte montis habitaffent, deriuatum deinceps vt tutiflima vrbium,arces nominarentur. Arcus infuper fagittandíque A pollinem ferunt extitiffe reperto ré, qua de caufa Cretéfes pręcipue arcu delectati funt, qué Scythicú nominarút.

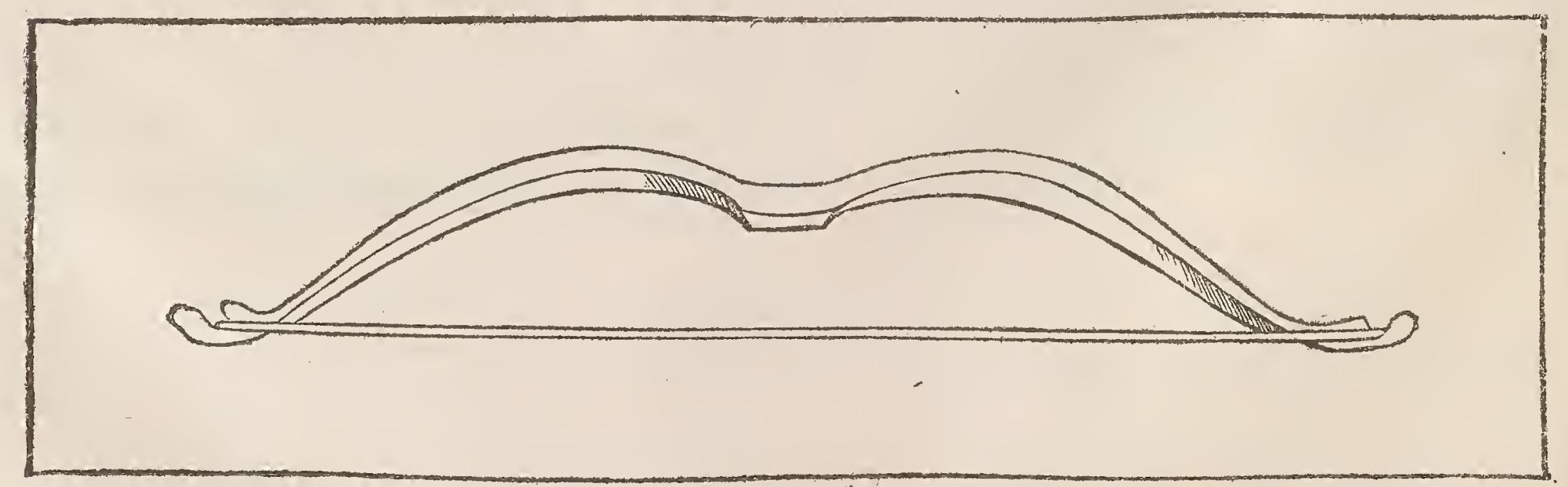


Coriti, propriè funt arcuum thecæ : dicuntur tamen effe fagittarum foruli, quos \& pharetras nominamus.

Virgilius in xii.

Quid tela, Sagittre,

Coritióp leues humeris \& latifer arcus.

Ouidius metamorph.

Exuit hic humeros pharetram lentośq tetendit

Arcus.

Scorpiones, vt inquit Vegetius libro quarto, dicebantur quos nune manuba liftas vocant, ideo fic nuncupati quòd de paruis fubtilibúfque fpiculis inferant mortem. Regum libro primo, Et Atatuit illic baliftas, \& maculas, \& ignis iacuLa, \& tormenta ad lapides iactand os, \& fpicula, \& fcorpiones ad mittendas lagic tas, \& fundibula. Cafar comment. lib.vii. Quidam ante portam oppidi gallus per manus feui ac picis traditas glebas in igne, \& regionem turris prohibebat, fcorpione à latere traiectus exanimatus concidit. Sunt \& qui fcorpionum ictibus non fagittas tantum fed et lapides mitti annuant. A mmianus Marcellinus rerum geftarum $\mathrm{xxv}$. Et fcorpiones quócumque manus perite duxiffent, rotundos lapides euibrabant. Idem vigefimoquarto, Scorpioni onagri vocabulum indidit ætas nouella, ea re quòd afini feri cum venatibus agitantur, ita eminus lapides polt terga calcitrando emittunt, vt perforent pectora fequentuü, aut perfractis offibus capita ipfa difplodant. Vegetius Renatus libro quarto, Per forpiones, fpiculis, faxis item grauioribus per onagrum deftinatis, non folum equi eliduntur, fed etiam hoftiu machinamenta franguntur. Nonius Marcellus fcor pionem teli genus effe afferit: alii à Nonio minus diffidentes, fcorpionem fagittam fed veneno oblitam effe aiunt, qux virus quó figitur infundit, vnde $\&$ for pio nomé accepit. Scorpiones huiufmodi à Scythis originem traxifie arbitror, illi enim viperea fanie $\&$ humano fanguine tinctis fagittis, quolibet vulnere, leuilicet tactu fed irremediabili illico mortem afferunt.

De his Lucanus,

Spicula nec folo fpargunt fidentia ferro

Stridula, fed multo faturantur tela veneno.

Vulnera parua nocent fatum'q in fanguine fummo eft.

Ad poltremùm fue Scytha fiue Cretefis fiue alio cælo genitus fuerit, qui fcorpi onem ad mittendas fagittas primus inuenit, aut proditor fane fuit, aut nocendi auidus, aut metuens holtis: cogitauit enim, quòd idemLucanus inquit, Longe tendere neruos, Et quó ferre velit committere vulnera ventis. 


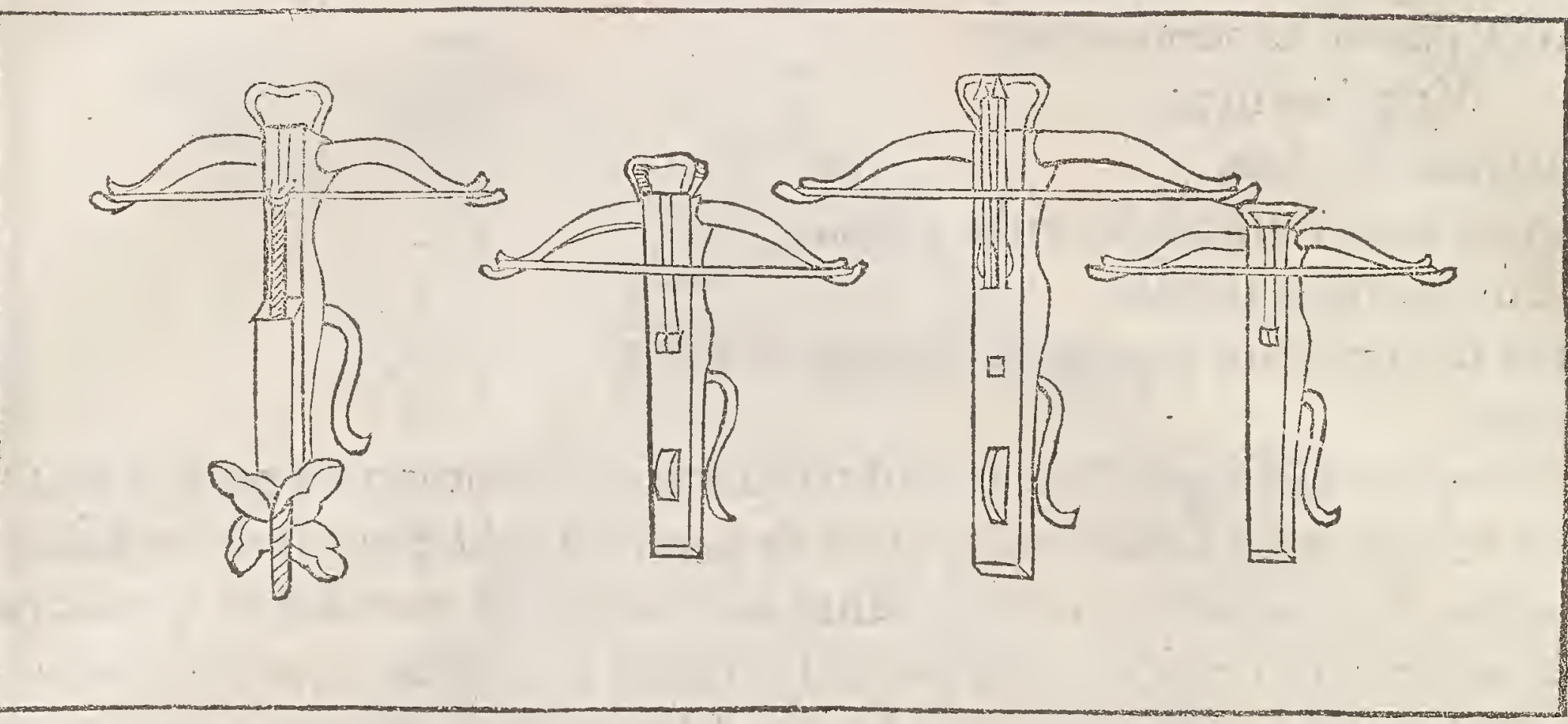

Sagitta à fagaci ictu, id eft, veloci vocata, vt quibufdam placet : fiquidem vt ocius mors perueniret ad hominem, alitem illam fecimus, pennasíg ferro adiecimus, quod fcelere humani ingenii, ac fraude inuentum arbitror. Has primú Cre tenfes, vt inquit Solinus, alii vt refert Plinius nat. hift. Saterem Iouis filium, vel Perfem Perfei filium inueniffe afferunt, frequênfque circa hęc orientalium vfus. Hi calamis fpicula addunt irreuocabili hamo variég mortem accelerat penna calamis addita,fitóg ex ipfis telum aliud priore facto in vulneribus. Hanc barba ram Sagittam appellant, huivfmodi telis folem ipfum obumbrant,propter hoc maximè ferenos dies optant,oderúntque ventos $\&$ imbres qui inter illos pacem effe cogút. Hic vfus in Creta bellatores fuos pręcipitauit. In hoc, vt in cæteris vicis Italia, in agro maximè Bononienfi, ac penes flumen Rhenum fagittis nullus aptior calamus eft, quibus pondus voluere effe contra flatus quoque peruicax.

Spiculum, fagitte præacutę ferrum. Curtius lib. feptimo, Quos dum obfidet rex, inter promptiffimos dimicans fagitta ictus eft, quæ in medio crure fixa reliquerat fpiculum. Idem in nono, Medici lignum fagittr, fcilicet corpori infixum ita ne fpiculum moueretur ab findunt, corpore deinde nudato animaduertunt hamos effe telo, nec aliter id fine pernicie corporis extrahi poffe, quàm vi fecundo vulnus augerent.

Murices, tribulos aiunt ferreos, qui tribus radiis abiecti quoquomodo fituentur ftant, \& erecto quarto infefti funt. Q.Curtius lib. quarto, Quum homo quidam tranffuga quanto maximo curfu ad regem peruenit, nuntians murices ferreos in terram diffudiffe Darium, qua milites emiffurú effe credebat, notatumóg certo figno locum, vt fraus euitari à fuis poffet. 


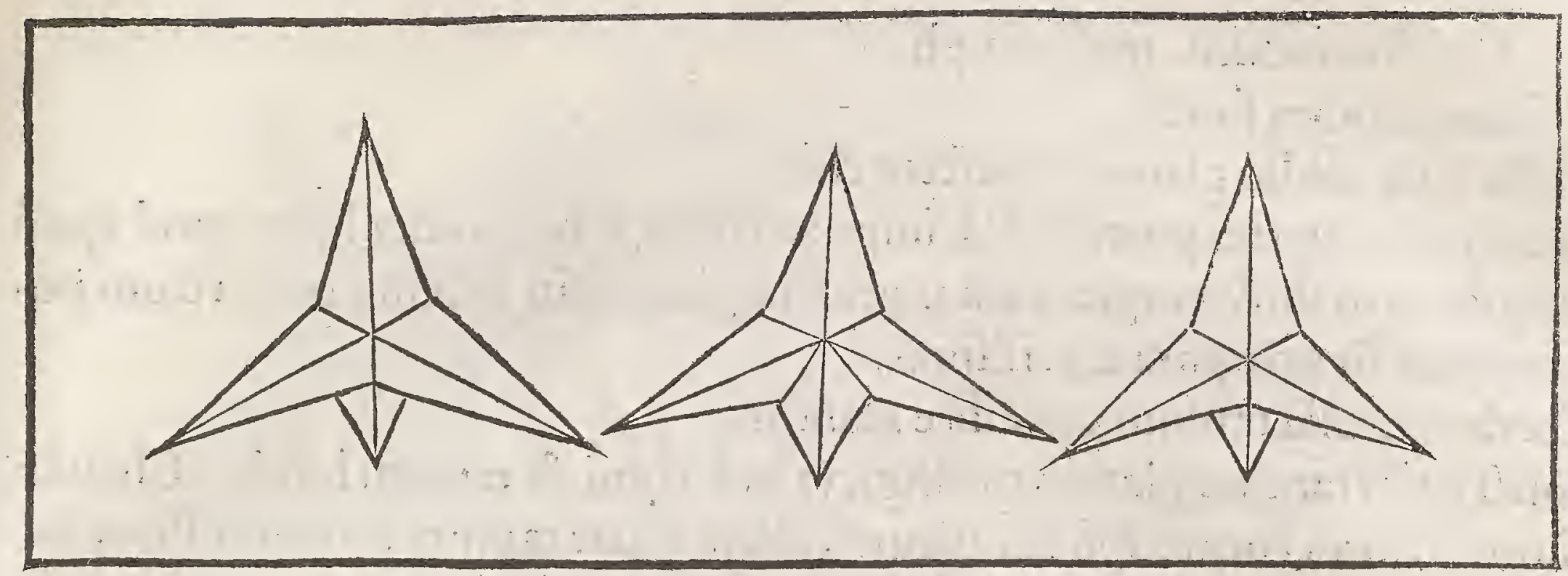

Scalprum,præacutum ad feriendum ferrum. Liuius belli Punici lib.vii. Ele phanti plures ab ipfis rectoribus quàm $a b$ hofte interfect, fabrile fcalprum cum malleo habebant: id,vbi fauire belux ac ruere in fuos coeperant, magifter inter aures pofitum ipfo in articulo guo iungitur capiti ceruix quanto maximo poterat ictu adigebat, ea celerrima via mortis in tantæ molis bellua inuenta erat. Scalpellum à fcalpro im minutum. Cicero.ii.de diuinat. Aut quorum lingue fic inhęrent vt loqui nó poffent, hæ fcalpello refectæ libera rétur. Hieremiæ xxxvi, Cumógleguffet ludi pagellas tres vel quatuor, fcidit illud fcalpello fcribę,et proiecit in ignem. Veruinz,genus aculı longi, tefte Fabio Placiade. Flautus in Bacchide,Si tibi machæra eff foris,at mihi veruina eft intus qua te \& illos con-

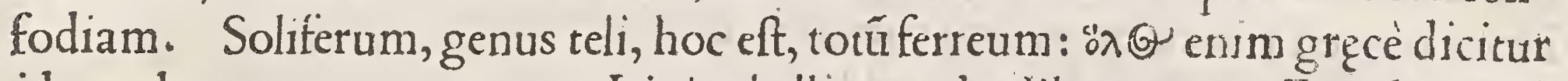
id quod nos totum vocamus. Liuius belli macedo. libro quarto, E $\mathrm{t}$ cohortes à tergo ftantes pauidi refpiciebant, vt emiffis foliferis falarcífque gladios ftrinxerunt. Funda, quòd ea fundantur lapides, id eft, mitiátur. Hoc telum habena volutatur in iactu,glánfog librata quư lederit, velut nesuo miffa excutitur. Liuius xxviii. Fundis vt nunc plurimú, ita tunc folo eo telo vtebãtur, nec quifquam alterius gentis vnius tantum ea arte quantum inter omnes alios Baleares excellunt,apud quos, vt inquit Flauius, matres à teneris vnguiculis ita natos erudiffe produntur ut nullum cibi genus cötingere finerent nifí quem ex funda immif folapide percuffiffent. Proinde funt qui Balearium infularũ habitatores huius telı vfum primos iaueniffe afferant, quàmquam Plinius natur. hifto.hoc idem apud Syrophonicas dicat inuentun.

Glans vel glandis, telum eft fue maffa plumbea inftar glandium qux funda baliftáve proiicitur. Claudianus iib.vii.

Nunc fpicula cornu

Tendere,nunc glandes baieari $\lceil$ pargere funda.

Saluftius in Iugur.Pars eminus glẩde, aut lapidibus pugnare . Virgilius in vi。 Pars maxima glandes Liuentis fpargit plumbi. 
Ouidius in xiiil. metamorph.

Vt lata plumbea funda,

Inifa folet medio glans intabefcere cælo.

Similiter Lucretius protulit \& Liuius.xxvii.ab vrbecondita. Nam quod apud Virgilium in iiii. Georgicorum inuenitur glandis, in dubium venit vtrum nominatiuus fit an figuratè genitiuus,

Nec de concuffa tantum pluit ilice glandis.

Poteft enim tantum glandis intelligi, vt hoc regni, \& tantum lucri. Chelido nium auctores vocant ipfi falcaftrum, altera parte tantum acie tenuifima fed latiore, vlnx longitudine, cauda bifurca ceu hyrundinis, vnde \& nomé habet: vaginis non conditur, fed vnco dependet à cingulo. Danica, fecures productiores quibus acies fubtilior, quibílque non modo Dani fed etiam alie gentes. iam vti coperunt : in vuiuerfum aurem qux pro te militari circa hæc cófideran da funt, ferramentorum genera fi oleo reftinguátur delicatior fit acies, aqua duratur in fragilitatem. Hyrcorum lang uinis táta vis eft vi ferramentorum fub. tilitas uec alıo acrius induretur. Ferrum aurem omne à rubigine tuetur oleum, ceruffa aut liquida pix. Falx lunatum ferrum haftx affixum, militare quon dam,nunc agrefte telum. Valerius libro quinto, Vnumquemq ex his falce percuffum in cadem fuam compulit. Liuius $1 x$. ab vrbe condita, lere paftorali habitu agreftibus telıs, falcibus, gefífque binis armati. Martialis, Fraus me certa ducis quon dam curuauit in vfus,

Agricolre nunc fum, milit is antè fui.

Fuit \& quondam falx riedum terreftris militiæ, fed \& nauticæ inftramentum. Erant enim Romanis inaudita magnitudine falces, quas cum artificiofo quodam impulfu rudentibus hoftium inieciffent nauigio rem is aduerfum acto, $\&$ rudentes veluc cultri acie ton' orii fcindebantur, \& antennæ fimul ac fuperba. ruebant arma méta, erántọ fuis impedimento nauibus quibus fuerant præfidio adiumentóque. A falce falcati etiam currus dicti: falcibus nanque præmuniebantur, atque in hunc maximè modum falcibus armati prodibät in bella. Cufpides circa temonem ab iugo decem cubita extenfas velut conna habebant, quibus quicquid obuium daretur träffigerent, in extremıs ingis binæ circà emi nebant falces, altera æquata iugo, altera inferior in terram deuexa: illa vt quicquid à latere obiiceretur abfcinderet, hæe vt prol apfos fubeuntéf que contingeret. Item in axibus rotarum vtrinque binx eodem modo figebantur falces, ex omni parte acie prominente, vt in fubiecta huiufcemodi currus defcriptione continetur. 


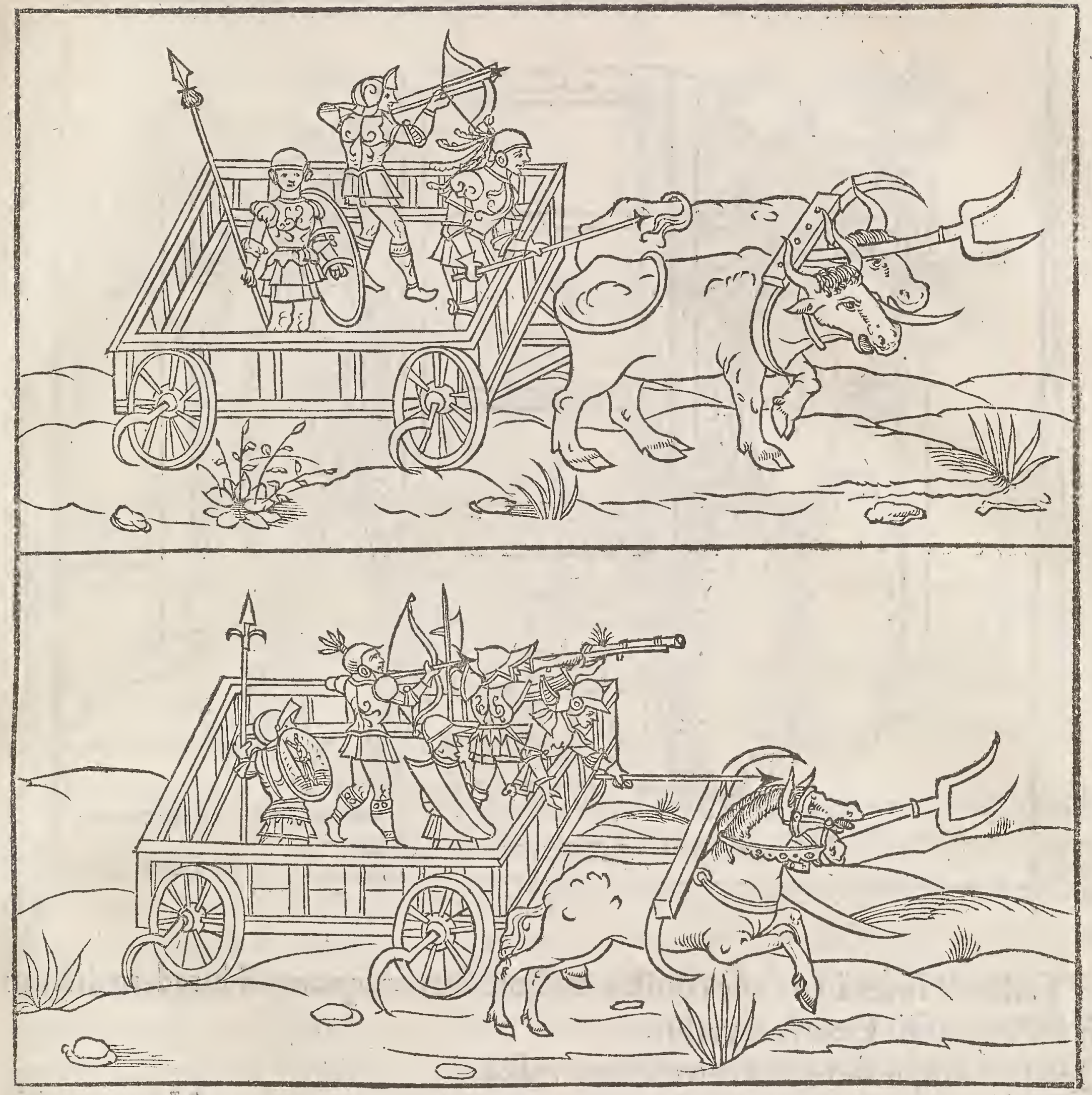

His quadrigis vt femper duces holtium acies perturbaturos fe credebant, in fuasterrorem perfxpe verterunt, vt Antiocho maximè contigit . Nam Eumenes vbi eas vidit, haud ignarus pugna, \& quàm anceps effet auxilii genus, fin quis pauorem magis iniiceret quàm iufta adoriretur pugna, fagittarios fundiroréfque $\&$ iaculatores equitum non confertos, fed quàm maximê poffet difper fos excutere iubet, 2 omnibus fimul partibus tela ingerere. Hac velut procella, partim clamoribus diffonis ita cófternauit equos, vt repentè velut effrenati paffim incerto curfu vagarentur. Romani murices ferreos in terrá fundebant gua holtes éniffuros quadrigas arbitrabantur : in quos cum incidiffene paulò pòft faucii, pigri,inutiléfque reddebantur. Eft \& alia mirifica bellici currus non falcati forma, fiabellis ventoque in hunc modum adacti. 


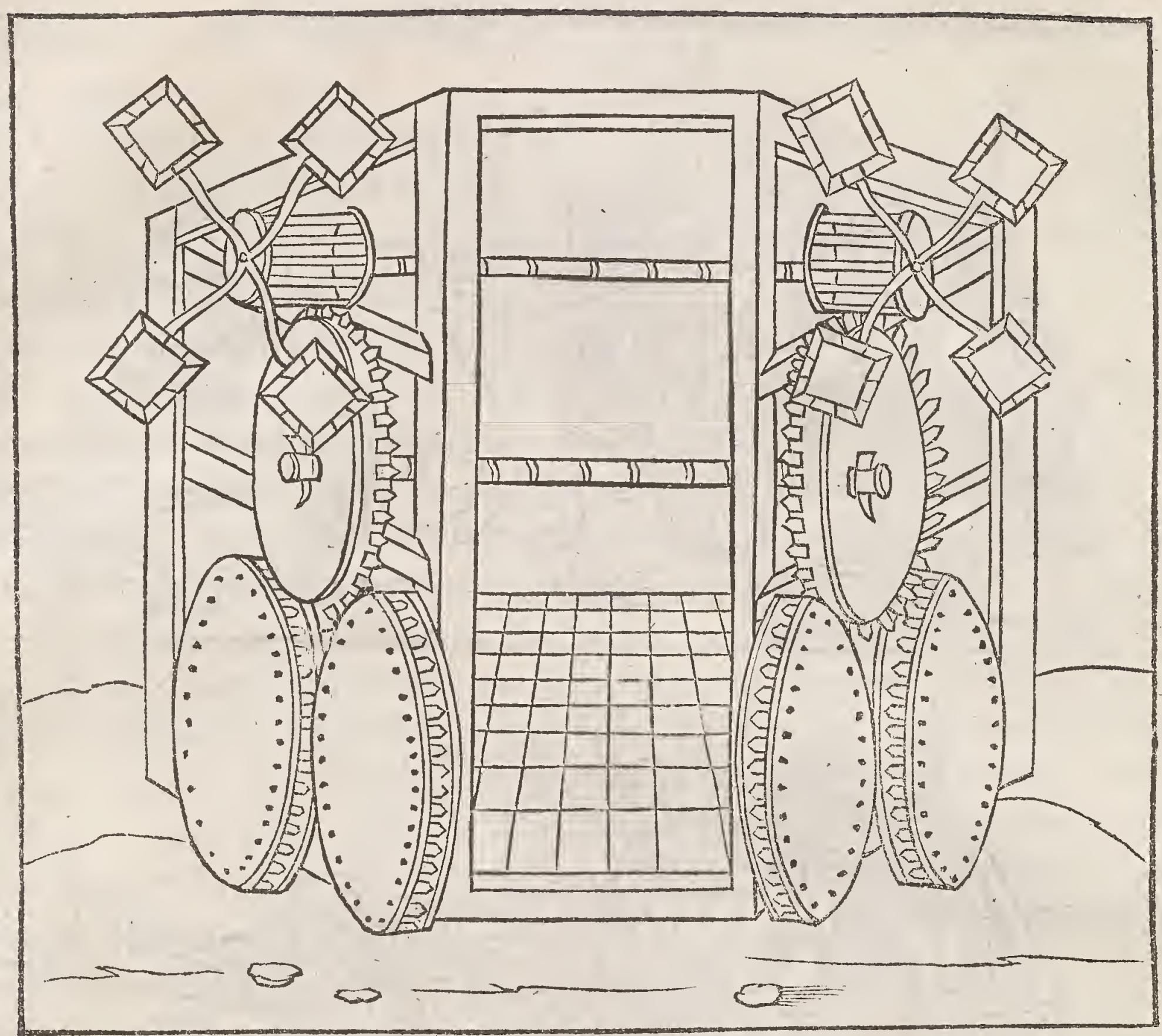

Vallos \& fudes idem effe conftat, auctore Seruio, quanquä bis iden diçum fit à Virgilio ii. Geor. his verbis,

Quadrifidálque fudes \& acuto robore vallos.

Valli nangue foffarum fuftes funt, quibus vallum præmunitur . Nam munitio ipfä proprè vallú dicitur neutraliter, licet mafculino genere Albius Tíbullus pofuerie, Non arces,non vallus erat, fummumíg patebat. Vallı etiam denomina tio, tefte Varrone, inde eft, quòd ea varica re nemo poffet, vel guòd fingula ibi extrema bacilla furcillatam habent figuram literæ $v$. Terra autem illa quæ vallo facto propius ponitur,agger propriè dicitur: abufue tamen, \& muros, \& muni menta omnia, $\&$ omné è terra lignisóg coaceruationé ad fubruédas vrbes quòd agantur \& ducantur,aggerem dicimus . Liuius lib.iii. bel. macedo. Thaumatos eo tempore fum ma vi expugnabat, aggeribus vineífque, $\delta^{\prime}$ iam aries muris ad motus erat.Idem in eodé, Omines inde fpes pugnãtibus, in vi, $\&$ armis, $\&$ cperihus erant: vidiq̧̧ aggeres haud facili aditu ad monia ad mouebäur. Idem in codem, lib. vi.Hęc milior difficultas Macedonibus erat, $\varphi$ R omani aggere, \& vi neis, \& omnibus fupra terram operibus aut praliis effent,fubter Macedones cuniculis oppugnabant. Idem in eodem, Sed armati frequentes quidam ignes,etiam quos agger bus iniicerent,ferebant. I dem in eodem, lib.vii.Vtrinque vineas \& aggerem muro iunxit, \& cum teftudinibus arietes admouit. 


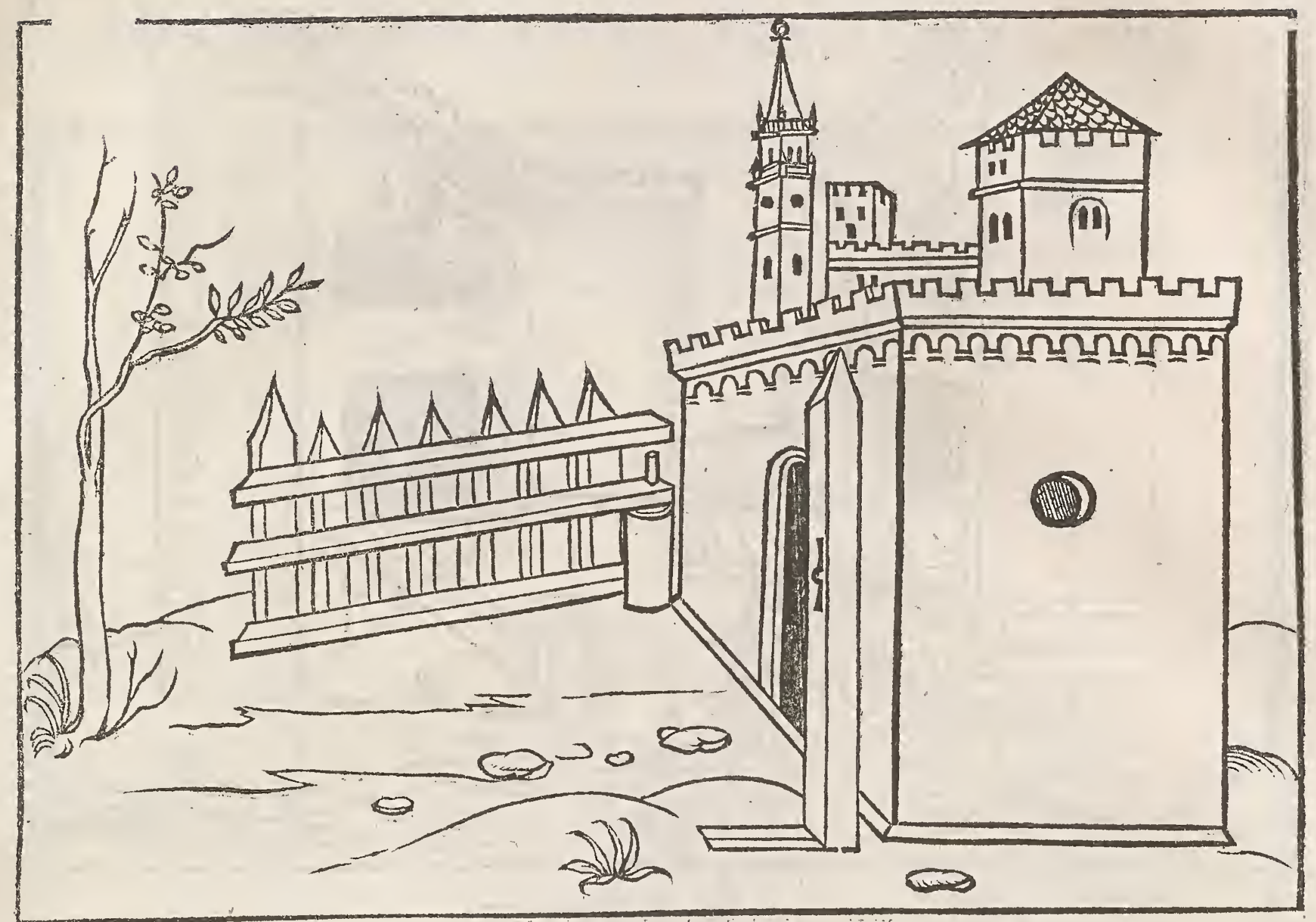

Cataracta phęneftra vel porta ferrea, crati perfimilis, qux annulis \& clauis ferreis à funibus pendet, vt fi holtes intrauerint, demiffa eadem extinguátur inclufi. Liuius.xxvii. Hannibal quarta vigilia fermè ad vrbé acceflit,primi agminis erant perfugæ Romanorum \& arma romana babebant : hi vbi ad portam eft'ventum, latinè omnes loquentes excitant vigiles aperirique portam iubent, confulem adeffe: vigiles velut ad vocem eorum excitari, tumultuanti trepidatione moliri, porta cataracta claufa erat:eam partim vectibus leuant, partim funibus fubducunt in tantum altitudinis vt fubire recti poffent: vix dum fatis pa tebat iter,cum perfugę certatim ruunt per portam, \& quum quingenti fermè in traffent, remiffo fune qua fufpenfa erat cataracta magno fonitu cecidit. 


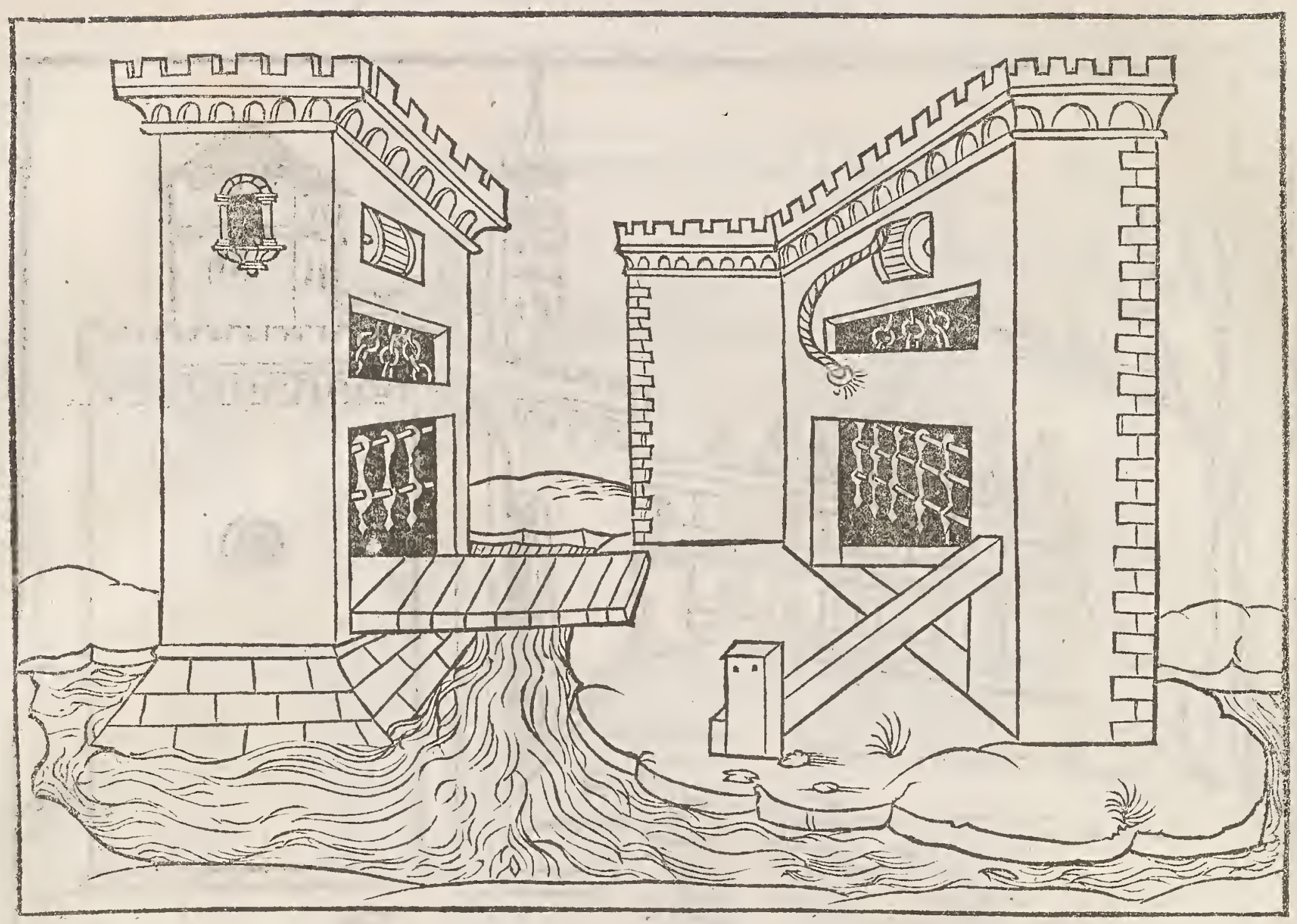

Infrumentum exurendi portam.

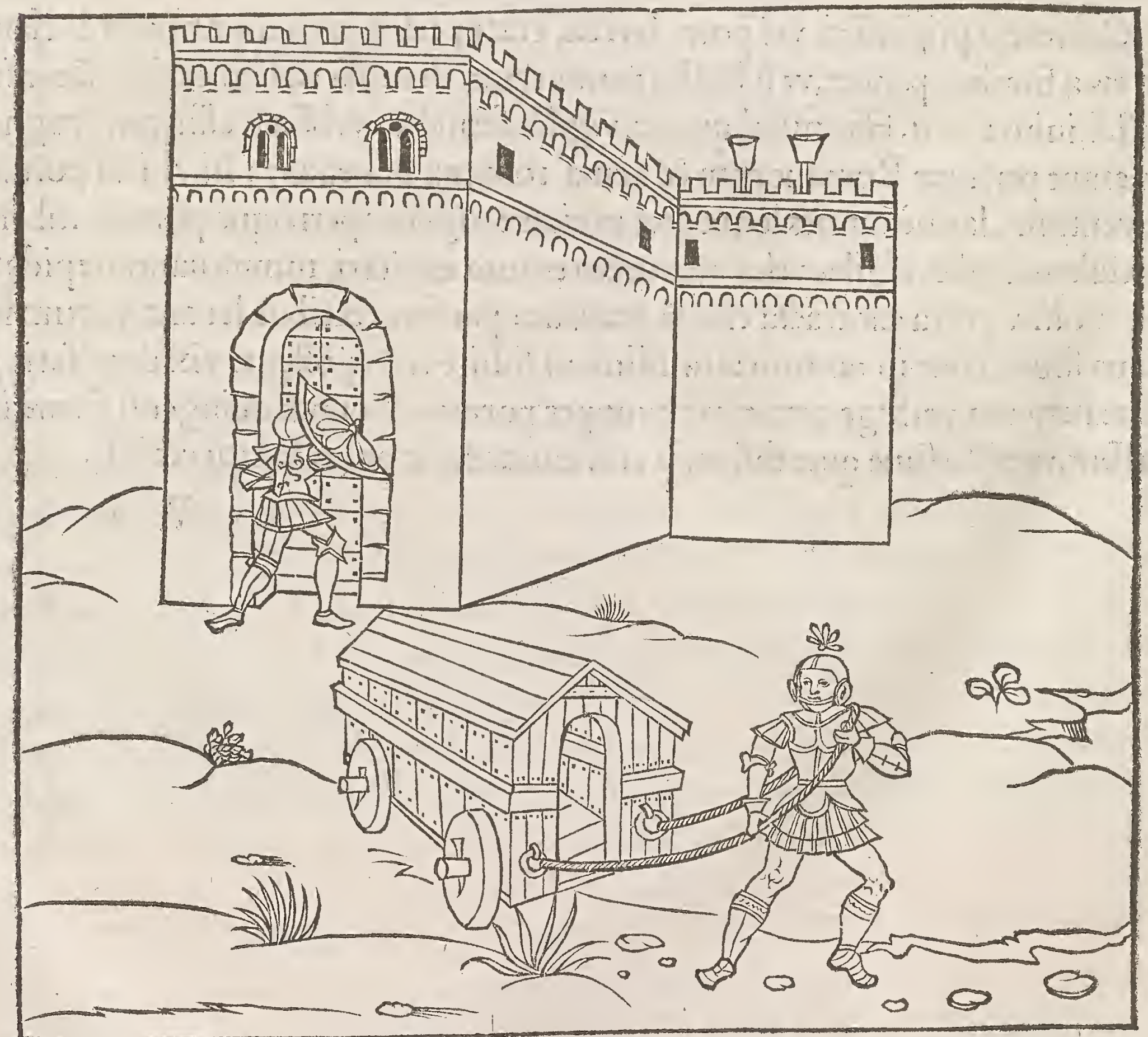


Inftrumentum perfringendi cataractam vel feneftram ferream.

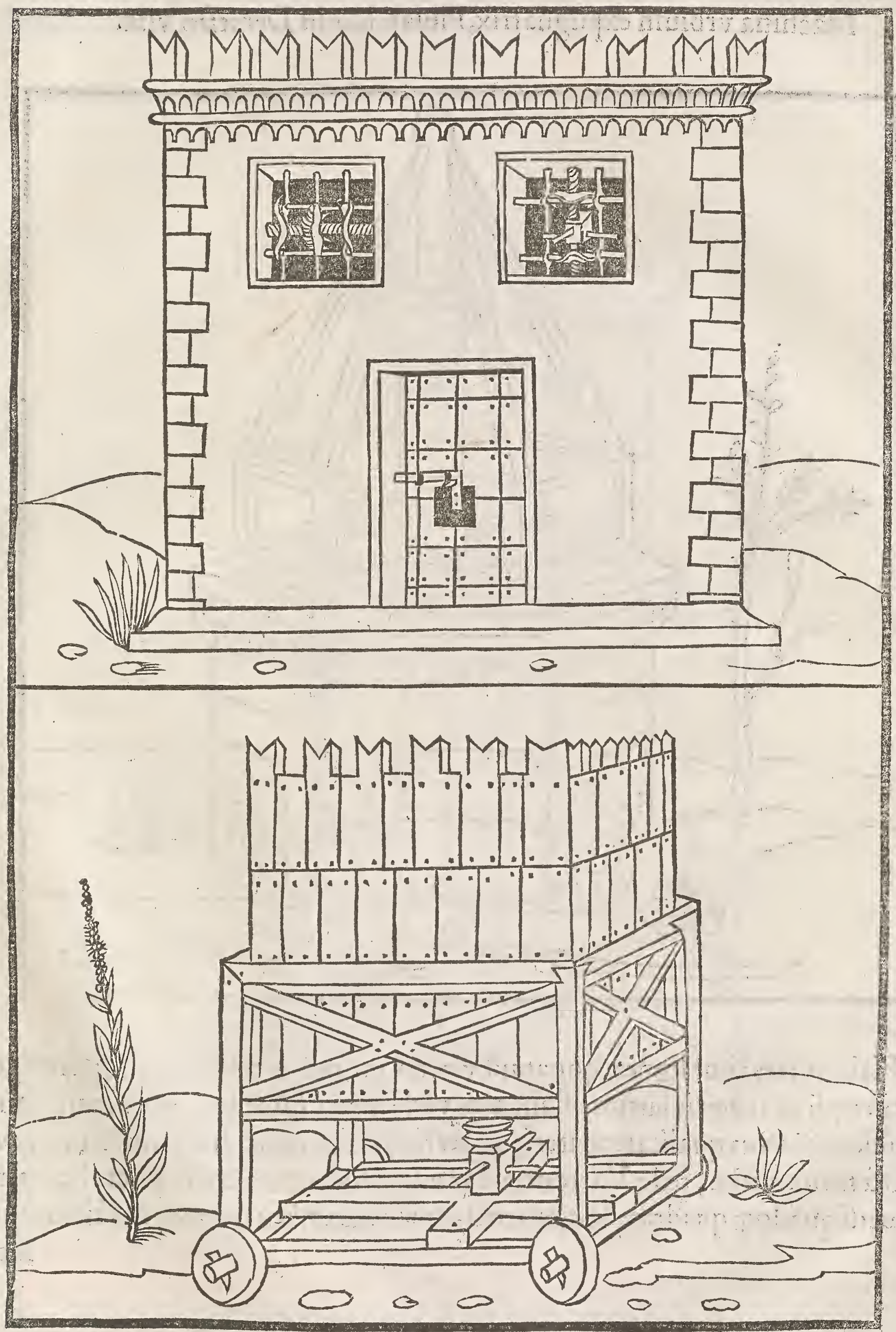

Turris in fublime ductilis. 
Turris mobilis ac verfilis omnia munimenta aduerfa vrbi fuperans altitudine fua, qux admota, catapultis balifífue per omnia tabulata difpofitis, hoftum muros defenforibus nudat.

Machina vrbium expugnatrix, Plutarchus in Demetrii vita.

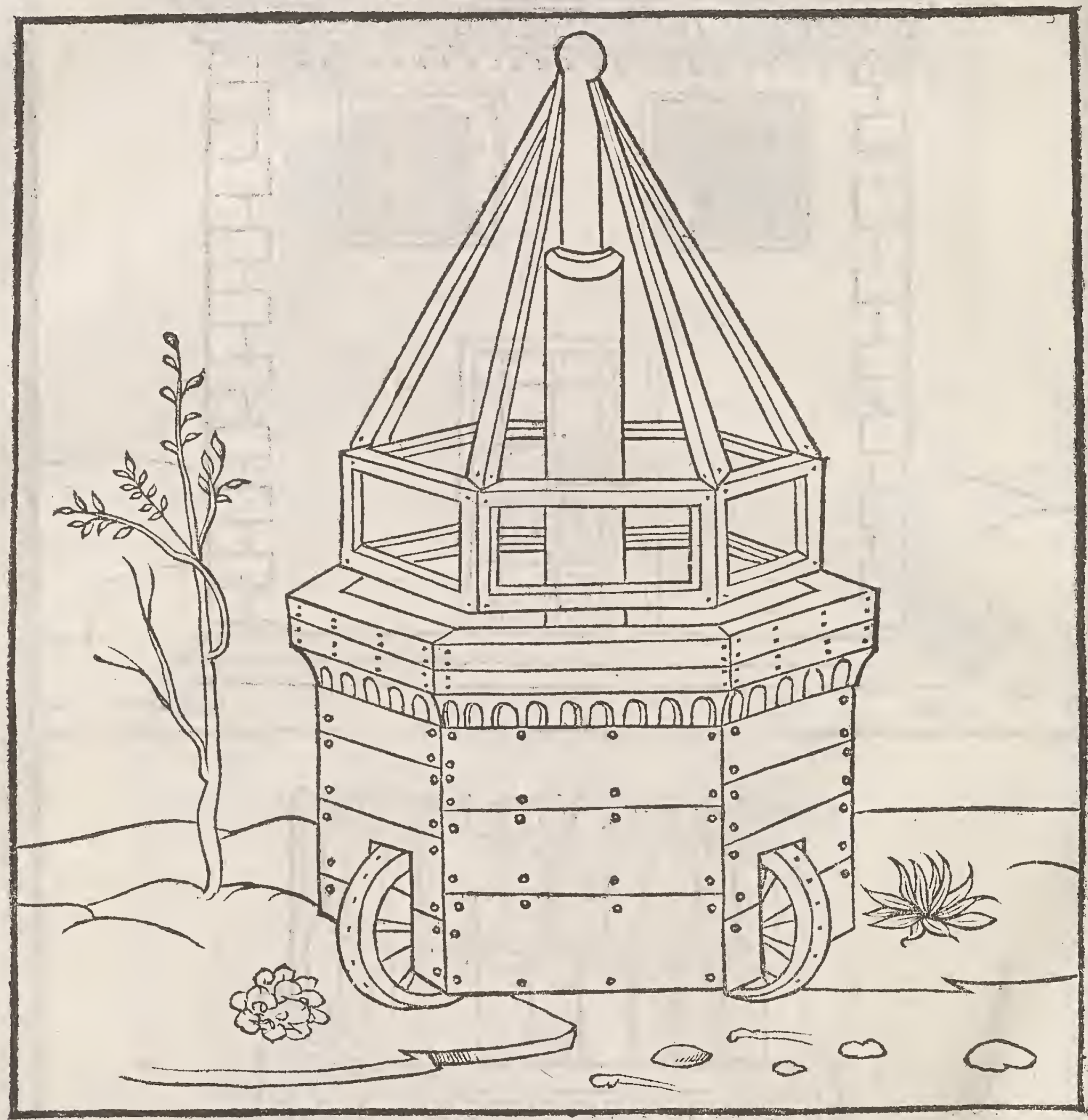

Halæ turres funt lignex quęapud veteres propter fpectatores è lignis erigebátur: $q$ fi ex materie larigna fiant atộ verfiles, tutiffimæ funt: flammam enim miffilem, \& ictus qualitate materiz ac vertigine fua non admittunt. Turres autem à tornis dictæ, tefte Varrone,vel vt alii, quòd teretes fint \& rectr: hr enim tamet fuã̉doọ quadratę fint,procul tamen yidentibus rotundę exiftimantur. 
ideo quia omnis cuiufque anguli fimulachrum per longum aéris fpacium enas nefcit atque confumitur, $\&$ rocundum videcur. $K$ otund $x$ itaque aut pol ygoniz

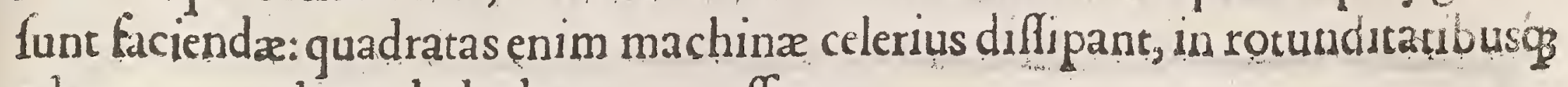
ad centrum adigendo lædere non poffunt.

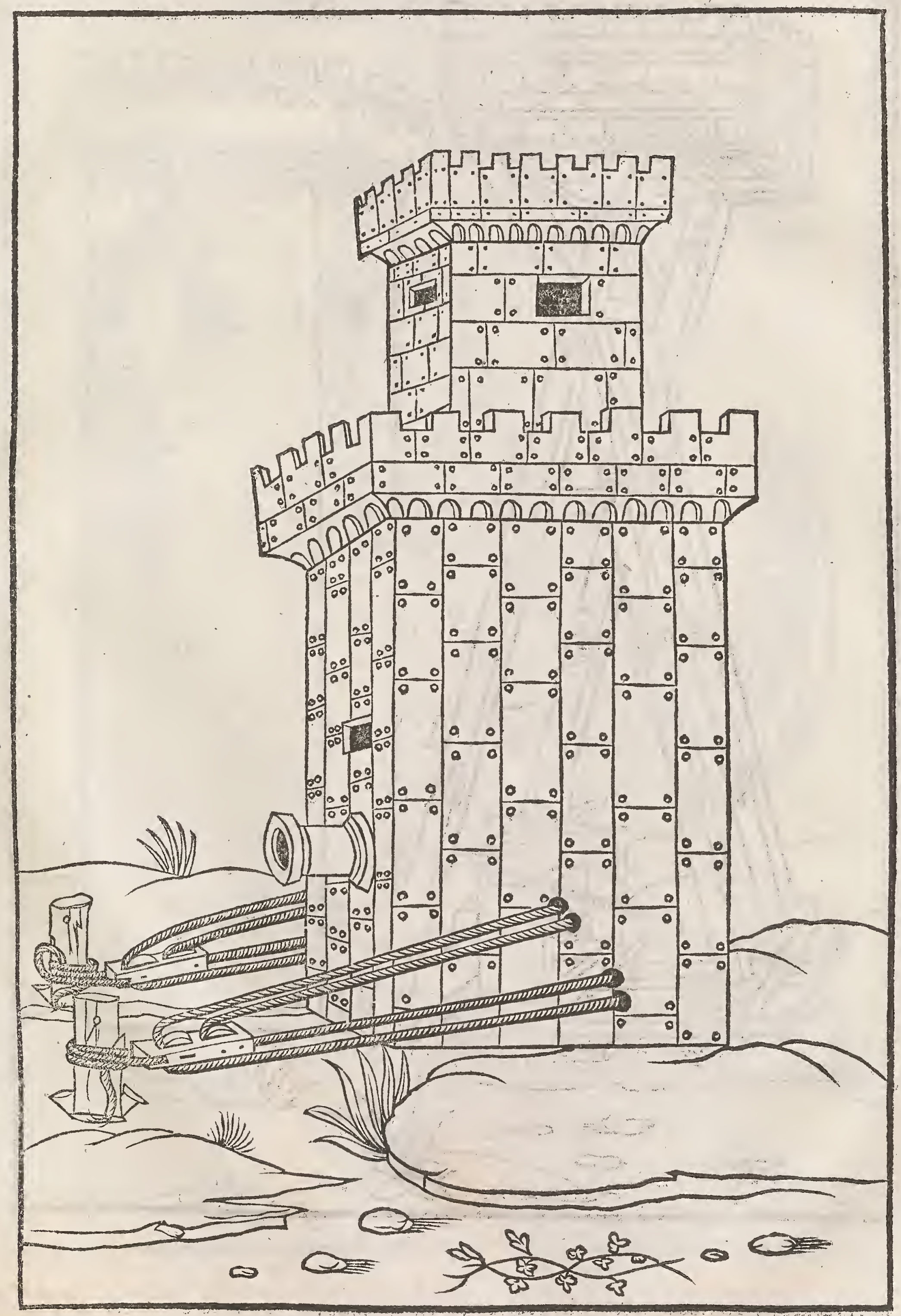




\section{Expugnanda turris inftrumentum.}

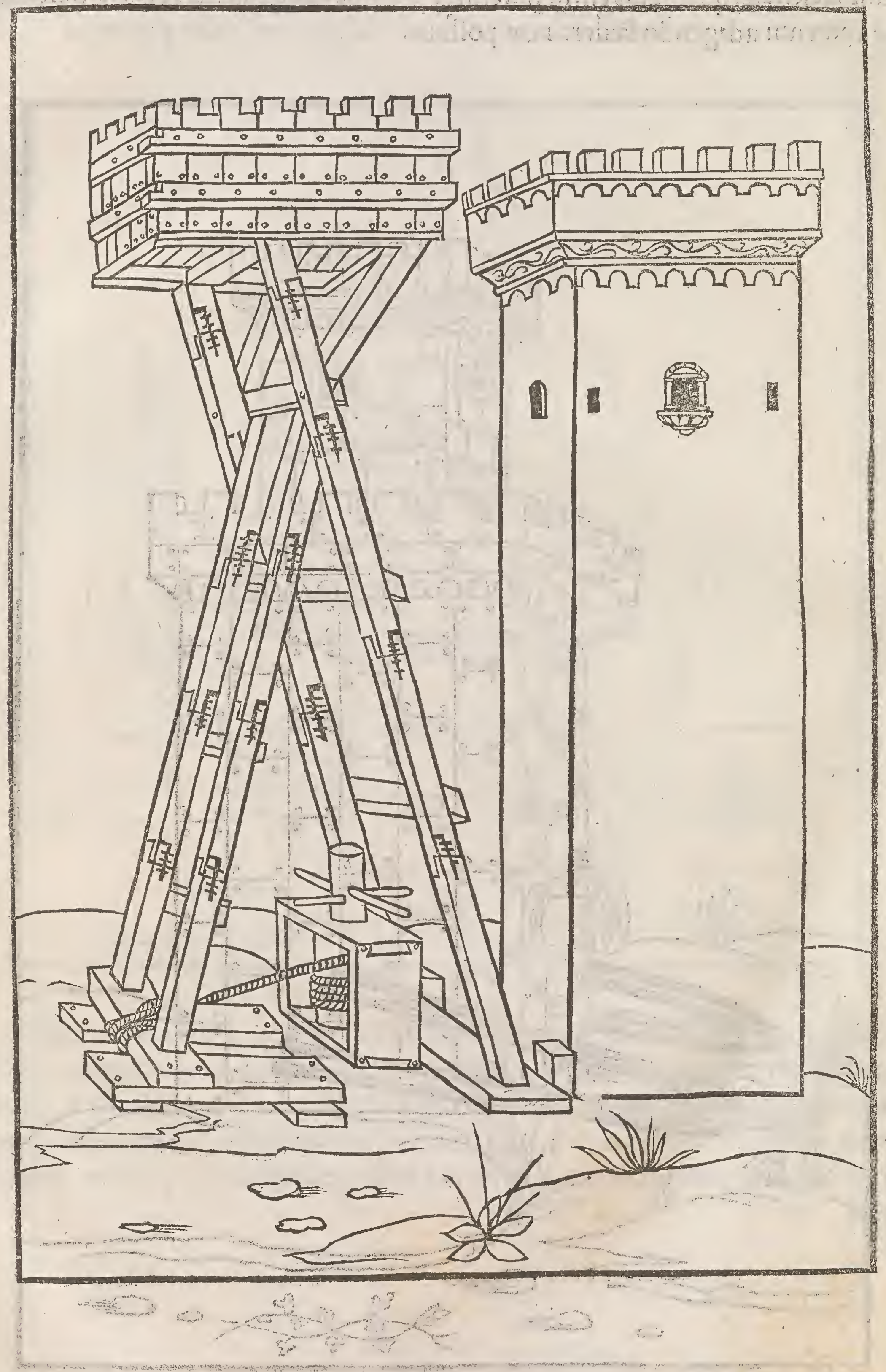


DERE MILITARI LIB. X.

Arabica machina ad expugnationem vrbium, magna $\&$ ingens, viris, pontibus, falis, varilfque inftrumentis bellicis referta.

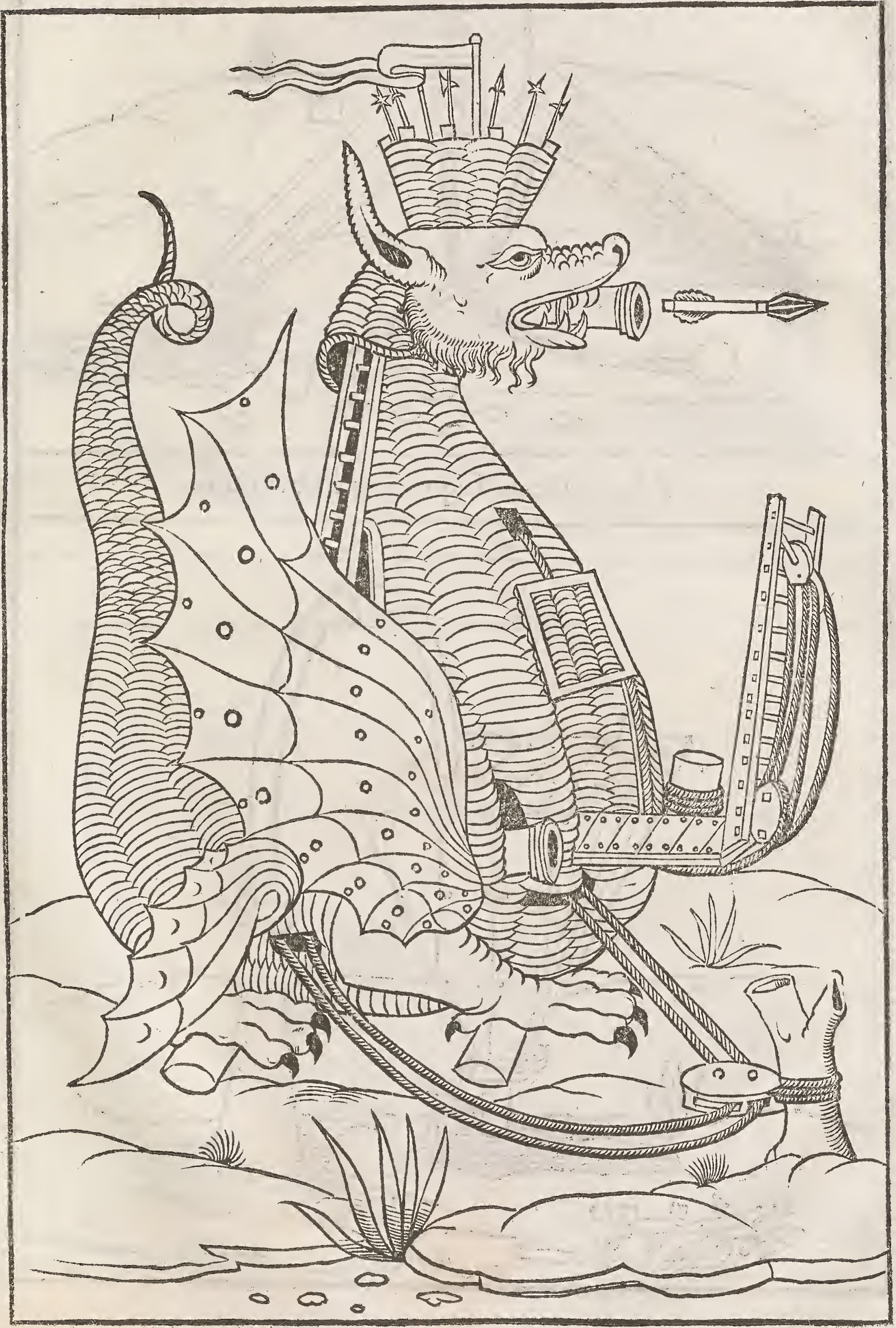


Fiftula per quam à foffa vel à caftello aquam exhauriendo educas.

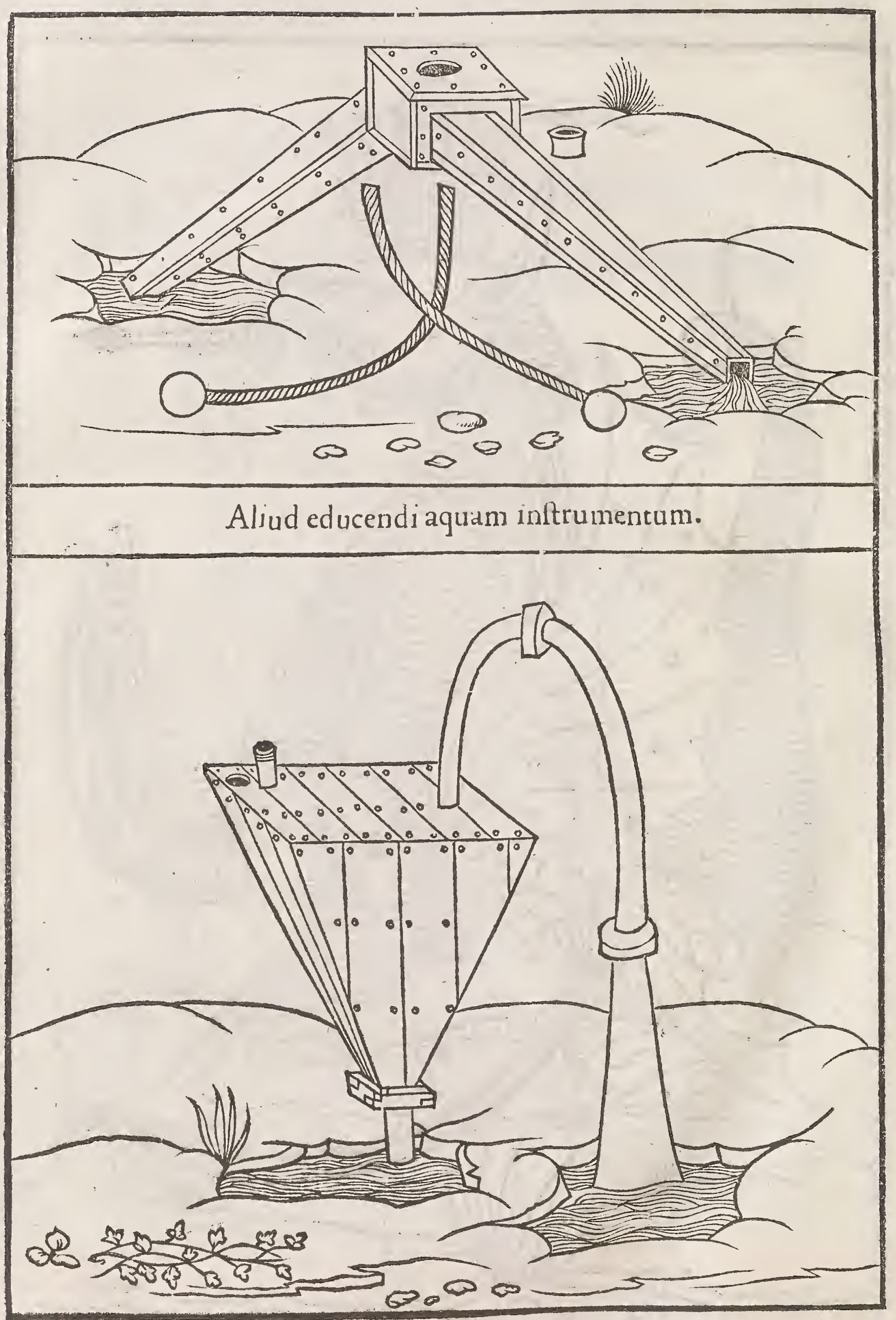



DERE MILITARI
L I B. X.

Alia duo ad exhauriendum aquam inftrumenta.

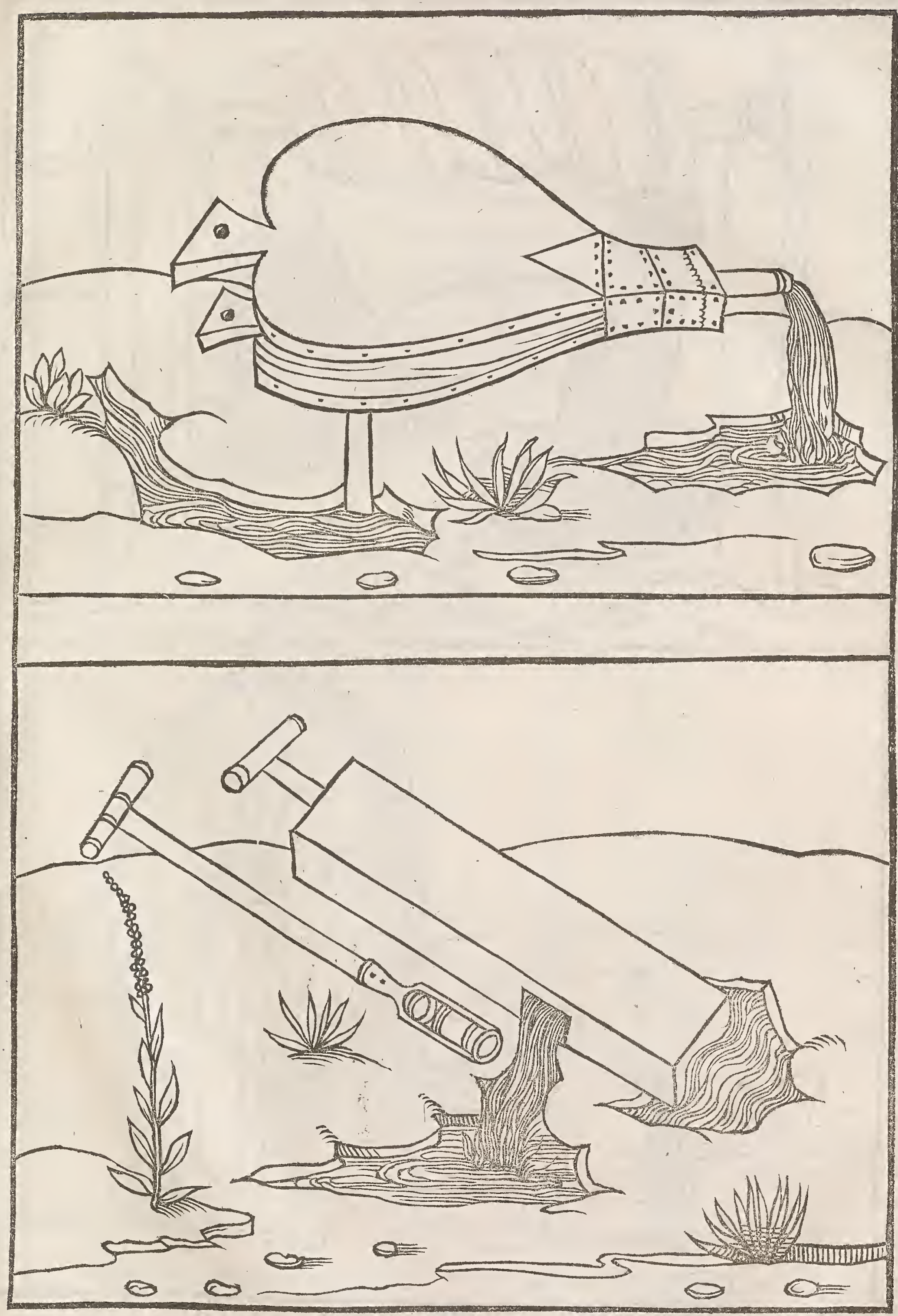


Alia duo inftrumenta ad hauriendum aquạm.

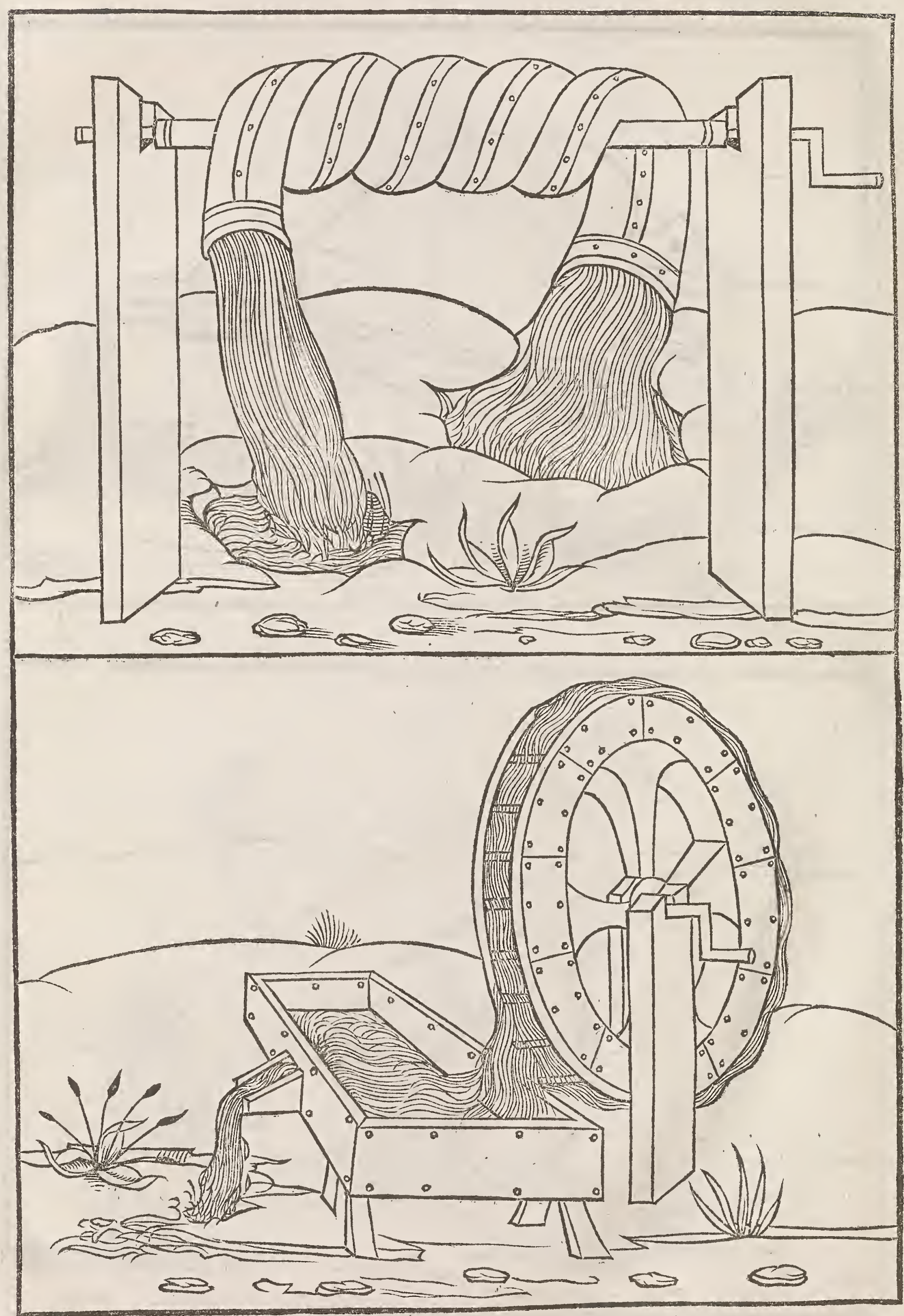




\section{Pons pro defenfione.}

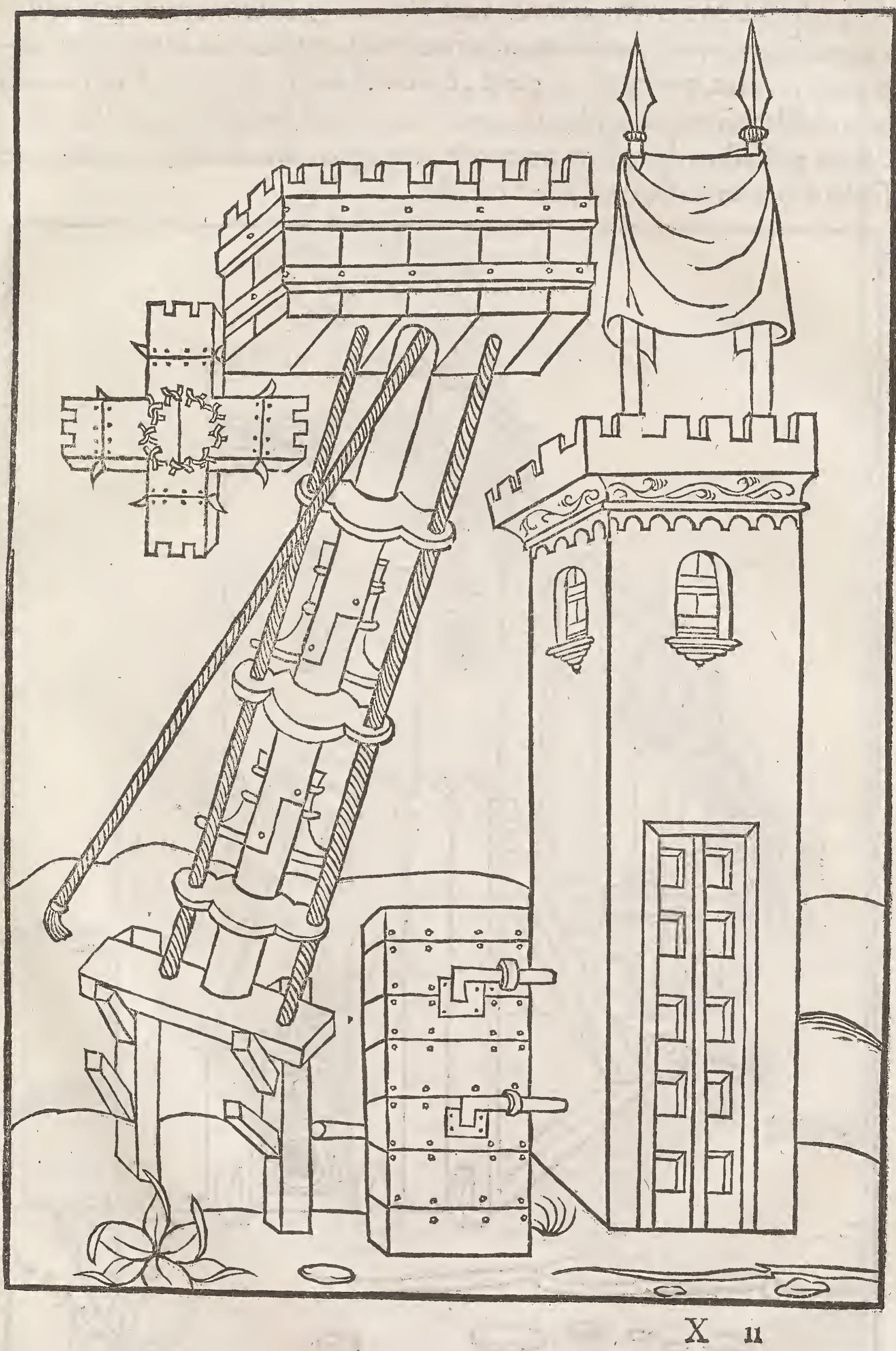


Plutei,crates è vimine funt, quę folebant opponi militibus opus facientibus, \& appellabātur militares, nunc \& tabulæ quibus quid præfepitur eodem nomine dicútur: hi è vimine funt, \& ciliciis, vel coriis crudis proteguntur, trinífque rotulis confiftunt, quarum vna in medio,dux in capitibus ap. ponuntur,vt in quacunq, vis parte admoueri more carpéti poflint. Hos plu teos obfidentes muris applicant,corum munitione protecti, fagittis fiue fundis, vel miffilibus defenfi res omnes de propugnaculis ciuitatis exturbant,ve fcalis afcendendi facilior detur occafio.

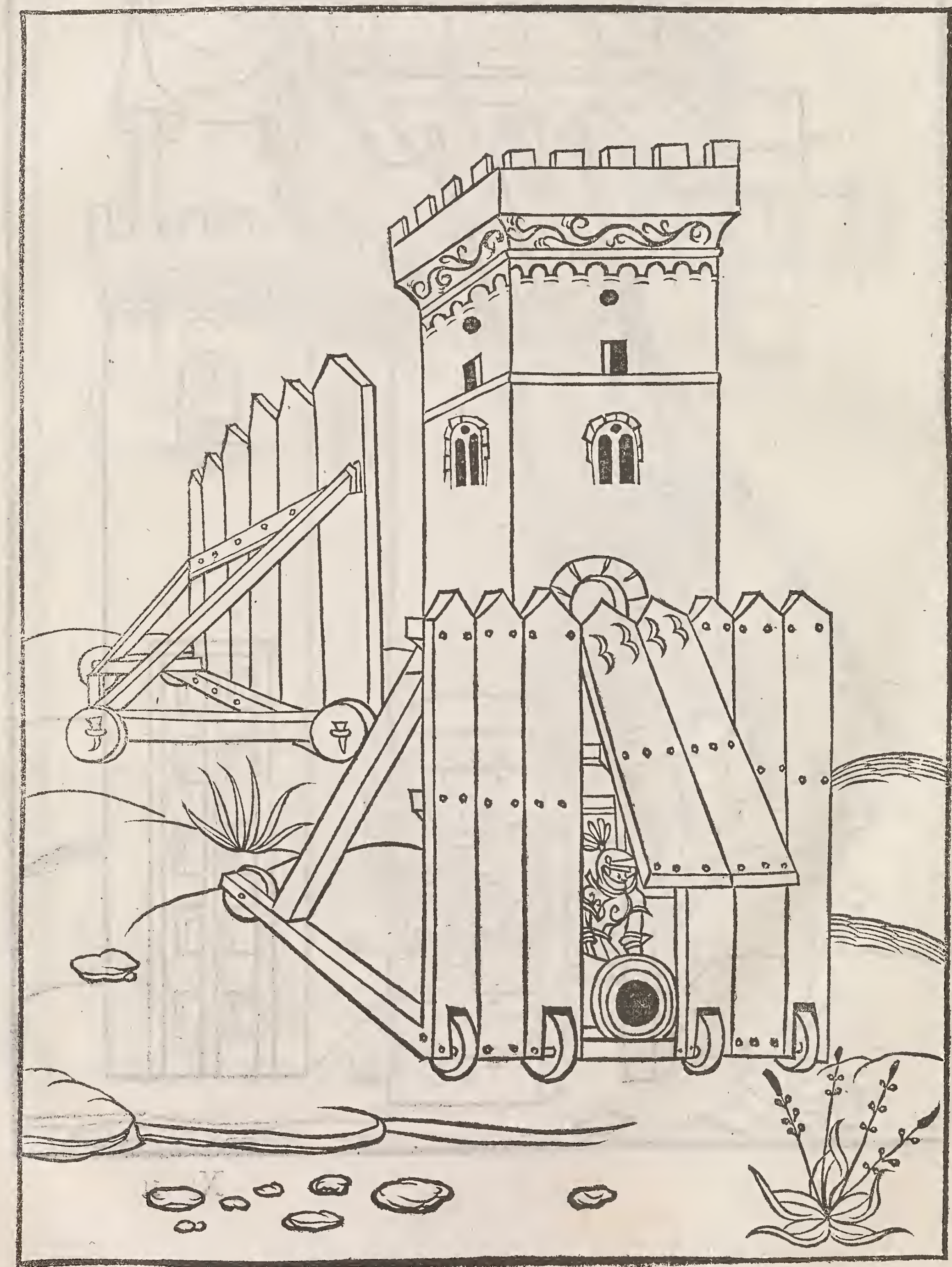


DE RE MILITAR I LIB.X. 245

Inftrumentum angufti loci, eundi hoftibus obuiam velint nolint, cui ponè ftet funditorum fagittariorumóg tela miffilia fpargentium manus.

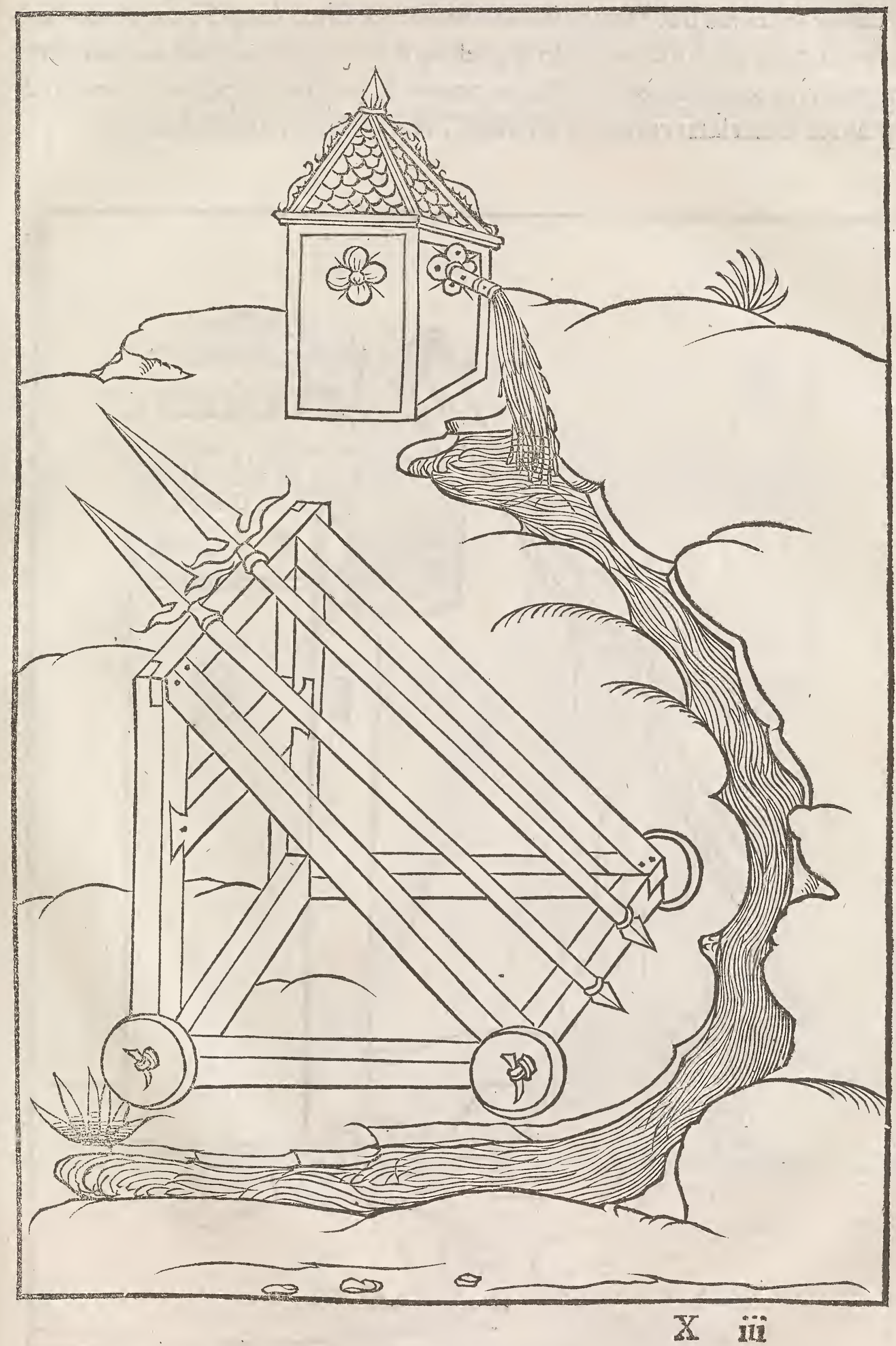


Telonum dicunt à longitudine quotiens vna trabs in terram præalta defigitur, quum in fummo vertice alia tranfuerfa trabs longior, dimenfa medietate connectitur, eo libramento vt fi vnum caput dimerferit, aliud erigatur. In vno ergo capite cratibus fue tabulatis contexitur machina, in quá pauci collocantur armati: tunc per funes attracto depreffóque alio capite, eleuati imponuntur in murum, vbi tuto ftantes, \& hoftibus nocere, $\&$ profpicere poffint, $\&$ renunciare quas res aduerfarii conentur efficere. Telonis autem forma hæc eft.

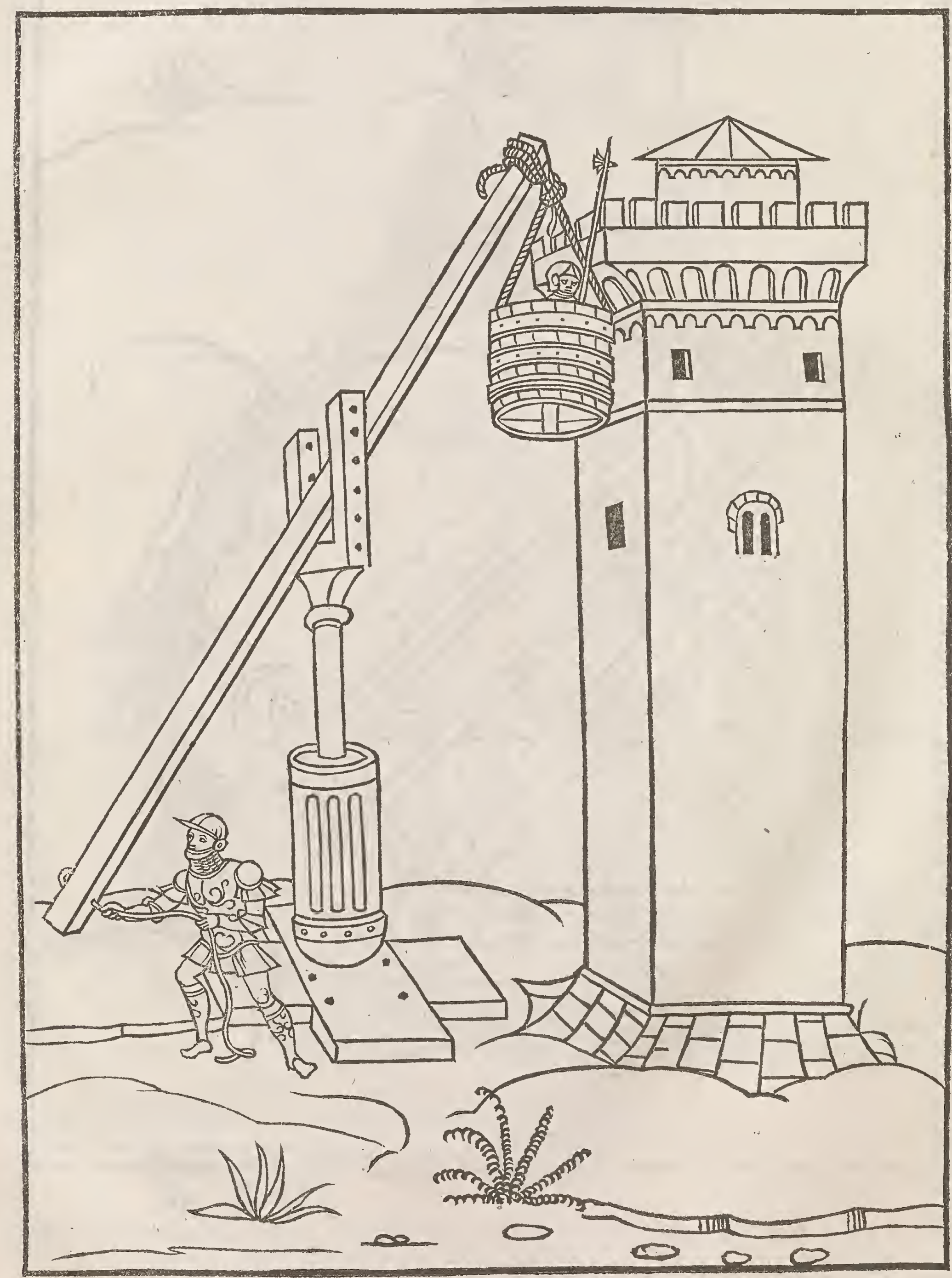


Sambuca, dicitur ad fimilitudinem citharæ vel organi machina, qua vrbs oppugnatur. Nam quemadmodum in cithara vel organo chordx funt, ita in trabe qux iuxta trabem ponitur funes funt, interdúmque de fuperiori parte tur ricula pontem laxant trocleis vt defcendant ad murum, ftatímque de turri exeunt bellatores, \& per eam tranfeuntes, monia vrbis inuadunt.

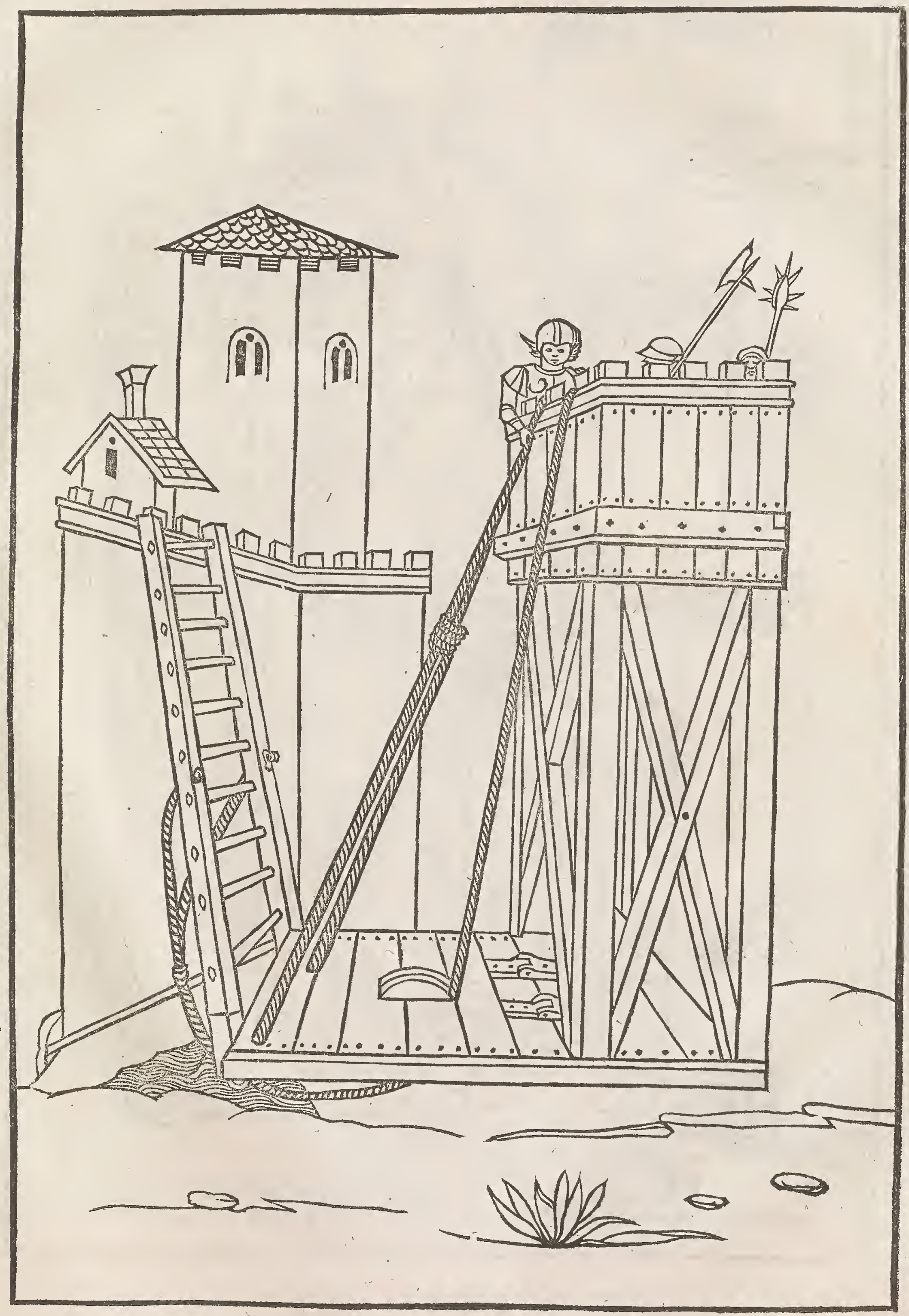


248 ROBERTI VALTVRII

Exoftra pons dicitur qui de turri lignea in murum repentè producitur. Factuseft duabus trabibus feptúfque vimine, quem fubito prolatum inter turrem murúmique conftituunt, \& per eam egredientes machinam bellatores in ciuitatem tranfeunt, $\&$ muros occupant.

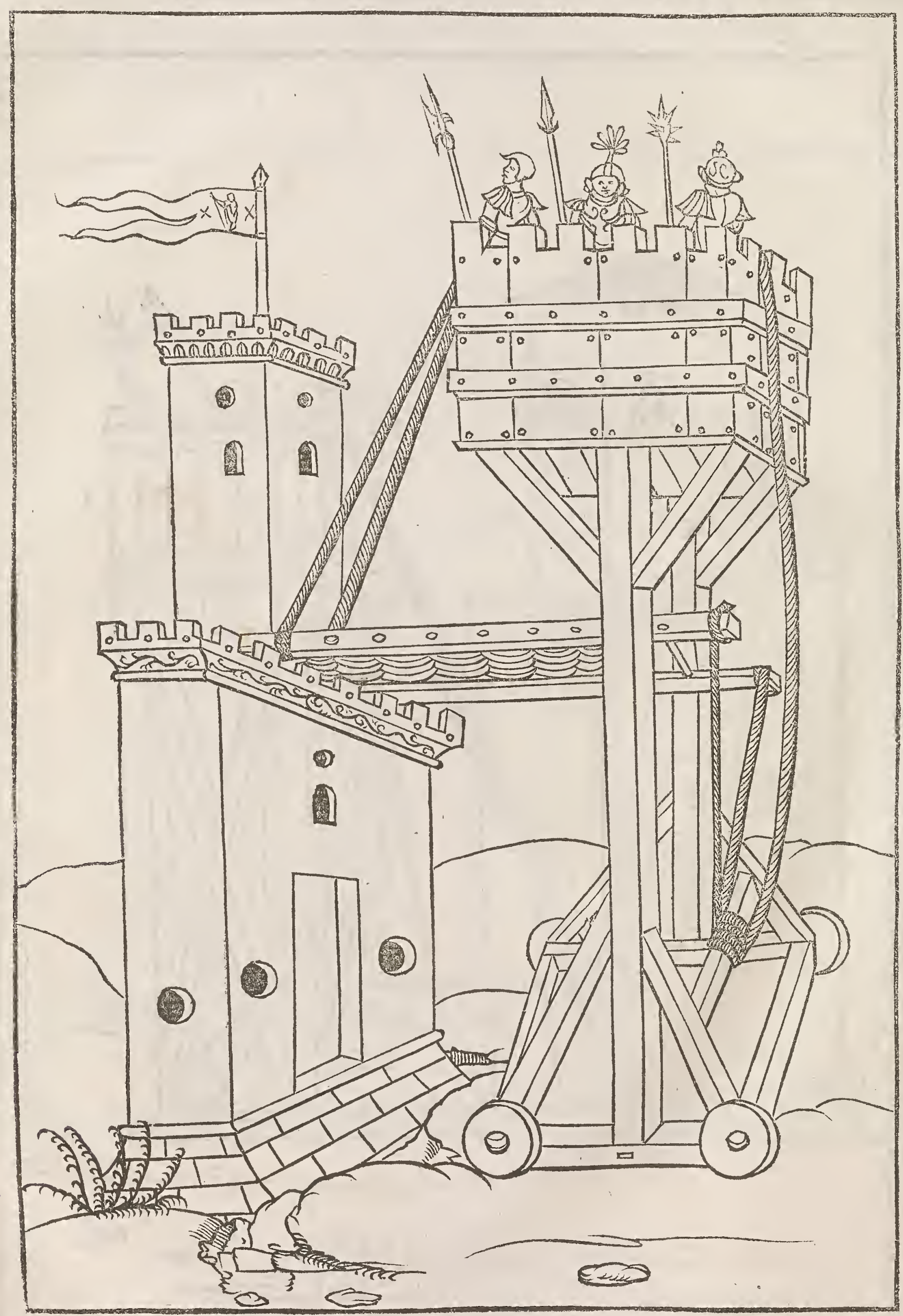




\section{Rota dentata pontem producens,cum gradibus quibufảam} intus ad motum $\&$ hominum afcenfum per eam.

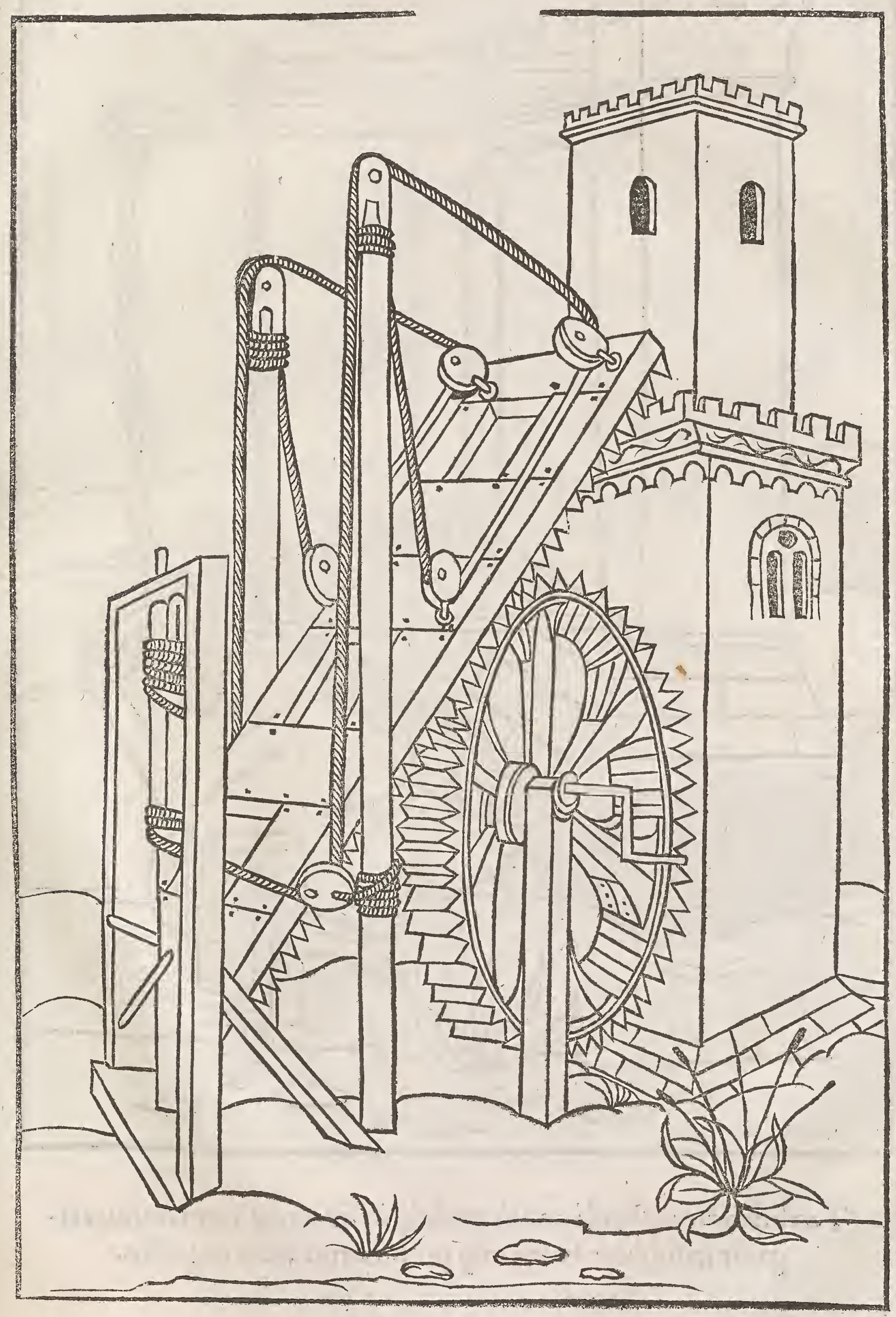




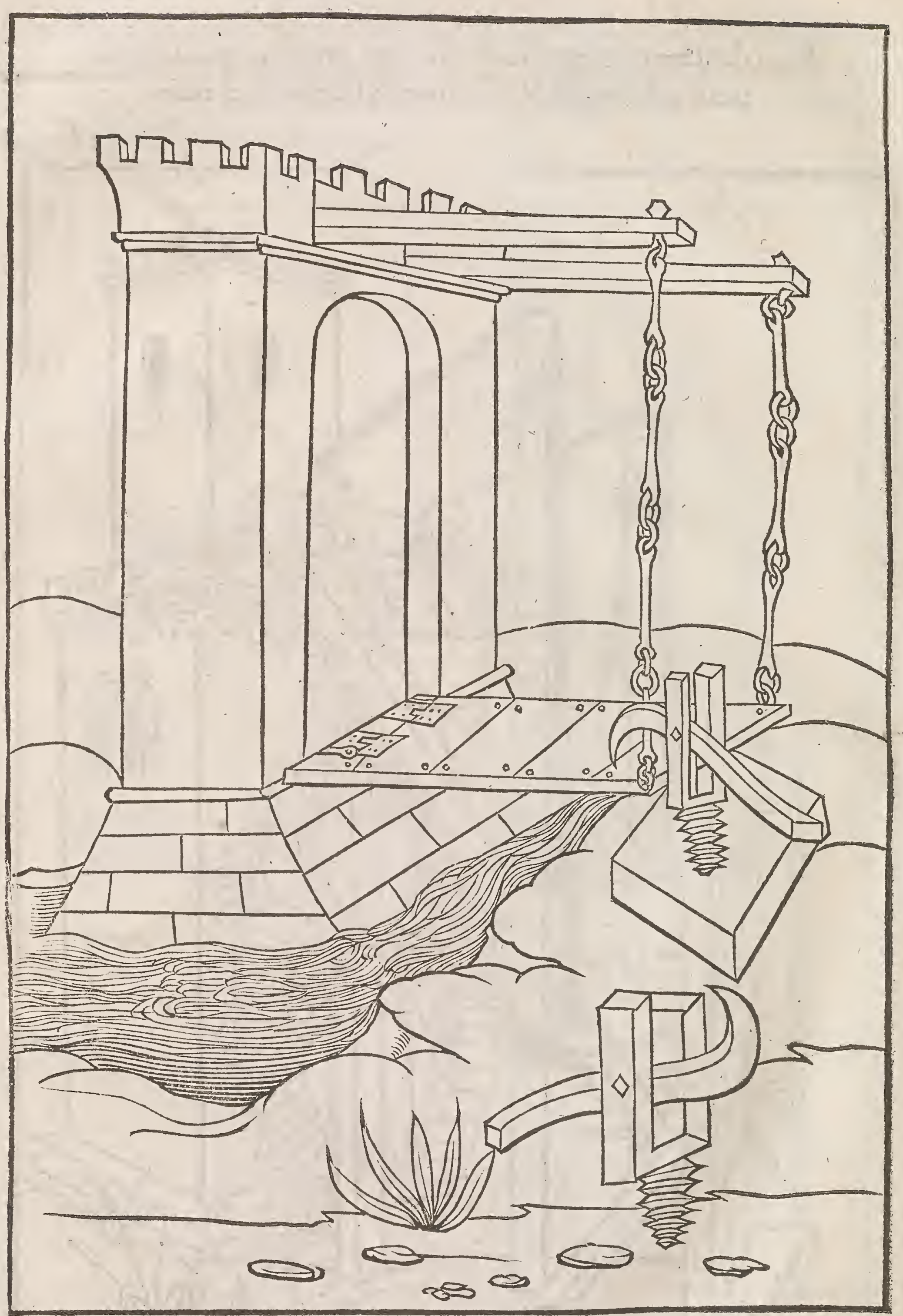

Terebra ferrea fiftendi pontis verfróg in ipfius cafu quo minus erigatur in fublime holtibus'óp prohibeatur vrbis ingreffus. 
DE RE MILITAR I LIB. X.

Erigendi pontis inftrumentum.

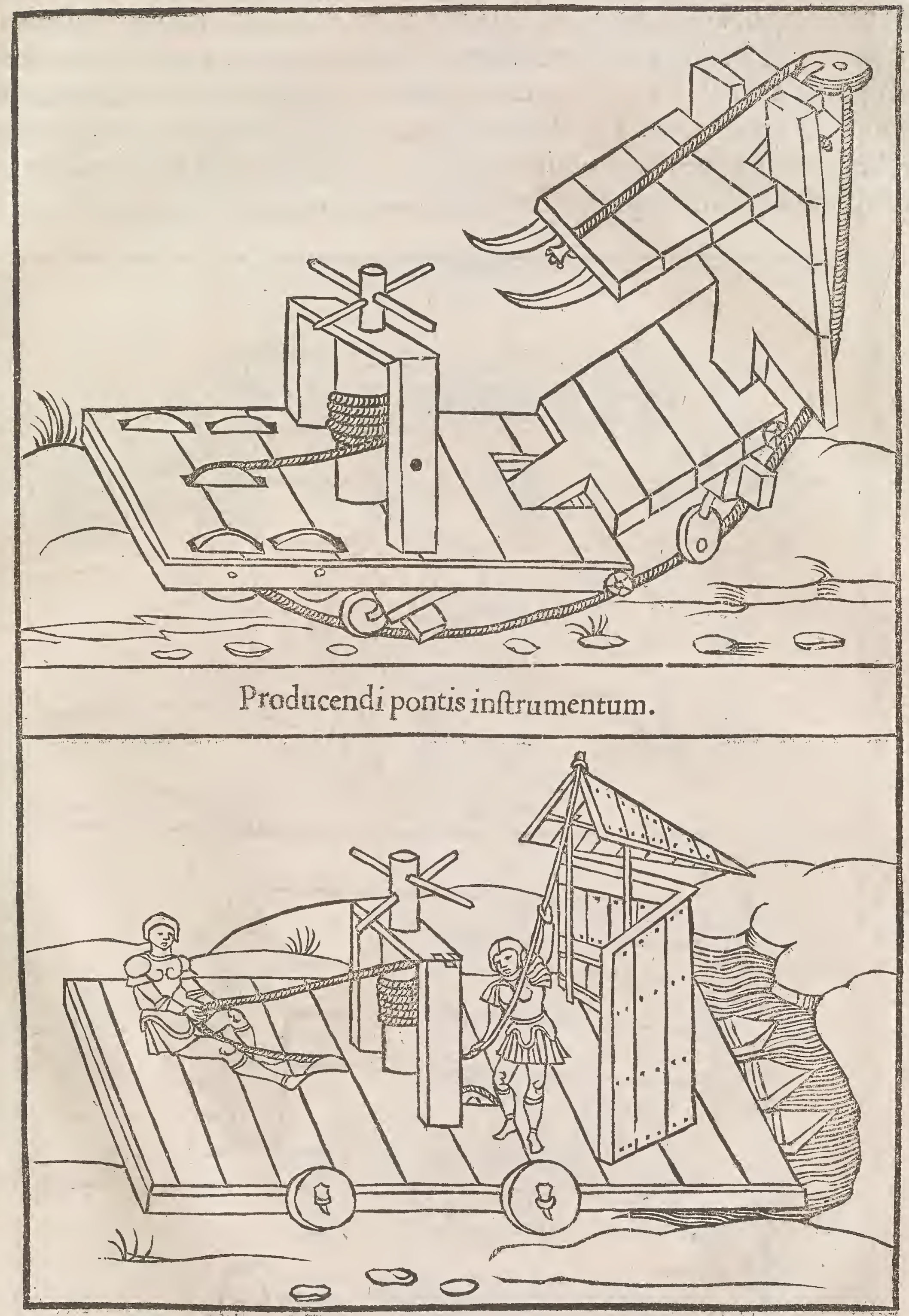


Mufculus cuniculo fit fimilis, quio murus pręfoditur,ex quo \& appellatur, quafi murufculus: vel mufculi,vtinquit Vegetius Renatus, à marinis belluis nomen fibi vendicant. Nam quemadmodun illæx quum minores fint, tamen balenis au xilium adminiculúmqgiugiter exhibent, ita ifti quum fint machinæ breuiores vel deputatæ, turribus magnis aduentu illarum parant viam itinetáque præmuniunt.Mufculum autem appellauit antiquitas machinas minores, quibus protedi bellatores fudibus præmunitas oppidorum foffas demolirentur, quibus turris ambulatoria fine impedimento iungeretur ad murum.

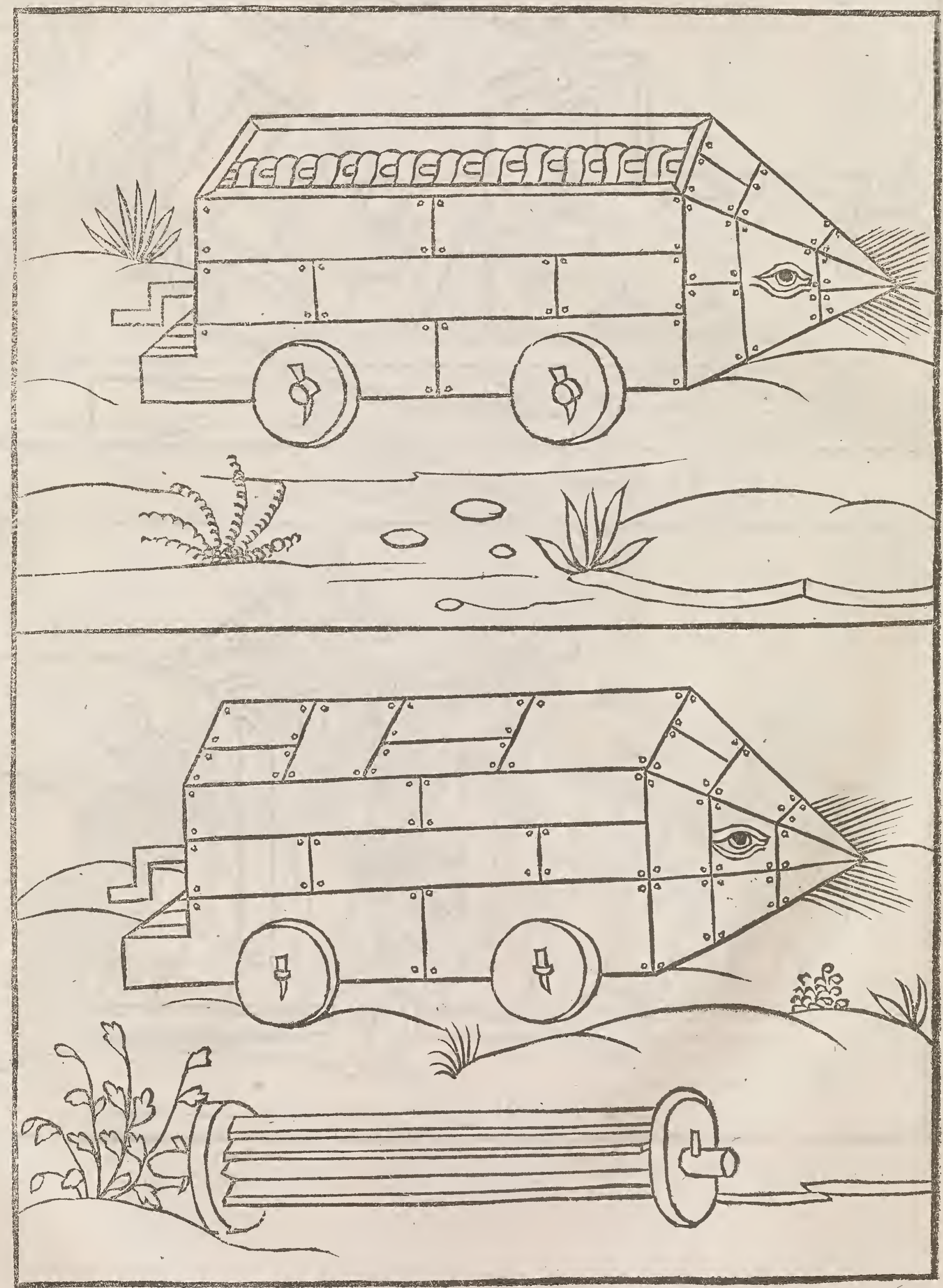


Scala licetà quibufdả fingulariter vfupetur, \& facris in literis, in libro Ge nef. Vidit Iacob fcalam, lcriptum fit, fcalę tamen fecundü Varronem, Quin tilianum, \& Focam dicuntur propriè,aut latinè magis, fiue vnæ frnt, frue plu res, quia numeri tantum pluralıs eft nomen, vt litere quum epiftolam fignifi cant. Saluftius in I ugurthino, Dẹinde vbi vnę atque altere fcalæ communutę funt, qui fuperftiterant afflicti funt:non dixit vna ato altera. Harum autem formam variam licet ac multiformem, facile quifque intelliget, fi quas funt infrà picturæ lineamentis oculis fubiecta profpiciet.

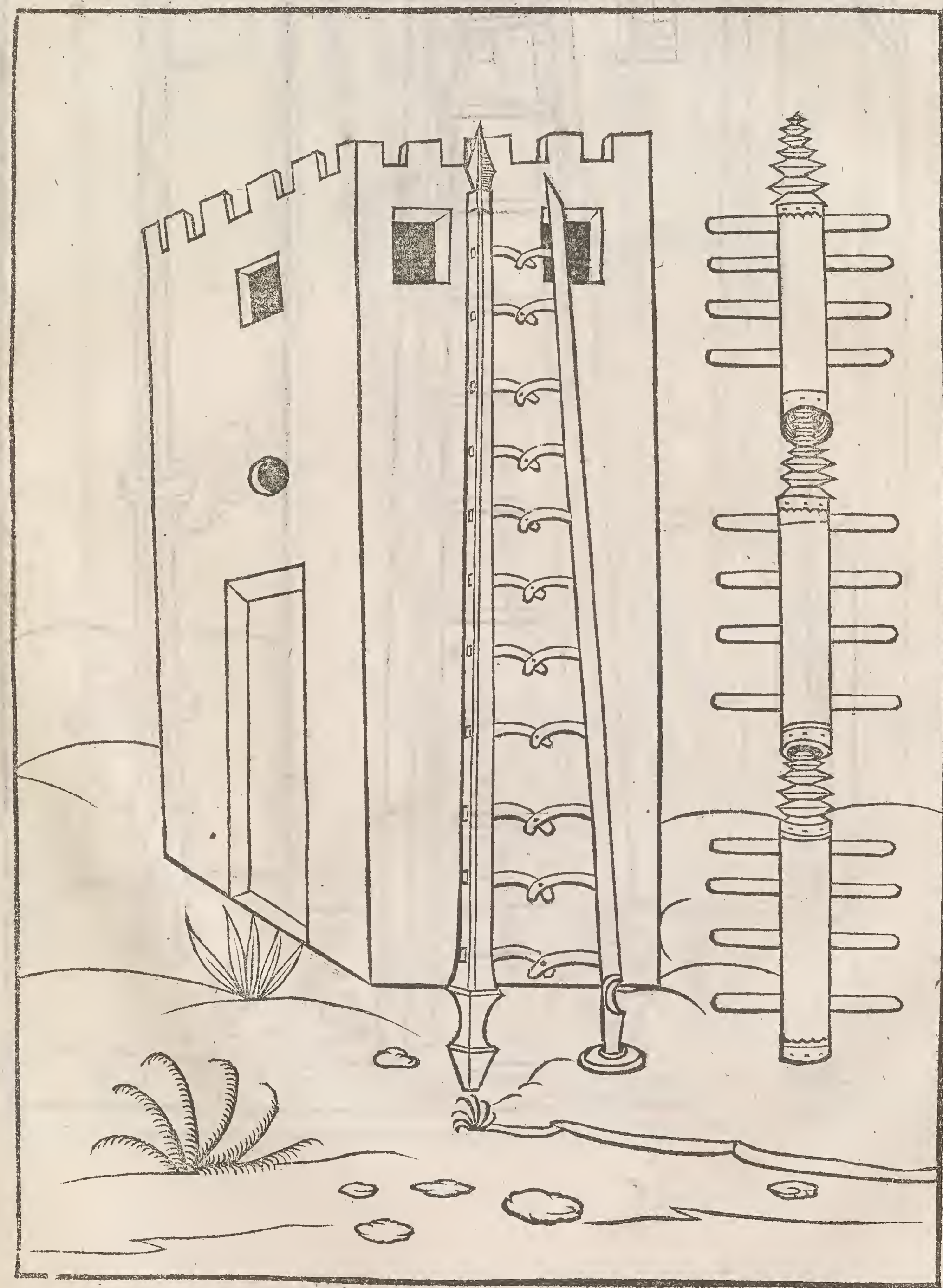


Aliud genus fcala. Calceus cum annulo ferreo.

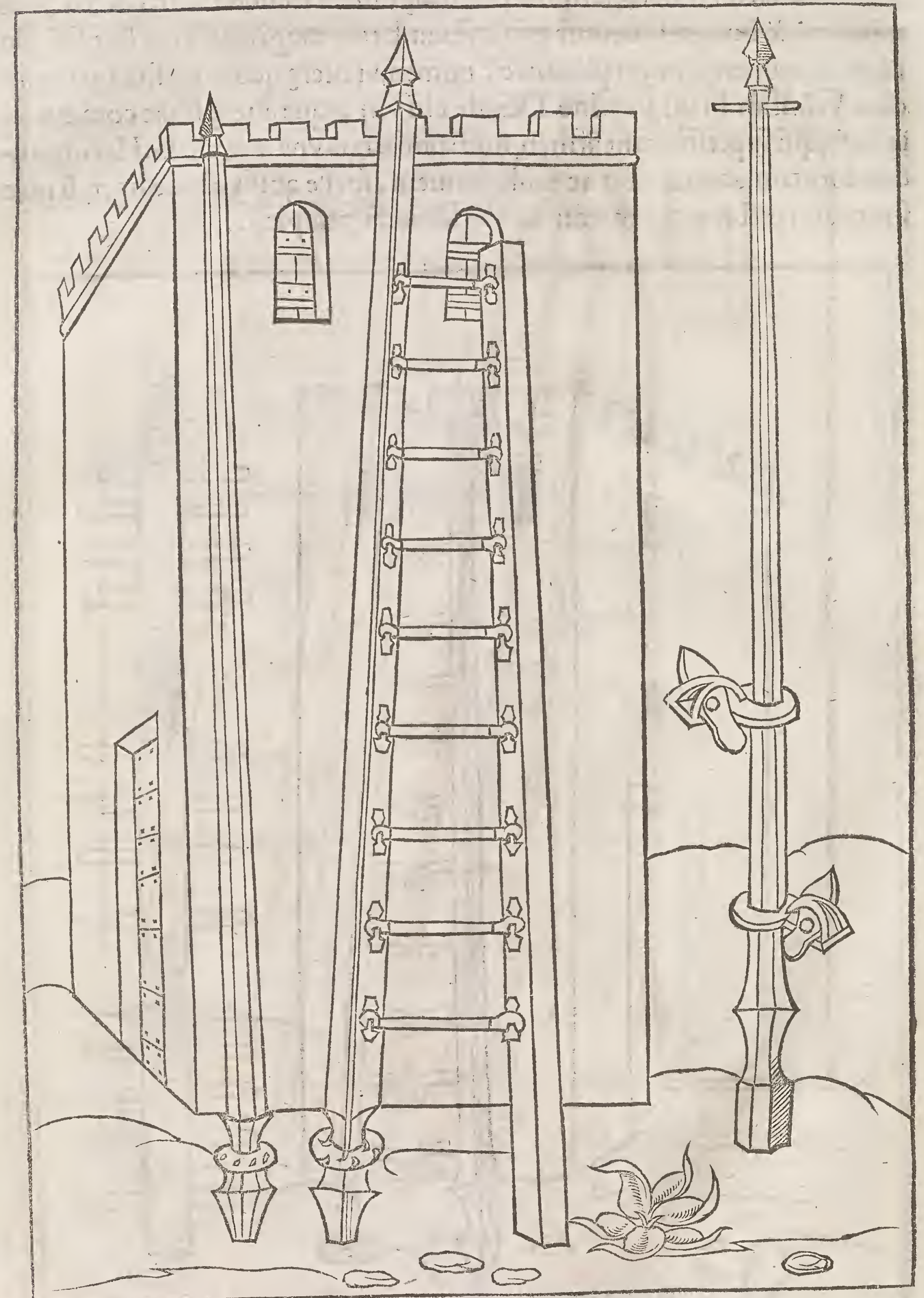




\section{Alix fcalæ difiunctx.}

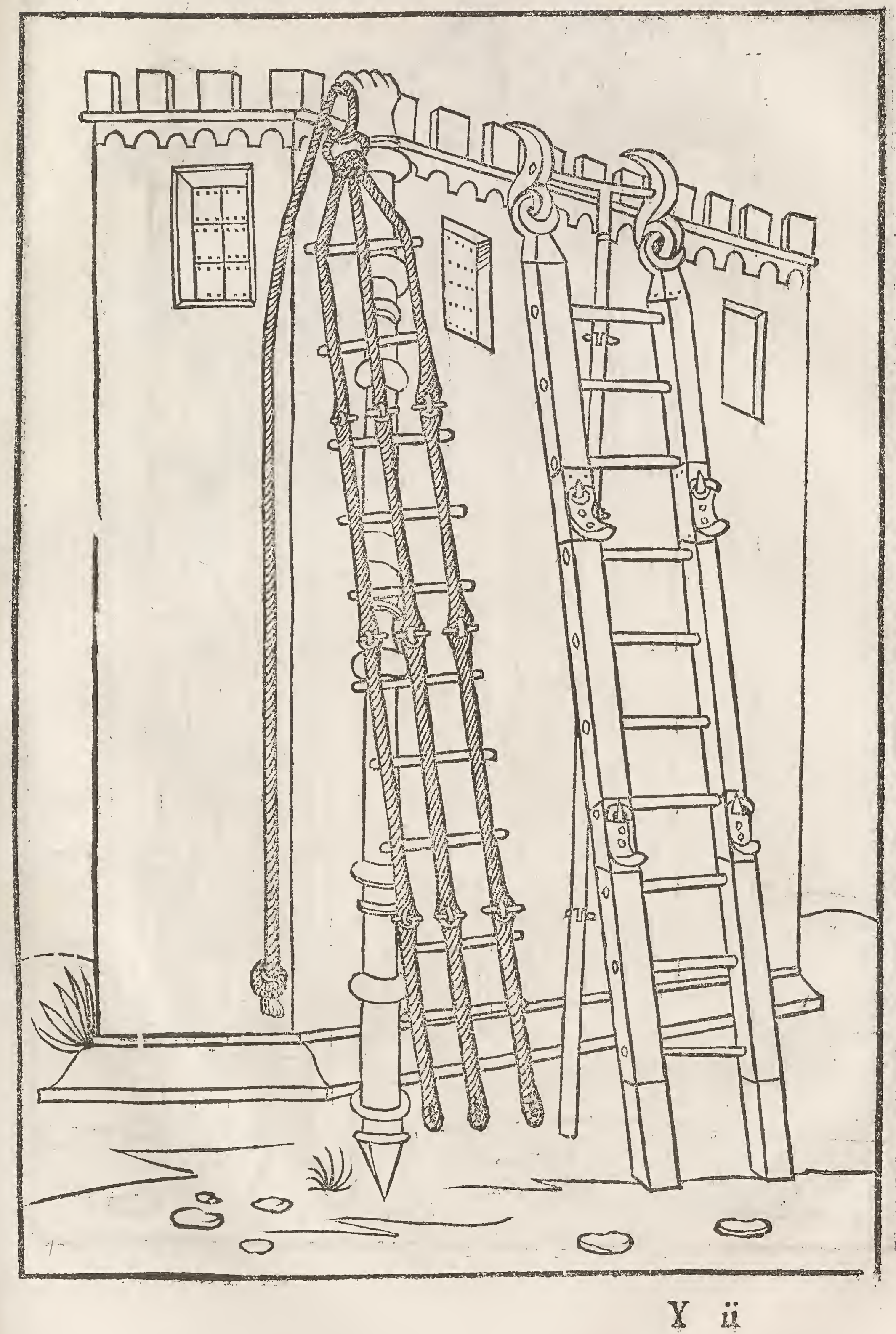




\section{Alia genera fcalarum.}

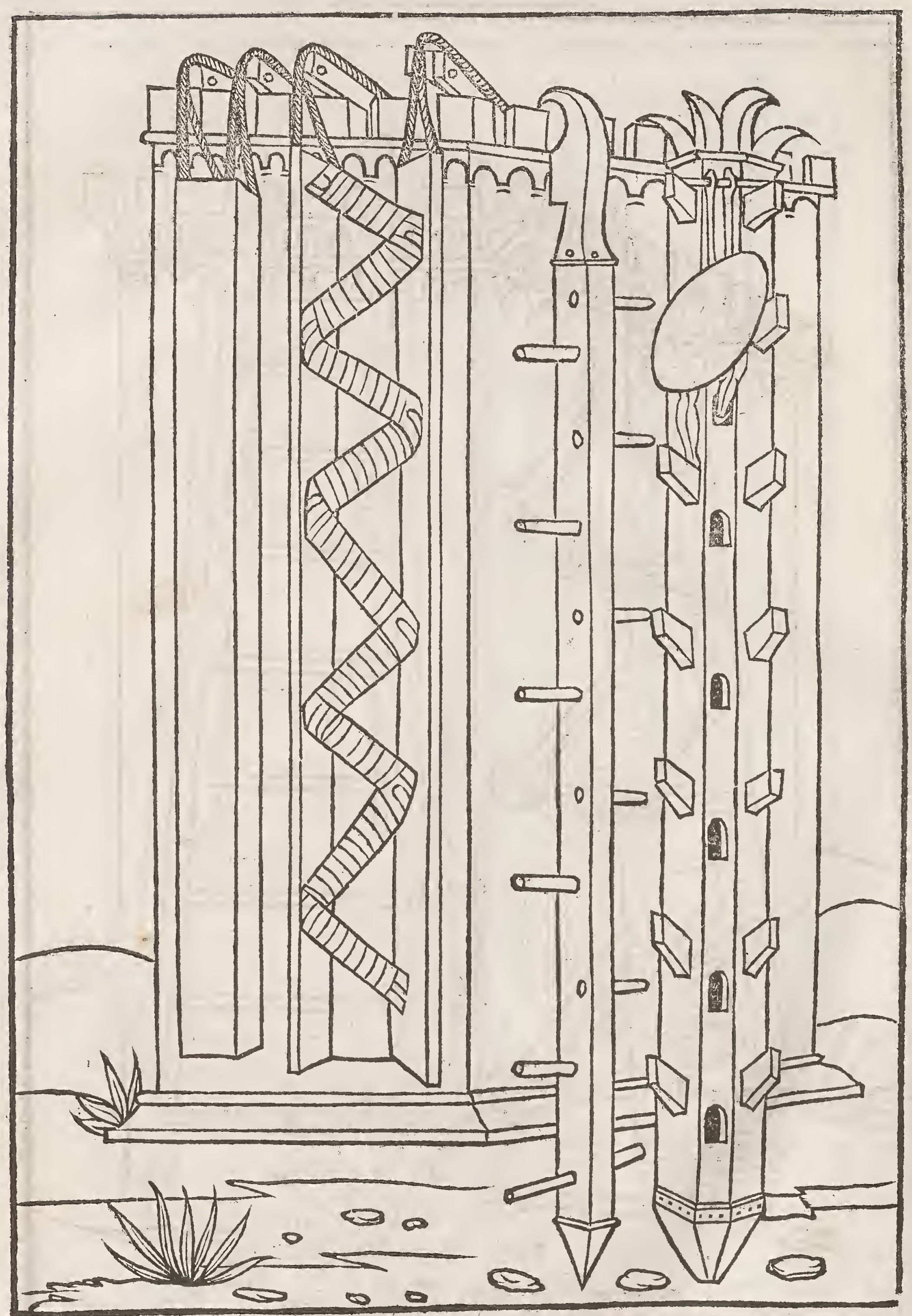


DE RE MILITARI LIB. X. 259

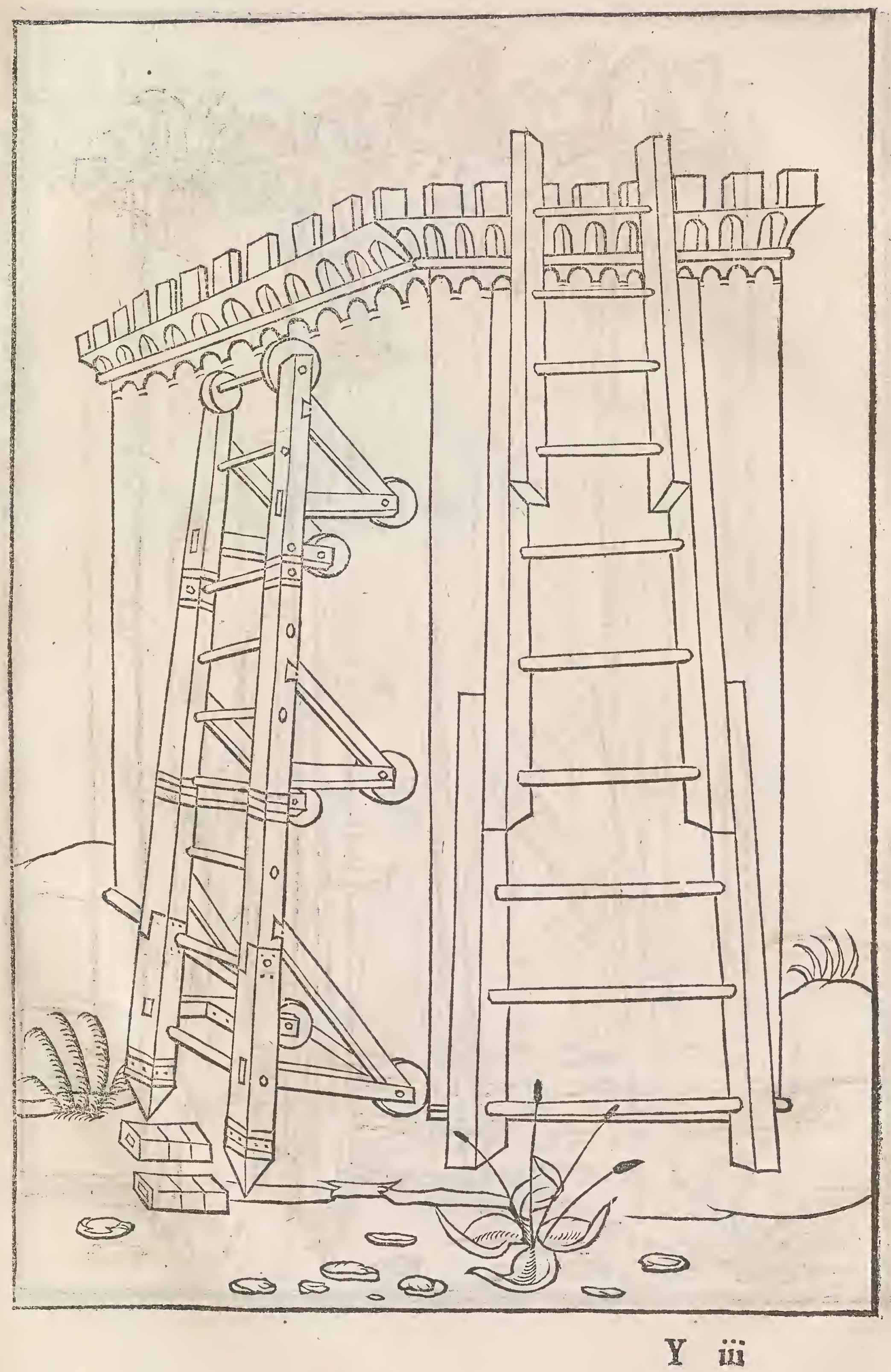




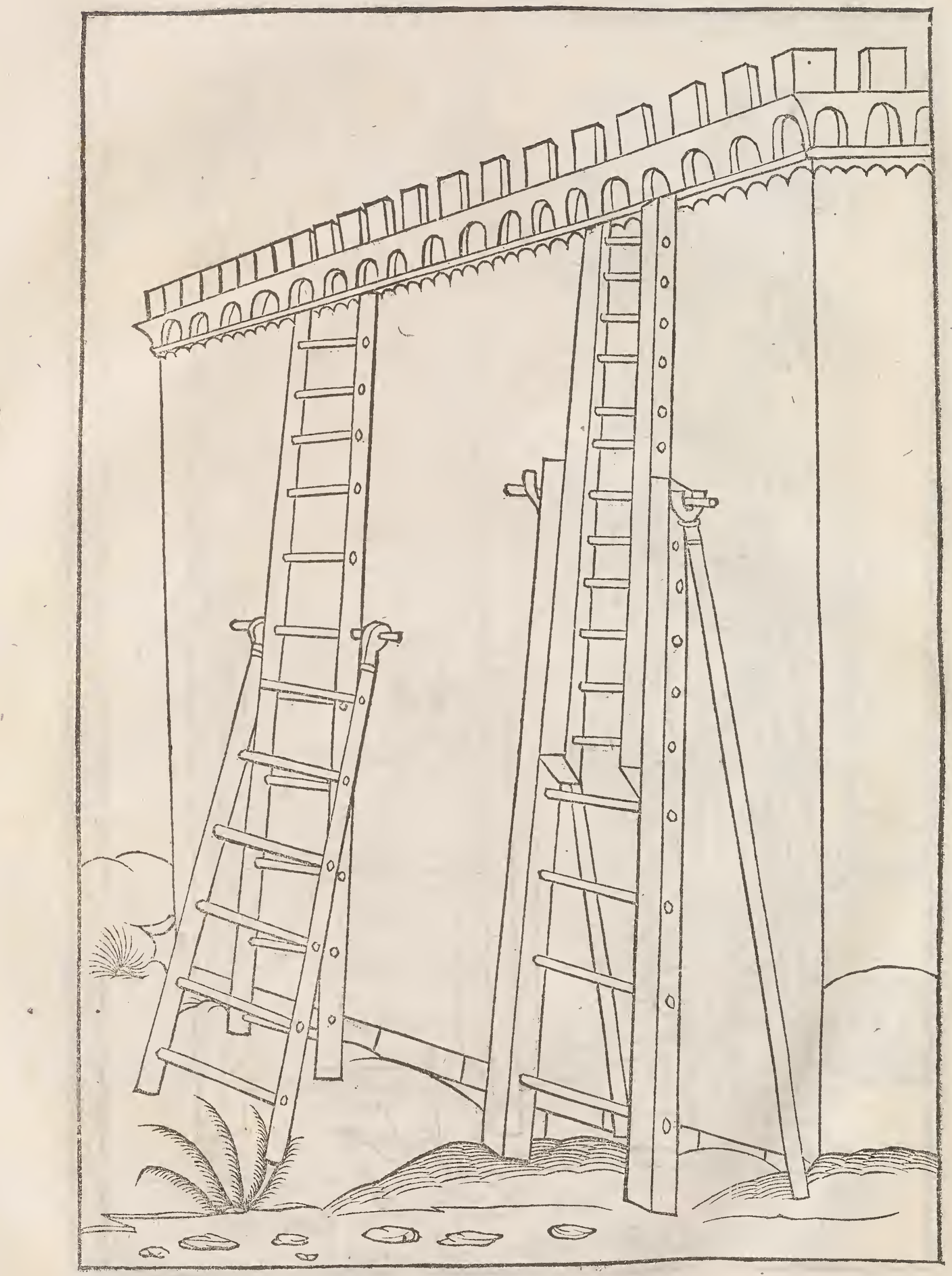




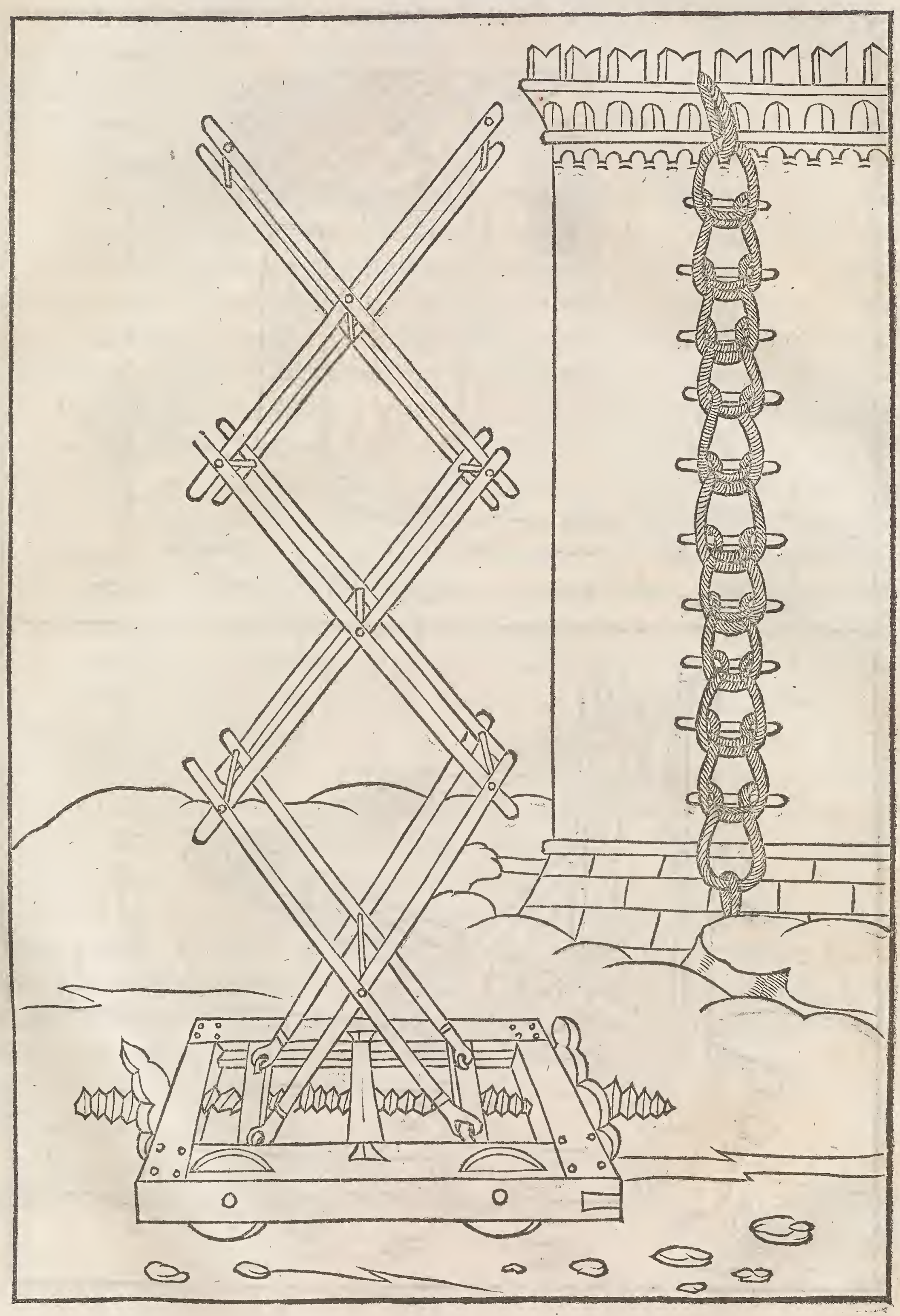


Aliud genus fcalarum quod rotis $\&$ cantho vehitur.

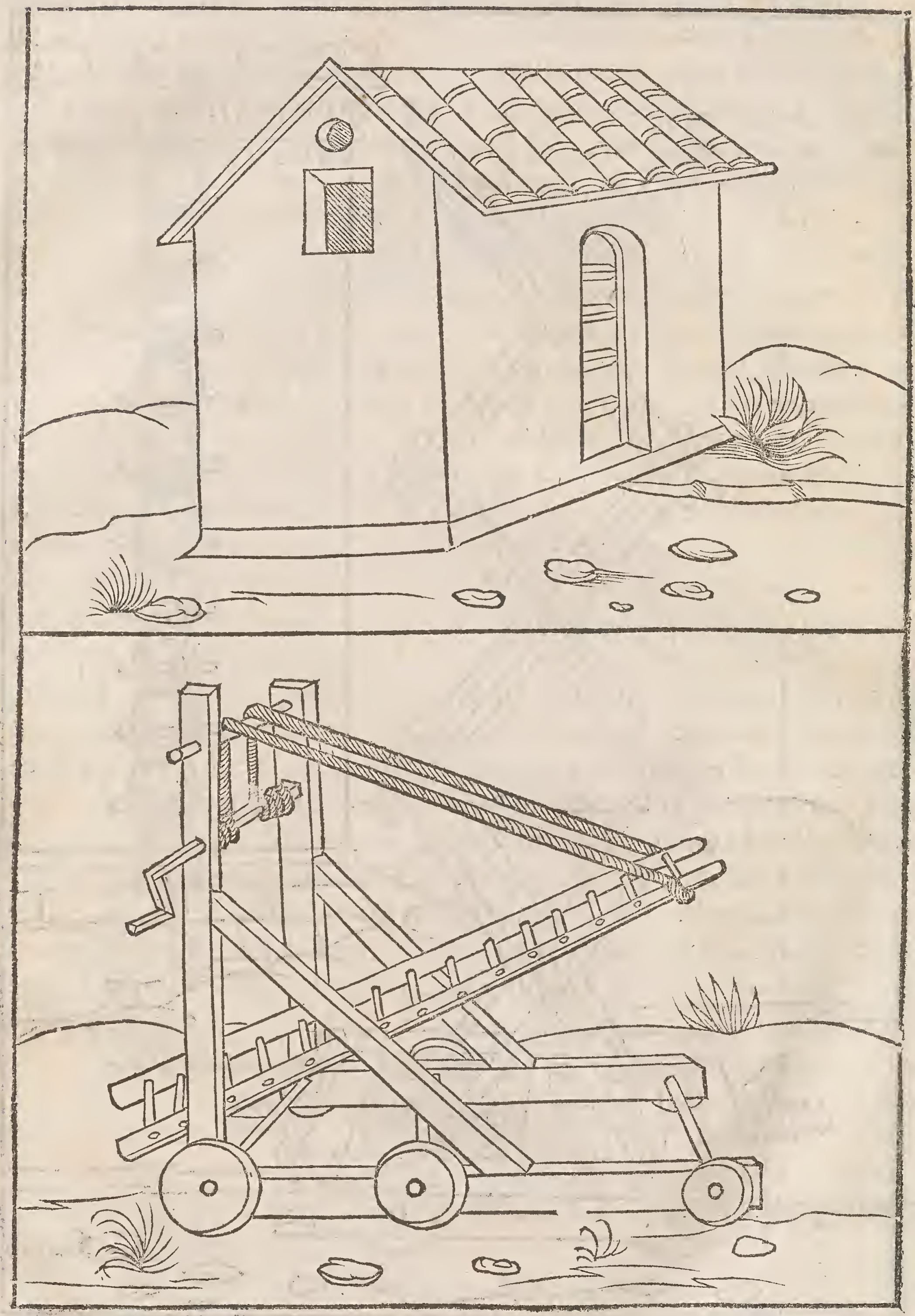


Bombar da, vt vulgo dicitur, metallica machina eft quax ignis incendio \& ful phuteo puluere, immo tartareo magis,glandes æneas, flammeas'́p pilas, \& globofa grauioráģ faxa conuoluens, horrifono fragore ac tonitru longe latéque ia ctat, muros vrbium quatiens, \& obftantia quxq demoliens, Archimedis, vt putatur, inuétum, eo tempore quo Marcellus Syraculas obfidebat, vt fuorum ciuium libertatem tueretur,patriáǵg excidium vel auerteret, vel differret, \& quo noftri ten poris duces ac imperatores vt liberos populos, vel iugo, vel excidio premant vtuntur. Hoc autem nomen Bombarda apud idoneos latinæ lingux fcri ptores nufquam inuenio,quamö huiufmodi nominis impofitio à fonitu tracta mihi nequaquam videatur abfurda. Quid enim aliud eft Bombarda quàm bóbus frue bombizatio quædam ardens?'Sed nolim eiufdem dictionis originé aliquam ab aliis doftiffinis intactam feriptoribus pertinaci nimis fenfu atque iudicio afferere,ne cui forte videar argutior: id autem audacter dixerim, baliftx, vel tornenti, vel machinæ appellatione contineri. Balifta enin à græco verbo Báx $\gg \omega$ de lucitur quod latinè dicitur iacio . Quicquid igitur, frue faxa iacit,flue fagittas,recte balifta poteft appellari. Nonius Marcellus, Balift $x$ funt,maiora $f_{a}$ sa $\&$ grauiora quibus iaciuntur. Victruuius lib.x.arch. Sed tamen nulla balifta perficitur, nifi ad prapofitam magnitudinem ponderis faxi quod id organum mittere debet . Orofus lib.iii.hiftoriarum, Regulus bellum carthaginenfe for titus, iter cum exercitu faciens, haud procul à flumine Bragada caftra conftituit: vbi quum plurimos milites aquandi neceffitate ad flumen defcendentes ferpens miræ magnitudinis deuoraret, Regulus ad expugnandam beftiā cum exercitu profectus eft, fed nihil in tergo eius proficientibus iaculis atque omni telorum ictu irrito,o,gux per horrendam fquamarum cratẹm quâfíper obliqua fcu torum teftudinem labebantur, mirúmque in modum ne corpus læderent ipfo corpore pellebantur,quū in luper magnam multitudinem morfu comminui,im petu proteri,halitu etiam peftifero exanimari videret, baliftas deferri imperauit per guads murale faxum fpinæ eius incuffum compagem totius corporis foluit Valerius Maxinus de eadem ferpente lib.i. Quum telorum iactu perforari nequiret,ad vltimum baliftarum tormétis vndiqg petitan, filicum crebris \& pon: derofis verberibus procubuiffe. Ouidius de triftibus libro primo. Nec leuius tabulæ laterum feriuntur $a b$ vndis,

Quàm graue baliftx monia pulfat onus. Idem in nono metamorph.

Nec leuius pulfata fonat quàm ferreus oling, 
Quum lacerasaries baliftáque concutit arces.

Seneca quęft.natur.libro fecundo, Nam balifta qŭoque \& forpiones tela cum fono expellunt, ficque non imitabile fulmen, vt Maro inquit, humana rabies quodam magno auctore tefte imitata eft. Quòd auté fagittas iaciat balifta,auctor eft A mmianus Marcellinus, rerum geftarum.xxiiii. Affifit, inquit,artifex: contemplabilis, \& fubtiliter apponit in temonis cauamine fagittam ligneã fplculo maiore conglutinatam, $\mathbb{Q}$ cum ad extremitatem neruorum acumen vene: rit fummum, percita interno pul lu à balifta ex oculis auolat, interdum nimio ardore fcintillans, \& euenit frepius vt antequam telum cernatur, dolor læale vul: nus agnolcat.Idem $x x v$. Tum aptatæ ligneis fagittis baliftr,flexu, ftridore torquebantur, creberrima ficula funditantes. Hieronymus libro primo cótra los vinianum, Balifta quanto plus retrahitur tanto fortius emittitur.

Lucanus in fecundo,

Tortáque per tenebras validis balifta lacertis

Multifidasiaculata faces.

Hanc $\&$ græci in fiue addétes Bå $\lambda$ sspap dicunt, quam et Syrophoenicas inueniffe vi. natur. hifto. Plinius auctor eft. Ancon autem antiquiflimus hiftoriaram auctor fcribit pul lum à loue Saturnum fugifle in Græciam, vbi mótruoforum hominum exercitum congregauit, contra quem Iupiter al peftrem partem occus pans, baliftarum vfum docuit. Proinde victoria potitus,fingitur à poêtis louem de calo pepuliffe, 8 Cretz regno priualfe.

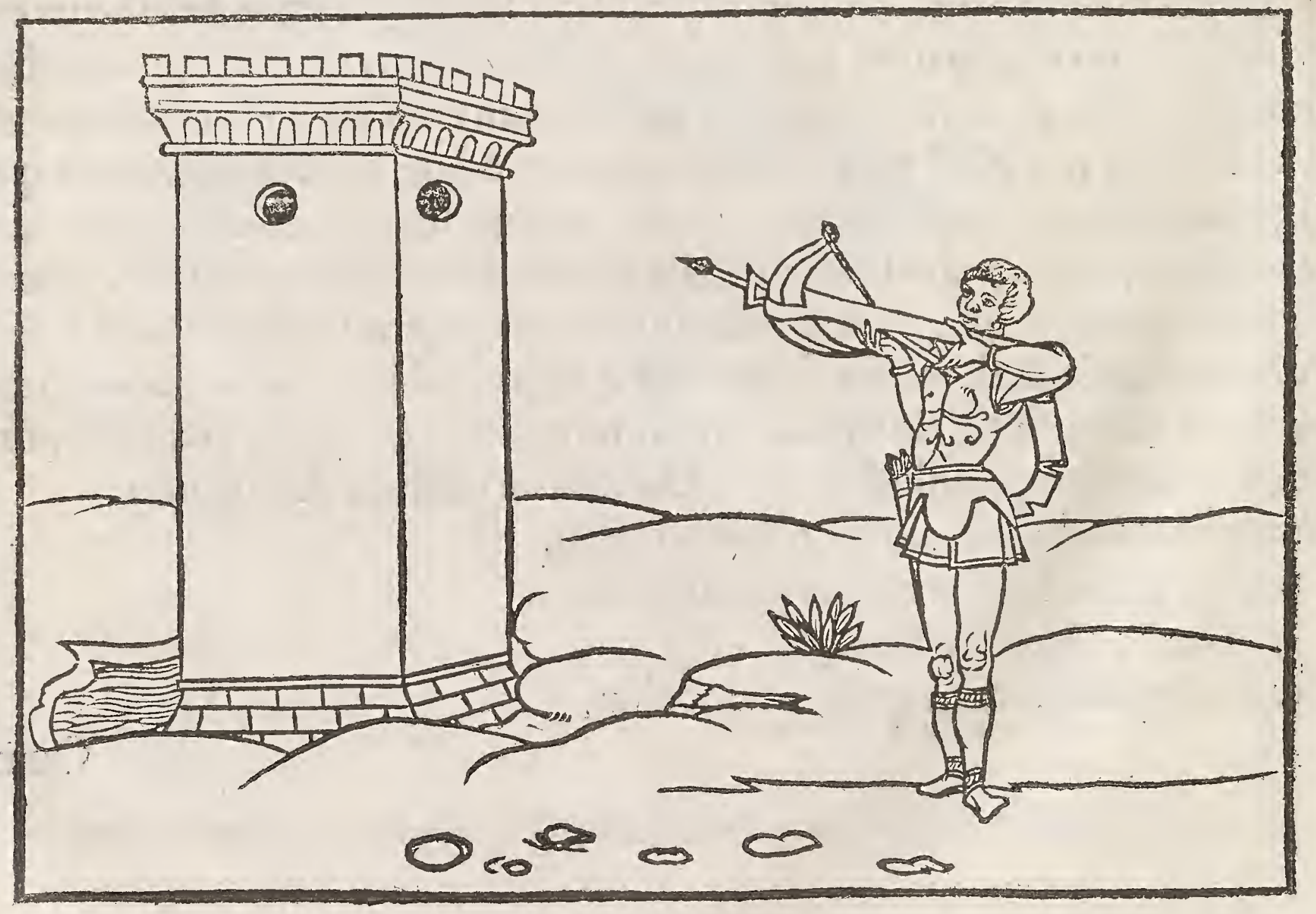


DEREMILITARI LIB. X. ${ }^{263}$

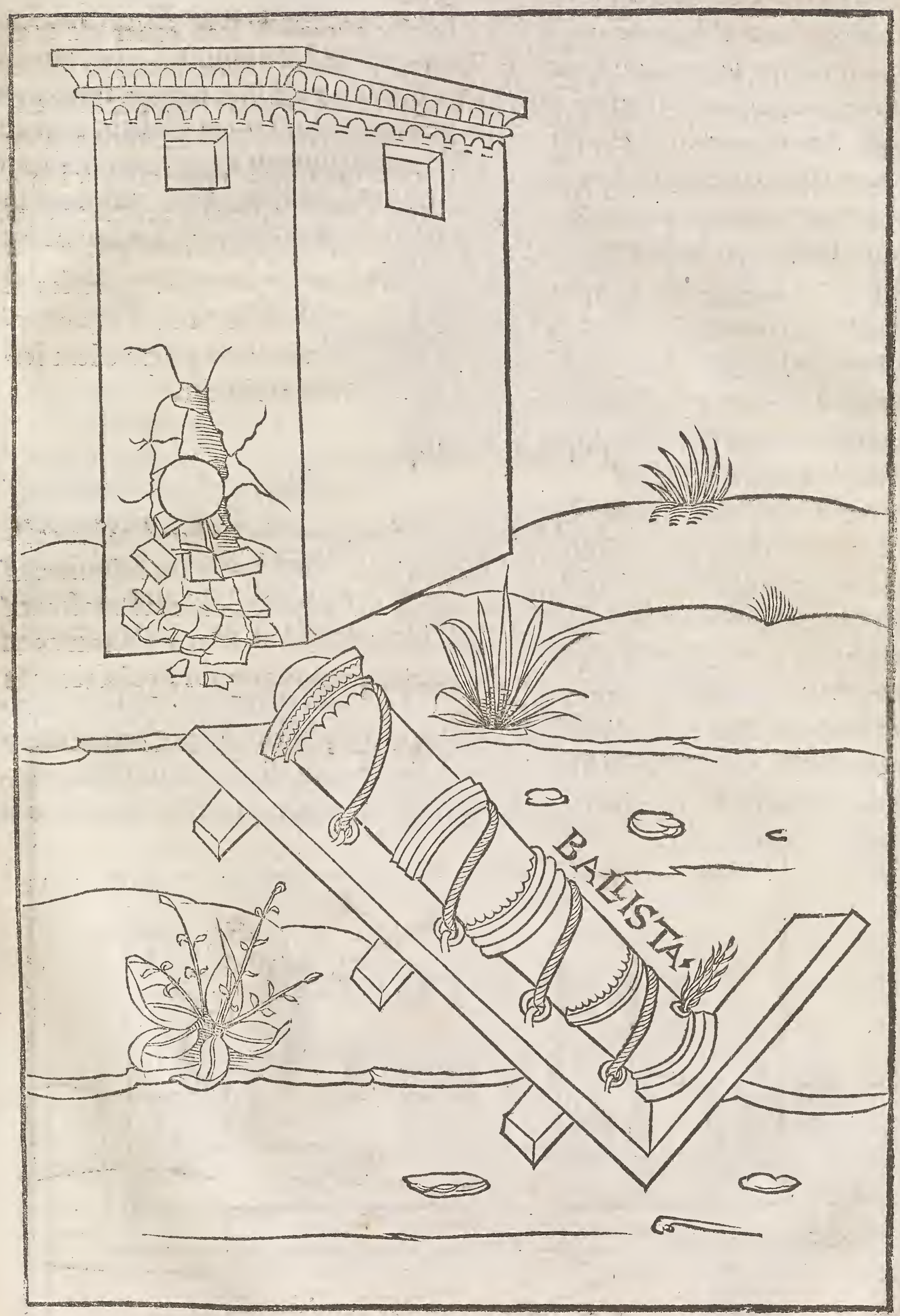


Tormenta, inftrumenta bellica ad diruenda oppida cuertendasóp vrbes, fic di cta quòd tela torqueant, hoc eft, gyro celeri faxa rotent, iaciant, \& mittant. Liui us xxiiii. ab vrbe condita, Aduerlus hunc naualem apparatum Archimedes va riæ magnitudinis tormenta in muris difpofuit, in eaśg quæ procul erant naues faxa ingenti pondere emittebant. Iofephus belli iudaici lib.vi. Habebant etiam baliftas CCC. \& L.torméta faxorú, quibus difficiliorem aggerú extructınem Romanis efficiebãt. Cicero Antonianarum viii.Quid?ille faceret inducias?an= te confules oculófọ legatorum, torméntis Mutinam verberauic. Virg.in vndec. Continuó aduerfis Tyrrhenus \& acer aconteus

Connixi incurrunt haftis, primíque ruinam

Dant fonitu ingenti,perfractạ́ quadrupedantum

Pectora pectoribus rumpunt, percuffus aconteus, Fulminis in morem aut tormento ponderis acti,

Præcipitat longe \& vitam difpergit in auras.

Murali concita nunquam

Tormenta fic faxa fremunt, nec fulmine tanti

Idem in duodecimo,

Defultant crepitus.

Seneca quęt. natur.lib.ii.Nubium intra fe cöpreffarum anguftix medium fpiritum emittunt, $\&$ boc ipfo inflammant ac tormenti modo eiiciunt. Tormenta criam miffilium inftrumenta funt à torquendo dicta. Virgilius ii.georg. Itureos taxi torquentur in arcus.

Firmianus libro fecúdo contra gentes, Vrbe à Gallis occupata obfeffi in capitolio Romani cum ex mulierum capillis torméta feciffent, æedem Veneri caluæ confecrarunt. Seneca de ira libro primo, Quum opus eft cócitatur remittitúrque,non aliter quàm quæ tormentis exprimuntur tela, in poteftate mittétis funt guantum torqueantur.

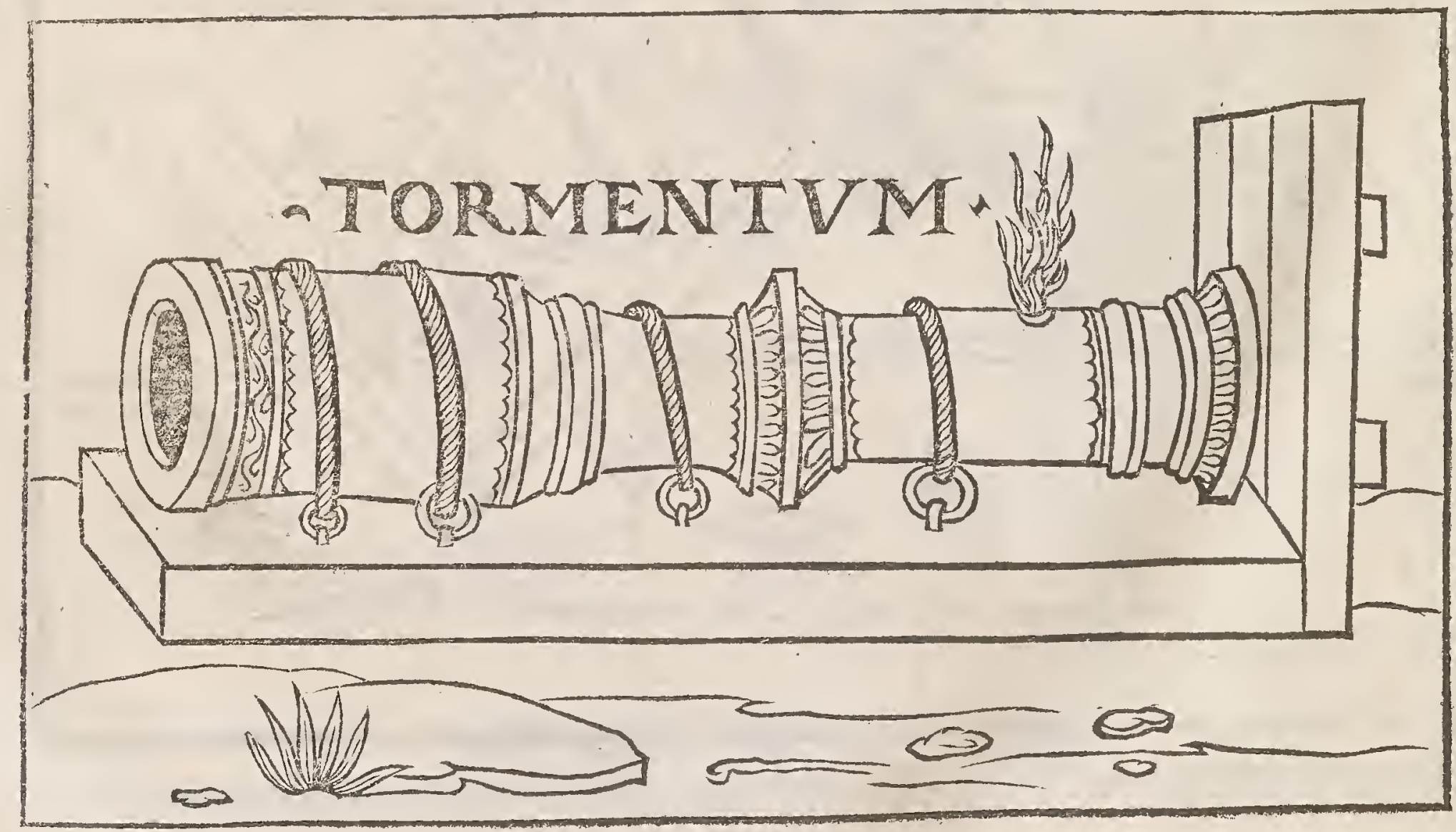


Machina, tormentum murale vrbes labefaciens, 8 oppidorumi mœnia. Tra gicus in Thyefte, Admot is nihil eft opus vrbes fternere machinis, loge faxa ro tantibus. Valerius Max.libro quinto, Q.verò Metellus celribericü in Hifpana gerens bellum quú vrbeni Centobricam obfideret,\& iam ad mota machma par tem muri que fola cóuelli poterat drfiecturus videretur, humanitaté propinguæ victoriæ prætulit. Nam quum Rethogenss filios qui ad eum tranfierat Centobricenfes machinæ ictibus obieciffent, ne pueri in confpectu patris crudili genere mortis confumerentur, quanquam ipfe $R$ ethogenes negabat effe Impedimento, quo minus etiam per exitum fanguinis fui expugnationem perageret, ab obfidione difceffic. Quo quidem tam clementi facto, etf non vnius ciuitatis monia, omnium tamen celciberarum vrbium animos cepit, effecitge vt ad redigendas eas in deditionem populi Romani non mulcis fibi obfidionibus opus effet.Seneca epirt.lib.xvii.Multi inueniuntur qui ignem inferant vrbi,qui inexpugnabilia fæculis, \& per aliquot ætates tuta profternãt, qui æquum arcibus ag gerem attollant, $\&$ muros in miram multitudinem adductis arietibus ac machi nis quaffent.Idem decimo quarto, Philofophia circundanda eft inexpugnabili muro, quem fortuna multis machinis laceffitum non tranfit. Plutarchus in vita Marcelli, $V_{t}$ verò machinas. inftruxit A rchimedes, varia mifliliú genera \&' immen $æ x$ magnitudinis faxa,incredibili fragore $\&$ celeritate iacula aduerfum ter reftres emittebat copias.lofephus lib.iii.belli iudaici,Miffáp machinis faxa 8 murorum minas auferebant, $\&$ frangebant angulos turrium. Virorum autem nulli tam fortiter conftipati erant, vt non vfque ad extremam aciem, faxi magnitudine \& violentia fternerentur. Sciet aute aliquis huius machinæ vis quan tum valeat ex his qux illa nocte contigere, In muro cuidam ex circunftantibus Io ippo caput auulfum eft, eiúfque ad tertium ftadium veluti funda excuffa cal uaria. 'nterdiu quoque pregnâtis foemina icto vtero ad dimidium ftadium infansabactus eft,tanta tormento vis fuit. Ergo machin is terribilior erat impetus \& mifflium ftrepitus. Idem in eodem, libro fexto, Omnibúfque agminibus contra excurfus erant machinæ comparatæ mirabiles, præcipue verò legio . ni decimæ: baliftæ verò vehementiores, $\&$ tormenta faxorum quibus nó folum irruentes fed etiam fuper murum ftantes euertebantur. Nam \& fingula faxa talenti pondus æquabant, \& vltra modum ftadii torquebantur. Ictus autem non folum prim is quos offendiffent, fed aliquando pofterioribus quoque intolerabi lis erat. Iudxi primo cauebant à la pidibus quòd erant candidi: nec tantum lo. no \& fremitu nofcebantur, fed claritudine profpiciebantur, denique fpeculd tores in turibus prefidentes prædicebant quando impelleretur machina, laxum 
que ferretur,patria lingua clamantes, Filius venit. Itáque pradicebant in quos veniret, atque ita vitabant, \& hinc eueniebat vt illis declinantibus lapis irrtus intercideret. Proiride contrà Romani excogitabant atramento decolorare lapides: tunc enim miffi non fimiliter incertos ictus habebant, multófque fimul vnius impetu corrumpebant. Idem in eodem, Ad Antonianam veróab ipfis fociis cum multitudine Źlotarum, nó folum $q$ de loco fuperiore pugnabant, verùm etram quòd machinis vti didicerant. Paulatım enim vfus aluit peritiam. Arifto teles lib. vii. Politi.Præfertim hoc tempore in quo torméta 8 machinæ ad obfidiones vrbium cú omni fubtilitate funt adinuéta. Laërtius. Diogenes libro de vita philofophorú, De metallicis,inquit, machinis feripfic Strato philofophus. Hæc fi nota forent, frueremur fimplice cultu: Claudianus libro lecundo, Claffica non fremerent, non ftridula fraxinus iret,

Non ventus quateret puppes, non machina muros.

Vtóg in his bellicis inftrumentis tua tibi, Sigifmunde Pandulphe, quandoo me morem inuenta, memoren \& cæe eris quibus illa vfu fore non ambigo, Ponitur ante oculos machina prius inuifa, à laculíque inaudita : quippe gux lecundo fine fubfellio, aliarum præter omnium norem, dictu mirabile, librata innixáç folo,ac grauitate pòft fua preffa perfiftit. Egregium fane inuentum au store te, præclaríque ducibus prafentibus ac pofteris quàmmaximè dignum.

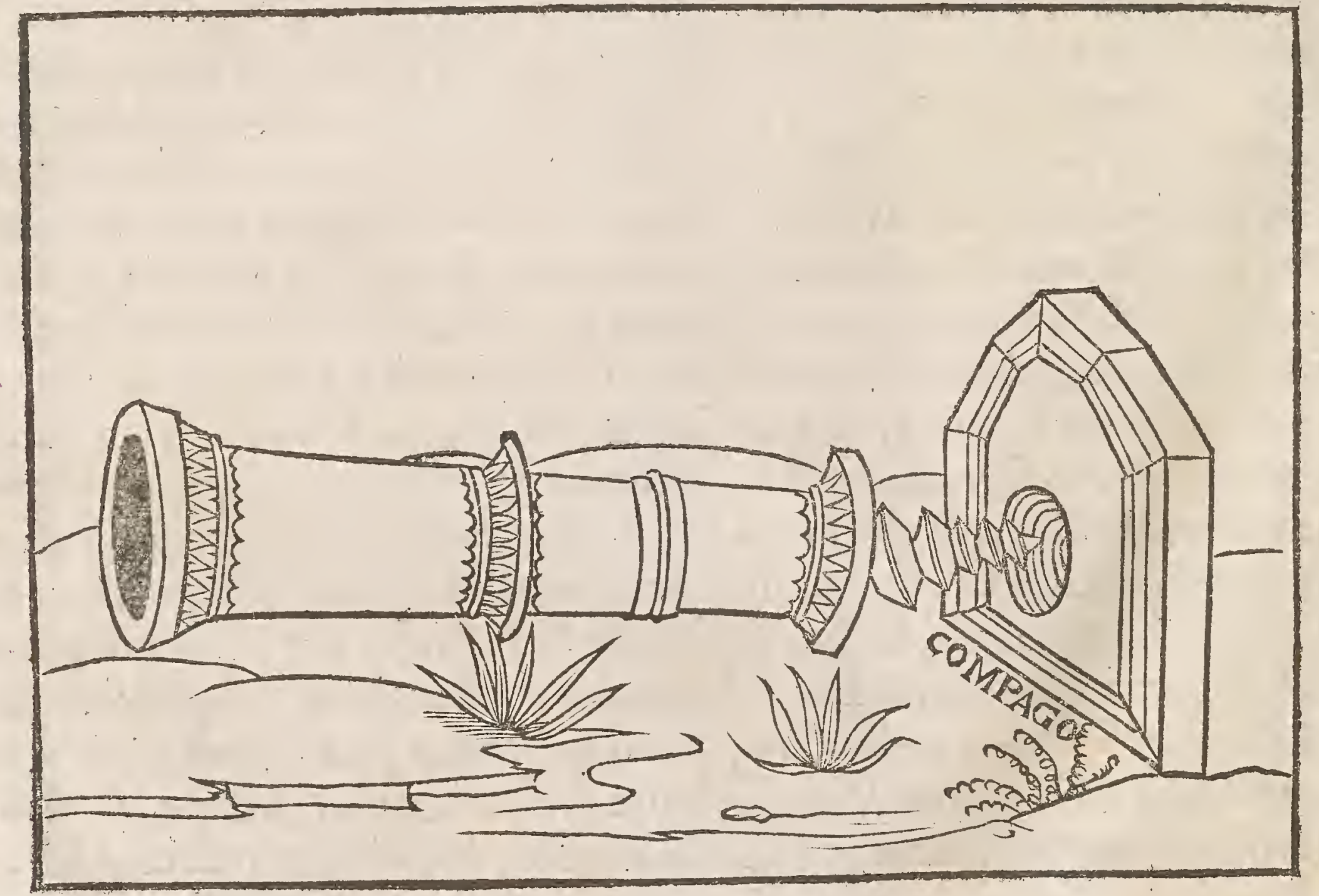


Inuentum eft quoque machin $x$ huiufce tuum, Sigifmunde Pandulphe, qua pilææneæ tormentarii pulueris plenæ cû fungi aridi fomite vrentis emittuntur.

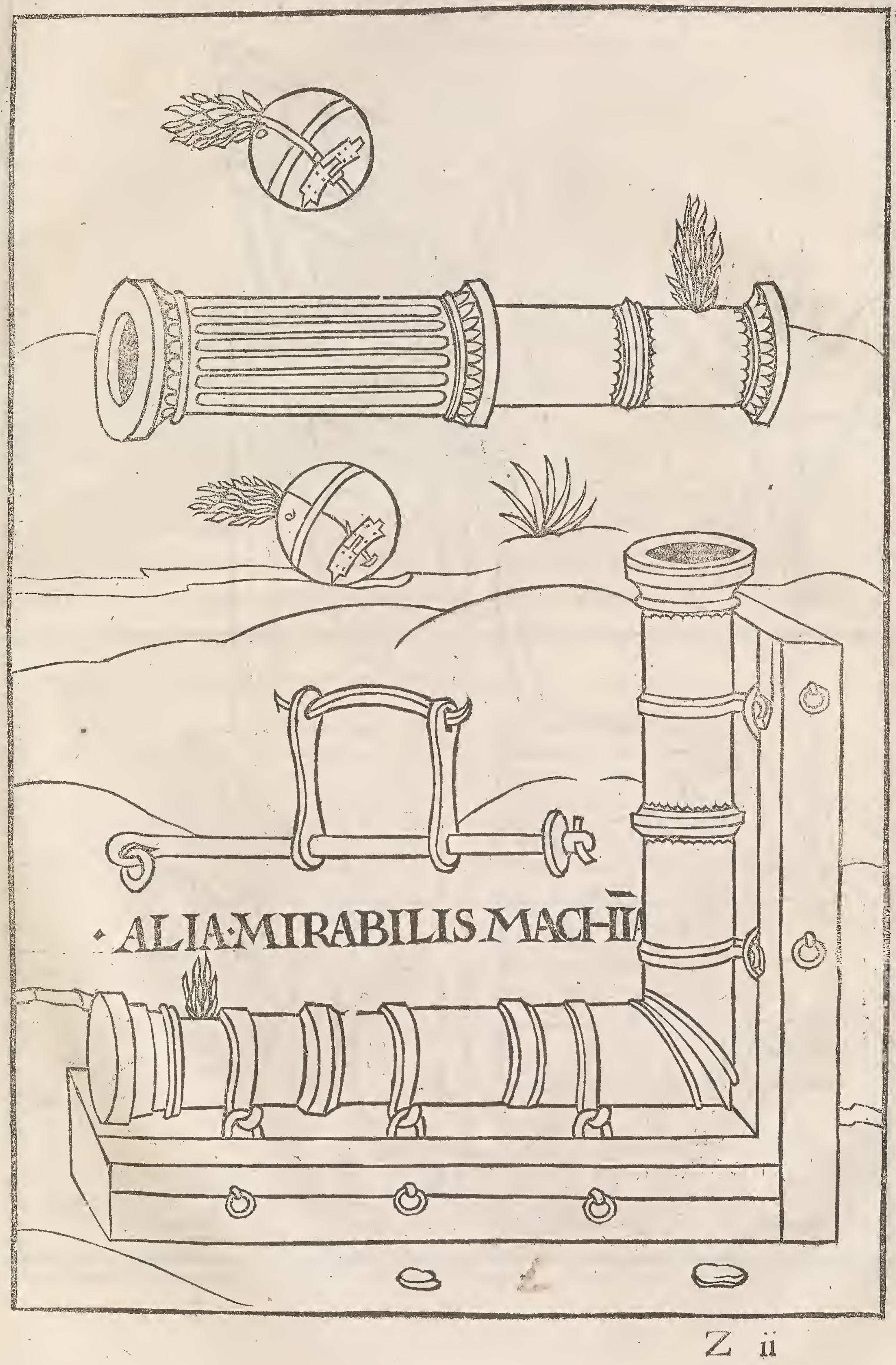




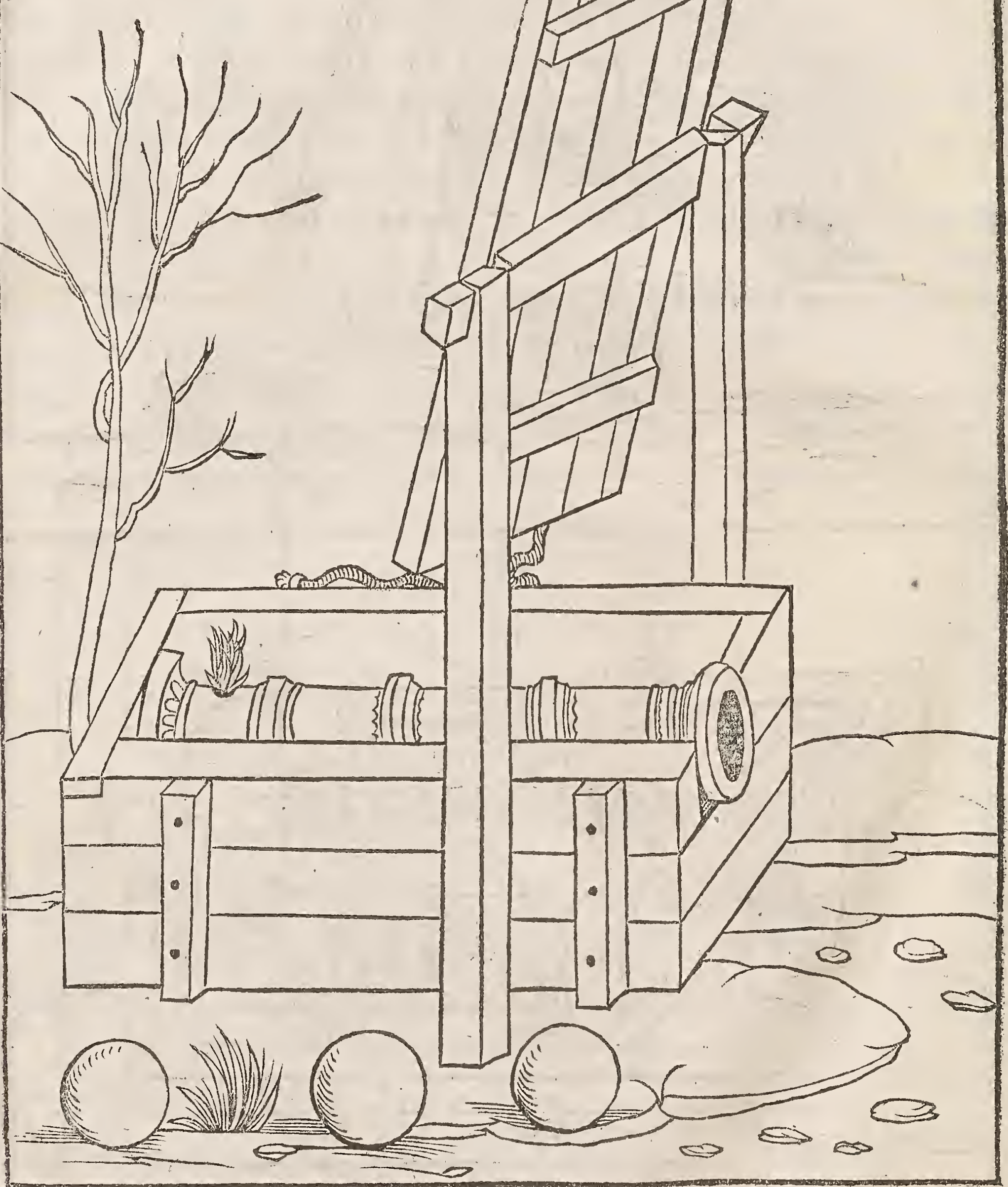


DE RE MILITAR I

L. I B. X。

Vefricula duo tormentaria.

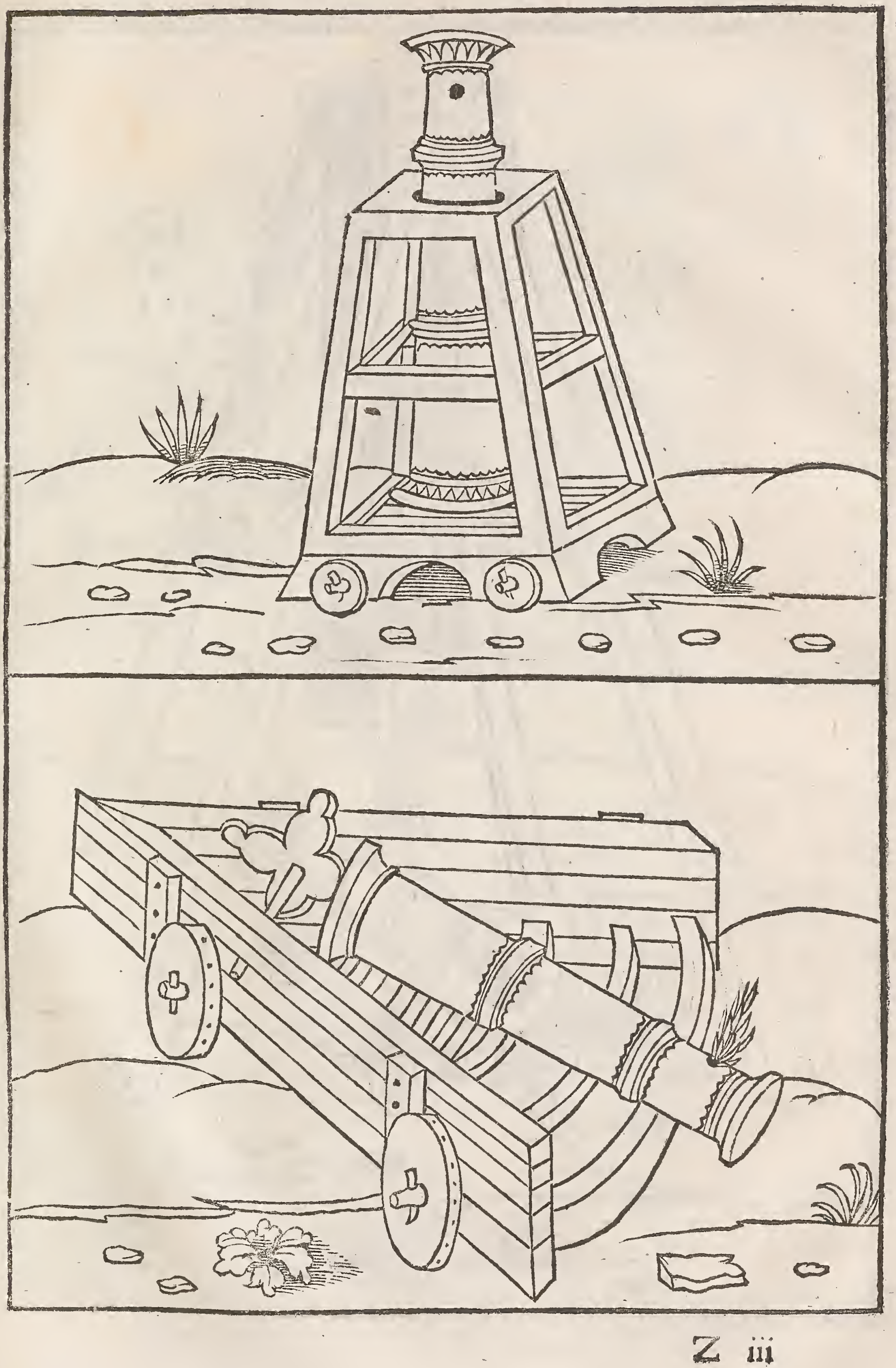




270. ROBERTI VALTVRII

Inftrumentum erigendi machinam in fublime.

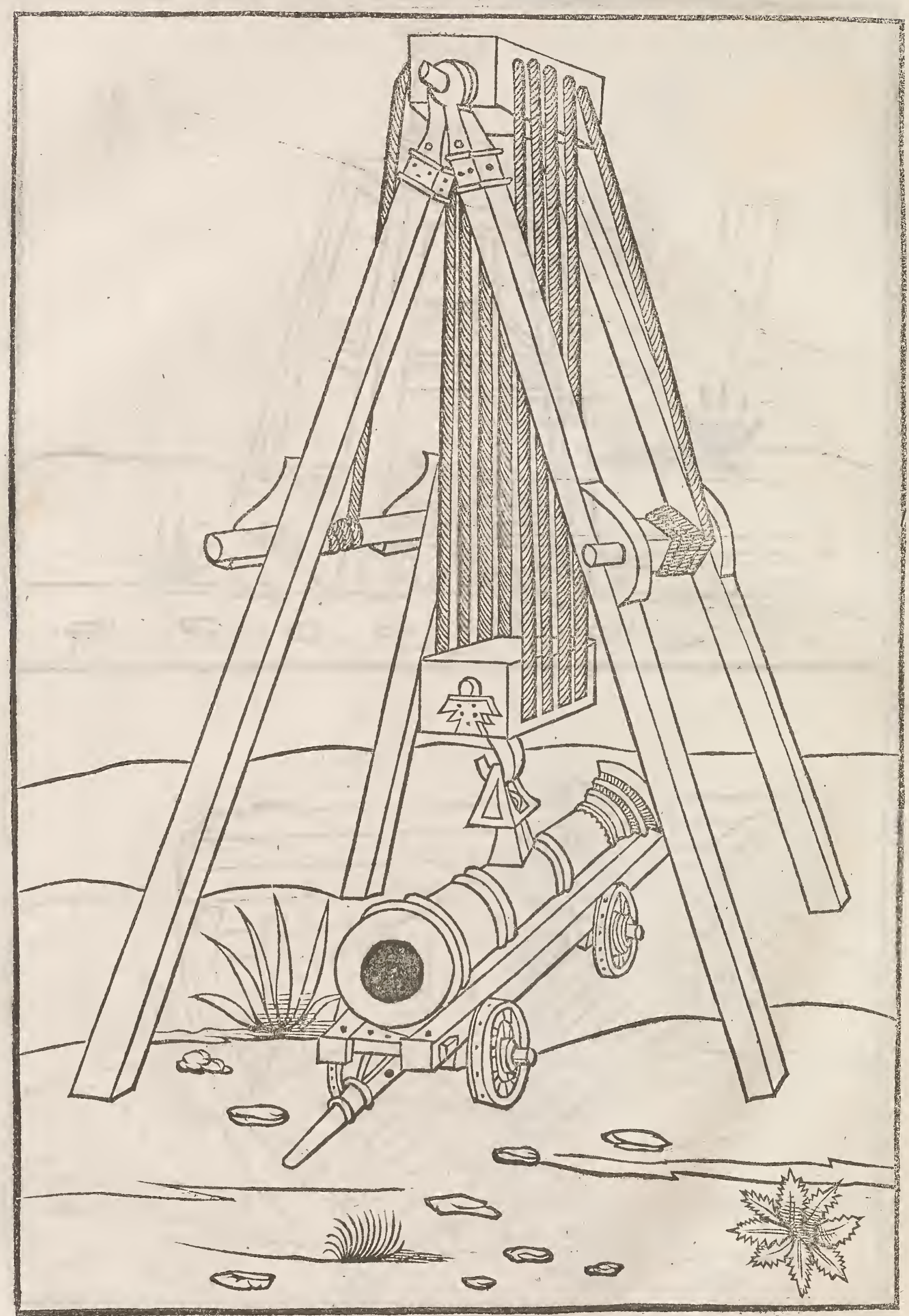


DERE MILITARI IIB. X. $\mathrm{X}_{0}$ Inftrumentum erigendi ponè machinam deprimendíque.

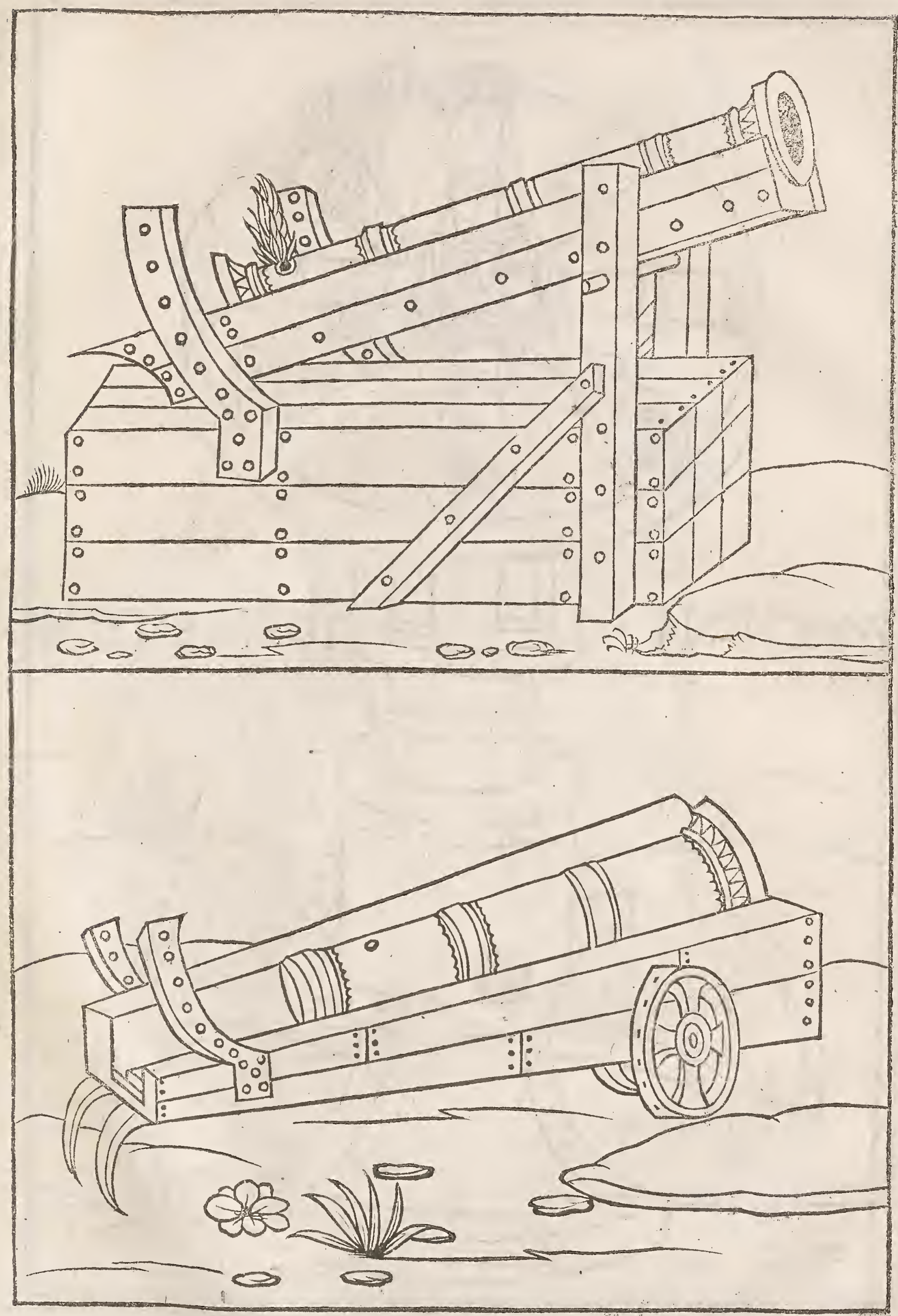

Infrumentum ad tor menta deprimenda extollendáque. 


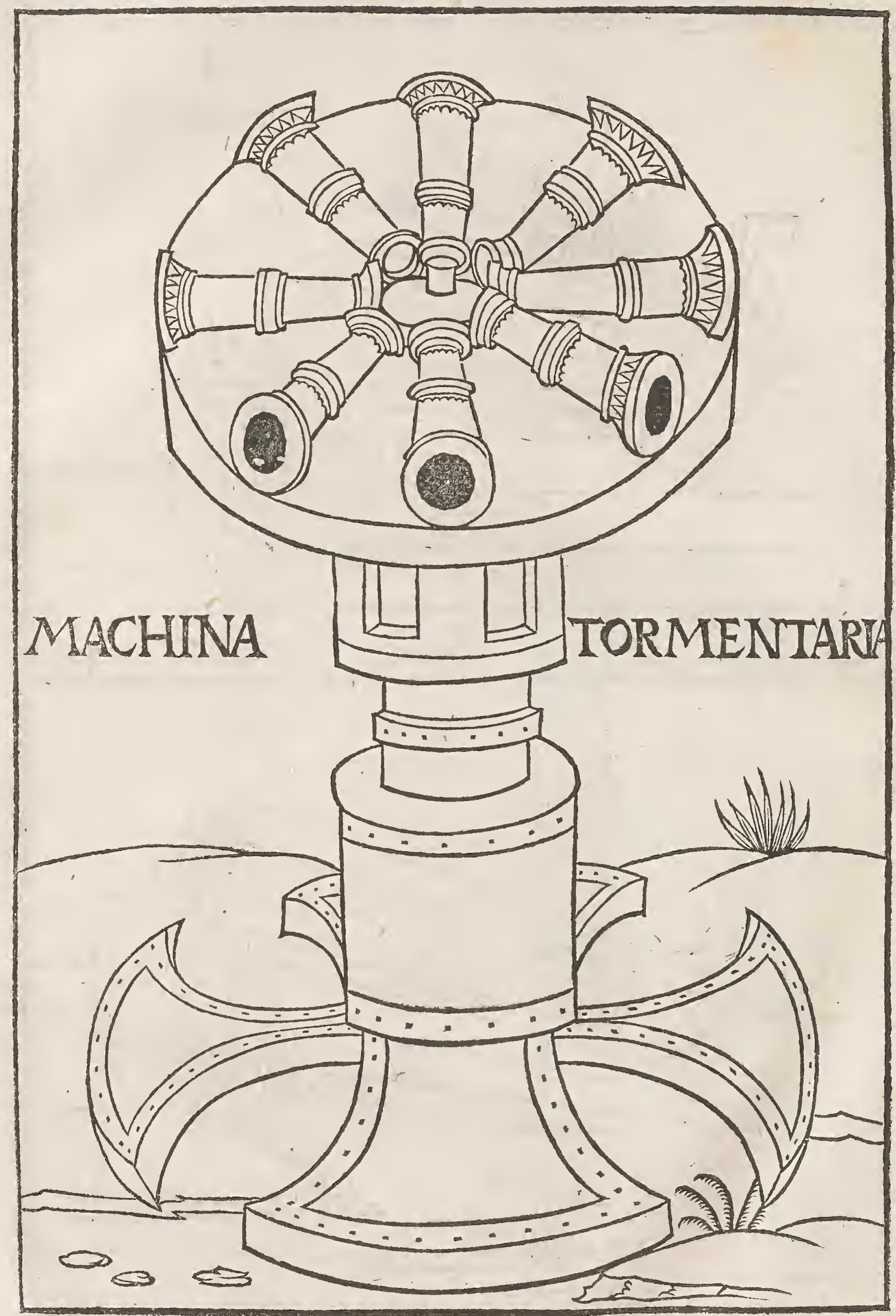


DEREMILITARI LIB. X. ${ }_{273}$

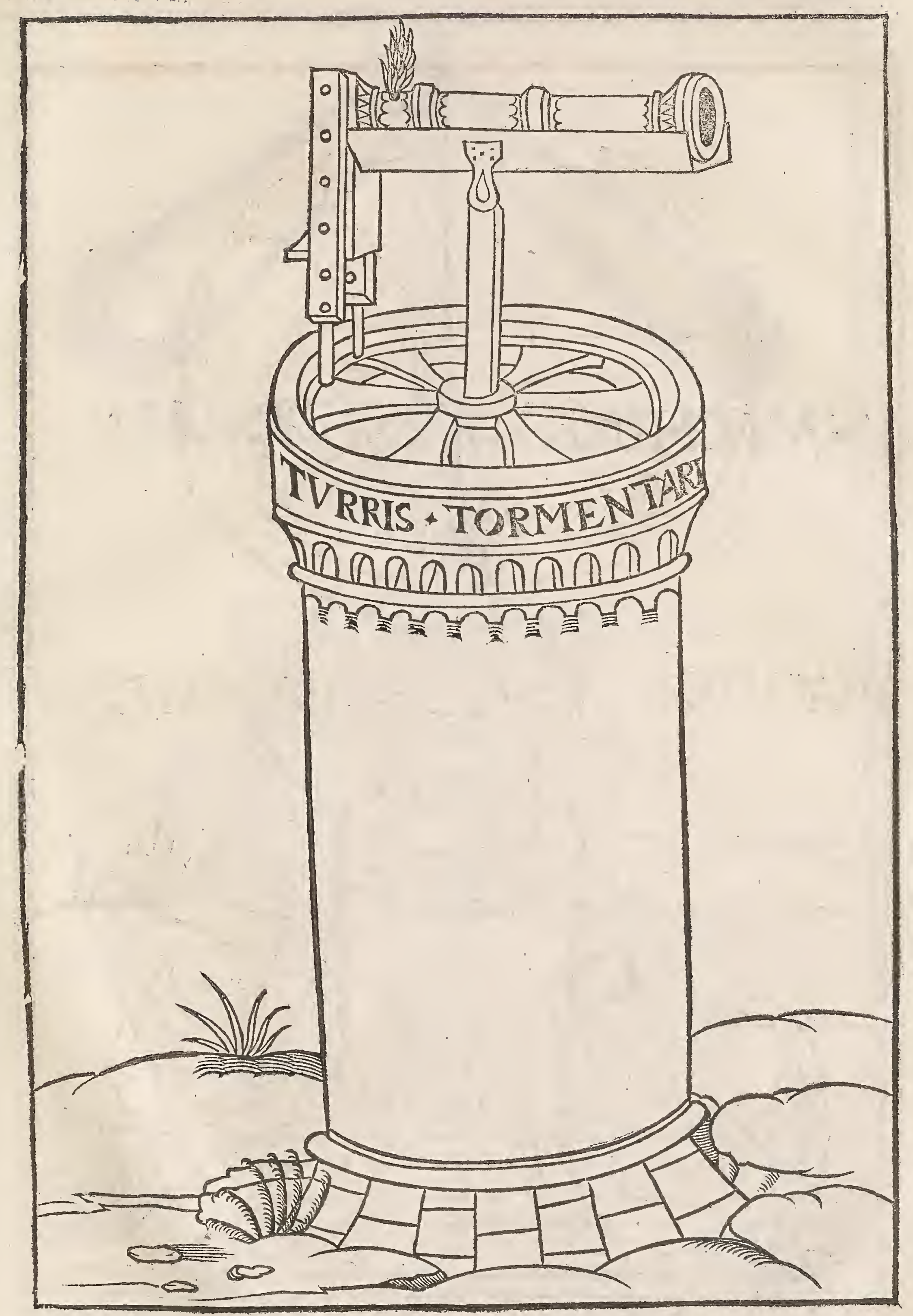


2\%A ROBERI VALTVRII

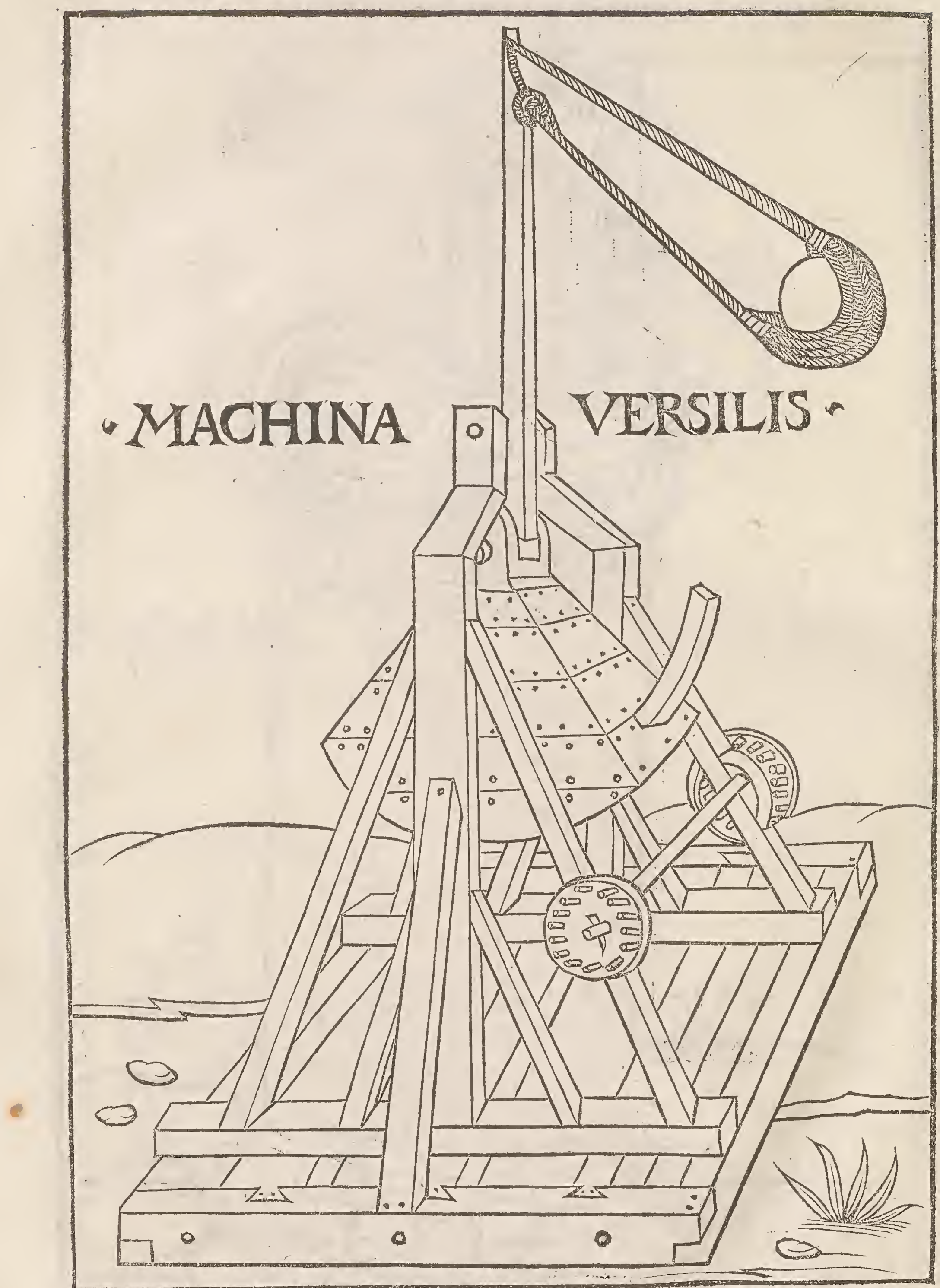


DEREMILITARI LIB. X.

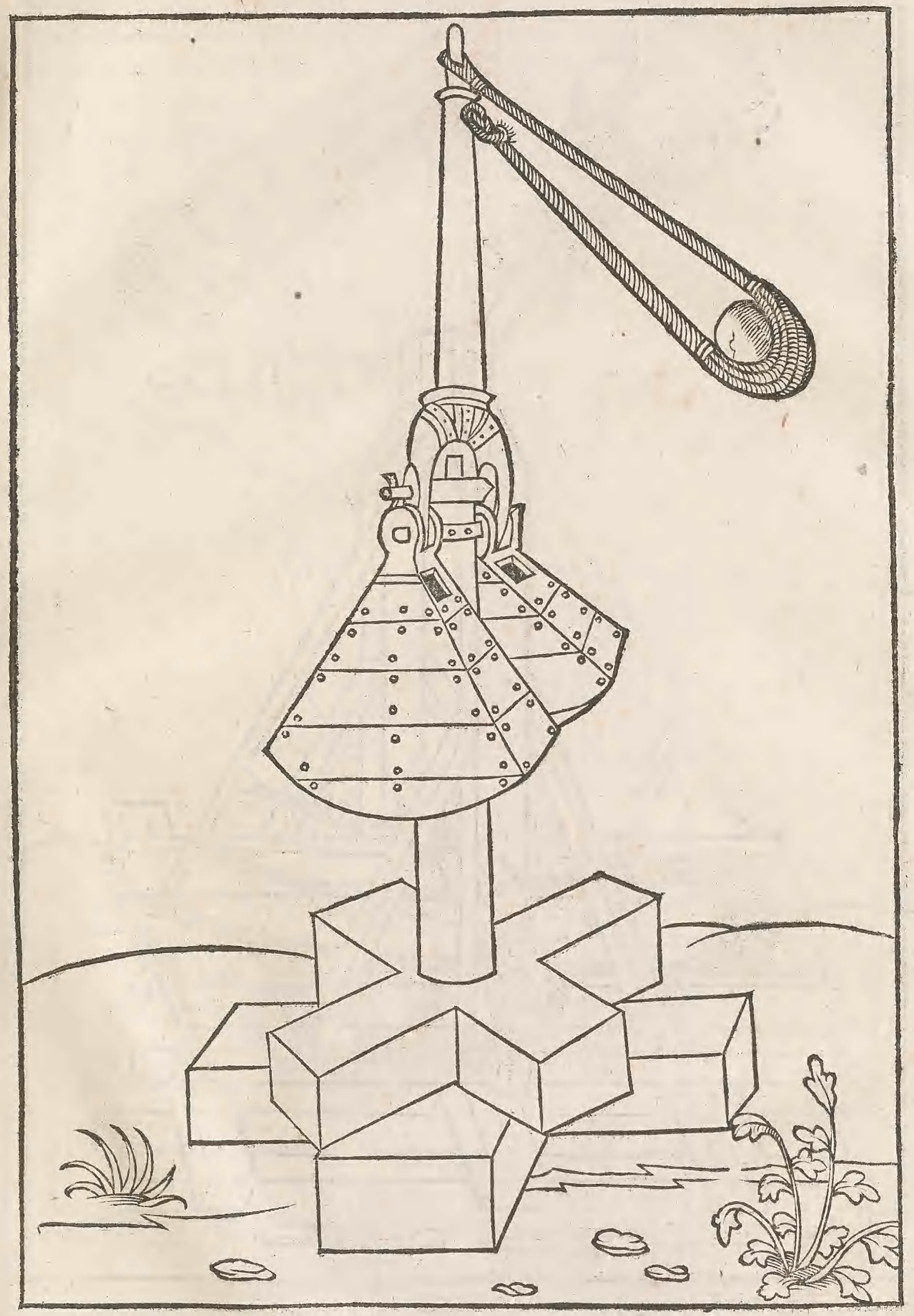




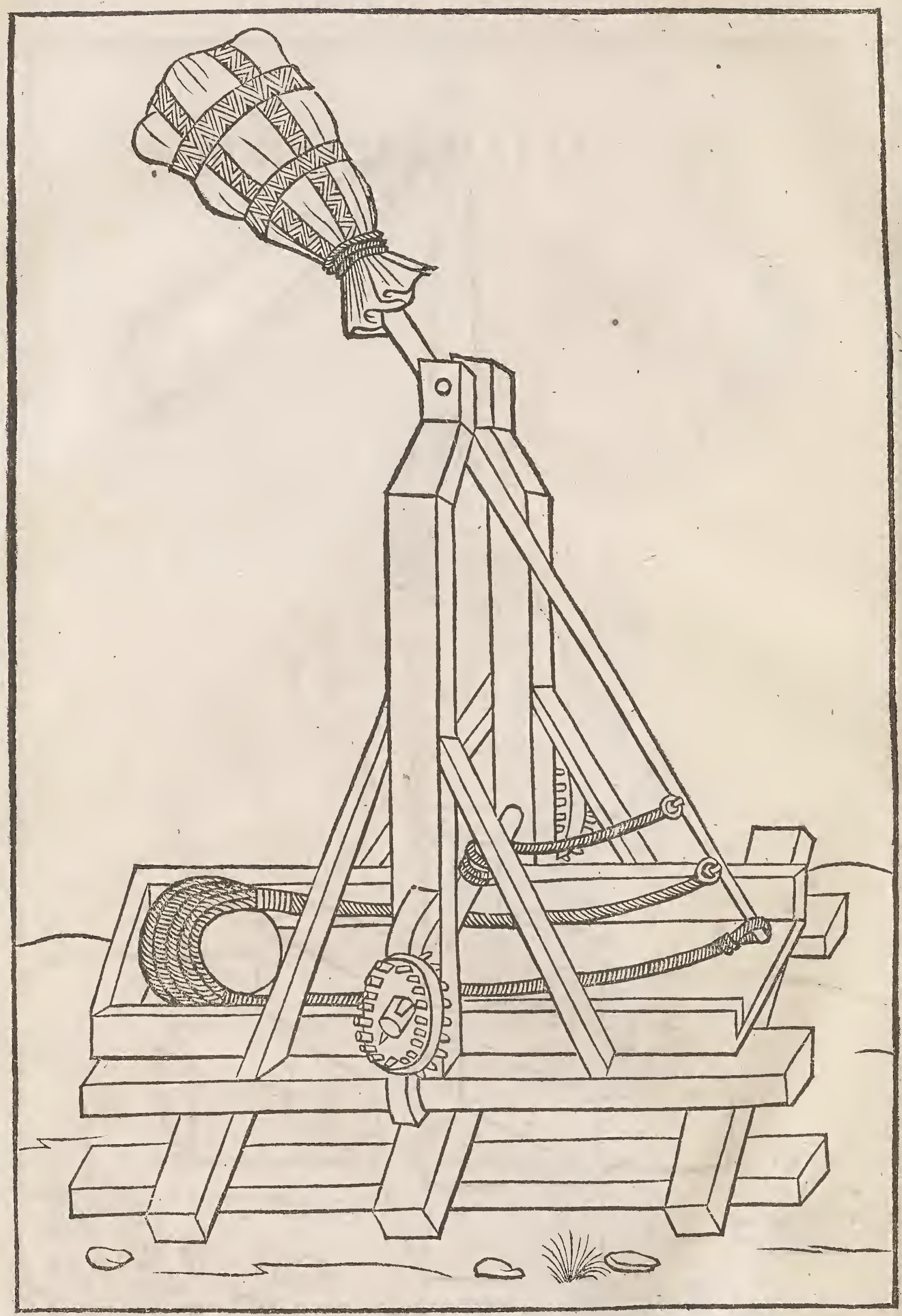




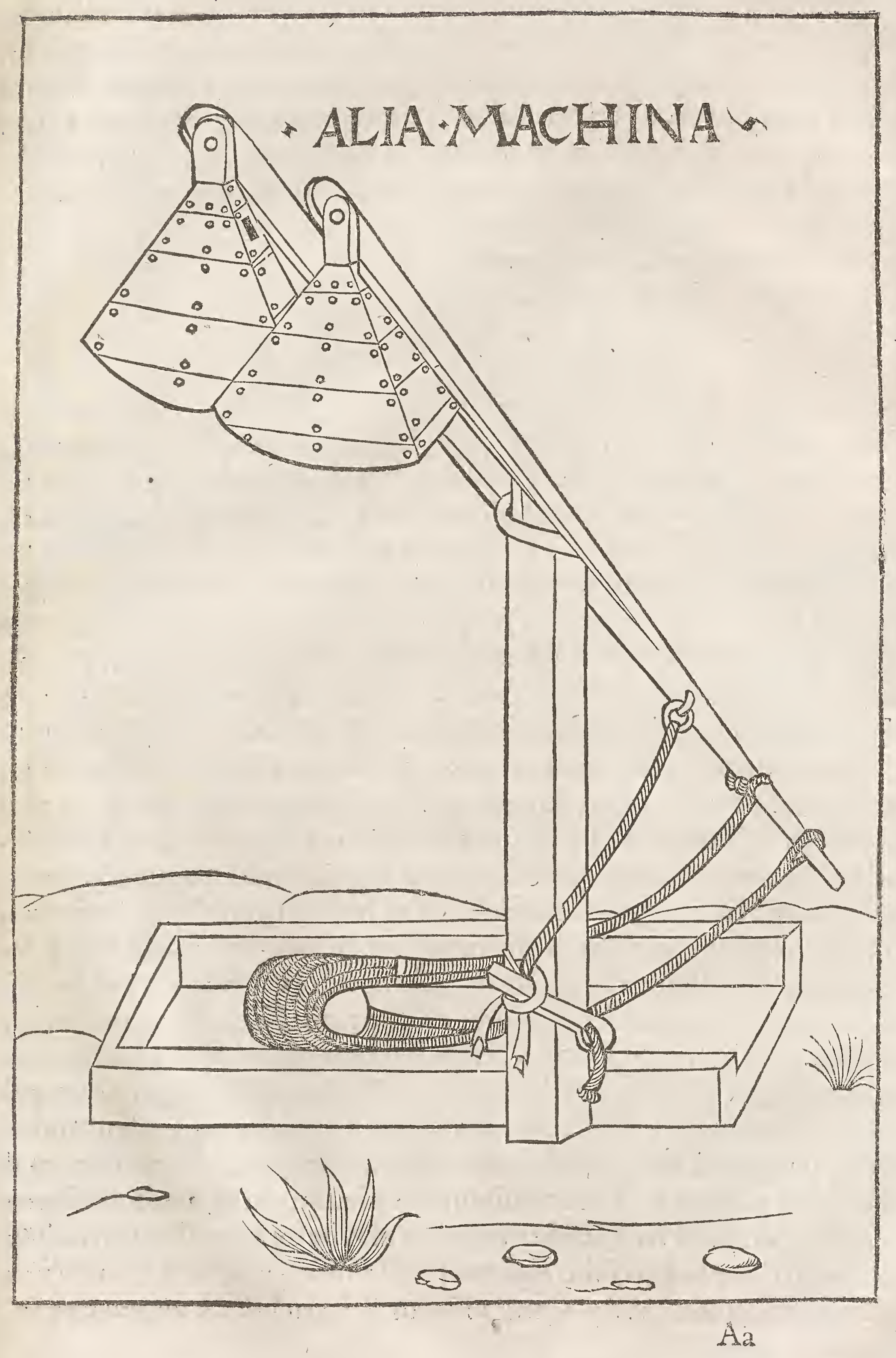


Vinea, machina ex lignis leuioribus colligatur, latitudine pedum octo,altitu dine feptem, lógitudinis veró xvi.cuius tectum munitione duplici, tabulatis, cra tibúrfque contexitur: latera veró vimine lepiuntur, vnde nomen ortum putant, ne faxorum telorumg impetu penetrentur. Extrinfecus autem ne immiffo con cremetur incendio, crudis vel recentibus coriis, vel centonibus operitur, quumág plures facte fuerint, iunguntur in ofdine ac rotis ducuntur: his deniqg tuti obfidentes, ad fubruenda murorum penetrant fundamenta. Lucanus in tertio, Tunc adoperta leui procedit vinea terra,

Sub cuius pluteis, \& tecta fronde latentes

Moliri nuncima parant, \& vertice ferreo

Monia nunc aries fufpenfa fortiter ictu,

Incuflus denfi compagem foluere muri

Tentat, 8 impofitis vnum fubducere faxis.

Liuius ab vrbe condita xxi. Aduer fus eum vineas agere conftituit, per quas aries monibus admoueri poffet. Idem in eodem, I taque acrius de integro ortum eft bellum, pluribúfque partibus, vix accipientibus quibufdam opera locis, vinexe ceptæa agi,admoueríg aries. Teftudo, eft fcutorum connexio in modum teftudinis: nanque in armorum generibus fumunt milites ab animalibus nomina,vt aries, teftudo. Hæc ex materia \& tabulat is etiä contexitur, qua ne exuratur incendio, coriis, vel ciliciis vel centonibus veftitur, $\&$ ad fimilitudinem veræ teftudinis vocabulum fumpfit. Nam ficut vbi collecta in fuum tegmen eft; tutam ad omnes ictus videmus effe, vbi uerò caput nudat, \& modo reducit, modo profert, ictibus patere, ita machinamenti hoc genere inclufi, tuti funt interdum, dum reducunt trabem, interdúmque exeunt vt fortius cædant detecti, \& perfape caduntur. Teltudo etiam qua acceffus ad murum poteft haberi fic erit facienda,Bafis compaginatur quadrilatera, cui in quibus verfantur fupponuntur rotarum axes, laminis ferreis conclufi, ita vt habeant cardines $\&$ foramina, quo vectes traiecti verfationes earum expediant, vti antè $\&$ pòn ad dextrum leưmop latus, fiue oblique ad angulos opus fuerit ad id verfatis, progredi poffit. Poffunt autem fi opus fuerit hi maximè ex octo rotis effe quibus agatur,verum fecundum loci naturam opus erit téperare. Tegatur autem teftudo hac ex omni materia que maximé vim habere poffit, refiftendóg robur, pręter pinum, vel alnum, vel aliud id genus, hæc enim fragilia funt, \& ignem facile admittentia: vel vtiignis omnino non poffit huic machinæ obeffe, argilla infuper cum capil lo fubacto ad eam quam decet craflitudinem inducatur, circa tabulata collocen tur crates ex tenuibus virgis creberrime texte maximég recentibus, percrudisq́p coriis duplicibus confutis, fultis alga aut paleis in aceto maceratis, circumcirca regatur machina tota, vtà plagarum ictibus $\&$ incendiortàn impetu tuta fit. 


\section{DERE MILITARI $\quad$ LIB. X. $\quad 27 \%$}

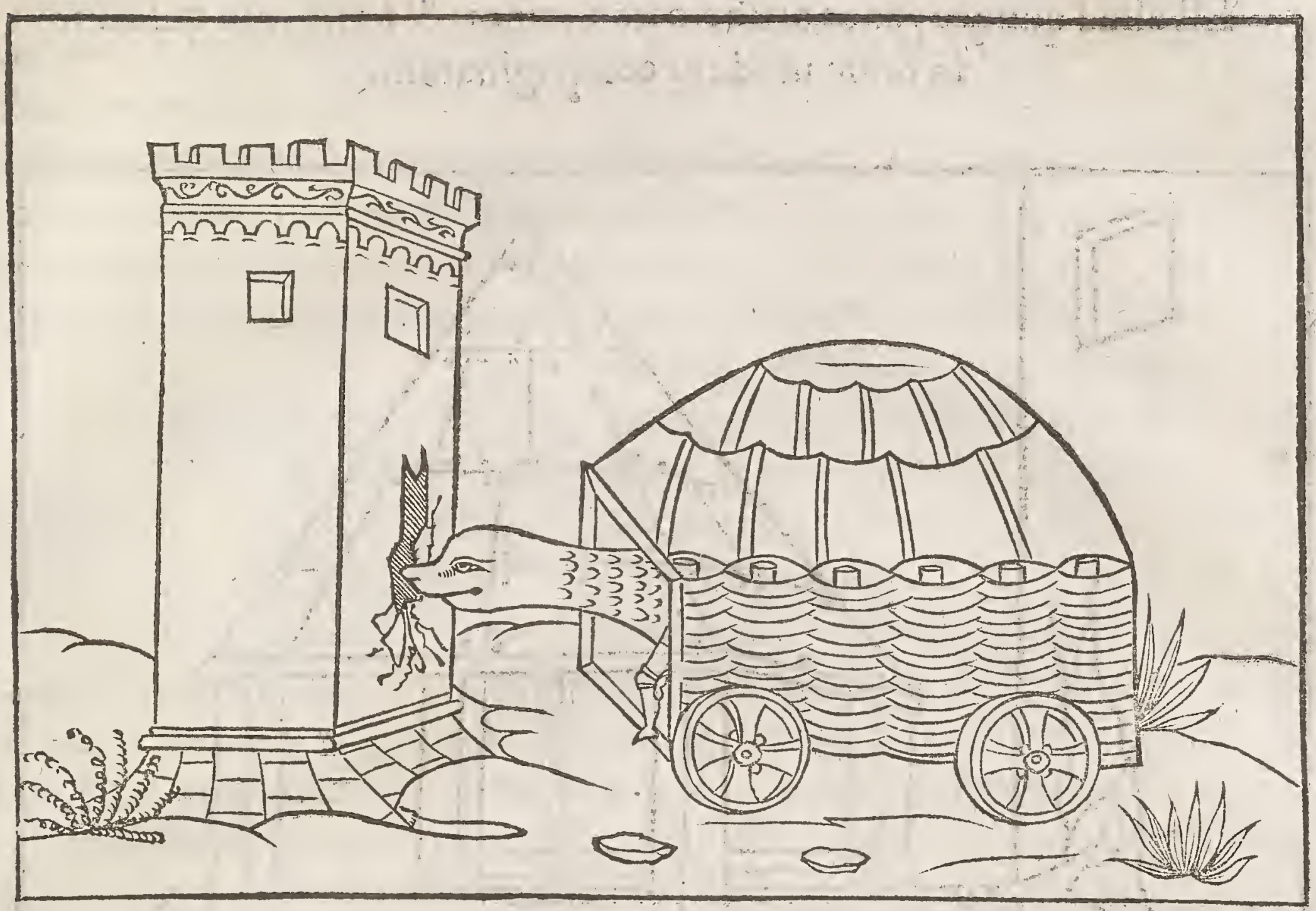

Non mihi etiam videtur alienum de teftudine quam Hector Byzantius fecit, quibus rationibus fit facta exponere. Frons eius erat quemadmodum anguli tri goniorum, vti à muro tela cum in cos mittantur non planis frontibus excipiant plagas,vt hic,

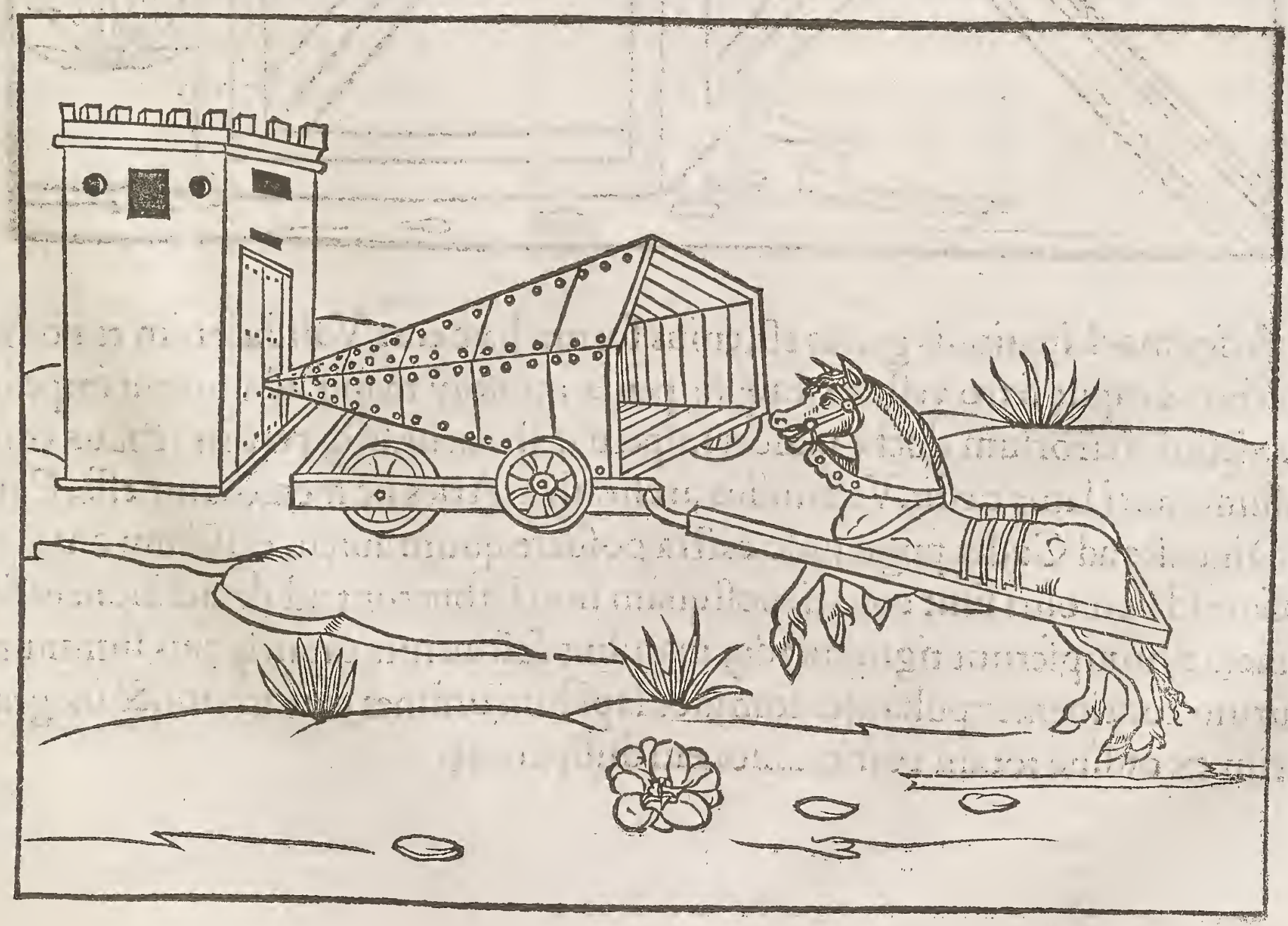

Aa ii 
EAt aliud quoque genus, artificio non minori,\& terrificum quidem, in hunc modum compaginatum.

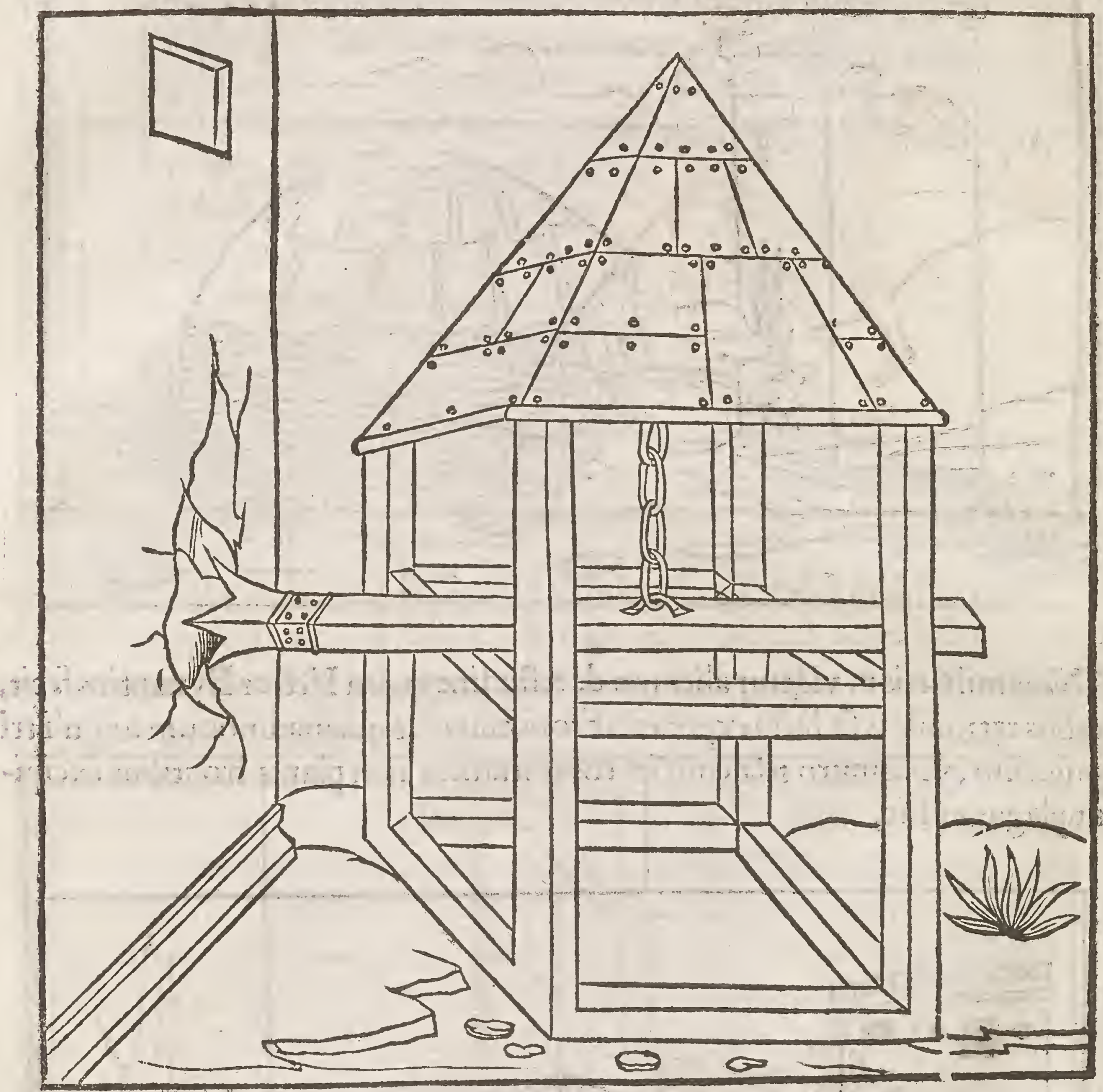

Aries machinationis genus eft, cuius forma hac erat, $V$ alidx enim et nodofearboris caput ferro veltitur, ea g fulpenfa multorủ manu ad murum impellitur: deinde retror fum ducta maiori impetu deftinatur, fić́g crebris ictibus concuffum muri latus caedit. Victruuius archi.lıb.x. Arses fic memoratur effe, Carthaginenfes ad Gades pugnando caftra pofuere, quum autem caftellum ante cepiffent, id demolin funt conati: polf quàm non habuerunt ad demolitionem fer ramenta, fumplerunt tignum, id $g$ manibus fuftinentes capiteóp eius fummum murum concinenter pulfantes, fummos lapidum ordines deiiciebant, \& ita gra: datim ex ordine totam communionem duffiparunt. 


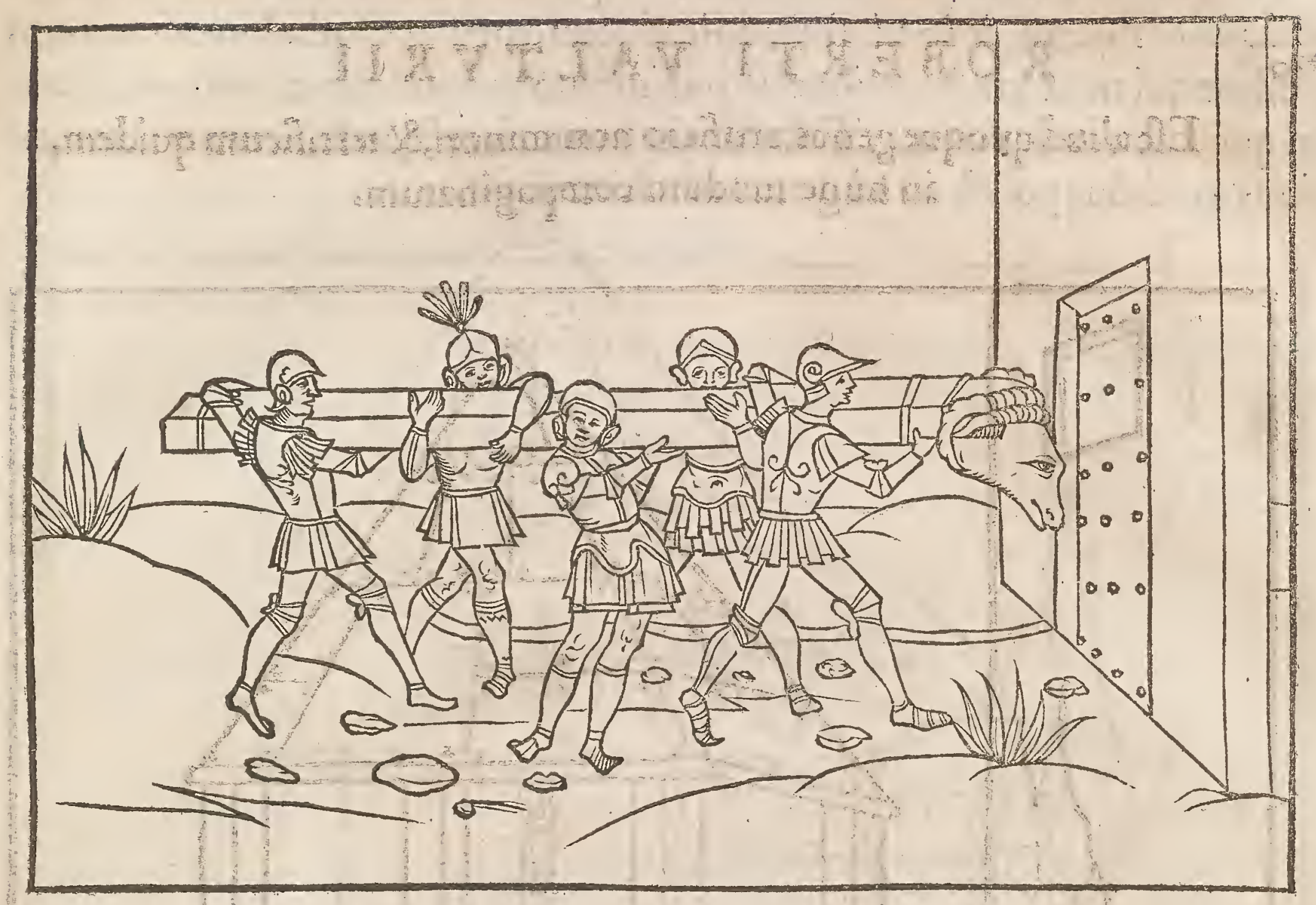

Poftea quidam faber Tyrius, nomine Phefarfemenos, hac ratione $Q$ inuentione inductus, malo ftatuto, ex co alterum tranfuerfum vti trutina m fufpendit, $\&$ in reducendo \& impingédo venientibus plagis deiecit Gaditanorú murum,

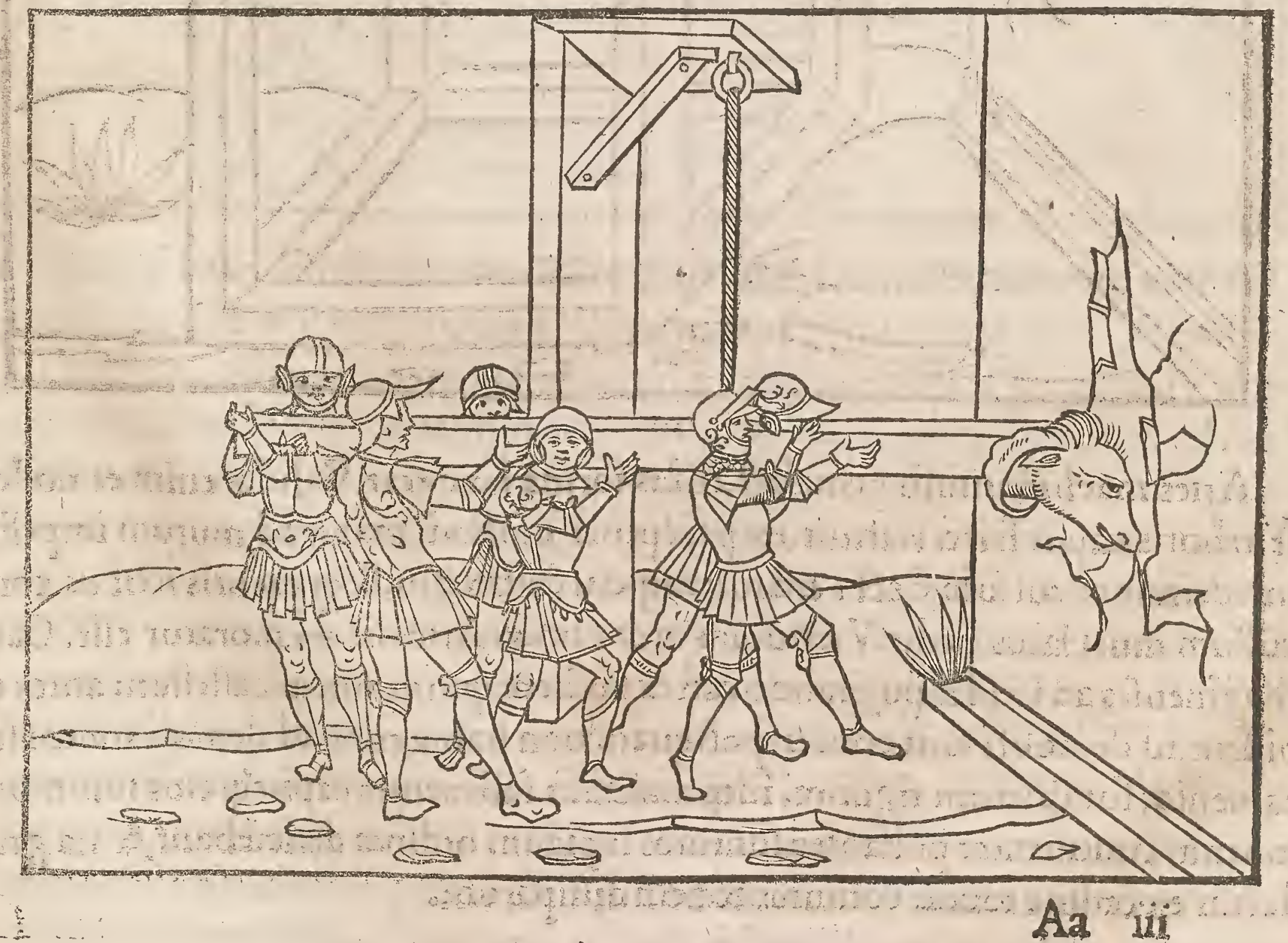


Tetras autem Chalcedonius de materia primum bafim fubiectis rot is fecit, fupráque compegit, \& in his fufpendit arietem, corífque bubulis texit vt tutio res effent qui in ea machinatione ad pulfandum murum effent collocati:id au. tem quod corios habuerat, Teftudinem arietariam appellare cospit, his tunc primis gradibus politis ad id genus machinationis.

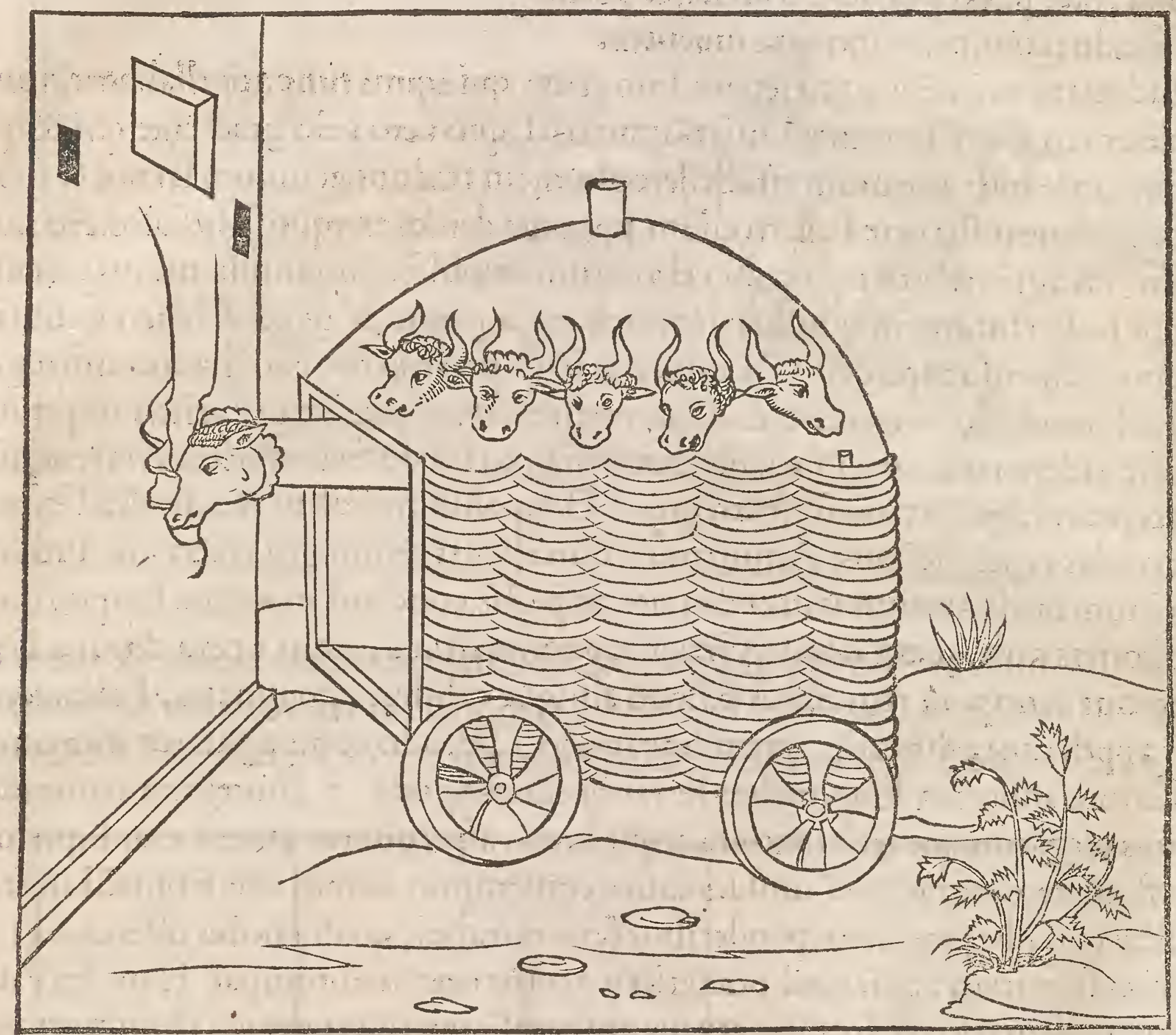

Eft aries quoque, belli iud. lib.iii.auctore Iofepho,immenfa materia malo na uis affimilis, cuius fummum graui ferro folidatum, eft in arietis effigiem fabricatum, vnde etiam nomen accepit. Dependet autem funibus medius ex trabe alia, velut ex trutina palis vtrinque fultus bene fundatis ; retrorfum autem magna virorum multitudine repulfus iifdemóg fimul rurfus impellentibus niffus, in fronte prominente ferro mœnia percutit. Nec eft vlla tả valida turris, aut murorum ambitus adeò latus, vt etfi priores ictus fortiter fuftinuerit, affiduos vinsat. Cærar, frue alius pro eo commentariorum fuorum xiil. Iiteras in Siciliam nunciófque mitteré, vt frbi crates materiéfque congeri poffet ad arietes, cuius inopia in Aphrica effet. Ammianus Marcellinus rerú geftarum quarto, Ad arietem veniemus, Eligitur abies vel ornus excelfa, cuius fummitas duro ferro concluditur, \& prolixo,arietis efficiens pronam illam fpeciem, qux forma huic ma chinamento vocabulum indidit: $\&$ fic fulpenfa vtring tranfuerfis afferibus $\&$ ferratis quafi ex lance vinculis trabis alterius continetur, éque quantum menfuræ ratio patitur, altitudo retropellens, rurfus ad robora quæog rumpéda protendit ictibus validiflimis, inftar affurgentis vel cadentis armati: qua crebritate 
veluti reciproci fulminis impetu, ædificiis fciflis, in ruinas cócidunt ftructurę la xatæ murorum. Huiufce autem arietaria trabis formam Romæ in L. Septimii triumphali arcu, marmoreo lapide celatam inuenies. Alii quoque arietem non muros demoliri, fed faxa rotare perhibent. Claudianus, Tum tua murali libretur machina pulfu, Saxa rotet praceps aries,protectáque portas Teftudo feriat, ruat emerfura iuuentus.

Illud etiam nec denuo prætereundum, eum qui equus tunc appellabatur,nune arietem in muralibus machinis nominari. Equo vero vehi gradente qui $\&$ ip. fe militare infrumentum eft, Bellerophontem tradunt,equorum frenos $\&$ Atrata equófque infternere Pelletronium, pugnare deniqg ex equo Theffalos. Ad huiufmodi auté crebros equorum vel arietum impulfus quominus murus percuffrone laderetur, maiores noftri demittebant laqueum, 8 eo conftricto circuma gentes fufpenfo capite eius declinabant ictus murorú nec patiebantur infringi. Simili modo faccos paleis,aceto maceratis refertos, qua femper arietis impetum ferire viderent demitti iubebant ex muro, vt eo modo fecundi ictus errarent,aut exceptas plagas laxitas fruftraretur. Helepolim muralem machinã ad expugnandas vrbes dicimus. Ammianus Marcellinus rerum gettarú xxiiii. Pro his arietum meditamentis iam crebritate defpectis, conditur machina friptoribus

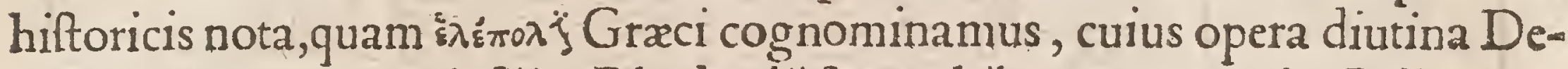
metrius Antigoni regis filius R hodo aliifque vrbibus oppugnatis, Poliorcetes eft appellatus: æedificatur autem hoc modo, Teftudo compaginatur immanis afferibus roborata longioribus ferreiśg, clauis aptata, \& contegitur coriis bubulis virgarúmque recéti textura atque limo, a perguntur autem eius fuprema ve flammeos detractet \& milliles ca lus: conferuntur autem eius frontalibus trifulcæ,cufpidis præacutæ, ponderibus ferreis trabes, qualia nobis oftendunt pictores fulmina, vt quicquid praterierit aculeis exertis abrumpat Hanc ita validam molem rotis \& funibus regens numerofis intrinfecus miles, láguidiori mu rorum parti viribus admouet concitis, $\&$ nifi defuper propugnátium valuerint vires; collifis muris aditus patefacit ingentes. Ad hæc repugnantium licet vires plurimum poffint,eorum non minus valent ingenia, quod $\mathrm{R}$ hodiéfibus memo ratur vfui veniffe. Diogenes enin fuerat $R$ hodius, \& ei de publico quotánis certa merces pro arte tribuebatur ad honorem:ea tempeftate quidam prętanti ingenio nomine Callias R hodum quum veniffet, exempla protulit muri , fupéro eo machinam in carchefio verfatili conftituit, qux helepolim ad monia accedentem corripuit, $\&$ tranfulit intra murum: hoc $R$ hodil quum vidiffent, admi rati ademerüt Diogeni quod fuerat quotannis ei conftitutum, eum'q honorem ad Calliam tranftulerunt. Interea rex Demetrius contra R hodum bellum com parando Epimachum Athenienfem taliu inftrumétorum fummum artificem fecum adduxit : is autem coparauit helepolim fumptibus maximis,induftria, laborégue fummo,cuius altitudo fuerat pedum centum xxv.latitudo fexaginta, ciliciis \& coriis ita confirmatam, vt pati poffet quoflibet ictus à balifta miffos: quum autem Callias rogaretur à $\mathrm{R}$ hodiis vt contra eam helepoliam machinam pararet, \& vt illam,vti polliciens erat, tranfucheret intra murum, negauit poffe: 
Nonnulla enim funt qua in exemplaribus paruis videntur verifimilia, quum au tem crefcere caperunt dilabutur, et quod pollicêtur definüt:vt etiã poffumus hic animaduertere, terebratur terebra foramen femidigitale vel digitale, fr eodé mo do eademó ratione voluerimus palmarefacere, non habetexplicationé: codém modo eademiog ratione $R$ hodii decepti iniuriam cum contumelia Diogenita fecerunt. I taque poftquàm viderunt hoftem pertinaciter infeftum, periculum fer uitutis, machinationem ad vrbem capiendam comparatam, vaftitatem ciuitatis expectandam, procubuerunt Diogeni rogantes vt auxiliaretur patrix:primò quia lacelfitus iniuria, negauit fe facturü, pofteaquàm ingenux virgines $\&$ ephebi omnes cum facerdotibus venerunt ad deprecandü, tunc eft pollicitus, verum his legibus, vt fi eam machinam cepiffet, fua effet:omnibus vno ore annuétibus.

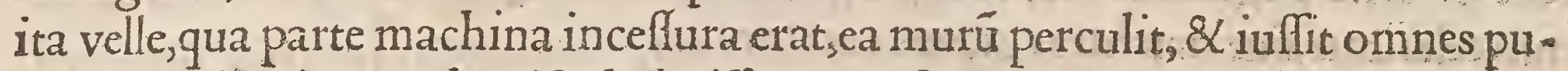
blicè\& priuatim quod quifg habuiffet aqux, ftercoris, \& luti per ea feneftram, per canales progredientes effundere ante murum: quum ibi magna vis aqux, lu ti,fercoris,nocte profufa fuiffet, poltridie helepolis accedens antequam appropinquaret ad murum in humido voragine facta confedit, nec progredi, nec regredi poftea potuit . Itaque Demetrius quum vidiffet fapientia Diogenis fe deceptum, delufum atộ fruftratú effe, cú claffe fúa difceffit: túc R hodii Diogenis folertia liberati bello, publicè gratias egerunt, honoribúfq omnibus \& ornamétis exornauerút. Diogenes auté helepolim reduxit in vrbê,et in publico collo cauit, \& infcripfit, Diogenes è manubiis id populo ded it munus. It a in repugnatoriis rebus nố tantũ machinæ, fed etiá conflia maximè funt cóprobanda.

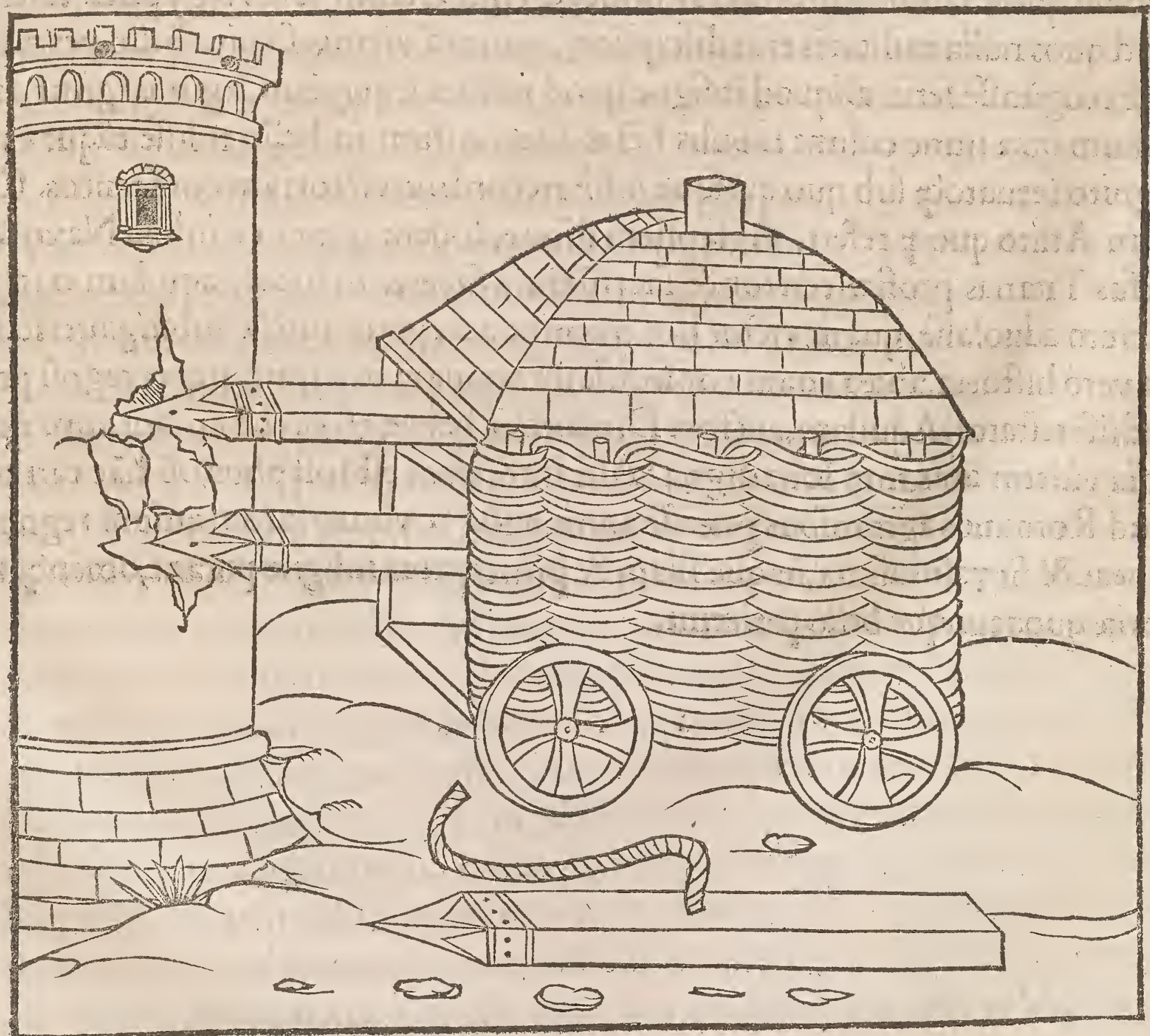


Sunt præter hæc quæ caftris vfui effe perhibent alia innumerabilia $\&$ penê infinita inftrumentorum $\&$ machinationum genera, ftructuris $\&$ demolitionibus quàm maximè neceffaria: \& ne fingula enumerando fim longior, vniuerfa qua in quacunque vrbe opportuma effe creduntur duci,prafto effe debent, vt in quouis loco caftrametabitưr,munitấ omnium rerú ciuitatem poflit effingere.

De repugnatoriis autem non eft literis explicandum: non enim ad foripta noftra hoftes comparant res oppugnatorias, led machinationes corum ex tem. pore ac trito pugnandi vfu, \& experientia rerum magiftra, ac folerti confilio rum celeritate,fine machinis fxpius euertuntur.

Hac inftrumentorum genera varix etiam fignorum fpecies confequuntur. Signa autem funt quæ comitantes milites riecognof cant in prælis, \& ad quæ conflictu fe fepe recipiüt,vexillo è lublimi, Romanorum more, quòd Mars gạdet fanguine, cocco velitante. Colores in his \& figuræ pro voluntate ducum ca fu aliquo, vel rerum occurrentiú auf picio fuere. A primordio nangue orbis conuenientes fimul homines ex fylueftri vita, primum carnibus humanis velceban tur, belligerabantúrque inuicem, co cui plus virium inerat fuperante: tum iniu riis potentiorum imbecilles vrgente neceflitate edocti acie facta fignum animalis fibi ex his quax poltea cófecrata fuerint prapofuere aliquod, poftmodum con gregati infirmiores aduerfus aliorum iniurias fe tuebantur : quo factum eft vt animali quod falutis caufa fuerat, honores tribuerentur 'Sic Aegyptios veteres, apud quos nulla militaris erat difciplina, quum à vicinis fxpius bello vexaren. tur, excogitaffe ferút aliquod infigne quod milites fequeretur, figuras igitur animalium qux nunc colunt tabulis fictas duces eorum in billo tulife, éque ex re cognito feruatóg fub quo quifque militaretord ine, victoriam confecutos. Cafar in Arato quop refert, Aglaoftem dicere, louem gum ex infula Naxo aduerfus Titanas proficifceretur, \& facrificium faceret in littore, aquilam ei in au fpicium aduolaffe, quam victor bono omine acceptam futelæ fubiugauerit: fa cra verò hiftoria, antea etiam confediffeilli aquilam in capite, atog ei regnú portendiffe teftatur. A quilam, auctore Diodoro, Thebxi etiam honorant, tum quia regịa videtur auis, rum loue digna. Alii inter quos eft lôfephus, ob hãc caulam apud Romanos agminibus praefle aiunt, quod $\&$ vniuerfarum auium regnum habeat, \& ft validiffima, itaque illam \& principatus infigne putant,omenóp victorix quodcunque bello petierint. 


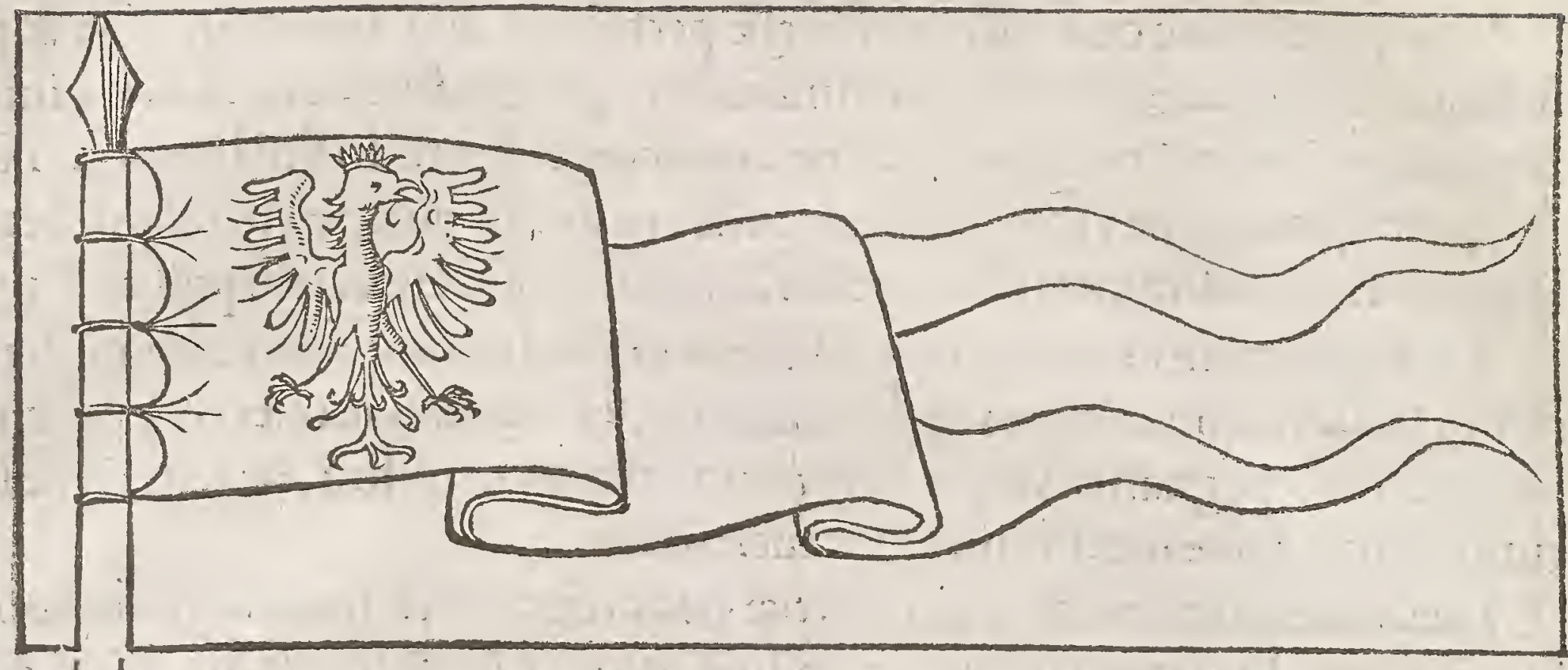

Draco etiam aliquando fignum fuit ex quo $P_{y}$ thonem ferpentem Apollo fagittis interemit. A pollinem enim quanquam diuinatorem \& medicum maiores noftri vellent, ipfum tamen etiam folem dixetunt, \& ipfum Titanem, quafi vnum ex Titanis qui cōtra Iouem bel la geffere. Pythium quoque Apollinem vocari aiunt à Pythone insmenfæ magnitudinis ferpente, cuius nó magis venena quàm magnitudo terrebat: húc A pollo fagittarum ictibus fternens, nominis quo. que fpolia reportauit, ve $P$ ythius vocaretur, vnde ad infigne victoria coronam lauream, vt Pindarus atque Callimachus memorant, $\mathrm{Apol}$ lo induit, ac Pythia facra celebranda conftituit. Alii non à Pythonis morte, verum ab Hercule vel Auétino, eius ac rhex nato, hoc infigne cepiffe ferunt: Nam quum horrenda perfape monftra Hercules ip fe domuiffet, \& victor ac ouans ftratarum fpoliis ferarum clypeis affixis fele populis oftentaret, inter cæetera'q monftra Hydram fuorum capitum excrefcentem cade profternens clariflimis trophęis eius adieciflet, poftea fatus eo Auentinus Turni caltra aduerfus Aeneam fe. cutus,ac pedes ipfe aciem agens, centúmque tulit ferpétibus hydram. Hæc de ferpétis nece ab A polline interempti, de fagittis, Pythiíg cognomine ac Hercule communis habet affertio, efto alia atque alia, \& naturalis quidem ratio, vt fcribit Antipater Stoicus, \& Cornificius in etymis, \& Plato,\& Eufebius in temporibus, haberi polfit. 


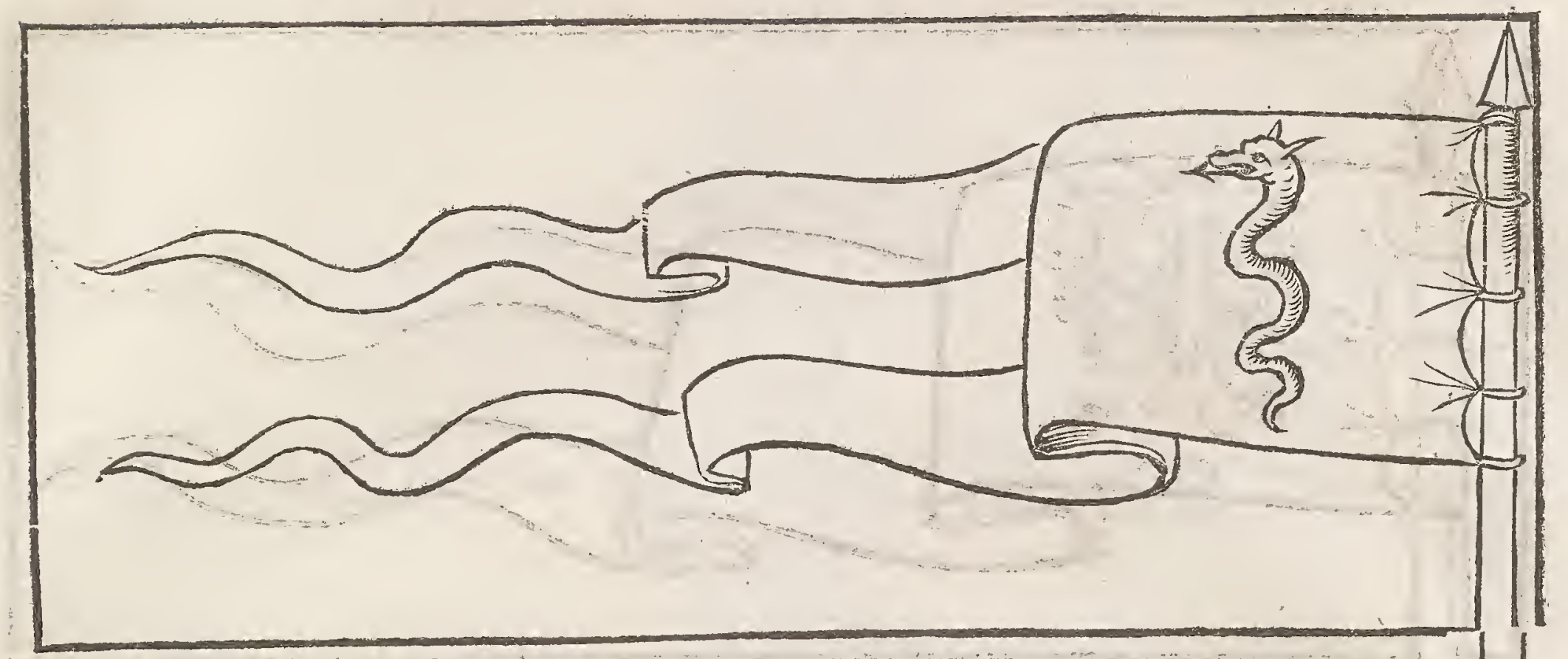

Porrò fub Romulo pauper adhuc romanus exercitus, haftis foni manipulos illigabat, $\&$ hos pro fignis gerebat.

Ouidius in faltis,

Illa quidem foena, fed erat reuerentia foeno,

Quantam nunc aquilas cernis habere tuas.

Pertica fufpenfos portabat longa maniplos,

Vnde maniplaris nomina miles habet.

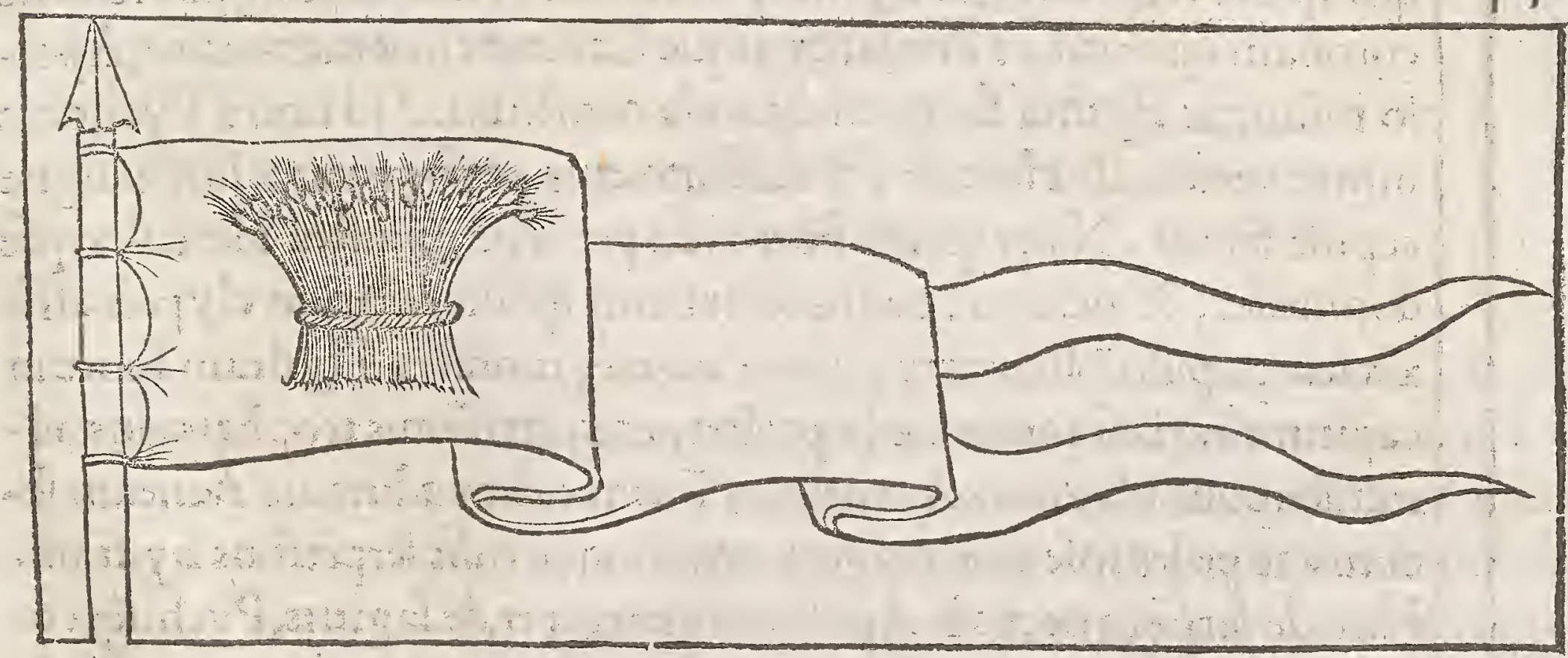

Dehinc quatuor principalia figna in caftris haberi coepere, lupi, minotauri, equi 2 apri. Verum duo tantum quorum apertam equidem rationem inuenerimus, apri fcilicet, \& minotauri. Apri nanque quòd confecto bello inter quos pax fieret cæla porca foedus folerent firmare,à quo qui refiliret, non aliter ac porca lapidibus crudeliter obruta, necaretur. 

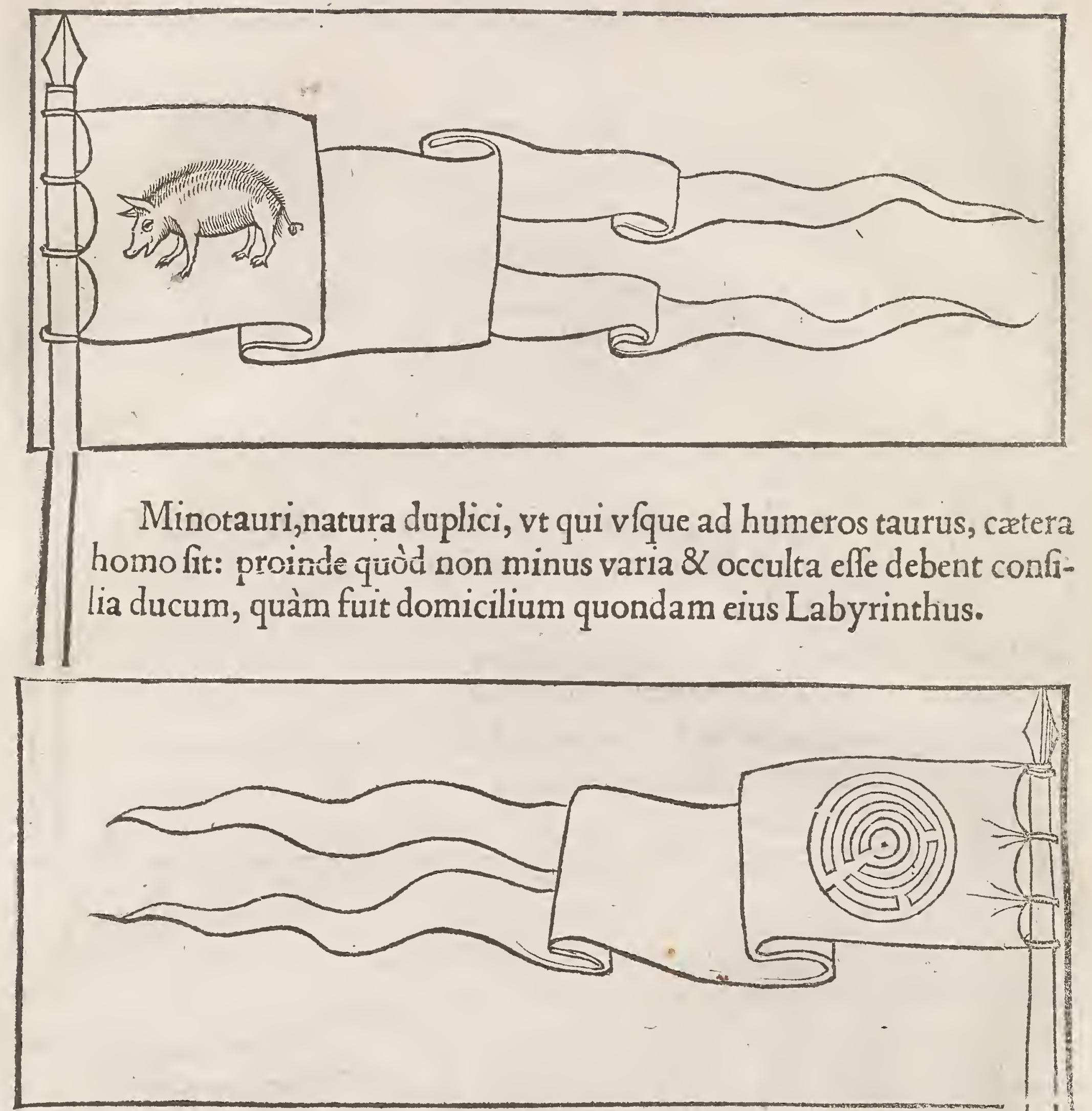

Lupi autem effigiem inter frgna militaria extitiffe, proinde quòd eiufmodi animalis lacte Martii pueri nutriti funt, vel quood in tutela Martis id animal fuiffet,eíg, dedicatum, manifeftis creditur arg umétis. Etenim lupus rapax animal, vorax, \& fuapta natura ablata cófumens, maximég id tépus aptum rapiendo pecori,quod milites in diripiendis vrbibus folent, obferuans, quod eft antelucanum, poft nocturnum. Reddunt \& ali am caufam animalis huius Aegyptii,fabulofiorem tamen. Nam ģuum If sis vnà cum filio Oro cum Typhone effet bello dimicatura, ferunt Ofiridem lupi forma ab inferis auxilio, $\&$ vxori, $\&$ filio veniffe, victores itaque Typhone interfecto, honorem ei animanti impendiffe, cuius interuentu fubfidióp victoria parta effet. Tradunt nónulli agros A egyptiorú incurfantes Aethiopes, à lupis facta acie vfque ad ciuitatem Elephantiam repulfos, qua ex re fit \& locus ille dictus Lycopolis, \& eis belluis honos à pofteris habitus. 


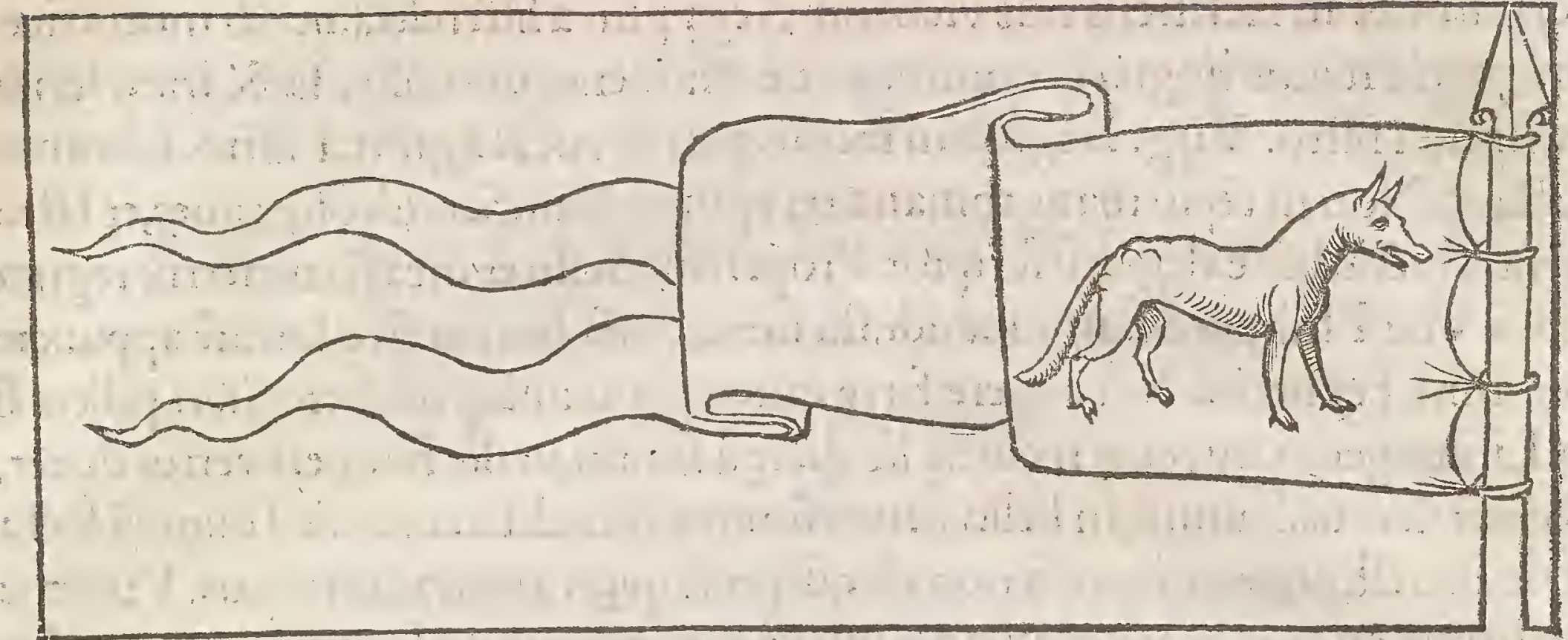

Deequorum quoque figno nihil praclarum, nihil exploratum fatis habeo, nif quòd per huiufce animátisfortaffe f peciem cum bell is intefit plurinumóg valeat, Martis commoditatem defignare voluerint, tum quia præfagit hoc animal pugnam, \& gloriæ \& victoriæ cupidum eft, tum quia armatos vehit, tum quia fit velox nonnunquam, vt Martem decet, 8 impetu ac furore maximo plenum.

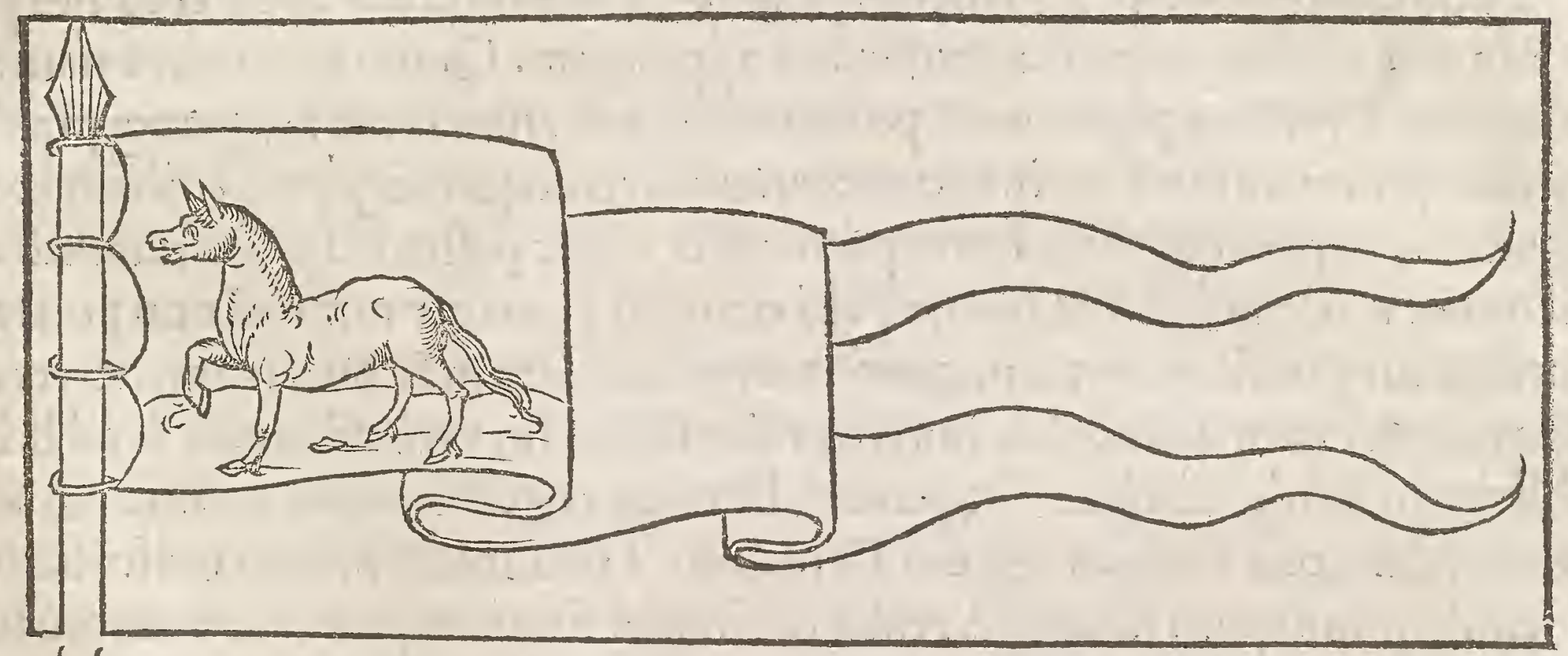

Denique Aquila paucis annis ante Marium fola in acie portari coepta erat, reliqua qua \& fingulos ordines anteibãt in caftris, relinquebantur,abdicauitóp ea in totum Marius fecundo confulatu fuo, \& Romanis legionibus proprie Aquilam dicauit. Gradiêdi deinde fiftendió ordinatio, difpofitio totius exercitus $\&$ moderatio frgnorum, cantibus gubernatur, quum ad bellú progreffioni $\&$ item receptui cátetur, cantu. $\&$ excitante, \& rurfus militu animos fedante. Hęc animorum excitatio fedatióg aliquibus ex tubis eft. Philippus \& maiores fui quum tolli iu berent figna eas habuerint in vfu licet, mutauerunt tamen, quod fonus impediretur tumultu $\&$ armorum fonitu, quominus ad omnes pertingeret: quum' $\$$; caftra fibi mouéda forent, cautum fuit vt pertica effet in fignum. Noctibus igne vel fumo fignificationé dare foliti $\mathrm{Parthi}, \mathrm{cym}-$ balis figna dabät in præliis. Inter A mazones fiftro ad bellum forminarum vocabatur fiftebatóp exercitus; etenim fiftrum tubæ genus, quo Ifis 
defcribitur, 8 in facrificiis eius vtebãtur Aegyptii, à fiftendo, fiue ab inuentrice, fue à patria mauis lingua denominationé aflumens.Iuuenalis, l fis \& irato feriat mea limina fiftro. Virg. Regina in mediis patrio vocat agmina fiftro.Lucanus in octauo, Non in téplo tuam romana recepimus Ifim, Semideófog canes, et filtra iubentia luctú. Itidé elegiarú fcriptor Propertius, Scilicet incælti meretrix regina canopi Vna Philippeo fanguine adufta nota, A ufa loui noftro laträté apponere Anubim, Et ty berim Nili cogere ferre minas, Romanäóg tubã crepitảti pellerefi Atro. Lituus genus buccine incuruę fic dictę à fonitu, vt ille Homeri verfus docet, Infonuit neruus. Ennius, In bello lituus fonitus effundit acutos. Sed quoniá facta lirui métio eft, prętermittendú non eft q đa poffe quęri animaduertimus, Vtrum à tuba lituus auguralis appelletur, an tuba à lituo augurum lituus dicatur:vtrúq enim pariter in forma $\&$ pariter in capite incuruum. Sed fi,vt quidã putát, tuba à fonitu lituus appelletur ex illo Homeri verfu, neceffe eft vt virga auguralis à tu bæe fimilitudine lituus vocetur. Vitur auté vocabulo ifto Virg. $\$$ tuba in vi.vbi ait, Et lituo pugnas infignis obibat \& hafta: tanquam lituus nomé fibi vendicet o litis fit teftis. Claffica, flexibiles, fecüdū Seruiū, tube, vel cornua funt reliquis minora cóuocádi caufa facta, \& à calâdo auctore Petronio,id eft, vocảdo dica.

Tuba ęnea eft, \& hac Tyrrhenos prius fuiffe v fos tradüt,et apud cos $P_{i}$ ifeú pri mum, atç ab illis propterea tyrrhenam appellatam. Quum enim circa mantimas oras Tyrrheni prędones \& pedeftres difperfi, non facile ad quang prædæ occafionem, voce aut buccina conuocarentur, vento plerungs prapediéte, tubam inuenere, vt puta qux buccina capacior effet : hinc poftea bellicis certaminibus adhibita ad denuncianda bella, vt vbi exaudiri preco per tumultú non poterat, fonitus tube obftrepentis attingeret. Inter tubam autem \& buccinam, veteres $d i$ fcernebant: nam quanquam buccina tubx finilis fit, verum longior $\&$ ad bella folicitudinem denuncians. Propertius, Buccina cogebat prifos ad bella Quirites: \& Maro, qua buccina fignum Dira dedit. Tuba autem bellum indicabat:vt idem, Ennium puto fecutus, At tuba terribilem fonitum procul are canoro Increpuit, fequitur clamor cælúqup remugit. At hic quidem clamor varius elt. Nam interdũ tuba canitur vt bella gerantur, interdú ad eos qui fugiunt infequédum, nonnunquam receptui. Nam receptus is dicitur, quo fe exercitus recipit, vnde \& figna receptui canere dicuntur. Cymbalorú autem tinnitus $\&$ tympanorũ pulfatio $\&$ cretici louis facris, $\&$ eo matris eius myfterio quod Ouidius expofuit in Faftis cotineri creditum elt, quum ait, Ardua iam dudú refonat tinnitibus Idx, Tutus vt infanti vagiat ore puer. Pars clypeis, fudibus paleas pars tundit inanes. Hoc Curetes habent, hoc Corybantes opus.Res latuit,prif́cíg manét imitamina facti. Aere deæ comites raucạ́̆ terga mouét. Cymbala pro galeis, pro fcutis tym pana pulfant, Tibia dat phrygios, vt dedit antè modos. Tametfi à poëtis fictam cam opinioné quidam refpuant, éamģ velint ingeniofe interpretari, verùm hæc quum apud varios varia fortiantur officia, in præfectorum confultationibus ter ra ac nari opportunis determinanda erunt. Quot verò in religione fint vel effe debeant, quando, qualiter, quo loco munus \& officiū furum exercere debeant,pręe fecti fubiectis deferent, vt rerum fignificationibus datis, pareant audientes. 


\section{ROBERTI VALTVRII}

A D ILLVSTREM HEROA SIGIS.

mundum Pandulphum, de re Militari

Liber Vndecimus.

e

De bcllo Nauali er quando primum apud Romanos quiğg primus

nauali trumpho dignus habilus fit.

cap.' I:

Mplitudo nobilifima rei militaris Romani imperii,Sigifmüde Pandulphe, non folum terreftribus, verum etram maritimis triumphis aucta eft,regni coronæ imperio maris adiecto, eiúfque gloriam maiores noftri teftati funt,vincétium merita fin. - 3 gulari fauore profequendo. Extat nanque memoria circa para de Ancio tpolia, anno vrbis cccc xvi que C. Meuius, qui pri fros deuicerat Latinos, Anciacibus victis, \& in fuggeftu fori capta holtıü cla?e fuffixit, fi tamen illa clafis, nam lex fuerant rofratæ naues, appellanda: verum hic numerus illis initis ingentss gloriæ fuit meritum, vt tribunali foro præfixa roftra, ceu populo corona im polica videretur, vnde \& pro roftris locus noméaccepic:quumóp pòt mirificis rerum geftarum titulis ram clarum nomen vrbis effe coepiffet, \& arma tum extra laliam mota non fuiffent, Po . Ro.quanquars ad torquendú remos nauticæó, artis omnis igna rus, nihul tamen interefle virtu tis oftendit,equisne an nauibus,terra an mari dimicandum effet: A ppióo $\mathrm{Clau}$ dio confule, anno vrbis cond.ccc lxxviii primum Carthaginéfibus bellum intulit, nirumós dictu, claffe ab arbore excila, fexagefmo die nauigauit: cötra verò Hieronem Syracufanum ducétas viginti naues effecit diebus quadraginta-

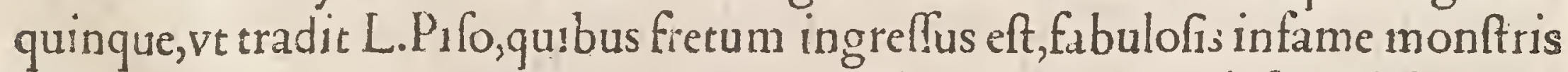
xefúque violentum : nec eft exterritus quin slla $m$ iplam mentis fuæ violentiam xltus pro munere amplccteretur, ftatimq ac fine mora Hieronem regem tanta celeritate vicit vt ille ipfe leppius victum fe $\mathrm{q}$ uàm holten vider et fateretur.Cn.au tem Dutlio, $8 \mathrm{Cn}$. Cornelio A fina coff. quun, Hannibal fenior fue Hamilcar Ponorum dux oram' ltalix maritimam inftructa feptuaginta nauiü claffe vaftaret,etiam mari aduerfus eum congredi aufus eft, cui etiam ipfa velocitas claf fis comparatæ, victorix aufpicium fuit Intra enim fexagefrmam diem q àm cæ fa fylua fuerat, cétum fexaginta,vel vt alii, centum triginta nauiü claffis in anchoris ftetit: quum enim videret Duellius, cos multum poffe mari, claffem magis validam quàm decoram fabrefecic, \& manus ferreas cum irrifione hoftium primus inftı uit,quibus inter pugnandum hoftum naues apprehëderet. Vt au tem audiuit Duellius Cornelium Afnam cof. alterum, fexdecim cum nauibus Lyparam expugnafle, támg ab holtium duce ad pacis colloquium euocatum,

$\mathrm{Bb}$ ii punicáç 
punicáque fraude ac aftu captum, atque in vinculis necatum, cum triginta extemplo $\mathbf{n}$ uibus aduerfus eum profectus eft, commiffoque nauali prælio fuccefit. Vna enim \& triginta naues punicæ captæ, fuppreffæ trefdecim, tria milia hominum cara, feptem milia capta referütur: ipfe denique Hannibal fue Hamilcar,ut diximus, punice claffis dux a miffa nauiqua vehebatur, fcapha lubductus Carthaginem fugit; $\&$ à fenatu,vafer plurimum cum effet, quia apud cos dux re male gefta puniretur, quafiuit quid faciendum iuberent, omnibus vt pugnaret referentibus, Feci,inquit, $\&$ victus fum. fic poenam crucis effugit. $C$ n.autem $D u$ ellius quem contrahendi nominis gratia Bellium nominarunt, quum fuperiores eius appellati effent femper Duellii, quia primum illum maritimü triumphum ex Poenis folus inuexerat, non contet us vnius diei triumpho, per omnem vitam vbi à cona rediret, crebra fibi prælucere funalia, præcinere fibi tibias, quafi præ tanta huius victoria quotidie triumpharet iuffit, quod quanquâ vltra vrbis mo rem priuatáque maiorum effet exempla, Romani tamen æquo animo tulere:nul la enim victoria illis gratior fuit vnquam, quòd inuicti terra pariter et mari plu rimum poffent: \& quia blandiffima rerum omnium eft gloria, qux nec levibus ftimulis infita egre $i$ s virorum a nimos agit \& verfat, affectatx iam glorix nomen nobilifini ciues adepti, magno ftudio fabricandis nauibus incubuere.

Que materics fabricandis nuibus utilior.

Cap. II: Auibus autem fabricand is animum applicantibus prima in deligen da materie confideratio eft adhibéda. Nos igitur primum in qua ma 15. terie fuerit prudentium contenfus, dehinc fternendi tempus ab folue-

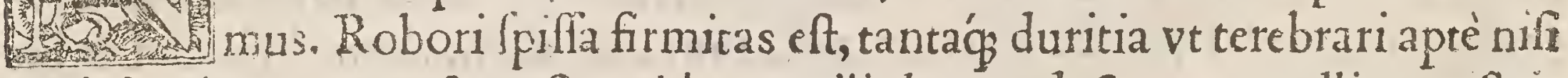
madefactú non queat, \& ne fic quidem auelli clauus adactus: nonnulli ex noftris in robore confenferunt, in eodem fenfu \& Galli conueniunt: durat hoc detoffum $\&$ in aquis, marina tamé aqua corrumpitur. Cedri ol to feruncta materie, nec rineam, nec cariem lentit. Iunipero non abfimilis huic virtus, qux in Hifpa nia vafta e? $\&$ fabricis aptifima. Non improbatur fagus in aqua, nec alnus in paluftribus: xterna enins eft, $\&$ oneris quantumlibet patiens. Larix propter pon dus ab aqua non bene fuftinetur,propter alia precipua eft: in humore nec flam. mam ex igne recipit, nec ab carie, aut tinea propter fuccum vehementi amaritate leditur verum in naritim is nauibus obnoxiam teredini tradunt, 8 omnia præter olealtrum \& oleam. Quæ łam enim in terra, \& quædá in mari vitiis opportuna funt infeftantibus. Tradunt abietem circa germinationes, ea qua deci dimus luna decorticatam nó corrumpi aquis. Rurfus in ipfis arboribus hoc eti am fatis notum effe debet, limites regionéfque cæli fpectandas elfe : robuftiores enim aquilonix partes, $\&$ in totum deteriores ex humidis opacis $q_{p}$, fpiffiores ex apricis ac diuturnæ. Eft $\&$ gentium in his quoque differentia. Alpibus, A penni no laudatiflimx abietes, in Gallia, in Corfica,Bithynia,Ponto, Macedonia dete riores, Pernaficx pelfimæ, quoniam ramofe, cötortæ, putrefcentéfque facile. Ale xandri Magni comites prodiderunt in Tyle, rubri maris infula, arbores effe ex quibus naues fierent quafi ducentis annis durantes inuentas, \& fi mergerentur incorruptas. Abies foctabilis glutino, eadem nauium malis anténífque propter 
leuitatem præfertur,tum quòd omnium arborum altiffima \& rectiffima eft. Hus ius inopia in Aegypto ac Syria reges cedris vfi feruntur ad clafles. Sefoofis Ae. gypti rex nauem ex cedro fecit ducentorum octoginta cubitorum longitudine, deauratam exterius, intus verò deargentatam, quam dono obtulit deo qui maxi me Thebis colitur.Celebratur quoque in Aegypto ac Syria fpina duntaxat nigra, quoniã incorrupta etiã in aquis durat, ob id vtiliffima nauiü coftis:è theda pix naualibus muniendis vtilis.

$$
\text { Cafionis luneóf tempus peectanduns. }
$$

Caps

III.

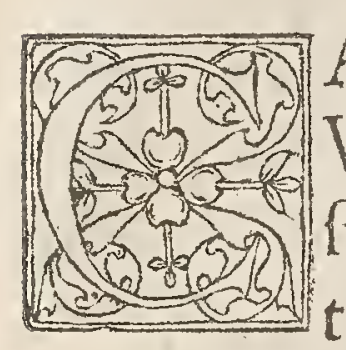

Aefionis quoğ tempus in perfeuerãte materie quàm maxime tefert . Vulgo fatis putant, obferuare ne dedolanda fternantur ante æditos fuos fructus. Robur vere cafum teredinem fentit : bruma neqpiaciatur neque pandatur, aliâs obnoxium erit vt torqueat féfe findátque, quod in fubere tempeftiue quoque cæfo euenit. In infinitum refert $\&$ lunaris ratio fiderímque. Sunt qui omnia quæ cæduntur, carpuntur, tunduntur in nocentius decrefcente luna quàm crefcente : funt qui $\&$ quinta, $\&$ decima luna ad vigefimam vfque fecundam arbores prafertim concidi debere exiftiment, vt immunis feruetur à carie, \& æterna materies reddatur : idós religionis argu mento, quòd aternitatem his tantum diebus placuit celebrari.Sunt qui non nif à vigefima ad trigefimam cadi velint: ligna enim qua luna adhuc crefcente deiecta funt, quafi emollita per humoris conceptionem, fabricis quibúfque inepta effe dicunt:proinde circuncifas quog; ad medullá aliqui non inutile relinquunt, vt omnis humor ftantibus defluat. Inter omnes verò architectos conuenit, arbores viliffime fterni in coitu lunæ, quem diem alii interlunium, alii filentis lunæ appellant. Sic certe Tyberius cæfar quum cremato ponte naumachiario larices ad reftituendum cædi prefiniuit. Cato hominum fummus, in cmni vfu de materiis hoc addidit, Materiem onnem non effodies luna decrefcente, eximito poft meridiem fine vento aufro. Tunc erit tempeftiaa, quum femen fuum maturum erit. Caueto ne per rorem doles, idóg mox nifi in trimeftri lunágg dimidiata: nec tangas materiem tum, ne effodias, aut præcidas ab terra. Diebus quattu or proximis quibus luna plena fuerit,optime eximitur. Onnino cauto nigram integrámg materie ne doles, néve cędas, néve tãgas, nifir ficcam, néve gclidâ,néve rorulentá.Hac Catonis precepta \& fr ab his ducibus quos pauloáte diximus minus obferuata videant, nimirü neceffario vel tëpeltiuo cafionis tépore cóciderüt.

De clauis quibus iungenda eft matteries,, 0 , criufmodi effe debednt. III!

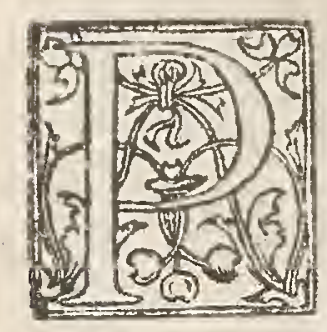

Lurimum deinde id etiam refert, ferreine an ærei more maioris, quin bus iungenda materies in vnú eft claui effe debeant. Ac de clauis æne is, ni fallor, cólectura mea à veritate haudquaquā aliena eft. Eft enim ari vis acrior, quam medici ftypticam vocant : vnde fquammả eius adiiciunt remediis, qux contra perniciem putredinis aduocantur. Aura etiam qua ex ære producitur haurit $\&$ exficcat quod male influit . Vis præterea quædam remediabilis \& ficcifica rri ineft quam dimittit in vulnere: proinde autor eft Ariftoteles vulnera quæ ærea cufpide fiunt nocuméti minus afferre $\tilde{q}$ ex fer ro faculius's curari. Pari ergo ratione infixum ligno propriam feruat fubftanti- 
am, \& lunari \& aqueo repugnat humori, quum ferrum huic cedat \& tempori, eueftigio rubigine exefum atque confumptum.

Primus nauium ufus, or prima edrum forma d̀ prifcis probata, edrum nomina, quiqg gubera nandl adminicula feorfum primus inuenit.

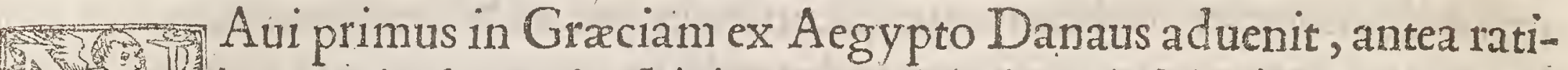
J. 1. Tunc enim, Nondum cæruleas pinis contempferat vndas, Effulum

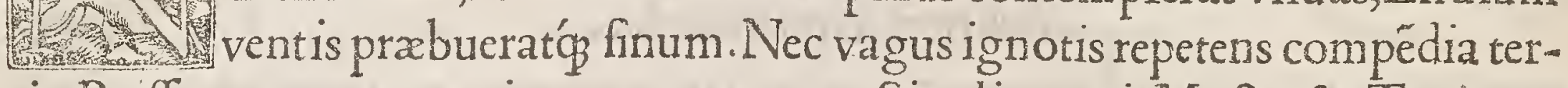
ris Prefferat externa nauita merce ratem . Sint licet qui Myfios \& Troianos priores, rates excogitafle in Hellefponto putent,cum tranfirent aduerfus Thracas. Rates enim rigna vocantur colligata, quæ per aquam aguntur: quovocabu lo interdum etiam naues longas, tefte Varrone, fignificari non dubium eft.

Codicarias autem naues dicimus, quòd ab antiquis plurium tabularum contextus, codex appellabatur,quòdóg qui primus Romanis perfuaferat nauem con fcendere, Claudius Codex is fuit,à quo nomen deductú fićṕp confuetudo pona te nuit, eo quòd in fluminibus vfui plurimum effent. Schedia, genus etiam nauigii inconditum eft, trabibus tantum inter fe nexis factum, vnde \& mala poëmata, fchedia appellantur. Trabica nauis, dicta of frabibus confixa. Sumia nauigii genus, auctore Cecilio. Sclata genus nauigii latum magis quàm altum, fic appellatum ea confuetudine qua fclocum per locum, \& ftlitem per litem dicebant. Mufculus curuú nauigii genus ac breue. Scaphæ Aphricano tefte nauiculæ funt paruæ, quæ maiores naues confequunt ur. Cicelibro primo ad Heren. Magnitudine tempeftatis omnes perterriti, nauim reliquerunt, in fapham confcenderunt. Actuariæ, nauicula celeres qux remis $\&$ velis aguntur: fic dictx $q$ citò agi pollint. Celox, nauigiú breue à celeritudine dictũ, \& à R hodiis inuentum. Liuius punici belli fecundi,lib.i.Naues ducentas, vigintiquinque remes, celoces viginti deducit. Mioparo, Pyratarum nauicula ex corio \& vi. minibus contexta, quafi minimus paro. M. Tul. Nam quun quæreretur ex co quo fcelere impulfus mare haberet infeftum vno mioparone, Eodē, inquit, quo tu orbem terræ. Fafellus, nauigium cápanum. Saluftius, Et forte in nauigan do cohors vna grandi fafello vecta, à cateris deerrauit, maríque placido duobus pradonum mioparonibus circumuéta. Cercirus, nauis maxima eft \& Afrana, $\&$ quam Cy prii inueniffe feruntur. 'Trieres, quas dromones Graci dicunt, maiores naues funt \& löge, I faie.xxxiii. Neqg trieris magna träforedietur cum. Daniel.xi. Et venient fuper eum trieres, \& Romani innumeri vigintiquatuor veniêt in trieribus de ltalia. Longa naue Iafonem primum nauigaffe, Philoftephanus auctor eft. Eo nanque Colchos petituro ab Argo fabricata eft, $8 \mathrm{X}$ argos ab eo auctore in finu pegafeo denominata: vnde Lucanus,

Prima fretum fcindens pegafeo littore pinus

Terrenum ignotas hominem proiecit in vndas.

Sunt qui longa nane vfum fuiffe ferant primum Sefoofm Aegypti regem, tefte Diodoro, dictáq, ve diximus, \& quidam fcriptores afferút, , ab Argo eius architecto qui etia inter nauigandum eius refarciendx curam ceperat: vt alii,ab eius velocitate 
velocitate, quàm antiqui Argon appellabant. Piftris, nauigii genus à forma pitrium marinarum, qux longi corporis funt fed angufti: à fpina enim putrefa cti pifcis in littore, ad conftruendaslógas naues per imitationem doctrina fumpta eft, \& eiufmodi nauis fabrefacta. A pifcibus etiam funt qui fumptum velint quo ordine in pugnam acies deducendx fint: ab eifdem quoque quo pacto homines equíg ferro muniantur teganturóg, fquammis eorum infipectis. Iiburnæ quæ 8 roftratæà Liburnia parte Dalmatiæ dicłx. Augufto enim dimi cante, cum liburnorum auxiliis fuccubuiffet Antonius, tanti difcrimine certaminis ac periculo, quòd liburnorum naues cateris aptiores effent, earum finilitudo \& nomen à Romanis ducibus vfurpatæ funt. Horatius in Hippodo, Ibis liburnis inter alta naui Amice propugnacula. Legia,nauis velox, quòd vehe menti motu fuo legat \& colligat aquas ante fe, dicta. Corbita,nauigii genus tardum $\&$ gräde,fic dictú quơd malo in eius fummo pro figno corbes foleret fufpendi: nihilog differt ab Oneraria naui, omnium tardıffima oneríg deuehëdo quàm aptiffima, \& ab Hyppo Tyrio inuenta. Oria,Fabio Placiade Fulgentio tefte, nauicula admodū parua, \& pi fcatorum vfui quàm apta. Cymba \& Scalmus Phonicum inuenta, pifcatoriz etiam naues.Cic. iii.Officiorum, Tum Canius, Quefo,inquit,quid eft ò Pithi? tantúmne hic pifcium, tantímne cymbarum? inuitat Canius poftera die familiares fuos, venit ipfe mature, fralmum nullum videt. Lintres fiue monoxylos, hoc eft, paulo latiores fcafulas, bauiculas fluuiales cauatas $\mathrm{ex}$ arbore dicimus. Liuius fecundi punici belli lib.i.lta ingens coacta vis nauium $\&$ lintrum, qux temere ad vænalem vfum pyratarum nonaśǵ alias prinaum Galli inchoantes cauabant ex fingulis arboribus.

Virgilius.i.georg. Cauat arborelintres.

In his Germanix prædones, cauatis fingulis arboribus nauigant,trigintaç ho mines ferunt: nec id quidem incredibile, cum \& grâdiores multo noftris eorum fint arbores, $\&$ apud Indos harundines tantæ proceritatis funt $v t$ fingula corum internodia alueo nauigabili trinos interdum homines deuehant, quina cubita longitudine excedentes. I embus, nauiculax genus breuis \& velociffime, quam Cirenenfes ferütur inueniffe. Virgilius .i. georg.Quam qui aduerfo vix flumine lembum. Liuius belli macedonici libro quarto, 'Néve ip pe nauem vllam prater duos lembos qui non plus quàm fexdecim remis agerentur haberet. Bucentaurus, nauigii genus ad magnos viros deuehendos ac potentes fabricatú:à magnitudine enim boum qui in Iialia erant confuetudine factam fuife in libris de re ruftica inquit Varro,vt prepofita hac voce bu,magnú quippiam femper nun ciaretur: inde dici bulimian, id eft, ma gnam famem, \& bupadas grädes pueros, \& iram bumaniam, \& alia his fimilia ad magnitudinis rationem pertinentia, quod \& nunc obferuant fominæ in tranfpadana regione, qux ad fignificädum ingens $\&$ ad miratione dignum aliquid, prolatione eius vocis vtútur.Bucentaurus ergo, quia principes \& magni viri ea vehi folent, quafi magna centaurus, pri fcxillius vocis fignificatione appellata eft. Centaurus nanque nauis five fignum erat quod naui imponebatur. Expreffum autem hoc ef à Virg.elegäriffime illo verfu, Centauro inuehitur magna: qui humiliorem illam vocé in fublimi opere afpernatus, 
re afpernatus, digniore verbo ac carminis maieftati conuenientiore vti pruden tius voluit . Qui enim bucêtorium \& non bucentaurum à bucis cétum dici putant oportere,corruptis detractisóp pauculum literis propter lógum fa mulatum, qui ad feruitia præftanda potentioribus femper neceffarius eft, vana \& inepta nominis interpretatione falluntur. Triremis, nauis qux tris remorü ordines habet. Horatius in epift.

Naufeat ve locuples quem ducit prima triremis.

Has primum inftituiffe legimus Argonautas, quòd etiam armatis apt $x, \&$ congruæ probentur effe com merciss, vt qui peregrinas optabamus áficere, núc mit tamus aliis prouinciis terrorem pariter \& decorem. Quadriremes quoque ab ordine remorum dictx, qui numerus magnificentia vtentium perfape auclus inuenitur.Quinqueremem inftituiffefertur V eficon Salaminius, fex ordinum Ze nazetas Syracufanus, ab ea ad decemremem Nefigoton. Alexander porrò magnus ad duodecim ordines. Ptolemæus Soter ad quindecim, ad fedecim Perfeus, $\&$ P.Aemilius, Demetrius Antigoniad triginta, Ptolemæus Philadelphus ad quadraginta, $P$ tolomxus philopater qui Tryphon cognominatus eft ad L. Heraclius nauibus caftellatis A phrica veniens vfus perhibetur. Pręcipux admirationis quoque nauis quæ ex Aegypto Caii principis iuffu obelifcum in Vatica no circo ftatutum quatuoróg truncos lapidis eiufdem ad fuftinendum cum adduxit, qua naue nihil admirabilius vifum in mari,certum eft: triginta enim $\&$ centum modii lentis pro faburra ei fuere, longituć f faciü obtinuit ex parte ho ftienfis portus latere læuo: ibi nanque demerfa eft, Claudio principe, cum tribus po.ro.molibus, turrium altitudine in ea exadificatis, obiter puteclano puluere aduectis arboribus, eius craffitudo quatuor hominum vlnas complectentiú implebat . Caius etiam Cærar gallica expeditione legatis fuis aliam formam præbuit, $\&$ ad celeritatem onerandi fubductiorem, paulóg humiliorem quàm alio mari confueuerit, ideo quòd propter crebras xftuum cómutationes, minus magnos ibi fluctus fieri cognouerat ad onera multitudinemóp iumentorum trantwehendam. Gallorum infuper naues ad hunc modum factx armatxóg erant, $\mathrm{Ca}$ rine planæ quó fàcilius vada ad deceffum excipere poffent, proræ atque puppes erectę ad magnitudiné fluctuum tempeftatumóp. Naues $\&$ ipfx totæ ex robore ad omnem vim $\&$ contumeliam perferendam, anchoræ cathenis ferreis reuinctæ, pelles pro velis, quibus \& vim tempeftatum fubftinerent facilius, $\&$ in vadis confifterent tut ius, $\&$ ab $x f t u$ relictæ, nil cautes $\&$ faxa imerent. Contra has $L i$ burnicæe pręttant celeritate $\&$ impulfu remorum, non tamen propter firmitudinem roftro nocere polfunt, ne⿻̧ propter alcitudiné telú ad eas adigi facile poteft. 
Naues înctx ac quinqueremes, demptis interioribus remis, vt latus lateri ap plicetur, cum quibus exteriore ordine remorum velut naues aguntur,turyes con tabulatz, machinamentáque alia quatiendis muris portantur, claffem in hunc modum efficiunt bellicam.

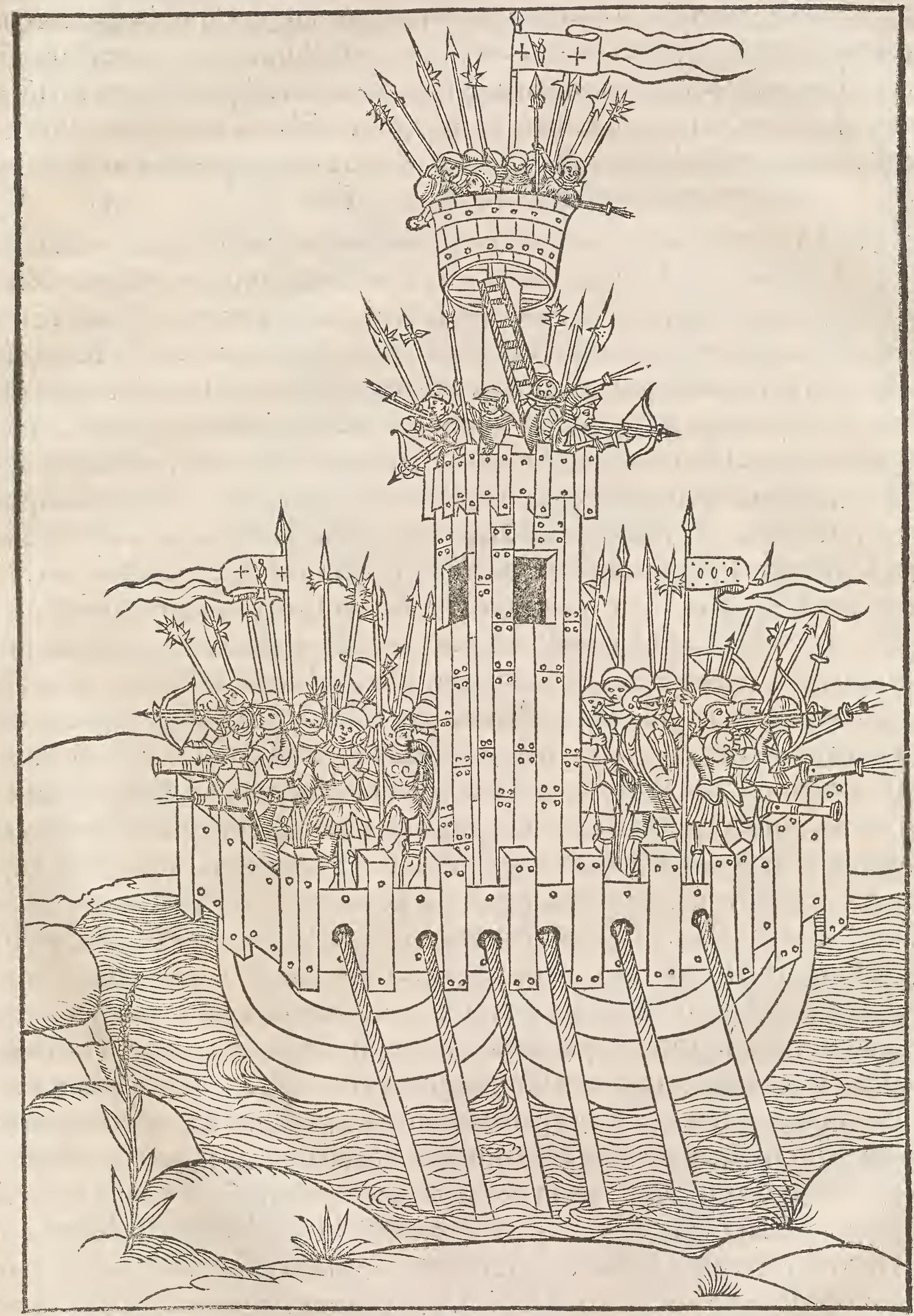

Eft enim claffis nauium multitudo, qua Tiphis princeps depugnauit, fint $l_{i-}$ cet qui Phonices, folers hominum genus, $\&$ ad belli pacisóp munia eximium, maria nauibus adire, claffe confligere commentos putent. Siderum obfervatio- 
nẻ in nauigando Phonices iidem inuenere, vêtorum rationem Acolus, Helenis filius Remum, Cope latitudinem eius, Plateus vela, I carus malum, $\&$ antennă De dalus, roftra Pifeus, Tyrrheni anchoram, Eupalamius tandem bidentem, Anacharfis afferes ferreo vnco præfixos, quos harpagones vocant, Pericles Athenien fis adminicula gubernandi à tergo, qux huc atque illuc curfum nauigii torque ant:atque horum, fi Anneo Senecæ credimus, exemplum à pifcibus tractum eft, qui cauda regútur, \& leui eorũ in vtrunģ latus mométo velocitaté fuam flectüt, fỉ Plinio,ab auibus, miluóg præcipue, qui hãc gubernādi artē docuiffe ac oftêdif fe videtur caudæ flexibus, in celo mötrante natura quod opus effet in pfundo. Numerus uentorum eorumg; nomina, rationes, $\sigma$ effectus.

Cap. VIr.

Voniam milites militúmque præfectos etiam adiuturam conftat no (a) . titiam non folum maris ac terre, fed flaminú quoq quæ ignaros tur (3. batura effent, quum abfque corum cognitione ac peritia haud cómo de fit nauibus notus \& curlus in mari, núc, pigeat licet fcribere, quip pe vbi alibi plura, alibi pauciora inueniam varijs ac diuerfis nominibus ab ex. cellentifimis rerum natura lium vtriufque lingux fcriptoribus explicata, feorfum tamen prout facultas dabitur in tanta doctorum hominú varietate ac diffonantia,ipforum numerum nomináque $\&$ loca naturas $\&$ effectus profequar atque complectar. Quidam igitur fapientum putantes ventum effe ärem mo. tum \& fluentem (Ventus enim fit,auctore Lucretio, vbi eft agitando aér percitus) vnum \& eundem aiunt ventum effe omnes ventos, nec differre propter loca vndecunque extiterit, fimili modo femper fluens. Et quoniam ex omnibus quidem duo veluti à cardinibus perflant, feptentrio videlicet $\&$ aufter, funt qui duos tantum ventos annuant, alıum quidem borealem, alium aufralem, cæterosautem horum effe exceffus, fed zephyrum quidä borealem, Eurū auftralem. Eundem numerum Oribafius orientem propter \& occidentem effe afferit. Quatuor alii ventos obferuauere per totidem mundi partes: nam curum fue Apeliotem oriens, boream feptem ftellarum regio,occidens zephyrum, auftrum medius dies mittit, nec Homerus plures quàm quatuor nominat, fed qui accuratius perquifiuerunt eos, octo effe tradiderunt, maxime quidem Andronicus Cireftes, qui et i am collocauit Athenis turrim è marmore octogonam, \& in fingulis octogoni lateribus, fingulorum ventorum imagines exculptas cötra fuos cuiufque flatus defignauit, fuprág eam turrim metam marmoreã fecit, $\&$ infuper Tritonem æreum collocauit, dextra manu virgam porrigentem, \& ita eft machinatus vti vento circumageretur, \& femper contra flatum confifteret, fupráp imaginem flantis venti indicem virgam teneret, itaóp funt collati, Inter folanü $\&$ auftrum, ab oriente hyberno Eurus, quem noftri vocauere vulturnū : \& Liuius hoc illü nomine appellat, in illa pugna Ro parú prolpera, in qua Hannibal $\&$ contra fo lem orienté exercitum noftrü, $\&$ contra ventú cóftituit, quum véti adiutorio ac fulgoris perftringétis oculos hoftiü vicit. Varro quog hoc nomé vfurpat. Inter aufrũ \& fuonium qué Zephy rü dicunt, ab occidéte hyberno aphricus: inter fiuoniü \& feptẽtriones caurus, qué plures corủ vocant:intér feptentriones \& folanum aquilo. Videtur hoc modo expreffum vti capiat numerus \& nomina \& 
DE RE MILITARI LIB. XI. 2s

partes vnde flatus certi ventorum firent. Ominia hæc ante oculos locare poteft turris defcriptio fubftituta cum Tritone buccinam perflẩte, dicête Nafonie; $\mathrm{Po}$ fitóg, tricufpide telo,Mulcet aquas rector pelagi fupráğ profundum; Extantem at q̧ humetos innato murice tectum, Cęruleum Tritona vocat,cóchä́p fonanti lnfpirare iubet,fluctus's \& flumina figno lani reuocare dato: caua buccina fu mitur illi, Tortilis in latum, qua turbine crefcit ab imo, Buccina quę medio có. cepit vbi aëra ponto, $L$ ittora voce rẹplet fub vtroque iacentia phoebo.

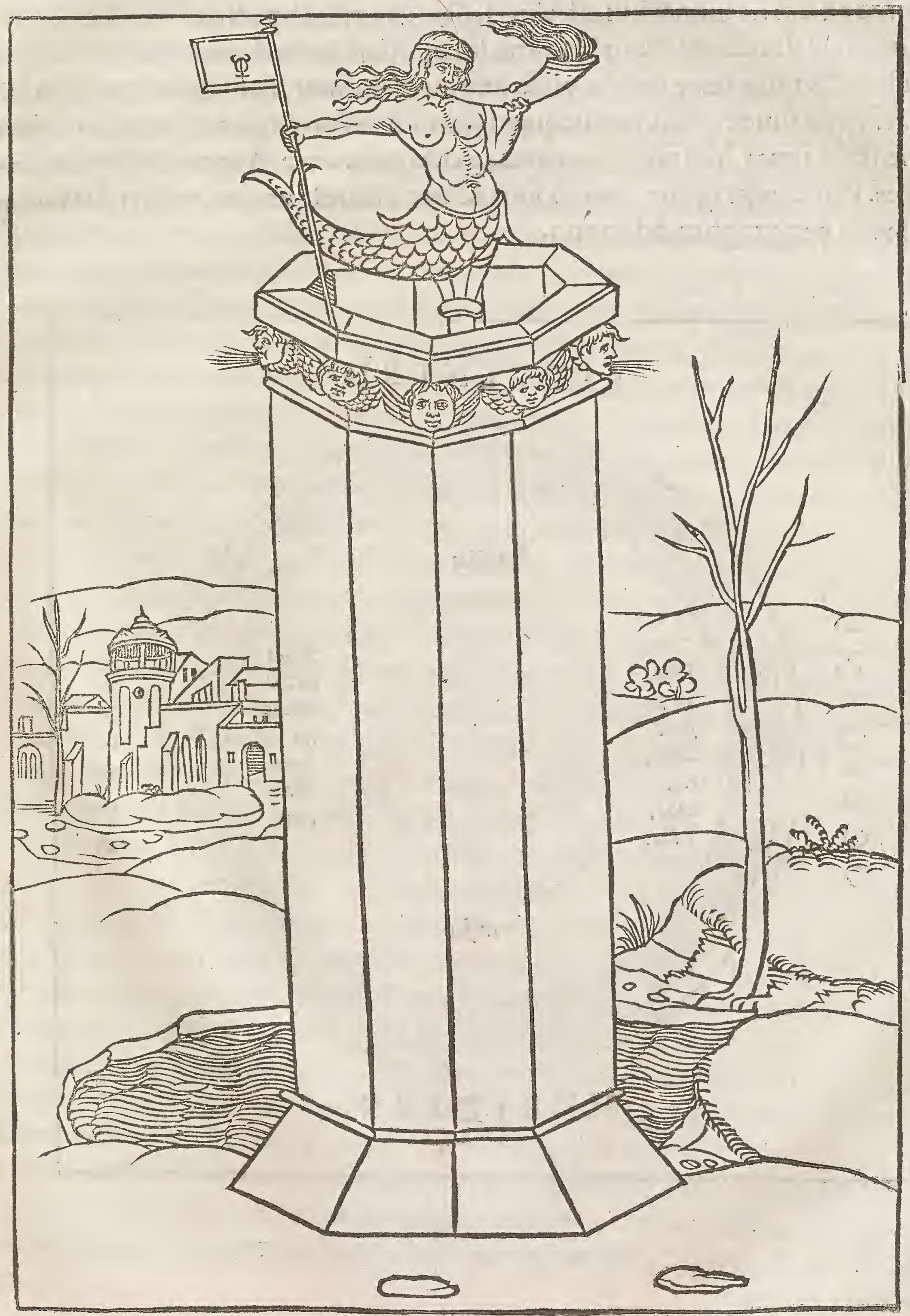


Hanc verò defcriptionem tanquam veram cxterífque pracellentem, Mediter ranei maris nauita omnes obferuant, Genuen fes potifimum, totidem adicientes interponentéfque. Applicantur pradictis octo primoribus alii quidam fe. cundum A riftotelem, \& quatuor quidem etiam fecundum Varronem, duodecim $q_{\beta}$ frunt. Quatuor enim cali partes internas diuidunt, \& fingulis ventis binos fuperaddunt. Arifoteles hac arte $\&$ Varro, viri diligentes, $\&$ omnium qui fue rint fcrip (erintque inf tructifimi, illos ordinant: nec fine caufa , Non enim codem femper loco fol oritur aut occidit, fed alius eft ortus occafif $f$ æ æquinoctia lis; hic autem rquinoctium eft: alius folftitialis, alius hybernalis : fic fiue fecundum quòd duodecin aër difcrimina fufcipit, fue iuxta duodecim in noftra pla ga habitationis notx puncta vnde originem trahunt, fiue iuxta duodecim zo diaci figna totidé efficit ventos, quos fignorum etiam triplicitas concitat. Nam orientales ignea, Meridionales terrea, occidentales aërea, A quea verò feptentrionales. Principales igitur venti hi funt, \& hoc diftincti ordine, vt oftend it vtraq fubiecta perigraphiz defcriptio.

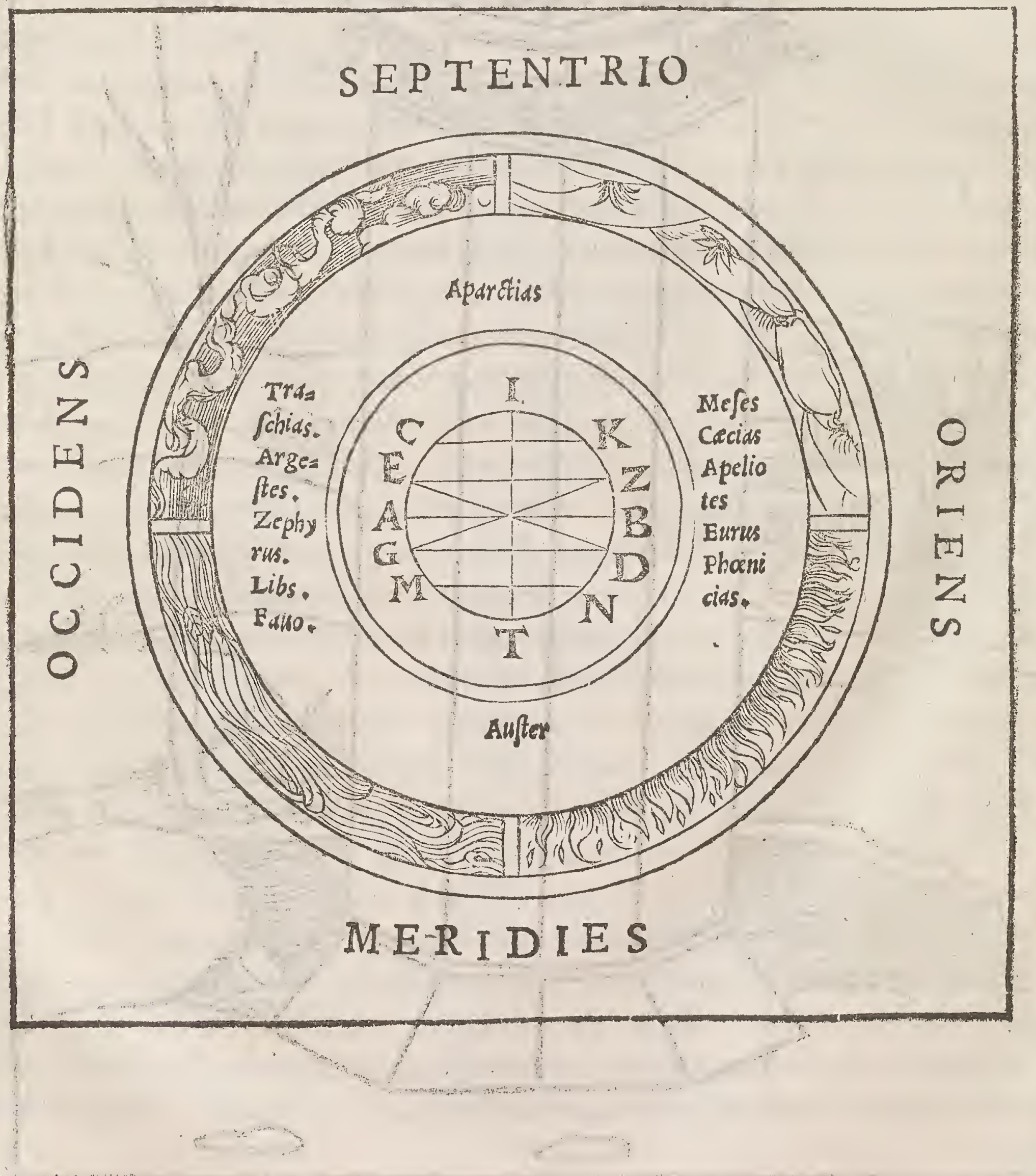


Sunt etiam Tranquillo approbante, plura nomina flatû́fue ventorum èlo cis quibufdam, aut ex conuallibus, aut fluminibus, aut montium procellis, aut aliquo finu tracta, ex aliqua caula qua ad faciendú vocabulü acciderat, \& qux nó tranfmittútur, ed in proximú feruntur:itag Virg. Cleopatrá è nauali pralio Aegyptú fugiente vêto lapyge ferri ait,ex lapygix finu, id eft,ex ipfo Gargano veniente. Equum quoog apulü eodem quo ventum, vocabulo lapygis ap. pellauit. Hunc caurum effe manifêtum eft: nam ex occiduo vènit, $\&$ V irg . fic meminit. Simili modo Calabriam Iapyx vexat \& A puliä infeftat A thabulus, Athenas chiron, Pamphiliam tagreis, Galliã circius, quem in libro originum Cato Cacium nominat, cui æedificia quaffanti tum incolx gratias agunt, tanquam falubritatem celli fui debeár ei. Diuus etiam Auguftus têplum illi quum in Gallia moraretur \& vouit \& fecit. Infinitú eft fi fingulos vêtorưn flatus eorúmque nomina perfequi velim, quum nulla propemodú regio fít qua non pe culiarem habeat aliquem flatum ex fe nafcentem, \& circa fe cadentem: quumós præterea antelucani flatus plures fint,nullúfque eorú fit pertinax, fed cadat fortiore iam fole, nec feratur vltra certum tractum terrarúnig afpectum:nec fi vere coperit, vltra aftatem perduret, duo funt tanen extra hos vbigh fpiritus magis quàmventi,aura \& altanus: aura in terra,altanus in mari . Sed vt ad id de quo agitur propius reuertar, fole vigefimamquintam partem obtinente aquarii, ver aperit mare nauigantibus,cuius in principio fauonii genitales mundi f piritusà à fauendo dicti hy bernum molliunt calum. Fauonium autem quidam ad viii. $\mathrm{kl}$.martias chelidonium vocant ab hyrundinis vifu. Nonnulli verò orchiams vno \& feptuagefimo die poft brumam ab aduentu auiun flâtem per dies octo. Fauonio côtrarius eft qué fubfolanum dicunt. Eft autem exortus Virgiliaram in totidem partibus tauri, fex diebus ante idus maias, quod têpus auftrium eft. Huic vento feptentrione contrario ardentifimum xitatis tempore exoritur ca nicula fydus,fole primam partem leonis ingrediente, qui dies xv. calendas auguftas eft, cuius ortum diebus viii. ferme aquilones antecedút. Poft biduum autem iifdem aquilonibus conftantius perflant dies triginta quos Etefias vocant, mollirég eos creditur folis vapor geminatos ardore fyderis. Poft eos rurfus auftri crebri vfque ad fydus arcturi, quod ante xquinoctium autumini vndecim diebus exoritur, nec fineferme procellofa grandine emergit. Cum hoc corus incipit, cortus autumnat, huic cọtrarius vulturnus. Poft id xquinoctium diebus fere quattuor \& quadraginta virgiliarum occafus hyemem inchoat, quod inci dit tertio idus nouem bris, hoc eft, aquilonis hy bernis, multúmg aftiuo illi dif fimilis, cuius ex aduerfo eft aphricus, ante brumam autem diebus feptem: totidem poftea fternitur mare halcyonum foeturx cuius dies nouere qui maria nauigant:eas aues videre rariffimum eft, nec nifi virgiliarum occafu foctificant bruma, qui dies halcyonides vocantur, placido mari per eos \& nauigabili,maxime ficulo,vt reliquis partibus eft quidem mitius pelagus ficulum, vtrunq $\$$ tune tractabile,faciüt feptem diebus ante brumam nidos, \& 2 totidem fequentibus pariunt: $\&$ his quiden diebus, maris natura benigna, nautis tutiffima nauigatio eft. Reliquum verò tempus hyemat, \& quanquam pyratæ primum mortis pe-

$\mathrm{Cc}$ riculo 
xiculo, 8 in mortem ruere $\&$ hyberna experiri maria coperint, nunc itidé aua I' quidam $\&$ atidaces faciant, hi tameí naturales per fatuta tempora vêtorum cürfus porro naturales effectus ventorum hifunt. Onnes enim vicibus fuis fpi xât matori ex parte, vt contrarius in definenti incipiat, furgátgue ex oppofito cum proxme cadenti. Ouidius, vix nunc obfiftiturillis, Quun fua quifque regat diuerfo fla mina tractu, Quin laniêt mundun, tanta eft difcordia fratrum. Eurus ad auroram, Nabatheá̧ regna recelfit,Perfidág $\&$ radius iuga fubdita matutinis. Vefper \&occiduo qua lit tora fole tepefcur, Proxima funt zephyro, Seythiam fepemo triones Horrifer inuaft boreas, contraria tellus Nubibus af frduis pluuió nadefcit ab autro. Vel fi breuius coplecti mauis; in vnam tempeftatem, quod fieri nullo modo potelt, cógregentur, Vna eurusóp notúfọ ruunt crebérque procellis Affricus, \& qui loca in illa rixa non habuit aquilo. Ab ort flantes calidiores diuturnioresóg ac tutiores funt ab occafu flantibus. Ouidius in faftis. Luce fecutura tutos pete nauita portus, Ventus ab occafu grädine mix tus erit. Vuleurnus frà ferena cell parte flare coperit, non durat in noctem.Quif guiserit ventus f feruidus fentietur, pluribus diebus permanebit. Sol auget flatis oriens, $\&$ comprimit occidens: medio autem diei ac noct is plerunque fopiun tur, quia nimio frigore aut æltu foluuntur:ex imbribus boreas feu aquilo inter feptentriones; reliquos compelcit nubef'́p abigit atque diffipat. Ouidius deco, A pta mi hi vis eft quia triftia nubila pello, Et freta concutio nodofág robora verto, Induróg̣ niùes et terras grâdine pulfo. Idem ego quá fratres cælo fum na-

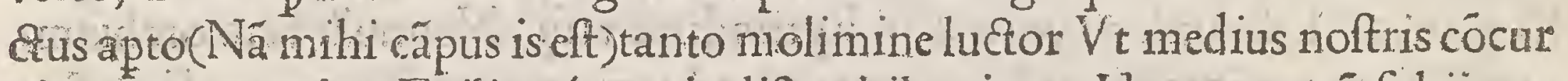
frbus intonet xther, Exiliantóg cauis elifr nubibus ignes. Idem ego quä fubii con uexa foramina terræ, Suppoluíp ferox inis mea terga cauernis, Sollicito manes tot móp tremoribus orbem. Auftro maiores fluctus edütur q̃ aquilone, quo rảa hic funmo maris,ille inferius ex imo fpirat. Interdiu aquilo vehemétior,no çu aủter, $q$ a grzeco vor 3 w notus dicitur, quia nebulofus atọ humectus. Idem po éta, Madidis notus euolat allis Terribile picea tectus caligine vultú. Barba gra-

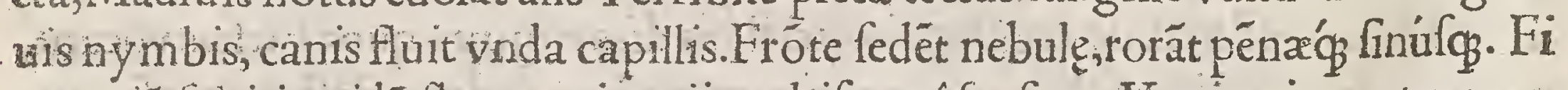
unte etia fubiti quida flatus, qui varii multiforméfog funt. Vagi quippe atç̧ ruen tes teloru more, tonitrua \& fulgura ędüt, que vocât hi quide Vulcanú, hi autem

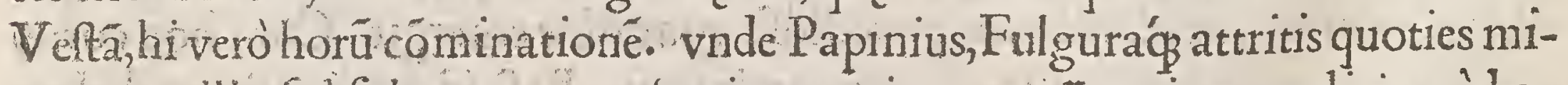
cuere pcellis: fed fulgura et corutcationes prius cerni q tonitrua audiri, quòd co fufcare prius calücreditur, \& mox tonare: fue quá fimul fiant, vt alii phibent, tǘ ingesilli, fui pnicitate dicto citius noftrę fe vifioni ingerút. Sonus nó aliter ac icto \& verberato aêread aures venit férioréque fenfu concipitur. Herodotus extinat fulgurationé effe velut a pud nos incipientium ignium conatus, et prinam flamman $\&$ certam, nodo intereuntem, modo infurgentem : hoc anti qui fulgetra dicebant, tonitrua nos pluraliter dicimus, antiqui autem tonitrum aut tonum. Hoc à Cecinna facudo viro dictum inuenio, 11 habuiffet in elogien tia nomen, $\&$ nifillum Ciceronis verba prefliffent. Etenim illo verbo vtebancurantiqui correpto quo nos producta vna fyllaba vtimur : dicimus enim ve fplendére fic fulgére. Atqui illis ad fignificandum hanc fubitam è nubibus Winck eruptio 
eruptionê lucis, mos erat vti media fyllaba correpta, vt diceretur fúlgere: flẩma verò illa quam nubiun afflictus excuffit, fr robuftiore fuerit incendio, impetü deuehitur in terras, $\&$ fulminis babet nomen atque fortitudinem:vbicun $q$ au tem ceciderit, fulphuris odorem enittit, vt inquit Virg. Et late circum loca ful phure fumant, \& Lucanus, Aethereóg nocés fumauit fulphure ferrum. Quòd fi arctius rotatus effregerit impetus ille frne igne, hoc eft, fine fulmine \& aliquo promontorio repercuffus eft, aut locorum coéuntium in canalem deuexum cer nuumóp collectus, fxpius in fe volutatur, aquáfós quum voluit vorticë facit, iam Typhon vocatur, id eft, vibratus. Rapida enim vettigine contorquetur humus arida $\&$ ab infimo erigitur ad fúmmum, nec antennâs modó, verùn ipfa nauigia contorta frangit, tenui remedio aceti in aduenientem effufi. Illifo enim ipfo repercuffus, arrepta fecum in celú refert, forbétog in excelfun. Contra hunc inter falutaria quoque, coralli materiá effe dicút: nam Metrodorus Gorgiam nominat, idem $q$ refiftat Typhonibus \& fulminibus . Quum autem circumactus \& eundem ambiens locum repentinis flabris proflit $\&$ vniuerfa perturbat atq $\$$ peruoluit, turbo dicitur :Lucretius, Verfabundus enim turbo defcendit, \& illam Deuertit pariter lento cum corpore nubem, Quam fimul ac grauidan detrudit ad xquora ponti, llle in aquam fubitò totum fe immittit, \& omne Excitat ingenti fonitu mare feruere cogens. Hic idem pugnacior fi eft ac diutius volutatus inflammatur, efficit quem nassïgo Græci vocant, qui \& igneus turbo eft .

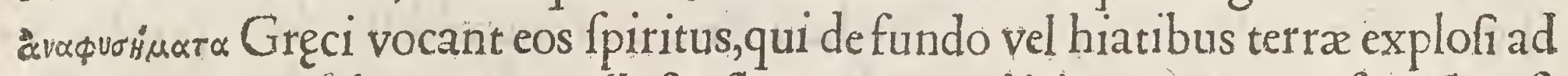
fuperna meare folent:at procellolus flatus ratou ris dicitur, quem præfractủ poffumus dicere, quód de fuperiore cæli parte fubmiffis, inferiore repentinis impul fibus quatiat. Vocatur $\&$ columna conf picatus humor rigens, ipfe fe fultinet, ab codem $\&$ in longam veluti fiftulã nubes aquam trahit, nec minus fingula qux illi obiiciürur, vnde Lúcretius, Nam fit vt interdun tantum demifla columna In mare de cello defcendat, quam freta circum, Feruefcunt grauiter fpirantibus vndiq flabris. Et quæcunque in eo quú fint deprenfa tumultu, Nauigia in fum mum veniunt vexata periclum: \& hæc ferè omnia pericula venti erupti de nubibus producunt, quibus armamenta rapiuntur, $\&$ totæ naues plernnque in fus blime tolluntur: \& quanquam nihil moleftius in marı ventis turbinibúlue ac procellis huiu fmodi fit, nec maiore hominum ingenio vlla fui parte nauigatio zdiuta $\mathrm{q}$ remis velisóg,tamen hæc omnia pariter eodé impellétia vnus $\&$ paruuIus admodü pifciculus affuetus petris, Echinus appellatus, tenet, in fe folus ele mentorū atọ̧ hominú vim recödens: nullo quidem actu, nullo cona mine, fed na tura ipfa: \& ruant véti licet, f̧̣uiant procellę,imperat ta men furori,tâtaśǵ̣ vires compefcit,vt cogat ftare nauigia: quorú non vincula, non anchorę pódere irre uocabili iactę iuuãt, infrenat impetus, ac domat nullo fuo labore: nó recurrēdo, aut alio modo quàm carinis adhęrêdo, et vtroq̧ fefe latere colligete retinêdo: q \$ \& fr fcriptis illuftribus infitü inuenio, tamë incredibiliü videri poffet, fi de oceano indico fortaflis aut fcythico folú fcriptĩ effet, \& non potius in noftro mari monftü hoc Romanis imperatoribus accidiffet: hoc enim inhęréte, plená vẻtis ftetifle naué, portanté núcios Peliandro vt caftrarent nobiles pueri. Hic tenuiffe 
fertur Actiaco mari prætoriá nauim Antonii,properantis circuire \& exhortari fuos, donec tranfiret in aliā,ideó́g cæéariana claffis impetu maiore protinus venit. Tenuit $\&$ Caii principis Aftaira Antium renauigantis, fed non longa fuit illius moræadmiratio. Animaduerfa enim è veftigio moræ caufa, quodd tota claffe prodeúte quinquerem is vna ac fola non proficeret, im mo velut in anchoris ftaret, neque prorfus loco moueretur, ê naui protinus exilient ibus qui id quęrerent, circa nauim inuenere adhærentem gubernaculo, oftenderunt'́s Caio indignanti mirantíq hoc fuiffe quod quadringentorum remigum obfequium na uigio adhærens contra fe tenuiffet. In nauigium receptum pifciculum qui tunc videre, eum limaci magnæ fimilem effe dixere, indici maris conchæe fimili poten tia,labiis fuis nauium dorfa fixerunt, quarum quietus ac tenuis leuifque tactus plus dicitur retinere quàm exagitata polfintelementa complere: Atat enim pigra ratis tumentibus alata velis, \& curfum nô habet cui ventus arridet:fine anchoris figitur, fine rudentibus alligatur, \& tã parua animalia plus refiftunt quàm tot auxilia profperitatis impellant: ita quum fubiecta vnda præcipitet curfum, fupra maris tergum nauigium cogitur ftare infixum, miróg modo natantia incócuffe tenétur, dum vnda innumeris motibus rapiatur. Sed vt dicamus aliam pifcis naturam, Forte nautæ prædictarum nauium tactu torpedinis fegniffime tor puerunt, à qua tãtum infigentium dextræ pergrauantur, vt per haftam qua fuerit vülnerata ita manum percutientis inficiat, vt viuæ fubftantiæ pars fine fenfu aliquo immobilis obftupefcat. Tradunt alii,quod incredibile videri poteft,tardius ire nauigia, teftudinis pedem dextrum vehentia. Ferunt $\&$ alterum monftri genus, haud minus incredibile, effe circa idem mare indicum aué inaudita magnitudine quampiam, noftri Rocum vocant, cuius penne longitudine funt paffuum decem,neque tantæ magnitudini vires deeffe. Elephantum enim efuriens quum ceperit $\&$ aliquädiu per aërem volitando tulerit, in terram iacit, quo cafu peremptum depafcit ur: nec elephantum folum, fed tota infuper roftro prehenfa nauigia fecum tulit in nubila, \& pendentes per inane miferos nauigantes volatu ipfo terribili delet ac morte confumit.

A ftrologia nautica, fecundum folis, lune, fideruago; ob feruationem,

Cap. vili. Xacta ventorum ratione, tranfre cónenit ad alia tempeftatum pro1. 20. Inoftica: \& quoniam claffem ipfam concuti proteríque ventorum 1 2 rim præliis, \& nautarum imperitia fapenumero cópertum ef, impręen- tiarum opportuna,tum belli, tum nauigationis tempora defcribétes, futuri motus ventorum, \& imbrium tempeftatún que præfagia diligentifime perquifita trademus. Et primûm à fole \& luna cæeteríque fideribus : hinc enim vt poêta inquit doctiffimus, tépeltates dubio prædifcere cælo Poffumus, \& quan do infidum remis impellere marmor Conueniat, quando armatas deducere claffes, Aut tempeftiuam fyluis euertere pinum. Sol itaque quem louis oculum appellauit antiquitas purus oriens $\&$ non feruens, ferenum diem nunciat : idem quum ante eius exortum nubes rubefcunt, ventum: quòd fi nigræ rubentibus interuenerint, pluuias : fi ante exortum nubes quoque conglobabuntur, hyemem afperam denunciabunt: fi ab ortu repellentur, 
\& ad occafum abibunt, ferenitatem: fr ante ortum radii fe oftendent, a quam \& ventum prænunciant:fi nubes folem circunduxerint, quanto minus luminis relinquunt tanto turbidior tépeltas erit: fin exortu fpargentur partim ad auftrum partim ad aquilonem, pura quanquam circa eum ferenitas fit, pluuiã tamen ven tofque fignificabunt: cuim oriente radii non illuftres imminebunt, quàmuis cir * cundati nube non fint, pluuiam portédunt: fr oriens cingetur orbe totuśg deflu. xerit æqualiter, ferenitatem dabit:fi veró partim fe aperit, ex qua parte is fe aperit expectetur ventus: fi verò duplex orbis fuerit, atrox tempeftas inuadet. Porrò fi circa occidentem rubefcent nubes, ferenitatem futuri diei fpondent: fr cęruleum vultum induent, pluuiam denunciant: fi igneum, euros. Itidem fi maculæ ru tilo interuenerint, venti nymbióp non deerunt: it em fi circa eúdem occidenten candidus circulus erit,nectis leuem tempeftatem:fi nebula,vehemétiorem: fr aus tem circulus fuerit, ex qua regione is eruperit, ventum magnum. Soli proxima funt \& lunæ præfagia:nam fi f plendens exorta puro nitore effulferit, ferenitatem: fi rubicunda, ventos: fi nigra, pluuias portendere creditur: fi ante quartam non apparuert fauonio flante, toto hyemale erit méfe: fr fextadecima vehemen tius fla mmea apparuerit, afperas tempeffates práagiet: fi in ortu quarto quem

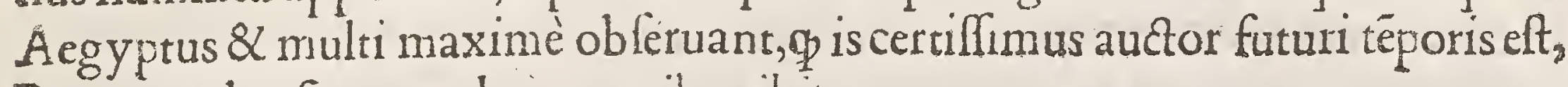
Pura nec obtufis per cælum cornibus ibit,

Totus \& ille dies, \& qui nafcentur ab illo

Exactum ad menfem pluuia ventiśg carebunt,

Votáque feruati foluent in littore nautæ,

$V_{t}$ Maro inquit:fi plenslunio per dimidium fura erit, dies ferenos fignificabit: fi rutila,ventos: nigrefcens, imbres: fi caligo nubis orbem incluferit,ventos: qua fe ruperit fi gemini orbes cinxerint, maiorem tempeftatem, \& magis, fi tres erüt nigri,aut interrupti, aut diftracti: fi plena circa te habebit orbé,ex qua parte is maximè Cplendebit ex ea verstum oftédet. Interlunii auté tempus diram nauigan tibus peftem non folum ratione, fed viu \& experientia rerum magittra cóprobat. Tertio loco ftellarum obferuationem effer oportet. Hæ quum difcurrere interdum videntur, venti protinus fequútur.Quú fereno cælo fulgent, pluuiz̨ erunt: atrociffimę: quum repente fiderúm fplendor hebetatur, neq nubilo neq, caligine, graues denunciantur tempeftates:fi volitare plures ftell $x$ videbuntur, quo feruntur, albefcentes ventos ex his partibus nunciant: fi in pluribus partibus fiet, inconftantes ventos effundent. Sic reliquorü quogs fiderum propria eft quibufog vis, \& a fuã cuiq̧ naturam fertilis, nec meãtıum modo difcurretiumọ́, fed mul. torú etiam adhęrentiú cælo, quotiés errant iú acceflu impulfa, aut coniectu radio rum extimulata funt, qualiter in fuculis étimus accidere, quas Graci ob id pluuio nomine vádes appellant. Et folis lunęqga ac fiderum obleruationem diximus. Nune de his qux ex paffionibus elementorum fiunt, aut ex ipfis originem fumentibus, prolequanur. In his enim non dubia futuri motus prafagia funt, quum in ipfis initia iam cernãtur à quibus caufarum principia fumunt. Nubes cum in montium cacuminibus confident, hyemabit:fic cacumina pura fient, dif ferenabit tonitrua. Ex his vt matutina ventum fignificat, fic imbrem meridia- 
na. Nebulæè montibus defcendentes, aut cælo cadentes, vel in vallibus fedentes, ferenitatem promittunt. Arcus quum funt duplices, pluuiam denunciant: fimplex verò arcus non eafdem vndecunq̧ apparuerit minas affert:à meridie enim ortus, magnam vim aquarum vehet, qua vinci non poterunt vehemétiffimo fo le,tantum elt illis virium: fi circa occafum refullerit,tonabit; \& leuiter impluet: fi ab ortu circáue furrexerint, lerena promittet.Quum xftate vehensentius tonu erit quàm fullerit, ventos ex ea parte denunciat : econtrà fí minus tonuerit, in’brem. Quum ex omnibus quatuor cali partibus fulgurauerit, ventü $8 \mathrm{imbrem}$ ex his regionibus demóftrabit: cú ab aquilone tantû, in pofterum diem aquam: cum à feptentrione tãtum, eum ventum: quum ab auftro, coro vel fauonio, nocte ferena fulgurauerit, ventum imbrémque ex his regionibus fore indicat. His terreni etiam ignes proximi fignificant: pallidi nanque murmurantesóp,tempeftatum nuncii fentiuntur \& pluuix. In lucernis fungi fi flexuofe volitet flamma,ventum quoque defignant: vel quum cinis in foco concrelcit, \& quum carbo vehementer perlucet. Ent fua etiam aquarum fignificatio. Maris nanq ipfius tranquillus fonitus, fpumæve difperfa aut aquæ bullantes, plurium dierum hye mem portendunt,

Atque etiam ventos præmonftrant fxpe futuros

Inflatum mare quum fubitò,pofitumóp tume Ccit,

Saxáp caua falis niueo fpumata liquore

Triftificas certant Neptuno reddere voces.

Antè denfus fridor cum celfo è vertice montis

Ortus adaugef cit fcopulorum fape receflus.

Ex animalibus portò terreftribus, \& marinis belluis, diuerfisçp volucribus reliqua plurima fuperfunt prognofica, tempeftatum' $\$$ præfagia, quę apud Tran quillum, Varronem, Nigidium, Aratum, Lucanum, \& vatem onnium clarifimum Maronem, in georgic.qui fcire volet abfoluta diligenter inueniet.

Remedia periculo affectis

Cap.

IX.

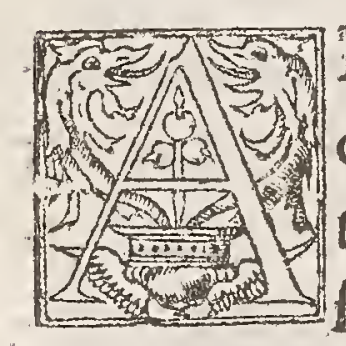

Dda mus autem \& remedia periculo affectis. Mare motú, olei afperfrone fedatur: \& ob id nantes ore fpargere tradút, quoniam mit iget na turam eius afperam tranquillimg reddat. Si longa fit nauigatio,ab Inthium potum naufeas arcet.Quia verò nauigantes dulcis aque de fectu fxpelaborant, hrec quoque fubfidia demóftrabimus. Expaffa circa nauem vellera madefcunt accepto maris halitu, quibus dulcis humor exprimitur. Item remiffæreticulis concauæ cera pilæ, vel vafa inania obturata, dulcem intra fe colligunt humorem. Aqua quoque marina, argilla colata, dulcefcit.

Quid agendum antequam curfus in boftes dirigantur.

Cap. $\mathrm{x}$.

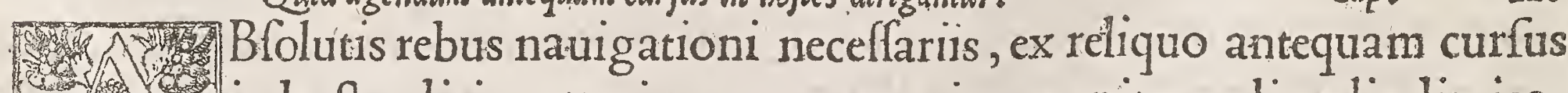
1. In hoftes dirigantur, in portu exerceri conuenit nauali prelio dimica3. 5 . turos, \& in träquillo mari affuefcere flectere gubernacula, remos tra 1. 1 here,ferreas manus \& vncos,afferes, bipennes fal céfque præacutas pre parare, difpofitófque per tabulata milites pendente gradu 8 labenti veltigio Rare, vi quod in fimulata pugna didicerint, in vero certamine haudquaquam perhorref 
perhorrefcåt. Ipfius etiam certaminis ratio eft, eminus conftitutos appetere fa gittis accedere aufos, priufquàm faciát cogere pati, \& cum ipfis nauigiis mergere : defiliendo item in naues gladis interficere, aut concurrentibus nauibus cum nauigiis capere. Pugnatorum etiam numerus fingulis nauibus imponen dus pro copia nauium \& militum exiftimatione augeri \& minui poteft.Quum autem ignota regio plerunque petenda, non tamen incertú vagari oportet, fed locorum portúmog opportunitatem exquirete, vt latétibus fopulis inuia qux* que ac ficca vitentur.

\section{Quid fi cla Bis claßi obijciatur.}

cap. XI. Vòd fi holtes claffem tenent, inuenta calliditate Græcorum nauium holtilium compendiofa expugnatio êt, Ignem græcú appellant con fectionem quandam bullitionémque faligni carbonis, falis, ardentis aqux, vitis, fulphuris, picis, thuriśg cum mollis Aethiopum lanæ filo, \& camphora, qux dictu mirabile fola ardet in aqua materiem omnem adurentem. Callimachus architectus ab Helepoli fugiés id Romanos docuit primùm, \& eo fane imperatores multi poftea in hoftes vfi funt. Tépore enim Leonis imperatoris quum orientales populi contra ciuitatem Conftantinopolim nauigaf fent in dromonibus mille octingentis, imperator igniferis nauibus cótra eos di rectis, hoc ignis genere omnes abfumpfit . Idem paulò pòf cccc holtium naues itémque cccl eodem igne confecit. Sunt qui alio igne,\& quidem miffili, huićp perfrmili,fed vehementius vrête vtantur, his additis, liquenti vernice ac librario oleo, petroleo, terebentina, aceto quàm acri, confectis, compreflis, ad folémque deficcatis, ac poftea ftupa inuolutis cum acutis ferris imminentibus glomeris inftar funiculo contexti, que omnia denique fint vno foramine pretermiffo,colophonia \& fulphure in fequentem modum oblita. Eiufmodietiam igné fed the dis inhærentem hoftium claffibus obiiciunt alii, Quam pelago diuerfa lues,nam pinguibus ignis Affixus thedis, \& tecto fulphure viuax Spargitur ac faciles præbent alimenta carinæ, Nunc pice, nunc liquida rapuere incendia cæra, Nec flammas fuperant vndæ, Iparfis'́p per æquor Iam ratibus, fragmenta ferus fibi vend icat ignis. Idem de codem alibi, piceo iubet vnguine tinctas

Lampadas immitti inunctis in bella carinis,

Nec piger ignis erat per ftuppea vincula,pérque

Manantes cæra tabulas, $\propto$ tempore eodem

Tranftráq̣ nautarum fummíg arfere Cheruci

Iam propé femuftæ merguntur in æquore claffes,

Iámque hoftes \& tela natant,nec puppibus ignis

Incubuit folis, fed qux vicina fuere

Tecta mari,longis rapuere vaporibus ignem.

Verum ne ignis abeffe poffit, la pide pyrite excutiatur, qui chalibe, aut aliquo lapide ictus fcintillam edet, qux excepta fulphure, aut foliis, aut linteo pauli- 
fper ambufto, fulphurea materia illico reddit flammam. Sunt aliis gentibus fua circa hæc inuenta. Nam aliquando fiunt etiam igniaria ex moro,lauro, hedera, qux exploratorum vfus in caftris, paftorum'q reperit. Et quoniam ad excutiendum ignem non femper lapid is filicis occafio eft, teritur ergo lignüligno, igné concipit attritu, excipiente materia aridi fomitis fungi : fed nihil hedera præftantius qux teritur lauro laurumque terit, ignem fcintillis excutiendo. Igné-in annum quoos afferuare ferula Prometheus reperit: de hac proinde Martialis, Inuifæ nimium pueris gratæóp magiftris

Clara Prometheo munere ligna fumus.

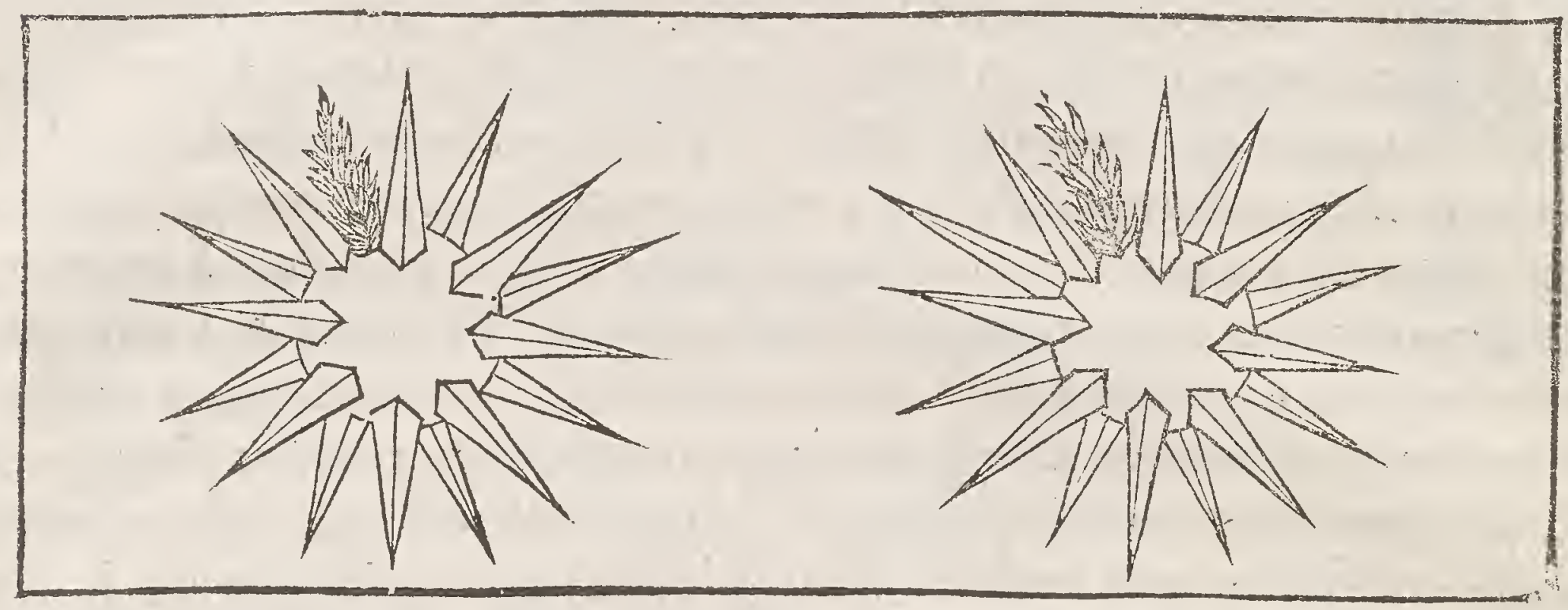

Probatur fummopere in aquis \& illud Hannibalis inuentum. Nam quum Prufias terreftri bello ab Eumene victus pręlium in mare träftuliffet, Hannibal nouę cómen to auctor victorię fuit.Quippe omne ferpentú genus in fictiles lage nas coniici iuffit, medióque prælio in naues hoftium mitti, id primûm Ponticis ridiculun vifum eft, fictilibus dimicare qui ferro nequeant: verùn vbi ferpëtibus ccepere naues oppleri, ancipiti periculo circunuenti hoft $i$ victoriam cefferunt. Saponem alii nigrum oleo vel amurca permixtum fictilibus fimili modo deiiciunt quo aduerfx partis tabulata lubrica fiant, quíø pugnant nullo pacto poffint lnctando cófrftere. Si quis autem \& illud experiri velit, ha bemus in exem plis lectos agilitate iuuenes enatantes fub aquis, quum proximi holtiü nauibus hæfiffent, carinas terebra perforaffe.

Flsminum tranfitus ex inuentis memoratu dignis.

Cap. XII.

Nnectendum \& illud arbitror, vt fi aduerfo flumine ab holte preclu(I)/: I) damur, quéadmodum libero tranfitu polfimus vti, $\&$ id ex geftis do11. cebimus priorum exépla tradentes. Alexädro Indiam vafta nte quum DE Porus ei occurriflet, caftra inter vtranq ripam Idaf pis fuminis difpo fta funt: latus hic erat ftadiis quatuor, altus vadis nunquam repertis. Alexãder Attalum quendam fibi fimillimum caftra feruare iufit, regiis veltibus indutum, ipfe cû parte equitatus aliquantum progreflus, dum dêfa caligo diem fubtexiffet, in vlteriorem ripam tranfuectus ancipiti pralio diu fatigatus eft, donec pedibus elephantorum fecuribus fuccifis, agmina perturbata funt. Cxfar haud diffimili ratione vfus eft. Nam quü flumine ab hofte impediretur è regione illis caltra 
caltra poñentibus, nactus vnum ex pontibus quos illi refciderant, fylueftri loco fubftitit. Poltero die omnes copias longo agmine præmittens, ipfe cum duabus legionibus parumper moram trahens, pontéque refecto, legiones traduxit, loco idoneo caftris delecto, reliquas copias reuocauit. Labienus, vnus ex ducibus eius noctu opportunitatem quafiuit: is quum hoftes aduerfo flumine Sequanæ confediffent tranfitum prohibentes, nactus aliquantas naues fingulas gubernẩtibus tradidit. Lintres etiam conquifiuit, quas magno fonitu remorum in eandé partem mifit: hoftes fufpicati Romanos tribus locis tranfire, ipfr quog in tres partes fuas copias diuiferunt. Labienus ad naues contendens tres legiones traduxit, acie inftructa, quum copiarũ hoftilium partem diffipaffet telique fugãarripuere. Fit pons aliquando, vbi holtis nó vrget, pluribus nauibus tabula to conAratis. Plurimi interdum equi flumini opponuntur, aquarum impetum excepturi, quo catera turba molli vado, \& tuto,ac fabili greffu traiiciatur,vt per Cæfarem in Rubiconis noftri tranfitu fieri contigit . Geminæe nonnung̈ equitum acies delectis pragrandibus equis, ordine, $\&$ intercapedine quadam fua $\mathrm{Ce}_{\text {- }}$ iunctx currenti aque obiiciuntur, ac inter vtranque impediti expedití $q$ milites tranfeunt: fuperioris nanq̧ beneficio, current is impetus aqua, viśg perfringitur : inferior fi qui forte deciderút, mox raptat $\&$ tranfuehit. I dem Cæfar quum Liger fibi traiiciendus effet, vado per equites inuento, vt brachia tantum $\&$ hu meti ad fuftinenda arma liberi ab aqua effe poffent, equitatu fic difpofito, qui fluminis vim perftringeret, incolumem exercitum duxit. Cellius auctor eft, $\mathrm{Ma}$ gonem cum equitatu $\&$ hifpanis peditibus flumen extemplo träfnataffe,ipfum Hannibalem per fuperiora $\mathrm{Padi}$ vada exercitum traduxiffe, elephantis in ordiném ad fuftinédum impetum fluminis oppolitis, quod periti amnis eius vix fe cerunt. Quòd fi altior vnda vtrinque militem refpuat, foffis plurimis ac diuer ticulis minuenda eft, ficut $C x$ far in tranfitu Licoris, ne quid repetitis audeat vn dis, Spargitur in fulcos, \& fiffo gurgite riuus, Dat pơnas maioris aquæ, vt Lucanus inquit. Cyrus potentiffimus Perfarum rex Babylona oppugnaturus, Gangem fluuium, adeò grandé,ve vbi minus occupet, latitudine viii. m. paffuum pateat:vbi immodicum fiue plurinum, ftadiorum $\mathrm{c}$. altitudine verò ea vt nufquàm minus viginti pafuum reperiatur, fic leui licet caufa permeabilem fe cit. Nam quum vnum ex regiis equis candore at $\$$ forma pracipuum à vorticibus vndarum circumagi atq̧ abfumi cum equite vnà cerneret, aiunt ira perci tum iuraffe fe adeò illum extenuaturum vt mulierum greffibus vadofum red. deret, nec dictis defuit, nam totis in hoc expofitis copiis, tam diu operi huic incubuit $\&$ affedit, donec centum octoginta cuniculis diuifum alueum in ceclx. riuulos difpergeret, \& ficcum in dinerfum fluentibus aquis relinqueret. Simili fane opere perdoctis fofforibus, etiam Euphratem inter cæteros fluuios memoratu plurimo,tum veterum literis, tum inundationibus fuis celeberrimú, \& lon . ge validiffimum, Babylonem quödam Chaldeę caput petenten Mediamó permeantem deriuauit, ac fic meabilibus vadis ficcum partibus aluei patentibus interfecit,copitóg vrbem quam ab humano opere extrui vel humana virture de ftrui polfe, pene apud mortales incredibile erat. Sapor Perfarum \& fuo in his 
ingenio vfus eft. Nam quü Nicomediam que Nifibis dicta eflet obfideret, \& flu. mine præpeditus, \& plurima molimina ponens eam obtinere non poffer, tádem impetum Mygdonil fluminis, per mediam ciuitatem properantis,à longe retinuit, vtrafque ripas eius faciens excalfiores, vt aqua in fe collecta concrefceret: quum'q̧ copiffent ripæ fublimes impleri, fu bito auferentes quas fecerant cataractas, dimiferunt impetum fluminis contra murum, qui vehemétis aque pondus non ferens cecidit,aliamó muri partem qua fluuius egrediebatur, cum ingenti ruina deponens, eadem aquæ moles perrupit. Sunt qui raptim cæé materia ra tes fabricent, in quibus equi viríg \& a alia onera traiiciantur,vt Cæafar \& Xerxes auctore Lucan. maxime vf funt,

Ergo,inquit, vbi nulla vado tenuit fua pondera moles

Tune placuit cæfis innectere vincula fyluis,

Roboráq immenfis late rigare catenis.

Tales fama canit tumidum fuper æequore Xerxem

Conftruxiffe vias, multis cum pontibus aufus,

Europan Afiæ,Sefton'̧́ admouit Abydo,

Inceffitó fretum rapidi fuper æquore ponti,

Non eurum zephyrum'q timens, cum vela rates'́p

In medium differret Athon,fic ora profundi

Arctantur cafu nemorum, tunc aggere multo

Surgit opus,longég tremunt fuper æquora turres.

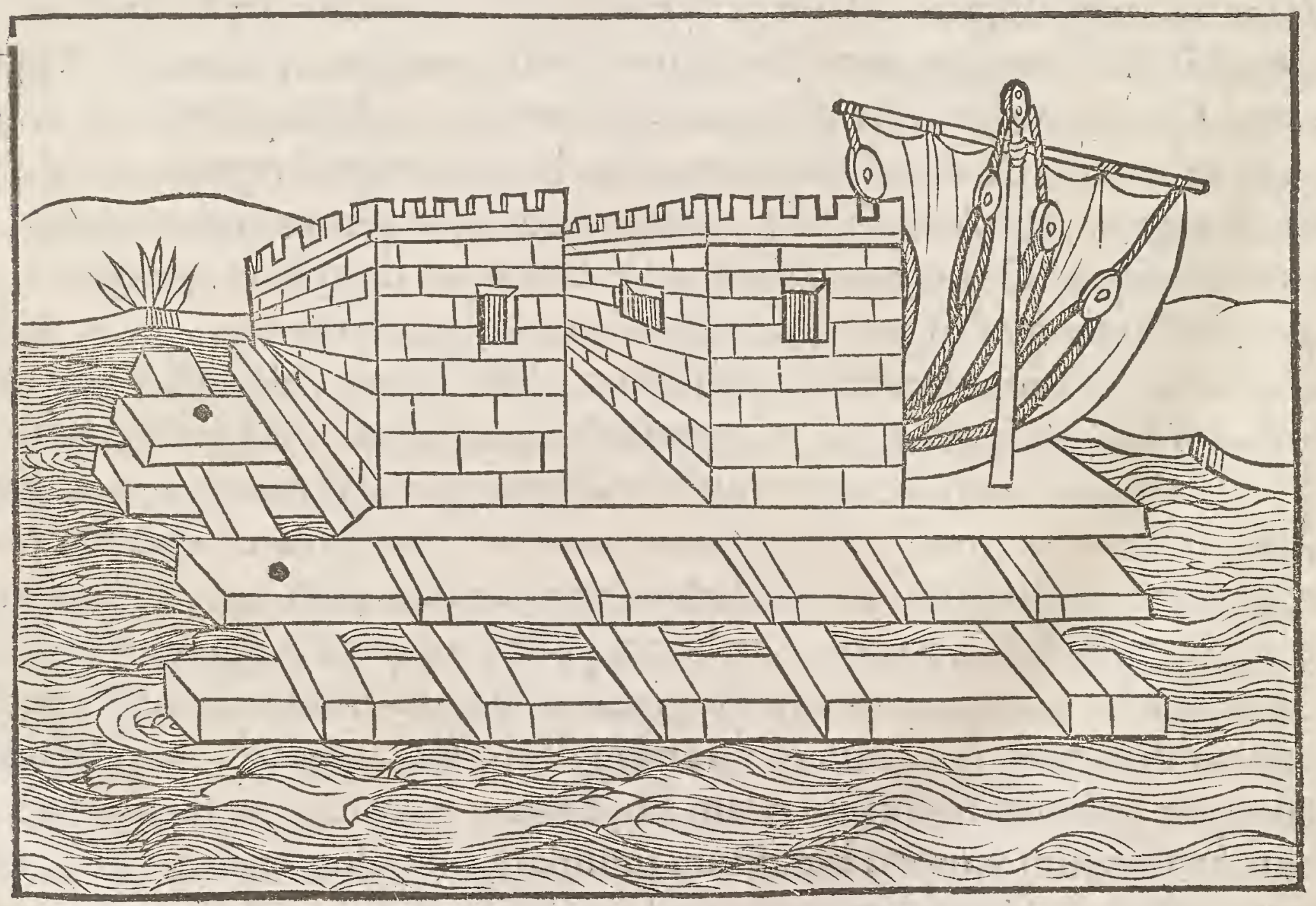


DE RE MILITARI LIB. XI. 呅

Sunt qui pontem difinctum iumentis vehibilem, commiffuris fuis \& funibus annulífque ferreis confutilem, duplicatis tabulis quibuf $\int_{3}$, ac vacuis, $\&$ contra aquaingreflum coniunctis glutino, in hanc formam conftruant.

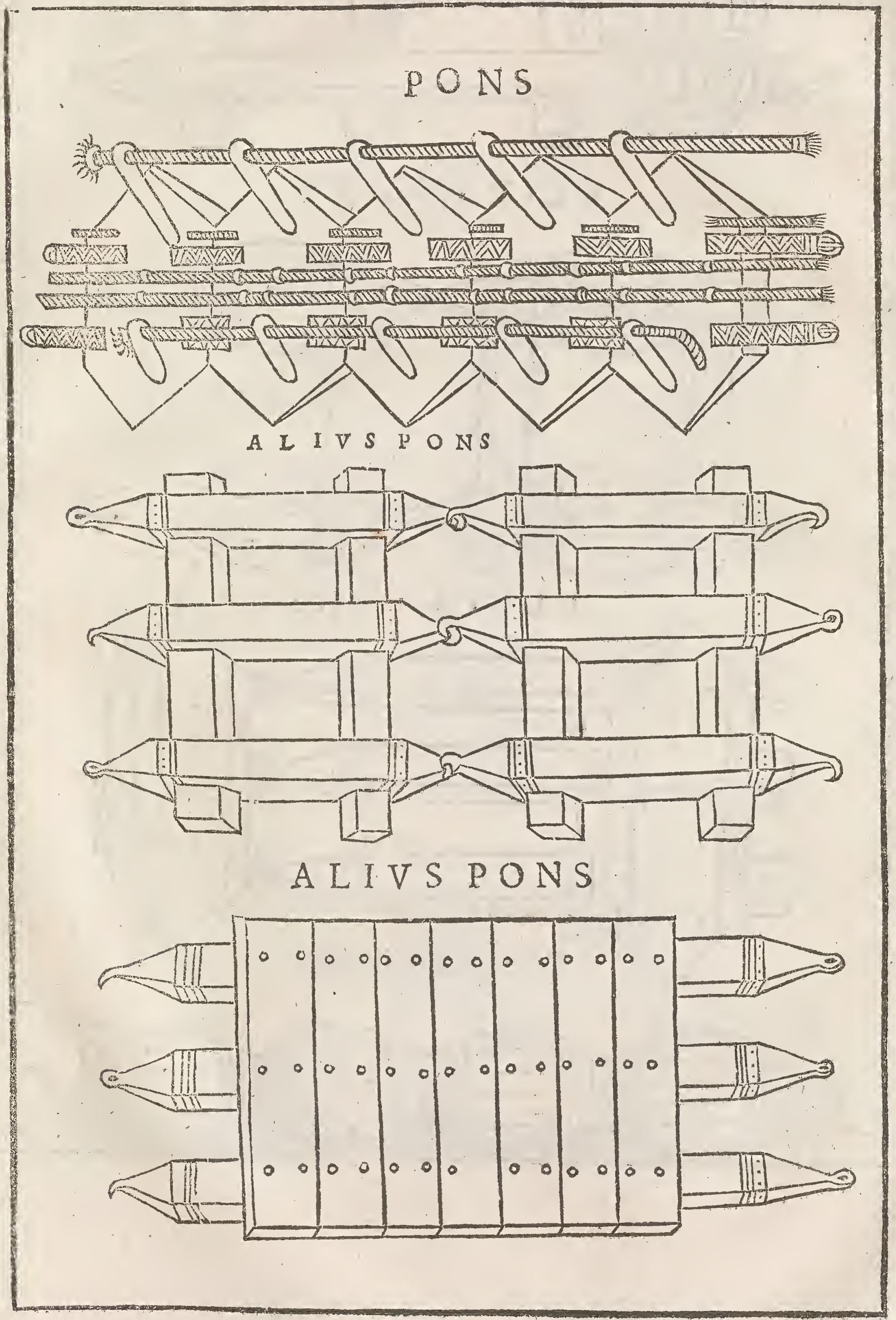




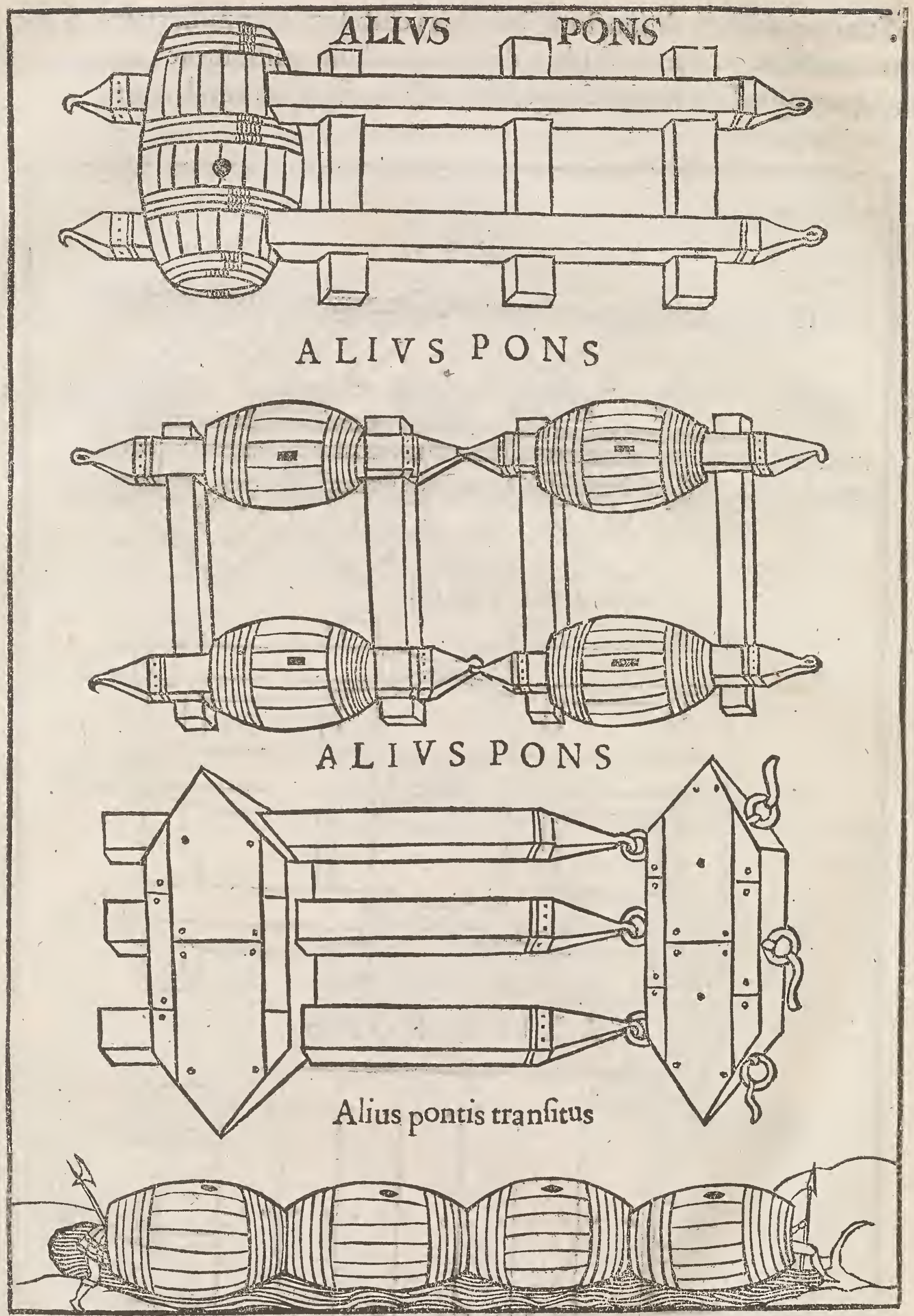


Apud alios inuétum hoc etiam extat, vt monoxylos ex fingulis trabibus excauatos, pro genere ligni \& fubtilitate leuiffima, carpentis fecum ferat exercitus: tabulatis pariter \& clauis ferreis præparatis, vt fublata omni mora, quum opus fit,hoc ponte conftructo aduerfus hoftes fuperuenientes incurfus $\&$ infidi as facere poffint.

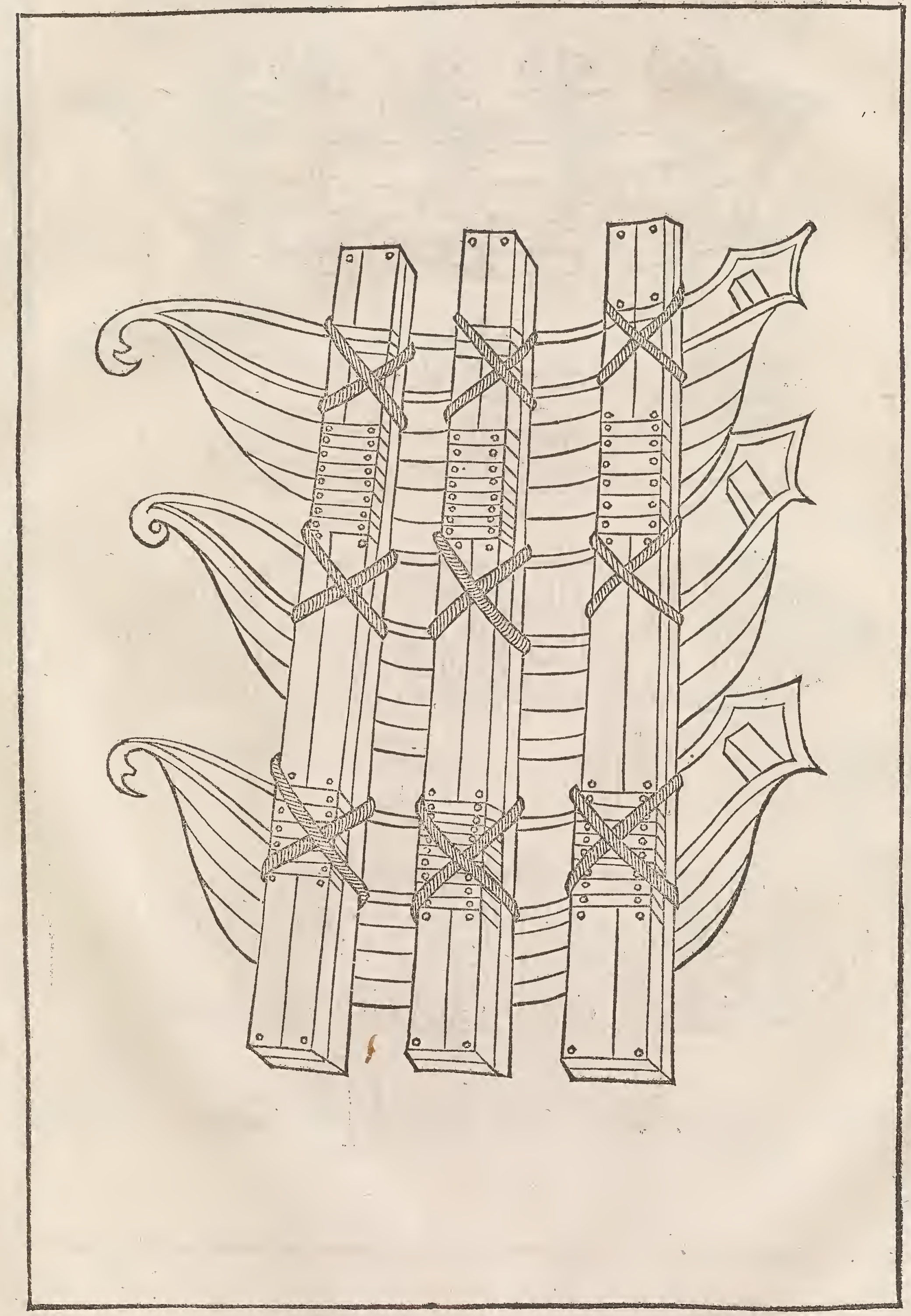


Sunt qui nates magnas in tris partes, trium cymbarum inftar difunctas, coniunctáfque deinde, ac tela lini cæra oblita tectas in hunc modum fine remis flumina traiiciant, maioríque celeritate vecti quàm fi duodecim remorum obfequio agerentur.

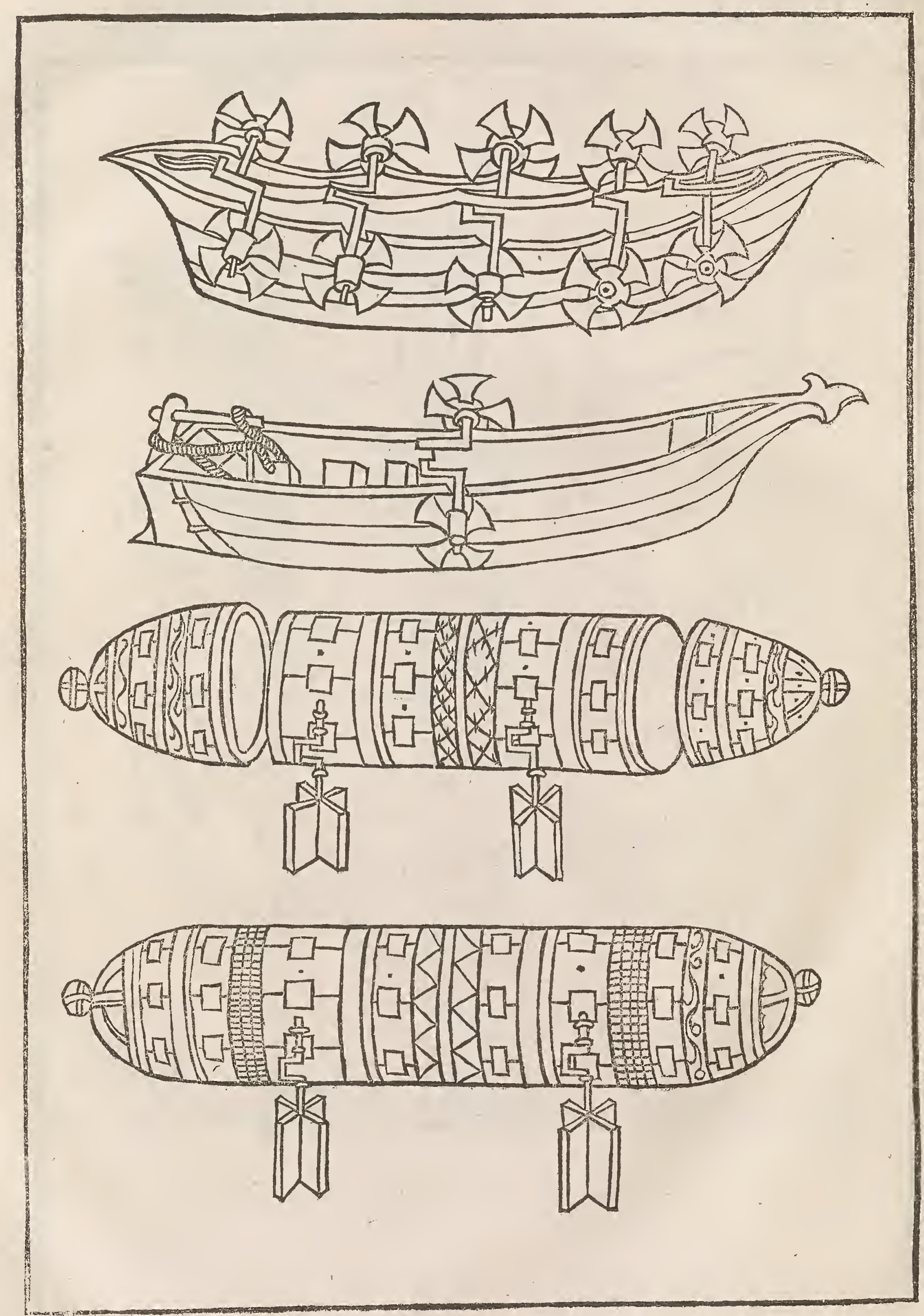




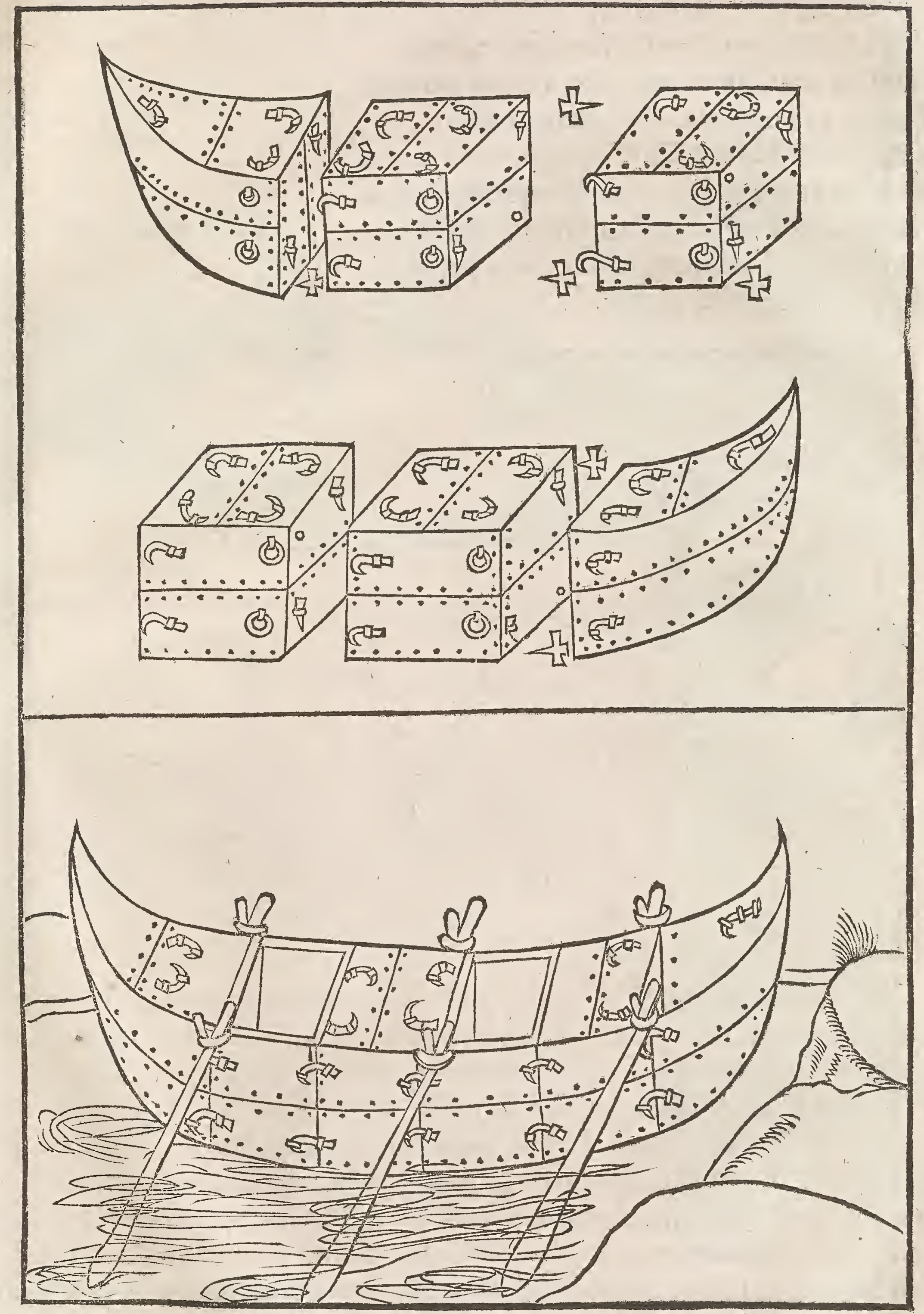

Da ii 
Nauiculas alii faligno vimine texunt bouisóg corio tegtnt, vt Cęar in tran. fitu Sicoris, Lucanus,

Vtóp habuit ripas Sicoris campófque reliquit,

Primum cana falix madefacto vimine paruam

Texitur in puppim cafos induta iuuencos

Vectoris patiens tumidum fuperemicat amnem.

Sic Venetus ftagnante Pado fulóque Britannus

Nauigat oceano, fic cum tenet omnia Nilus

Conferitur bibula memphitis cymba papyro.

His ratibus traiecta manus.

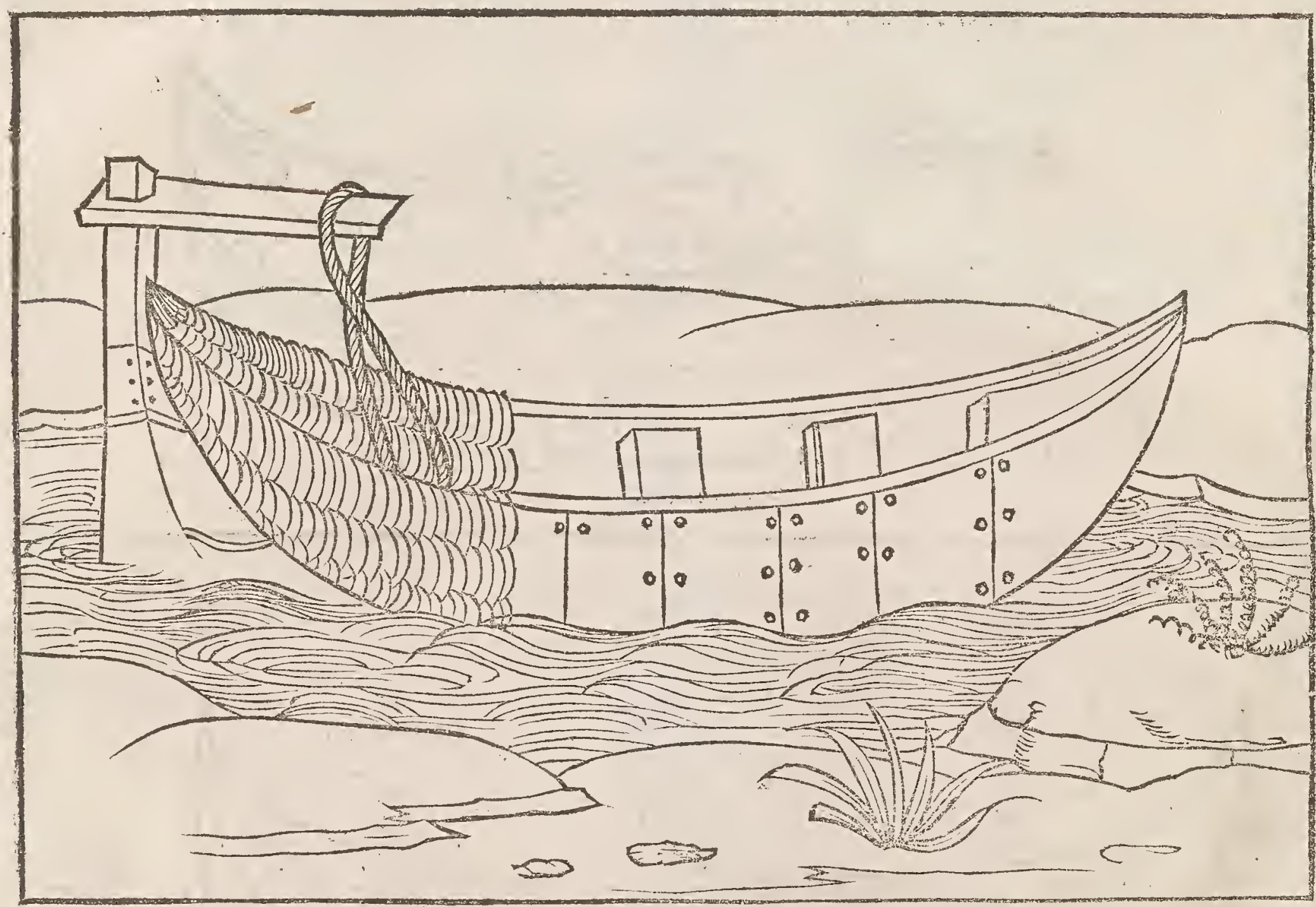

Vada etiam plerifg cafus attulit,vt Henrico imperatori,qui fluminibus glaciali rigore conftridis, terram Lucianorum ingreffus, cos nimia cæde proftrauit, $Q$ terram eorum depopulatus eft: verùm in cafu fimili plerique decepti funt, vt Perfeus Philippi filius,congeftis in vnum copiis, pradarú fpe folicitatis: tunc enim forte Danubius, qui \& Hifter, craffa glacie fuperftratus pedeftrem tranfitum facile patiebatur, cum toto $\&$ maximo fimul agmine inextimabilis hominum $\&$ equorum multitudo ad tranfitum conflueret,mole ponderis \& gradien tium concuffione concrepans glacialis crufta diffiliit, vniuerfumíg agmé quod die fuftinuerat, mediis gurgitibus victa tandem et comminuta deftituit, atq, eadem fragmentis prapedientibus fuperducta fubmerfit. Notãda in his parui ani malis folertia eft, obferuatum quippe vulpem locis rigentibus folerti auditu aurem ad glaciem apponere, \& coniectura craffitudinem gelu perpendere: quare non nifi ad eius acceffum reditúmque amnes frigore concretos lacúfque plerigh tranfeunt. Subera quidam quàm lata pectori fubnectunt,quidam dolia inania, inde leuitate vebiculi fifi in flumen defcendunt, faciliúque placidéque deducti, tutò aduerfan pertingunt ripam. 


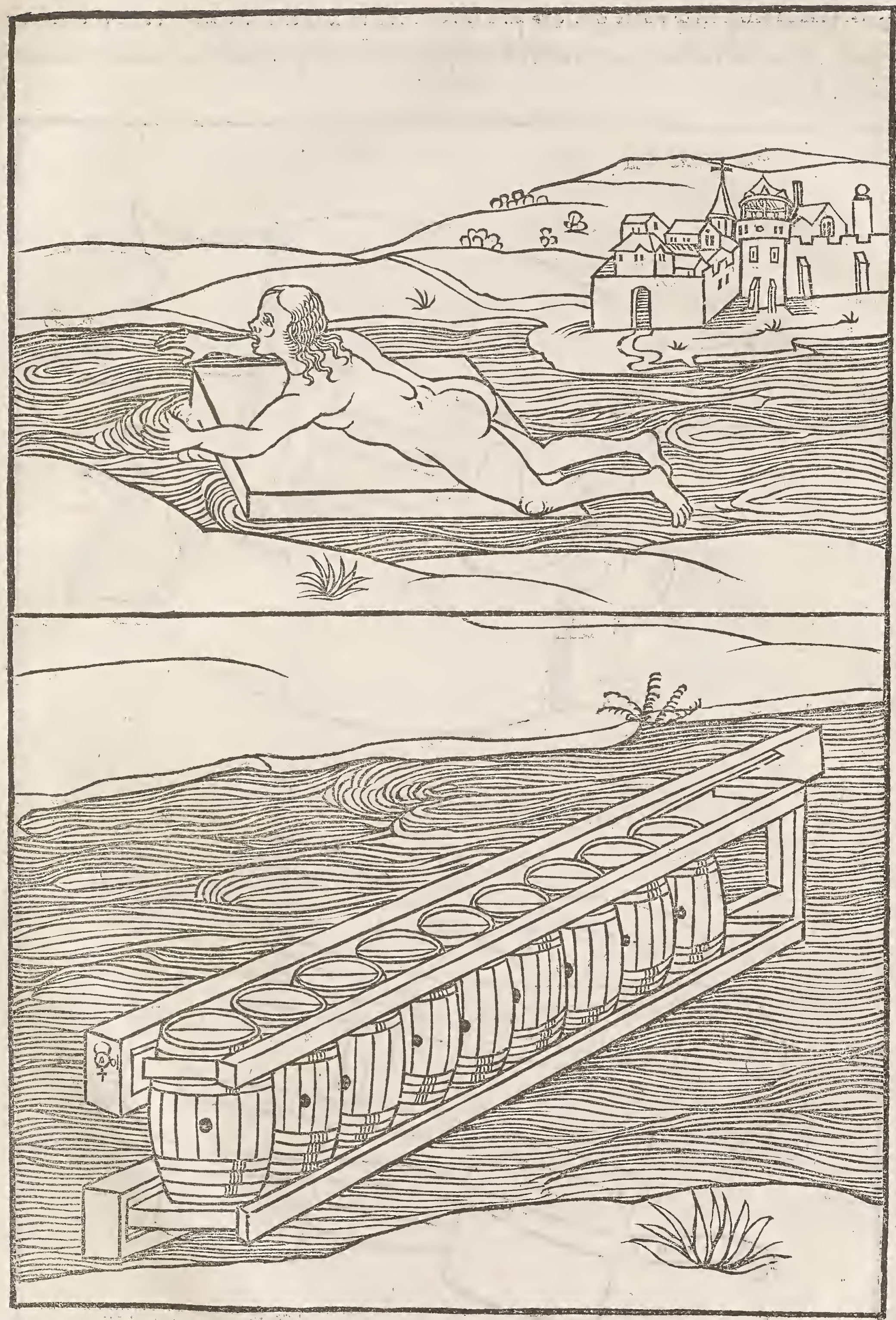

Dd iif 
Hifpani verò, Afchitz, A rabes bubulis vtribus contabulatas crates fuperimponunt, vectitatiog hoc ratis genere prætereuntes infeftant fagitt is venenatis, fine vlla mole in vtres veftimentis coniectis, ipfi cæteris fuperpolitis incubantes flumen tranfnatauere.

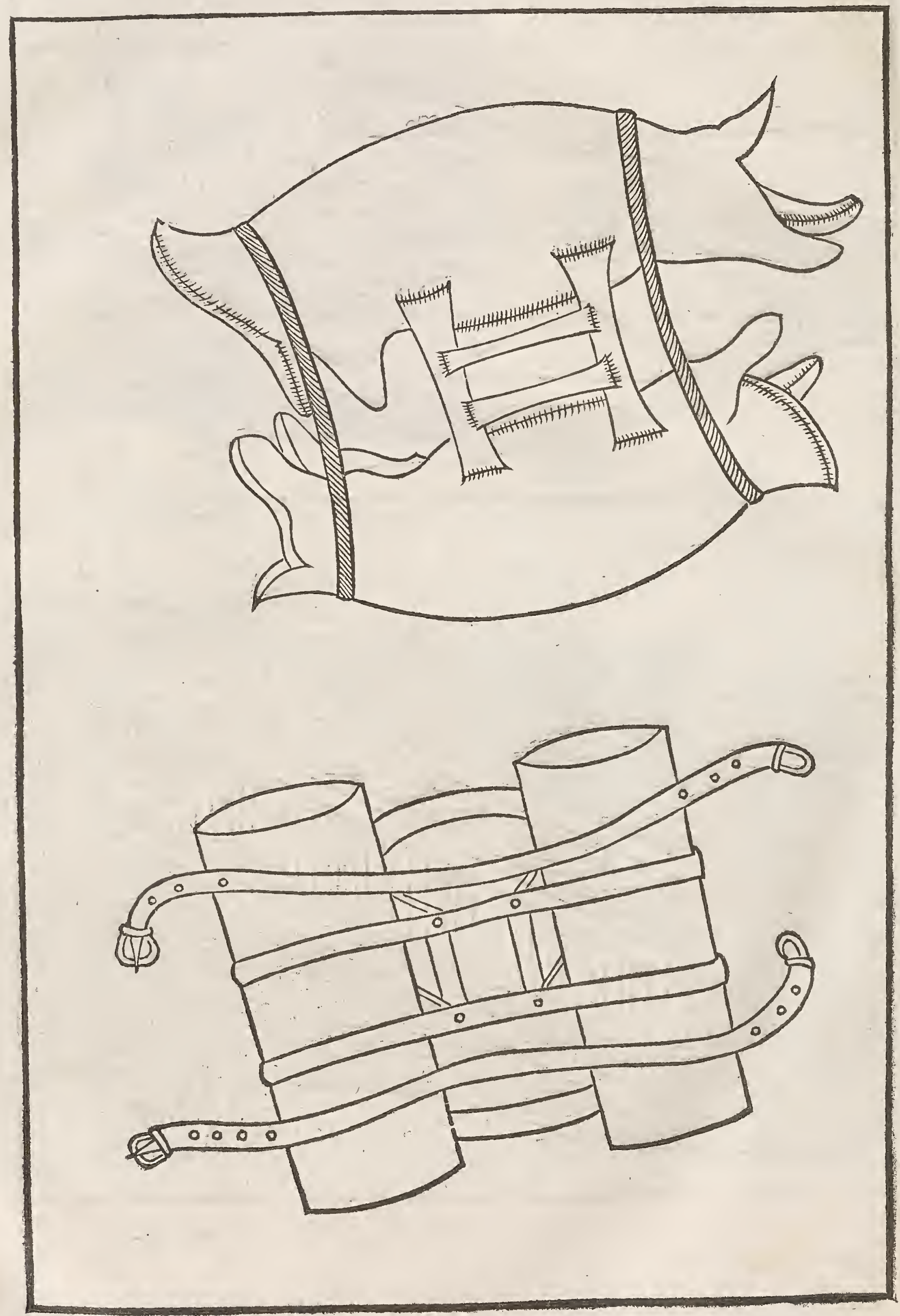


Nec aliter,fi Floro credimus, fiduciam oppidanis refiftendi nuncius quifpiam fecit,docens aduentare Lucullum, qui,horribile dictu,per medias hoftium naues vtre fufpen fus \& pedibus iter gubernans, videntibus procul quafi marina piftrix euaferat. Cæalar quoque, vt in cæteris, in hoc fimili modo multorum opinionem fuperauit: vtrem enim ex corio côfutili follis inftar inflatum traiiciendis a mnibus habuit,eoós vfus fertur, cruribus infidétis velut gubernaculis dimifo fis curfum dirigentis:quod fi quis hoc fictum aut commentitium de Cęare for te dictum putet,Suetonius Tranquillus, opulentiffimus auctor ac teftis eft, Si flu mina, inquit, morarentur, nando traiiciens, vel innixus inflatis vtribus,vt perfæpe nuncios de fe praueniret: atque hic nos quoga afferendi melius quod dicitur, quod'ģ ipfi vidimus gratia, minuemus laboré legentibus, fubiiciendo picturam.

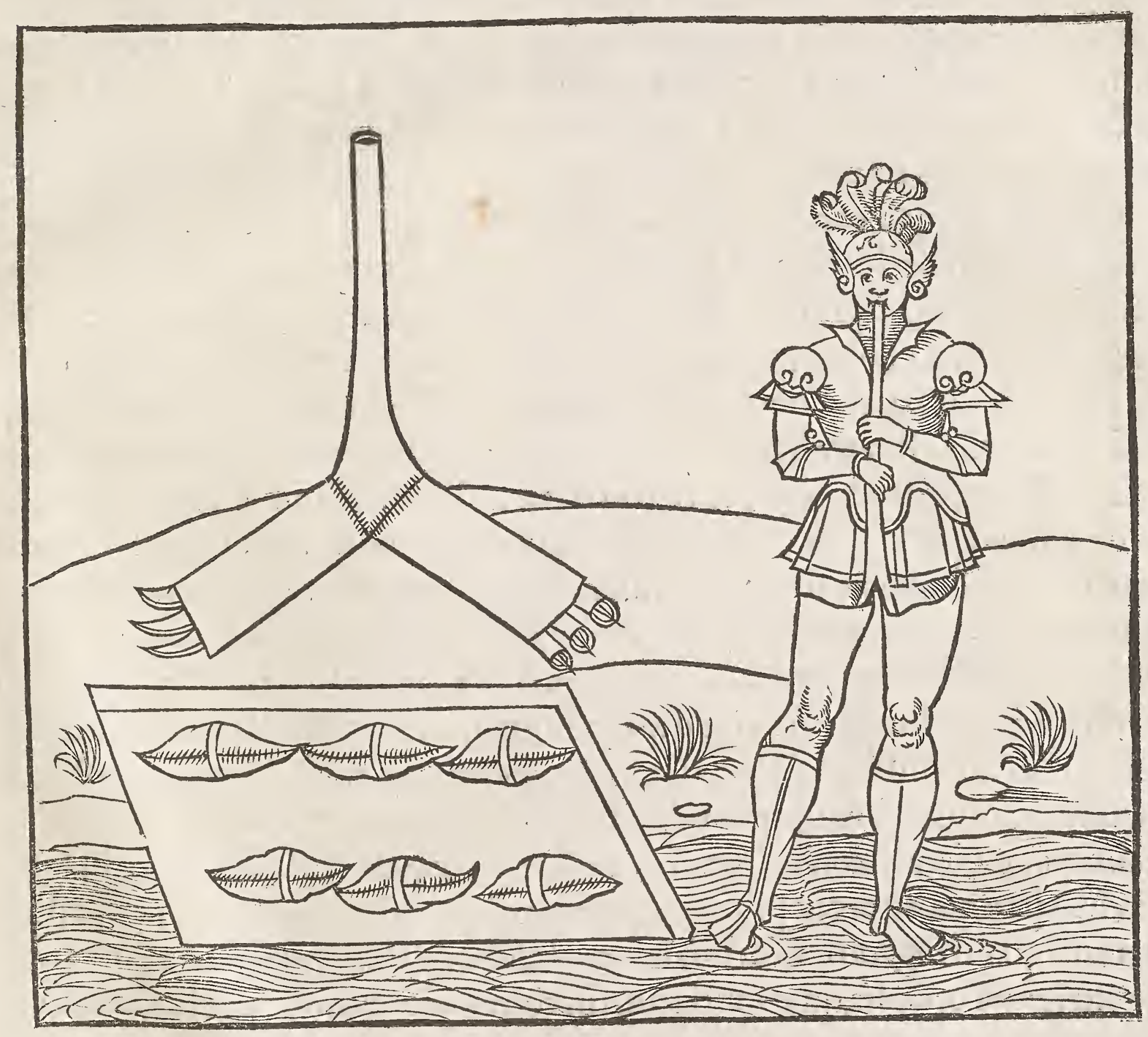


लक [lud quoque nec erit inutile, nec prælenti materix incongruu $\mathrm{m}$, vt aliquorum qui in re militari claruerunt copix, vel numero, vel auxi liorum multitudine comparentur: \& fi à facris quæ mentiri, \& nefci unt ac nequeunt, literis initiü aufpicari voluerimus, vbi fingulos dies regum omniú illum regem $\&$ principem deum $\&$ dominum exercituum belligerare fxpenumero, imò fi dicere fas eft, $\&$ ab religione noftra non abhorret, $\&$ furere aliquaádo, $\&$ defeuire legimus, inueniemus hebræe gentis numerofitaten intantú excreuiffe, vt in exitu eiufdem populi ex Aegypto fexcenta milia homi num fuiffe referantur bellicæ iuuentutis, vt omit tamus genté Idumęorũ ad populum I frahel minime pertinenté. Sub Iofue nu merü fuiffe armatorú fexcétatria milia \& mille feptingentos proditum eft. In expeditione autem A frana fub Moyfe numerus filiorü ifrahel per domos cognationú fuatú $\&$ turmas diuifi ex ercitus fexcentatria milia quingenti quinquaginta inuentus. Eft autem omnis numerus ifrael M. milia \& c.milia virorum educentiú gladiú. De luda a utem ccclxx.milia bellatorũ: nam Leui \& Beniamin non numerauerim eo $\phi_{1}$ inuiti exequerêtur regıs imperiū. Habuit etiam Afa in exercitu fuo portãtium fcuta $\&$ haftas, \& de luda ccc.milia. Hos autem contra egreffus eft Zizara Aethiops in exercitu fuo decies centena milia \& currus trecentos fecum afferens. Deniq fub iudicibus, fub regibus tot milia variis bellis, diuerfo calo, diuerfis deftructa temporibus inueniuntur,vt pene non tot natura in lucé edidiffet, quot bello ipfi confeciffe \& dicæarchi omniú de interitu hominú circúfcripto numero extinxiffe videantur. Præter hanc Hebræorum infinitam pene multitudinem fuere Sefoof Aegyptiorum regi pedeftres copiæ milia hominum fexcenta, equitum milia quatuor \& viginti, currus bello apti octo milia $\&$ viginti củ claffe haud parua. Nec eft quod quifög gentis huius miretur exercitus, quum olim numero hominum omnis fere orbis gentes Aegyptus fuperarit. Oppida enim infignia ciuitatesóp prifeis temporibus vltra decem $\&$ octo milia fuilfe in Aegypto,libri facri continent. Ptolomęi Lagi tempore amplius tria milia. Vniuerfi autem po puli numerum fuiffe antiquitus fepriesdecies centena milia Diodorus teft is eff. In Gange, infula eft magn̨̧amplitudinis genté continens, vnã nomine Modro ga linguam, circa quam fữ funt non nulli, cum oppido eiufdế nominis magnifico Modros, quorum rex peditum quinquaginta milia, equitum iiii.milia, Elephantos quadringentos in armis habet. Validior deinde gens Andare plurimis vicis, triginta oppidis, qux muris turribusóg muniuntur, regi præbet peđitú cen tum milia, equitü duo mslia, elephátos mille. Omnium in India propé,nó modo in hoc tractu potentiam claritatémó antecedunt Tarfé a mplifima vrbe ditiffimáq̧́ Balibotra, vnde quida m jpfan gentem Balibotros vocant, immo verò tractum vniuerfum à Gange. Hanc Tarfram gentem, validiflimam adeò fuiffe percelebre eft, vt gentis eius rex fexcenta milia peditum, equitum xxiii.elephan torum ix.omnibus diebus ad ftipendiú habuiffe memoretur. Incredibilia fimiliter tradunt Alexand ri Magni comites, in eo tractu Indiæ qué fibi fubegerant fcriplerunt viii,oppidorum Indiam, tertiam partem terrarum omnium, multi- 
tudinég populorum innumeram. Quantus autem Gotticus in Romanos fue rit exercitus.Claudio Quintilio Augufto renitente, eorumóp impetum retúden te, teftis eft corum turba qui perierunt, quum tot capti reges, tot diuerfarum gen. tium nobiles foemine, implete barbaris ferruis fenibuśg cultoribus romanx pro . uincia vt nulla fuerit regio qux gotticum feruum triuphali quodam feruitio non haberet. Huius etiam rei teftis \& index eft Claudii ipfius Quintili epifola ad Iunium Broccum Illyricum tuentem, in hunc modum confripta, Deleuimus cccxx milia Gottorü, duo milia nauiü merfimus, tecta funt flumina fcutis, fpathis 2 lanceolis omnia littora operiunt, cãpi offibus latent tecti, nullú iter pu. rü eft, ingens Carthago deferta, tantú múlierū cepimus vt binas \& ternas mulieres victor frbi miles polfit adiungere. Quid Cyrus?nóne, ve Xenophontis tradit hiftoria, exercitú omnê Babylonix coẻgit, in quo eqtum milia centú \& vigint ferútur cồuniffe, duo milia fal cati currus, peditú vero milia fexcêta? Ninus expe ditioné in Bactrianos moturus, ex fingulis gêtibus elecko ingëti exercitu aduerfus eos pfectus eft, traditóg Ethefias fcriptor in exercitu eius ad fepties decies cen tena milia peditú fuiffe, equitum milia ducéta, currus verö falcatos paulominus decé milibus et fexcêtis. Bactrianorú rege Zaorte,cöparato hominü cccc niliứ valido exercitu, $N$ ino in finibus occurrete, Semy ramis Nini huius Affyriorum regis vxor gloriæ cupiditate flagrans, vt Diodorus non contemnendus auctor tradit, cum tredecies centenis milibus peditum, quingétis milibus equitum, cen tum milibus curruum in Indiam traiecit, Indóg illius regionis nobili flumine duarum milium nauium ponte conftructo, qui militum numerus incredibilis nunc fit forfan audiétibus, fed haudquaquam in poffibile videtur, Affe magnitudinem multitudinêm in ea nationum animo aduertenti. Nam fí quis Darii aduerfus Scythas expeditionem, fi quis item Xerxis in Gręciam tranfitú, fi quae in Europa pauloante res getta confideret, minime dictis noftris abrogauerit fidem. Nam ex vnica Siciliæ ciuitatum Syracufs Dionyfrus præter naues magnas, partim triremes, partim quinqueremes ad quadringentas, exercitum peditum cêtum viginti, equitum duodecim milium confecit. Traditur Anazonum reginam nomine Mirinam exercitum triginta miliú peditum, dứmgue milium equirum confeciffe. Xerxes quum \& mari $\&$ terra bellum vniuerf $x$ inferre vellet Europx,cum tantis copiis accinctus peruenit in Graciam, quantas nec antea nec poltea quifpiam alter habuiffe nemoratur. Nam vtclaffem cius prateream de qua nobis paulopoft differendum eft, terreftrem eius exercitum, fi Probo Aemilio credimus, ducentorum milium peditum, equitú quadringentorum fuiffe conftat: fi luftino \& Orofio, feptingentorum milium \& Perfarum quiden, auxiliorum verò ccc.milia: fi Herodoto, pedeftrem eius exercitum centum et feptuaginta myriadum, equitum octo: eorum verò qui camelos et currus ducerent,duarum:ad hæc feptem milia fexcentos $\&$ decem, fine impedimentis feruorum, piftorumg turba $\&$ aliorum quorum affertio tanta eft vt haud fanx mentis cuipiam iure videri debeat. Artaxerxes autem egit in pralium, vt Ethe fras tradit cccc milia hominum. Dion \& Xenophon eos qui dimicarunt longe plures fuiffe teftes funt: neque hoc cuipiam fupra fidem videri debet, quum rex 
adeò magnus eflet diuina narrante hiftoria, vt ab Indià vfque Aethiopi : am c xivii . prouinciarum ducibus ac principibus qui fux obedirent iuffioni praeffet, fcribénfque falutem diceret. Antophrodates ab Artaxerxe in $\mathrm{Ca}$ padociam miffus aduerfus $D$ athanem habebat barbarorum equitum viginti milia, peditum centum milia, eiufdémque generis tria milia, funditorum præterea Capadocum ccto, A rmenorum decem, Paphlagonum quino, Phrygum decem, Lydorum quinque, A fpendiorum \& Pifidarum circiter tria milia, Cilicum duo, leuisarmaturæ maximum numerum. Philippus Alexandri pater delectu militum in fubfidium regiæ difpoftionis ex tota Gracia habito, cc milia peditum, equitum $x v$. milia confecit, in $A$ fram expeditionem miffurus, abfop exercitu Macedonico, \& infinita gétium Barbarie. Copiarum numerum Alexandri qui minimum afferunt xlviii milia peditum ac equitum quinque fuifle tradunt: qui verò plurimum, peditum xlviii.milia, equitum quatuor \& quinque ex titiffe fcribunt. Dario campis alpeftris contra Alexandrum prima congreffione in acie Perfarum fexcenta milia fuere militum, quæ non minus atte Alexandri,quàm virtute Macedonum fuperata,terga verterunt: in fecûda verò congref frone cum ccc. milibus peditum $\&$ cétum milibus equitum proceffit in aciem: tertia veró congreffione bellum reparatum, \& cum cccc. mulibus peditum $\&$ c. milibus equitum obuiam rediit Alexand ro. Si quis denuó Darii aduerfus Scy. thas expeditionem mente reuoluerit, cum octingentis enm militum milibus fuiffe cöfirmet neceffe eft. Hannibali copiæ quantę fuerint $\mathrm{P}$ yrenæos mötes tranf greffo in I taliam traiicienti, haudquaquá inter auctores couenit,illis tamen qui exercitum eius in centum milibus peditum, equitum uerò $x x$.milibus fuiffe affe runt, affentiendum magis putem, quum poftea quàm $R$ hodanum tranfgreffus eft in xxxvi.milibus hominum ingentíque equorum, elephantorum \& aliorum iumétorum numero exercitus eius imminutus eft. Gallorum copix quum eos præ multitudine abundante non caperent terre quas tenuerät,ccc. milia ho minum ad̉ nouas fedes occupãdas miferunt, horúm q cum portio altera in Pannonia confediffet, vrbem loniam captam incëdit. Altera I taliâ eft ingreffa. Romanorum qui in ea re plurimum valuerunt hæ fuerunt ab initio copia. Anno enim ab vrbe condita ccc lxxxiii. quú Gallorum inundatio ad quartum ab vr be lapidem confediffet, fociis Romanorum in Latinis, qui à Romanis fubiugati erant, m!lites preftare volentibus delectu habito, ex Romanis tantum tyro. nibus decem legiones confecta funt. Anno verò cccclxx. quum iam clarum no men vrbis effet, quia arma tum extra Italiam mota nō fuerät, vt cognofcerentur qux copix Romanorum effent,cenfus eft habitus, inuentáque funt tunc civium capita ducéta xcvii milia \& cccxxxiiii, quanquá à condita vrbe nulla bella ceffaffent. Anno quoque dxvii cum cifalpinæ Gallix, vel etiam ex vlteriore Gallia ingens numerus aduentare nunciaretur, permoti confules ad præfidium imperii contraxere vires, quo facto in vtriufque confulis exercitu octingéta milia armatorum fuiffe referuntur, ficut Fabius hiftoricus qui bello interfuit fcripfit: ex quibus Romanorum fuerunt peditum cccxlviii milia, \& equitum xxvii milia fexcenta, cxtera multitudo fociorum fuit. Nunciato gallico etia tumultu. L. Ae milio 
milio Paulo,C. Attilio Regulo coff. folam Italiam etiấ fine tranfpadanis \& externis auxiliis arnjauiffe equitum triginta milia, peditum feptingenta in naturali hiftoria Plinius teftis eft.Hac incredibilis apparatus magnitudine,licet $\mathrm{Gal}$ lorü potêtiam exiftimare . Romani pauloante Hannibalis tempora futuri belli praxuidentes magnitudinem, céfu in Italia tum ciuium, tum fociorum qui bello apti effent habito, Diodoro tefte, decies cëntena ferme milia hominum defcripere. Quantz autem Ronnanorum copiz fuerunt, quando maiores adeò nume to $\&$ genere variant auctores, vt vix quicquam fatis certum affirmari queat? $\mathrm{Se}-$ ptem $\&$ octoginta milia armatorũ $\&$ ducétos fuiffe in caftrịs Romanis, quú pu gnatum ad Cannas eft, quidam auctores funt. In hoc haudquaquã difconuenit maiore conatu atog impetu rem tum actam quàm prioribus annis, quia fpem poffe vinci hoftem Dictator prabuerat. Numerum verò omnium qui tum peditể equitũóg in Hannibalis acie ad Cannas fteterunt xl M.peditum,decé milia equitum fuiffe ferunt.Qų auté poftea Romanorú copig Philippicis in campis, vltimo $C$ æaris \& Pompeii conflictu fuerint, inter cos quos legiffe memini me, qui hunc numerum dicant, rémq hanc elegantiffima grauitate perftringant, Plutarchus \& Anneus Florus longe variant maximé́g diffentiunt. Qui cư illo itagg in fententiam eunt,duo \& viginti milia militum cum Cærare, cum Pompeio non multo plures quàm bis totidé fuiffe afferunt: qui verò củ hoc, trecenta. Q eo amplius milia bellatorum hinc inde prater auxilia regum, vade immenfum quiddam lector poffit mente concipere, affuife memorant : frenim hoc, auctores, belli duces infpicias,totus fenatus in partibus: fr exercitus, hinc xi legiones, inde duodeuiginti, flos omnis \& robur italici fanguinis: fi auxilia fociorum, hinc gallici germanicíg delectus, inde Deiotarus, Ariobarzanes, Tarcon dimocus, Corinthus omnis, Thracix, Capadocix, Cilicix, Macedonix, Grxcix, Aetholix'́, totiúfque robur orientis deniqg coiere : nec vnquam tam varixe cultu gentes, tam diffona vulgi ora, tot immenfæ comites mifura ruinæ, vt $\mathrm{Lu}$ canus inquit,vtóg idem Florus: nec vilo vnquã loco tantú viriü Po. Ro.tantứqg dignitatis fortuna vidit.Poft hos, quatuor et quadraginta legiones fub vno Au gufti cælaris imperio numeratæ funt, quas ad imperii columë tutaméǵ per di uerfas orbis partes fumma cú dignitate diftribuit . Duo demũ quę nố paruam legentibus ingerết admirationê, de Romanis libet attingere. Siquidê anno vi. Claudii Tyberii principis defcriptione Romæ facta, inuenta effe ciuiü Romanorum fexagies nouies cêtena quadraginta quatuor milia, cuius tei quia fidem excedit, teftis clariffimus adeft Eufebius $\mathrm{C}$ ffarienfis, in libro de têporibus, quũ. iam antè fub Augufto, anno eius quarto \& quinquagefimo inuenta effent nonagies trecenta \& feptuaginta milia. Horum viribus ac confliorum grauitate Romanorum virtus inuicta per totum olim terrarum orbem habita eft. Eo verò in bello quod cum Romanis geffere Indęi fexcenta milia Iudg̨orum interfecta Cornelius \& Suetonius referunt. Egefippus illorum temporum vicinus libro quinto decies centena milia ab obfidionis illius principio ad finem vfque interempta $\&$ in captuitatem ducta nonagintafeptem milia dicit. Cęterum Io fephus Iudæus qui ei tunc bello prafuit, fcribit vadecies centena milia gladio 
\& fame periffle, reliquias verò ludæorum diuerfis actas conditionibus toto orbe difperfas, quarum numerus ad viginti milia hominum fuiffe narratur. Et hæc de terreftris militiæ copiis in præfentia dicta iam fint. M. autem Aemilio, Seruio Euluio Nobiliore coff. iam clarum Romę nomé quum videretur, $Q$. etiam Luctatio Catulo præfecto, primo bello punico trecentarum nauium claffem Romanorum aduerfus A phros Aphrorǘǵ aduerfus Romanos apud Hegates infulas inter Siciliam \& Aphricam Hamilcare dace fexcentarum fuiffe conftat. Gręcorum verò regis aduerfus Troianos claffem mille quadringentarum nauium, $\&$ eo ad huc a mplius cum multis $\&$ nobilibus earum prefectis, Ilia dos lib.ii. Homero tefte fuiffe comperio . Xerxem Perfarum deinde regem non horum modo, fed aliorum omnium numerum, hac in re difputent licet auctores, facile fuperaffe haudquağ obfcurü eft. Nauium enim eius claffem Perficam Herodotus auctor ef trium milium fuiffe, in hiśq hominum quatuor $\&$ vigin ti myriades, hoc eft, ducenta quadraginta hominum milia : huic claffi codem etiam auctore additx funt ex Thracia naues cxx , hominú xxiiii milia continentes. Aemilius Probus lögarum nauium mille \& ducentarum, quas onerariarum duo milia lequebantur. Orofus roftratarum mille ducentarum,onerariarum autem trium milium. Iufinus poftremo nauium tantú apud eum aftruit; nam decies centena milia numerus eft, vt non ab re aliud dici queat etiam de pe deftri,quàm quod his verbis Satyricus inquit,

Creditur olim

Velificatus Athos \& quicquid Græcia mendax

Audet in hiftoria, conftratum claffibus iifdem

Suppofitumque rotis folidum mare credimus altos

Defeciffe amnes epotáque flumina Medo

Prandente, \& madidis cantat qua Softratus alis.

Darius autem cum ex Europa in A fram rediiffet, hortantibus amicis vt Gręciam redigeret in fuam poteftatem, claffem quingentarum nauium comparauit, éque Darim præfecit \& Arthaphernem, hifque ducenta peditum, decem milia equitum dedit. Alexander verò cxcii nauium claffe, quam trium milium alii fuifle perhibent, Afiam petiit . Cæar octingentarum Britanniam . Heraclianus Aphrice comes quofque priores prater Xerxë clariflimos in ea re vel ६quauit vel exceflit: nam nauium trium milium feptingentarum habuiffe fertur nu merum, qui a pud paucos \& nobilifimos ac potentiffimos quidem vix eft inuen tus : cunque is fimul ac cum agmine militum ab vrbem pergens littore egreffus eft, occurfu comitis Marini territus, \& in fugam verfus,arrepta naui folus $C a r$ thagine rediit, atque ibi continuò militari manu interfectus eft. Sic itaq̧ ingens tức numerus timori iam effe coepit: vnde \& Scipio Carthagine victa quum res A phrica difponeret, prohibuit ne plus quàm decem naues earum quæ belli vfibus forent pacto traditas haberent, reliquas omnis generis quæ remis agerentur, quingentas numero fuiffe quidam fcribunt, in aliquantum maris fpacium prouectas, in confpectu Carthaginis iuflit incendi : támque lugubre earum fuiffe incendium, quàm $\mathrm{f}$ Carthago ip fa conflagrare videretur. Q.T. Flaminius 
quoque quum aduerfus Philippum regem Macedonum pugnaflet, his ei condis tionibus pacem dedit,vt quinquaginta folum relictis naubus, reliquas Romanis traderet. Q.denique Fabius I abeo, cum à rege Antiocho quem bello fuperaues rat ex foedere dimidiam partem nauium accepturus, dimidiam relicturus effet, medias omnes fecuit, vt quod tutius erat tota eum claffe priuaret.

Ex relatu terra mari res clarißime militum get tex,

Cap. XIIIt.

Eferenda funt etian tam terra quàm mari ex virtute praclara mili1 . Lum gefta:non enim hactenus fortuna duces extollëdo profecuta eft, 1. 1) vt ocio 2 ignauia foluti rebelles hoftium animos domuerint, quos 1 non minor plerüque 1 m manitas $\&$ pertinacia oppofuit victoréfógecit. In acie enim quũ dux hoftú ex media Barbarie, trux, ferus, immanis 2 hor rendus contra Romanos, Qui eftis vos aliquando inclamaffet, refpófum eft inui cem, Romani gétiu m domini: 2 ille, lta fiet, inqt, fi vos viceritis, acceptó́p belli omine Marcus Craflus Barbarosadortus, graui tandem cóflictu corum res fublimes pugnando depofuit, nec minimunn vnà terroris barbaris incuflit Chonidius Centurio, fatis barbaræ, efficacistamen apud pares homines ftoliditatis, qui forulum gerens fuper cafidem, \& fufcitatam motu corporis flamman hoftes cædendo velut ardenti capite fundebat. Pyrrhus quum $R$ omanos acie vicif fet, $\&$ eorum omnium vul sera in pectore conlpexiffet, omnium in manibus enfes, $\&$ relictas in vultibus minas, $\&$ in ipfa morte ira, vt ita dixerin, viuentes, tuliffe manus ad cælum dicitur hac voce, $\mathrm{O}$ quàm facile erat orbis imperium occupare, aut mibi romanis militibus, aut me rege romanis: quapropter quum in templo Tarentini louis titulum affixiffet, hæc fcripfit, Qui antehac inuici fuere pater optime Olympi, hos ego in pugna vici, victusóg fun ab eifdem, \& quưm à fociis \& a micis increpitaretur, cur fe victum diceret, cum viciflet, refpödiffe fertur, Ego fi iterum fimili modo vicero, folus $\&<$ fine nilite Epirum reuertar. Mirum et illud contra Hannibalem in Cannenfr pugna, è romanis nanq̧ miles ita faucius vt manibus non valeret, quum ei Numida quidam humi detrahere fpo lia vellet, ceruicem hoftis vinis deprehendit, tenuitog tam diu donec nares atque aures morfu detruncaret. Claris memoriz monumetis celebratur Eleazar: nam quum fupereminentem cæteris elephantum lorica veftitum regia aduerteret,ar bitratus in ea beftia regé effe, curfú cócito in mediả legioné le proripit, \& abie cto clypeo vtraq̧ manu hoftes cædens eam fubintrauit, fubiectóg gladio interemit,à beftiág cadente opprimitur: hac ruina inclufus magífque oppreffus, fuo eft fepultus trüpho. Tanto virtutis fpectaculo defixi hoftes, inermem occupatum inculate non auf, poft cafum ruentis beftix fic trepidauere vt impares fe vnius virtuti arbitrarentur: denique rex Antiochus Lyfix filius, cum cxx mili bus hominum armatorum \& xxxii.elephátis vnius territus fortitudine,pacem popofcit: Itáq̧ Eleazar bæredem virtut is fue pacem reliquit, æternum'q́ nomen adeptus eft. Hannibal quum Romanorum captiuos dimicare inter fe cöegilfet, vnúmque quiforte fuperfuerat obieciffet elephanto, ille dimitti pactus finteremiffet, folus romanus acri ingenio elephantum aggreflus magno $P_{c e}$ 
norum dolore confecit: Hannibálque quum famam eius dimicationis contem: pum allaturam intelligeret, equites mifit qui abeuntem trucidarent. Et quanquam exploratum \& perfpectum habeam,tefte Liuio, milites omnium qui $A f_{1 *}$ am colunt gentium Gallos fama belli preftare, cognouerim's auctore Crifpo, paruis copiis bella gefta cum opulentis regibus, ad bxc fxpe fortunæ violétiam toleraffe, facüdia Græcos, gloria belli Gallos ante Romanos fuifle,plures tamen propè de Gallis,vt diximus, etiam apud nos triumphi quàm de toto orbe terrarum habiti funt: nec legionibus legiones eorú folum experti, fed viri vnius cum viro fortitudinem atque præftantiam. Nam M.Manlius vnus agmine fcandenres in capitolium Gallos deiecit, annorū fexdecim voluntariú fe militē obtulit, xxxvii mulitaribus donis à fuis ducibus ornatus, xxiiii cicatrices habuit. M.autem Valerius, Tituṣ̨́ Manlius quâtum gallicam rabiem vinceret romana virtus, documenta funt. Ille enim ducem Gallorū vafta \& ardua proceritate inaniter $\&$ arroganter telum manu reciprocãtem, pérque contenjptum $\&$ fuperbiam confpicientem onnia ac prouocátem congredi fiquis pugnare fecum ex omni romano exercitu auderet, fingulari certamine congreffus occidit: hic vero fimili modo Gallum quendam nudum præter fcutum \& gladios duos, torque, atg armillis decoratum, qui \& viribus, \& magnitudine, \& adolefcétia fimuliq̧ virtute cæteris anteftabat,cum voce maxima concla maret, frquis fecum depugnare vel let vt prodiret,quumóp nemo auderet propter magnitudinem $\&$ immanitaté ho minis faciémos,tum irridere coepiffet \& hiulco linguam ore in Romanos exerere,T.Manlius fummo genere natus, tantú flagitium ciuitati fuæ accidere, vt e̊ tanto exercitu nemo prodiret, indignabundus in medium proceflit, neque paffus eft virtutis romanx per Gallum gloriả ad fuos tranfferri,eápg tranfgreflione vtroque exercitu infpectante Manlius animo magis quàm arte cófifus, afperum \& immite certamen tam diu cum Gallo fubiit quàmdiu Gallum euertit, caput decídit, torquem detraxit. Huius poitea filius bello aduerfus Latinos hofté à quo fimiliter prouocatus fuerat occidit. Q.etiá Coccii militis romani,qui ob infigné bellicæ virtutis gloriam Achillis cognomentú fibi a ciuit, nec fubticéda duplex animi corporíque prættantia: nam quum a pud Celtiberos gentem pugnaciffimam à duobus ad dimicandum prouocaretur, alterum \& equitem quidem pugnæ accinctum, excurfantem, luftrantemóp omnia, a c infolentiffimè procaciffiméque futuri victoris inftar iritantem adortus occidit,armáqg detraxit: alterum generis claritate $\&$ fortitudine omnibus. Celtiberis facile pracellentem cedere fibi non folum compulit, fed enfem illi fuum $\&$ induuias fpectantibus vtring legionibus tradere. In Cafaris etiam congreflibus infignis virtus emicuit Volcacii Tullii,qui cũ tribus cohortibus legioné Pompeianã perculit repulitọ. V na quoq Cæfaris cohors caftello præpofita quatuor Pompeii legiones quũ diu fuftinuiffet,tãtus fuit in ea fagittarú imber, vt fine vulnere defenforú nullus euade ret, quin et cëturiones quatuor,oculis capti effent, vt quü ferò diurni laboris ac pe riculi fummâ imperatoris nó tam auribus q̄ ocul is fubiicere ac reprefentare decreuiffent, centû ac xxx fagittarủ milia inter vallú inuenta numerarêt. Fuerunt $\$$ in legione Ciceronis qui legatus quog Céfaris erat duo senturiones qui per- 
petuas inter fe controuerfias habebant, vter vtri præferretur : horum alter $\mathrm{Pul}$ fius, Varrenus alter dicebatur: accidit ve caftra oppugnarentutur, tum verò $P$ uhfius, Quid dubitas, inquit, ò Varrene, hac dies de noftris cótrouerfis iudicabit: hæc dicens procedit extra munitiones vbi holtes confertiffimi erant, fnbfequitur Varrenus mediocri fpacio relictus, Pulfius pilo hoftem exanimans impet i. tur ab omnibus tranffixus fcutum $\&$ baltheum, gladiü educere non potuit, fuc currit inimicus ille Varrenus protegitóg ab holtibus, in quem quü fe hoftes con uertiffent, ipfe vno interfecto in locum iniquum decidit, cui circunuéto fuccurrit Pulfus, atque ambo copluribus interfect is incolumes fe in caftra recipiunt. Fuit eidem Cæfari Scæua miles fortiffimus qui pugna ad Dyrrhachium commiffa vulnera accepit ca pite, humero, \& foemore, excuffóṕp oculo traiectus, \& fru to cxx telorum ictibus perforato, hoftes pinde ac fe dediturus effet accibat, fubeuntibusqu duobus, alterius humerum enfe cecídit, alterum ore percuffum verti in fugam. De hoc quidem varia eft fama: Quidam tradunt Cafarem viri $\&$ de fe $\&$ de repub. vt aiunt, ita meriti, eximia virtute permotum, qua commiffi caftelli portæ cuftodia prope fola feruata effet, pecuniaris eum donis ingentibus, \& magnis honoribus cumulaffe apud alios. Scequa idem duce abfente ceden tibus'́g comitibus, contra omnem Pompeii exercitum ftetit, $\&$ clypeo c xx telorum ictibus tranffixo, miris \& incredibilibus rebus geftis, \& commiffi loci cuftodiam relinquens, fuorum receptus amplexibus relatus occubuit, iacens quogs victoribus terribilis ac ftupendus, qui tot eximias pugnas in Gallia Britanniaque fecerat, cötra holtes femper inuictus, et à fuis tandem ciuibus interfectus eft. L.Siccius Dentatús tribunus plebis centies vicies praliatus, ocijes ex prouocatione vtroque exercitu infpectante victor, quadraginta quinque aduer las habuit cicatrices, in tergo nulla notam, fpoliis ex hofte tricies \& quater ceptis, quatuordecim ciuibus ex media,vt aiunt, morte raptis a tque feruatis: nouem quin etiam imperatores qui opera eius vicerant profecutus, haftis puris, faleris, torquibus, $\mathrm{ci}$ uicis coronis, aureis, muralibus, obfidionali vna, armillis ato $p$ haretris plurim is donatus infignis emicuit. M. Sergius poft hunc duobus ftipendiis primo aduer focorpore ter \& vicies vulneratus, fecundo dextram manum perdidit: guare po ftea Iibi manum ferream fecit, $\&$ cum neutra pene manu idonea ad pręliâdum valeret, vna die quater pugnauit $\&$ vicit, finiftra duobus equis co infidente confollis, éque religata pręliatus Cremonam obfidione exemit, Placentia mọ́ tutatus duodena holtium caltra in Gallia cepit, bis ab Hannibale captus, bis à vinculorum eius nexu profugit, cum $x x$ menfibus quibus captiuitatis fortem pèrferebat, nullo momento fine compedibus fuerit $\&$ cathenis, omnibus afperrimis præliis, qua tempeftate illa $\mathrm{R}$ omani experti funt infignitus donis militaribus, à Trafimeno, Trebia, Ticinóque coronas ciuicas retulit . Cannenfi quoque præxlio de quo refugiffe eximium opus virtut is fuit, folus accepit coronam. Flaminio confule, quum eum Hannibal circuniacentium locorum vaftatione in bellum excitaffet, tantus vtrinque pugnandi ardor extitit vt grauifimum terræmotum qui tunc forte tam vehemens factus eft vt vrbes diruiffet, montes tranftuliffet, difcidiffet rupes, flumina retrorfum egiffet, pugnantes omnino non Ee ii fenferint. 
fenferint. Anftomenem Mefenum cccc Lacedæmoniorum occidiffe proditum elt,captum per cauernas latrinarum euafiffe, anguftias vulpium aditu fecutum: iterum captú, fopitis cuftodibus ad ignem aduolutum cum loro corpore excuffif fe: tertio captum Lacedæmonios pectus diffecuifle, hirfutumíg cor ei repertum. In Britannia dum commilitones Cæfaris in paluftrem quendam locú $\&$ aquofum incidiffent irriflfentque in eum innumeræ hoftium copięac prælium fpectante Cafare fieret, quidam miles eius, nomine Scauola, in medios irrupit,plurima ftrenux fortitudinis opera edens: folus enim immobili gradu perfiftés,mif fa vndique in eum teloru infinita multitudine, quinq militü vnius diei pugnæ fuffecura tela manu fua holtibus adegit, trictoóp gladio fortiffimos quof o ho fium cateruatim affuentium incredibili dimicatione propulfans, tandem tragula $\&$ faxo ictus, verfis in fugam hoftibus commilitones reduxit incolumes, ip fe verò egre cunctos euadens, in limofam fe prorupit paludem, quam nunc natando, nunc pedibus commeando,vix randé duabus loricis onuftus amiffo tra iecit fcuto. Admirãte deinde Cęfare \& magno cú gaud io \& clamore obuiü excipiente, mœftus ille ante pedes Cæraris prócidit, amiffị́ veniã fcuti obfecrans, centurionatus honore donatus eft. Cynegiri, A thenienfis militis glorra, magnis fcriptorú laudibus inclaruit: præter enim ingêtes præliorum cædes quum fugientes holtes ad naues egiffer, onuftá nauem dextra manu tenuit, nec prius dımi fit quàm manum amitteret: tunc quog amputata dextra, nauem cú finiftra cóprebédit, quam \& ipfam quum amififfet ad pofremum morfu nauem detinuit, tantä́p. denique in eo virtutem fuiffe tradunt, vt non tot cædibus fatigatus, non ambabus manibus amiflis victus, quin truncis etiam ad poftremum \& détibus velut rabida quxdam fera dimicauerit. Simili pertinacia in confectandis hoftibus Attilius vfus fertur, non Maffilienfum, vt Lucanus inquit, fed Cæraris miles,quemadmodum reliqui \& quidem non incelebres auctores tradunt . Nauali náq̧̧ apd' Maffiliã certamine quú hoftilem in puppim dextrá inieciffet,illa gladio amputataMaffilienfum, nauim nihilomimus ingreffus læua tam diu retinuit, quoufque holtes atroci vultu obterrens proftratis omnibus nauim victor occupauit,occupatamóp profundo immerfit,equauítque Cynegiri façum,quod loquacifima Gracia laudibus in calum vque fublatum eft.

Emulatio gloric o ducum comparatio atque preftantia.

cap. $\quad x v$. (1) $\checkmark$ ne vt gloriæ auidis pręmiffis ad fummámque rerum afpirantibus honos red datur, qui nobiliores duces quíq incly ta fuis facultatibus gefferint fubnectemus. Verum quoniam in huiufmodi rerum fumma fpectari difcutió maxime folent, rei militaris peritia,virtus, ingenia, mores, vires, \& fortuna, potifimum in his fuperioris ætatis exterarum noAtrarúmque gentium duces $\&$ reges aliquot prima fronte mutua inter fe viden tur comparatione quàm fimiles extitiffe. Sic enim maiorum fententia freti,non fumus nefcii folitum Romulo Thefeum comparari, Camillum Bruto, Brutóg Dionem, Numæ Lycurgum, Marcello Pelopidem, Fabio Periclem: Q.itè Maximo Iafonem Pheræú, \& Themifonem Themitodi, Ariftidi Eumenem, Sercorio Simoniq́p Lucullum : quanquam de hoc ipfo ita fcriptum inuenio, Bel- 
licis in artibus, vt Aefchylus auctor eft, quem huic comparabimus, quem huic opponemus, quis huius fimilis? quum Antiochum grauem philofophum fcripfiffe conftet; Lucullum victoriam ompium quas vnquam fol viderit maximam ex hoftibus retuliffe. Exploratum eft $\&$ Photionem quinquies \& quadragies imperatoriam iniiffe dignitatem, quum ne femel comitiis intereffet, $f \in d$ femper abfens $\&$ crearetur $\&$ accerferetur. Ex hoc igitur quantus ille dux fuerit facile coniici potêt. In Alcibiade, cui flagrantifímum fuit ingenium, côfilii plú rimum, eloquentia fingularis, corporis fpecies præftans, præcipua potentia, virtus eximia, nobilitas, in re militari fummum imperium \& fumma gloria, quicquid natura effingere poffit, videtur experta. Conftat enim inter omnes qui de co memoriæ prodiderunt, nihil co duce fuiffe excellentius, quum pleraque hæc omnia animi, \& corporis, \& fortunæ commoda inter fefe in eo duce præcellen tia certare videantur. Thrafybuli virtus fi per fe abfque fortunæ numine penfitanda eft, dubius fum an eum omnium primum pofuerim: illud dubio procul, neminem huic preferendum cenfeo, fide, conftantia, magnitudine animi,in patriam's a more. Nam quod multi voluerunt paucíque conceffú ab vno tyranno patriam liberare, huic contigit vt à triginta oppreffam ty rannis feruitute, in libertatem vindicaret. Iphicrates non tam cumulo \& rerum geftarum magnitudine quàm difciplinæ militaris peritia nobilitatus eft, \& præcellentibus ducibus annumeratus. Eiufmodi enim dux fuit vt nó folum ætatis fuæ cum primis comparandus, fed ne de maioribus quidem natu ei quifquam fit anteferendus: imperator enim \& dux fape delectus, nufquam culpa rem male geffit, confilio femper inuictus, quo tantum excelluit vt multa in re militari noua quum inuenerit,inuenta plurima meliora red diderit. Ly fander Lacedæmonius magnam præclari ducis $\&$ imperatoris famam pręentibus \& pofteris reliquit,verum ma gis foelicitate quàm virtute partam. Thymoleon Corinthius fine dubio magnus omnium iudicio hic habendus, nanque huic vni contigit quod nefcio an vlli, vt $\&$ patriäà tyranno oppreffam liberaret, \& Syracufis quibus auxilio erat miffus inde inueteratam feruitutem depelleret, totamón Siciliam multos annos vexatam bello à barbarifque oppreffam, fuo aduentu in priftinum reftitueret: $\&$ quum effet non fimplici fortuna conflictatus, id quod difficilius putatur, multo fapientius fecundam quàm aduerfam pertulit fortunam. Agelinus rex , $\&$ contemptor fuperum Mezentius, vtpote qui non folum hominum fed deorum fibi honores expofceret, in hac quogp clarorum ducum concertatione quodam magno auctore numerandum fêfe offert, nec iniuria id quidé: nam fi Na. foni accedimus,

Clarus erat fumptífueferox Mezentius armis,

Et vel equo nullus, vel pede maior erat.

Legimus \& Cyrum Gracorum maximis laudibus celebratum, quòd in expeditionem profectus, Aegyptum in fuam deditionem redegerit $\&$ omnes qua a Syria finibus ad mare vfque rubrum pertinent gentes nationéfque fubegerit - Epaminundx quoque res ftrenue geft à plurimis omnium anteponuntur virtutibus. Thebas enim ante hüc ducem natum \& poft eiufdem interitum

$$
\text { Ee iii perpetuo }
$$


perpetuó alieno paruiffe imperio conftat, ecôtra eos quàm diu ille pręfuerit reipublicæ, caput fuiffe totius Gręcię nemo inficias ibit.Ex quo fanè intelligi poteft hunc vnum ducé pluris quàm nobilifimá ciuitatem fuam fuiffe, maximê quum eius mortem tanta præter feruitutem, Thebanorum iactura \& perditio fublecuta fit,vt non amififle ducem fuum et columen, fed ipfi cum eo finul tüc funditus periiffe viderentur. Et quãquam Homerico præconio exploratum $8 *$ notum fit, etiam illud Achillis \&. Hectoris mutuü vitza ac fanguinis certamen quod monomachiam appellant, \& eam vittutem qux fupra nos eft heroicam atque divinam præ cæteris Hectorem habuiffe, neq proinde videri mortalis ho minis filium effe fed dei, nó inepte tamen, quum non homerica fed paterna illa commendatio fuerit, debet Achilles, Hectorem qui vicerit, \& virium, $\&$ animi rerúmq̣ geftarú præconio ac dignitate minor haberi,quarn $\&$ ipfam in aurea capra ita fcriptam offendes, Si cor, fi vires, fi bella requiris Achillis, Paucis expe diẫ Hectore maior erat.Videbis etiä Daretis Phrygii, Troiani friptoris attefta tione, maioris fortitudinis, \& virtutis Achillë fuiffe $\ddot{q}$ Hectorë. Achillem praterea louis nepoté $\&$ Thetidis filium vult Homerus, cæteríg fine cótrouerfía poétæ, qui homines morum \& virtutum pracellentia, non folum deorum progeniem volunt, fed etiam deos fieri: guòd fr eodem præcone, $\&$ fenfu, $\&$ decoris feftiut tate in celum tollatur Neftor, Atridas apud fuos, fama claros, \& motos fu rore Aiaces, \& dolis \& altu Vlyxem reddant, Milciadem Marathon, Themiftoclem Thermopylæ prædicent, Homerúfque idem \& Maro nedum Barbaris fed Latinis \& Graiis ducibus praficied o regem illum quo iuftior alter, Nec pietate fuit nec bello maior \& armis,

quicquid denique aliarum gentium præclaræ laudis vfquam extat, in vnum fi conferatur, profecto citra Romanos rerum dominos gentemóp togatam fub-a fiftet: quocirca funt qui fuo quodá iure Brenum animi magnitudine \& rerum geftarum gloria extollendum putent, quòd Gallis Senonibus in militiam fumptis Romam mundi dominam armis inuaferit, in Romanos tanquam imbelles impetus fecerit, eófque fic ftrauerit vt non facile quifpiam fimilé ruinam romanæ milicie recenferet, etiam fi Roma infuper incenfa non foret: verùm vt vicerunt, fic victi funt $\&$ ad internitioné Dolobella duce deleti vt nullus ex ea gente fuperfuerit qui incenfam à fe Romam gloriaretur. Neq̧ verò Hannibalis res geftro ob furæ, neck pofteriores erunt:annis enim $v . \&$ xx. minor natus imperator factus, proximo triénio ille, viris armíf qu nobile $\&$ exercituú feminarium bellatricem fubegit Hifpaniam, Saguntum potentifimâ vrbem Romanis ami ciffimam,ac foederatá expugnauit ac obfidione deleuit, tres exercitus maximos comparauit, altero in Hifpania cú Hafdrubale fratre relicto, altero in A phricam miffo, tertium in Italiam fecum duxit: cum hoc exercitu $P_{y}$ reneos mótes faltusóp tranfgreffus, velut fulmen qux $\not$ obftantia proterens, ad vrendam Itaa liam deuaftandáque feftinat, nec nifi ferro $\&$ fanguine iter fibi præftruens, ad Alpes pofteaquàm venit quæ Italiã à Gallia feiungunt, \& quas nemo vnquam præter Herculem Graium ante eum tranfierat,alpinis Gallorú quo minus tran firet quanquam refiftentibus, ac tandem duro Marte depulfis, igne ac ferro diru 
ptis rupibus, iuga illa afpera inuicta \& inacceffa, ac frigore intractabilia ita mu niit, ve elephanti poffent ire onerati, quę antea vnus homo inermis vix potuiffet irrepere, qua res ei \& virtutis admirationem \& immortalitatis fidem non paruam contulit: inde exercitum traducens, in Italiam peruenit : conflixit apud Ticinum cum P. Cornelio Scipione cof. eum que fauciú repulit, à filio pubeicen te feruatum, Scipionis huius collegam Tyberium Lögum, fecúdum Probum, fiue magis fecundum Liuium Sempronium, apud Trebiam cum ingenti Romanorü clade profligauit. Cum hoc apud Placétiam equo licet Marte pugnatum parique clade dilceflum, maior tamen Romanis quàm pro numero iactu. ra fuit, vt inquit Liuius, qa equeftr is ordinis aliquot $\&$ tribuni militares $\&$ præfecti nonnulli ea dimicatione conciderunt. His tot prolperis ac lettis fuccelfibus elatus Hannibal, fua fidutix plenus, ad fpens propofiti armauit animum, inde per Lygures Apenninum tranfiens petit Etruriam, quo itinere adeò graui oculorum morbo affectus eft, vt in pofterú dextri oculi beneficio nunquam bene æque vfus eft, hac tamen mala qua tüc detinebatur valetudine lectica deuectus eft, C. Flaminiú cof.ardentioris fpiritus virum quàm res ipfa poftularet, apud Trafimenum cum exercitu infidiis circunuentum occidit, neque multo poft $C$. Centenium pratorem cum delecta manu faltus occupantem. Fuerunt autem hoc in loco qui in acie ceciderunt Romanorum xv. milia T. Liuil fententia de multis electa: aliorum nam que aliter, apud quofdam enim viginti milium numerum inuenio, hoftium non nifi mille quingent is in prælio cæfis, \& hæc alia romanx reipub. peftis. Motis hinc caftris in A puliam ad Cannas quum perueniffét obuiamóp ei duo cófules Claudius Teren. Varro,\& Paulus Aemilius fefe obtuliffent, Varronem committedi pralii temerarium auctorem primum tur pis fuga corripuit, nec fugienté hunc am plius quàm quinquaginta equices profecuti funt. Confulum alter prudés forti ac honefta morte procubuit, cum hoc quoque quæetores duo, tribuni militum vndeuiginti, confulares, pretores, atque eqdilitii aliquot, fenatores infuper octoginta defiderati funt: reliquorũ numerus caforum ambigue traditus videtur: quod cóftat, $x$ l.milia peditü, equitum duo milia feptingenti fuerunt: funt qui hos legionarios tantú pedites atque equites, aliorum ciuium ac fociorum parem quippe numerum effe afferant.Quum inde polt aliquot dies Capuam, quam Cannas fibi fuiffe percelebre eft, reuerteretur,Q.Fabi.max dictator romanus in agro ei falerno fe obiecit. Hic locorum anguftiis claufus, noctu fine aliquo detrimento exercitus fe expedinit, Fabio cal lidiflimo imperatori dedit verba: nanque obducta nocte, farméta in cornibus iumêtorum deligata incendit, eírlque generis multitudinem magnam diffipatam immilit, quo repétino obiectu vilo, tantum terrorem iniecit exercitui Roa manorum vt egredi extra vallum fit aufus nemo. Poft hæc nó mul to M. Minu tium Ruffum magiftrum equitum pariter ac dictatorem impèrio, dolo productum in prælium, fugauit. Ty berium Senupronium Gracchum iterum cof. in Lucanis abfens in infidias fubductú fuftulit . M. Claudiü Marcellú quinquies cófulê apud Venufiam pari modo interfecit,cúmog ferò tảdem vt Capuã ipfam romana preffam obfidıone liberaret, $\&$ ad tertium lapidé Anienémq̣ fluuium 
caftrametatus portas vrbis acceffiflet intra cuius muros folus hoftiú emifit haftam, indignantes qui fupererant tantú illi licere Romani coff. obuiam egreffí $\&$ in aciem vtring deductis copiis parati ad pręlium cum effent, illico grando cęli fragore demifla ex fumma capitolii rupe maximo turbine vetorum in ad. uerfa hoftium ora, prohibuit: quod pofteaquam bis tétatum accidiffet, miracu lo concuffus Hannibal dixiffe traditur, Romam capiédi tum fibi animú deeffe, tum fortunam:cum's diu antea in l talia fuerit,nemo ei in acie reftitiffer, nemo aduerfus eum poft Cannenfem pugnam in campo caftra poluiffet. His itaque ad vaftitatem Italix geftis Scipio ille A phricanus fuperior dum clades patrix, cladibus in A phrica vindicaret, hinc reuocare potuit \& acerrimú hoftem,eum inquam à quo pater apud Ticinum fugatus fuerat ad bellum arcefcere vinceréque. Quo in bello vt valentior poftea congrederetur, collatis iam fignis, de legibus pacis colloquium fecit, conditiones quum haudquaquam conuenirent, tubx cecinere, fit pugna \& quidem nouiffima, in qua nec melius inftrui aciem, nec acrius potuiffe pugnari,vt de victore victus, \& de victo itidé victor ipfe con feffus eft, vterģ ingens talium rerum xftimator, ceffitque tandem Hannibal, adeò confternatus vt nunquam poftea refurgeret,Scipioni'ǵp præmium victorie Aphrica fuerit. Horum autem duorum qui non fux modo atatis, Liuio tefte, maximi duces, fed omnis ante fe memorix omnium gentium, cuilibet regum imperatorúmve pares, vel, vt Florus inquit,qui omnium antea \& poftea ducum clariffimi fuere, vter vtro fit prior habendus imperator, præter Scipionis cedes qui magnam partem fceleris humani extinxit atque perdidit, vt de feiplo apud Ennium fum his verbis loquitur,

Si fas cædendo cæleftia f candere cuiquam eft

Mi foli cæli maxima porta patet,

hoc vnum dictum fatis erit, quo intelligi poffit quantus ille imperator fuerit. Si verú eft enim, quod nemo dubitat,vt Po.Ro. præ cæteris virtute bellica præfidentiâ fibi vindicet Hannibalémq conftet potuiffe eum fuperare, confequens videtur Scipionem tanto non folum hunc,verùm cæteros imperatores anteiffe, quanto Po.Ro.Ponuśćs Hannibal rerum geftarum gloria antecellút, quod nec tantus quidem hoftis Hannibal ipfe diffimulat. A pud E phefum enim quò am bo conuenerant, altérque viktus confugerat, alter ad Antiochum legatus \& romanus orator accefferat, quum Hannibal dignioren deambulando locum pri mus arripuiffet, idóp A phricanus tam equo tulifiet animo vt facile nulla cú con tentione ea fuerit ambulatio, habito poftmodum de ducum praftãtia inter eos fermone, interrogantíg Scipioni quis fibi ducum maximus videretur, corú on nium qui præcefliffent quíg ad id vique temporis fuperftes fuiffent, tum $\mathrm{P}_{0}$ nus, Philippi filium Macedonúmq regem Alexandrum profectò primú:quem item fecundum fcifcitanti, Epirotarum regem Pyrrhum fubieciffe, tam illius quàm huius dici rationem afferendo: exquirenti porrò quem tertiò præficeret, dubio procul feipfum, inquit : obortoós rifu, Aphricanú tum adiecifle, Quàm maximi te faceres, quóve loco te dignum diceres Hannibal, fi vti ego, fuperior euafifles? tum ille, Non folum atatis huius, fed omnium fuperioru temporum, 
gentium, ac nationum imperatoribus anteferendum iudicarem: quo quidem. dicto nó obfcurú eft fane pèr Hannibalem innui, Scipionem velut inæftimabỉ lem, cæterisóg ducibus \& imperatoribus longe diffimilem anteponendum. Seuerus auten feptimus, dux \& imperator inclytus fimili modo quum de primo principum loco fermo effet, Auguftum Velpafanü, Titum, Traianum, Pium, Maximum magni præ cæteris fecit,reliquos formineos vèl venenatos nominãs: maxime in hiftoris Hannibalem, Marium, Camillum, \& Q.Marium Coriola. num dilexit, fummáque laude ac loco dignos cenfuit. Interrogatus porrò quid de vtroọ Aphricano fentiret, refpondiffe fertur, Fôlices illos fuiffe magis quàm fortes, id que probare domefticam vitam, \& iuuentutem qua in vtroque minus fpeciofa domi fuiffet. Non minus etrấ laudis \& gloriæ Scipioni Naficæ in ocio $\&$ toga quàm in negocio et armis,vtíģ Scipioni maiores noftros tribuiffe percelebre elt. Ferunt $\&$ Antigonum interrogatum, quis ducum fibi optimus videretur,refpódiffe, Pyrrhum fi fenefceret omnium fuæ ætatis ducuin fibi opti mum videri: fed quanquam hic ętatis fux ducibus duntaxat eum preferat, fatis tamen conftans, auctore Iuftino, in ter omnes auctores fama eft, nullum nec eius nec fuperioris atatis regem comparandun Pyrrho fuiffe,raróque non inter reges tantü,verum etiam inter illuftres viros, aut vitæ fanctioris aut iuftitix probatioris vifum, fcientiam certe rei militaris in illo tantam fuiffe, vt cum Lyfimacho, Demetrio, Antigono, tant is regibus bella gefferit, \& inuictus femper fu erit, lly ricorum quop, Siculorum, Romanorum, Carthaginenfium bellis nunquam inferior, plerunque etiam vietor extiterit: qüi patriam certe fuam ang tiftam ignobilemque rerun geftarum fama \& claritate nominis fui toto orbe il luftrem reddiderit. Bellacifimum enim regum om nium vque adeò fuiffe conftat,vt quum cæteri mortales pro gloria próque imperio,pro falute próque inits riis pugnare foleant, hic pro voluptate pugnaret,neque hæc illi maior ex imperio, quàm de bello voluptas erat. Adde quơd militaribus artibus inftructifimus ductandi exercitum, ordinandi acies, eligendi locumi caltris idoneum, conciliandi hominum animos, rei pace bellóque efficaciffimx. Cęterum ad bellandum quærendáfque victorias, quàm victoriarum præmia feruanda, vir quàm longe melior. Qui verò hanc ip fam palmam Alexandro Macedonum regi tribuunt; non infcite id quidem facere videntur, nec minimis rationibus initi. Hic enim rex $\&$ imperator, parta manu vltra quàm credibile cuipiam videatur, peragrauit orbem, innumeras gentes fudit atque fubegit. Vigefimum nanque ętatis an num agës.Macedonum rex declaratus, $\&$ ad bella promptus,vbi Macedoniam, Gręciam, \& Illyrix partem ordine compofuiffet,vltra Hellefpontum in Afiam trâfgreffus, primo Darium Perfarum regem maximum expugnat, mox Phry gia \& Paphlagonia in ditionem redactis per anguftas ruprum dubiófgaditus Cilicia intrat, qux ex improuifo exterrita victori paruit. Darius interea quingentorum milium inftaurato exercitu, vel vt alii perhibent, ccc milia peditum $\&$ centum milia equitum in aciem producens inter arctas Ciliciæ rupium fauces commiffo certamine vicus ac fugatus terga celeri ftudio vertit, peditum oftoginta milibus, equitum decem milibus cafis, quadraginta milibus captis, 
direptis caftris cum regia matre, vxore, ac tota familia, fobole ctiam victor infignis. Hinc ad profictionem Damafci prouectus, ex proximis nationibus lega ti venere fe fuálque vrbes dedétes. Syria, Phonices \& Sydon cum maritimisin. fulis victori obtemperauerunt. Tyrum ferociter expugnatam \& virtus \& fortuna obcinendam dedit. Aliquamdiu oblefla Tenedos regi paruit, centum lx nawium claffe deuicta Gaza, decem milibus hoftium cefis expugnata eft. Victricin bus armis ceffit Aegyptus, \& Cy renæ ceruicé flexere: ad louis Hammonis tem plum quem fibi patrem finxerat gentium domitor per arida $\&$ fole adufta vertit iter, vnde remeans, diuina ftirpe fe natum voluit credi haud quaqua m mortali patre contentus. Reuerfus vrbem condidit, quam ex fuo nomine Alexandriam appellauit. Hinc aduerfus Dariú qui Arbelam ignobilem vicú, fed $\mathrm{Per}-$ fica ftrage nobilitatum ingenti armorum copia venerat, deintegro arma conuertit, \& paribus vtriufque partis \& copiis \& fortuna hic quoq victor, orientis fibilimen aperuit, ita vt proximæ gentes Perfidis \& Babylonii paterentur imperia. Per difficiles aditus æthereaón iuga ad feptentrionem conuerfus, Parthos Hyrcanófque fregit. Caucafum montem ad montis extrema cum fuis labore deductus, maréque Cafpium cuncta fternendo fubegit, ad flumen Tanaim \& Scythas circumtulit figna, $\&$ in finibus Afrę partem tenuit Europe, \& I dafpen a mnem. Porum Indorum maximum regem, quia armis contradicere aufus, ter ribili pręlio vicit: \& quia victum le tam iniquo animo tulit, vt cibum vulnerüóg remedia refpueret, mori volens, magnitudine animi delectatus Alexander, in amicis habuit, \& honoribus auctum regnare compulit. Multa præterea cú aliquot regibus \& exteris gentibus per Indorum longifinos tracus pralia gefta funt, tantis illuftrata victoriis fiue Græcorum affertione contra Romanum nomen,Parthorum gloriæ fauentium, fue leuifimorum quorundam Gallorum, quos non veriftudium, non fides veri, non denique Alexãdri amor vllus, led Ro manorum inuidia atque odım femper impulit, vt inuulgatum fit eum totum terrarú orbem peragralle, illinf̧̣ dominum fuiffe: que opinio quia quorundam mentes irrepfit minuenda on nn no eft, éque maxime, quòd rerú geftarum fcriptores aliqui et quidem non incelebres videntur in häc lententiâ trahi.Primum itaque inter cateros Annei Senecæ de Alexand ro illudattingam, alterius rerú fuarü \& loci huius et dicti, memoria licet polleret eximia,reor obliti, Agebat, inquit, infoelice furor aliena vaftãdi, \& ad ignota mittebat. An tu putas fanum, quià Gręcix primú cladibus in qua eruditus eft incipit,qui quod cui optimun eft eripit? Lacedæmona feruire iubet, A thenas iacere non contentus, tot ciuitatum ftrage quas aut vicerat hilippus, aut interemerat, alias alio loco proiicit, $\&$ toto orbe arma circumfert, nec fubititit viquam laffa crudelitas, immanium ferarú modo, qux plufquam exigit fames mordét, iam in vnum regnum multa regna coniecit, iam Græci Perfæóp eundem timent, iam etiam à Dario liberæ naciones iugum accipiunt. Hinc tum vltra oceanum folémque indignantur ab Herculis Liberiós veftigiis victoriam flectere, ipfi naturæ vim parat, non ire ille vult, fed non poteft frare, non aliter quàm in pręceps deiecta podera quibus eun di eft finis iacuiffe: quod à tanto viro tam'ǵ pręclaro dictum miror. Nec minus 
\& illud Iuftini, Vniuerfum terrarum orbem vtrum fit mirabilius quia viceric an aggredi aufus fuerit, incertum eft. Nota enim hæc fint licet tamen illud in Ciuitate dei nec minus incognitum effe debet, Quantalibet autem fide rerú vel ifte vel Trogus, inquit, fcripferint(addo his ego \& qué diximus Senecam) que dam tamen illos fuiffe mentitos fideliores litere oftendunt, quum non Romans qux florere iam coperat,aut Italix oram vllam, fed nec Germaniam, nec Britanniam nec Hifpaniam, Galliam vel Aphricam per fefe aut legatos vnquam adierit,nedum vicerit. Quid ergo?orientem adiit orientémque vicit,vnam, Ale xandri Epirenfis regis $\&$ huius auúculi fententia, ex omnibus vinci facillimam mundi partem, quod fxpe alibi idem anctor ait: $\&$ vt $Q$. Curtii hunc eundem regem ftilo nobilitant is verbis vtar, $\mathrm{Ab}$ Hellefponto vfque ad oceanum omnes gentes victoria emenfus, vtóp in quaftionibus naturalibus in quit Seneca, Imperium ex angulo Thracix vfo ad or ientis terminos protulit. Quanquam quod conftat,ante alias Carthagini infenfus, fe fubacta Afia in Aphricam migraturum minaretur, \& forte cogitaret inde ad Gades herculeas \& Hifpaniam traie curum, ac porrò inde per Galllas fecus Alpes \& Italiam in Epirum atç Macedoniam reuerfurum, fić́ nondum alteram fortem adortus, exceffit è vita, nec aliter, vt ille inquit, quàm Babylone fua Parthóg verédus. Nam fibi libertas vn. quam fi redderet orbem Ludibrio feu ratus erat non vtile mundo Editus exem plum eft. Et quamdiu fuit de hoc ipfo quem modo diximus Alexandro \& Phi lippo patre ac Macedonum rege inter doctiflimos de vtriufque proftantia difceptatio non leuis, \& quanquam magno fe iudice quifq et ftrenue anteactis tueri poffit, $\mathrm{Ph}$ hilippú tamen virtute, viribus animi,magnificentia, fide, rerū moderatione, rebus geltis \& gloria fuperatum à filio, facilitate verò, humanitate, confiliorum prudetia, frugalitate, folertia, verborum deniqgac orationis cultu Alexand ro fuperiorem fuiffe non dubium eft. Et licet regum clariflimus tefte IuAtino fit Alexander, clariorem tamen, inquit Liuius, eum facit, quòd vnus fuit, $\Phi$ adolefcens, quòd increméto rerum, nondum alteram fortunam expertus deceffit . Philippum aurem Alexandri patrem Theophraftus tradit non folum genere \& dignitate regia fed etiam fortuna \& moribus maiorem cæteris regibus moderatiorém que extitiffe. Sunt qui hoc decus imperii $\mathrm{Cn}$. Ponspeio Magno ob res ab co præ cæteris magnificentiffimé geftas deferendú putent: maximum enim \& fplendidifimum fuit, quod Romanorum nemini antea contigit, quòd tertiú è tertia vniuerfi orbis parte triúphum duxit.Ná licet tres ex hac vna parte triumpharint,ipfe tamen primum ex Aphrica, fecundum ex Europa, tertium hunc vltimum ex Afia ducens triüphum, quodam quafi modo vifus eft ex vniuerfo ambitu orbis triumphaffe. Ex quo autem genere gëtium feorfum triumpharit ex his qua fubiiciemus licet agnofcere. Erant quippe regionum illarum nomina huiufnodi,Pontus, Armenia, Cappadocia,Paphlagonia,Media, Colchis, Hyberia infula, Albania,Syria,Mefopotamia. Præterea hi qui circa Pho niciá \& Palętiné incolunt Iudęi, A rabes.In oriêtis etiâ partibus, ac Cilicibus, \& Ifauris, Pyratis latronibúfọ fuperatis fui nominis inter Ciliciā \& I fauriă cōdidit vrbë. Inter hęc trophxis etiä fuis quẹttatuebat in pyrenæo annotätur octin 
genta feptuaginta vii oppida ab Alpibus ad Hifpanie vlterioris finem in dedi tionem à fe redacta; ciultates ferme noningentæ, pyraticæ naues cviii, captiui poft principes pyratarum in triumpho ducti, Tygranes A rmenus Tigranisq́ filius cum vxore filiaque ipfus regis, rex Iudxorum Ariftobolus, Mithridatis foror cum liberis quing, fufis, fugatis, occifis, in deditionem acceptis hominum centies vicies femel l xxx milibus. Nec huic quidem Cn. Pompeio ad hac tanta tam'\$ præclara facinora virtusaut ratio fuadebat, fed infanus a mor magnitudinis falf $x$, quòd fi modo vt in Hifpaniam, modo in truces Lepidi motus \& Al pina bella, modo in Sertoriana arma, modo ad colligendos pyratas, maria tot ac varia pacanda proficifceretur,caứ per eú prætexebantur ad continendã po tentiam.Quid illum ergo in Aphricam, quid in feptentrionem, quid in. Mithri datem $\&$ omnes Áfix angulos traxit, nifi infinita cupido crefcendi, quum fibi vni parum magnus videretur? Quid Cxfarem in fua facta pariter ac publica immifit nifi gloria, \& eius ambitio, \& nullius fupra cæteros cminendi modus, quum vnum ante fe Cafarem ferre non poffet? cuius ècontrario fi quilpiam fimili modo velit percenfere res fortiffimè geftas, ob quas Deus eft à veteribus ap pellatus, immenfum $\&$ infinitum quippiam aggrediatur necefle eft. Huic enin primum bellum cum Heluetiis fuit Gallorum omnium fortiflimis, quibus tan tus nedum pugnádi ardor, fed rabies erat vt patria profecti xvi corum vrbibus vicifque cccc à fe cócrematis, ne quid his defiderii foret ex fpe reuertendi vlteri us, per Romanorum terras obftinati magis in omné fortunã migrarent, quemadmodum antea Cymbri \& Theutones, quibus non audacia, non fortitudine, vlla ex parte inferiores erant. Horum plane mulcitudo numerúfque cæterarum gentium qua auxilio illis exierant, in tabulis æneis, quæ in caftris inuente funt, dictu mirabile, literis græcis infcriptus erat. Fuerant autem omnis generis hominum capita ccclxviii milia, ex quibus nonaginta \& cétum bellaciffimorum erant quos omnis quum apud $R$ hodanum fluuium obuiam $C$ far habuifet magno difficilique bello bis vicit,victó $f_{\not \beta}$ ad deditionem ccégit. Germanos eti am cum eorum animos fortilegarum vaticinia mulierum nó committere prælium antè finerent quàm noua luna fulgeret, congredi fatius duxit trepidãtibus, quàm idoneum illis tem pus expectantibus. Facto itaque in eorú munitiones et rumulos impetu, non antè ftimulare \& inceffere deftitit, quàm ira detricti pugnã capefferent. His in fugam verfis quorum fertur numerus cccclx milia fuiffe, $\mathrm{C}_{\varepsilon}$ far ftadiis cccc adufque $R$ henum perfequés, cadaueribus, fpoliisóq referfit: cq́orum numerum Ixxx milia fuiffe perhibent. Inde confluent is $R$ heni bis difiunctiffmasripas ponte coniunxit, et primus Romanorum armis Germaniam inuafit, verim Barbari fyluas petere properarunt ac paludes non auficertare quod pro victoria fuit. Hinc A riouiftum Germanorum infolentiffimú ducem vno prælio vicit ac expulit. I dê contra ferociffimos \& bellaciffimos Neruios \& Atrebates qui denfffimas incolunt fyluas duxit exercitum. Vbi igitur in profundiffimo nemore filios ac fuppellectilem quàm procul ab hofte collocaffent, cum Ix milibus armatorú contra Cxfarem repentinos fecerunt impetus, érmọ caftra locantem prelióque abftinentem offenderunt $\&$ verfo in fugam equitatu feptem 
feptimå \& duodecimam legionem circúuenientes, vniuerfos trucidabant centuriones : quòd nifi Cæarar correpto fcuto \& his qui coram fe praliabantur detentis, inter barbaros irruiffet, ac fubinde quodam ex tumulo decima legio per hoftiles irrumpens acies periclitanti fuccurriffet, neminem eua furum incolume liquet: ac virtute Cæfaris \& audacia fupra vires (vt dici folet) decertantes, haud tamen Neruios dare terga coégerunt,verùm fortiter oppugnantes obtruncauerunt. Ex lx enim milibus, quingentos euafffe traditur. Hinc deditiones vr biun ad extremos vfque oceani terminos confecutx. Adriatici eo em impetu fortune profligatiad quatuor milia cæfa,L.milia vęnundata. Cum Venetis qui ad ocee anum terras incolebant nauale pralium $\&$ memorabile fuit, $\&$ hi quog victi $\&$ armis fuperati Equitanorum qui ad defenfionem cum finitimis coniurarant. Fuit $\&$ bellum ei cum Belgis vnà cum Germanorum auxiliis, hornn copix ad cclxxii milia lectiffima numeratæ funt,quibus repentè è fyluis erúpétibus, milites $\mathrm{C}$ æfaris eos excipientes fumma quidem arte obftando ad internitionem deleuere, quoufque ad fua remeare compuliffent. Domuit præter hos omnem $\mathrm{Gal}$ liam quæinter Alpes,flumen R hodanum, R henum $q$ \& 8 oceanum eft, $\&$ circuitu patet ad bis tricies centena milia paffuum. In ea fiquidem nec totum belligerans decennium octingenta viribus copit oppida, trecentos fubingauit fopulos, aduerfus trecentas parum inftructus myriades, centum quidem ferro cafis, totidem vitæ referuatas habuit captiuas: corpore, arnis, fpiritúque terribilem, nomine etiam quafí ad terrorem compofito Vercingétricem Aluernum Gallo rum regé fortuna multis fxpe ac nagnis praliis atque conatibus retentata, poft aliquot certamina horrida hinc inde vario difcrimine gefta, in Allexia oppido vallo xi milibus paffuú circunducto conclufit, donec cexlviii miliú armatorum exercitu congefto, auxilio regis ferme tota Gallia furrexerat; $\&$ hi quoog cæli, fu fi, fugati,qui potuere ad fua remearunt, Rex ipfe nouiffime in deditionem redactus, maximum \& ampliffimú victoriæ decus, depofito omni faftu fupplex cum in caftra veniffet, ante $\mathrm{C}$ faris genua faleris abiectis \& armis, Habe, inguit,fortem virum, vir fortiffme, vicift. Inde quafi hic terrarum orbis non fufficeret, alterum cogitauit, $\&$ in Britannam cranfuectus, cui ne nomen quidem Roma. norum antea cognitũ erat, $\&$ de qua nõ parua etiã inter fcriptores $\&$ hiftoricos contêtio eft, cum eã non re fed verbo folü ac nomine fictam nufquã extare contendãr,fubiugare adortus eft, huirusǵg facinoris audacia magnã illi gloriam pepe rit.Primus nanģ̧ occıduú slaffe ing reffus oceanum perọ́ atlanticum pelagus ad belligerandú tranfportans exercitü annauigare coppit, mira celeritate träluectus armáğ \& obfides accepit à trepidis: \& vlterius iffet, ni improbã claffem naufragio caftigaffet oceanus. Reuerfus igitur in Galliä, claffe maiore,aucisiśg̣ admodum copiis in eundē rurfus oceanum eofdë Britannos fubfecutıs eft, qui tâdem expugnati cú regibus, victoris iugo ceruicem flexere. Contentus his,non enim puincix fed nomini ftudebatur, cú maiore ğ prius pręda reuectus eft. Triüphauit quater, vt teftes fere omnes auctores funt,vt certiores, quinquies. Primus triüphus fuit de Gallia atque hac ipfa Britannia, íf̨ omniü clarifimus.Secüdus de Aegypto, tertius de Pharnace \& Ponto, quartus de Iuba \& Aphrica, quintus Ff de 
de Hifpania.Egovero adderem fextum de Maflilia, nifi quia forfitan ifte trium phus fub gallico cótinetur: nam de Maffilia illum triumphaffe, haudquaquam eft dubium cuipiam qui acerrinam illam Ciceronis de Cxate loquentis querimoniam in libris Officiorum legerunt, Vexatis, inquit, ac perditis exteris nationibus, ad exemplum amiffi imperii portari in triumpho Maffiliam vidimus, \& ex ea vrbe triumphari fine qua noftri imperatores ex tráfal pinis bellis triumpharunt .Prælia deniqg plura geffit quàm recenfere quifpiam poffit. Huius inquam ductu, vt ab illuftribus quibufdam traditum eft auctoribus vndecies céties triginta \& duo milia, vel vt ab aliis,vndecies centena nonaginta milia hoftium cæea funt, fignis collatis bis \& quinquagies, vel vt alii, quinquagies tâtum di micauit,M.Marcellum folus tranfgreffus qui nouies \& tricies, vel vt alii atq alii, quadragies nouies pari penè modo fuerat præliatus. Quid cętera eius getta profequar? His tot bellis exactis, tot laboribus exantlatis, quos nedum pati, fed fcribere, fed legere, fed audire difficile ef, victor Cæfar Romam rediit,vrbémq̧ vacuam ingreflus, dictatorem fe fecit,negatámq pecuniam ex ærario publico fractis foribus inuafit: poftea Pom peium infecutus, infinitas cius copias cápis Phar falicis fugauit. Inde victo, \& fugato in Aegyptum Pompeio, cum Alexandrinis terra maríque ingens bellorum ei negocium fuit,demũ abfumpto fluctibus rege,victor Cęar Cleopatram gentis reginam relinquens, per Syriam profectus, reftituto in regnum minoris Armenix Deiotaro, Pharnacem bello victü Ponti regno priuat.Inde tenuit Aphricam, \& poft aliquot clariffima bella vnice geAta,tres duces partis diuet $\{$ Scipionem, lubam regem, $\&$ Labienum proftrauit. Cato Vticenfss vltro repetitum gladio pectus traiecit. Victor ad Italiã Cafar rediit, mox ad Hípanias conuerfus, apud Mundam ancipiti euétu $\mathrm{Cn}$.\& Sextum Magni filios expugnat,xxx milibus Pompeianorum cxefs, obtruncato Cneo. Quantum autem his bellis romani fanguinis fuderit,noluit annotari. Ad lummum Vefte pont ifex creatus relatúfque eft in numerum deorum, nó modo prin cipum auctoritate, fed opinione etiam populari. Nam ludis quos ibi Auguftus Cæfar hæres eius inftituit, crinita ftella feptë continuis diebus circa vndecimam horam lucis effulfit, perfuafum'q credulx plebi $\mathrm{C} x$ aris effe animam in calum tran fmifl. Huius ftellę \& Virg. poéta meminit in Bucolico carmine, \& fimulacrum ip fum Cælaris indicio eft, cuius in vertice ftella eft. Poft hæc Numidici lapidis columna in eodem loco pofita, $x x$ pecum altitudine, Parenti patrix infcriptione addita,ad quam facrificare, \& vouere, \& iurafe per Cæfarem diutius obleruatũ eft. Sed clari fint licet illi quos antè diximus, cla rus Scipio cuius confilio atque virtute Hannibal in Aphricam decedere coactus eft, ornetur \& alter Scipio A phricanus qui duas potentifimas vrbes imperio romano infeftifimas, Carthaginem, Numantiámque deleuit, habeatur vir egregius, L. Paulus ille cu ius currum rex potêtiffimus quondã $\&$ nobiliffimus Perfes honeftauit, fit æterna gloria Marius, qui bis Italiam obfidione et metu feruitutis liberauit, miris tol latur in cælum laudibus, cui cum vel dictatoribus vel coff.Macedonú rege Alexandro in Italiam traiecturo erat dimicandü,M.dico Valerium Coruú, Carum Martium Rutilium, Caiü Sulpitiu, T.Manlium Torquatum,Q.P.Philoné, L. 
Papyrium curforem, Q. Fabium Maxi.duos Decios, L.Volumnium, M. rorm uum loga beli experietia Philopomenem celebret,anteponatur omnibus Fom peius, criius res geftr atque virtutes iifdem quibus folis regionibus, curfu ac terminis continentur, lulius tamen Cęar in rebus bellicis, nec illis,nec his profecto', nec vlli hominum fecundus fuiffe memorabitur. Ita nanque de eo per turropium friptum eft, Vir quo nemo vnquam bellis magis emicuic. De huius etiam bellica virtute atक praftantia etfi abunde fit dictum, non eft ta mé omittendum aliud Ciceronis teftinonium, quod vulgatiffimum omnibusóg notifimun fit, tamen \& clariflimum eft fimul'g veriffimum, Soleo fxpe, inquit, ante oculos ponere, idque libenter crebris vfurpare fermonibus,omnes noftrorü imperatorum, omnes exterarum gentium potentiflimorumiģ populorum, omnes regum clariffimorum res geftas, nec contentionum magnitudine, nec numero pręlorum, nec varietate regionum, nec celeritate conficiendi, nec diffimilitudine bellorum poffe conferri,nec verò difiunctiffimas terras citius paffibus cujulquam iam po tuiffe peragrari,quàm tuis non dicam curfibus, led victoriis illuftrata funt. Negs $v t$ alibi idem Cicero inquit, fi tue res geftę caterorum laudibus obfcuritat $m$ at tulerint, idcirco $\mathrm{Cn}$. Pompeii memoriam amifimus, quantum nomen ipfius fue rit,quantz opes,quanta in omni genere bellor um gloria, quanti honores Eo. Ro. quanti fenatus.quanti tui, quis ignorat? tanto ille fuperiores vicerat gloria, quan to tu omnibus prętitifti. Itaq $\mathrm{Cn}$. Pompeii bella, victor ias, triumphos, confulatus admirantes numerabinus, tuos enumerare non poffumus. Et quoniam in quo maxime conftet hæc ducum excellentia immélæa quaftionis efle folet. Plutarchus tertius eòdé clarifimus teftis accedat, Summor ü, ir quit, virorû \& clariffimo:um ducum neminem huic bellatori imperatori pręponendum cenfeas. Nam fi quis Fabios, Scipiones, Metellos, \& atat is fue, \& paulo fuperioris cuces, Syllam, Marium, verüg Lucullum, \& jpfum deniq Pompeium, cuius omnín:oda in re militari virtus $\&$ gloria ad calum vfque perfloruit,comparandos duxerit, eos profectò Cęfaris gefta fuperant. Quòd fi prater hos alics quoque quofdam intueri libet, Tarquinium Superbum, Regulum, Fabricium, Curium, atç Camillum, Oratio Hacco quarto etiā grauifimo tefte, micat inter omnes fidus, velut inter ignes luna minores. Ouidius quoque ad hæc, nec ipernendus, nec fubricendus auctor in faftis,Magne tuum nomen rerum eft menfura tuarü, Sed qui te vicit nomine maior erat. Denique Solini vltimi teftis verbo fretus, vt omnes huius imper laudes compelctar, quantum inter milites Sicinius aut Sergius, tantum inter duces, im mo vt verius dicam, inter homines omnes $C x$ far dictator enituit. Catonum deinde fi nobis inter maximos duces fermo habendus, im paui dus profectó, \& inter hos duos Cæfarem \& Pompeium inceffens erit Vticenfis il le, ciuili fe bello inferens: huic enim obuium non alium quempiam affignaues rim. Altius certe nemo progredi potuit, quàm qui fimul in illa reipub.trepidatione contra vtrü क् fe fuftulerit, \& aliis cæéarianas opes, aliis pompeianas fihi vouentibus vtrof $\phi_{\beta}$ contem plerit, prouocaueritó, ac oftederit effe alias reipub. partes. Eleganter $\&$ compofite etiam Crifpus Saluftius cómemorat, illam rempub. mon habuifle quépiam virtute magnum, $\mathrm{ed}$ memoria fua ingenti virtute $\& \mathrm{~d}$ di- 
uerfis moribus fuiffe duos magnos \& praclaros viros, M. Catonem \& C.Cæfa rem:alterú feuerum,clementem alterum: conftantem illum, hunc facilem:illum nihil largiente, hunc affluentem copiis onnibus. In huius etiam laudibus polu it; quòd fibi magnú imperium, exercitum, bellum nouum exoptabat, vbi virtus enitefcere poffet. I ta fidebat in votis viroru virtute magnorum, vt exercitaret in bellum miferas gentes, \& flagello agitaret Bellona fanguineo, vt effet vbi virtus corum enitefceret. In alterius auté commendatione fr animo compleet i volueris

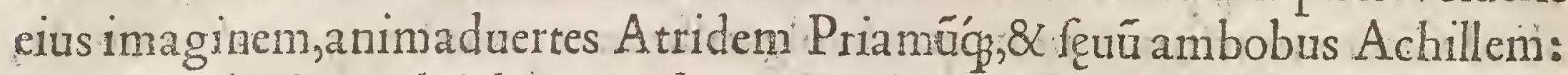
vtrunç enim improbãs hầc verã de vtrog tulit fentêtiám, ait enim, fi fe Pompeius vicerit exulaturum, $\mathrm{f}$ Cæfar moriturü quod cum victore Cæfare mature pa raret,admirari libet illius vltimum vulnus; ac nobile lætum; per quod, vt Seneca inquit, libertas a mifit animá,vtóg om nem deniq viri \& ducis huius dignitatem in vnum coëgerim pariter \& gloriam; alterius romanx fcriptoris hiftoria fententia fretus, Si veris magna paratur Fama bonis,et fi fucceflu nuda remoto Infpicitur virtus, quicquid laudamus in vllo Maiorü fortuna fuit: quis Marte fecundo, Quis meruit tantú populorum fanguine nomen? Hunc ego per Syrtes; Libyæóp extrema triúphum Ducere maluerim, quàm ter capitolia curru Scandere Pompeii, frangere colla Lugurthæ: Ecce parens verus patrix, digniffimus aris Roma tuis, per quem nunquàm iurare pudebit, Et quem fi fteteris vnquam ceruice foluta, Nunc olim factura deum:Alterius \& primiCa tonis illius Porcii, domi,foris \& militix, laudum plena funt omnia. E gregium enim \& fummum præter fapientix nomé in qua nulli mortalium ceffiffe creditum eft, magna hic $\&$ ingenti literarum illius temporis peritia ac eloquentia claritate fuit : nódum enim latinæ lingux fplendor ad fummú \& vltimum dignitatis fuę culmé afcen derat, quod fub Cicerone factun vult Seneca. Cenfura $\&$ triumpho fimili modo cæeteris nec inferior, pręceptis omıiü rerú expetédarú ac feorfü rei militaris datis generi romano. Inter prima verò agri colendi illius æui confeffione fine æmulo agricola optinus fuit; \& quaftor fortiflimus, iuftiflimus pretor, tribunus militú præcelles. Tres quogs res in homine fummas præftitiffe legit, vt optimus orator, optimus fenator, \& optimus impätor exiftimatus fit, quas om nes et finon prius, a tramé clarius fulfifle in Scipione Aemiliàno nó dubiü eft. Süma etiá pręter illa quę diximus virtus Catonis Confulis in Celtiberorú bello fuit; qppequi plura fe oppida cepiffe gin Hifpania dies egiffe cómemorat, éque haud fanè iactantia eft, fi re vera quadringenta fuere. Fuit, vt fertur, fumma quęda inter Cęfaré,et $M$. Antonium comparatio:nam cum ludis relaxandi animi gratia ambo perfape occuparetitur, vt aleis j aut perdicum, vel Gallorum certamine, \& aliorum ani mantium, femper ab Antonio abiiffe victorem eum conftat: vnde non ab re quidam ex confuetis a gurio fapenumero monuiffe eum his verbis vifus eft, Quid rei eft tibi Antoni cum illo a dolefcente? Cararem indicans, fuga ipfum: clarior enim licet fis, \& fenerior, dignitate plurimú domineris, bellisóg magis infudaueris, \& plurimarum rerū v fu excellas, tuus tamen genius tứm q̧ fatum hu iufce genium fatum que reformidat tuáque fortuna in feip fa permagna præclaraque licet fit illius tamen fortuna vquequags blanditur. Harent in fuperioris 
Aphricani dicto vii C.Marii cólulatus, immo reuera non fepté, fed vnus, quumi cæteros præter vnum minus acceperit, fed rapuerit. Inhærent \& duo fpeciofiffimi triumphi. Nam quum apud Numantiam fub eo duce equeftri ftipendio mereret, $\&$ forte vt fit inter coenandum quidam Scipionem interrogaffet, fi quid illi accidiffet, quë nam refpub.xque magnum habitura effet imperatorem, refpiciens fe fupra ipfum Marium cubantem, Vel hunc dixit: quo dicto perfectifima virtus maximam orientem virtutem viderítne an certius acciderit perpédi vix poteft. Illa nimirü cona militaris fpeciofiffimas tota in vrbe futuras conas $\mathrm{Ma}$ rio ominata eft. Quum enim poft Aphricam fubactã \& Iugurtham regem ante currum ductum, Theutonicorum exercitum deletum per Marium conftet,ac porrò cc milia Cymbrorum cæfa, l xxx per eum capta cum duce Hermodo in initio noctis nuncium retuliffet, nemo fuit qui non illi tanquam diis immortalibus apud facra menfax fux libauerit . Subit in hac reputatione M. Claudius Marcellus qui primus Hannibalem vinci poffe docuit, ingentis ardentiśg animi vir, bellator acerrimus vnus ex paucis, ings omni clarus hiftoria, fed imprimis Virgiliano carmine nobilis: fic enim de hoc loquens ait, A fpice vt infignis fpoliis Marcellus opimis ingreditur, Victórque viros fupereminet omnes. Plura quidem viri huius \& ducis in laudem dici poterant, plus autem haudquaquả: Quid eft enim homini,et quid effe poteft amplius quàm omnes excellere? quanquam id Virgilius non tam veriftudio dixerit, quàm laudandi illum alterú gra tia qui hunc ibi fequitur Marcellum, Octauix fororis Augufti filium: multos enim ifte, fed omnes haud dubie nó excellit. Non indignabuntur fuperiores ro manorum, exterarü gentium preter Hannibalem duces, fi inter eorum eximium fulgorem Q.Fabius Maxi.fe iterum immifcuerit, tú quòd romani generis prudentiffimus habitus eft(nondum enim Cato Cenforius famæ huius primum lo cum præoccupauerat) tum quòd huic ipfi Cato idem apud Ciceronem clarum magnæ fapientix ac virtutis teftimonium præbet. Apprime autem honeftatus eft illo Ennii carmine notiflimo, V nus homo nobis cunctãdo reftituit rem.Non hic rumores ponebat ante falutem. Ergo póftque magiṣ̨́ viri nunc gloria claret. Nota funt reliqua quibus hoc famæ decus Maximique cognomen iure fibi debitum, etiam fi ab eo ortú, effe cenferi poffet. Et quanquã huius viri plura con filia ö pręlia memorentur, nó defunt tamen prælia \& ad æquandã aui gloriam Fabii Maxi. Rutiliani qui haud dubie victoriarú numero \& magnitudine pręliorũ fuperior fuit. Vnum holê̄Hannibalê, quem mora \& patientia fregit, fatis effe vult Liuius, inter romani ducis laud es magnum hoftis et fingulare pręconium. Q.etiã Catullú in hoc fummorú imperatorủ numero \& præcellêtia po. ro. voce fua ad fidera $v f_{q}$ produxit. Nam quú ab eo pto roftris interrogaretur, fi in vno Pópeio Magno omnia reponere pfeueraret, affumpto illo fubiti cafus incurfu, in quo fpê effet habiturus, fummo cófenfu acclamauit, In te, iudicióg tali Magnú Pompeium cú omnibus ornamentis que paulò ante retulimus duarum fyllabarú pacio inclufum, Catullo xquauit.Merito etiam huic cómemorationi pracipuu L.Marius, inufitati decoris exemplum adiicitur, quem equité roma num duo exercitus, P . \& Cn . Scipionum interitu, victoriaque Hannibalis la- 
cerati ducem legerunt, quo tempore falus eorum in vltinas anguftias deducta nulli ambitioni locum relinquebat. Adiicietur \& aliud pulcherrimum maxi marum optimarum'q́ rerum L. Metelli vnicum exéplum, pontificis imprimis, bis deinde confulis, dictatoris, ma giftri equitum, ag ris diuidendis vigintidun̂m viri, fummi fenatoris, oratoris optimi, primarii bellatoris, imperatoris fortiffimi,fapientiffimi denique $\&$ ditiflimi, clariflimág in vrbe fua ciuis, qua fibi fimul foli contigiffe nec vlli alteri ab vrbe condita, fatis conftans opinio eft. Alterum L. Syllam qui foelicitatis nomen afferendum fibi putauit, neq laudare,neque vituperare quifquam fatis digne poteft. Dum enim quærit victorias,Scipionem fe popu.ro.quum exercet fauitiam, Hannibalem reprælentat. Auguftus etiam rariffimum virtutis ornamentum fe inter ftrenuiffimos foeliciffimófque duces $\&$ principes digne quidem enumerandum tradit . Decimum enim $\&$ feptimum annum agens, comparatis exercitibus, Hyrcio \& Panfa coff.aduerfus Marcum Antonium \& Decium Brutum tunc Mutinæ obfidentem pro præto re miffus,primo licet conflıctu parú profpere gefto,interempto Panfa, \& fecundo prælio exanimato Hyrcio, ferox iuuenis fuperftes deuictum fugauit Antonium, Romamóp reuerfus fenatui fe inuifum quum videret, aduerfus in gratifi mos ciues cum Lepido et Antonio fe coniunxit,vbi cof, creatus, relicto Lepido cum Marco Antonio, interfectores Cęaris Caffiú \& Brutum infecutus in Gra ciam, tenuit Emathiam, poltreno vi et armis fuperati parricide, inter tres viros tripartito imperio, A fram tenuit A ntonius, Lepidus Aphricã, Octauianus Europam. Hac inter L. Antonius cof.M. Antonii frater vrbem hoftiliter inuafit, imperiofum iuuenem oppreffurus, quem prælio victum ac fugatú Perufix obfeffum, impellente fame, viribus fuis Octauianus fuccúbere coégit. Inde Sextum Pomp. Magni filium, qui infeftatione pyratica vndique maria terrore cópleverat trecentarum nauium claffe toto mari difperfa, expugnatum reddidit, in fugam verfum, eodém og fucceflu cum Lepido qui ex A phrica multitudine armatorum venerat occafione data in Sicilia conflixere, ibíque victor mífere vitam implorãti remifit. Ad Adriaticum littus profectus, Illyricos, Liburnos, Dal matas vincere maturauit:ad Actium deinde Græcię promontorium, vbi cum regina Cleopatra ducentarum nauium claffe $M$. Antonius venerat armis petiturus Italiam, ad fummum cladis terreftri naualíque prælio certatum eft:denique Augufto victore Antonius cum regina, infaufta vela in Aegyptum dedere. Octauianus eum infecutus penes ipfum Pharú deleuit. Victor ad Italiam profectus bis ouans, poft Philippenfe,rurfus polt Siculum bellum, de Dalmatia fue Illyria, déç ad Actium victoria \& Alexandrina triplici curruli triumpho continuóg triduo vrbem introiit, claufo Iano, pacis indicio. Caterum diutius quiefcere non potuit, rebellione gentiú concitus. Reclufo igitur Iano ad Hifpanias extremáque oceani littora traductus, ad Cantabros \& Aftures, fub iugo ro mano ceruices reffectere coëgit, et totam peruagatus prouinciam, terrore armorum docuit feruare mádata. Sarmatæ fimul $\&$ Parthi qui inter feptentrionem \& ortum folis terras incolunt, ad Auguftum fe ad obfequia paratos miferunt. Tigranem in Syria à Cafaris Augufti legato victú ponituit defeciffe. Ad ori- 
entem deinde per legatos omnibus pacatis;ex occiduo littore \& Hifpania Ramam reuectus Ianum deintegro claufit, quem paulò pòft referare opportunum fuit, indéque ad arcticum polum ire coactus, vbi ferociflimæ gentes cótrà facere aufer erant,ideóq Vindelicos, Salaffos, Germanos, Marcomanos, Sueuos, Si cambros, \& quicquid citra vltrág R henum, Danubiumve Barbaria effera fpe êtat fic perdomuit, vt enixè paterentur imperia. Ad meridiem conuerfus, Getulos vicit,\& Garamantes, \& Marmaridas, \& quicquid ad auftrum pacädum reftabat cópoluit. Nec eft de reliquis prouinciis aliqua præter A phricá \& Sardiniam, quấ non ille adierit,fine exemplo rerú potitus, totóg denũ fubactis, $R$ omæ quum eflet; terra maríq pace parta, Ianum Quiritum tertio firmauit, \& perpetuus dictator ac patrie pater factus elt, foeliciffimus omniú principun, necdum aliorú fed fuo etiam iudicio habitus eft. Nam quum nepotem in militiam deftinaret, à diis optauit vt illi fortitudinem Scipionis, beneuolentiam Pompeii,fus ique ipfius fortunam darent, veluti fibiipfi permaximum opus fuiffe fortunam diceret. Præter ipfus fortunam, finilem denique ei ducem vt nulla vnquá tempora tulerunt, fic nulla forent,po.ro. fententix fi credimus, grauiffimíque poéta Flacci dicentis,

Præenti tibi maturos largimur honores,

Iurandasóp tuum per nomen ponimus aras,

Nil oriturum alıàs, nil. ortum tale fatentes,

Sed tuus hic populus fapiens \& iuftus in vno,

Te nolt ris ducibus, te graiis anteferendo.

Hæc de ducú pręftantia fuperioris æui pauca quędả attigiffe fat fit, Nino, Libes ro, Caftore, Polluce Herculég deinduftria omiffis: ea enim eos fingulari amplitudine fuiffe finguli fatentur, vt omnium qua memoria hom inú complexa eft res geftas fuperare videantur. Quifquis verò tantorum clarifimorum quos diximus ducum $\&$ imperatorum rebus geftis acta recentia comparanda côtuma ci ac proterua obltinatione duxerit, à vetuftatis veritatisíg omnis cognitione alienus fit neceffe eft. Ego enim hanc ducú pracellentiam noftris \& temporibus et ducibus deferendã maxime cuperé, fed va fra \& callida maiorú noftrorú conGlia, admirabilemó illam \& incredibilen ac pene diuinam rerum militarium gloriam animo mecum ipfe voluens, velut equus arbiter om ni vtrinque affectus vacuus, cui iure quodam fuo comparanda fint inuenio neminé. Cæterum, ftre nuifime dux, Sigifmunde Pandulphe, quum fiat inter claros et illuftres viros, vt perfape folet, non iniocunda fuperftitum concertatio ducum, qui rei militaris peritia, qui armorum exercitatione, qui praliorum numero, qui nationum ac hoftum varietate, qui probitate, qui prudentia, grauitate, fide, conftantia, animi magnitudine, celeritate, cæteriś́p præclaris monumentis \& imperatoriis virtutibus digniores cenfeantur, maioribúfque illis propius videantur accedere,aliíg alios quofque noftra atatis in medium vnum que locum conferant, femper ca: teris te denigh fine controuerfia probabilibus adducti rationibus nó folum pręferunt, led fummos quoque \& maximos, rerúm que huiufcemodi gnaros homines, ac aliorum omnium mortalium fama celebres, fecum in eandem fentétiam 
trahunt:quanquam hoc minime dubium effe debeat, fed luce clarius, cuiuis re* cte rerum tuarum cumulú recenfenti, quum folus laceram et infractam tot bellorum incendiis hactenus Italiam atque ruinam extremam minitantem, hume ris tuis velut Atlas cælum, ne in fe ipfam funditus tota collaberetur, in auxilia hinc inde accitus iple fuftuleris. Nota quin ita etiam funt illa, qua hoc afpero \& difficili temporum curriculo, pro clariffimo imperatore Francifco Sphortia in eius tutelam aduerfus Eugenium, Pontificem Maximum, qux pro Eugenio aduerfus hunc ipfum ftrenuiffimum ducem, qux pro illuftrifimo Taraconenfum rege Alfonfo, qux pro Infubrium, Genuenfiumó bellicofiflimo duce Philippo Maria, qua denique ab vtriufque fuperi atop inferi maris littore pro Florentinorum, Venetorum'ó ac Senenfum, potentiflimarum rerum publicarum amplitudine, fplëdore ac gloria, virtute animi,aut dextre robore palfim \& vbique cógrediendo, audendo, agendo perpeflus es, vt omnibus non folum noftris, fed exteris nationibus, et remotiffimis populis inter excellentiffimos ac probatifimos imperatores, qui bellicofiffimi \& ftrenua manu docti fint, iuxta Home

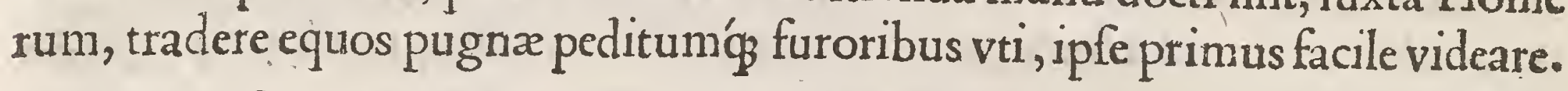

Poena defertorum, er miltum animaduerfo uaria, ducibus non obtemperantitum, (1) eos vero qui ducis aut legis minus obtemperaffe n tarbitrio, varia diffimiliś́g animaduerfio procedebat. Nam alii in fortuna,infamia lii,atque alii in fanguine lędebâtur: \& quoniam acerbitas vlcifcen 1.2. di plerunque maleficii, poenarúm $q$ formido, bene atque caute viuen di difciplina eft, violatæ fidei quã femper maiores noftri maximi fecere fume. musinitia. Hiftoria de Metio Suffetio Albano nobis ignota non eft, quoniam pactum atç condictum cum Tullo rege po.ro.perfide ruperat, binis quadri gis euinctus in diverfa nitentibus laceratus eft: nouvm fane atque afperum fupplicii genus. Diffectum enim antea fuifle apud Romanos, neminem equidem neque legi,neg audiui. Et quoniam nihil videri poteft efferacius, nihil ab ho* minis ingenio diuerfus, quàm quòd mébra $\&$ artus breuiffimo laniatu diftrahantur, reftat vt quod de fectione partitionéque corporis inhumaniffimum vifum eft,rationem breuibus reddamus. Omnibus quidem virtutū generibus exercendis colendif $f_{\beta}$ po. ro. è parua origine ad tantæ amplitudinis inftar emicuit, fed omnium maxime atque pracipue fidem coluit fanctámque habuit tam priuatim quàm publice. Sic confules, clariffimos viros, hoftibus confirmanda fidei publicx caufa dedit : fic cliêtem in fidem acceptü cariorem haberi quàm propinquos, tuendumóp effe contra cognatos cenfuit, neque peius vllum facinus exiftimatum eft, quàm fi cui probaretur clientem diuifum habuiffe. Hanc autem fidem maiores in officiorum militarium vicibus, vfu atog commercio maxime fanxerüt, quòd aliter totius rei militaris dif́cipling neruos adimi putarent, fi hominum perfidia fine immani \& horrenda poena eluderet : in aliis conftat, nulli gentium mitiores poenas placuiffe. Sic Aurelius Cotta cof. quum ad opus equites neceffitate cogente iuffiffet accedere corúm que pars detrectaffet imperium, queftus apud cenfores effecit vt à patribus notarentur, deinde obtinuit ne eis propterea xra procederent, quos quia ftipendium menftruale vel annuum 


\section{DE RE MILITARI LIB. XI.}

ignominiæ caufa adimebatur, dirutos ære appellabant antiqui,quôd æés dirué batur in fifcum, non in militis facculum. Artaxerxes Arbacem quendam, me dum hominem, qui in pręlio ad Cyrum defecerat ac rurfus eo mortuo rebella. rat; quum eum ignauix non proditionis neque fimultatis reum fatuens cödem nalfet, iuflit nudum fcortum impofitú ceruicibus diem totum in foro circunferre. Alterius veró quòd ad defectionem duos quoque ex hoftibus fe aditurum pollicitus in médacio deprehenfus effet, linguã tribus clauisaffigi iuffit. Quum Hannibal Ponus cum exerciru in I talia effet, \& aliquot pugnas po.ro.aduerfus pugnaffet, primi totius I talix Brutii ad Hannibalem defciuerüt, id romani egrè palli pofteaquam Hannibal Italia deceflit fuperatique Poni funt, Brutios igno minia caufa non milites forrbebant nec pro fociis habebát, fed magiftratibus in prouincias euntibus parére \& præminiftrate feruorum vice iufferunt: itaq hi fequebantul magiftratus tanquam in feenicis fabulis qui dicebantur lorari, aut quos erant iufi vinciebant, aut verberabant. Appii Claudil fententia fenatusóg confultum omnes qui à Pyrrho rege Epirotarum capti, \& poftea ab co vl tro remiffi erant, decreuit vt ex his qui equo meruifent peditum numero militarent: qui pedites, funditorum auxiliis ad Criberentur, néve eorum cuipiam ad priftinum tandem militie ordinem liceret redire, nifi bina quifque folia ex ho ftibus reportaret. Fuit \& antiquis quog animaduerfo militaris, iubere ignominix caufa militi venam folvi $\&$ fanguinem mitti: cuius rei rationem etfi in veterum libris'haudquaquam potuerunt inuenire, hoc tamen pòlt factum opinati in militibus fupentis animi \& à naturali habitu declinantis, vt non tam poena quam medicina videretur, poltea tamen ob pleraque alia delicta id factum effe credunt per confuetudinem, quafi minus fani viderentur omnes qui con tra officium deliquiffent. Craflus is qui à Sempronio A fellione \& à plerifg aliis hiftoriæ romanæ fcriptoribus traditur habuiffe quinque rerum bonarum maxima \& pracipua, quòd ditifimus, quòd eloquentifimus, quồd nobiliffimus, $q$ iureconfultifimus, quòd pontifex maximus effet, cum confulatu obtineret $A$ fiam proninciam $8 C$ circúlidere $\&$ oppugnare Leucas pararet opusóg effet firma \& procera trabe qua arietem faceret quo oppidanorum muri quaterentur, fcripfit ad magiftrum graxcum, maiorem Athenienfum fociorum, anicorum po. ro.vt ex malis duobus quos apud eos viderat maioré ei mittere procuraret: tunc: magifter græcus cóperto qua mobrem malum defideraret, non vti iufferat maioren, fed quem magis effe idoneum aptiorémop faciendo arieti faciliorémque portatu exiftimabat, minorem mifit. Craflus eum vocari iuffit, \& quum interro gaffer cur non quod iufferat mifffet, caufis rationibúfque quas dictabat fpretis, vefiméta detrahi iuffit virgifque cecídit, corrumpi atque folui ratus omne officiü imperantis, fr quis ad id quod facere iuffus eft, non obfequio debito, fed conflio non defiderato refponderit. L.Papyrius dictator Q. Fabiú R utilianum magittrum equitũ, quòd aduerfus dictú eius quàmuis folici pugna dimicallet, Samnitibus fulis, virgis tamen cæfum popofcit, lecuri percuffurus, $\&$ contentione aut precibus exercitus occafionem Fabio confugiendi in vrbem dedit,eunich profugienté Roman profecutus eft, ne 1 bi guidem remiffo fupplicii prius metut quàn 
quàm ad genua eius \& Eabius cú patre prouolueretur, \& pariter fenatus ac po: pulus ro. rogarent: teftatus tandem eam ponam non Fabio, fed populo \& tri. bunorum concedere poteftati. L. Calfurnius Pifo cof. quum in Sicilia bellum aduerfus fugitiuos gereret, \& $T$. equitum præfectus fugitiuorü, multitudine hoftium circunuentus arma tradidiffet, his præfectum ignominia generibus affici ịlfit, Eum toga lacinis abfciffis a mictum, difcinctáğ tunica indutú nudis pedrbus totum diem ad principia vfop per omne tempus militia quo ab eo meruerat adeffe iubens, conuictu hominum, balneorun vfu, turmisóp equitum ac equis quibus præfuerat ademptis, in funditorum alas tranfcripfit.Q. etiamFuluius Flaccus cenfor Fuluium fratrem cohortem legionis in qua tribunus militum erat iniuflu confulis domū dimittere aufum fenatu amouit. T . Manlius Torquatus filium quơd is cótra edictum cum hofte Gemino Metio Tufculanorum duce, infcio vel ingnaro patre prouocatus pugnauerat, quamuis victorem, in cöfpectu exercitus cęfum, fecuri percuff t. Pofthumius Tyburtius dicta tor, A. Pofthumium \& filiü quòd nó fuo iuffu, fed fua fpöte fuos egreflum hoItes fuderat, victoria gloriä licet reportaffet, fecuri percuti iuffit. Nec minus ani mofe A. Fuluius fenatorii ordinis euntem in aciem filium iniuffu fuo è vita fuftulit, quàm $T$. Manlius, aut Pofthumius dictator . Iuuenem nanque ingenio, literis, \& forma inter aquales prętantem prauo conflio Catilinæ familiari tatem affecutum, ińp caftra eius temerario impetu ruétem in medio itinere ab Itractum vltimæ ponæ fupplicio affecit, præfatus non fe Catilinæ aduerfus pa triam, fed patriax aduerfus Catilinā genuilfe filium. Milites autem qui hoftium caftra iniuffu principis aggredi effent aufi exauctorauit omnes Claudius, fecundus eius nominis imperator,eófque Romam vt digne punirentur mifit, fićṕ in belo fxpius feueriúfque vindicatú effe conftat apud maiores noftros in eos qui contra imperium in hoftem pugnarunt, quíque tardius reuocati pralio excefle runt, quàm qui figna relinquere aut pulî loco, cedere aufi erant. Q. Fabius Maximus $\&$ fr rranlfugarum dextras qui $\&$ in præfidiis Romanorum ad hoftium ftationes cófugerant iple aliquando pracidit, vt defectionis metum reliquis iniiceret, fuapte tamen natura $\&$ clementia defectiones prohibendas placandas $q$. effe manfuetudine ac miti oratione cenfuit, neque omnem fufpicionem accufare atop omnino omnibus fufpectis moleftum effe. Nam quum animaduertiffet, militem quendam Marfum fortitudine \& genere inter focios primarium defe ctionis accufari,nullam in eum animaduerfionem egit, fed cum fineret $f e$ præter dignitatem neglectum iri, Tunc, inquit, duces ad gratiam ineundam potius accufantur, quum pro eorum virtute honores impartiantur: deinde illum accufauit, qui nulla in re officium eius expofcebat. Hæc enim cum dixiffet, acerrimo equo, alíl q $_{\beta}$ muneribus eum ornauit: quare exinde virü fibi fidelifímum ftudiofffimúmque effecit . Apud eundem Fabium quum miles Lucanus effet accufatus quòd mulieris amore noctu fxpe à caftris vagaretur, cxterùm mirabili armorum virtute vir effe narra retur, quã deperibat comprehédi ea clam iul fit, \& ad fe adduci: vt autem adducta eft,accerfito homine, quòd prater legem, inqt,pernoctaret haudqua $q$ nos latuit, ac ne prius quidẻ latuerat $q$ pbitati ftu- 
deres, quare fortiter ac recte factis èrrata códonêtur : reliquü nobifcú eris, habeo enim fponforem, $\mathcal{Q}$ ad ductá mulierculam ei cómendauit, ac tradidit Non frnit nos Q. Fabius Max.inter has rei militaris poenas hoc in loco de te filentium facere,Sigifmunde, quòd militum peccata more fuo neque obferues omnia, neq meritis ac debitis eos poenis profequaris, verùm ex induftria permultas diffimu les, fciens genus hominum ad peccandum pronum, nec facile naturam \& confuetudinem eorum inüeteratầ extirpari pofle, vtóp lafciuiæ \& latitiæ frena perfape relaxas, fic quim hoftis in propinquo eft, fegnes, contumaces, defides, neglí gentes, feditiolos, ac defertores feueriffime punis, quòd hae vitia non ad finguilorum mores tantum, fed ad fummam rerü $\&$ omnium falutem pertinere intelligas.Illud etiam femper tibi innatun $\&$ ingenitum intelleximus, vt vehementer vfque dolueris pro erratis militum $\&$ aduerfum quéquan arma fumi opor tere: contrà verò læatari ad modum, abs te plurimos feruatos \& exornatos iri : \& quod diuini muneris eft, hac fua feueritate non hominum interitum cupere, fed falutem potius fingulis pro virili prętare velle. Admirantibusautem multis ac reprehendentibus quỏd vt mitis nimium fis, ita \& truculétus nimis \& atrox aliquando videare,refpódere foles crudelitatem fcilicet nemini minus quàm principi conuenire, imperatorémg exercitus vt victoria potiatur potius timendum effe quàm hoftem. Iulius Cxlar oborta feditione militú paucis percuffis caftra fedaffe legitur, $\&$ fidem militum reparaffe: vbi verò facrificia committerent mi licia, milites fuos fertur compefcuiffe, maxime quando vrbem ingreffos non licuit homines fpoliare, aut templa deorum, quod eis poftmodum ingrauefcente feditione exprobrauit. Numinibus nanque Romanis ciuibusóp iurati impugna re non poterant qux facramento militix fufceperant defendenda. Qui autem tali ignominia notabâtur milites, nec ęra percipere,nec militaribus gaudere pri uilegiis, nec habere aliquod cum gladio telóque commercium, neque porro ad cingulum reftitui fas erat, nifr cos antè præ cæteris virtutú meritis inffgnirent. Auguftus militarem difciplinam feueriffime rexit,legiones contumacius paren tes, ac immodeftè miffioné poftulantes dimifit exauctora uitọ́. . Céturiones item ftatione relicta,itidé vt manipulares capitali animaduerfone puniit. Pro catero autem delictorum genere variis milites ignominis affecit, vt ftare per totuni diem iuberet ante prętorium, interdum tunicatos difcinctófque, nonnunquam celpitem portâtes.C.Curio bello Dardanico circa Dyrrhachium quum vnam de quinq legionibus feditiofam vidiffet, eam procedere iuflit inermem, difcinctámque in confpectu armati exercitus ftramenta coégit fecare. Poftero autem die fimiliter foffam difcinctos milites facere, nullífque precibus legionis ab eo impetrari potuit, ne figna eius fubmitteret nomenó $\$$ aboleret, $\&$ milites in fupplementum aliarum legionum diftribueret. L.Domitius Corbulo in Armenia duas alas, \& tres cohortes qux fecum ad caftellum initio hoftibus cefferãt, extra vallum iuffit tendere, donec affiduo labore \& profperis excurfionibus redimea rent ignominiam.P.Cornelio Nafica, Decimo lulio coff. qui exercitum deferuerant damnati, virgis iśp cæefi publicè vænierunt. M. Cato ab holtili littore in quo per aliquot dies mäferat, cû̉ tardo profectionis figno daffem foluiflet, $\&$ reli 
ctis è militibus quidã acerrima voce et geftu expoltularet vti tolleretur,circum acta ad littus vniuerfa claffe comprehenfum fupplicio affici iuffit, \& quem occifuri per ignominiam hoftes fuerant,exemplo potius impendit. L Paulus, Perfa rege fuperato, externorum quofdam tranffugarum eléphantis conculcâdos cenfuit. A phricanus item pofterior euerfo punico imperio, eiufdem generis $\&$ culpr hominis in edendis populo. fpectaculis feris beftiis obiecit. Eundem cenforem declaratum, ferunt adolefcentem priuaffe equo quoniam fumptuofè in cona quo tempore Carthago oppugnabatur placentã melle confectam guam in vrbis fmilitudine formarat, $\&$ hanc Carthaginem appellarat, conuiuis prępofuit rapinæ, percúctantióg adolefcenti quam ob rem equum fibiabftuliflet, Prior quàm ego, Carthaginem, inguit, diripuift. Xerxes Perfarum rex Phitio quing filiorum patri vnius vacationem petenti, quem vellet eligere permifit, deinde quem elegerat in partes duas diftractum ab vtrog latere vie pofuit, $\&$ hac victoria luftrauit exercitû. Actifanes Aethiopum rex Aegyptiis in deditionen fuam redactis, fumma eis equitate imperauit. Latrocinia enim nouo more con pefcuit, fontes neq̧ morte plectens, neque linqués impunitos,iudicio conftituto, reos omnes in vnum cogens miti fentetia damnauit. Amputatis enim naribus in vltimam deferti ire cos compulit, ibióg ciuitatem condidit ab excifis naribus Rhinoceram appellatam . Afluerus quum cuperet famam $\&$ fermonem apud omnes gentes \& nationes vulgari à fe Cyrum interfectum effe, Mithridate qui primú Cyro vulnus inflixerat, Chare deinde à quo fuccifa poplitis vena Cyrus conciderat quàm ægrè ferentibus fe iniufte ea gloria muneribus à rege miffis fpoliari, his regi nuntiatis vehementer ira incenfus, caput Charis à ceruicibus abfcindi iuffit: hisóg quú intereffet mater, $\mathrm{Ne}$ tu, inquit,rex ita hunc Charé capitalem hominem breui poena neces:à me enim fibi eorum quę diu audet merces perfoluenda eft. Permittente autem rege matri fupplicii fumendi poteftatem, à tortoribus fuis hominem comprehendi iuflit, decémque dies in tortura haberi,tum oculos effodi, $\&$ in aures liquefactum æes infundi,fic omni fupplicio excruciatum necari. Paulò pòft ob eandé caufam Mithridatem quòd apertè profitebatur manu fua Cyrum concidiffe, nec vt Artaxerxes vanum negi irritum telum adieciffe, fed tranifixo tempore hominem ftrauiffe éque vulnere tädem. interiiffe, fcaphis necari iuffit. Genus autem mortis ac fupplicii huiufmodi fuit, Duabus exadificatis fcaphis inter fe congruentibus, in altera hominem qui ad fuppliciü datur refupinant, alteram defuper imponentes, fic ambas coniügunt vi caput, manus, ac pedes foris excludantur, reliquum verò corpus totum intus claudatur: præbent homini cibum, ftinulisóg oculos fodientes vefci et inuitum cogunt: vefcenti autem pro potu las melle mixtu m in os infundunt, faciémque eodem confpergunt, fic eius verfantes fcapham femper aduerfo foliopponunt, 8 mufcarum infidentium multitudine ora quotidie obtegunt, cump virtus ea faciat quæ edentes bibentes $q_{\not}$ h homines neceffitas cogit, ex cor ruptione $\&$ pu tredine varii pullulät vermes, quibus intra veftes penetrantibus corpus abrodarur : quum enim perfuncto vita homine fuperior amouetur fcapha, exefa caro afpicitur, \& circa vífcera taliun ferarum aliarúmque quottidie fubcrefcétium. multitudo 
multitudo apparet . Huiulmodi fupplicis Mithridates excruciatus ad deciñ vfque diem calamitofam vitam perduxit, atog fic demum extinctus eft. A uidius Caflius qui fe Mariü dici voluit, mılites qui prouincialibus per vim aliquid furripuiffent his in quibus peccauerät locis in crucem fuftulit. Primus etiam id cru delıtatis potius quàm feueritatis fupplicii genus excogitaffe fertur, vt pergrandi \& procero ftipite terræa affixo à fummo ad imum vfọ̉ dănatos ligaret, áb imóque ignem adiiciens incenfis aliis, alios fumo cruciatúg ignis, alios metu ac timore necaret. Idem denos cathenis vinctos in profluentem mergi iuffit, multílque defertorum manus excidit, aliis crura \& poplites, maius exemplum effe affe rens viuétis miferabiliter criminofi quàm occifí. İdem cú ipfo infcio manus au xiliaris tria milia Sarmatarú negligentius agentiú in Danubii ripis occidiffet, 8 cum præda ingenti ad eum rediiffet, [perantibus tribunis præmium q quàm parua manu tantum hoftium occidiffent, rapi eos iuflit, \& in crucem tolli,atque vltimo fupplicío affici, dicens euenire potuifle vt eflent infidia, ac periret roma. ni imperii reuerentia: \& quum ingens feditio in exercitu orta effet, proceffit nu dus in medium, campeftribus folum tectus, $\&$ ait, Percutite me fi audetis, $\&$ corruptædifciplinæ facinus edite : tunc quiefcentibus cunctis timeri meruit, quia ipfen non timuit. Pefcenius Niger decem milites qui prouinciali ablatum gallinacium comediffent necari iuffit,exercitum autem qui ne occiderentur, non ar mis, fed precibus impediret, interdixit igni $\&$ cibo cocto, hec re vefci alia nifi aqua frigida, et pane conceffit, decupli precio prouinciali primum reddito ac foluto. Alexandri vero Seueri vel Aurelii fententia mulierculę niles carpentarius adiudicatus eft, vt qui conuitia dixerat, feruili opere annofæe foeminà nutrimen ta præftaret: \& quu egre hoc ferrent milites, perfuafit omnibus vt ne molefte fer rent,ac modefte eos terruit. Libidinis autem caftigator Aurelianus maximie fu it. Nam \& feipfum continuit, $\&$ adulteros atroci poena coërcuit milites: natrique qui hof pitis vxorem violaffent, duabus inflexis arboribus fune alligauit, quo de miffo reus è veftigio vitrinque pendens laceratus occubuit. Longe afperius $\mathrm{Ma}$ crinus caftigauit milites, qui cum ancillä hofpitis violaflent,eos viuos(duo nanque erant) boum in corio emiffis modo capitibus fepeliuit, vt vermium multitudine fuccrefcentiun diutius torquerentur. Inuenerunt alii crucibus non vnius quidem generis capite conuerfos in terram fufpédere, alii per obfcona ftipitem immittere, alii patibulo brachia explicare, alii viuentibus cadauiera alligare, ve Opilius Macrinus \& Mezentius, de quo Maro;

Mortua quin etiam iungebat corpora viuis,

Componens manibusq́p manus atque oribus ora,

Tormenti genus, \& fanie tabóque fluentes

Complexu in mifero longa fic morte necabat.

Statuerunt etiam in infligend is ponis aliquādo maiores noftri vt fi à multis effet flagitium rei militaris admiffum, fortitione in quofdam animaduerterentr, vt metus videlicet ad omnes, poena ad paucos perueniret. Nam miles qui locun non tenuit, qui holtium impetum vímque pertinuit, poteft idem poftea $\&$ miles effe melior, \& ciuis vtilis $\&$ vir bonus. Circa ducum itaque \& imperatorum edi- 
cta boni milites parebunt \& obfequentur, nifi forte quod pracipitur faluti reip. aduerfum inueniatur. In co enim haudquaquam obtemperar, nifi perfidus $\&$. impius miles. Quid enim iniquius quid deteftabilius quàm fine difcrimine ag gredi quacung dictauerit amperator? Nonne apud omnes vox ifta quondam in caftris forfan probata funefta eft, $\&$ crudelis plenág perfidix habita, Pectore fi fratris gladium iuguloóp parentis

Condere me iubeas,plenóg in vifcera partu

Coniugis, inuita peragam tamen omnia dextra.

Si fpoliare deos,ignemóp im mittere templis,

Numina mifcebit caftrenfis flamma monetæ.

Caftra fuper Tufifi ponere Tybridis vndis,

Hefperios audax veniam met ator in agros.

Tum quolcung voles in planum effundere muros,

His aries actus difperget faxa lacertis.

Illa licet penitus tolli quam iufferis vrbem

Roma fit.

Et quanquam hoc nequius dici ab homine potuerit nihil, $\&$ vnde magis deberet, $f 1$ fidelis effet, romanus imperator offend $\mathrm{s}$, in co tamen fceleratus miles officii fui fidem his verbis facere ftuduit, vnde feipfum circunfcripta militari obedientia maxime infidelem \& perfidum effe conuincit.Hęc cótra eos qui militaria fegnius ac negligen. tius, vel aliter ac difciplina cómunis exigit tractantes, ignominię ac dedecoris notã fubiere dicta fint,

\& exemplis plurimis cöfirmata,vt ex alie no milites malo fuum difcant pręcauere, aut alienis virtutis exem: plis prouocentur.

Finis Vndecimi. 


\section{ROBERTI VALTVRII}

\section{A D M A G A I M V M E T ILL V S T R M}

Heroa Sigifmundum Pandulphum Malateftam fplendidiffimum

Ariminenfum regem, ac imperatorem femper inuictum;

de re Militari Liber Duodecimus.

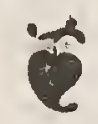

De triumphis, quidq;; triumphus, or unde.

cap. i:

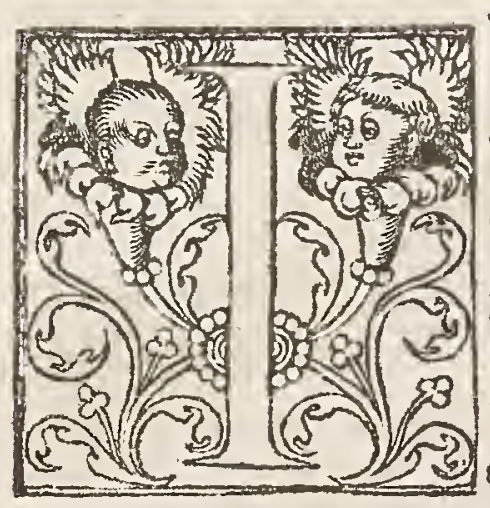

Vfto denique ac debito narrationis noftræ ordine; Sigifmun: de Pandulphe,operi confummationem triüphis imporiemus; quum hi bellorü fint finis, victoribus decus $\&$ glora. Eft enim triumphus omnium miltarium rerum honcs fuprensus, maxi máque omnis vtriufque fexus, atatis, vniuer læ vrbis exultatio, \& occurfus quidam, quod fiebat honorifica holtuum clade duci $\&$ victrici turbæ redeunti, rerúmque fortiter ac foeliciter geftarum fpeciem

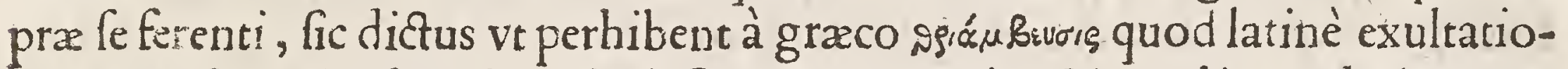
nem fignificat.Credunt hoc alii à Græcis nomen in cóluetudinem deriuatum, fimúlque huius honoris quicquam ad $L$ iberum patrem, primum eius auctorem pertinere, quem şiqusbap nominant: quod etfi haudquaquam verum effe, Plutar cho auctore conftet, vir tamen omnium vndecunque doctiffimus atque acutiffi mus, M. Varro, hinc inde afferit inclinatum. Tranquillus autem triumphum latinè dicit potius appellatum, quôd is qui trium phâs vrbem ingrederetur, tripar * tito iudicio honoraretur. Prius autem de triumpho duci concedédo exercitumi iudicare folitum erat, fecundò fenatum, tertiò populum:atqui de co maxime qui vel dictator, vel conful,fiue prætor res gefliffet triumpho dignas. Liuius, $\mathrm{Omni}$ bus locis re bene gefta de hoc iudicabat exercitus, fenatulconfulto, iuffitique populi triumphans, dictator in vrbem rediit. Idem xxxi.L.Cor. Lentulus procof. ex Hifpania rediit, qui quum in fenatu res ab fe per multos annos fortiter focliciterọ́ geftas expoluiffer, poftulaffétque vt triüphanti fibi inuehi liceret vrbem, res triu mpho dignas effe cenfebat fenatus, fed exemplum à maioribus non acce piffe,vt qui neque dictator, neque conful, neque prator res geffiffet triumpharet, proconfulem sllum Hifpaniam prouinciam, non confulem aut pratorem obtinuiffe: decernebatur tamen vt eo ouans vrbem iniret, intercedéte etiam Sempro nio L ongo, Tribuno pleb qui nihilominus more maiorum hand vllo exemplo futurum dicebat. Poftremo victus confenfu patrum tribunus ceflit, \& ex fenatufronfulto L. Lentulus ouans vrbem eft ingreflus.

$$
\text { Gg } \ddot{i} \quad D
$$




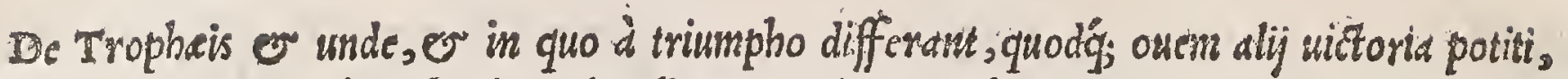
ali bouem; huncq; alij, wel gallum immolare confueterant. Cap.

Llud etiam animaduertendum, ne quod de triüpho \& trophax male accipiunt,nos quoque confundat,opinantes vnam rem duobus no minibus appellari debere. Vt enim re vera qui Martiam \& terrificam holtum crede pompan lege triumphali agebat triumphans $\mathrm{di}$ cebatur, fic qui hoftes fugaffet trophęu m appellabãt: non ab re,à græco r sóøalop, hoc eft, ab hoftium conuerfone dictum. Vocabant etiam veteres trophaum ftipitem fiue truncum montanæ quercus abficifum, inftar fuperati hominis fabricatum, \& veluti fpoliis \& armis eiuldem indutum: affixa enim quaqua verfum fpolia impendebant, ornatu plurimo, ac decore difpofita,neque hoc nifi in eminentioribus locis figebatur: vnde Crifpus de Pompeio, Deuictis Hrfpanis trophæa in Pyreneis conftituit, ex quo more in vrbibus trophæa figebantur in arcubus exadificatis: vnde poêta nofter elegantiflimus,

Ingentem quercum decifis vndique ramis

Conftituit tumulo, fulgentiaque induit arma.

Mezenti ducis exuuias tibi magne tropxum

Bellipotens aptat rorantes fanguine criftas,

Telíque trunca viri \& bis fex thoraca petitum,

Perfoffumque locis, clypén que ex ære finiftræ

Subligat,at que enfem collo fufpendit eburnum.

Alio idem in loco,

Indutófque iubet truncos holtilibus armis

Ipfos ferre duces, inimicáque nomina figi, pro inimicorum.

Dicit autem affixos trophæis titulos cum nominibus occiforum. Ad hrcilunius Iuuenalis Aquinas,

Bellorum exuuiæ truncis affixa trophæis,

Lorica \& fracta de caflide bucula pendens,

Et curuum temone ingum victx'p̣ triremes,

Ampluftre \& fummo triftis captiuus in arcu.

Illud quoq nec prætermitten dü,triüphi genus non ab ouatione, hoc eft, clamore Bacchico,ficuti multi putauere, ouationé appellari, táetfi ouantes illam canétéf tranfmittant,vt Plutarchus inquit, at quum milites in magno trium pho \& plena victoria bouem, in hoc immolare ouem côfueuerunt, vnde huic triüphi generi nomé extat: vtó́p qui de pugna venientes cum multitudine obuiă ad numina minora ibant, $\&$ ibi fugatis holtibus oues diis immolabát, Ouantes dicebantur, fic $\&$ ouatio ppriè minor triüphus, \& qui ouationé meretur, \& vno equo vti tur,et à plebeis vel equitibus romanis deducitur ad capitoliú,et de ouibus facrificat, vnde et,vt dictü eft, ouatio: qui aute triumphat, equis albis vtitur quatuor, \& fenatu præeúte in capitoliu de tauris in eo facrificat: in quo nec illud fíentio obuoluendú quod ad mitiores triüphos, $\&$ ad ouationes attinet, fuper quo diffen fiffe veteres fcriptores inuenio. Partim enim fcripferunt, qui ouaret introire folitum equo deuectü, \& Sabinus Maffurius pedibus ingredi ouantes dicit non fequentibus 
quentibus eos militibus, fed vniuerfo fenatu.Dignü \& opportunử etiäarbitror Spartanorú legiflatorem cótemplari, qui aliquanto aliter ac Romanorú more fa crificandum inftituit. Nam fi quis Laced moniorum dux quod velit dolo aut perfuafione cófecerit, bouem mactat: fi in bello res gefta fuerit, Gallum.Hi enim etf bellaciffimum genus fint; \& apud omnes habeantur, ampliora tamen magiśq homine digna quæ ratione ac prudentia, quàm qua vi aut fortitudine facta fint,iudicabant.

Varia fecundum diuerfas gentes or ndtiones triumphorum gentra.

Càj. IIjo

16. Th: T'q non idem in triumphorum facrificiis apud omnes feruatæ religionis exemplú extat,fic varium apud diuerfas nationes triumphan (1) di morem fuifle cóftat. Et vt triumphi primun omnium repeta2. mus auctorem, Dionyfum, qui latine Liber pater dicitur, India fubacta,multarum gentium fpoliis triumphantem, vincti primum elephanti fubi iffe currum eius memorantur. A pud Aegyptios Sefoftris eorum rex, tam elato, tam immani animo fuifle fertur, vt quotannis non elephâtos, fed forte reges fingulos è fubiectis ịngere ad currum folitus erat, fićs triumphaffe, nullo maiorum fretus exemplo, quod equidem inuenerin: tantú licentix dabat gloria, im manitas , \& intoleranda fuperbia . Erichthonius etiam victor, quadrigam \& equos quatuor primus iunxit in Gręcia. A pud noftros Coffus et Marcellus opima fpolia ferentes, quadrijugo fimiliter curru inuecti funt. Romulum verò non recte Diony fius ait curru effe vfum :erant enim Rome, in promptúq omnibus vt menorie proditú eft, Romuli pedeftres ftatux fpolia ferétes, ex quo pedeftres quoqg eius fuiffe triumphos nō ob curum eft. Tarquinium Prifcum deinde; deinde Damarati filium indecoram huiufmodi currus \& equorum quatuor formam, \& magnificétiam triumpho ftatuiffe memorät, ab Hetrufcis tamen prius fumptam $\&$ in vfu habitam:affirment licet alii Publicolam primum in curru. tali pompa triumphaffe, quam \& ipfam vt maiorum legibus plurimis \& maximis ducibus conceffam, fic nonnullis ademptam denegatam'ǵp non fine maximis rationibus inuenio.

Quód non omnibus triumphi decernebdncur, or quibus.

Cap. IIjil:

V um enim eo triumphandi honos perueniffet, vt poffe maius quic(c) quàm neq imperatori fenatus populuś́s ro.ac exercitus dare, nec ab (1. 20$)$ his imperator accipere, deuict is holtibus ampliffimo pro honore $\&$ 2. gloria videretur, proinde ob exigua quog pradia leueś $\beta$ conflictus, honorum maximum fibi decerni dux quifg triumphü expofceret, lege fuit occurfum vt ei foli liceret vrbem triupho inuehi, qui rebus fortiter ftrenuéq geftis clarus effet imperator, \& hoftiles exercitus ad quing miliú vfọ numerüm fun. dendo profligädóg vna dimicatione cecidiflet. Pona deinde per L. Mariü Mar cump Catonem trib.pleb.ducibus iniecta, qui fallo vel peréptorum hoftiú vel defideratorum ciuium numerú Cenatui per literas retuliffent, iubentép pręterea ingrediêtibus vrbem, quaftorú officium his de rebus iureiurädo adigi, vana fcì licet ea nequaquá fuifle qua fenatui nunciaffent tribuni ple, itidem vt antè fole bant triúphum poftulátibus aduerfari, ita vt nonnung viros fortes ac ftrenuos $\mathrm{Gg}$ iii impedien 
impedientes, aliorum triüphos deterrebant,vtó triumpharent,ficut de Manlio proditú ef efficiebẫt. Moris etiâ erat vt imperii auctione, nó $p$ reftitutis que aliquando eius fuiffent, laureá decerni ius éflet, fićóg ab Q. Fuluio, Campano populo fubacto,et L.Opimio Fragellanis in ditionem redactis, triumphandi potefta tem à fenatu petentibus, illis triumphus minime decretus eft, miniméque obten tus : femper enim exiftimationem arbitriumque huius honoris penes fenatum fuiffe, Valerio licet, \& Horatio coff. (quod antea núquam actum) tum primum fit fine auctoritate fenatus, populi iuffu triüphatum. Inftituti etiam huius pom$p æ$ veteris fuiffe comperio, vt illis haudqua quam triumphi deberentur, qui ad res quanquam maximas atque clarifimas bello conficiendas, abfque vlla magi ftratus auctoritate tranfmiffi fuiffent: vnde nec M.Marcellus,nec P. Scip io cur ru triumphali inuecti funt, quum Syracufas alter, alter Hifpanias fine magiftratu in poteftatem romanam redegiffent. Itaetiam more maiorum comparatum erat ne quis qui exercitum non deportaffet triumpharet, nifi perdomitam paca támque prouinciam tradidiffet fucceffori: fic L. Manlio proconfuli ex Hilpania redeunti poftulantíque ab fenatu in æde Bellonæ triumphum, rerum geftarum magnitudo impetrabilem faciebat, exemplum aliorum obftabat: medius tamen honos Manlio habitus, vt ouans non triumphãs vrbem iniret. Ad hæc frmili modo triüphum ita decerni à fenatu folitum, vt nullius ipfe nif eius qui triumphaturus effet, \& eorum qui bello interfuiffent verba audiret, inftitutumóg ideo vt legati, tribuni, centuriones, milites denique triumpho adeffent, vt virtus reram geftarủ eius cui tantus honos haberetur publicé videretur. Veteri etiam Romanorum more, nunquam triumphus lachrymis ac ciuium cruore quærebatur, nec admittebatur oblatus. M.enim Fabius cof.inclyta Hetrufcis, Veientibus fuperatis pugna, oblatum fibi fummo fenatus populíg ftudio triüphum ducere renuit, quood eo prælio Q. Fabius frater atque col. fortıffimè dimicãs cecidiffet, inquiés, quia tantis reipub. detrimentis luctus potius deberetur quàm tri umphus. Triumphi negådi caufa fenatui, vel ab eo aliis oblatum renuendi etiam fuit ei qui alieno aufpicio, \& in aliena prouincia pugnaffet,vt Helius primo $\mathrm{Cn}$. quoque Claudius, Nero deinde, qui Liuiilicet Salinatoris in Hafdrubale opprimendo glorix particeps fuiffet, tamen triüphantem eum equo fequi, quàm triumpho quem ei fenatus aque decreuerat vti maluit. Et quia res in prouincia fuerat Salinatoris gefta, fine curru triumphauit. Ei fimiliter triumphus adimebatur qui alieno exercitu rem geffiffet, prouinciä́g reliquiffet vtilitate rapiendi, vt L. Furio prætori pene contigit, cui nullo licet exemplo id ipfe feciffet,amplitudine tamen rerum geftarum, gratia \& amicorum orationibus, \& cófulis abfentia, de Gallis præter morem triumphum decreuerunt. Militaris etiam licentie fuperioris $x$ tatis currum triumphalem profequentibus fuiffe legimus, vt tri umphans per iocum plurimis ea die impune falibus \& carminibus afpergeretur:ea tamen a militibus in imperatorem ita dicebantur, vt facile appareret in ducem indulgentem ambitiofímos ea dici. Citeriam infuper, hoc eft, effigiem. quandam argutam \& loquacem ridiculi gratia in pompa vehi folitam accepimus cum populo colloquentem:vnde M.Cato in M.Cacilium, Quid ego dixe- 
rim amplius, quem ego deniqg credo in pompa vectitatum ire ludis pro citeria, atque cum fpectatoribus fermocinaturum. Sanctiffimum denique ac omnilaude inter cætera digniffimum vrbis inftitutum, que ideo communibus incipien dis gerendífque deos adhiberet, quia nullius calumnix fubiiciebátur ea quę dii comprobaffent, $\&$ in folénibus verbis haberet, cum fupplicationem aut triumphum decerneret, quờd bene ac foeliciter rempublicam adminiftrarit.

Triumphantium infignid or ornatus,

Capis.

$\forall$

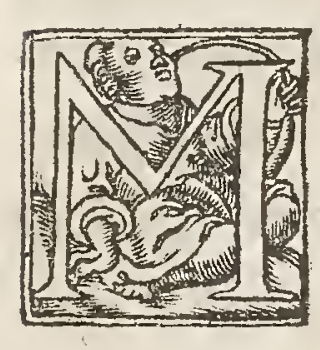

Vlta quin etiam triumphantium erant infignia, aurea corona fiuc laurea, aurea patera \& facrificalis, ferreus annulus, toga picta \& palmata, fcipio eburneus, fiue louis optimi maximíque fceptrum, facies præter hæc minio illita coloris inftar ætherei, vtóp Iouis fimulachri faciem diebus fettis minio illiniri folitam, maximi nó folum fed facri auctores teftantur, fic triumphantium corpora ficóp Camillum hac religione triumphaf fe.Bulla etiâ vt prætextatorum puerorú,ita \& triumphantium erat infigne à pectore cordetenus depédens cordiṣ́́p figuram habens, \& ea intra fe remedia qux aduerfus liuoris ftimulos $\&$ inuidize morfus arbitrarentur maxime profutura, háncque ideo cordetenus geftaffe trium phantes conftat, vt intuëres eam ita denique fe hominum appellatione dignos putaret $f \mathbf{f}$ ea corporis parte cateros an-

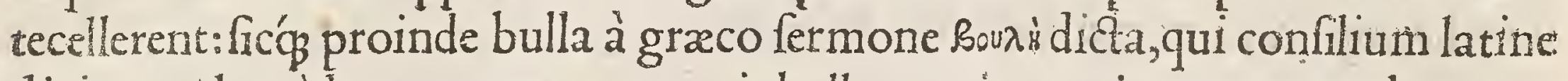
dicitur: vel quod eam partem corporis bulla contingat, in qua naturale manet confilium. Homines quoque fe effe in illo fublimiffimo curru triumphantes admonebantur à tergo: fuggerebatur enim, Refpice poft te, hominem te meméto: \& vtique hoc maxime gaudebant, tanta fe gloria corufcare vt illis admonitio fux conditionis effet opportuna. Cum enim corona fuftineretur à tergo annulúfque digito ferreus effet, æque fortuna triumphantis \& fui coronam retinentis annotabatur. Indui porrò folenni geftamine ac cultu triumphantes ius erat; \& quem fingulis vfurpare fas non effet. Ex virtute nanque petita, non omnibus eadé. Veltis ipfa \& materia,\& colore,\& forma plurimú differebat.Purpuræ vfǘ femper Romæ fuiffe video, (ed Romulo in trabea. Tullus Hoftilius Hetrufcis deuictis è regibus primus vifus inuenitur toga prætexta \& latiore clauo. Tarquinium Prifcum deinde tunica aurea triumphaffe Verius docet: hanc palmatam auctores vocant, vel quòd veftis ea fit qua qui palmam meruerunt vterentur, vel quòd palmæ in ea expreffæ viderentur.Palmæ enim arborem non ab re inter victoria $\&$ triumphantium infignia connumerari teftis eft Ariftoteles vi. problematũ, \& Plutar.in 8 Symp. Si enim fuper huiufce arboris lignü magna fuperimponas pondera, ac tam grauiter vrgeas onereś́p vt oneris magnitudo fu ftineri non queat, non cedit palma deorfum, nec in terram flectitur fed aduerfus pondus refurgit, $\&$ furfum nititur recuruatúrque : propterea, inquit Plutarchus, in certaminibus Palmam fignum placet efle victoria, \& quoniam ingenuum huiufmodi lignum eft, \& vrgentibus opprimétibúfque non cedat. Hinc palmarum ramos triumphantes geftaffe proditú eft. Ex lauro etiam coronam portari mos inoleuit, $\&$ ramum manu teneri : non quia, vt quidam perhibent, inter armatos hoftes quietis indiciü, Romanis pracipux laticia victoriarumg 
nuncia fuiffet, nec quia perpetuó vireat, nec quia pacifera, nec quia in gremio Iouis optimi maximique deponeretur quoties laticiam noua victoria attuliffer, præferenda enim vtroque olea, fed quia fpectatifima in monte Parnafo, idéóp \& grata Apollini, affuetis eò dona mittere iam \& regibus, \& Romanis tefte L. Bruto: fortaffis etiam in argumentum quod ibi libertaten publicam is meruif fet, lauriferam tellurem illam ofculatus ex refponfo: \& quia manu fatarum receptarú in domos fulmine fola non iacitur. Ob has caufas equidem crediderim honorem habitum in triumphis potius quàn quia fuffimentum fit cæadis hoftiu, \& purgatio, ve tradit Mafurius. Fuerunt $\&$ arboris huius circa Auguftum euenta digna memoratu, ob qux etiam triumphis vfurpatum arbitror. Nanq Liuix Druflle, qux poftea Augufta matrimonii nomen accepit,adfidenti gallinam confpicui câdoris a quila ex al to obiecit illefam intrepide, miranti acceffit miraculü, quoniă teneret roftro laureum ramú Baccis fuis onufü : afferuari hanc alitem \& fobolem iuffere arufpices ramúmque feri ac rite cultodiri, quod \& fáctum in villa Cęarum fluuio Tyberi impofita, iuxta nonum lapidem via Flaminia, quæ ob id vocatur ad Gailinas cãdidas, mirép Sylua prouenit: ex ea triumphans poftea Crefar laurum in manu tenuit coronam'q capite geffit ac deinde imperatores cuncti, traditúfque mos eft ramos quos tenuerint ferendi, durabantóp fyluæ nominibus fuis diffcretæ.

\section{Romanorum mores in triumphis,}

Cap.

vi. Pfum autem triumphantium morem profequemur, Romanum in
his ordinem exprimentes. Die itaque quo futura erat pompa po.ro.
multitudo vifendi ftudio ad fpectaculum triumphi effufa cofluebat nemóque ex multitudine tota ciuiú domi remanebat, led finguli nocte qux tri umphi die præceffura erat, loca praeniebant in equeftribus theatris quos Circos appellat, in locisóg circa forum ad hoc ipfum ligno exadificatis, in templis, in porticibus, in viis patentibus $\&$ publicis, in feneftris ac domorum tectis, $\&$ in aliis quibufcunq $\mathbf{p}$ rbis partibus per quas tranfitus erat fefe ad fpectandú comparabant, imperatori neceffario tranfitu prætermiffo, inftratóque paflim floribus fertis'g odoriferis, verbenis ac herbis aliis fuauitatem odoris affatim redolentibus. Multitudo deinde miniftrorá haftilia manibus geftantium ex medio confluêtem dimouebat turbam, \& vias puras apertáfque præettabant. Pars verò militaris ante lucé per turmas atque ordines cum rectoribus progrediebatur, $\&$ iuxta Ifidis tem plum(ibi enim principes illa nocte quiefcebant)conftituebatur: v vi verò illucefcebat aurato fublimiffimóque curru inuecti vt confpici poffent, eburnea curruliqg fella in maieftate fedétes, purpurãauro cõtextã induti \& Lau ri ramú dextra gerentes ferebãt. Hos peditatus omnis fub fgnis ac tribunis anteibat. Ferebantur poft hæc hoftium fpolia,coronæaurex, dona fociarum ciui tatũ tranllata. Tubarü deindeclangor fequebatur ac obfidum captiuorúóg nobilitas om nis vultu $\&$ amictu fubtrifti, et qui hoftiü dux fuiffet, fi captus aderat, captiuis polterior omnibus, cathenis vinctus ante currü ducebatur, quadrigam equi pulcherrimi niueíg ac phalerati quattuor trahebant: pơft verò captiui qui 
pểr prouinciam vęnerant vniuerfi rafis capitibus ob deterfam feruitutem vel pi leo capiti impofito, qui donata libertatis fignum erat, currum triumphantis fequebantur. Hunc etiam milites \& equites currum imperatorum fecundum legiones, cohortes et manipulos lauro manibus fequétes, partim carmina patria falibus permixta \& iocis, partim triumphantium laudes cantantes, ad vrbis am bulationes tranfibant, vbi fenatus $\&$ omnes ordines obuiam effufi corum praftolabantur aduentum, qui erat fiebat'́p non nifi per portam frue viam triüphalem iuxta Vaticanum, qua ab eo quòd per illam femper triumphorum pompa ducebatur nomé accepit. Ibi votis prius diis folutis cibúm capiebät, 8 magnificis ac triumphalibus veftibus amicti, diis ad portam collocatis cæfa hoftia inter fpectacula tranfeuntes triumphum ducebät, vt multitudini facilior pręberetur afpectus. Pro merito auté narrari multitudo illorú fpectaculorú \& magnifi centia non poteft: in omnibus quiqg cogitauere, vel artium vel diuitiarú vel na. turæ nouitate. Nam pene que cum hominibus qui vfquam funt fortunatis, aliis alia mirabilia magis atque magnifica quæfita funt. Etenim argenti auriqg facti \& infecti, atque fignati, necnon eboris ac gémarum, clariffinarum etiam rariffi mi generis veftium infinita multitudo fequebatur :crateras alii \& phialas calicéfque ornatiffimos, \& ingentes geftabant, alii vafa permulta ex auro \& gemmis eximix artis \& magni ponderis. Torques deinde \& montes aurei cú ceruis $\&$ leonibus $\&$ pomis omnis generis circundati certo ordine deferebantur. Ferebant fimulachrorum figilla, deóf̧́ quos illi habebant \& magnitudine mirabili \&arte nó defunctiore facta : frgna deinde ænea, marmoreáq̧, tabulæ \& coloffi vehiculis portabãtur. Adhæc tela $\&$ cætera hoftiú fpolia,catapultra, baliftæ, tor menta queque $\&$ arma porrò ornatiffima atque pulcherrima fplendentia ære $\&$ ferro abfterfo, atque ita difpofito vt cafu maxime cecidiffe viderentur: galex; fcuta,thoraces,ocreæ, peltæ, gefa, cory ti, equorum frena \& enfes ftricti per hæc iacentes, $\&$ fariffa infixæ ita vt nec victorum quidem $a b f \not p$ metu a fectus effet. Maxime autem ftupor erat machinarum qua portabantur, pro cuius magnitudine timendum viribus portantium occurrentes putabant. Ferebantur in triüpho figna militaria, vrbes, \& oppidorum fimulachra: quinetiam equorum captorum greges, $8 C$ animalium diuer a genera, elephantorum $\&$ leonum producebantur, propriis ornamentis induta: ducebantur $\&$ boues pòft auratis cornibus,vittis ơrnati \& fertis, ducebant cos adolefcétes fuccincti ad immolädum, $\&$ pueri aureas \& argenteas pateras facrificii gratia deferebant. Atque hæc eadem denique præ multitudine rerum \& copia fi non vna die tranfuebi poterāt, in altera nonnunquam tranfuehebantur, atque altera belli poft hęc facies praferri videbatur ex ludis: erâtque cernere valtari fortiffimas terras, interfici acies hoftium, alios credi,alios fugere, alios captiuos duci, murófque excellentes magnitudine machinis dirui, caftella excindi,ciuitates populofas difturbari, exercitum intra muros fundi, cædífque omnia loca plena, \& eorum qui manu refiftere non poterant preces,ignémọ templis immiflum, ædium'ó fuper dominos fubuerfionem. Ars autem \& operum magnitudo nefcientibus ad huc illa, fieri tanquam vera prefentibus oftendebant, in Ponto etiam dicente Nafone, 
Oppida turritis cingantur eburnea muris,

Fictáque res vero more putetur agi.

Huius autem pompe finis louis Capitolini templum erat, vbi poftquan eò peruentum eiat, more vetere victores operiebantur donec mortem ducis hoftum quifiam nunciaret.(Nam holtium rex duxve qui fuiffet,aut publicæ cuftodia perpetuò dãnabatur, aut traductus la queóve circundatus per publicú ad necem trahebatur): Poltquam igitur eum finem vitę habere nunciabatur,omnium'q fauor fecutus erat, votis lecundò celebratis peractífque, folenniter in palatiú rece debant, \& alios quidem epulis excipientes, confules de more inuitari faciebant $v t$ conę adeffent: deinde rogari quo minus venirét,ne celebritatis illius diei ma iore quifpiam imperio fructum fiue locum fibi praoccuparet. Aliis autem omnibus domi conuiuiorum inftructi erant apparatus, fiḉ omnium plaufu vltra. omnem confuetum honorandi modum, hunc fauftü $\&$ foelicem diem ob rempub. auctam imperiúmque Populi Romani propagatú, \& malorum ciuilium finem vrbs romana celebrabat.

De Coronis leges,

Cap. VII.

(5tereft coronarum quoque maieftatem fpeciali confideratione metiri,vtpote quibus ingens dignitas infit \& ingentiffimum ad fortitu dinem calcar. Morem nanque hunc à veteribus traditum incitandos ad animos Romana prudentia tenuit, quod imperator re bene, faufte, ac foeliciter gefta, tribunal afcenderet concionéque aduocaret milites vt operam quam nauaffer quifque laudaret, virtutis quoopad teftimonium, vt eflet fauoris qualitas, de repub. bene meritos corona donaret. V tóp ab ipfis propemo dum incunabulis ordiar, tenuiores in vfu antiqui habebant ftrophios appellantes, vnde nata \& Arophiola: quin etiam vocabulum ipfum tandem communica tum eft inter facra et bellicos honores, coronis fibi nomen fuum vindicantibus, Quum verò è floribus fierent ferta, à ferëdo feruix appellatæ funt, fuaria eadem ob limilitudiné Suarii cuiufdam,negociatoris, cognominata: quod apud Grae cos quoque non adeò antiquitus placuit. A rborum enim ramis coronari in facris certamınibus mos erat primum, in caltriśg romanis aliquandiu obferuatus. Sic Romulus fródea coronauit Hoftilium Tulli Hoftilii regis auum, quòd Fidenas primus irrupifet: fic Publium Decium patrem, tribunum militúfron dea donauit exercitus, ab eo imperatore Cornelio Coffo col. Samnitú bello feruatus.Poltea variari coeptum, mixtura verficoloris florúmque inuicem odores coloréfque acceffere. Nec in promifcuum quorumcunque vfum, fed ingenti feueritate ad mifi: horum enim licentix exen plum apud maiores non eft aliud $\bar{q}$ in filia Diui Augufti, cuius luxuria noctibus coronatum Marfiam literæ illius indicant. Florum quidem populus romanus honorem Scipioni tantum adhibuit. P.enim Mutianus quum demptam Martia coronam è floribus, capiti fuo impofuiflet, atgo ob id duci eum in vincula trib.pleb.iuflifet, appellauit Tribu nos pleb.nec interceffere. L.etiam Fuluius argétarius in bello Carthaginenfí fecundo cum corona rofacea interdiu in foro profpectus effet,auctoritate fenatus in carcereñ abductus, non ante finem belli eniffus eft. Sic coronis eiufmodi re. 
ceptis paulò mox fubiere que vocantur agyptix, ac deinde hy berna cü terra fo

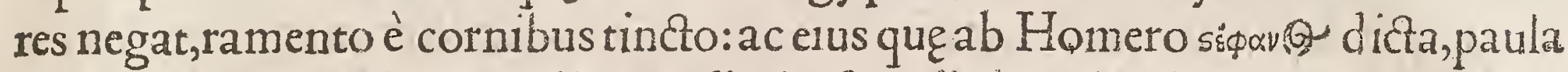
tim Romæ fubrepfit à Lucilio appellatio. Corolle inter initia propter gracilitatem nominatæ, mox $\&$ corollaria poftquam maxime è lamina aurea tenui, \& ea inaurata aut inargentata dabatur. Coronandi autem morem, gentilium pri mo deorum fuiffe conftat, feruntóg alii Dionyfium, auctore Diodoro,fi quando ex potu bibentis caput agitaretur, mitra id illigare, vnde \& urrpoфóg $(\vec{\theta}$ dictus eft,regéfque deinde pro mitra caput diademate vinciri folitos, fiććp proinde primum omnium Liberum patrem impofuiffe capiti fuo quum ex Indis trium phaffet ex hedera: alii Saturnum,vt Phęrecides, ante omnes coronatum referút. Iouem nonnulli quoque poft deuictos Titanas hoc munere præ cæteris honoratum. Romulo infuper qui aruorum facerdotes in primis inftituerat, fég duodecimum fratrem inter ipfos appellauerat, fpicea corona qux vitta alba colliga retur in facerdotio pro relig iofifimo infigni data, qux prima apud Romanos corona fuit, honófque is non nifi vita finitur. Poftea veró guàm deorum honori tribui copere, victinis fimul coronat is, facris deinde certaminibus vfurpatæ funt. Coronare nã ${ }_{p}$ apio victores facri certa minis Nemex, honos maximus ha bebatur in Achaia,ficut A mbrofia, qux à quibufdam botrys vocatur, ab aliis Artemifia:coronantur illa apud Cappadoces. Nec his victores donari tantum, fed patriam quoque coronari pronunciabant. Inde natum vt triúphaturis con ferrentur in templis Dianæ, mox vt ludis darentur, qua donatice dicta funt $\phi^{2}$ his victores in ludis donabantur, nec aliter minoribus triumphis ouantes. At he nas quoģ nó victores felü, fed virtute praftantes ciues primum oleæ vfum introduxiffe, clariflimum Periclis caput ambiendo: Gręcos autem oleaftro Olym pir, vnde Hercules nunc oleaftri, nunc populi, nunc apii fronde redimitum ca put præferebat: nunc Athenienfes quidem foli, 8 Gracorum plurimi coronæ oleaginæ: cæterum romanæ quoque maieftatis honoré magnum præbuit turmas equitum coronando. Hac corona a pud noftros non peruetufta eft, nee pri fcis illis temporibus; fed Q. Fabii Rutiliani tëporibus collata : hic enim primus inftituit vti equites romani idibus quintilibus ab ædeHono ris equis infidentes in capitolium tranfirét, olę fertis de more redimiti: inde poftea increbuit vt co genere frondis coronentur in equeftri ordine admittendi, quafi tunc primum tranfueherétur ad eam dignitaté additi. Hac etian corona non qui praliis interfuiffent, fed qui triuphum procuraffent decorari folitos legimus . Cur autem ex olea fuerit ea corona quàm ex alia fronde non facile dixerim, nec apuid alios fcriptores quum curiofe quxfiffem legiffe memini me, \&fi minus ignorem ad diuerfas fignificationes ac potius ineptias quafdá $\&$ deliraméta pertrahi poffe : fed quum hanc apud gentem vnam terrarum vrbiúmque principem plura fint coronarum genera, quàm cunctis,que magno interuallo magnáque differentia fuere, vt aureæ, vallares, murales, roltrata, ciuicæ, profectò corona quidem nulla fuit, graminea nobilior. Hanc ftatuit in triumphis Senatus, cura belli folutus $\&$ ociofus, populus nunquam, in defperatione fuprema nulli contigere, nec nifi ab vniuerfo exercitu feruato decerni, coronas cęteras imperatores dedere, hanc folam 
folam miles imperatori. Eadé vocatur obfidionalis, quòd hi qui obfidione liberati fint, ei dant duci qui liberauit. Huic fummus honos, fummáp gloria: nam fi ciuica honos vno aliquo vel humillimo ciue feruato preclarus facérque habetur, quid tädem exiftimari debet vnius virtute feruatus vniuerfus exercitus? Donabatur hæc viridi è gramine, decerpto inde vbi obfeffos feruaffet aliquis. Nanque fummum apud antiquos fignum victoriæ erat, herbam porrigere victos, hoc eft, terra \& altrice humo, \& humanitate cedere, $q$ mos diu valuit apud Germanos : herbam enim veteres palmam vel victoriam dici voluerunt,quod Actius in Meleagro plane oftendit, Gaudët, inquit, currüt,celebrant, herbä conferút, Donant, tenent pro fe quifq̧ cú clarú circúftat corona caput.Proinde quú herbam do inquit Plautus, fignificat victum me fateor, quod eft antiqux $\&$ pa $=$ Itoral is vita indiciū. Nam qui prato,curfu aut viribus cótendebát homines, quú fuperati erant, ex eo folo in quo certamen erat decerptã herbã aduerfario tradebant. Hac corona donatus eft $L$. Siccius Détatus femel quú ciuicas quatuordecim meruiffet.Quidam et iâ hac corona imperatores \& fæpius donati füt, veluti Decius vna tribunus nilitum ab exercitu, altera $\mathrm{ab}$ his qui in præfidio obfefli fuerant.Quanta effet honoris huius auctoritas, confeffus eft religione: fiquidem donatus bouem album immolauit Marti, \& centum fuluos qui ei virtutis caufa donati fuerant fimul ab obfeffis. Præter hos cótigit coronæ eius honor M. Calphurnio Flamini,trib.militum in Sicilia. Céturioni verò vni per id tépus Treio Acinati Cymbrico bello. Scripfit \& Sylla dictator ab exercitu fe quogp ea donatum apud Nollam legatum bello Marfico,íd $\$$ etiam in villa Tufculana, qux fuit poftea Ciceronis, pinxit: quod fi verum eft, hoc execrabiliorem eum dixerim, quandoquidem eam profcriptione fua ipfe detrahit, tanto paucioribus ciuium feruatis quàm poftea feptem milibus trucidatis \& occifis. Hæc corona Sertorio ceffit, \& Fabio illi, Hannibale pulfo. Aemilianum quogue Scipionem hac ipfa obfidionali corona donatum in A phrica, Manilio cof. cohortibus feruatis, totidémque ad feruádas eas eductis M. Varro meminit.Ipfun quoque Auguftum idibus feptëbribus à fenatu obfidionali etiấ donatum memorix Laus sigis proditum eft. Er quanquam ea confuetudo ficut $\&$ pleraque alia maiorum nofmundi. ftrorum deleta eft, hac tamen corona noftris temporibus, Sigifmunde, Populonea expeditione vno omnium ore donata eft pracellens animi magnitudo tui. A b vniuerfo náque \& vnanimi primum Hetrufcorum exercitu abs te leruato, $\mathrm{a} b$ his deinde qui obfidebantur,à fenatu porrò Florentinóque populo, à tota $\mathrm{He}$ truria, ab omni deniq I talia, ab exercitu \& populo barbaro per te liberata (qua claritate nihil profectò humanis in rebus fublimius duco) quum Tarraconenfl, rege maximo, Sicilię, citra \& vitra Pharú, Valentię,Hierufalem, Vngariæ, Minoricarum, Maioricarumóp, Sardinia, Corficæ, comite Barchinone, duce Athenarum \& Neopatrie, ac etiâ comite Rofilenis et Ceritanię per te ex Hetruria pul fo,iamiá plures fuis qui extremæexpeditionis illius muros afcenderát militibus murales coronæe decernerentur, tam parua manu tantis periculis te illi obiiciendo, rémque omnem Hetrufcam labantem iam ac penè prolapram reftituendo, fulminis inftar eius caftra peruaferis, ad cuius reftituentis redeuntifque exercitus 
fpeciem atö̧ pompam effufa omnis incolarum \& oppidorú multitudo obuian proceflit, \& vniuerfi quidem milites tuos tâtumóp te vnum inter tot tribunos $\&$ clariffimos eorum duces Sigifmúdum admirabantur, in te oculos vniuerfa Flo rentia ciuitas, in te omnium ora pédebant; tég tan q̈ diuum hominem cælitus miffum vt ipfam victoriam contuebantur, laudabãt'́p te finguli pro eorum patriæ tutela, nec minus admirabantur tantú in te vno principe fuiffe mometi vt antiquiffimæ ditionis libertatiśg, fux penè per regem reftinctę, $\&$ rurfum per te receptæa auctor effet, $\&$ vnde ftetiffet iam eò fe victoria tranfferret, fierétque cum eo mira quædam regiæ glorix inclinatio. Adde quòd Hetruria relicta ex his re bus ftrenue in ea geftis, tui nominis gloria increbefcente, Veneti céturiatis comi tiis ex fenatufconfulto omnibus non humanis tantü, verìm etiam diuinis te ho noribus profequútur, te tollunt in eorú tutelam cótra Francifcum Sphortiäm; Infubrium agro apparatu maximo maximiş́́ impenfis, corum te gétibus pràficiunt, te inquam, fuis primùm per eủ ex fuperioris pralii dimicatione infauftè \& infoeliciter gefta cófectis, fufis, fugatis, captisç̣ quàm plurimis terris expofitífque præda \& exponédis, in cunctisq́q qua fiue ingenio, fiue aftu, frue locorü pràoccupatione, pręuetione holtiliü, vigiliis, mora, celeritate, fallaciis, circũuentionibus, \&dolis conficienda, quẩdo, \& quoties opus erit; aduerfis in rebus, \& fecúdis; in fubitis improuifiśg tanq̣ profundiflimü artificẻ obiiciunt, quo res fuas om ${ }^{4}$ nes tueantur $\&$ foueant, neq quàmdiu monitis vf funt tuis optate in te fpei defuit euentus. Simili enim modo nec aliter ac per Hetruriam fama tui Galliæe ci falpinæ terras peruagấte, fumma rerú merito prę cęteris in te collata. Nòn multò pòft Cremam fortiflimum oppidú ac inexpugnabile cum vniuerfo exercitiù traiiciens, fata exurés, diruens tecta,pradas hominum pecorumóp agens,fingula quaque \& vniuerfa agri illius populatione fernendo, ficcatis deinde paludibus; monia nó folum quæ nunquã antea cuiufquàm ductu vel imperio obfidionem paffa erant, aliquädiu expugnata victori tibi paruere: cæterum alia plurima lo$\mathrm{ca}, \&$ ardua quidem, $\&$ ineunda conatibus tuis ceruicem flexere. Quid quòd an. no fequéti in Hetruriam $\mathrm{p} S$. C.inter tot clariffimos duces tertio imperator defignatus $\&$ accitus, Ferdinandum regis Tarraconenfum filiü cum omni exercitu regio ad mare vfo $T_{y}$ yrhenum repulifti,\& Folianum primúm, pręter plurima loca,maximú $\&$ a mpliffimú oppidú gentibus regiis occupatum; omni coñmeatu armorüqó genere munitum, quú Florentini ad priftinam fui ditioné redi-

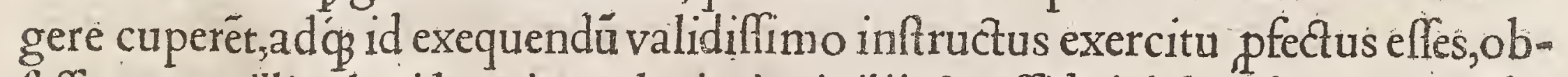
feffos per te illius loci homines, plurimis vigiliis $\&$ affiduis laboribus, praliis diurnis, $\&$ nocturnis dinicationibus feflos non fine maximo tui tuorumó difcrimine atqu cæde in poteftatem eorú redactos fuiffe conftat? Vada deinde maritimum et vetufta nobilitate inclytum oppidũ, horreũóq quafi belli ad pugnam régiam in Hetrufcos, quanqua maxima in mari clafe, imméfóg terra vallum fpa tio portusóp vicinitate, inex pugnabili loco fitum, ac tanta vi annonæ $\dot{\&}$ a rmato rum felectorú copia refertum (quatuor enim milia erant) vt ne fpes vlla effet cuipiam potiüdi loci, turribus, mœnibus, ${ }_{i}$ vallo, folla, aggeribus muniti, hac tamen velocitas fagacitatis tux valentiorem armis excogitauit rationem, qua proter 
omnium iudicium \& opinionem interceptum exitio multorum ac fuga, dèmo. litione loci,cui deftinatum fuerat Florentinorum imperio adiiceretur. His atç aliis virtutibus tuis quum dignitaté, laudem,immortale nomé et fempiternam gloriã nō folum tibi \& nobiliffime Malateftarum familia, fed toti etiam I taliæ cóparaueris, fummus tibi cedit honos \& gloria, quum tuę laudes nó modo noftris fed Hetrufcorum, Gallorum, Hybernorum ac reliquarum quæ vfquá funt gentium linguis celebratæ fint, ac futuris feculis celebranda. Corona ciuica,cuique cú ciuem ex nece feruaffe cótigerat ex lege dabatur, ilignea quæ prima fuit. Id autem arboris eft genus, frödem habens perënem:vnde Cęcilius, Aduehütur cum ilignea corona,et chlamyde in nofträ fidem. Poftea magis placuit eadem ex efculo louis. Variatum'q́ \& cú quercu eft, fiue propter Arcadas is præcipue quercui reddatur honos quos glandiphagos vocare diuinú oraculú folebat, fiue propterea $q$ ea arbor inter fylueftres fructu lóge belliffima atog fertiliffima:inter mi tigatas autem, validifima. ( $A b$ ea enim cibus $\&$ opes multarủ gentium, etiam

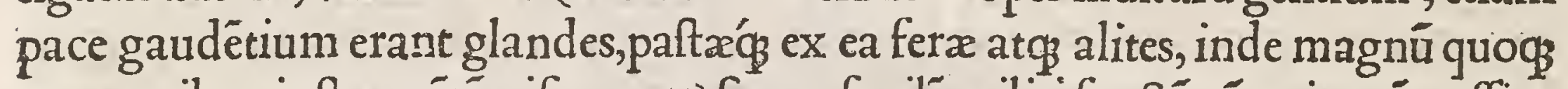
vena toribus inftrumétú vifcus erat) frue $q$ facilé militi fructú, tú ocius, tú paffim quercus exhibebat, fiue id cóueniens feruati ciuis exiftat præmiü, quoniam loui in cuius tutela funt ciuitates, facra quercus eft: vnde poéta nobilis Claudianus,

Mos erat in veterum caltris vt tempora quercu

Vallatet validis fufum qui viribus hoftis

Cafurum potuit morti fubducere ciuem.

Sunt ergo ex glandiferis ciuicæ coronæ militum virtutis infigne clariffimú. Ce dunt his murales vallareśq $\beta$ aureæ, quanquam precio antecedétes fint: cedunt \& roftratæ, quãuis in duobus maximè fuerint celebratx, $M$. fcilicet Varrone è pyraticis bellis dante Pompeio Magno: itê M. Agrippa, tribuente Cæare ê Siculis, qux \& ipfa pyratica fuere. Antè roftra nauium tribunali præfixa fori decus erant,veluti po:ro. ipfa corona impofita videretur, poltquã verò tribunitiis feditionibus calcari ac pollui coeperunt,poft'quã vires ex publico in priuatú ma gis finguliṣ́́ ciuiū quari, ac facrofancta omnia, prophana fieri, tunc à pedibus corum fubiere in capita ciuium roltra. Dedit hanc Auguftus coronam Agrippæ, hac \& Iulius Cęfar à Thermo in expugnatione Mitylenarú donatus eft. Hu ius quoọ honore donari contigit à romano populo latini parentem eloquii, M. T.Ciceroné, L. Gellio, viro Cenforio in fenatu fauente, quod huius ampliffimi oratoris induftria \& eloquentiæ neruis effet truculentiflima Catilinæ coniuratio detecta vindicatâque. Sabinus autê Maffurius libro memorabilium xi,tefte Gellio, Ciuicam hanc coronam ei dari folitum dicit qui eodem tempore \& ciuem feruaffet $\&$ hoftem peremiffet,atque eum locum in quo effet actü certamen obtinuiffet: Tyberium tamen Cæfarem cófultum, hóc ne honoris infigne fumere quiret qui ciuem in pugna feruaffet $\&$ hoftes inibi duos de medio fuftulif fet, verùm locum in quo certamen effet actum amifffet, éumque locum amoto eo holtis potius accepiffet, refpondiffe ait, ei huius coronæ decus \& honorem iure negari non debere, quum tam iniquoloco dimicatum effet, vt neque à quoquam etiam fortiffime pugnanti feruari potuiffet. Addunt alii prater 
hac qux à Sabino Maffurio ad ciuicam coronam fpectare dicta funt, conuetire maximè fenatus vt eo die fateatur, aliàs teftes nibil $p$ effe vt ciues fuerint anxilio quàmuis rege feruato. Decus non dant, oec crefcit bonos idem imperato. re feruato, quoniam conditores in quocügs ciuem fummum effe volverunt. $A$ ccepta licet vti perpetuò : ludos ineunti femper affurgi etiam ab fenatu in more eft, fedendi ius in proximo fenatui: vacatio munerum omnium ipfi patríque $8 \mathrm{auo}$ paterno. Corone trium phales funt illæ que impcratori victors auree p: $\varepsilon$ feruntur.Equidem quis corona ex auro dona tus fit no inuenio, quis autem primum donauerit à L.Pifone traditur. A. Pofthumius dictator apud lacum $k e-$ gillum expugnatis Latinorum caftris, eum cuius maximè osera capta effent do nauit ex præda hac, qua laurea veterum téporibus, aurea poftea facta, idiģ aurú coronarium vulgo dictum. Lauream coronam Pindarus ato Callimachus memorant A pollinem interfecto dracone induiffe, efculeam alis. Ouidius,

Né ve operis fámam poffir delere vetuftas

Inftituit facros celebri certamine ludos,

Pythia perdomita ferpentis nomine dictos.

Hic iuuenum quicunque manu pedibúsve rotáve

Vicerat,efculex capiebat frondis honorem.

Nondum laurus erat, longóquedecentia crine

Tempora cingebat de qualibet arbore Phobus.

Laurea etiam L iber pater inceffrt cinctus, quu ex Indis triumphauit, cui heda ra etiam facrata erat, ex qua coronam alii per hibent primú onnium capiri fuo impofuifle.Cxlar Auguhus triuphans, lauruns teruit coronámque capite geflit ex lauro, quę quanquàm triumphis propriè dicata fit, gratifima tamé multis va rif que rationibus domibus ianitrix Cælarum. Ouidius,

Tu ducibus lætis aderis, quum læt a triumphos

Vox canet, \& vifent longas capitolia pompas.

Poltibus auguftis eadem fidifima cultos,

Ante fores ftabis media móg tuebere quercum.'

Cur tamen appolita velatur ianua lauro,

Cingit 8 auguttas arbor opaca fores?

An quia perpetuos meruit domus ifta triumphos?

An quia Leucadio femper amata deo?

Iplá ne quòd fefta eft, an quoood facic om nia fefta?

Quam tribuit terris pacis a n ifta nota eft?

Vtque viret laurus femper nec fionde caduca

Carpitur,aternum fic habet ille decus?. .

Caufa fuperpofita fripto teftante corona

Seruatos ciues indicat huius ope.

Hæc deniqg vt Cæa a rum pontificumque, fic poetarum quoque do mos csornabat \& tempora; quibus coronand is a pud veteres obferuatum le gimus, cófuewiffe Græcos fingulis luftris triplex certamen celebrare,muficü, gy mnicum, equeftre, quę Nero Claúdius Romá primus omniü inuexit,neronianáģ à nomine fno ap 
pellauit,poftea \& Domitianus eum fecutus celebrauit. $V_{t}$ igitur athletarum, fie communium fcriptorum $\&$ maximè poétarum victoribus præmia $\&$ honores conftituebantur, deligebantur'́s ex omni numero literatorü doctiflimi aliquot, vt eorum iudicio qui carminibus decertaturi præ cęteris laudarétur, coronis $\&$ honoribus meritis, inftar militum inter fe pugnantiú illuftrarentur. Nec id quidem ab re,eadem enian vtrifque propemodum gloria, idem vtrifque pene honos debetur, $\&$ his qui gefferunt, $\&$ his qui rerum geftarú $\&$ literarum et ingenii fui monumentis, pofterìs demádando, immortalitaté frnt nominis affecuti. Oualis corona bellicis etiam fe rebus inferit, leniter tamen \& fine cruore, deditione hoftium è veft igio fublecuta. Huic lenitati maxime cóuenire $V$ eneris victricis fró dem prodiderunt, quòd non Martius, fed quafi Venereus quidam triumphus foret. Eam coronam non in curru nec circú clangentibus tubis, fed pedes, patritiis in calceis, modulatibus tibiis quifß̧ geftabat, ducendo $P$ xanis cantu pópam. Tibia enim pacis eft, Venerisóg arbufcula myrıus, quæ vim maximê bellumọ́ perofa eft. Hac fronde myrtea triüphans de Sabinis Pofthumius libertus in con fulatu, qui primus omnium ouans vrbem ingreffus eft, coronatus inceflit,optabi lémg arborem fecit. Hxc omnium poltea ouantium corona fuit, vno excepto M.Craffo, qui cum bello fugitiuorum cófecto ouans rediret, fenatus conf. facto per gratiam myrtum paruifaciens, lauro coronatus inuectus eft. Maximus auctor eft, curru quoque triumphantes myrtea corona vfos.L.Pifo tradit, Papyrium Nafonem qui primus in monte Albano triumphauit de Corfis, myrto coronatum ludos circenles fpectare folitum, auus maternus Aphricani fequentis hic fuit. M.Valerius dua bus coronis vtebatur, laurea $\&$ myrtea, qui $\&$ hoc voue rat.Corona muralis eft qux donatur ab imperatore ei qui primus murum fubiit, ínque oppidum hoftium per vim afcendit:idcirco, inquit Liuius, præcipue um muralis coronæ decus cius effe qui primus murú a cendiffet. T.auté Romilius primus omnium eques hanc accepiffe coronam dicitur. Hac quog $\mathrm{Q}$. Tre bellius, \& Sextus Digitius paritèr in murü afcédentes, virtutis caufa ambo à Sci pione donati funt. Caltrenfis corona ea eft qua qui primus holtium caftra pugnando vallo introiflet donabatur, $8 x$ cui infigne erat ex auro vallú. Corona naualis eft que folet donari maritima pugna ei qui vi primum in hoftium nauem armatus tranfilierit. Atqui hâc et muralem \& vallarem ex auro fere donari con fueuiffe long um effet $\&$ operofum nimis externa domefticáque oratione complecti : quis item quamque prius inuenerit, quís ve primus acceperit:innume rę enim funt $\&$ penè infinitę, ac multiplices de his libri à diuerfis auctoribus con fcripti.In vniuerfum autem de his coronis apud Græcos quidem priuatim feri pere Mnefteus ato Callimachus medici, \& Theophraftus:ex noftris autem infcripfere aliqui libros, flores veró profecutus eft nemo quen equidem inueniam. Deorum autem gêtiliú coronas perftrinxit libro de ipfis edito cómétator Clau dius Saturnius, in quo ita exarauit caulas $\&$ origines, fpecies $\&$ folennitates, vt nulla gratia floris, nulla lætitia frondis, nullus celpes aut palmes fit qui non alicuius capiti inueniatur confecratus. Et hæc de coronis hactenus dicta fint. 


\section{DERE MILITARI LIB. XII. \\ priutorum honores \\ Cap. \\ Vith}

far fubeunt in praentiarum bellicre virtutis infignia que imperato* M. 25 buscertaminum labores participarent: non enim ab te Dauid in $\mathrm{mi}$ 2 litem fuum, Pofuit,inquit, cruorem pralii in baltheo qui erat circa lumbos eius, $\&$ in calciamento quod erat in pedibus eius, nifi quia $\&$ in habitu ipfo priuatorum, quadam infignia virtutum funt. Eft enim baltheus non tantum quo cingimur, fed etiam à quo arma depédent, \& figna legionis ex fumma internof ci polfunt. Romanos etiam auxilia externośg torquibus aureis donaffe, ciues non nifi argenteis conftat, iidém que armillas dedere, quas non haberent externi: donabantur ob virtutem phaleris quog $\&$ haftis antiqui. L. enim Sic cius Dentatus qui trib. militũ fuit, duodeuiginti phaleris \& haltis clx ,éog amplius donatus eft: armorum nanque $\&$ imperii fumma erat hafta, quam ob cau fam viri ea fortes donabantur, \& captiui fub ea vęniebant,fićp tempore regum

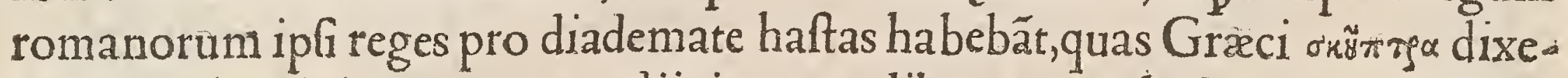
re. Nam ab origine rerum pro diis immortalibus veteres haftàs coluere, ob cuz ius religionis memoriam poftea fimulacris haftx addebantur. Nec phaleris fo lum $\&$ haftis ob virtutis merita veteres cóftat effe donatos, fed \& bullis. Tarqui nio enim Prifco omnium primo filium quum prętexte annis occidiffet hoftem, bullá aureã donatam legimus, vnde bullæ vfus poftea fúcceflit, adeô vt eơrü quỉ equo meruiffent infigne id haberent, quo \& nobilium quoog filii à plebeis fecer: nerentur. Erat $\&$ exteris gentibus $\&$ noftris hominibus auctoritatis $\&$ ample di gnitatis ornatus annulus aureus, cuius fabulæ prinjotdiư arufpices ex Afia trat didere, vinculorum potius interpretatione fatali quàm geftaminis. De Prometheo nanque fabulofum reor,quod illi annulun: primum \& ferreum dederit an tiquitas. Midæautem annulum quo circumacto habëtem nemo cerneret, quantquam fieri id quidem polfit, vt inquit Cicero, quis non etiam alienum à verò, ac magis abhorrentem quogue dixerit? Fama eft etiam Pyrrho regi qui bellum aduerfus Romanos geflit Achatem fuiffe lapidem, non fabulofum, fed preciofiffimum, in quo quidem rerum diuerfarum, iumétorum, fluminum, nemorum, volucrum, ferarumóg nulla penitus manu artificis, fed naturæ fpectarentur imagines, non impreffis, fed ingenitis figuris, tam fparfis támque nexís inuicem notis, vt tot imaginum in tam paruo fpacio vnaquxque fuis digno difcerneretur infignibus. Eft etiã Polycratis annuli fama vetuftior, cuius fardonyx ille in delitiis habitus abiectus in mare capto relatus eft pifce, ipfo circiter ccxxx anno vibis noftrę interfecto. Et quâqu iliacis téporibus nullos fuiffe annulos apud Homẻ rũ legimus, tủ \& codicillos epiftolarử gratia inufitatos, nodi nó annuli nota colligatos funfe non dubium fit, apud Carthaginéfes tamen ferunt annulor ü orná tum accipi folere $p$ numero expeditionú in quibus militaffet. Lacedęmonii ferreis vf ferütur. A pud Romanos equeftris ordinis annulus quonda fuit ornatus, equites à plebe fecernens : nec fimul cú equeftri fenatorió́b ordine cœẹit, verùn aliquamdiu pòlt annulos habuiffe aureos cos manfeftũ eft: frquidem his tâtun qui legati ad exteras gentes ituri eflent, aurei publicè donabantur, quibus quư⿱艹 Hh iil 
intra domos ferreos geftarent, in publico tantum vterentur: credo quoniam ita exterorũ ornatiflımi intelligebätur, neq aliis vti mos fuit quàm qui ex ea caufa publica accepiflent, vulgoóg fic triüphabant vt cú corona Hetruf́ca aurea fuftineretur à tergo, annulus tamen in digito ferreus erat. Sic triúphauit $\mathrm{C}$. Marius de lugurtha. Aureum tertio confulatu fumpfiffe traditur: fić́p R omæ quidem non fuit aurum nifi admodú exiguum longo têpore : certe à Gallis capta vrbe vt pax emeretur, non plus quàm pondo M. foluere potuere. Secundo etiam punico bello, annulorú perō rarus erat vfus. Nam quũad Cãnenfis maximę cladis pópam Hānibalis iuffu in veftibulo curiæa annulos aureos effufos cóftet, eorum tátus aceruus fuit vt metientibus dimidiü fuper tres modios, qdã auté tres, qda m duos integros Carthaginë miffos afferant: ğ fama tenuit,vt I iuio placet, qux propior vero eft, haud plus fuiffe modio : adiecíto deinde verbis quo maioris cladis indiciú effet,neminem nifi equitem aut eorum ipforú primores id geffiffe infigne. Multi etiam equitũ \& qui prætura functi fint è numero, in ferreo cenfu erãt,annulorũ huiufmodi aureorum vfum afpernati,vt Manilius, L. Suffidius, Calphurniüfog \& alii pleriog fortiffimi Romanorú,tãquam pbrofum, muliebre, \& nota dignú id effet : vnde adhuc illud Gracchi in Neuiu celebre memoratur, Cöfiderate, inquit, Quirites finiftram eius: en cuius auctoritatem fequimini, qui propter mulierú cupiditatem vt mulier eft ornatus. Qui primus itag annulum inftituit non ab re lauis manibus atog latentibus induit, quafi non fecurus dextrę fuerit oftentandę. Craflus imperator maximus in fenectute duos habuit annulos caufam præferens quia pecunia ei immenfa creuifet: vtóp feueritatis illius prifcæ nonnullis annuli omnino nulli, fic præcipuis etiam viris quibufdá lafciuiête tunc ætate gẽmati fculptió̧ fuere. Ad id auiditatis ftudiū progreffus elt Sylla, vt annuli gëmæ infculptam eius rei geftæ circúferret inaginé,éág continue vteretur. Erat auté fculptura Bocchus, is fuperioris Mauritanix rex erat qui viuú Iugurtham generủ traderet Sylla qui manibus fufciperet, quod inter Syllam \& Mariü infanabilis cius difcordiæ caufa fuit, quæ ferè rem romaná euertit, quum multi qui inuidıa in Marium flagrarent, id fuiffe opus Syllæ inuulga rent. Pompeii quog annulú gémam legimus habuiffe, enfiferi leonis cellaturam habentem. Verùm etiam non ornatus tantü, fed fignandi caufa annulum geftare moris erat, vnde neqg plures quàm vnum, neq fingulis nifi liberis quos folos fi des decerneret, que fculptura afferuabatur, habere licebat, ideo geftádi huius annuli ius famulis nó erat. Annulos etiam quidam mortis gratia, in cerauneis, \& hyacinthis \& fmaragdis aliisog gemm is fub quibus venena includebantur parauere. Sic Demolthenes belli dux \& fummus oratorum Græciæ, fic Ponorum dux Hannibal,fic Heliogabalus, vt haufto quod fub géma annuli habebantveneno, quû́ opus effer, hoc eft, fi quando vis aliqua vrgeret, ilico abfumerétur. Au reorü itaq̧ annulorü vfus equites, vt diximus, à plebe fecernebat, quum eos quí equites non effent ferreos habere mos effet,nec aliud quicquam pacis témpore. Nam in pręliis auro quibufdã arma decorare mos etiâ fuit́,pręfertim apud Gal los, de quibus nó ab re extat adhuc Homericủ illud, Aurea cæfaries ollis atø̣ au rea veftis. Virgatis lucêt fagulis tum lactea colla Auro innectütur. Simili modo 
Alexandri quogo exercitus Argyrafpides nonnullos, ob arma argentea appellatos legimus,ficut noftri temporis duces equitéfg lophos habent \& galeas, ac lacernas,auro plurimo argentógue redimitas.

Merita uictorum ac triumphantium, cognominibus fiue pronominibus celebratd, Cap. Ixa

Ed præter dictarú cumulum rerum, cognomina fue prænomina eti 7. am his qui meruiffent ex rebus clariflime gefts ad nominis diutur-

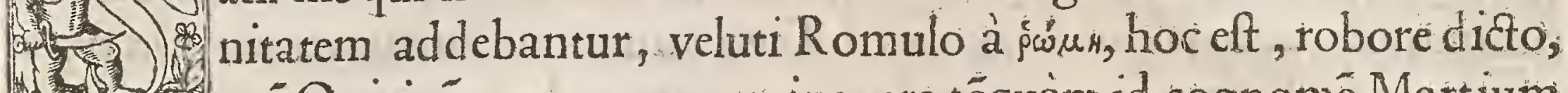
qué Quirinú veteres cognominauere,täquàm id cognomê Martium quippiam \& bellicofum prę fe ferret. Veteres enim láceam Quirinũ vocare folitos legimus, eam quoq in regia pofitam Martem appellare. Läcea quog donari confueuiffe illos qui in bellis quàm acriter ftrenuéq pugnâtes fortitudinis lau dem meruiflent, proinde effectú effe vt Romulus veluti Martius quidam deus et pugnax, Quirinus diceretur: quanquam nec clari defint auctores qui id cognomen ex eo ductü afferant, $\phi$ ciues quirites a ppellarentur, qui regi fuo nomen inpofuere, fue $q$ Cures rex ipfe Romanus vixerit . Camillus dictator recuperata ex holtibus patria, ac in vrbem triüpho inuedus, rediens iocis militaribus quos de more incóditos iaciebát, Romulus ac parés patrix códitórq̧alter vrbis haud vanis laudibus appellatus eft: nec aliter M. Claudium quinquies cof.Marciog fi lium cognominatum perhibent: quú enim effet exercitatione bellicofus, manu ac toto corpore potens, et vir fuapte natura ad dimicandū ardens, ei ficuti Poffidonius inquit, cognomen quod Martium eft primum ex familia fuiffe Marcello: atọ vt eodem Polfidonio auctore Fabiú clypeú, fic húc à Romanis gladium vocitatum conftat. Sic M. Manilio quia Gallos primus ab arce depulit; quú per nocté inuafere capitolium, Capitolino ei cognomen eft inditum. A phricani au tem militarísne prius fauor, an populares auræ celebrauerint, an ficuti Folicis Syllæ, Magníq̧ Pompeii patrum memoria coeptú ab affentatione familiari fit, non fatis compertum habeo, primus certe hic imperator nomine victa à fe gen tis, vt inquit Liuius, eft nobilitatus : quod equidem profiteor apud tantum au. ctorem me non parum adinirari, quum $\mathrm{Cn}$. antè Martius captis Coriulis vrbe Volfcorü,Coriolanus ob egregia militix facinora dictus fit. Quid Cato ille primus, nónne Cenforius à feueritate cenforia , quum Prifcus antea vocaretur,poftea Cato virtutis \& fapientix quafi cognomentum ei eft additum? fue vt $C x-$ farienfi placet, à catus, quod non, vt aiunt, fapiētem fed acutum fonat, vt Helius Sextus \& Varro tradunt: fue $\propto$ quum Plutarcho auctore Romani in quo mul tarum rerü vus \& experientia vigeret Catonem nominauere? Fabiusitem $\mathrm{Ru}$ tilianus fimul concordiæ caufa,ne humillimorú manu comitia effent, omnem foréfem turbam excretam in quatuor tantúmod o tribus cóiecit, $V$ tbanáfqge eas appellauit: adeoóp eã rem acceptã gratis animis ferunt,vt Maximi,qd’ tot victoriis non poterat, nomen, hac fibi ordinú temperatione pararet. $Q$. quoç Fabius Cunctatoris fibi cognominationem afciuit, fue $q$ ingenio $\&$ fuapte natura remiffror effet, quippe qui armorú clementia ouicula iudicaretur, fiue queinduftria nouã victoriam ac fálutarem cunctando, nec củ hofte confligendo romanam rempub.reftituerit. Alter quidam $q_{2}$ paucis poft patris obitum diebus funebribus 
nebribus ludis gladiatorum munus exhibuerit Celerem vocauerüt, celeritatem ac apparatus maturitate admirati, ficut Appium Claudiü victis $V$ ulfinéfibus au daciæ cognomento nominatú. In annalibus etiam fcriptum effe inuenio, L.Sicciū trib.pleb. plus quàm credi debeat Atrennuú bellatorem fuiffe, nomenọ́ ei factum ob ingentem fortitudinem, appellat ímg romanum Achillem: nec aliter hac L. Siccius, Q.Cottius propter fortiudinem cognominatus eft. T. Manlio fummo loco nato cognomentum eft Torquatus, caufámque cognométi fuiffe accepinus, Torquis ex auro induuias, quam ex hofte quem ceciderat detractam induit, quo ex facto ipfe pofteríg eius Torquati funt cognominati. Valerius autem Maximus adolefcens ac tribunus militaris fua etiam virtute nixus $\&$ opera corui alitis repentè diuina quadam vi aduolantis $\&$ aduerfarii oculos \& profpectum alis \& vnguibus prępedientis; quia ducé Gallorum vicit interfecitóg, ob hanc caufam cognomen fibi Coruini védicaffe haudquaquam eft no bilium fcriptorũ qui fecus dixerit.Idem ob victam Meflanam, nobilifimã Sicilię vrbem, primùm honoris caufa Meflana,deinde paulatim vulgo literam permutante Meffala nuncupatus. Cornelius Rufus eo decemuiro, bello punico fecundo, fuadête vt libri A pollinares ex libris Sibyllinis inftituerétur, Sibylla ob eam rem poftea vocatus eft, \& vt nos antè diximus corrupto deinde vocabulo Sylla nominari copit: vnde \& Sylla dictator poftea fequitur, qui Foolix cognomento vt apud Latinos habitus eft, fic apud Gracos fe infcripfit L. Cornelium Syllam venereum, ve in chæronia Plutarchi qui de hoc græcè defcripfit notum elt, et vt de bello Mithridatico trophæa pariter infcripta reperta funt: nec id in eptè, Plurimú enim Veneris,nó nox, vt inquit Menāder, fed fortuna fortitur,cui cú clariffime rebus ipfius geftis fefe ipfe dicauit, exclamás iuxta Oedipodem Sophocleú,Ego meipfum fortunæ filium fero.Iulius Cæfar prænomen imperatoris \& cognomé patris patriæ inter alia permulta nomen fuú illuftrantia decerni fibi voluit. Huius fucceffor Octauius quoog $\mathrm{C}$ far, ampliore Augufi cognomine dictus eft: vel $q$ magnos, fãctos, foelicesó, au guftos vocát: vel $q$ loca religiofa et in qus quid auguratò có fecraretur, augufta dicerentur, $a b$ auctu, vel $a b$ auiü geftu, guftự̧, quę idé funt.Q. Fabius Maximus gallica victoria cognomê Allobrogis fibimet ac pofteris peperit: fic à deuictis holtibus bello, Germanici fibico gnomen meruit. Hac itaq̧ cognominationem fue prænominationé affumunt apud noftros,quemadmodum apud Græcos huiufcemodi indi folebant præno mina fue cognomina: fic Diony fro plurima ab rebus quas egit funt ab hominibus indita. Nam alii Bacchum à mulieribus qua bacchantes illum fequeban cur dixere, alii à torculari quo vinum exprimitur Lenæum, quidam Bromium, à tonitu qui in eius ortu contigit. Pingenius infuper ex eadem appellatur caufa. Quinetiam triumphator dicitur, 9 primus omnium de Indis, multis cum fpoliis in patriam reuerfus triumpharit. Liberum etiam appellatú putant, non ob licentiam lingux, fed quia liberat animum à feruitio curarum efficiatóp vegetiorem, $\&$ audaciorem in omnes conatus reddat: patré proinde, $q$ de Indis victoria potitus, Thebani fefe liberos ipfo viuéte \& quafi fub optimi patris tutela fer aatos arbitrarentur. A rebus geftis infuper alia, ficuti Sotera 86 Callineon:à 
virtute, vt Euergete \& Philadel phon. Iam excellentem virtute abftinentix $A \dot{i}-$ ftidé fuiffe afferứt, tanta vitze integritate Phorioné ve cognomine ille iuftus, hic bonus fit àppellatus. A virtutis quoós præeftantia prudétię̣́ ac viriü, Louis filios appellauerunt,vt A eacü,Minoa, \& Sarpedona. Ferociffimos \& immanes \& alienos ab omni humanitate tanquan è mari genitoss, Neptuni filios dixerứ, $\mathrm{Cy}$ clopa, Geriona et Lęftrygonas:à for tunę foelicitate, vêt Eudęmona,ficut Baffumi fecundum vocatum legimus: ab exitio verò vrbium, fiue peritia difciplináp obfidionis faciende, machinarumq folertia, $\&$ ad expugnanda oppida inuentione Poliorcetes cognomentum fuit Demetrio Antigoni filio,duci illius temporis inclyto. Nonnullos adhuc è nafcendi forte nuncupamus, vt Proculos qui foris procul abfentibus parentibus nati funt,Pothumium qui patre mortuo, Vopifcum quum ex gemellis fuperftitem alteri effe contigerit, Ceqarem quum enecta parente excifo vtero gignitur, fic Scipio Aphricanus prior natus, primúfíg Ro manorum ob cxfum matris vterum Cæár dictus eft, Seruium qui mortua matre in viero feruetur. Nonnullos corporeum etiam prænomen fiue cognomen habuiffe legimus. Horatius enim Cocles quum alterú oculum antea bello amififfet, cognométum admifit quafi lufci et vno lumine tantum cernentis. Lufcos enim et vnoculos coclites dixerüt veterès, fićóp Cyclopàs coclites legimus dictos qoculum vnum habuiffe memorantur. Quidam tamen id ex frmitate nafi traEtum autumant, qui fub ipfa fronte ita depreffus demiffusóg erat vt nullum fere inter oculos difcrimen extaret,ipfág fupercilia commixta inuicem confufáque forent: iccirco volétibus eú multis Cyclopem nominare, delapfa loquendi confuetudo obtinuit ve iam cocles à plurimis appellaretur. M. quoog Tul.in extrema nafi parte eminens quoddam in figuram ciceris habuit,á quo Ciceronis cỏ gnomêtum fibi inditum eft. Q etiam Fabius Cúctat or à verruca in labiis verrucofus, \& Cneus ob infigne nęui appellatus.M.Curius \& $\mathrm{Cn}$.Papyirius Carbo quia cum dentibus eos nafci contigit, ob id Dentati cognominati funt. Neoptolemus à capillorum qualitate Pyrrhus,à quo \& pyratica primum ars perhibetur inuenta. A fcanius à prima barbæ lanugine, que ei tépore victoriæ nä fcèbatur, Iulius. Artaxerxes à dextrà nanu illius læua lógiore, Longimanus. Ancum prænomen Varro ex Sabinis tranflatum putat. Valerius Ancias fcribit $\$$ cubitum vitiofum habuerit, quod grecè áskì vocant. Papyrius è precipúa pedum pernicitate Curfor. Quorum vero in nalcetido non caput fed pedes primi extiterant, qui partus difficilimus \& egerrimus habetur, Agrippæa appellati; vocabulo ab egritudine \& pedibus cóficto. A cognatione alios dictos legimus, vt Manlios, \& Cornelios, \& Pompeios, quos quia auctor ex Hifpania Pompeius boum pompan duxerat alii cognominatos perhibent. Sic apud Grecos Hera clides, \& Pelopidas à morũ imitatione \& quadã quafí fimilitudine aliis plurima contigerunt, viuentium gloriam prorogantia: quum alii fulmina, $v t$, geminos duo fulmina belli Scipiadas, cladem libya:alii victricés aquilas \& accipitres in uictos, alii \& diuos deóog genitos, vt Alexander ille Macedo, \& prater eun dus cem plerigh alii cognominari fe.ingenti cum voluptate voluerint. 
T quoniam eò impendi labor ac periculú perfæpe folet vnde emolu (3) - mentum atq honos fperetur, nec difcriminis quippiä fontaggrefluri 2. ${ }^{2}$ homines fi magnis conatibus magna præmia haud pponartur,fuL crunt pręter hęc quæ modo diximus alia ob ftrenue gefla fortifimis ducibus, auxiliariis, \& legionibus, tũ ex fenatufconfulto, tum ex maiorú liberalitate concefla, quæ plurima quidé $\&$ varia prodútur. Decreverüt enim ad præmia fuperiori A phricano paribusiornamétis exoluêdas ftatuas plurimas, \& tri umphali etiam habitu vifendas, in pluribus $\&$ celeberrimis vrbis parubus, in comitio, in roftris, in curia, in capitolio ponere decreuerunt, continuum per om nes vitæ annos confulatum perpetuam'q dictaturam tribuere : decreuerunt vt imago eius triumphali ornatu è templo louis optimi maximi exiret, \& que fit i neq plebifcito dari, neq̧ fenatufcöfulto illius magnitudo animi ac fpectata mo deftia palfa eft, poft obitum recufare non potuit.Liberalis etiam po.ro.magnitudine munerú, $\phi$. Attalo regi A liam dono dedit: fed Attalus teftamenti æquitate accepti muneris haud immemor,qui eandem Afiam moriens po ro.legauit. Eumenes Attali regis frater, \& qui auxilio aduerfus Antiochü Macedonem fuit,omnibus Afrx ciurtatibus quas Antiochus bello a mifer at à fenatu donatus eft. Pompeius Deiotaro Galatiæ regi Armeniá minoré contulit', $\phi$ focius bello Mithridatico fuerit. Numidarum item rex Maffinfla in a micitiam receptus à P.Scipione Aphricano, multa \& præclara rei militaris facicora quú feciffer, ob qua victis Cart haginenfibus \& capto Syphace cuius in A phrica magnum atq̣, latü imperıú, magnã głoriã nof ris hom inibus peperit, po. ro.quafrüg vrbes \& agros quos manu ceperat fibi dono dedir.M. Curus quá lalia Pyrrtum regem exegiffer,decret is à fenatu feprenis iugeribus agri populo, fibi autem quinquaginta, popularis aflignationis modum nó exceflit, parum idoneum reirub. ciuem exitumans qui eo quod reliquis tribueretur contentus non effer. P. Corneli guog, Scipionis confulis decream de ag ris militum eius fuit, ve quot quifque cor ü annos in Hifpania aut A phrica militaflet, in fingulos annos bina iu gera acciperer. Scipionem ité pofterioré dona militaria his qui ftrenuá operam cdideranc diuidentem, T. Labienus vt forti equiti aureas armillas tribueret admonuit, eóp fe negante id facturum ne caltrenfis honos in co qui paulo antè

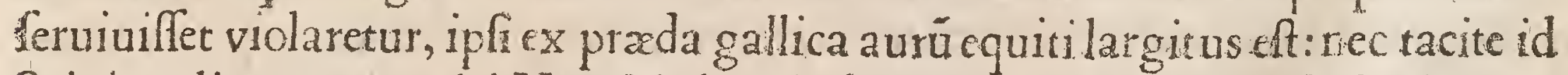
Scipio tulit, nang equiti, Habebis, irquit, donum viri diuitis: quod vbi ille acce pit,proiecto ante ped es Labieni auro,vultú demifr. Idem vt audiuit Scipionem dicentem, Imperator te argenteis armis donat, alacer gaudénfq abiit. C.eiam Marii pracipuus non folum, cæterum prapotens gratæ métis fuit affectus: duas enim Camertium cohortes mira virtute vim $\mathrm{Cymbrorum}$ fuftinentes in ip fa acie aduerfus cöditioné foederis præter omnes leges ciuitate donauit: quod quidem factum quum à nonnullis accufaretur, aiebat verba legum propter armo rum ftrepitum exaudire nequiuiffe. In luper quum C. Lucius fororis filius atque prafectus in eius fecundo confulatu militi cuidam præftanti forma Trebonio nomine fub fe militanti vim afferret, $\&$ ab adolefcente occifus eflet, mul tis Tre- 
bonium accufantibus ac null is patrocinantibus, Trebonitus à fe illum occifund qui in magiftratu effet non negauit, fed hanc necis caufam dixit atö probauit, q Lucio fe folicitâti obftitiffet, \& quamuis multa darentur, fuum tamen corpus nunquam proftituere voluiffet: itag Marius qux pro præclaris militix faci noribus corona dari cöfueuerat ferri ad fe iuflit Trebonióg impofuit. Bãdius quum aliquando Marcellum falutaffet,quis nam fit homo Marcellus rogat,ğuis illú probe norat antea:eo autem refpondente; L. Bandius, quafi lętatus magnopere admiratíş̧ Barcellus, Tu ille Bãdius es, inquit, cuius maxima inter Can narum bellatores fama eft $q$ P. Aemilium cófulem folus ne deferueris, in quens cum denfiffima coniicerentur miffilia ea corpore fubiiciens excepifti?affentien te Bandio \& vulnera quxdam oftentante, Talia,inquit, quum in nos amicitia figna proferres, ad nos cur non cófeftim ibas? an nos ad retribuéda amicorum virtutis præmia quibus $\&$ penes hoftes tantus habetur honos iniquos cêfuifti? Hæc benigne locutus comprehêfum dextra iuuenem eximio ad pugnam equo \& quingêtis argêti drachmis donat. Hannibal militibus fuis quoøg Infubrium. agro in concioné vocatis,am pliffima \& certiffima pręmia pronunciat. Agrum enim fere daturủ in Italia, Aphrica, Hifpania,et vbi quifq̣ velit immuné ipfi qui accepiffet liberisóq: qui pecuniam $q$ a agrü maluiffet, eius fe voto fatiffacturú: qui Carthaginenfes ciues fieri vellent,poteftatem facturú: qui domos redire mallent; daturum fe operam ne cuius fưorü populariü immutatam fecum fortunam effe vellent.Seruis quoģ dominos profecutis libertatê proponit, bináọ pro his man cipia dominis fe redditurum,eáq $\mathrm{vt}$ fcirent rata fore, agnum lęua manu,dextra filicé retinens, fi falleret, loué cęterosóg̣ precatus deos ita fe mactarent, quéadmo dum ipfe agnü mactaffet,et fecúdú precationé pecudis caput elifit. Et tne fua de effent præmia claris geftorú titulis,eminentibus Cæfar grauioribus prallis, fingulis legionibus quaftores præficiebat qui fortiter agentes agnofcerent, \& $8 \mathrm{re}-$ muneratione dignos afficerent. Diuitias idem ac pecunias non voluptatis aut fuarum gratia delitiarum ex bellis cumulaffe, fed cómunia potius virorum for tium pręmia apud fe conferuata iacere voluit féģ maxima ex parte locupletari putans quoties illa benemeritis viris militibúfog impartiffet. Aurum nanque \& argentum cæteráfø̧ diuitias ex hoftibus partas, quấta horum aderat copia ma gno in numero Romam mittebat,ædilibúrfg ad fpectacula tribuens,prętoribus quoq̧ atç cófulibus eorúmq̧ donans vxoribus multos fribi allexit, aliófq̧ omni fpe doniś́p dimifit. Illud inter cuncta nec filentio prætereüidum, q ærarium po. ro.quod tot reges victi, tot Afix populi, tot nationes, tot bella,tot triüphicom pleuerant, $\&$ tot annis intactum mäferat,primo introitu in ciuili bello fuo, vno die folus exhaufit,intérqgalia vt fcriptú eft protulit ex eo laterum aureorú xxxvi。 milia, \& innumera pondo, trium milium, frue vt alibi, quatuor milium centum triginta \& quinque, argenti verò nógentorum propè milium . Nec aliam ob rem, vt diximus, quàm cupiditate largiendi : nam vt alter ait, Nemo liberalins victoria vfus eft: nihil enim fibi retinuit nifi difpêfandi libertatem.Inde magnifica \& probāda omnibus Titi vox , \& exhortatio illa Hierofolymarum obfidione, Me pudeat, inquit, nifi eum qui prius murum afcenderat remuneratione: inuidendung 
inuidédum fecero, ve fi quidem vixerit fimilibus prafit. Nec pollicitis minor inuentus, qui in cócione, ea deuicta dixit illis,qui maiore vi decertaffent, \& pracla ris facinorú titulis naturam fuam rebus bene ac fortiter geftis nobiliorem reddidiffent, præmia $\&$ honores redditurum, nec corum vllum qui plus alio laboraffet iufta neceffitudine cariturum. Confeftim itaque iuffit cos guorum partes erant, indica re quofnā fcirent omnes fortiter gefliffe, \& nominibus fuis quofog interpellans pręfentes collaudabat, quafi qui domefticis recte geftis, fatis fuper'q lætarentur, \& coronas eis aureas imponebat, \& torques longas $\not$ p haftas \& figna ex argento $f_{a}$ cta donabat, $\&$ vniufcuiufo, ordinem mutabat in melius: quin eti am ex manubiis aurum $\&$ argétum, veftes item aliámque prędam fumma qua dam liberalitate diftribuens.

Superftitum non folum fed defunctorum ducum memorie celebres tituli, et de columnis, obelifcis,

pyramidibus, arcubus, ftatuis, clypeis, tabulis, cantarifque ad id exedificatis, Cap. XI.

V. Vnc memorix nedum fuperftitum fed defunctorum ducum proro-
gatæ celebres titulos referamus,ac primum louis, qui vt cateris dei-
tatis nomine, ita $\&$ rebus geftis multorú opinione fuperior fuit. Etecolligens, hiftoriamóg contexens ex titulis \& infcriptionibus facris quae in anti quiffmis templis habebantur auctor eft, in phano louis triflii auream columnam effe pofitam ab ipfo loue conftat, in qua titulo monftrante fua gefta perfcripfit, vt monumentü effet polteris rerum fuarum. Sefoofis finem expeditionis in Thracia ftatuens, multis in locis ab fe deuictis colunas erexit, in queis Aegypriis quas facras dicunt literis fcriptum extat, Hanc prouinciam armis fubegit rex regum,princeps principum Sefoofis. Quid Alexander ille Macedo? nónne in Sogdianorum finibus Alexandriam condidit ad cóteftandos itineris fui terminos? quo in loco ab Hercule primú, à Libero deinde patre, Cyro item $8 \mathrm{Se}$ myramide atç ab ipfo Alexád ro deniqg aræ funt conftitutx, quòd proximum gloriz omnium duxerint illò vfque promouiffe itineris fui metas, ab illa parte terrarü fluuio fines fecante, quem Bactri foli laxatem vocant, Scythæ Filin nominant, hunc eundê effe Tanaim exercitus Alexandri magni crediderunt: verum vbi Demodamas Seleuci \& Antiochi regú dux, fatis idoneus verò auctor tranfgreffus amnem iftum titulos omnes fupergreffus, alium effe $q$ Tanaim deprehêdit, ob cuius glorix infigne dedit nomini fuo vt altaria ibi ftrueret A pollini Dindimo, hoc eft, Colliminio, $q$ limes Perficus vna cum Scythis iügeretur. Idem Alexander triüphorum fuoru aufpiciis condidit in ægyptii maris littore vrbé aliam fui nominis, quam metatus eft Denochares fue Democrates,architectus memorabili ingenio,xv milia paffuúlaxitate cóplexus, ad effigiem Mace donicæ chlamyd is, hoc eft,orbe gyrato,lacunofo dextra lequáq, angulolo pcur fu,iam tũ tamen quinta fitus parte regi dicata. In diverfis infuper Afiæ regionibus xii inuenitur cōdidiffe muros eorũ, infigniés græcorú quibufdam elemétorú characteribus,vti legeretur in eis, Alexander rex filius louis fecit. Idem Her culis \& Liberi patris laboribus fuperat ispræcepit ei quen Perfidi præfecerat, vt pilas folidas auri pedum vicenûm quinûm erigeret, $\&$ in his facta eius friberet ponerétg 
ponereto in vltima India vltra Liberi patris \& Herculis trophęa: vnde ad preceptore fuú Ariftotelê fcribés, Et ego,inquit, mea quinq̧ aurea trophęa priorıbus altiora denis pedibus ftatui, at $\$$ imperaui, quæ miraculo fint futura, chariffime præceptor, polteris, fcilicet nō parua admiratione nouú perpetuúmq virtutibus monumentum, non inuidendü mortalibus perpetuæ de nobis opinionis \& animi induftrix. Huius regis gloriam emulati funt Romani, fed non diuitias adæquarunt: ftatuerüt enim columnas \& ipfi quę rerum geftarum referrent memoriam, fed æreas atque marmoreas. Auguftus nanq victor totius Aegypti quam Cæfar pro parte fuperauerat, nulta de nauali certamine fuftulit roftra, quibus conflatis quatuor fecit columnas, qux poftea à Domitiano in capitolio funt col locatæ: nâ roftratas Iulius pofuit victis Ponis nauali certamine, è quibus vnam in roftris,alteram ante curiam pofitam conftat. Fuerunt $\&$ marmoreæ colúne, quibus apud maiores, nobiles aut fub montibus, aut in mótibus fepeliebantur: vnde natum eft vt fupra cadauera aut pyramides fierét, moles ab imolatiffime, in fummitates acutiffimas definentes, fic dictè, quòd ad ignis fpeciem in conum tenuarétur, aut ingentes collocarentur columnæ . Verum quanquã de pyramidum mole ac forma fcripferint Herodotus \& Homerus Durifianus, Ariftagoras,Dionyfus, Artemidorus, Alexander,Poly hiftor,Buthoriades, Antifthenes, Demetrius, inter omnes eos tamen non conftat à quibus coptæ fint auctoribus. Erigendarun autem dicandarúmque pyramidum caufa in Aegypto, regum pecunię ociofa \& ftulta oftentatio à plerifque traditur, ne pecuniä fuccefforibus aut emulis infidiantibus præberêt, aut ne plebs ociofa langueret. Colúnarum verò vfus in Romanis coepit à Cornelio Menio qui prifcos deuicerat, anno vrbis códite ccccxvi. Erat $\&$ in foro Traiani columna fub qua offa eius pofita in vrnam aureã collocata fuiffe conftat, permanentóp duæ adhuc Romæ Hadriani \& M. Antonii fuis nominibus celebres. Harum auté ratio eft, quibus dicatę fue . rint attolli fuper cæeteros mortales, quéadmodum in vrbe Roma inter diuerfas moles obelifcos videmus plures, aliośq iacentes, alios erectos, quos imperatores maximi bello domitis gétibus \& profperitatibus clariffimarú rerum geftarum elati diis fuperis in religione dicarunt. Sic Sefoofis Aegypti rex obelifcos ex lapide puroduos erexit, vtrúqg altú cubitis centumuiginti, in quibus tum imperii magnitudinem, tú quas fubegit nationes defcripfit. Sic apud $\mathrm{Hyberos}$ pugnacë getem tot obelifcos erigere circa cuiufop fepulchrü moris erat quot homines ex numero hoftiū ille necaffet . Erät $\&$ Triüphales arcus, funt'́g adhuc Romæ fuo loco,imprimis imper.Cæraris, L. Septimil, \& imper.Cæl.M. Aurelii, Antonini Pii, rerum fuarum infigni marmore $\&$ claro artificio, vt impreffa docet infcriptio. Et arcus etiam triumpho infignis Conftantini, quen incifa, literæ libera torem vrbis, fundatoré quietis indicãt. Eft \& nobilis atọ triüphalis Hierufalem, hunc titulü habens,Diuo Vefpafiano \& Dino Tito filio.S.P.Q.R.Pauca reli quorü deinde veftigia fupfunt, quanğ trecêtos et viginti triüphos ab vrbe cond. ad hęc ipfa quę modo diximus tépora numerent. Nec etiâ. dubium eft ob virtu tis miraculü quin maiores noftri reges ipfos vita functos iactare fümis laudibus. ac nouis et exquifitis honoribus coeperint, frue vt fieri folet in adulationé eorum, 
fue ob beneficia quibus erāt humanitate compofiti, ipfir reges deinde cum chariffimi fuiffent his quorum vitan compofuerant multis'q honoribus referferât, non paruum deniqg fui defiderium de medio fublati reliquerunt: fića homines ætatis illius fue Samii, frue Corinthii,fue Affyrii,fue Aegy ptii,fue alterius gẽtis fuerınt, fimulachra finxerunt $\&$ ftatuas, vt haberét quo aliquam voluptatem ex imaginum talium profpectione reciperent, progreffique lógius per amorem memoriam coperút colere defunctorum vt $\&$ gratiam referre benemieritis viderêtur, et fucceffores eorú allicere ad bene imperandi cupiditaté: quod orator eximius in Natura deorum monet dicés, Sulcépit autem vita hominis cófuetudóque communis vt beneficiis excellentes viros in cælú fama ac voluptate tollerét. Hinc Hercules, hinc Caftor, hinc Pollux, hinc Aefculapius, hinc Liber, \& alio loco,atç alio, \& in plerilog ciuitatibus intelligi poteft, acuend $x$ virtutis gratia: aut quo libentius reipublicæ gratia periculum adiret optimusquifque, virorum fortium memoriam honore deorum immortalium confecratam. Hac ratione Mauri proprios reges, Romani fuos Cę̧ares, \& qui viri fortitudine infignes erät confecrauere. Inde per gentes \& prouinciás fingulas varia deorum religio mutatur, dum non vnus ab omnibus deus colitur, fed propria cuiqg maiorú fuorum cultura feruatur. Hoc ita effe Alexander Magnus infigni volumine ad matrem fuam fcribit, metu fux poteftatis proditú fibi à diis, hominibus, à facerdote fecretum, quòd maiorum $\&$ regú memoria feruata fit: inde paulatim cultu in metum verfo, fuperftitionem mortiferam irrepfiffe, verímque effe poëticum illud, Primos in vrbe deos fecit timor. Quo autem tempore huiufmodi divini honores mortalibus effe coperint, non eft obfcurum, præfertim quum nulli reges ante Saturnum vel Vranum fuerint, \& Iouis temporibus ab initio templa confituta effent, $\&$ noui deorum cultus inuenti. Sic hominum effigies quum nō folerent, exprimi copere, nec nifi ab aliqua infigni eorú qui diuturnitatem nominis meruiffent: primóg facrorum certaminum victorix, maximeóp Olynupix,vbiom nes quicüg victores fuiffent fimulacra effingi folere moris erat, eorum qui ter huiufmodi in certamine fuperiores cuafffent, ex vniuerfo corpore lineament is ad ipforum fimilitudinem expreffis. Primus tamen hic ftatuarum honos,vt videre videor, Græcis debetur, nullisque apud eos reor plures dicatas $\vec{q}$ Demetrio Phanoftrati flio $\mathrm{Phalereo,qui} \mathrm{quum} \mathrm{apud} \mathrm{Athenienfes} \mathrm{cócionaretur} \mathrm{vrbi} \mathrm{prę-}$ fuit annis decen, æreisíp ftatuis honoratus eft trecentis fexaginta, quarum plures equeftres erant, $\&$ in curribus leu bigis ftabant fummóque ftudio ferme intra quadringentos dies confumatę erant. Iam quum apud Âthenienfes clariffimus effet,fic quog ipfe ab ea que cuncta confumit inuidia tentatus, quippe infi dias paffus à quibufdam, mortis fententiam abfens excepit, non tamen eius corpore potiti funt,verum ipfius deiciētes imagines, arugine de induftria foedatas, alias quidem vendiderunt, alias fubmer lerunt, alias in frufta conciderüt, vna au tem in acie feruata: atque hoc intuliffe Athenienfes huic Demetrio, iubente rege proditum eft. Apud Romanos etiam \& pedeftres et equeftres ftatuas proculdubio aliquâdiu in fumma veneratione $\&$ auctoritate habitas conftat, equeftrium tamen origo perquàm vetus eft, $\&$ cum fominis etiam honore comnunica- 
to, exemplo Clodix cuius ftatua equeftris erat, ceu parum effet toga eam cing ${ }_{\text {. }}$ quam nec Lucretiæ, nec Bruto qui expulerant reges, propter quos Clodia inter obfides fuerat decerneretur: \& quanquam Catonis in cenfura vociferationes ef fent, mulieribus romanis in prouinciis ftatuas poni, non tamen potuit inhibere quominus Romæ quoque ponerentur,ficuti Cornelix Gracchorum matri , quæ fuit A phricani prioris filia. Togatæ antiquitus ftatuæ dicabantur, deinde nudæ, haftam tenentes: græca enim res erat,ftatuas nudas dicare, nihil'o in eis condere: ecótrario verò romana, togas \& militares thoracas fuperaddere.Cæfar quidem dictator loricatam fibi in foro dicari paffuseft ftatuâ. Fuit Marci Trèmelii equeftris toga, qui Samnites bis deuicerat,captág Anania populá ftipendioliberauerat. Fuit eriam Scipionis qui bellum in A fia geflit, Antiochúmque deuicit non folum cum chlamyde fed etiam cum crepidis in capitolio fita. Dicabantur quibufdam argentex, quibufdam aurex. Pompeius nanq, in triüpho Pharnacis qui primus regnum tenuit in Ponto argëteam träftulit. Mithridates item currus aureos \& argenteos, quanquá nec defint quiargenti vfum pri mum Diuo Augufto dicatum in ftatuis falfo arbitrentur. Aurea autem ftatua, ac omnium prima nulla inanitate, in templo Anetidis, numine gentibus illis fa cratifima pofita eft. Antonii deinde Parchicis rebus direpta ftatua quog regis Affarii quã non adoraffe capitale erat, ex auro fuit lexagintarumos cubitcrum proceritate. Domitianus etiam apud noftros quum de Dacis Germanisóp.triumphaffet, tantæ fuit infolentix atque fuperbix vt aureas at $\$$ a a rgenteas ftatuas fibi in capitolio poni iufferit. Ex ære etiam primam Romæ ftatuam cóflatan, $\&$ Cæreri primùm dicatam ex Spurii Caffii peculio quem regnum appetentem pater eius occiderat inuenio. Statua quoque Horatii qui \& Cocles cognominatus eft enea fuit, $\&$ in æxde Vulcani pofita eft, quę detrimentú corporis acceptum (claudus enim tefte Plutarcho poftea fuit)quod armatus in T y berim defiliens tyrrheno, telo fautius ille ad miferat oftendit, Liuius licet obfter, multifog fuperincidentibus telis incolumé ad fuos tranfnatauifle alferat. Cæéar diçator nó folum fibi in foro dicari ftatuas paffus eft, led difiectas Pompeii ftatuas repofuit. Ex hoc etiam Augufti Cefaris morem probandum céfeo, quòd illuftrandis ducibus antiquis qui romanú imperium auxiffent exactifimam diligentiam impendit,opera cuiuis reintegrans ac titulos, dedicatis on nium fatuis triumphali habitu in porticibus fui fori: factum placet, nec minus ratio: frquidem edicto prafatus elt,eo fe propofito id agere, vt effent quorum ad exépla $\&$ ipfius \& fuperioris temporis clarorum virorum formarentur mores, ad quorumque velutí præfentem regulam inftitutos principes fuos po. ro.exigeret: fapienter vtique: Nam quum aliquando ftatux fuiffent infignia virtutum $\&$ his ponerentur qui ingenio \& doctrina præftarent, quíque magna gefiffent, aut mortem pro republica obiiffent, quales decretas legatis à rege Veientium interfectis legimus, nullum mortuo, Ciceronis fententia, ab homine mortali vel carius vel diuturnius præmium vel gratia maior vlla pręttari poteft quàm ftatuæ vel fepulchri.Ha rum rerum geftarum \& gloria memoriă quamplurimi ex his quos diximus bel lorum duces aternitati commendari poffe exiftimantes ardenter affectarunt, Ii ii tanqua 
tanquam plùs præmii de vrnis \& figmêtis huiuf modi fenfu carentibus adepturi, quàm ex confcientia honefte rectéq factorũ. Quòd autem fit pulchrum velu. ti exigua hęc \& minima fpernere ad afcenfum veræ gloriæ tendentë, Cato Cen forinus monftrauit, qui interrogatus quá ob rem inter multos ptæclaros ftatuam non haberet, Malo,inquit,ambigere bonos quả ob rem id non meruerim, $\vec{q}$ quod eft grauius cur impetrauerim muffitare. Militari etiam gloria clypei fe ingerunt, quos in facro vel in publico priuatim dicari inftituti veteris fuiffe cóperio. Primus qui hoc egerit, Appius Claudius fertur: is dico q cú Seruilio cof. fuit, anno vrbis cclxx. Pofuit enim in Bellonæ æde maiores fuos, voluit'ó in fublımi videri, \& clariffıme geftorú titulos legi. M. Aemilius in confularu collega Q. Luctatii poft eú nó in bafilica modo Aemilia, verùm \& domi fux pofuit, pla cuitós plenã virtutis imaginê reddı clypeo cuiufqg qui fuerit illo vfus. Hos $\mathrm{P} \propto$ ni ex auro factitauere: fićó clypeos $\&$ ima gines fecü in caftris vexere. Eiufmodı quoque fcutis apud Troiam pugnatũ eft, expreffis quoq̧ imaginibus: \& clypeus fupra fores capitolinæ æd is vfóp ad incendium primü fuit, tấtáģ maiorum quidem noftrorum auctoritas in ea re annotatur, ve L. Manilio Fuluio cor.anno vrbis dlxxv M. Aufidius tutelæcapitolii redéptor,docuerit patres argenteos effe clypeos qui pro æreis per aliquot iam luftra affignabantur. Tabulis fimiliter pictis funt qui rerum fuarú memoriam excoluerunt,vt L. Aemilius Paulus, Luciusóg Scipio,ac Meffala princeps. Horum enim primus de Liguribus trium phans geftorum ordinem in tabula pictum publicè reliquit, fecundus tabulam victorię fux afiaticæ in capitolio pofuit, tertiam tabulam pictá pręlii quo Carthaginenfes \& Gerionem in Sicilia vicerat in latere curix hoftilix affixit,anno ab vrbe cond.decccxl. Arator aute ille Arpinas \& manipularis imp.C. Marius non clypeis pendétibus, non pictis tabulis,non toreumate fignóve, non ftatuis, marmore, aut ære, nó obelifco,non triumphali arcu, non pyramide, non colum na,non pila aurea $a$ dificióve quopiam tantum, fed cantharo res fuas clariffime geftas illuftrauit. Poft I gurthinum enim \& cymbricum theutonicumq trium phum, cantharis potaffe Liberi patris exemplo traditur, quo inter bibendu in dice illius victoria ex Afra ductr fuam compararet ac fimillimam redderet.

Ludoruns celebrationes,

cap. XIr. Of hæc infuper ludorum celebrationes, fiquidem ad natales eorum,
vel templorum nouorum dedicationes, vel vota ducum perfoluen-
da ingenti confluentis multitudinis copia funt conftituta: $\&$ primi-
tus quidé venationes que vocätur munera Saturno deo funt attributæ, fue $\phi$ ad expeditiones ituri, debeant pugnas $\&$ coëuntes inter fe acies fpectare, ne in bello armatos hoftes, vel vulnera, vel fanguinem perhorrefcant, fiue vt nonnulli perbibent, hãc apud veteres deuotionem factan, vt contra hoftes ci uium fanguine primú tali deo litaretur. Pefcenius enim Feltus in libris hiftoriarum refert Carthaginêfes Saturno humanas hoftias folitos immolare, 8 cum victi effent ab Agathocle Siculorum rege iratum fibi deum putauiffe, itaque vt diligentius piaculum folverent, ducentos nobilium filios immolaffe,tantum religio potuit fuadere malorum, vt tâtam ciuitatis partem occiderent, quantã for- 
taffe nec A gathocles victor occiderat. Idem in Latio quog eodem genere facrificii cultus eft, non quidem vt homo ad aram immolaretur, fed vt in Tyberim de ponte Miluio mitteretur. Verùm id genus facrificii ab Hercule fuit poftea cum Geryonis pecore ex Hifpania per Italiam reuertente fublatum, perfuafín illorum populis vt fauftis facrificis infaufta mutarent, ritu tamen permanente, vt pro veris hominibus imagines iacerentur è fcirpo,vt Ouidius in faftis docet, Donec in hac venit Tyrinthius arua, quotannis Triftia Leucadio facra parata deo. Illum ftramineos in aquam mifffe quirites Herculis exemplo corpora fal fa iace. Hæc facra veftales etiam virgines feciffe his verbis idé poéta meminit, Tum quog prifcorum virgo fimulacra virorum Mittere roboreo firpea ponte folet. Ex his caufis qua de origine huius f fti relatæ funt apparet, Saturnalia vetuftiora effe vrbe romana, adeò vt ante R omá in Gracia hoc foléne copiffet. L. Accius in annalibus fuis refert his verfibus, Maxima pars Graium Saturno \& maxime Athenæ Conficiunt facra qux cronia effe iterantur ab illis. Químque diem celebrãt per agros vrbesín fere omnes Exercent epulis lati famulófque procurât Quifg fuos.Noftrifg itidem etiâ mos traditus illinc eft, ve cü dominis famuli epulentur. lbidem eodê quog tempore quum diu etiam humanis capitibus Ditem placare fe crederent, eundem ferunt Herculem frmili modo redeuntem per Italiam gétibus fuafiffe ve facrificia mutarent, inferentes Diti nó homi num capita fed ofcilla ad viuá effigiem arte fimulata. Inuenio poftea quum ludi per vrbem in cópitis agitabantur, reftitui fcilicet à Tarquinio Superbo laribus ac Manix ex refponfo A pollinis, quo praceptum eft vt capitibus pro capitibus fupplicaretur, id q̧ quàmdiu obleruatụ vt pro familiarium fofpitate pueri mactarentur Maniz dee matri larium, ideft, deorum inferorum: quod facrificii ge nus Iunius Brutus col.pulfo Tarquinio aliter conftituit celebrandum. Nam ca: pitibusallii \& papaueris facrificari iuffit vt refpon fo A pollinis fatiffieret de nu mero capitum, remoto fcilicet fcelere infaufta facrificationis, factumque eft ve pila 2 effigies viriles \& nuliebres ex lana cópitalibus fulpéderentur, tótque his pilæ quot capita feruorum, tot effigies quot effent liberi ponerent ur,quæ denique effigies Manix fulpenfx pro fingulorú foribus periculum fi quod im mine ret familiis expiarent, ac dea viuis parceret his pilis \& fimulacris contenta. I udos autem iplos ex viis cópitorum in quibus agitabantur compitalia appellita uerunt . Deinde quọniam fuiffe Pani lyceo rem diuinam 8 cum hac L uperca lia fefta quódam celebrata primum fuiffe a pud vetufta tis affertores cóftat, de his nobis tertio loco differendum videtur. Ea itaque facrorum genera vt elegantiffi mis rerum geftarum fcriptoribus vifum eft, ab his qui ex A rcadia cum Euan dro in eum locum qui nunc romanæ vrbis eft profect funt, ad nof ros primum delata fuiffe ferü, ac ritu fuo celebrata. Ouidius in faftis, $\mathrm{P}$ ana deos pecoris veteres coluifle querútur Arcades Arcadiis plurimusille iugis. Pan crat arméti, Pan illic numen aquarum, Munus ob incolumes ille ferebat oues. Tranfulit Euan der fylueftria numina fecum, Hic vbi nunc vrbs eft, tunc locus vrbis erat. In qua quidem vrbe conftat Euandrum confituiffe, vt diuifa paftorali turba,nudi iuuenes ac pellibus immolatarum holtiarum inuoluti lyceum $P$ ana 
venerantes, per luxum ato lafciuiam ex epularum hilaritate profufioréc vino prouecti perfonati currerent, loráque manu ferentes obuios quofq ac mulieres maxime adultas, his vltrò manuú palmas cędendas porrigentes verberarét, exiftimantes id fibi foelicem pariundi facultaté præftare poffe,eodem poftea poéta dicête, Nupta quid expectas?non tu pallétibus herbis Nec prece,nec magico car mine mater eris. Excipe focundæ patienter verbera dextræ, Iam facer optatum nomen habebit aui. Cur auté nùdi currentes hunc deum coluerint, pleraq̧ curriculo vetuftatis ad nos viog delapfa indicant, fiue $q$ ipfi deo qui nudus eft celeritati fuz eo pacto longe aptius nudos miniftros habere vifum fit, five of Arcades omnium populorü qui Græciam coluerint vetuftiffimi, feris fimilem adhuc fyluis \& montibus vitam agentes, expertes legis artífque, primum hunc deum venerari patrio cultu coeperint.Idem auctor in faftis, Cur igitur currant, \& cur fi currere mos eft, Nuda ferant pofita corpora vefte rogas? Ipfe deus velox difcurrere gaudet in altis Montibus, \& fubitas concipit ille feras. I fe deus nudus nudos iubet effe miniftros, Nec fatis ad curfus cómoda veftis erat. C. verò Attacilius, vt fcribit Plutarchus, fcribit Romnlum quü ante conditam vrbem eius pecora à latronibus rapta fuiffent, Lupercalium folemnitate in honoré Fauno fupplicem primo excoluiffe, nudum deinde ne fudore prępediretur;omneis faltus currendo fyluasógl luftraffe, ideo nudatos Lupercales hæc ludicra celebraffe. Lupercos alii nudos fieri folitos aiunt, $q$ Faunus vefte delufus à fuis, eam facris procul arcuerit . Ouidius item in faftis, Vefte deus lufus, fallentes lumina veftes Non amat, $\&$ nudos ad fua facra vocat. Iuftinus quoop magis ex habitu dei cui ea facra fiebant, quàm ex alio nuditatis caufam refert, quú polt hunc tertio loco regnalfe Faunum ferunt fub quo Euander ab Arcadia vrbe Palanteo in Italiam cum mediocri turba popularium venit,cui Faunus et agros et monté quem ille poftea Palanteú appellauit benigne affignauit: in huius radicibus têplü Ly ceo qué Græci Pana, Romani Lupercal appellant,conftituit,ipfum dei fimulachrum nudú caprina pelle amikum eft, quo habitu pólt etiam Romæ Lupercalibus decurrebatur:vtcunqg res fe habeat, in têpora tamen vfog C.Cæfaris hu jufmodi obferuationé fuiffe cópertú eft: ea nanq̧ facra quü fedens Cęfar fpectaret $\&$ inter eos qui folennia celebrarent $M$. Antonius cof.qui triüuir poftea fuit adeffet, aiunt eü diadema capiti Cęaris imponere conatum, quod quum Cęar amoto capite ac fimul manibus reieciffer, Iouis capitolini ftatux ilico iuffit imponendum. De nomine Lupercalium non vna etiam ratio, fed varia proditur: alii nanque locum deo Pani facratum Arcadix ferunt, cui etiam mons in Arcadia lyceus confecratus eft, $\&$ dictus gracè $\lambda$ viros, id eft, lupus, $q$ lupos haud fi nat in oues defauire: ideo $\&$ Euander deo gentis fuæ facrificauit locum, \& nominauit Lupercal, $\Phi$ prafidio ipfus, lupi à pecudibus arcerentur. Alii, referente Plutarcho, putant a I upa quę Romulum educauit potius emanaffe, quũ (vtait) lupercales ludicrum inchoént, vbi expofitum Romulum fuiffe fama eft, tametin qua ad facra pertinét minus ei conueniant rei dum de Lupa Romuli nutricelo quitur.Idem poeta his verbis fidem facit, Illa loco nomen fecit deus ille lupercal Magna dati nutrix præmia lactis habet. Quis vetat Arcadio dictos de monte 
lupercos? Faunus in Arcadia têpla lyceus habet.Inueniuntur etiấ auctore Quỉ tiliano qui Lupercalia aque tres partes orationis effe contédant, quafil ludere per caprum. Ob temporis deniqg obferuationem ludicrú hoc, vt inquit Plutarchus, ad expiandos manes conftitutú creditur: fiebat enim, vt ille inquit, nefaftis diebus méfe februarii, quẽ piacularé interpretâtur,eodé poëta in Faftis dicente, Ter tia polt idus nudos aurora lupercos Afpicit, \& Fauni facra bicornis eunt. Cófualia ludi dicebátur quos in honoré Confifaciebant,qué deú confilii putabant. Circenfes verò quos primus Romulus raptis Sabinis Confualium nomine celebrauit, Neptuno dicabantur. Hi in littore olim fluminis agebantur, ab alio late re pofitis enfibus $\&$ gladiis, vt ab vtraq parte effet ignauiæ præfens periculum, vnde $\&$ circenfes dicti funt, $\phi$ exhibebatur, in circuitu pofitis enfibus, licet alii à circuédo, ab, Aftercienfibus alii circenfes dicant vocari folitos. Horú ratio ludorum quid aliud habeat nifi leuitatê, \& vanitatem, \& infaniam non video: tanto nanqs impetu concitabantur animi in furore vt iam plus fpectaculi exhiberent quàm fpectandi gratia cóueniffent,cum excla mare, \& efferri,\& exilire copiffent. Equiria, ludi funt quos Romulus idem Mar ti inftituit, per equorum curfum qui in cápo martio exercebantur. Gladiatorum quoø munus dictú quod populo tanquẩ munus donatur, \& quı donat mü nerarius: \& qui familiam gladiatorú habet, gladiatoréfog domi in difciplina, \& in ludo exercet, ac poftea vendit, lanifta vocatur: gladiatorṹq̧ ideo dictû, $\Phi$ nos erat in fepulchris mortuorú, virorum fortium captiuos necari, quod quia poftea inimane vifum eft, placuic dimicare gladiatores ante fepulchra: quem morem. Homerus nofter Mantuanus his verbis expreffit, Viuêtes rapit inferias quos im molet vmbris, Captiuógr rogi perfundat fanguine flâmas. Nec abnuit ille tefte Floro, de ftipendiario Thrace miles, de milite defertor, inde latro, deinde in honore viriú gladiator, qui defunctorú quog̣ pralio ducum imperatoris celebrauit exequiis, captiuóf $q$ circo regio iuflit armis depugnare, quafi plane expiaturus omne pręteritum dedecus, fi de gladiatore munerator fuiflet. Liuius ab vrbe cód.xxix, Scipio Carthagine ad vota foluéda diis, munúfqg gladiatorum quod mortis caufa patris patruióg parauerat edédú redit. Gladiatorú fuit fpectaculü nó ex eo genere hominú ex quo laniftas cōparare mos eft, feruorứq vanalé fan. guinem habent,voluntaria omnis $\&$ gratuita opera pugnátium fuit. Nam alii miffi ab regibus funt ad fpecimé infitæ genti virtutis oftendendü, alii ipfi profeffi fe pugnat uros in gratia ducis, alios æmulatio in certamen vt prouocarent, prouocative haud abnuerët traxit. Quid enim miretur quifö in hoc primum, inuentoré an inuétum, artificem an auctoré, aufum aliquem hoc excogitare, an fufcipere, an iubere, an fuper omnia populi furorem ? quàm vile enim nefas ani marum iftarum, quantú inde querelarum, quantú mali potuit hauriri,quis non videt? Nouendiales ludi funt, qui in honorem mortuorum celebrantur.Proinde apud maiores vbi quis fuiflet extinctus, ad domum fuan referebatur : vnde eft, Sedibus hunc refer antè fuis : \& illic feptem erat diebus, octauo incendebatur, nono fepeliebatur domi etiå fux: vnde orta eft cófuetudo vt dii penates colätur in domibus. Similiter Funebres, Plebeios,Megalenfes, Apollinares quos omnes 
currules ædiles munere publico curabãt, magno plaufu celebratos inuenio. Fu nebres ad detinendú populum inftituti,dum pöpa funeri decreta in honore $\mathrm{Pa}$ tricii viri plene inftruitur.Plebeii qui $p$ ralute plebis edútur exactis regibus, pro libertate, aut pro recóciliatione plebis poft feceffionẽ in Auentinū. Magni ludi, Romani ludi appellabantur, quos in honoren Iouis faciebät: vel romani Regii ludi, Q. Afconio tefte, fuis fub regibus inftituti funt, magníq appellati, $q$ magnis impéfis dati, cum primú ludis impenfa funt ducenta milia nummûm,adeò magnos ludos factos putant, $q$ confiliorũ fecretorũ deo, id eft, Neptuno lari \& diis magnis, id eft, laribus vrbis $R$ omę dati funt, quibus aiút raptas Sabinas efle, quod videtur Virgilius notaffe, Et magnis Circenfibus actis. Megalenfes verò nobiliü ludi \& magnis diis confecrati, a loco inuentionis cius fic dichi. His pr $x$ torum erat lud is intereffe \& lufores códucere. Iuuenalis in Satyris, Interea Megalefiacæ fpectacula mappæ Ideum folenne colunt, fimilifop triumpho Præda caballorum prætor fedet, ac mihi pace Im menfę nimizép, licet fi dicere, plebis, Totam hodie Roman circus capit, $\&$ fragor aurem Percutit,euentum viridis quo colligo panni. Nam fi deficeret mœftam attonitam'q videres Hanc vrbem veluti Cannarum in puluere victis Confulibus fpectent iuuenes quos clamor $\&$ audax Sponfio, quos cultę decet affediffe puellę.Ludos fenicos Valerius Áncias auctor eft, $M$ egalefia appellatos, \&, fi Firmiano credimus, Libero attributos, cui ex Indis Thebas redeunti, à triennio bis peregrinationis exacto Græcos inRituiffe trieteridas tradunt.Ludorum Apollinarium origo victoria non valitudinis ergo, vt quidam an saliu feriptores produnt, ex duobus Martii vatis car minibus, cuius duo in fenatu volumina illata erant, memoratur: priore carmine Cannenfis prædicta clades in hęc propemodú verba erat, A mnem troiugenam Romane fuge Cannä,Nec te alienigenæ cogát in câpo Diomedis conferere nia nus: led neģ credes Tu mihi donec fanguine campú, Multáqg milia occifa tua defert Amnis in pontum magnum extra frugifera pifcibus Atqpauibus feris quoque qua incolunt terras, his fluat efca caro tua: nam mihi ita Iuppiter fatus en, Diomedis argiui campum \& Cannam flumen qui militauerat in his locis iuxta atop ipfam cladem agnofcebant: tum alterum deinde carmen inuentum eft ita fcriptum, Hoftem Romani fi ex agro expellere vultis Vomicã qua gentium venit longe Apollini vouendos cenfeo ludos, qui quotannis comiter Apol lini fiant. His ludis faciendis praerit prator,qui ius populo plebíg dabit.Summum dicm viri greco ritu hoftiis facra faciant. Hoc fi recte facietis gaudebitis Lemp fetộ respub - veftra melior: nã is dies extinguet pduelles veftros q veftros campos palcunt placidè . Ex hoc carmine quum procurandi gratia dies vnus rebus diunis impenfus effet, poftremo fenatufconfultum factum eft, vti decenviri quo magis infruerentur de ludis A pollini faciend is, rég diuina recte facienda, libros Sibyllinos adirent, in quibus quum eadem reperta núciatumi effet, cenfuerüt Patres A pollini ludos vonendos faciendosóg, nópeam rem duodecin milia zris prætori \& duas holtias maiores dari, Deceuirífo pręceptú vt grảe ritu,id eft,capite operti hifce holtiis facrum facerent, Apollini boue aurato $8 \mathrm{~L}$ capris duabus albis auratis, Latonæ boue formina aurata. Hos ludos in circo po pulus 
pulus coronatus fpectare iuffus erat, matronx fupplicare, vulgus apertis ianuis in propatulis epulabatur, celebérg dies is omni cerimoniarum genere habebatur:fićp paulatim ceteris diis huiufmodi ludorum honos tribui copit,fingulique ludi,ficut Sifinius Capito in libris fpectaculorum defcribit , nominibus eo. rum confecrati funt.

CAP. XIII

N fuprema demum nottri laboris parte,fummam reponemus prin1. cipum,ex bellis diis oblata in medium relaturi.Quis enim bellotum S. - Surbinibus victor egrediens dominum exercituum inhonorum dereliquit, quum illi etiam ipfi qui veri dei cognitioné minus haberée quodcung illud effet numinis haudquaqua prætermitterent, quin fumma qua dam veneratione profequerentur?de quibus ne forfan hafitare quifpiam poffit, teftes adfunt pracelletiffimi duces, fed in prinis Dionyfius qui \& Liber dictus eft, \& Alexäder Macedo,Indiam enim ingreffus ille,primitias deo loui in orien te à captiuis habitas primus abtulit: quod fi non abunde conftaret, Ouidius in faftis teltis eft opulentifimus, dicens, Ante tuos ortus ara fine honore feruntur, Liber, \& in gelidis herba reperta focis. Te memorant Gange totógg Oriête fubacto, Primitias magno propofuiffe Ioui. Cinnama tu primus captiuáque thura dedifti, Déq́ triumphato vífcera tofta boue.Nomina ab auctoris ducunt liba mina nomen Libáque quòd fanctis pars datur inde focis. Huic à teneris Græcorü more vnguiculis fine parfimonia thura ingerenti aris, pædagogus Leonidas eam thuris profufionem agre ferens, thúfque perfape adimens inquit, Heus tu puer,large fic odores offeres quum regionis thuriferæ potiere. Qui A rabia tan dem potitus rex, thure onuftam nauim mifit ei, ac epiftolam in hac prope verba, Mifi ad te thuris \& caffix talenta, ne qux minima fant, maximi facias in diuinis rebus, vtpote qui non fis nefcius nos pigmentiferi potitos foli.Eidé Ale xandro poftea adulto placuere \& lychni penfiles in delubris, arborum non mala ferentium, lucentes, vt in templo quondam Apollinis palatini, quem ide Ale xander Thebarum expugnatione captum Lucinixe dicauerat, Apud Innonis quoop Lucinix templum in Brutiis xetatem agens Hannibal aram ibi condidit dedicauitóp cum ingenti rerum ab fe geftarum titulo, punicis gręciśóp literis in fcripto. Idem pro tot tamóp foeliciter in Italia geftis, maxime poft labefactam ex Cannêfi clade rem romanam ad internitionemós penè redaçam, diis inmortalibus facrum agi haberíg iuffit. Iouis autem templo quod primûu in vrbe confe cratú eft, Romulus primus fpolia ab Acrone Ceniêfum rege à fe occifo detracta retulit. Cornelius deinde Coffus quứ Columnium Hetrufcum Fidenatư du cem obtruncafet, eidem deo fpolia confecrauit.Nec M.Marcellus filétio inuol uendus, qui apud Padum Briomatum Gallorum regem ab eo fuperatum $\alpha$ ç fum armis exuit, inde procedens ad Feretrii louis têplum a feendit, $\&$ ea illi folen ni dedicatione fulpendit. Neq his contentus Marcellus eft, captis nanç Syracu fis, ornamenta, figna vrbis, tabulasóp quibus ciuitas illa florebat Romam deue xit,patrilíg diis fufpendit. Vifebãtur ea ad portam Capenam in templo ab eo dedicato . Ab eodem legimus Virtutis templum \& Honoris renouatum, quod 
multis antèannis fuerat bello lyguftico Q. Maximo dedicatū. Tullum Hoftili«m quü bis de Albanis, de Sabinis tertio triumphaffet, inuenio phanum Saturno ex voto conlecrauiffe, etiàm Saturnalia tunc primùm Romæ inftituta, quis Varro libro qui eft de facris ædibus vi. [cribat, ædem Saturni ad forum facien: dam locaffe L. Tarquiniü regé, T. verò Lartiú dictatorē, Saturnalibus eã dedicaffe. Nec me fugit Gelliü fcribere renatú decreuiffe vt æedes Saturni fieret, eíģ rei L. Furiú trib. militú præfuife. Tarquinius, cui cognomé fupbo ex moribus datŭ, téplü ex hoftiú poliis erexit, quod quú inauguraretur cedétibus diis cæateris, mirabile diêtu, reftitere iuméta \& termini, tan q numina hac cótumacia, fir ma omnia \& æterna pollicerentur.Scipio Numãtinus Virtutis phanum erexit, deinde C.Marius de manubiis Cymbricis \& Theutonis ædë Honori \& Virtuti fecit.Pòlt Scaurus Aemilius templú Menti,quc̀d circiter bellú Cymbricú nasus,cum fcilicet eloquentia \& eruditio vrbem ingreffæe, eam coeperint a mplifime exornare. Aemilius conful quum Gallos acie vicifet, ex ipfis Gallorum tor quibus aureum loui trophęum erexit, quòd deuouiffent Galli fi viciffent, de Ro manis Spoliis Marti Gallico torquem aureum cófecratũ iri. Atqui Furius Camillus quú Gallorum extinxiffet incendium, \& Romam auro liberandá è lance abłtuliffet,nó confilii,nó fortitudinis, fed famæ \& vaticinii tếplum iuxta viam nouam erexit. Pulcherrimú operum Pantheon Ioui vltori ab Agrippa factum veterum monumenta produnt.Minerua R omæ iuxta Capitolium quondá fita, quæ Euphranoris erat, Catulliana poftea dicta,à Q. Luctatio Catullo dicata: aliam Mineruam Romæ ad ædem Fortunæ Aemilius Paulus dedicauit. Fecit \& Spurius Clauilius Iouem in capitolio victis Samnitibus facra lege pugnantibus, ex peçoralibus eorü, ocreis \& galeis. Diuus Iulius thoracem quem Veneri genitrici in templo eius dicauit, ex Britannicis margaritis factum voluit intel ligi. Pompeius Magnus imperator vitem auream cum botro in téplo Icuis $\mathrm{Ca}$ pitolini facrauit. Erat autem quingentorum talentorum auri, titulum habens, Ariftoboli fili Alexandri regis. Auguftus Cæfar omnium templorum con ditor legitur aut reftitutor. Oiuus Velpafianus Concordix fue Pacis templum ædificauit, effecitque. Ac ne ifta in re vniuerfa perfequar, quoniam longum nimis $\&$ operolum id quidem effet, horum illufrium ducum $\&$ aliorum fubfequentiam imperatorú contextu, certamine religionis, ac laudis emulatione, nec inferior, Sigifmunde, (vt aliquando in te iure fuo noftra definat, vnde cœ pta eft,oratio) polt confummationem Italici belli, inuicta animi tui virtute cunctis holtibus profligatis, proftratifque, $a b$ armis ad negocia vrbana men tem conuertens, de manubiis obfelfarum deditarúmque per te vrbium, fumma facratifimi diuiníque principis religione fretus, præter ædes facras extra tertio ab vrbelapide in monte maríque profpectu fitas, templum illud percelebre omníque admiratione dignum, ac vnicum denique monumentum regii nominis tui, intra monia vrbe media ac forotenus à fundamentis extructum deo dicatum reliquifti, tantáque diuitiarum largitate, tam miririficis picturæ toreumatúmque ornamentis, vt in hac celeberrima vrbe plurima quum fint cognitu \& memoratu digna, nihil antiquius fit, nihil quod 
magis vifendum putetur, amplifimis prafertim parietibus, permultifque altiffimis arcubus, peregrino marmore exædificatis, quibus la pidex tabulæ vefti untur, quibus pulcherrimè fculptæ infpiciuntur, vnáç fanctorum patrum,virtutum quatuor, ac cæleftis zodiaci fignorum, errantiumq fiderum: Sibyllarum deinde mufarúm $\$$ \& aliarum permultarú nobilium rerum imagines, qux nedum praclaro lapicide ac fculptoris artificio, fed et iam cognitione formarum, liniametis abs te acutifimo \& fine vlla dubitatione clariffimo huius feculi prin cipe ex abditis philofophix penetralibus fumptis, intuentes litera rum peritos, $\&$ à vulgo fere penitus alienos, maxime pollint allicere. Præcellentiffimis præterea loca hac fanctiflima pontificis privilegiis $\&$ innumeris donis ac fanctorum reliquiis ornafti, quum vltra hæc maximum quotannis æris $\&$ auri reditum per te his deo dicatum, gémas, margaritas, pateras aureas, calices, acerras, thuribula, cruces, cādelabra,tabulas, organa,tunicas purpureas, \& trabeas textili auro, plurima deniq facrorú ethnicorúmg librorun, ac omnium optimarú artiunj volumina vna donatione contuleris. Nouitium fanè,præclarum, $\&$ ingens ad immortalitatem inuentum, quum non auro,argento, ere vel marmore, calce vel la pidibus tantùm, verùm in bibliothecis ab illis dicari volueris quorum im morta les animæ in locis iifdem loquuntur.Cęterarum rerum tuarum cumulü referre, haud facile duxerim, quú præter hæc tot claris operum monumentis adeò nomen tuum paffim illuftretur vt nulla vnquam tam furda pofteritas, nulla tam ingrata fama futura fit, quæ non illud in cælu tollat, ac debitis $\&$ optatis laudi. bus profequatur. Videor certiffima falus lumen'q̣ ac patrix decus \& pater,Sigifmunde Pandulphe Malatefta,optatum iuflionis tue meíg operis rerum milita. rium munus abfoluiffe, non nefcius potiora effe qux iubebantur quàm fuftinere mediocre cuiufpiam poffet ingenium, proindég plurima me incognita præteriiffe, qux commode potuiffent his voluminibus inferi:cæterùm cum commu nis humani( $v t$ ita dixerim)animi morbus fit,vt plura lóge quifọ nefciat quàm fciat,nec vt Flaccus inquit, quiuis horrëtia pilis Ágmina,nec fracta pereũtes cu fpide Gallos, Aut labentis equo defcribat vulnera Parthi,fi quid in his libris pa rum eft vel nimium, fi quídque quod ex illo prifco $\&$ difertiflimo veterü dicendi more fluere, ac retro fublaplum referri vifum fit, mihi fuccenfeant foli rogo: fi quid autem fatis quod pofteritate dignú in arcép poni queat quafi Minerua illa Phidiæ, vel ex ipfrus Mineruæ officina exiiffe videatur, non mihi fed diuino numini tuóque deinde gratias mecum magnas nedum agant, fed ingẽtes $\& \mathrm{cu}$ mulatiffimas referant, qui ad fulcepti laboris metam in magnis bellorum æeftbus effes licet, ftudia tamen noftro ductu $\&$ aufpiciis tuis lucidiora $\&$ alacriora foués, calcar femp addidifti, \& currenté vt aiunt ad curfum affiduè prouocalti.

\section{FI N I S.}

Lutetix apud Chriftianum Wechelum, Anno M.D.XXXII. menfe Iulio. 

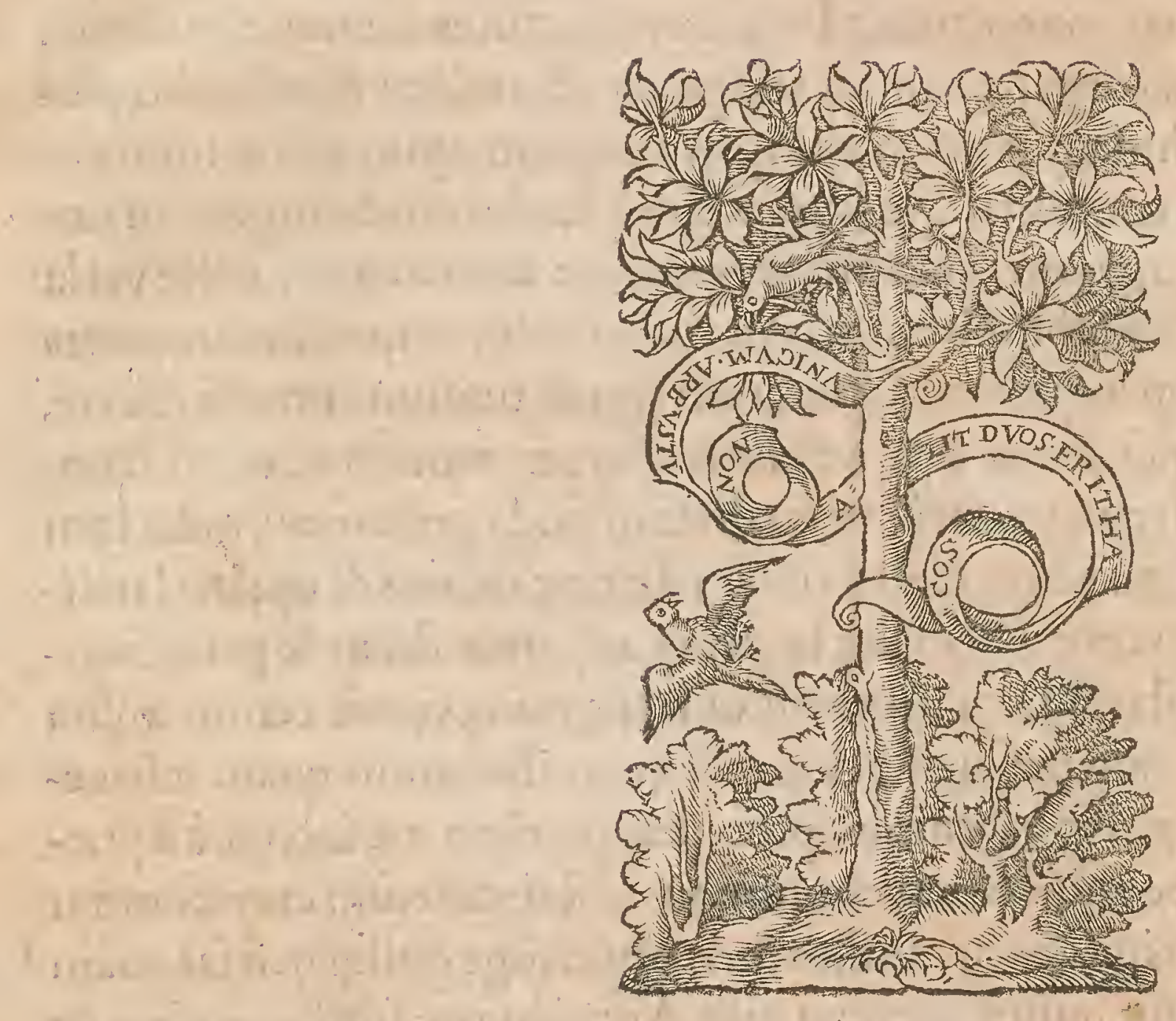

(:-1:-

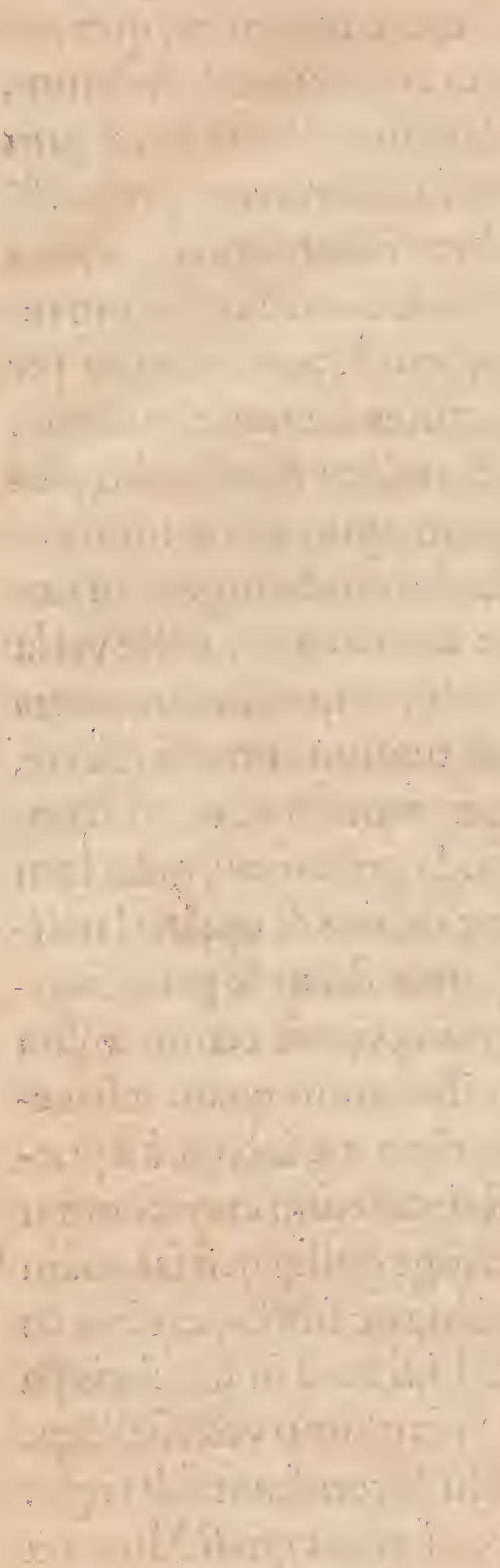

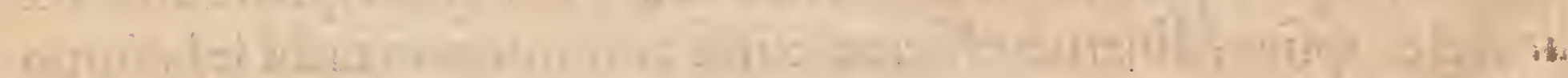

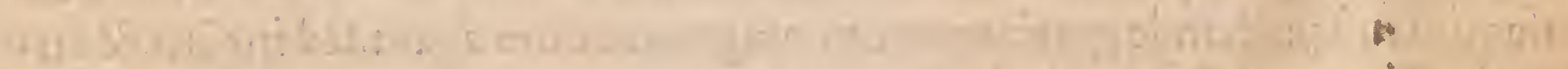

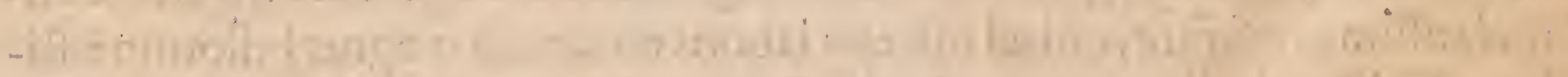

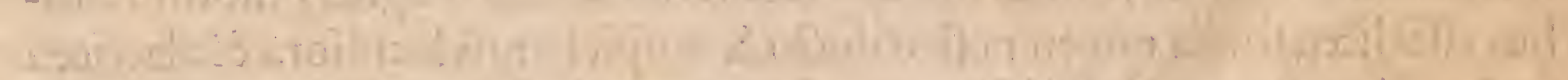

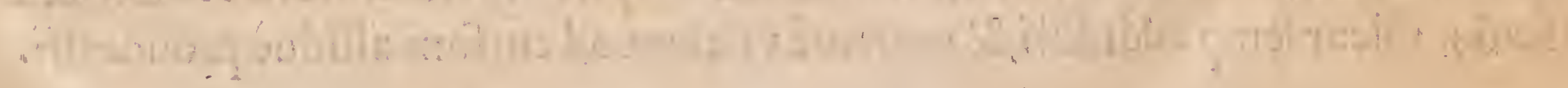





